\title{
Savannah River Site Environmental Report for 1998
}

Editors

Margaret W. Arnett

Albert R. Mamatey

Prepared for the U.S. Department of Energy Under Contract No. DE-ACO9-96SR18500

Westinghouse Savannah River.Company

Savannah River Site, Aiken, SC 29808 
Front Cover-A bumble bee (Bombus sp.), a variegated fritillary butterfly (Eupteoieta claudia), and, in the background, a buckeye butterfly (Junonia coenia) visit federally endangered smooth purple coneflowers (Echinacea laevigata) at the Savannah River Site. The three insects, common in the Southeast, are pollinators and likely are tapping the flowers for nectar, an important source of energy. This population of flowers, located near Road 9, is the largest of two on site, with more than 700 individual plants; the smaller population, near Burma Road, has about 150 plants. The background photograph shows pebbles on the creek bed of Tims Branch, near A-Area. The photographs were taken by Al Mamatey of the Westinghouse Savannah River Company's Environmental Monitoring Section. The cover was designed by Eleanor Justice of the company's Multimedia/Network Publishing group.

For more information about this report, or to obtain additional copies, contact:

Bob Lorenz, Manager

Environmental Sampling and Reporting

Westinghouse Savannah River Company

Building 735-16A

Aiken, SC 29808

Telephone: 803-725-3556

This report was prepared as an account of work sponsored by an agency of the United States Government. Neither the United States Government nor any agency thereof, nor any of their employees, makes any warranty, express or implied, or assumes any legal liability or responsibility for the accuracy, completeness, or usefulness of any information, apparatus, product, or process disclosed, or represents that its use would not infringe privately owned rights. Reference herein to any specific commercial product, process, or service by trade name, trademark, manufacturer, or otherwise does not necessarily constitute or imply its endorsement, recommendation, or favoring by the United States Government or any agency thereof. The views and opinions of authors expressed herein do not necessarily state or reflect those of the United States Government or any agency thereof.

This report has been reproduced directly from the best available copy.

Available to DOE and DOE contractors from the Office of Scientific and Technical Information, P.O. Box 62, Oak Ridge, TN 37831; prices available from (615) 576-8401.

Available to the public from the National Technical Information Service, U.S. Department of Commerce; 5285 Port Royal Road, Springfield, VA 22161. 


\section{DISCLAIMER}

Portions of this document may be illegible in electronic image products. Images are produced from the best available original document. 


\section{BUSINESS REPLY MAIL}

POSTAGE WILL BE PAID BY ADDRESSEE

Attn: Bob Lorenz

Westinghouse Savannah River Company Building 735-16A, Savannah River Site Aiken, SC 29803-9899

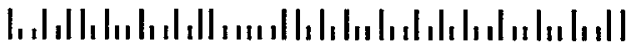




\section{Can We Make This Report More Useful to You?}

We want to make the Savannah River Site Environmental Report more useful to its readers. Please take a few minutes to let us know if the report meets your needs. Then fold and tape this page so the postage-paid notation and the mailing address are visible, and place it in the mail.

1. How do you use the Savannah River Site Environmental Report?

$\square$ to learn general information about the Savannah River Site

$\square$ to learn about doses received for the current year

$\square$ to learn about site compliance information

$\square$ to gather effluent data

$\square$ to gather environmental surveillance data

$\square$ other

2. What part(s) of this report do you use?
$\square$ main report
data book
summary pamphlet

3. Does the Savannah River Site Environmental Report contain

$\square$ enough detail?

$\square$ too much detail? For example,

$\square$ too little detail? For example

4. Is this report

$\square$ too technical?

$\square$ about right?

not technical enough?

5. If you could change this report to make it more readable and useful to you, what would you change?

6. What is your affiliation?
$\square$ DOE Headquarters
$\square$ university/academy
$\square$ other DOE facility
$\square$ library/public reading room
regulator
$\square$ media
. other government office/agency
$\square$ industry
$\square$ environmental group
elected official
$\square$ other group
$\square$ other individual

7. To help us identify our audience, please indicate your educational background.

$\square$ graduate degree in scientific field

$\square$ graduate degree in nonscientific field

$\square$ undergraduate degree in scientific field

$\square$ undergraduate degree in nonscientific field

$\square$ experience with science outside college setting

$\square$ little or no scientific background

If you are interested in attending a workshop to critique the 1998 report, please provide your name, address, and telephone number.

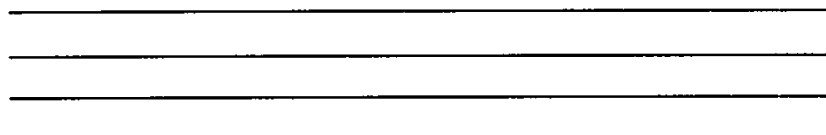

For more information, please call Bob Lorenz, Manager - Environmental Sampling and Reporting, at 803-725-3556, or send an e-mail message to robert.lorenz@srs.gov. 


\section{Acknowledgments}

- The editors acknowledge with deep appreciation the efforts of the following individuals, who-in addition to the chapter authors and compilers-reviewed and/or contributed valuable resources, information, or technical data to the Savannah River Site Environmental Report for 1998:

$\begin{array}{llll}\text { Linda Basinger } & \text { Teresa Eddy } & \text { Nordette Lawrence } & \text { Babu Patel } \\ \text { Marie Berry } & \text { Steve Etheridge } & \text { Dave Lester } & \text { Priscilla Patterson } \\ \text { Brent Blunt } & \text { Natalie Ferguson } & \text { Jeff Lintern } & \text { Larry Pike } \\ \text { Jim Bollinger } & \text { Dave Filler } & \text { Nancy Lowry } & \text { Luke Reid } \\ \text { Palmer Bowen } & \text { Angie Fitzgerald } & \text { Bill Maloney } & \text { Jesse Roach } \\ \text { Sandra Boynton } & \text { Lynne Geary } & \text { Donna Martin } & \text { Jack Roberts } \\ \text { de'Lisa Bratcher } & \text { Steve Glover } & \text { Lynn Martin } & \text { Dan Rogers } \\ \text { Alan Carvo } & \text { Sonny Goldston } & \text { Tony Maxted } & \text { Paul Rowan } \\ \text { Mike Caudell } & \text { Susie Grant } & \text { Jack Mayer } & \text { Joe Shake } \\ \text { Charlene Cochran } & \text { John Harley } & \text { Robyn McBeath } & \text { Ali Simpkins } \\ \text { Beverly Collins } & \text { Chuck Hayes } & \text { Hugh McGovern } & \text { Steve Smith } \\ \text { June Cooley } & \text { Dawn Haygood } & \text { Frank Melendez } & \text { Monte Steedley } \\ \text { Lori Coward } & \text { Doris Hoel } & \text { Hal Morris } & \text { Bob Steitler } \\ \text { Brian Crandall } & \text { Robert Kemmerlin } & \text { Billy Morrison } & \text { Keith Stone } \\ \text { Joe D'Amelio } & \text { Paul Hunt } & \text { C.E. Murphy, Jr. } & \text { Cliff Thomas } \\ \text { Lou Davis } & \text { Chuck Hunter } & \text { Lindy Nowak } & \text { Joe Trahan } \\ \text { Tad Dickinson } & \text { Bobby James } & \text { Joe Odum } & \text { Curt Walker } \\ \text { David Dimmick } & \text { Linda Karapatakis } & \text { Vernon Osteen } & \text { Gary Wein } \\ \text { Marcia Dunn } & \text { Larry Koffman } & \text { Happy Parker } & \text { Michele Wilson } \\ \text { Keith Dyer } & \text { Gene Laska } & \text { Matt Parker } & \text { George Wingard } \\ \text { Chuck Dynarski } & \text { Bruce Lawrence } & \text { Bar }\end{array}$

Environmental Advisory Committee: Dr. Edgar Berkey, Dr. Bernd Kahn, Dr. Dennis Paustenbach,

Dr. Milton Russell, Dr. Bernard Sweeney, and Dr. Gordon Wolman

- Listed below are those who provided expert publications support.
Steve Ashe, Bruce
Joan Toole and
Bernadette Hobbs
Greg Jansen, Yvonne Nixon, and
Boulineau, Emily
(customer service)
Michelle Norris
and Byron Williams
Lynn Gleason and
(offsite printing)
Dennis Hendrix, Eleanor Justice, and (photography)
Cherry Glisson (forms)
Ed Landry (illustrating)

- A special thanks to Mary Langford for coordinating the DOE-SR review and approval process. This process requires dedication and support from both WSRC and DOE-SR.

\begin{tabular}{llll}
$\begin{array}{l}\text { Trish Baughman } \\
\text { (WSRC) }\end{array}$ & Pat Dominey (WSRC) & Bart Marcy (WSRC) & Mina Perrin (DOE-SR) \\
$\begin{array}{l}\text { Randy Collins (WSRC) } \\
\text { Tom Coughenour }\end{array}$ & Juli Hearn (WSRC) & Bob Shankle (WSRC) & Gail Whitney \\
(WSRC) & $\begin{array}{l}\text { Sharon Lybrand } \\
\text { (WSRC) }\end{array}$ & Ben Gould (DOE-SR) & (DOE-SR) \\
\hline
\end{tabular}

- Thanks to Karl Bergmann, John Ellinger, Gary Fuller, Chuck Harvel, Tracey Humphrey, and Marvin Stewart for providing computer support.

- Gratitude is expressed to the following for management, administrative, and other support:

$\begin{array}{llll}\text { Brenda Alejo } & \text { Calvin Hamilton } & \text { David Hughey } & \text { Mark Spires } \\ \text { Chris Arenz } & \text { Tim Hartley } & \text { Jay Hutchison } & \text { Becky Sturdivant } \\ \text { Jerrie Fitzgerald } & \text { Jim Heffner } & \text { Bob Lorenz } & \text { Brenda Walker } \\ \text { June Hall } & \text { Dean Hoffman } & \text { Wayne Pippen } & \text { Robin Young }\end{array}$




\section{Preface}

The Savannah River Site (SRS) conducts environmental monitoring-consisting of effluent monitoring and environmental surveillance-to ensure the safety of the public and the well-being of the environment. U.S. Department of Energy (DOE) Order 231.1, "Environment, Safety and Health Reporting," requires that SRS submit an environmental report. The report's purpose is to document the impact of facility operations on public health and the environment, present summary environmental data that characterize site environmental management performance, confirm compliance with environmental standards and requirements, and highlight significant programs and efforts.

SRS has had an extensive environmental monitoring program in place since 1951 (before site startup). In the 1950 s, data generated by the onsite environmental monitoring program were reported in site documents. Beginning in 1959, data from offsite environmental surveillance activities were presented in reports issued for public dissemination. SRS reported onsite and offsite environmental monitoring activities separately until 1985 , when data from both programs were merged into one public document.

The Savannah River Site Environmental Report for 1998 is an overview of effluent monitoring and environmental surveillance activities conducted on and in the vicinity of SRS from January 1 through December 31, 1998. It is prepared by the Environmental Monitoring Section (EMS) of Westinghouse Savannah River Company (WSRC). The "SRS Environmental Monitoring Plan" (WSRC-3Q1-2-1000) and the "SRS Environmental Monitoring Program" (WSRC-3Q1-2-1100) provide complete program descriptions and document the rationale and design criteria for the monitoring program, the frequency of monitoring and analysis, the specific analytical and sampling procedures, and the quality assurance requirements.

Variations in the environmental report's data content from year to year reflect changes in the routine program or difficulties encountered in obtaining or analyzing some samples. Examples of such problems include adverse environmental conditions (such as flooding or drought), sampling or analytical equipment malfunctions, and compromise of the samples in the preparation laboratories or counting room.

\section{Report Documents Available on Web}

Readers can now find the SRS Environmental Report-as well as the accompanying data book and summary - on the World Wide Web.

The address for access to these documents on the Web is as follows:

http://www.srs.gov/general/srenviro/endrpt/index.html

To inquire about the report documents, or to request hard copies, please contact

Bob Lorenz, Manager

Environmental Sampling and Reporting

Westinghouse Savannah River Company

Building 735-16A

Aiken, SC 29808

Telephone: (803) 725-3556

E-mail address: robert.lorenz@srs.gov

Unless otherwise indicated, the figures and tables in this report are generated using results from the routine monitoring program. No attempt has been made to include all data from environmental research programs. A more complete listing of data can be found in Savannah River Site Environmental Data for 1998 (WSRC-TR-98-00314).

The following information should aid the reader in interpreting data in this report:

- Analytical results and their corresponding uncertainty terms generally are reported with up to three significant figures. The last significant figure of a result is determined by the quantification of the uncertainty term. EMS attempts to report the appropriate confidence in the result with the correct number of significant figures.

- Units of measure and their abbreviations are defined in the glossary (beginning on page 231) and in charts at the back of the report.

- The reported uncertainty of a single measurement reflects only the counting error-not other components of random and systematic error in the measurement process--so some results may imply a greater confidence than the determination would suggest.

- An uncertainty quoted with means represents the standard deviation of measurements about the mean value. This number is calculated from the 
results themselves and is not weighted by the uncertainties of the individual results.

- All values represent the weighted average of all acceptable analyses of a sample for a particular analyte. Samples may have undergone multiple analyses for quality assurance purposes or to determine if radionuclides are present. For certain radionuclides, quantifiable concentrations may be below the minimum detectable activity of the analysis, in which case the actual concentration value is presented to satisfy DOE reporting guidelines.

- The generic term "dose," as used in the report, refers to the committed effective dose equivalent (50-year committed dose) from internal deposition of radionuclides and to the effective dose equivalent attributable to beta/gamma radiation from sources external to the body. 


\section{Contents}

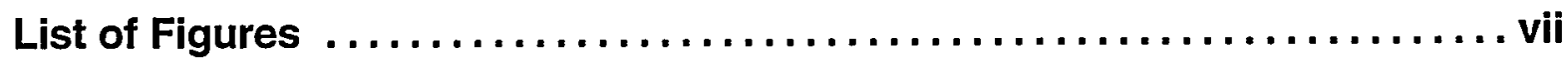

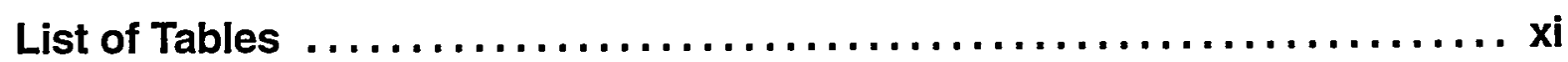

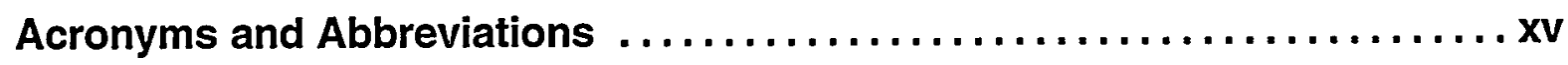

Sampling Location Abbreviations $\ldots \ldots \ldots \ldots \ldots \ldots \ldots \ldots \ldots \ldots \ldots \ldots \ldots \ldots \ldots \ldots \ldots$

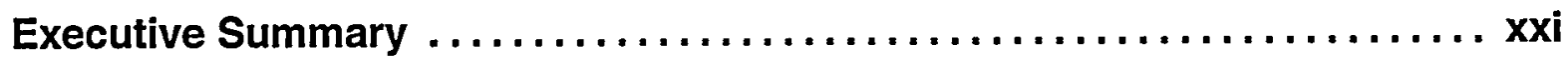

Potential Radiation Doses $\ldots \ldots \ldots \ldots \ldots \ldots \ldots \ldots \ldots \ldots \ldots \ldots \ldots \ldots \ldots \ldots \ldots \ldots \ldots \ldots \ldots \ldots$

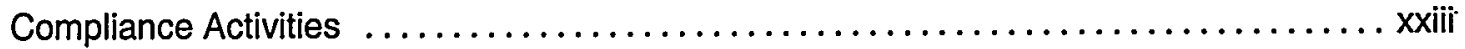

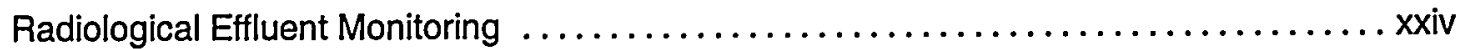

Radiological Environmental Surveillance $\ldots \ldots \ldots \ldots \ldots \ldots \ldots \ldots \ldots \ldots \ldots \ldots \ldots \ldots \ldots \ldots \ldots$

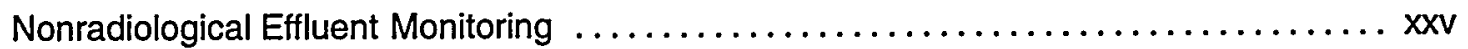

Nonradiological Environmental Surveillance $\ldots \ldots \ldots \ldots \ldots \ldots \ldots \ldots \ldots \ldots \ldots \ldots \ldots \ldots$

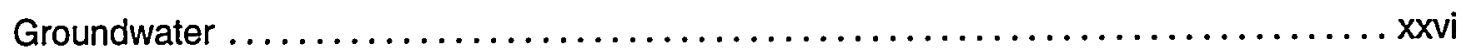

Special Surveys $\ldots \ldots \ldots \ldots \ldots \ldots \ldots \ldots \ldots \ldots \ldots \ldots \ldots \ldots \ldots \ldots \ldots \ldots \ldots \ldots \ldots \ldots \ldots \ldots \ldots \ldots$

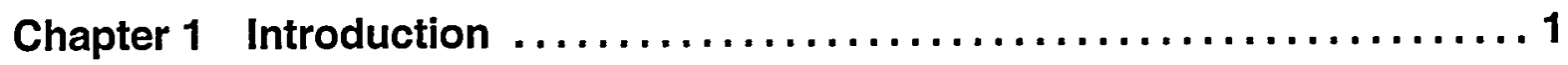

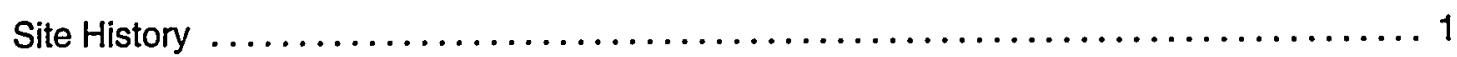

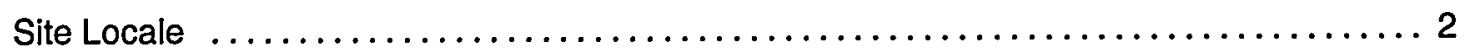

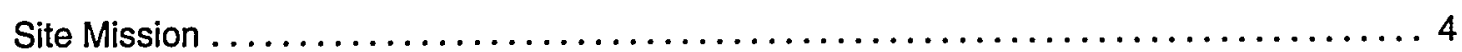

Site Areas and Major Facilities and Operations $\ldots \ldots \ldots \ldots \ldots \ldots \ldots \ldots \ldots \ldots \ldots \ldots \ldots \ldots \ldots \ldots \ldots \ldots$

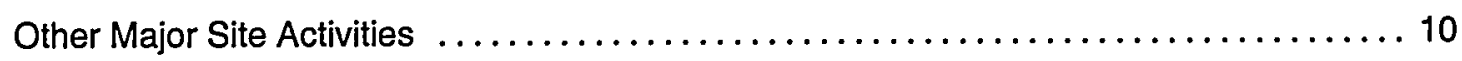

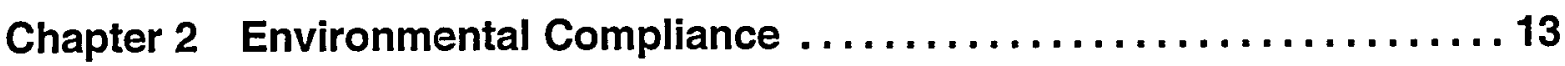

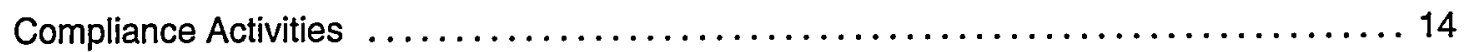

Environmental Release Response and Reporting $\ldots \ldots \ldots \ldots \ldots \ldots \ldots \ldots \ldots \ldots \ldots \ldots \ldots \ldots$

Assessments/Inspections . . . . . . . . . . . . . . . . . . . . . . . . . . 34

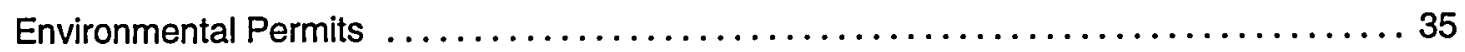

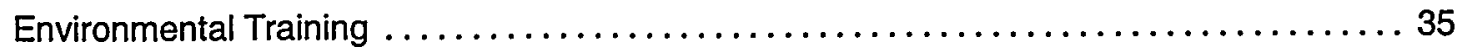

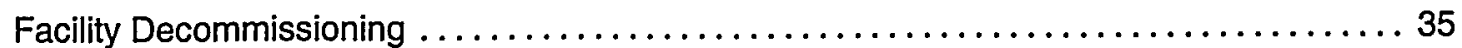

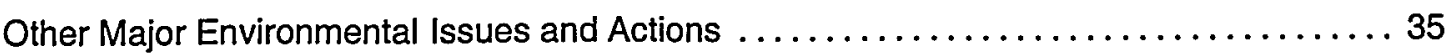


Chapter 3 Environmental Program Information $\ldots \ldots \ldots \ldots \ldots \ldots \ldots \ldots$

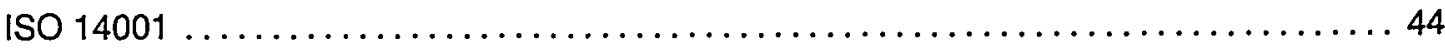

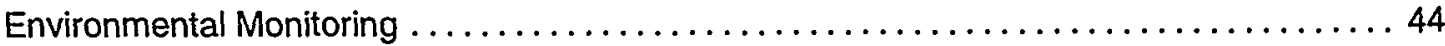

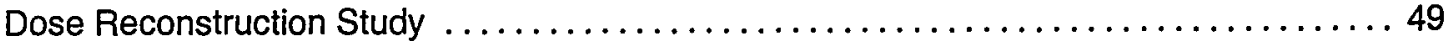

Pollution Prevention ............................................. 49

Public Involvement ............................................ 51

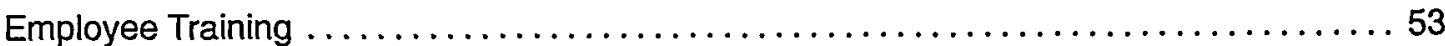

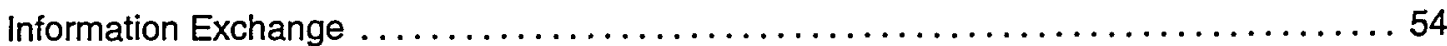

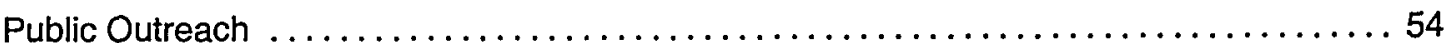

Chapter 4 Environmental Management $\ldots \ldots \ldots \ldots \ldots \ldots \ldots \ldots \ldots \ldots \ldots$

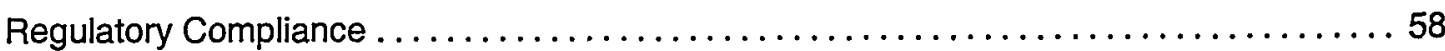

Environmental Restoration ........................................ 58

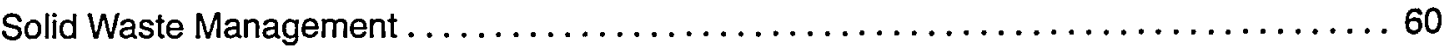

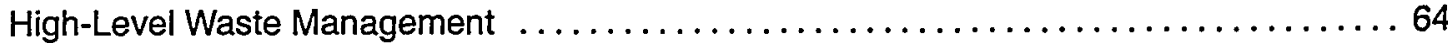

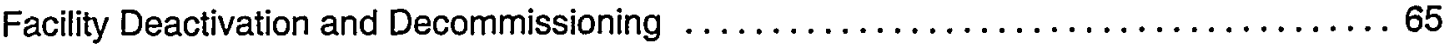

Chapter 5 Radiological Effluent Monitoring $\ldots \ldots \ldots \ldots \ldots \ldots \ldots \ldots \ldots 71$

Airborne Emissions . ............................................ 72

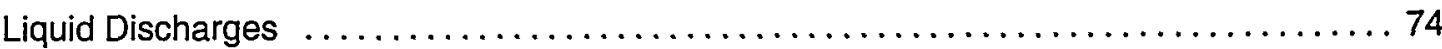

Chapter 6 Radiological Environmental Surveillance $\ldots \ldots \ldots \ldots \ldots \ldots \ldots 85$

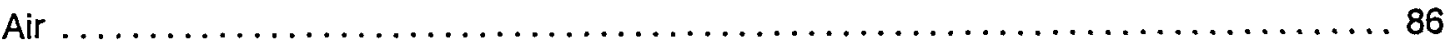

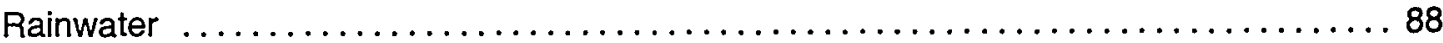

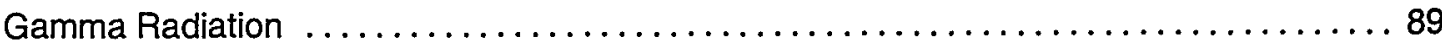

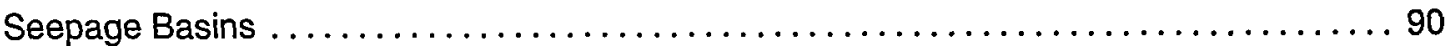

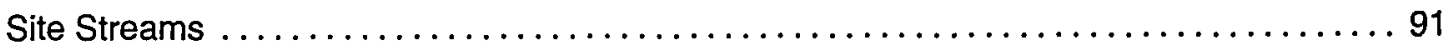

Savannah River .............................................. 95

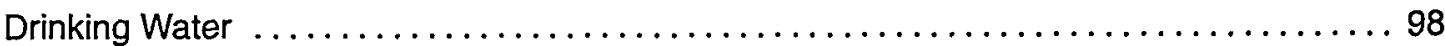

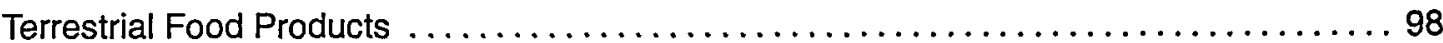

Aquatic Food Products .......................................... 100

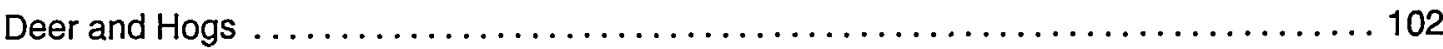

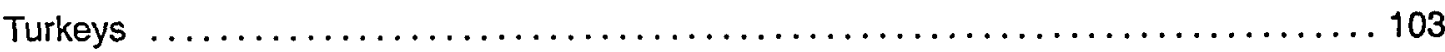

Beavers .................................................. 104

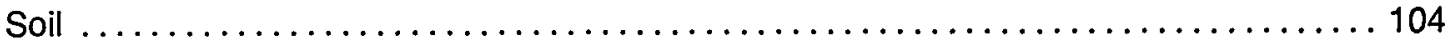




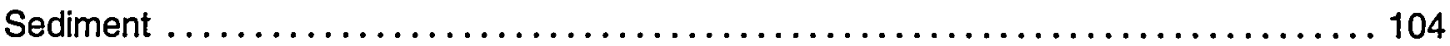

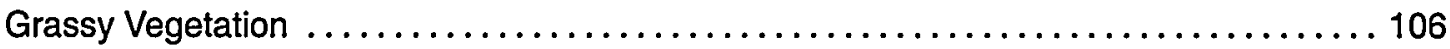

Chapter 7 Potential Radiation Doses ......................... 111

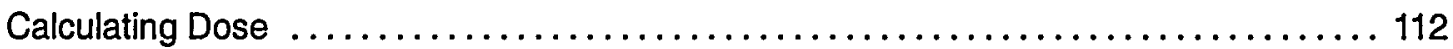

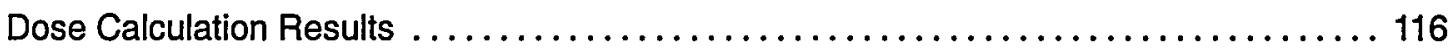

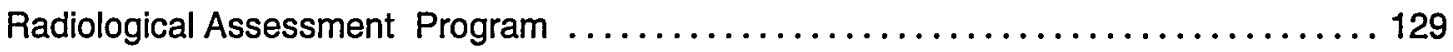

Chapter 8 Nonradiological Effluent Monitoring $\ldots \ldots \ldots \ldots \ldots \ldots \ldots . \ldots 131$

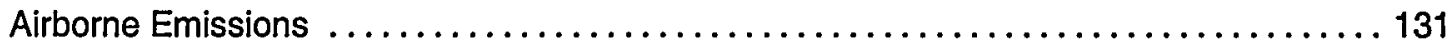

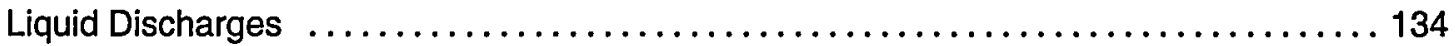

Chapter 9 Nonradiological Environmental Surveillance $\ldots \ldots \ldots \ldots \ldots \ldots 141$

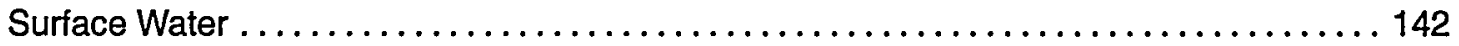

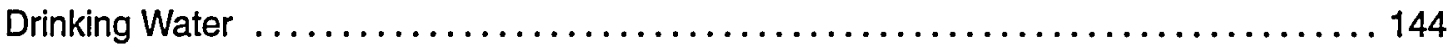

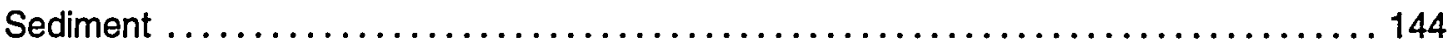

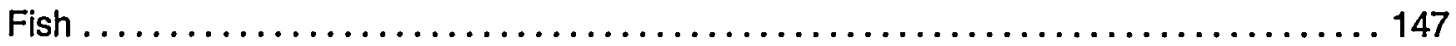

Chapter 10 Groundwater ............................. 149

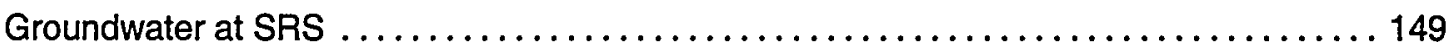

Description of the Groundwater Monitoring Program .................... 153

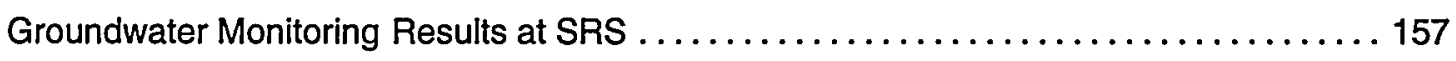

Chapter 11 Quality Assurance $\ldots \ldots \ldots \ldots \ldots \ldots \ldots \ldots \ldots \ldots \ldots \ldots \ldots \ldots$

Quality Assurance/Quality Control for Environmental Monitoring Section Laboratories ... 186

Quality Assurance/Quality Control for Subcontracted Laboratories .............. 189

Chapter 12 Special Surveys and Projects .................. 195

Site Monitoring - Accelerator for the Production of Tritium $\ldots \ldots \ldots \ldots \ldots \ldots \ldots \ldots$

Mitigation Action Plan for Pen Branch Reforestation . . . . . . . . . . . . . . . . . 195

Academy of Natural Sciences of Philadelphia River Quality Surveys . . . . . . . . . . . 199

Appendix A Applicable Guidelines, Standards, and Regulations . . . . 205

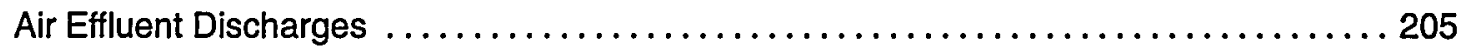

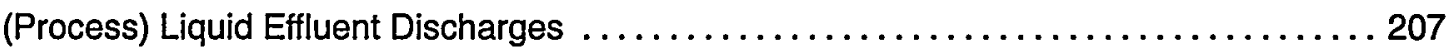

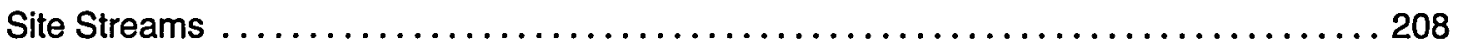

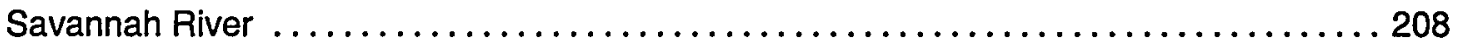




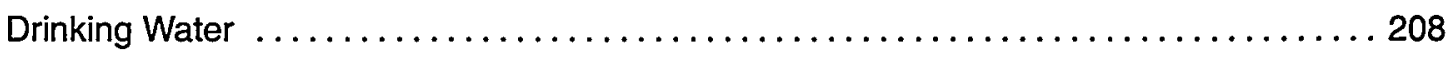

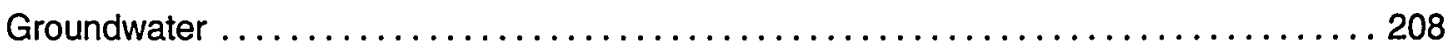

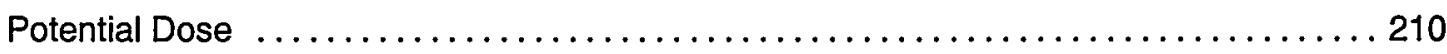

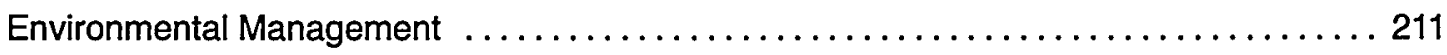

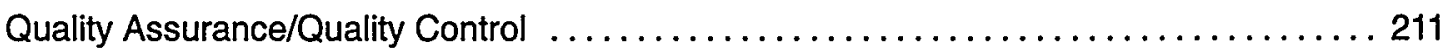

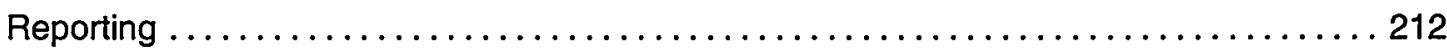

ISO 14001 Environmental Management System ........................ 212

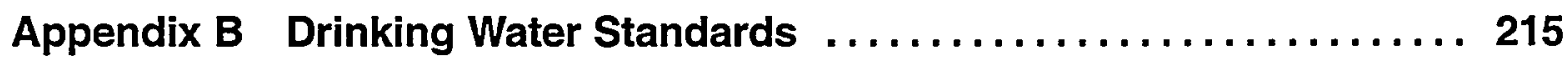

Appendix C Standard No. 8 Toxic Air Pollutants $\ldots \ldots \ldots \ldots \ldots \ldots \ldots 219$

Appendix D Radionuclide and Chemical Nomenclature ........... 227

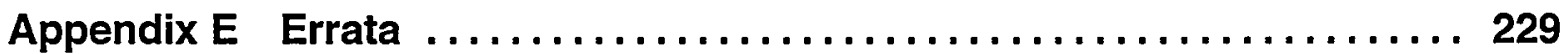

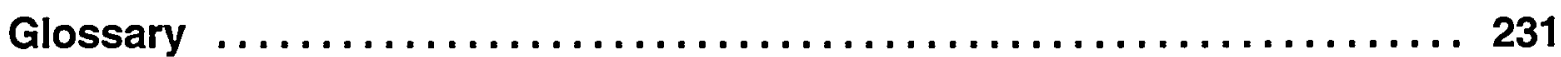

References $\ldots \ldots \ldots \ldots \ldots \ldots \ldots \ldots \ldots \ldots \ldots \ldots \ldots \ldots \ldots \ldots \ldots \ldots \ldots, 241$

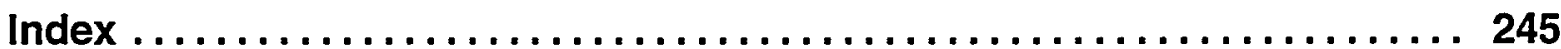




\section{List of Figures}

\section{Executive Summary}

Figure 1 Ten-Year History of SRS Potential All-Pathway Doses to the Maximally Exposed Individual (Airborne plus Liquid Pathways) .......... xxiii

Figure 2 Ten-Year History of SRS Annual Atmospheric Tritium Releases .......... xxv

Figure $3 \quad$ Comparison of Small-Mammal Captures $\ldots \ldots \ldots \ldots \ldots \ldots \ldots \ldots \ldots$. . . . . . . . .

\section{Chapter 1 Site and Operations Overview}

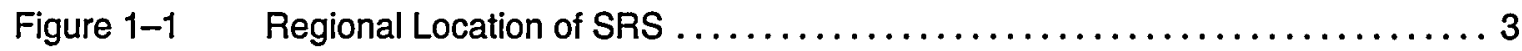

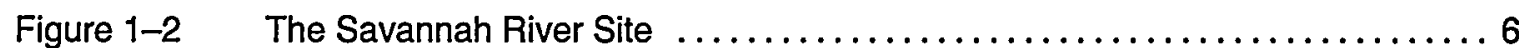

\section{Chapter 2 Environmental Compliance}

Figure 2-1 Total Toxic Chemical Releases at SRS, 1988-1997 ................. 19

\section{Chapter 3 Environmental Program Information}

Figure 3-1 Typical Airborne Effluent Monitoring and Environmental Surveillance ...... 45

Figure 3-2 Typical Liquid Effluent Monitoring and Environmental Surveillance ........46

Figure $3-3 \quad$ Some Potential Exposure Pathways $\ldots \ldots \ldots \ldots \ldots \ldots \ldots \ldots \ldots \ldots \ldots$

\section{Chapter 4 Environmental Management}

Figure 4-1 Recirculation Well Technology ............................ 59

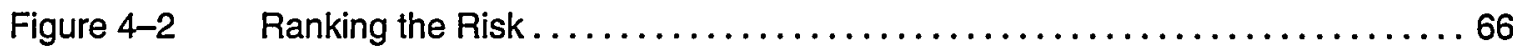

\section{Chapter 5 Radiological Effluent Monitoring}

Figure 5-1 Ten-Year History of SRS Annual Atmospheric Tritium Releases . . . . . . . 74

Figure 5-2 Direct Releases of Tritium to SRS Streams, 1989-1998 . . . . . . . . . . . . 76

Figure 5-3 Tritium Migration from Seepage Basins and SWDF to SRS Streams, 1989-1998 ............................................ 77

Figure 5-4 Total Tritium Releases to SRS Streams (Direct Discharges and Migration), 1989-1998, Based on Point-of-Release Concentrations and Flow Rates . . . . 78

Figure 5-5 Past, Current, and Projected Tritium Migration Releases to Four Mile Creek from the F-Area and $\mathrm{H}$-Area Seepage Basins and SWDF . . . . . . . . . . . 79

Figure 5-6 Tritium Migration Releases to Upper Three Runs from the General Separations Area and SWDF, $1989-1998$................ 80

\section{Chapter 6 Radiological Environmental Surveillance}

Figure $6-1 \quad$ Radiological Air Surveillance Sampling Locations $\ldots \ldots \ldots \ldots \ldots \ldots \ldots$

Figure 6-2 Average Concentration of Tritium in Rainwater $\ldots \ldots \ldots \ldots \ldots \ldots \ldots . \ldots . \ldots . \ldots$ 
Figure 6-3 Annual Average and Maximum Gamma Exposure Grouped

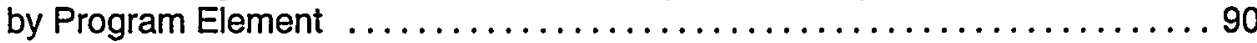

Figure 6-4 Radiological Surface Water Sampling Locations .................. 92

Figure 6-5 Average Tritium Concentration in SRS Streams, 1988-1998 . . . . . . . . . 94

Figure 6-6 SRS Tritium Transport Summary, 1960-1998 .................... 97

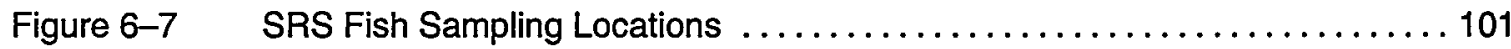

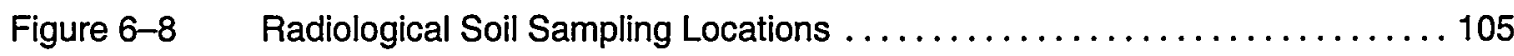

Figure $6-9 \quad$ Radiological Sediment Sampling Locations $\ldots \ldots \ldots \ldots \ldots \ldots \ldots \ldots \ldots$

Figure $6-10 \quad$ SRS Vegetation Sampling Locations ........................... 109

\section{Chapter 7 Potential Radiation Doses}

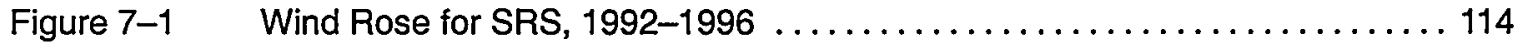

Figure 7-2 Savannah River Mile 120 Annual Average Flow Rates, 1954-1998 ....... 116

Figure 7-3 Annual Average Tritium Concentrations at River Mile 120, Beaufort-Jasper, and Port Wentworth (1989-1998) Compared

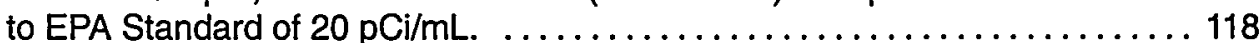

Figure 7-4 Sector-Specific Adult Maximally Exposed Individual Air Pathway Doses

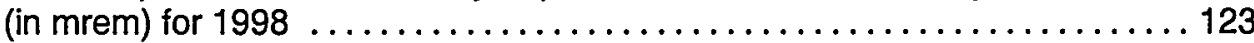

Figure 7-5 Ten-Year History of SRS Potential All-Pathway Doses to the Maximally Exposed Individual (Airborne plus Liquid Pathways) . . . . . . . . 124

Figure 7-6 Contributions to the U.S. Average Individual Dose ...................... 124

Figure 7-7 Annual Potential Radiation Doses from Consumption

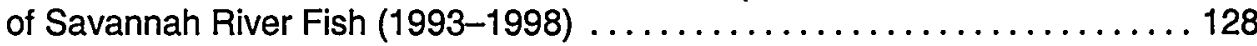

\section{Chapter 8 Nonradiological Effluent Monitoring}

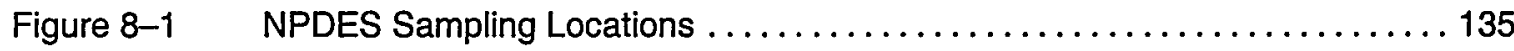

Figure 8-2 History of NPDES Exceedances at SRS, and Site's Compliance Rate, 1986-1998 ............................................ 138

\section{Chapter 9 Nonradiological Environmental Surveillance}

Figure 9-1 Nonradiological Surface Water Sampling Locations .................. 143

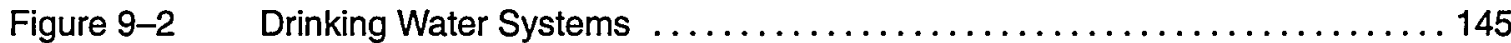

Figure 9-3 Nonradiological Sediment Sampling Locations ................... 146

\section{Chapter 10 Groundwater}

Figure 10-1 Facilities Monitored by the SRS Monitoring Well Network, Including Areas Having Constituents Exceeding Drinking Water Standards in 1998 . . . . . 150

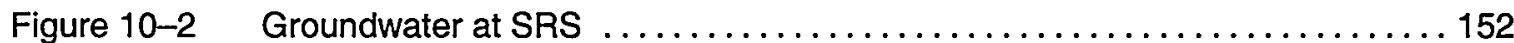

Figure 10-3 Potentiometric Surface and Horizontal Groundwater Flow Directions of the Middle Zone at SRS During the First Quarter of 1998 . . . . . . . . 154

Figure 10-4 Potentiometric Surface and Horizontal Groundwater Flow Directions of the Lower Zone at SRS During the First Quarter of 1998 ............ 155 
Figure 10-5 Extent of Groundwater Contamination Beneath A-Area and M-Area in 1998 and Location of Noteworthy Sources of Contamination Exceeding

Drinking Water Standards .............................. 160

Figure 10-6 Trichloroethylene Concentrations in Well Cluster ASB $6 \ldots \ldots \ldots \ldots \ldots \ldots 1$

Figure 10-7 Extent of Groundwater Contamination Beneath C-Area in 1998 and Location of Noteworthy Sources of Contamination Exceeding

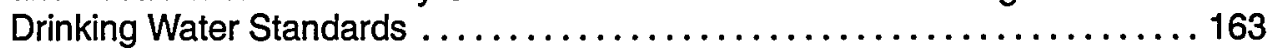

Figure 10-8 Extent of Groundwater Contamination Beneath D-Area and TNX in 1998 and Location of Noteworthy Sources of Contamination Exceeding Drinking Water Standards 166

Figure 10-9 Extent of Groundwater Contamination Beneath the General Separations and Waste Management Areas in 1998 and Location of Noteworthy Sources of Contamination Exceeding Drinking Water Standards . . . . . . . . . . . 170

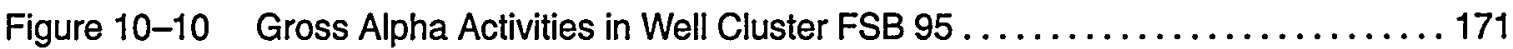

Figure 10-11 Extent of Groundwater Contamination Beneath K-Area in 1998 and Location of Noteworthy Sources of Contamination Exceeding Drinking Water Standards

Figure 10-12 Extent of Groundwater Contamination Beneath L-Area and the Chemicals, Metals, and Pesticides Pits in 1998 and Location of Noteworthy Sources of Contamination Exceeding Drinking Water Standards . . . . . . . . . . 175

Figure 10-13 Extent of Groundwater Contamination Beneath N-Area in 1998 and Location of Noteworthy Sources of Contamination Exceeding Drinking Water Standards

Figure 10-14 Extent of Groundwater Contamination Beneath P-Area in 1998 and Location of Noteworthy Sources of Contamination Exceeding Drinking Water Standards

Figure 10-15 Extent of Groundwater Contamination Beneath R-Area in 1998 and Location of Noteworthy Sources of Contamination Exceeding Drinking Water Standards

Figure 10-16 Extent of Groundwater Contamination Beneath the Sanitary Landfill and B-Area in 1998 and Location of Noteworthy Sources of Contamination Exceeding Drinking Water Standards . . . . . . . . . . . . . . . . . . 183

\section{Chapter 11 Quality Assurance}

Figure 11-1 SRS EM Program QAQC Document Hierarchy of Relevant Guidance Documents and Supporting Guidance Documents .............. 186

\section{Chapter 12 Special Surveys and Projects}

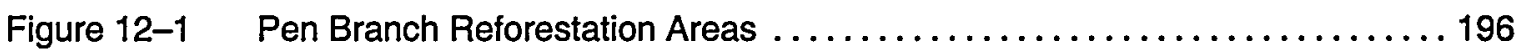

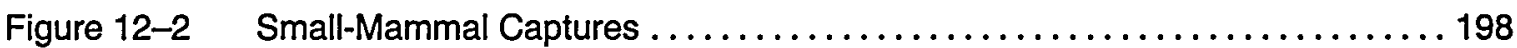

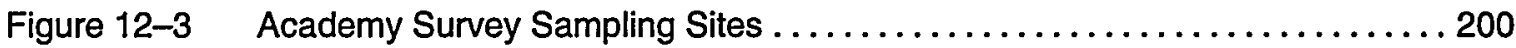





\section{List of Tables}

\section{Executive Summary}

Table 11998 Potential Radiation Doses from SRS Releases Compared with Applicable Dose Standards and Estimated Doses from Naturally Occurring Radiation $\ldots \ldots \ldots \ldots \ldots \ldots \ldots \ldots \ldots \ldots \ldots \ldots \ldots \ldots$

\section{Chapter 2 Environmental Compliance}

Table 2-1 Releases and Offsite Transfers of Toxic Chemicals (in Pounds) by SRS During 1995, 1996, and 1997 Reporting Years (Reported Under EPCRA Section 313) ........................ 20

Table 2-2 1998 SRS Reporting Compliance with Executive Order 12856 . ......... 21

Table 2-3 Types/Quantity of NEPA Activities at SRS During $1998 \ldots \ldots \ldots \ldots \ldots 21$

Table 2-4 SRS Project NEPA Documentation Activities During 1998 23

Table 2-5 CERCLA Releases Reported to Regulatory Agencies in 1998

Table 2-6

Environmentally Related Unusual Occurrences Reported Through SIRIM

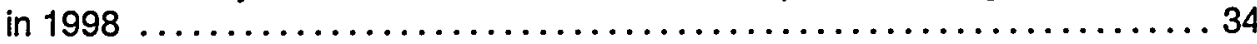

Table 2-7 SRS Construction and Operating Permits, $1994-1998 \ldots \ldots \ldots \ldots \ldots \ldots . \ldots 36$

Table 2-8 RCRA and RCRA/CERCLA Units at SRS - 1998

\section{Chapter 5 Radiological Effluent Monitoring}

Table 5-1

Radioactive Atmospheric Releases by Source 81

Table 5-2

\section{Chapter 6}

Table 6-1

Radioactive Liquid Releases by Source (Including Direct and Seepage Basin Migration Releases) .

\section{Radiological Environmental Surveillance}

Average Gross Alpha and Gross Beta Measured in Air (pCi/m3), 1994-1998 ............................................ 88

Table 6-2 TLD Surveillance Results Summary for 1998

Table 6-3 Average 1998 Concentration of Radioactivity in SRS and Surveillance Station Waters $(\mathrm{pCi} / \mathrm{L}) \ldots \ldots \ldots \ldots \ldots \ldots . \ldots . \ldots . \ldots 9$

Table 6-4 Average 1998 Concentration of Radioactivity in the Savannah River (pCi/L)

\section{Chapter 7 Potential Radiation Doses}

Table 7-1

1998 Radioactive Liquid Release Source Term and 12-Month Average Downriver Radionuclide Concentrations (Calculated Concentrations Are Based on Effective River Flow Rates) $\ldots \ldots \ldots \ldots \ldots \ldots \ldots \ldots \ldots \ldots \ldots$

Table 7-2 Potential Dose to the Maximally Exposed Individual from SRS Liquid Releases

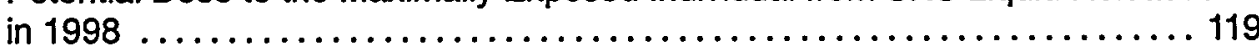

Table 7-3 Ten-Year History of SRS Atmospheric Tritium and Tritium Oxide Releases and Average Measured Tritium Oxide Concentrations in Air Compared to Calculated Concentrations in Air 
Table 7-4 Potential Dose to the Maximally Exposed Individual from SRS Atmospheric

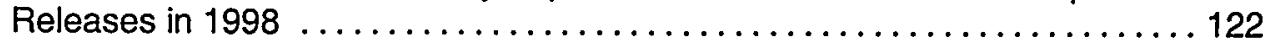

Table 7-5 1998 Maximum Potential All-Pathway and Sportsman Doses Compared to the DOE All-Pathway Dose Standard ..................... 125

Table 7-6 Potential Lifetime Risks from the Consumption of Savannah River Fish Compared to Dose Standards (1993-1998)

\section{Chapter 8 Nonradiological Effluent Monitoring}

Table $8-1 \quad$ SRS Power Plant Boiler Capacities ......................... 133

Table 8-2 Boiler Stack Test Results (A-Area, H-Area) . . . . . . . . . . . . . . . 133

Table 8-3 SRS Package Steam Boiler Capacities ....................... 133

Table 8-4 1997 Criteria Pollutant Air Emissions . . . . . . . . . . . . . . . . . . . . . . . . . 133

Table 8-5 1998 Exceedances of SCDHEC-Issued NPDES Permit Liquid Discharge Limits at

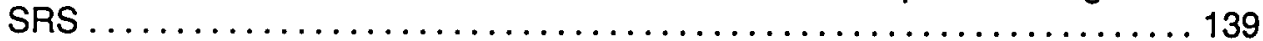

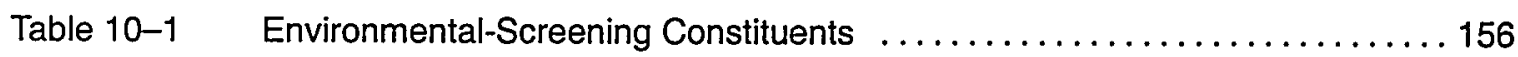

\section{Chapter 10 Groundwater}

Table 10-2 Constituent Groups Above Drinking Water Standards at A-Area and M-Area,

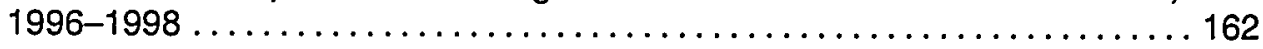

Table 10-3 Tritium Concentrations (in $\mathrm{mCi} / \mathrm{mL}$ ) in Selected C-Area Wells,

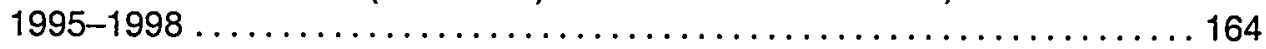

Table 10-4 Constituent Groups Above Drinking Water Standards at C-Area, 1996-1998 ............................................ 164

Table 10-5 Tetrachloroethylene and Trichloroethylene Concentrations (in $\mathrm{mg} / \mathrm{L}$ ) in Selected D-Area Wells, 1994-1998 167

Table 10-6 Constituent Groups Above Drinking Water Standards at D-Area and TNX,

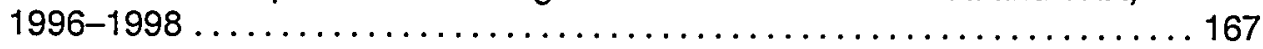

Table 10-7 Constituent Groups Above Drinking Water Standards at the General Separations and Waste Management Areas, 1996-1998 ........ 169

Table 10-8 Tritium Concentrations (in $\mathrm{mCi} / \mathrm{mL}$ ) in Selected K-Area Wells, 1994-1998.

Table 10-9 Constituent Groups Above Drinking Water Standards at K-Area, 1996-1998 ...................................... 173

Table 10-10 Constituent Groups Above Drinking Water Standards at L-Area and the Chemicals, Metals, and Pesticides Pits, 1996-1998 ............... 176

Table 10-11 Constituent Groups Above Drinking Water Standards at N-Area, 1996-1998...

Table 10-12 Constituent Groups Above Drinking Water Standards at P-Area,

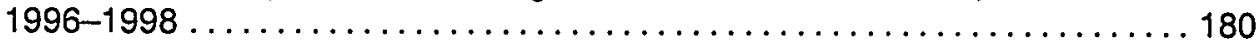

Table 10-13 Constituent Groups Above Drinking Water Standards at R-Area, 1996-1998 ....................................... 182

Table 10-14 Constituent Groups Above Drinking Water Standards at the Sanitary Landfill and B-Area, 1996-1998 184 


\section{Chapter 11 Quality Assurance}

Table 11-1 Subcontracted Laboratories for 1998 190

Table 11-2 Subcontract Laboratory Performance in EPA Water Pollution and Water Supply Studies

\section{Appendix A Applicable Guidelines, Standards, and Regulations}

Table A-1 Criteria Air Pollutants 206

Table A-2 Airborne Emission Standards for SRS Coal-Fired Boilers . 206

Table A-3 Airborne Emission Standards for SRS Consolidated Incinerator Facility . . . . 207

Table A-4 Airborne Emission Standards for SRS Fuel Oil-Fired Package Boilers 207

Table A-5

South Carolina Water Quality Standards for Freshwaters .209 



\section{Acronyms and Abbreviations}

A

ACPC - Accelerating Cleanup: Paths to Closure

AEC - U.S. Atomic Energy Commission

ALARA - As low as reasonably achievable

ANSP - Academy of Natural Sciences of Philadelphia

APT - Accelerator for the Production of Tritium

BTU - British Thermal Unit

CAA - Clean Air Act

CAAA - Clean Air Act Amendments of 1990

CAB - Citizens Advisory Board

CAS - Chemical abstract numbers

CDC - Centers for Disease Control and Prevention

CERCLA - Comprehensive Environmental Response, Compensation, and Liability Act (Superfund)

CFC - Chlorofluorocarbon

CFR - Code of Federal Regulations

CIF - Consolidated Incineration Facility

CMP - Chemicals, metals, and pesticides

CSRA - Central Savannah River Area

CWA - Clean Water Act

CX - Categorical exclusion
D

D\&D - Deactivation and decommissioning

DCG - Derived concentration guide

DOE - U.S. Department of Energy

DOE/EML - U.S. Department of Energy

Environmental Measurements Laboratory

DOE-HQ - U.S. Department of Energy-Headquarters

DOE-SR - U.S. Department of Energy-Savannah

River Operations Office

DWPF - Defense Waste Processing Facility

DWS - Drinking water standards

$E$

EA - Environmental Assessment

EIS - Environmental Impact Statement

EMCAP - Environmental Monitoring Computer Automation Program

EMS - Environmental Monitoring Section of the Environmental Protection Department (of Westinghouse Savannah River Company)

EPA - U.S. Environmental Protection Agency

EPCRA - Emergency Planning and Community Right-to-Know Act
EPD - Environmental Protection Department (of Westinghouse Savannah River Company)
EPT - Ephemeroptera, Plecoptera, and Trichoptera
ERD - Environmental Restoration Division
ESCO - Energy Services Company
ETF - Effluent Treatment Facility 
F

FDD - Facilities Decommissioning Division

FFA - Federal Facility Agreement

FFCA - Federal Facility Compliance Agreement

FFCAct - Federal Facility Compliance Act

FONSI - Finding of No Significant Impact

$\mathbf{G}$

GDNR - Georgia Department of Natural Resources

GPS/GIS - Global Positioning System/Geographic Information System

GOCO - Government-owned, contractor-operated

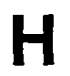

HBFC - Hydrobromofluorocarbon

HCFC - Hydrochlorofluorocarbon

HEAST - Health Effects Assessment Summary Tables (EPA)

HWMF - Hazardous Waste Management Facility

ICP - Inductively Conducted Plasma

ISO - International Organization for Standardization

ITPF - In-Tank Precipitation Facility

$\mathbf{L}$

LDR - Land disposal restrictions

LETF - Liquid Effluent Treatment Facility

LLD - Lower limit of detection
M

MAP - Mitigation Action Plan

MDA - Minimum detectable activity

MDL - Minimum detectable limit

MRD - Mean relative difference

N

NEPA - National Environmental Policy Act

NESHAP - National Emission Standards for Hazardous Air Pollutants

NHPA - National Historic Preservation Act

NIST - National Institute of Standards and

Technology

NOV - Notice of Violation

NPDES - National Pollutant Discharge Elimination System

NWP - Nationwide permit

ODS - Ozone-depleting substances

OWST - Organic Waste Storage Tank

PAR Pond - Pond constructed at Savannah River Site in 1958 to provide cooling water for P-Reactor and R-Reactor (P and R; hence, PAR)

PCB - Polychlorinated biphenyl

PEIS - Programmatic Environmental Impact Statement

$\mathrm{pH}-$ Measure of the hydrogen ion concentration in an aqueous solution (acidic solutions, $\mathrm{pH}$ from $0-6$; basic solutions, $\mathrm{pH}>7$; and neutral solutions, $\mathrm{pH}=7$

PUREX - Plutonium/uranium extraction (process)

PVC - Polyvinyl chloride 
QA - Quality assurance

QAD - Quality Assurance Division (Environmental Protection Agency)

QAP - Quality Assurance Program (Department of Energy)

QAVQ - Quality assurance/quality control

QC - Quality control

$\mathbf{R}$

RBOF - Receiving Basin for Offsite Fuel

RCRA - Resource Conservation and Recovery Act

RFI/RI - RCRA Facility Investigation/Remedial Investigation

ROD - Record of Decision

RQ - Reportable quantity

RTF - Replacement Tritium Facility

$\mathbf{s}$

SARA - Superfund Amendments and Reauthorization Act

SCDHEC - South Carolina Department of Health and Environmental Control

SDWA - Safe Drinking Water Act

SEIS - Supplemental Environmental Impact

Statement

S\&HO - Safety and Health Operations

SIRIM - Site Item Reportability and Issues

Management

SRARP - Savannah River Archaeological Research Program

SREL - Savannah River Ecology Laboratory

(University of Georgia)
SRI - Savannah River Natural Resource Management and Research Institute

SRIP - Savannah River Implementation Procedure

SRP - Savannah River Plant

SRS - Savannah River Site

SRTC - Savannah River Technology Center

STP - Site Treatment Plan

SUD - Site Utilities Division of Westinghouse

Savannah River Company

SWD - Solid Waste Division

SWDF - Solid Waste Disposal Facility

IT

TCLP - Toxicity Characteristic Leaching Procedure

TLD - Thermoluminescent dosimeter

TRAIN - Training Records and Information System

TRl - Toxic Release Inventory

TSCA - Toxic Substances Control Act

$\mathbf{U}$

USGS - U.S. Geological Survey

V

VIA - Values Impact Assessments

VTF - Vendor Treatment Facility

W

WSI - Wackenhut Services Inc.

WSRC - Westinghouse Savannah River Company 



\section{Sampling Location Abbreviations}

\begin{tabular}{|c|c|}
\hline Abbreviation & Location Name/Other Applicable Information \\
\hline$\overline{4 M}$ & Four Mile \\
\hline $4 \mathrm{MC}$ & Four Mile Creek \\
\hline $681-5 G$ & Georgia Department of Natural Resources/Environmental Monitoring Section site \\
\hline$A-14$ & Road A-14 \\
\hline AAP & Aiken Airport \\
\hline ATTA & Advanced Tactical Training Area \\
\hline AUG L\&D & Augusta Lock and Dam \\
\hline ALLEN & Allendale Gate \\
\hline BARN & Barnwell Gate \\
\hline BDC & Beaver Dam Creek \\
\hline BG & Burial Ground \\
\hline BGN & Burial Ground North \\
\hline BGS & Burial Ground South \\
\hline CSWTF & Central Sanitary Wastewater Treatment Facility \\
\hline DARK H & Dark Horse \\
\hline ETAL & East Talatha \\
\hline FM & Four Mile \\
\hline FMC & Four Mile Creek (Fourmile Branch) \\
\hline GR PND & Green Pond \\
\hline HP & HP (sampling location designation only; not an actual abbreviation) \\
\hline IBG & Indian Burial Ground \\
\hline IGB & Indian Grave Branch \\
\hline JACK & Jackson \\
\hline L3R & Lower Three Runs \\
\hline LSB & L-Area Seepage Basin \\
\hline LTR & Lower Three Runs \\
\hline PB & Pen Branch \\
\hline PATT MR & Patterson Mill Road \\
\hline PMR & Patterson Mill Road \\
\hline PSB & P-Area Seepage Basin \\
\hline $\mathrm{RM}$ & River Mile \\
\hline SATA & Small Arms Training Area (pistol range) \\
\hline SAV 1 & Savannah 1 \\
\hline SAV 2 & Savannah 2 \\
\hline SC & Steel Creek \\
\hline TB & Tims Branch \\
\hline TCR & Tabernacle Church Road \\
\hline
\end{tabular}




\begin{tabular}{ll} 
Abbreviation & Location Name/Other Applicable Information \\
\hline TNX & Multipurpose Pilot Plant Campus \\
U3R & Upper Three Runs \\
UTR & Upper Three Runs \\
WIND & Windsor Road \\
W JACK & West Jackson \\
& \\
Sampling Locations Known By More Than One Abbreviation
\end{tabular}

Beaver Dam Creek; 400-D

Four Mile Creek-6; FM-6; 4MC-6; Four Mile Creek at Leigh Road

Four Mile Creek at Road A7; FM-A7; 4M-A7

Lower Three Runs-2; L3R-2; L3R Creek and Patterson Mill

River Mile-0/8 Savannah River Mouth; Highway 17A Bridge Area; RM-0/8

River Mile 120; RM-120; River 10; R-10

River Mile 140; RM-140; R-8A

River Mile 160; RM-160; River 2; R-2

Steel Creek-4; SC-4; Steel Creek-4 at Road A; SC and Highway 125

Tinker Creek at Kennedy Pond; TC/KP; TC-1

Upper Three Runs-4 at Road A; U3R-4; U3R-Rd A

Vogtle Discharge; River 3B; R-3B 


\section{Executive Summary}

$\mathrm{T}$ HE mission at the Savannah River Site (SRS) is focused primarily on support of the national defense, nonproliferation, and environmental cleanup. SRS-through its prime operating contractor, Westinghouse Savannah River Company (WSRC)—continues to maintain a comprehensive environmental monitoring program.

In 1998, effluent monitoring and environmental surveillance were conducted within a 31,000 -square-mile area in and around SRS that includes neighboring cities, towns, and counties in Georgia and South Carolina and extends up to approximately 100 miles from the site. Though the environmental monitoring program was streamlined in 1998-to improve its cost-effectiveness without compromising data quality or reducing its overall ability to produce critical information-thousands of samples of air, rainwater, surface water, drinking water, groundwater, food products, wildlife, soil, sediment, and vegetation were collected and analyzed for radioactive and/or nonradioactive contaminants.

\section{Potential Radiation Doses}

Table 1 shows the 1998 potential radiation doses from SRS releases compared with the applicable federal dose standards and with estimated doses from naturally occurring background radiation. All potential radiation doses attributed to SRS in 1998 were below applicable regulatory standards.

\section{Liquid Pathway}

For 1998 , the potential dose to the maximally exposed individual from liquid releases of radioactivity to the Savannah River was estimated at $0.12 \mathrm{mrem}(0.0012 \mathrm{mSv})$. This dose is 0.12 percent of the U.S. Department of Energy (DOE) 100-mrem all-pathway dose standard for annual exposure.

The dose was about 8 percent less than the 1997 dose of $0.13 \mathrm{mrem}(0.0013 \mathrm{mSv})$-primarily because a 54-percent increase in the Savannah River flow rate resulted in more dilution.

The major contributors to the 1998 potential dose were cesium-137 (47 percent) and tritium oxide ( 36 percent).

The 1998 collective dose from liquid releases was estimated to be 1.8 person-rem ( 0.018 person-Sv).

\section{Drinking Water Pathway}

Offsite doses were calculated for persons consuming drinking water from two water treatment plants located downriver of SRS near Beaufort, South Carolina, and Port Wentworth, Georgia. The maximum doses from both facilities were 0.05 mrem $(0.0005 \mathrm{mSv})$. These doses are 1.25 percent of the drinking water standard of 4 mrem per year ( $0.04 \mathrm{mSv}$ per year). Tritium oxide in the drinking water represents about 72 percent of the dose.

\section{Airborne Pathway}

For 1998 , the potential dose to the maximally exposed individual from airborne releases of radioactive materials was $0.07 \mathrm{mrem}(0.0007 \mathrm{mSv})$. This dose is 40 percent more than the 1997 dose of $0.05 \mathrm{mrem}(0.0005 \mathrm{mSv})$ - primarily because of a 50 -percent increase in the amount of tritium oxide released from SRS during 1998 (due mainly to increased moderator consolidation operations in P-Area). The dose is 0.7 percent of the 10 -mrem per year (0.1-mSv per year) limit for exposure to airborne releases from a DOE facility.

Tritium oxide comprised approximately 67 percent of the potential airborne pathway dose.

The collective dose from airborne releases was estimated to be 3.5 person-rem ( 0.035 person-Sv), which is less than 0.01 percent of the collective dose received from naturally occurring sources of radiation (about 186,000 person-rem).

\section{All Pathway}

To demonstrate compliance with the DOE Order 5400.5 all-pathway dose standard of 100 mrem per year (1.0 mSv per year), SRS conservatively combines the maximally exposed individual airborne pathway and liquid pathway dose estimates, even though the two doses are calculated for hypothetical individuals residing at different geographic locations.

For 1998 , the potential maximally exposed individual all-pathway dose was $0.19 \mathrm{mrem}(0.0019 \mathrm{mSv})$ ( 0.07 mrem from airborne pathway plus 0.12 mrem from liquid pathway). This dose is about 6 percent more than the 1997 all-pathway dose of $0.18 \mathrm{mrem}$ $(0.0018 \mathrm{mSv})$-primarily because of the 50 -percent increase in atmospheric tritium oxide releases. A 10-year history of SRS maximum potential all-pathway doses to the maximally exposed individual is depicted in figure 1. 
Table 11998 Potential Radiation Doses from SRS Releases Compared with Applicable Dose Standards and Estimated Doses from Naturally Occurring Radiation

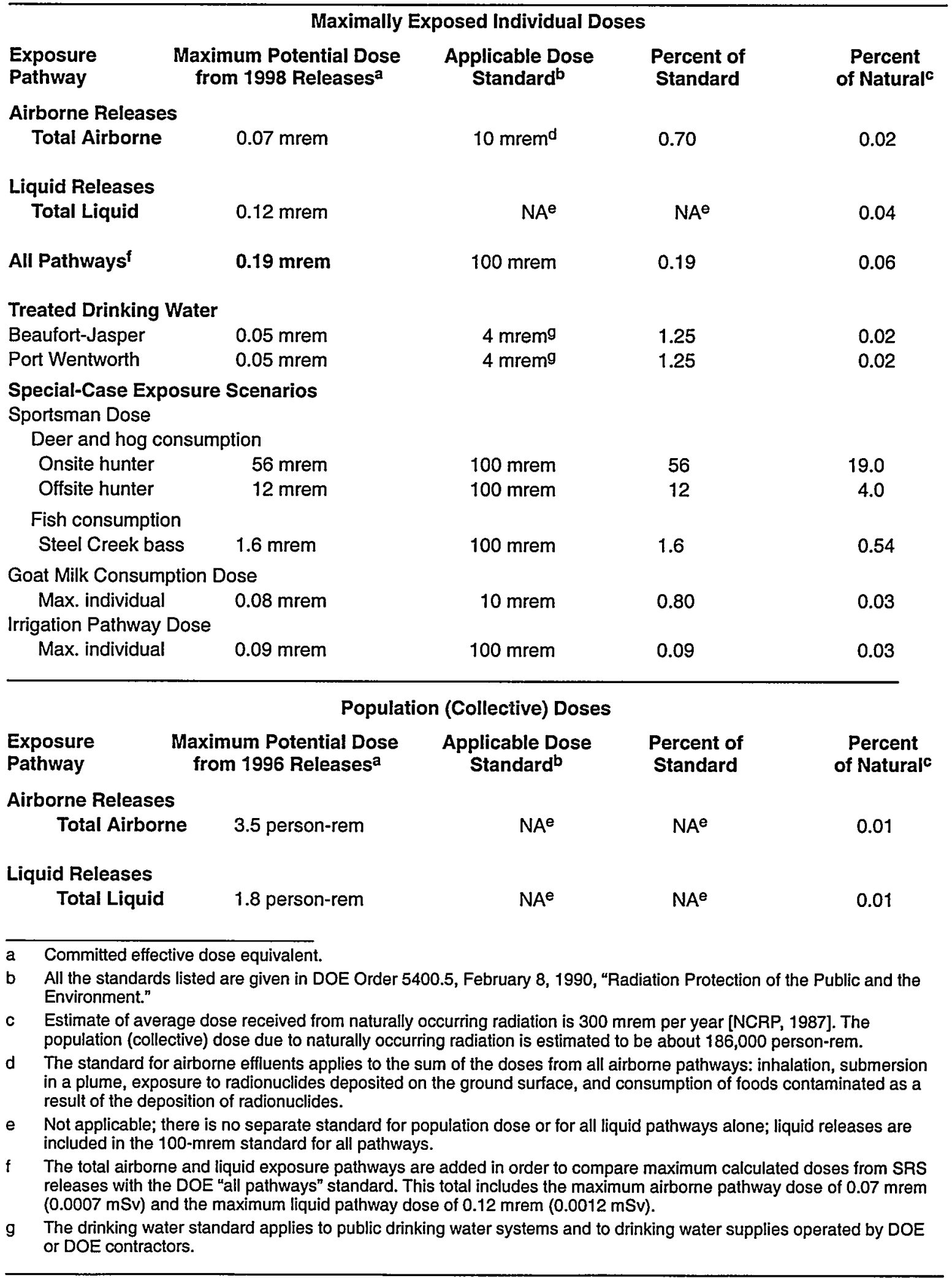




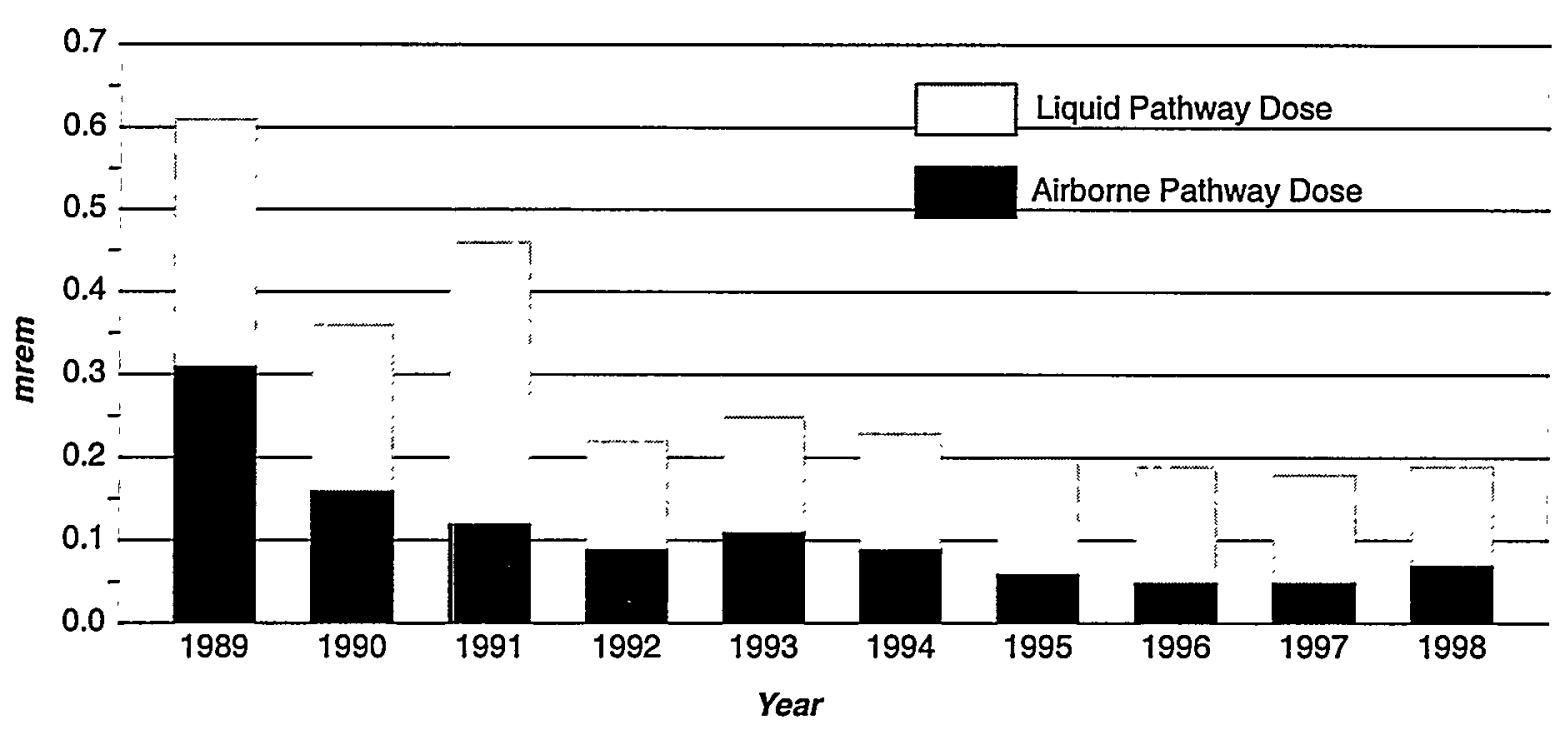

lleaf Graphic

Figure 1 Ten-Year History of SRS Potential All-Pathway Doses to the Maximally Exposed Individual (Airborne plus Liquid Pathways)

\section{Sportsman}

In 1998 , the maximum potential dose to an actual onsite hunter was $56 \mathrm{mrem}(0.56 \mathrm{mSv})$, which is 56 percent of DOE's 100 -mrem all-pathway dose standard. During the onsite deer hunts, this individual harvested five animals-the edible portion totaled about 110 kilograms ( 242 pounds) -and was assumed to have eaten all the meat.

If a hypothetical offsite hunter living near the site boundary consumed $81 \mathrm{~kg}$ (179 pounds) of meat-the annual maximum adult consumption rate for meat - taken from deer living on site prior to being harvested, the individual's maximum dose could have been $12 \mathrm{mrem}(0.12 \mathrm{mSv})$. This dose was based on the average concentration of cesium-137 measured in animals harvested at SRS during 1998.

The potential maximum dose for a recreational fisherman was based on the consumption of $19 \mathrm{~kg}$ (42 pounds) - the maximum adult consumption rate for fish-of Savannah River fish having the highest measured concentrations of radionuclides. In 1998, bass caught at the mouth of Steel Creek had the highest concentrations. Consumption of these bass could have resulted in a dose of $1.6 \mathrm{mrem}$ (0.016 mSv).

\section{Compliance Activities}

A major goal at SRS continues to be positive environmental stewardship and full regulatory compliance, with zero violations. The site's employees maintained progress toward achievement of this goal in 1998, as a vast majority of their efforts were successful. For example, under the Clean Water Act (CWA), the site's National Pollutant Discharge Elimination System (NPDES) compliance rate was 99.3 percent (42 exceedances in 5,790 analyses), and under the Clean Air Act (CAA), the compliance rate was 100 percent.

Compliance with environmental regulations and with DOE orders related to environmental protection is an integral part of the operations at SRS. Management of the environmental programs at SRS is a significant activity, and assurance that onsite processes do not impact the environment adversely is a top priority. All site activities are overseen by one or more regulatory agencies, including the U.S.

Environmental Protection Agency (EPA) and the South Carolina Department of Health and Environmental Control (SCDHEC).

A systematic effort is in place to identify and address all evolving regulatory responsibilities that concern SRS. As part of the process, communications are maintained with all appropriate regulatory agencies to emphasize the site's commitment to environmental compliance. SRS received three Notices of Violation (NOVs) from SCDHEC in 1998 but none from EPA.

SRS operations in 1998 continued to involve a wide variety of processes and chemicals subject to compliance with an increasing number of environmental statutes, regulations, policies, and permits. (For example, SRS had 697 construction and 
operating permits in 1998 that specified operating levels for each permitted source.) Compliance with all requirements helps to ensure that the site, the public, and the surrounding environment are protected from adverse effects that could result from SRS operations. This section offers an overview of some of the environmental compliance issues with which the site was involved during 1998.

\section{High-Level Radioactive Waste Tank Closure}

The mission of SRS high-level waste tank closures at the F-Area and H-Area tank systems is to close out tanks in a way that ensures protection of human health and the environment, and in a technically and economically prudent manner. This must be done according to SCDHEC Regulation 61-82, "Proper Closeout of Wastewater Treatment Facilities," and in compliance with Resource Conservation and Recovery Act (RCRA) and Comprehensive Environmental Response, Compensation, and Liability Act (CERCLA) requirements.

Tank 20F, a 1.3-million-gallon, single-shelled, carbon steel vessel, and tank 17F, with the same capacity, were closed in 1997. DOE determined in October 1998 that SRS should complete a tank closure environmental impact statement before conducting additional closure activities.

\section{National Pollutant Discharge Elimination System}

The CWA created the NPDES program, which is regulated by SCDHEC under EPA authority. The program is designed to protect surface waters by limiting all nonradiological releases of effluents into streams, reservoirs, and other wetlands. (Radiological effluents are covered under other acts.) Discharge limits are set for each facility to ensure that SRS operations do not impact aquatic life adversely or degrade water quality.

SRS had four NPDES permits for most of 1998-one permit for industrial wastewater discharge (SC0000175), one general permit for utility water discharge (SCG250162), and two general permits for stormwater discharge (SCR000000 for industrial and SCR 100000 for construction). Permit SC0000175 regulated 37 active and inactive NPDES outfalls at SRS until June 1997, when it was modified because of the elimination of outfall C-04. Modification of the permit January 1,1998 , removed outfalls P-13, P-14, P-19, and K-08 and added outfall X-19.
All results of monitoring for compliance with the industrial wastewater discharge permit and the new general permit for utility water discharge were reported to SCDHEC in the monthly Discharge Monitoring Reports, as required by the permits.

\section{Title V Operating Program}

The CAA provides the basis for protecting and maintaining air quality. Some types of SRS air emissions, such as ozone-depleting substances (ODS), are regulated by EPA, but most are regulated by SCDHEC, which must ensure that its air pollution regulations are at least as stringent as the CAA's. This is accomplished through SCDHEC Regulation 61-62, "Air Pollution Control Regulations and Standards."

Under the CAA, and as defined in federal regulations, SRS is classified as a "major source" and, as such, is assigned one permit number (0080-0041) by SCDHEC. SRS holds operating and construction permits from SCDHEC's Bureau of Air Quality, which regulates nonradioactive toxic and criteria pollutant emissions from approximately 208 point sources. Of these point sources, 157 operated in some capacity during 1998 . The remaining 51 either were under construction or were being maintained in a "cold standby" status.

\section{NESHAP Asbestos Abatement Program}

SRS began an asbestos abatement program in 1988 and continues to manage asbestos-containing material by "best management practices." Site compliance in this area also falls under South Carolina and federal regulations, including SCDHEC Regulation 61-86.1, "Standards for Performance of Asbestos Projects."

During 1998, contractors removed and disposed of approximately 3,775 linear feet and 8,940 square feet of regulated asbestos-containing material and demolished 17 regulated structures. Demolition and NESHAP projects performed by SRS employees accounted for the removal of approximately 885 linear feet and 1,525 square feet of regulated asbestos-containing material in 1998.

\section{Radiological Effluent Monitoring}

During 1998, SRS collected and analyzed about 4,200 effluent samples to quantify radiological releases to the environment from site operations. Tritium again was the major contributor to air and liquid releases, accounting for most of the total radioactivity released. 


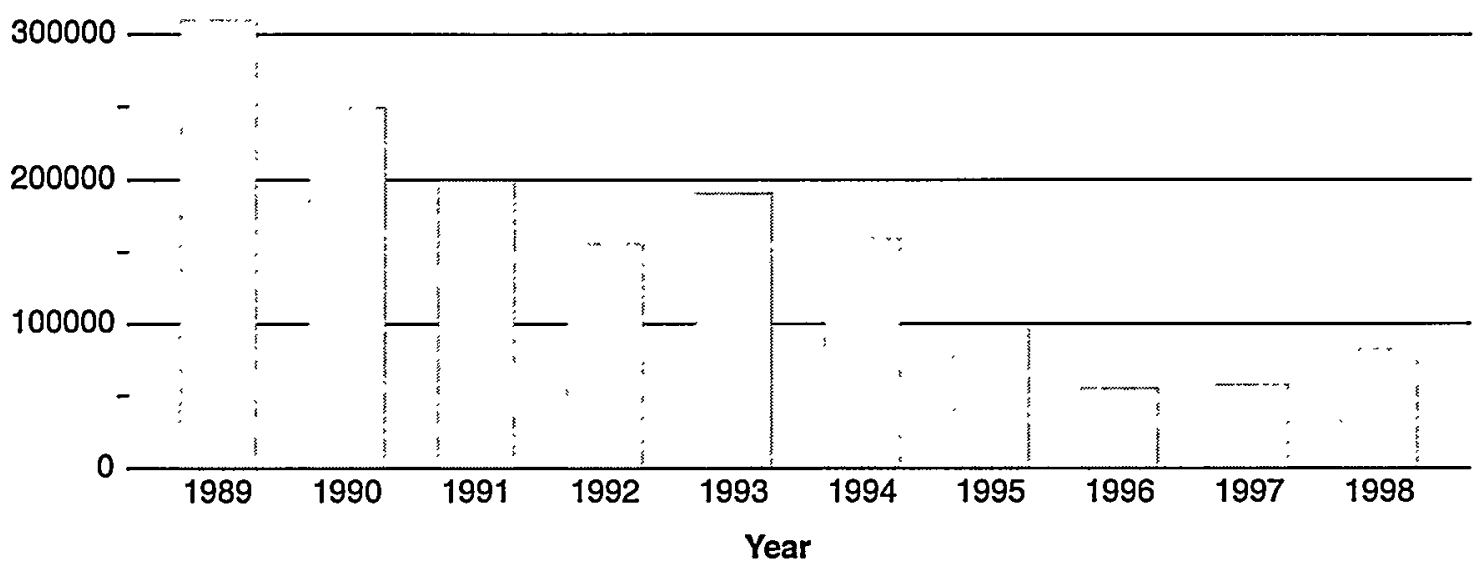

Ileaf Graphic

Figure 2 Ten-Year History of SRS Annual Atmospheric Tritium Releases

\section{Airborne Emissions}

Approximately $82,700 \mathrm{Ci}(3.06 \mathrm{E}+15 \mathrm{~Bq})$ of tritium (elemental plus tritium oxide) were released from the site in 1998. This was 43 percent more than the $58,000 \mathrm{Ci}(2.15 \mathrm{E}+15 \mathrm{~Bq})$ released in 1997 . The increase was due mainly to moderator consolidation operations in P-Area. Figure 2 shows a 10-year history (1989-1998) of SRS tritium releases. Since 1995 , because of changes in the site's missions and the existence of the Replacement Tritium Facility, the total amount of tritium released has been less than $100,000 \mathrm{Ci}$ per year.

\section{Liquid Discharges}

Tritium accounts for most of the radioactivity released to the Savannah River from direct process discharges and from seepage basin and Solid Waste Disposal Facility (SWDF) migration discharges. The amount of tritium released directly from SRS process areas (i.e., reactor, separations, heavy water rework) to site streams during 1998 was $1,092 \mathrm{Ci}$

$(4.04 \mathrm{E}+13 \mathrm{~Bq})$, which was 30 percent less than the 1997 total of $1,570 \mathrm{Ci}(5.81 \mathrm{E}+13 \mathrm{~Bq})$.

During 1998, the total amount of tritium released to the Savannah River from the site (i.e., direct liquid discharges plus seepage basin and SWDF migration releases) was about 26 percent more than the amount released during $1997-10,555 \mathrm{Ci}(3.91 \mathrm{E}+14 \mathrm{~Bq})$ in 1998 versus $8,350 \mathrm{Ci}(3.09 \mathrm{E}+14 \mathrm{~Bq})$ in 1997. The cause of this increase is not known but may be attributed to increased rainfall at the site from late 1997 through the spring of 1998.

\section{Radiological Environmental Surveillance}

The radiological environmental surveillance program at SRS surveys and quantifies any effects routine and nonroutine operations may have had on the site, the surrounding area, and those populations living in or near the site. Sampled media include air, rainwater, site streams, the Savannah River, drinking water, seepage basins, food products, fish, deer, hogs, turkeys, beavers, soil, sediment, and vegetation.

Overall, 1998 activity levels generally were consistent with 1997 levels. Concentrations of some radionuclides-such as tritium, cesium, and strontium - were at or slightly above their nominal lower limits of detection (LLD) and were consistent with observed historical levels in sampled media. In air and surface water, some onsite activity levels were, as expected, slightly higher than observed in offsite media. Because of production slowdown, most tritium transport in site streams, which has been decreasing in recent years, was attributed to the outcropping at stream banks of contaminated groundwater from retired seepage basins and SWDF.

\section{Nonradiological Effluent Monitoring}

Nonradioactive airborne emissions released from SRS stacks-including sulfur dioxide, oxides of nitrogen, carbon monoxide, total particulate matter less than 10 microns, and various toxic air pollutants-were within applicable (SCDHEC) 
standards in 1998. The site continued to maintain 100 -percent compliance with all permitted emission rates and special conditions.

SRS maintained its NPDES compliance rating for liquid releases above 99 percent for the 13th straight year. Results from only 42 of the 5,790 analyses performed in 1998 exceeded permit limits. This resulted in a compliance rating of

99.3 percent-again higher than the DOE-mandated rate of 98 percent.

\section{Nonradiological Environmental Surveillance}

The nonradiological environmental surveillance program at SRS involves sampling and analyzing surface waters (site streams and the Savannah River), drinking water, sediment, groundwater, and fish. In 1998 , more than 6,300 analyses for specific chemicals and metals were performed on more than 1,200 samples, not including groundwater.

The 1998 water quality data showed normal fluctuations expected for surface water. A comparison of the 1998 data with published historical data for site surface water monitoring did not indicate any abnormal deviations from past monitoring data. All results from analyses for pesticides and herbicides were below the detection limit.

\section{All SRS drinking water systems complied with SCDHEC chemical, bacteriological, lead and copper, synthetic organic, and volatile organic water quality standards in 1998.}

In Savannah River and site stream sediment samples, no pesticides or herbicides were found to be above the practical quantitation limits in 1998. All sample results were below the LLD of the EPA analytical procedures used.

The mercury concentrations in fish analyzed from onsite waters ranged from a high of $1.83 \mu \mathrm{g} \mathrm{Hg} / \mathrm{g}$ in PAR Pond and Pond B Bass to lows below the LLD at several locations. Mercury concentrations in offsite fish ranged from a high of $1.30 \mu \mathrm{g} \mathrm{Hg} / \mathrm{g}$ in a bass from the mouth of Beaver Dam Creek to lows below the LLD at several locations.

\section{Groundwater}

SRS monitors groundwater for radioactive and nonradioactive constituents to identify contamination that may have occurred because of site operations. Groundwater beneath 5 to 10 percent of the site has been contaminated by industrial solvents, tritium, metals, or other constituents used or generated by
SRS operations. This report describes groundwater monitoring results for approximately 1,133 wells in 101 locations within designated areas at SRS. In 1998 , approximately 34,801 radiological analyses and 172,249 nonradiological analyses were performed on groundwater samples. The numbers of analyses decreased considerably from 1997 to 1998, primarily because of increased efficiency and reduced duplication.

Nine new sites were monitored during the year, and additional wells were installed at several more sites to improve detection monitoring and plume definition and to support the RCRA Facility

Investigation/Remedial Investigation Program. Also, three wells were abandoned in the L-Area oil and chemical basin because their screens went through a confining unit.

\section{Special Surveys}

In addition to routine sampling and special sampling during nonroutine environmental releases, special sampling for radiological and nonradiological surveys is conducted on and off site. Both short- and long-term radiological and nonradiological surveys are used to monitor the effects of SRS effluents on the site's environment and in its immediate vicinity.

\section{Mitigation Action Plan for Pen Branch Reforestation}

The final Environmental Impact Statement for the continued operation of K-Reactor, L-Reactor, and P-Reactor at SRS predicted several unavoidable impacts to the site's wetlands. This resulted in the development of a Mitigation Action Plan (MAP) that documented the DOE approach to mitigating these impacts [DOE, 1990].

Natural revegetation has been occurring in the Pen Branch delta since K-Reactor last operated for an extended period of time (1988). K-Reactor thermal discharges were determined by a 1992 survey to have caused canopy loss or vegetation damage to 583 acres in the corridor, swamp, and marsh areas.

The Pen Branch corridor and delta are also being reforested by planting with indigenous wetlands species. The seeds were planted and grown at a State of Georgia nursery during 1993-1995 for use in the Pen Branch seedling planting program. These seedlings —of species appropriate to the area being reforested-subsequently were transplanted to the Pen Branch wetland areas. The reforested areas will be managed until successful reforestation has been achieved. This is the preferred method of mitigation for the Pen Branch corridor and delta because of the brief restoration time allowed by DOE. 


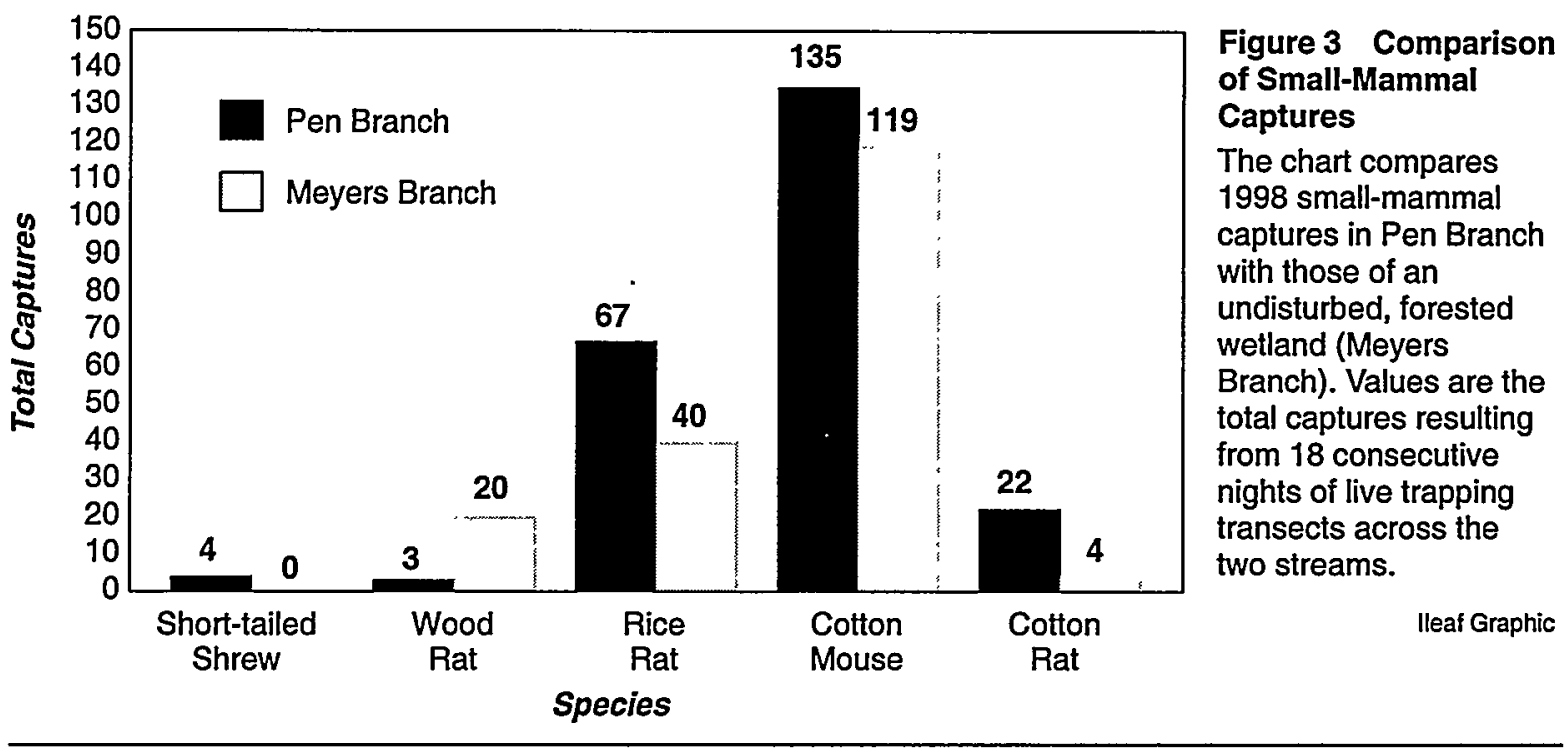

A study to identify species composition and the relative abundance of small mammals was concluded in the fall of 1998 to quantify recolonization of the bottomland hardwood forest. Pen Branch was compared to an undisturbed bottomland forest in Meyers Branch. Species diversity was equal in the two systems, but Pen Branch produced greater numbers of captures for the same number of trap nights. Figure 3 shows that, as with most prior studies examining the recolonization of the restoration area by various species, the early successional status of Pen Branch again was very productive for the small-mammal component. The cotton mouse (Peromyscus gossypinus) and the rice rat (Oryzomys palustris) were the most common found in both ecosystems. Also present in both systems were the wood rat (Neotoma floridana) and the cotton rat (Sigmodon hispidus), while the short-tailed shrew (Blarina carolinensis) was captured only in Pen Branch.

\section{Academy of Natural Sciences of Philadelphia River Quality Surveys}

The Patrick Center for Environmental Research of the Academy of Natural Sciences of Philadelphia
(ANSP) has been conducting biological and water quality surveys of the Savannah River since 1951. These surveys are designed to assess potential effects of SRS contaminants and warm water discharges on the general health of the river and its tributaries.

It had been anticipated that results from both the 1997 and 1998 studies would be published in the SRS Environmental Report for 1998. However, because of unforeseen delays in finalizing a contract with the Academy for fiscal year 1999-due to budget constraints-Academy personnel were unable to prepare a summary of the 1997 findings, or to complete analyses of the 1998 results, for inclusion in the 1998 environmental report. Conclusions of the 1997 study, as drawn from the nontechnical synthesis of the full 1997 report, are as follows:

As in previous Savannah River studies, the 1997 diatometer study and the algal component of the biological survey indicate nutrient enrichment at all stations, evidently due to sources upstream of the study area. Several differences among stations were detected in other components of the survey, but there was no consistent pattern of difference either within or among components that would indicate an SRS impact. 


\section{Highlights}

- After evaluating two options for tritium production, DOE chose the Commercial Light Water Reactor option using the Tennessee Valley Authority's Watts Bar and Sequoyah reactors as the primary source of tritium and the Accelerator for the Production of Tritium as a backup option. The Commercial Light Water Reactor option included a Tritium Extraction Facility to be located at SRS.

- Because of the formation of benzene in the In-Tank Precipitation Facility, normal radioactive operations were stopped. In November, WSRC recommended to DOE two alternative technologies to replace the in-tank precipitation process. As of December, DOE had not yet selected either of the technologies.

- Operations to remove light water and other impurities from degraded heavy water in the Heavy Water Reprocessing Area (D-Area) and to consolidate the purified heavy water for storage in fewer drums were completed in August. The degraded heavy water was a legacy from normal reactor operations.

- All residual heavy water moderator was drummed and removed from P-Area and consolidated at K-Area. By September, all operations at P-Area were terminated, and all facilities were closed.

$\mathrm{T}$ HE Savannah River Site (SRS), a facility in the U.S. Department of Energy (DOE) complex, encompasses approximately 310 square miles in South Carolina and is adjacent to the Savannah River.

The site was established by the U.S. Atomic Energy Commission (AEC) in 1950 to produce plutonium and tritium for national defense and additional special nuclear materials for other government uses and for civilian purposes. Production of these materials continued for more than 40 years.

When the Cold War ended in 1991, DOE responded to changing world conditions and national policies by refocusing its missions. The site's priorities shifted toward waste management, environmental restoration, technology transfer, and economic development.

This chapter includes general information on the site's history; location, demographics, and environmental setting; mission; and areas, facilities, and operations.

\section{Site History}

Responding to a 1950 directive from President Harry $S$. Truman to the AEC, E.I. du Pont de Nemours and Company and the commission negotiated a contract whereby Du Pont would design, construct, and operate what was to become the Savannah River Plant (SRP).
On November 22 of that year, the AEC approved the present site and purchased the land for approximately $\$ 19$ million. By February 1, 1951, construction had begun. The first facility to begin operating, the heavy water plant, started up August 17, 1952, and the first of five production reactors achieved operating status December 28, 1953. All five reactors had achieved operating status by March 1955. [Bebbington, 1990].

Until it was disbanded by the Energy Reorganization Act of 1974, the AEC oversaw and regulated site activities. In 1975, its functions were transferred to two newly established agencies-the Energy Research and Development Administration (overseeing government operations) and the Nuclear Regulatory Commission (overseeing commercial operations). By 1977, the Energy Research and Development Administration had evolved into DOE, which has overseen all site activities since that time.

Du Pont operated SRP until March 31, 1989. On April 1, 1989, Westinghouse Savannah River Company (WSRC) became the prime operating contractor, and SRP became SRS.

Beginning October 1, 1996, the site was operated under a new contract by an integrated team led by WSRC. Under this contract, WSRC is responsible for SRS's nuclear facility operations; Savannah River Technology Center (SRTC); environment, safety, health, and quality assurance; and all the site's administrative functions. Bechtel Savannah River, Inc., is responsible for environmental restoration, project management, engineering, and 
construction activities. Babcock \& Wilcox Savannah River Company is responsible for facility decontamination and decommissioning, and British Nuclear Fuels Savannah River Corporation is responsible for the site's solid waste program.

\section{Site Locale}

In 1950 , the site was selected by applying the criteria developed to select the most suitable location in the country to carry out President Truman's directive:

- a large land area for safety and security

- a buffer zone large enough to provide land around each operating facility for protection of human health and the environment

- land somewhat isolated yet near communities that could handle construction and operations personnel

- access to adequate transportation

- land not subject to floods and major storms

- the availability of millions of gallons of water, low in mineral content, for cooling and process use

- $\quad$ suitable terrain and topography

Du Pont, the AEC, and the U.S. Army Corps of Engineers considered 114 sites in 18 states before recommending the current site, which met all the established criteria.

\section{Location}

SRS covers 198,344 acres in Aiken, Allendale, and Barnwell counties of South Carolina and borders the

\section{Typical Climate at SRS}

- Summer

Hot and humid

Temperatures reach upper $90 \mathrm{~s}\left({ }^{\circ} \mathrm{F}\right)$

33 percent of annual rainfall

- Fall

Cool mornings, warm afternoons

Temperatures range from 50 to $76^{\circ} \mathrm{F}$

19 percent of annual rainfall

- Winter

Mild; lasting November through March

Temperatures normally above $32{ }^{\circ} \mathrm{F}$

21 percent of annual rainfall

- Spring

Most variable; cold snap often in

March

Temperatures average $65^{\circ} \mathrm{F}$

27 percent of annual rainfall
Savannah River. The site is approximately 12 miles south of Aiken, South Carolina, and 15 miles southeast of Augusta, Georgia (figure 1-1 ). It is included within the Central Savannah River Area, which is comprised of 18 counties surrounding Augusta.

The average population density in the counties surrounding SRS is 85 people per square mile, with the largest concentration in the Augusta metropolitan area. Based on 1990 U.S. Census Bureau data, the population within a 50-mile radius of SRS is approximately 620,100 . About 70 percent of the site's employees live in South Carolina-primarily Aiken County-and 30 percent in Georgia.

Various industrial, manufacturing, medical, and farming operations are conducted near the site. Major industrial and manufacturing facilities in the area include textile mills, polystyrene foam and paper products plants, chemical processing facilities, and a commercial nuclear power plant. Farming is diversified and includes crops such as cotton, soybeans, corn, and small grains.

\section{Climate}

SRS has a relatively mild climate, with an average frost-free season of approximately 246 days. The average annual rainfall, about 48 inches, is fairly evenly distributed throughout the year. There is no strong prevailing wind direction; however, there is a relatively high frequency of east-through-northeast winds during the summer and fall and of south-through-northwest winds during the late fall, winter, and spring [Hunter, 1990]. Except for the Savannah River, no unusual topographic features significantly influence the general climate.

\section{Geology and Hydrology}

SRS is on the Upper Coastal Plain of South Carolina. Coastal Plain deposits at SRS consist of 500 to 1,400 feet of sands, clays, and limestones of Tertiary and Cretaceous age. These sediments are underlain by sandstones of Triassic age and by older metamorphic and igneous rocks.

The sandy sediments of the Coastal Plain contain several productive aquifers, separated by clay-rich units, that drain into the Savannah River, its tributaries, and the Savannah River Swamp. The older, underlying rocks are nearly impermeable and are not a major water source.

\section{Water Resources}

SRS, bounded on its southwestern border by the Savannah River for about 35 river miles (as measured 


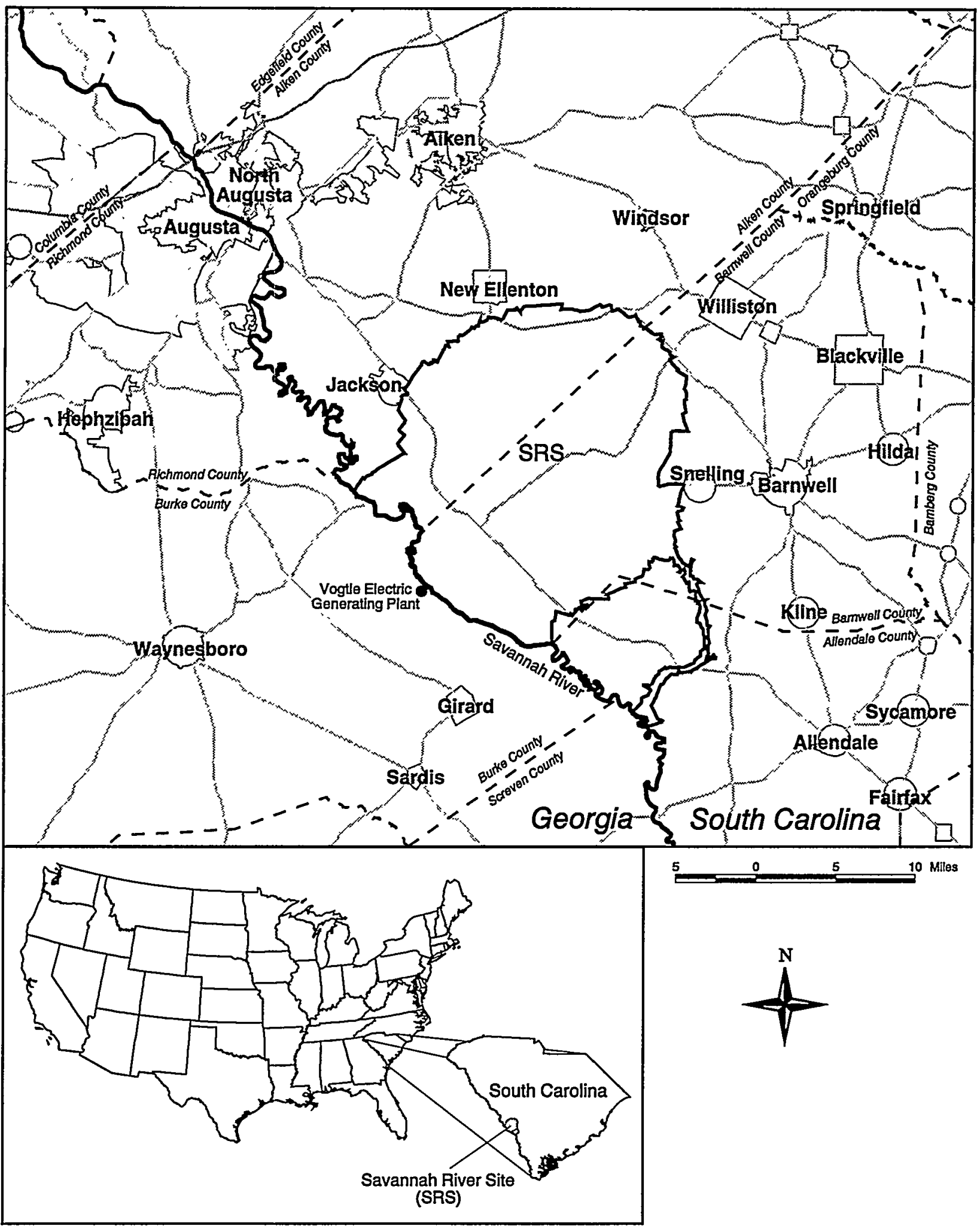

EPD/GIS Map

Figure 1-1 Regional Location of SRS

SRS is about 12 miles south of Aiken, South Carolina, and 15 miles southeast of Augusta, Georgia. The site, approximately 310 square miles in area, covers about 1 percent of the state of South Carolina. 
from the upriver boundary of the site, near Jackson, South Carolina, to the Lower Three Runs Creek corridor), is approximately 160 river miles from the Atlantic Ocean. Five major SRS streams feed into the river: Upper Three Runs Creek, Four Mile Creek (also referred to as Fourmile Branch), Pen Branch, Steel Creek, and Lower Three Runs Creek.

The two main bodies of water on site, PAR Pond and L-Lake, are manmade. PAR Pond, constructed in 1958 to provide cooling water for-and to receive heated cooling water from-P-Reactor and R-Reactor (hence the name PAR Pond), covers 2,640 acres and is approximately 60 feet deep. The 1,000 -acre L-Lake was constructed in 1985 to receive heated cooling water from L-Reactor.

The Savannah River is used as a drinking water supply source for approximately 56,000 residents downriver of SRS in Port Wentworth, Georgia, and near Beaufort, South Carolina (Beaufort and Jasper counties) [Fledderman, 1995]. The City of Savannah Industrial and Domestic Water Supply Plant intake, at Port Wentworth, is approximately 130 river miles from SRS; the Beaufort-Jasper Water Treatment Plant intake, near Beaufort, is approximately 120 river miles from SRS. The Savannah River also is used for commercial and sport fishing, boating, and other recreational activities. There is no known use of the river for irrigation by farming operations downriver of the site [Hamby, 1991]. SRS uses water from the river for some of its operations.

Approximately 200 Carolina bays exist on SRS, ranging in size from about 0.2 acre to 125 acres. Carolina bays are unique, naturally occurring wetlands found only on the southeastern Coastal Plain. They are elliptical in shape and oriented northwest to southeast along their long axes; their origin is unknown. Carolina bays are shallow and may dry up seasonally. At SRS, they provide important habitat and refuge for many plants and animals.

\section{Land Resources}

The SRS region is part of the Southern Bottomland Hardwood Swamp region, which extends south from Virginia to Florida and west along the Gulf of Mexico to the Mississippi River drainage basin. The main features are river swamps, rarely more than 5 miles wide.

\section{Plant and Animal Life}

In 1972, SRS was designated as the first National Environmental Research Park. These parks are used by government and university-related scientists as outdoor laboratories to study the impact of human activity on the environment. This designation has created a unique environment for preserving and studying vegetation and wildlife.

The site provides refuge for approximately 50 endangered, threatened, and sensitive species of plants and animals, such as the red-cockaded woodpecker, the southern bald eagle, the smooth purple coneflower, the Bachman's sparrow, the American alligator, the wood stork, the shortnose sturgeon, and the bog spice bush. Many site research projects are designed to protect and increase the populations of these species.

\section{Vegetation}

Most of the site's environs are rural. Approximately 40 percent of the countryside is forested with longleaf and loblolly pines and sweet gum, maple, birch, and various oak-hickory hardwood trees.

Major plant communities at SRS include cypress-gum and lowland hardwood swamps, sandhills, and old agricultural fields, as well as aquatic and semiaquatic areas. These habitats range from very sandy, dry hilltops to continually flooded swamps.

\section{Wildlife}

SRS is populated with more than 50 species of mammals, including deer, feral hogs (hogs that have reverted to the wild state from domestication), beavers, rabbits, foxes, raccoons, bobcats, river otters, and opossums. In 1952, there were fewer than three dozen white-tailed deer on site. Since then, however, the population has increased dramatically, and the site now is home to several thousand white-tailed deer [SRFS, 1982]. Since 1965, managed public deer hunts have been held annually on site to reduce the number of animal-vehicle accidents and to maintain the health of the herd.

More than 100 species of reptiles and amphibians-including turtle, alligator, lizard, snake, frog, and salamander-and more than 200 species of birds also inhabit the site.

\section{Site Mission}

The changing world caused a downsizing of the site's original defense mission; SRS's current mission is to serve the national interest by ensuring that programs, operations, and resources are managed in a safe, open, and cost-effective manner to

- support current and future national security requirements

- reduce the global nuclear proliferation danger 
- $\quad$ protect and restore the environment while managing waste and nuclear materials

- conduct mission-supportive research and technology development

The site's priorities today, therefore, involve (1) cleaning up waste sites by removing hazardous substances or by stabilizing, containing, or treating substances so that they do not affect human health or the environment (environmental restoration);

(2) managing newly generated waste and waste that is a legacy from the production of nuclear materials (waste management); (3) "disposition" of excess facilities that are no longer needed to produce or process nuclear materials; and (4) managing nuclear materials in an effort to curb an excessive spread of nuclear weapons

The remainder of this chapter describes the site areas and some of the major facilities, operations, and activities that support these points.

\section{Site Areas and Major Facilities and Operations}

SRS was constructed to produce basic materials used in nuclear weapons, primarily tritium and plutonium-239. Five reactors were built to produce these materials by irradiating (exposing to radiation) target materials with neutrons. Support facilities also were built, including two chemical separations plants, a heavy water extraction plant, a nuclear fuel and target fabrication facility, and waste management facilities.

The production process began with the manufacture of fuel and target assemblies produced from a variety of nuclear and other materials such as enriched uranium and aluminum. The assemblies were transported to the reactor, where they were loaded into the reactor core and used to produce a series of controlled nuclear reactions. During the reaction, neutrons from the fuel bombarded the target assemblies to produce the desired products.

The irradiated target assemblies and spent fuel assemblies then were moved to one of the chemical separations facilities-known as "canyons"-where the desired products were separated and waste products were processed. After refinement, nuclear materials were shipped to other DOE sites for incorporation into nuclear weapons.

SRS has adjusted to meet declining defense requirements. All five reactors are now shut down, a result of the end of the Cold War. However, recycling and reloading of tritium to maintain the nation's supply of nuclear weapons is a continuing site mission [Fact Sheet, 1996a]. Options for new tritium production are discussed on page 8 .

SRS is divided into several areas, based on production and other functions (figure 1-2):

- reactor materials area $(\mathrm{M})$

- $\quad$ reactor areas $(\mathrm{C}, \mathrm{K}, \mathrm{L}, \mathrm{P}$, and $\mathrm{R})$

- heavy water reprocessing area (D)

- $\quad$ separations areas ( $\mathrm{F}$ and $\mathrm{H})$

- $\quad$ waste management areas (E, F, H, S, and Z)

- $\quad$ administration area (A)

- $\quad$ other areas (B, N, TNX, and $G$ )

Data about emissions and discharges from the various areas and outfalls-occurring as a result of routine operations-can be found in the "Radiological Effluent" and "Nonradiological Effluent" sections of SRS Environmental Data for 1998

(WSRC-TR-98-00314).

\section{Savannah River Site: A Unique Outdoor Laboratory}

In 1972, the federal government designated SRS as the nation's first National Environmental Research Park. The park provides a unique outdoor laboratory to study the interaction between managed and natural systems. Research activities are conducted through site environmental organizations.

The Savannah River Swamp is 7,500 acres of natural swampland adjacent to the Savannah River. In the deep water areas of the swamp, two types of trees are dominant: the bald cypress and the water tupelo. These trees cover 50 percent of the swamp. The other 50 percent consists of islands that support bottomland hardwood forests, including oaks, red maples, and sweet gum trees. The swamp also is home to waterfowl and alligators. Studies conducted at the swamp track subtle long-term effects of land use changes on ecosystems.

SRS serves as a refuge for endangered species such as the southern bald eagle, a subspecies of the bald eagle. When fully mature, it is about 40 inches long with dark brown plumage, a white head and tail, and yellow eyes, beak, and feet. Eagles reach full maturity in 3 to 7 years. They are monogamous, mate for life, and tend to use the same nest every year. 


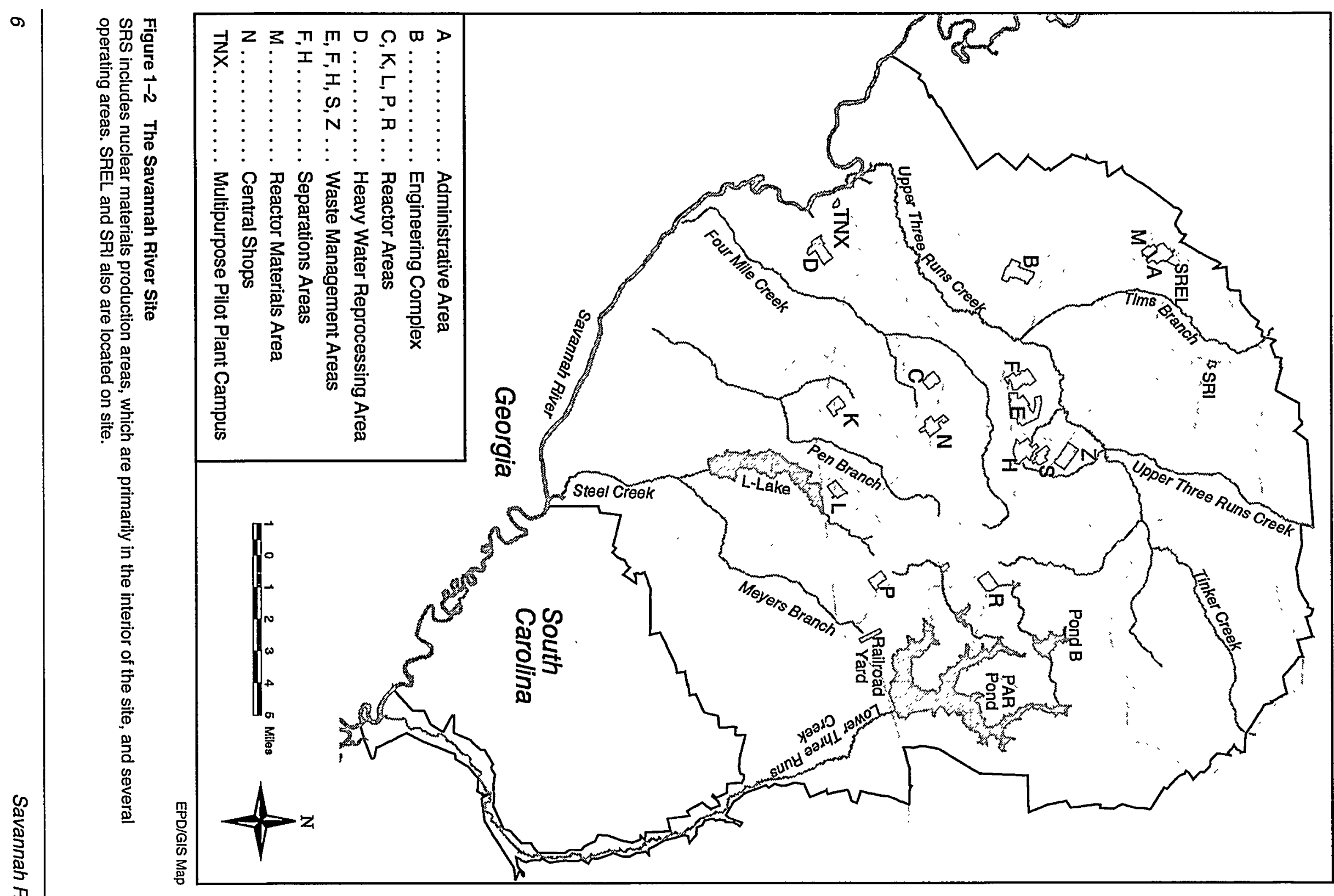




\section{Reactor Materials Area}

The reactor materials area (M-Area) consists of a fuel and target fabrication facility, three analytical laboratories, and the Liquid Effluent Treatment Facility (LETF). Also, the Vendor Treatment Facility (page 10) is in this area.

The fuel fabrication facility produced fuel and target assemblies to be used in the reactors. Control rods and other reactor components also were manufactured in the facility. The current mission of SRS does not require production of fuel and target assemblies.

The LETF treated wastewater generated by various M-Area processes and consolidated low-radioactivity residues from $M$-Area processes for eventual disposal.

\section{Reactor Areas}

Production reactors are in five areas: C, K, L, P, and $R$. Each area houses one of the site's five heavy water reactors. All five reactors, (R-Reactor, P-Reactor, L-Reactor, K-Reactor, and C-Reactor) are permanently shut down.

Some facilities in C-Area, K-Area, and L-Area are being used to store left-over heavy water moderator (material used to slow down neutrons from the high velocities at which they are created in the fission process) and/or spent fuel and targets. (More about spent fuel storage can be found on page 7.)

The ground level of C-Reactor has been modified to serve as a central decontamination facility for radiologically contaminated operations and maintenance equipment.

During 1998, all residual heavy water moderator was drummed and removed from P-Area and consolidated at K-Area. By September, all operations at P-Area were terminated, and all facilities were closed.

Although some of the areas are being used, no efforts are being expended to maintain any of the reactors themselves.

\section{Heavy Water Reprocessing Area}

A heavy water production plant in D-Area began operations in 1953 to produce heavy water to moderate and cool the site's reactors. The plant separated heavy water-present in small amounts in all water-from Savannah River water. The huge extraction plant discontinued operations in 1981 because of a sufficient supply of heavy water and was shut down.
Facilities currently operating in D-Area include a coal-fired power plant (leased by DOE to the South Carolina Electric and Gas Company), laboratory facilities to analyze the heavy water process samples, and the Heavy Water Facility, where various contaminants are removed from the heavy water. Although no reactor operations are ongoing, the degraded heavy water is a legacy from normal reactor operations and other DOE sites' activities. This degraded water is reworked to remove the light water and other impurities, increasing the heavy water purity to 99.75 percent. Some of this heavy water may be sold. Operations to remove the light water and consolidate the purified heavy water for storage in fewer drums were completed in August.

\section{Separations Areas}

Activities in the separations areas (F-Area and $\mathrm{H}$-Area) include separations, receipt of offsite fuel for processing, tritium processing. and waste

management. The first three are discussed here; a discussion of waste management activities, which take place in E-Area, S-Area, and Z-Area also, begins on page 8.

\section{Separations}

Two large chemical separations facilities, F-Canyon and $\mathrm{H}$-Canyon (called canyons because of their long, narrow shapes), and their associated liquid-waste treatment and storage facilities are located in F-Area and $\mathrm{H}$-Area.

These areas originally were designed to process irradiated fuel and target assemblies from site reactors. Since the end of the Cold War, the purpose has shifted to the stabilization of nuclear materials from onsite and offsite sources to ensure safe long-term storage or disposal. The materials are dissolved, and the products of interest are chemically separated and purified from waste products.

In addition to processing special nuclear materials for defense purpose, H-Canyon was equipped to recover plutonium-238 for use in power systems for deep space exploration [Fact Sheet, 1996b].

Some other facilities in the separations areas include the FB-Line and the HB-Line (located atop the canyons), the Receiving Basin for Offsite Fuel (RBOF), and the Replacement Tritium Facility (RTF). More about the RBOF and the RTF can be found on page 8.

\section{Spent Fuel}

Beginning in the 1950s, as part of the "Atoms for Peace" program, the United States provided nuclear technology to foreign nations for peaceful 
applications in exchange for their promise to forego development of nuclear weapons. A major element of this program was the provision of research reactor technology and the highly enriched uranium needed to fuel the research reactors. Research reactors play a vital role in important medical, agricultural, and industrial applications. However, the uranium initially used in the fuel elements for these reactors also could be used in production of nuclear weapons. Therefore, the used fuel elements ("spent nuclear fuel") were transported to the United States, where they were chemically separated to extract the uranium still remaining in the fuel. In this way, the United States maintained control over disposition of the highly enriched uranium that it provided to other nations.

For years, it was routine for the foreign researchers to return this U.S.-origin spent fuel to the United States-first, under bilateral agreements, and then, (from 1964 until 1988) under the "Off-Site Fuels Policy." The "Off-Site Fuels Policy" expired in 1988, and shipments no longer were accepted by the United States. The decision to return to the policy (of accepting spent fuel from foreign researchers) was made in 1996 [DOE, 1996], and the first shipment from foreign research reactors arrived on site in September of that year [Fact Sheet, 1996a].

Spent nuclear fuel is managed in several locations at the site. Most of the spent nuclear fuel remaining from SRS reactor operations is in water-filled concrete storage basins, which originally were intended as interim storage facilities. Spent fuel from offsite sources (primarily domestic and foreign research reactors) is stored in the RBOF (located in $\mathrm{H}$-Area). The spent fuel is repackaged for extended storage and/or shipment to an onsite or offsite facility.

Storage will be a major issue for fuels that are not processed or that arrive after SRS reprocessing facilities are phased out. Many of the original storage facilities were not designed for the long interim storage period that may be required pending disposition. $\mathrm{DOE}$ is developing an integrated, long-term spent fuel management program that will address storage and treatment of all spent fuel until an ultimate disposition is determined.

\section{Tritium}

Tritium, one of the materials produced by the site for national defense, has a half-life of 12.5 years and must be periodically replenished to maintain weapons in readiness for use. SRS is the nation's only facility for recycling tritium remaining after decay from nuclear weapons reservoirs returned from service.
This recycling allows the United States to use its tritium supplies effectively and efficiently.

The SRS tritium facilities in H-Area consist of four main process buildings designed and operated to process tritium. The newest building is the one-acre-sized underground RTF. The main mission of the tritium facilities is to purify and maintain the declining inventories of tritium for defense purposes.

With the SRS production reactors shut down, DOE evaluated two options for tritium production-using existing or partially constructed commercial nuclear reactors and using a linear accelerator. The linear accelerator, known as the Accelerator for the Production of Tritium, would be located at SRS if built. The commercial reactor option, known as the Commercial Light Water Reactor project, would include a Tritium Extraction Facility to be located at SRS if chosen. In December, DOE chose the Commercial Light Water Reactor option using the Tennessee Valley Authority's Watts Bar and Sequoyah reactors as the primary source of tritium and the Accelerator for the Production of Tritium as a backup option.

\section{Waste Management Areas}

Waste management activities are conducted in the following areas: E, F, H, S, and Z. E-Area, between F-Area and H-Area, includes most of the site's disposal and storage facilities.

Weapons material production at SRS has generated unusable byproducts, such as highly radioactive waste. About 34 million gallons of this high-level radioactive waste is stored in tanks on site [Fact Sheet, 1996a]. In addition, other wastes at the site include low-level solid and liquid radioactive wastes; transuranic waste (which contains alpha-emitting isotopes that have decay rates and concentrations exceeding specified levels); hazardous waste (which is any toxic, corrosive, reactive, or ignitable material that could negatively affect human health or the environment); mixed waste (which contains both hazardous and radioactive components); and sanitary waste (which is neither radioactive nor hazardous). An explanation of the various wastes and how the site manages them is discussed in chapter 4, "Environmental Management."

Facilities in waste management areas designed to store or treat the waste generated from onsite operations include the Solid Waste Management Facility (SWMF; also referred to in this report as the Solid Waste Disposal Facility); the Effluent Treatment Facility (ETF); the high-level waste storage tanks in F-Area and H-Area ("tank farms"); the Extended Sludge Processing Facility; the Defense 
Waste Processing Facility (DWPF); the Saltstone Facility; and the Consolidated Incineration Facility (CIF).

SWMF is a disposal site for low-level solid waste items such as protective clothing, tools, and equipment contaminated with small amounts of radioactive material. Most solid low-level waste is disposed of permanently in the engineered concrete E-Area Vaults, which provide significantly more protection for the environment than does SWMF. Soil and debris may be disposed of in engineered trenches.

Historically, seepage basins were used to dispose of wastewater from the separations facilities in F-Area and H-Area. The ETF, located in H-Area, treats the low-level radioactive wastewater formerly sent to the seepage basins. The ETF removes radioactive and nonradioactive contaminants, except tritium, from process effluents and discharges the water to Upper Three Runs Creek.

The F-Area and H-Area waste tank farms consist of large underground storage tanks that hold high-level liquid radioactive waste resulting primarily from the reprocessing of spent nuclear fuel. The waste is contained in 29 tanks in H-Area and 20 tanks in F-Area. Sludge (the portion of the waste-viscous and brown-that settles on the bottom of the tanks) and saltcake (the liquid resting above the sludge, which contains a lot of salt and some soluble radioactive materials, separates into a wet, thick "cake") must be removed from the tanks so the wastes can be processed for ultimate disposal.

The Extended Sludge Processing Facility washes the sludge to remove excess aluminum and salts before

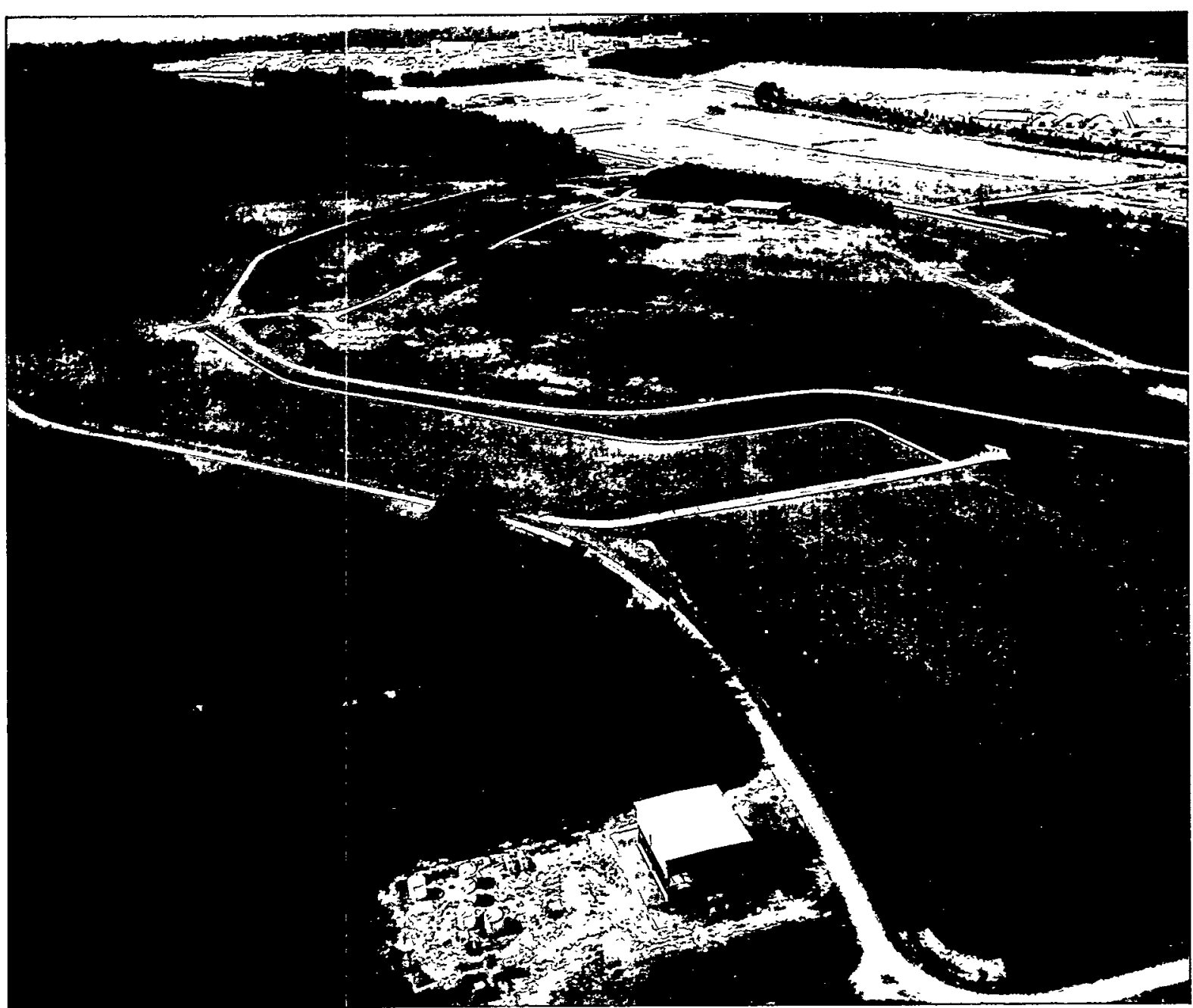

Steve Ashe Photo (WSRC-98-1395-60)

This remediated seepage basin originally was used to dispose of low-level wastewater from separations facilities in H-Area. Wastewater formerly sent to this basin is treated now by the ETF, also located in H-Area. 
the sludge is ready to be fed to the DWPF. The In-Tank Precipitation Facility in H-Area was designed to separate the highly radioactive solid portion ("precipitate") of the saltcake from the low-level radioactive liquid portion ("filtrate"); however, due to formation of benzene in the process, normal radioactive operations were stopped.

In November, WSRC recommended to DOE two alternative technologies to replace the in-tank precipitation process. In December, DOE recommended the addition of a third alternative. A decision on which technology to accept had not been made by the end of the year by DOE.

The DWPF, located in S-Area, immobilizes the high-level waste sludge and the precipitate by "vitrifying" it into a solid glass waste form. A component of the DWPF, the Saltstone Facility, treats and disposes of the filtrate by stabilizing it in a solid, cement-based waste form [Fact Sheet, 1996c].

The CIF, located adjacent to $\mathrm{H}$-Area, was designed to safely burn certain hazardous, low-level radioactive, and mixed (both hazardous and radioactive) wastes.

The Vendor Treatment Facility, one of the newer facilities on site, in located in M-Area and processes mixed waste (both radioactive and hazardous) sludge into glass beads.

\section{Administration Area}

The administration area (A-Area) contains organizations that provide direct support for SRS operations. DOE's Savannah River Operations Office and most of WSRC's administrative offices are located in A-Area, as are SRTC and the Savannah River Ecology Laboratory (SREL).

\section{Other Areas}

Other onsite and offsite facilities support SRS operations. Onsite areas include an engineering complex and some administrative offices (B-Area); Central Shops (N-Area); and TNX (now called the Multipurpose Pilot Plant Campus), a research and development area. Locations not within areas designated for specific purposes are called G-Area, or general area. Activities conducted off site are administrative and do not involve radioactive or hazardous materials.

\section{Other Major Site Activities}

\section{Facilities Disposition}

With the changing site missions, disposing of excess production facilities and equipment became a primary activity along with management of legacy materials. SRS will manage the excess facilities through final disposition in a manner that minimizes "life-cycle" costs without compromising environmental quality or the health and safety of site employees and the general public. Excess facilities and assets disposition activities are discussed in chapter 4 .

\section{Environmental Restoration}

In 1981, SRS began inventorying waste sites (referred to as "units") for eventual restoration. About 477 waste units were identified to be addressed through the site's environmental restoration program. Of these 477 units, 181 have been determined to require no further action. The remainder are in remediation or remediation design (e.g., engineering characterization, sampling studies, data compilation, designing a path forward) or have been proposed for no further action. Waste units range in size from a few square or cubic feet to tens of acres and include basins, pits, piles, burial grounds, landfills, tanks, and groundwater contamination areas.

Of the 500 acres to be addressed in the environmental restoration program, about 300 have been or are being remediated. Also, billions of gallons of groundwater have been treated to remove hundreds of thousands of pounds of solvents. Even though the site has had success in cleaning up some areas, a significant amount of environmental restoration work remains [Fact Sheet, 1996a]. More about environmental restoration can be found in chapter 4 .

\section{Environmental Monitoring}

Onsite and offsite radiological and nonradiological environmental monitoring is conducted by the Environmental Monitoring Section (EMS) of WSRC's Environmental Protection Department (EPD). The environmental monitoring program is discussed briefly in chapter 3, "Environmental Program Information," and more thoroughly in chapters 5, ("Radiological Effluent Monitoring"), 6 ("Radiological Environmental Surveillance"), 8 ("Nonradiological Effluent Monitoring"), and 9 ("Nonradiological Environmental Surveillance").

Also, the Division of Environmental Research of the Academy of Natural Sciences of Philadelphia has performed biological and water quality surveys of the Savannah River since 1951. More about the academy's surveys can be found in chapter 12 ("Special Surveys and Projects"). 


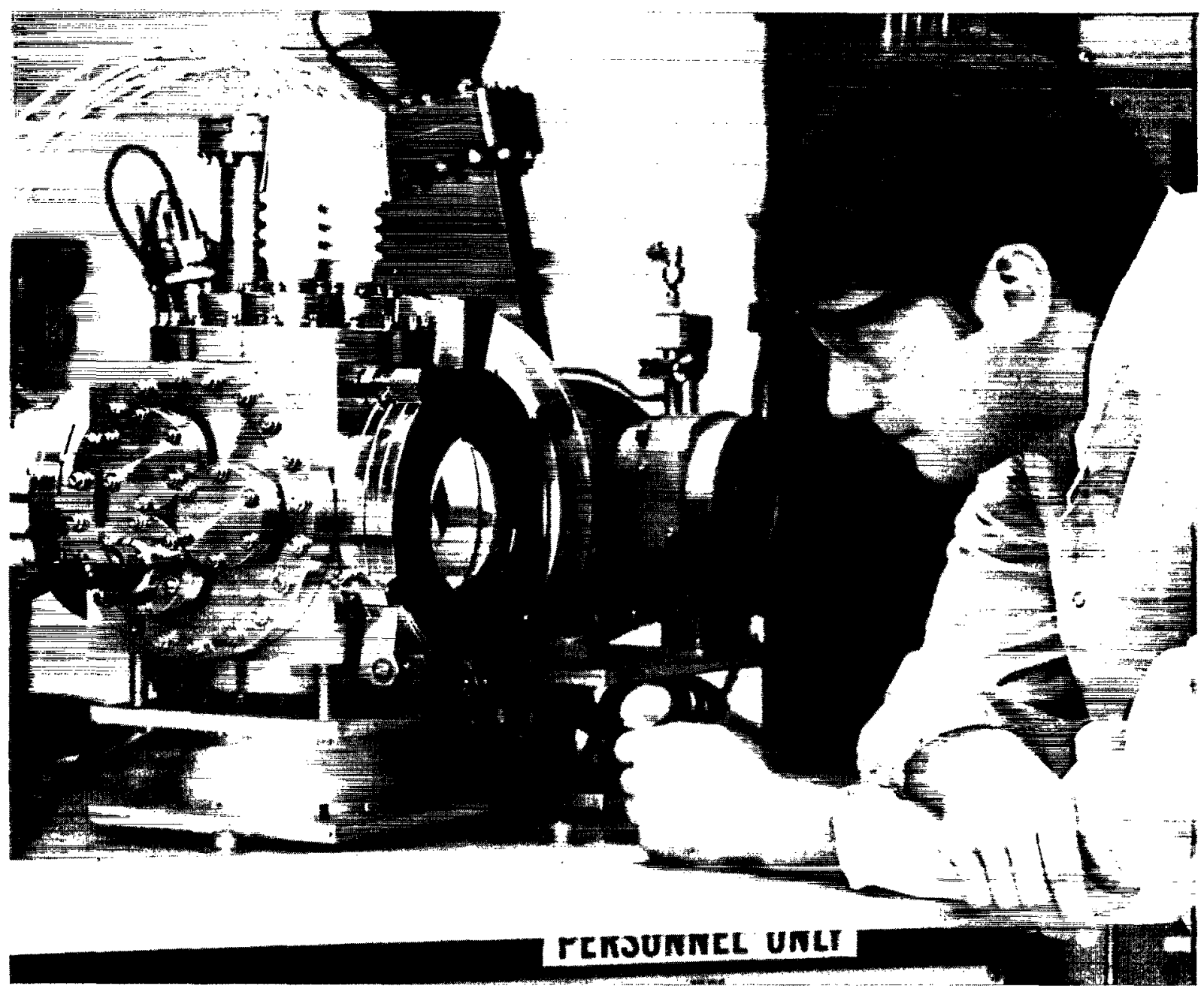

Steve Ashe Photo (WSRC-98-1113-16)

An SRTC scientist works with high-sensitivity equipment with forensic capability. This equipment has the capability to "read" the characteristic fingerprints of a material. For example, in some cases scientists can identify the particular factory that was the source of a substance, distinguishing the factory from all other possible manufacturers. Such information can be used in the fight against drugs, terrorism, and smuggling.

\section{Research and Development}

SRTC, the site's applied research and development laboratory, creates, tests, and puts into use solutions to SRS's technological challenges. SRTC researchers have made significant technological advances in hydrogen technology, nonproliferation, environmental characterization and cleanup, sensors and probes, use of glass for stabilizing and disposing of waste, etc.

SRTC's facilities include biotechnology laboratories, laboratories for the safe study and handling of radioactive materials, a field demonstration site for testing and evaluating environmental cleanup technologies, and laboratories for ultra-sensitive measurement and analysis of radioactive materials.

In recent years, SRTC's role has expanded and includes providing related support to DOE-Headquarters (DOE-HQ), other DOE sites, other federal agencies, and other customers. SRTC also forms strategic partnerships with private industry, academia, and other government agencies to apply the laboratory's unique expertise to challenges of mutual interest. For example, SRTC, working with a broad-based consortium, applied its extensive hydrogen expertise to the development of a hydrogen-fueled bus that became part of the Augusta public transit fleet. 
The laboratory also shares its expertise by licensing private companies to manufacture and/or market technologies created at SRTC.

\section{Other Environmental Research}

In addition, environmental activities are conducted by the SREL, the Savannah River Natural Resource Management and Research Institute (SRI), and the Savannah River Archaeological Research Program (SRARP).

\section{Savannah River Ecology Laboratory}

SREL is operated by The University of Georgia and funded by DOE to conduct research related to the impact of site operations on the environment. Research programs are organized into four main categories-radioecology, environmental chemistry, ecotoxicology, and ecosystem health.

Radioecology research assesses the distribution, fate, and ecological risk associated with radionuclides in the environment, including the genetic effects on flora and fauna at SRS and highly contaminated sites such as the Chernobyl site in the Ukraine. Environmental chemistry research addresses the physical, chemical, and biological processes controlling the mobility of organic and inorganic contaminants in the environment, particularly in soils and water of SRS and other DOE sites. Research in ecotoxicology seeks to measure or predict bioaccumulation of contaminants in natural populations of organisms. The program also seeks to evaluate genetic and demographic markers in various species for use as possible indicators of responses to environmental contaminants. Objectives of the ecosystem health research are to identify patterns of biodiversity on the site and to understand the natural and anthropogenic processes that maintain or change them.

Additional studies are conducted on the site's deer herd, fish, reptiles, amphibians, waterfowl, and endangered species, such as the wood stork. Other studies evaluate the potential of various experimental approaches for remediating contaminated soils, Carolina bays, and other habitats.

Information about SREL's education outreach program can be found in chapter 3. More information about all programs can be obtained by contacting SREL at 803-725-0156.

\section{Savannah River Natural Resource Management and Research Institute}

SRI manages the natural resources at SRS. In 1952, the $\mathrm{AEC}$ and the U.S. Department of Agriculture
Forest Service formed an interagency agreement to create an onsite natural resources management organization at SRS. Because the site had been farmland, an early task of the Forest Service was to play a major role in planting millions of trees to help establish a buffer around the facilities being constructed. Forest Service practices since have created a unique refuge for a variety of plants and animals, including six endangered species and more than 40 sensitive species. Today, major responsibilities include the following:

- SRI provides administrative support for more than 60 forest research projects in cooperation with Forest Service and site organizations, universities, and research laboratories.

- Soil, water, and air personnel provide support to other groups on site involved in erosion and sediment control projects.

- Wildlife and botany personnel maintain and improve a variety of habitats that will support native plants and animals.

- In fiscal year 1998, SRI sold 57,000 hundredcubic feet of sawtimber (timber large enough to be sawed into lumber) and roundwood products (wood not big enough for lumber but useful for making paper, etc.). At the same time, it planted more than 400 acres of new seedlings.

- Fire management personnel control-burn about 15,000 acres each year to protect site facilities and improve a variety of forest resources. They are responsible for suppressing any wildfires on site.

- Engineers maintain all secondary roads and exterior boundaries.

Information about SRI's education outreach program can be found in chapter 3. Information about other programs can be obtained by contacting SRI at 803-725-0237.

\section{Savannah River Archaeological Research Program}

SRARP was formed in 1973 under a cooperative agreement with DOE and the South Carolina Institute of Archaeology and Anthropology, University of South Carolina. Its primary purpose is to make compliance recommendations to DOE that will facilitate the management of archaeological resources at SRS. Other functions include compliance activities involving reconnaissance surveys, specific intensive surveys, data recovery, coordination with major land users, and reconstruction of the environmental history of the site. More information can be obtained by contacting SRARP at 803-725-3623. 


\section{Highlights}

- All 20 of the operational petroleum storage tanks at SRS met new tank standards.

- Consistent with FFA milestones, five signed RODs and 20 site evaluations were submitted to EPA and SCDHEC for approval. Investigations were initiated at five units to determine if hazardous substances were present in the environment.

- SRS submitted its Toxic Chemical Release Inventory report for 1997 to EPA ahead of the July 1, 1998, deadline. Seven chemicals, with releases totaling 280,649 pounds, were reported for 1997-compared with seven chemicals $(31,582$ pounds) reported for 1996 and six chemicals $(66,967$ pounds) reported for 1995 . The increase from 1996 to 1997 reflects active remediation of old waste sites and the transfer of contaminated soil to an offsite facility.

- A total of 235 NEPA reviews of newly proposed actions at SRS were conducted and formally documented.

- Under the CAA, SRS achieved a compliance rate of 100 percent, with no NOVs. Under the CWA, the site received two NOVs (now closed) for RCRA storage deficiencies and one NPDES-related NOV. The NPDES-related NOV involved 13 violations, of which 12 had been corrected and one remained under investigation by the end of the year.

- Forty-two NPDES exceedances were reported for the year, but the site's compliance rate of 99.3 percent still exceeded the DOE-benchmark of 98 percent.

- EPA approved the site's high-level waste tank closure plan and schedule.

- SRS had one CERCLA-reportable release, compared with three such releases in 1997, two in 1996, and four in 1995.

- Of the 561 SIRIM-reportable events in 1998, 24 were categorized as primarily environmental. Of the 24 events, none were classified as emergencies, one was classified as an unusual occurrence, and 23 were classified as off-normal occurrences.

SRS's goal--and that of the U.S. Department of Energy (DOE)-is positive environmental stewardship and full regulatory compliance, with zero violations. The site's employees maintained progress toward achievement of this goal in 1998, as demonstrated by examples in this chapter.

A systematic effort is in place to identify and address all evolving regulatory responsibilities that concern SRS. As part of the process, communications are maintained with all appropriate regulatory agencies to emphasize the site's commitment to environmental compliance.
The site's compliance efforts achieved a very high level of success in 1998. For example, under the Clean Water Act (CWA), 5,736 analyses were performed during the year to demonstrate compliance with the site's National Pollutant Discharge Elimination System (NPDES) permits; the site's compliance rate was 99.3 percent, calculated by dividing the number of analyses not exceeding limits for the year $(5,694)$ by the total number of analyses. The site received a total of three notices of violation (NOVs) from the South Carolina Department of Health and Environmental Control (SCDHEC), as described later in this chapter. 
Some of the Key Regulations SRS Must Follow

Legislation

RCRA

Resource Conservation and Recovery Act (1976)

FFCAct

Federal Facility Compliance Act (1992)

\section{CERCLA; SARA}

Comprehensive Environmental Response, Compensation, and Liability Act (1980);

Superfund Amendments and Reauthorization Act (1986)

CERCLATITLE III (EPCRA)

Emergency Planning and Community

Right-to-Know Act (1986)

NEPA

National Environmental Policy Act (1969)

SDWA

Safe Drinking Water Act (1974)

CWA; NPDES

Clean Water Act (1977); National Pollutant

Discharge Elimination System

CAA; NESHAP

Clean Air Act (1970); National Emission Standards

for Hazardous Air Pollutants

TSCA

Toxic Substances Control Act (1976)

\section{What it Requires/SRS Compliance Status}

- The management of hazardous and nonhazardous wastes and of underground storage tanks containing hazardous substances and petroleum products--in compliance

- The development by DOE of schedules for mixed waste treatment to avoid waiver of sovereign immunity and to meet LDR requirements-in compliance

- The establishment of liability, compensation, cleanup, and emergency response for hazardous substances released to the environment-SRS placed on National Priority List in December 1989

- The reporting of hazardous substances used on site (and their releases) to EPA, state, and local planning units-in compliance

- The evaluation of the potential environmental impact of federal activities and alternatives; in 1998, WSRC conducted 235 reviews of newly proposed actions-in compliance

- The protection of public drinking water systems; enacted in 1974, amended in 1980, 1986-in compliance

- The regulation of liquid discharges at outfalls (e.g., drains or pipes) that carry effluents to streams-in compliance

- The establishment of air quality standards for hazardous air emissions, such as radionuclides and benzene-in compliance

- The regulation of use and disposal of PCBs-nation has inadequate disposal capacity for radioactive PCBs generated and currently stored at SRS

critical part of the operations at SRS. Assurance that onsite processes do not impact the environment adversely is a top priority, and management of the environmental programs at SRS is a major activity. All site activities are overseen by one or more regulatory bodies, including the U.S. Environmental Protection Agency (EPA) and SCDHEC. Significant effort and funding have been dedicated to ensuring that site facilities and operations comply with all requirements.
Compliance with environmental regulations and with DOE orders related to environmental protection is a compliance rate was 100 percent. Some key

regulations with which the site must comply-and its above.

\section{Compliance Activities}




\section{Resource Conservation and Recovery Act}

The Resource Conservation and Recovery Act (RCRA) was passed in 1976 to address the problem of solid and hazardous waste management. The law requires that EPA regulate the management of solid and hazardous wastes, such as spent solvents, batteries, and many other discarded substances deemed potentially harmful to human health and the environment. Amendments to RCRA regulate nonhazardous solid waste and some underground storage tanks.

Under RCRA, hazardous waste generators are responsible for managing every aspect of the generation, treatment, storage, and disposal of the waste; this is referred to as "cradle-to-grave" management. Hazardous waste generators, including SRS, must follow specific requirements for handling these wastes. For many waste management activities, RCRA requires permits for owners and operators of operating or post-closure-care hazardous waste management facilities.

EPA is responsible for all hazardous waste regulations. However, EPA can delegate this authority to a state when the state passes laws and regulations that meet or exceed the EPA hazardous waste regulations. The state plan then must be approved by EPA. The agency has approved South Carolina's plan and delegated RCRA authority to SCDHEC.

Similarly, the Federal Facility Compliance Act (FFCAct) gives the state authority to enforce land disposal restriction (LDR)/treatment standards for mixed wastes. Mixed wastes contain both hazardous and radioactive wastes. Also, SCDHEC has been authorized by the FFCAct to play the key role in the implementation of FFCAct statutes and was the lead regulatory agency for implementation of the SRS Site Treatment Plan (STP), which addresses storage and treatment of mixed waste. More information on waste management at SRS can be found in chapter 4, "Environmental Management."

\section{Federal Facility Compliance Act}

The FFCAct was signed into law in October 1992 as an amendment to the Solid Waste Disposal Act to add provisions concerning the application of certain requirements and sanctions to federal facilities. For mixed waste, the FFCAct provided a 3-year delay (until October 1995) in the imposition of fines and penalties so that DOE sites could investigate mixed waste volumes in storage, evaluate treatment capacities, and develop STPs with schedules for mixed waste treatment for approval by their state or federal regulatory agencies.

Westinghouse Savannah River Company (WSRC) submitted a mixed waste inventory report January 13, 1993, and DOE Headquarters (DOE-HQ) issued a complexwide report-U.S. Department of Energy Interim Mixed Waste Inventory Report: Waste Streams, Treatment Capacities, and Technologies-April 21, 1993, to state governors and to regulatory agencies in states that host $\mathrm{DOE}$ sites. This was followed by a comment period for the regulators and states. DOE-HQ provided an update to the mixed waste inventory report in April 1994.

On March 30, 1995, DOE's Savannah River Operations Office (DOE-SR) submitted an STP-developed with State of South Carolina involvement--that addressed the development of capacities and technologies for treating SRS mixed wastes in accordance with LDRs, as required by the FFCAct. This plan was approved with modifications, and the FFCAct consent order was issued September 29, 1995. SRS prepares regular updates of the mixed waste inventory report to support the STP.

\section{Land Disposal Restrictions}

The 1984 RCRA amendments established LDRs, often referred to as "land ban." LDRs do not allow storage of restricted hazardous wastes, except for the purpose of accumulating such quantities as are necessary to facilitate proper recovery, treatment, or disposal. The amendments require that, prior to land disposal, all wastes meet treatment standards based on the "best demonstrated available technology."

The same restrictions apply to mixed wastes, which are composed of a mixture of radioactive and hazardous wastes. Because SRS did not have the capacity to treat all mixed wastes according to the applicable LDR standards, a Federal Facility Compliance Agreement (FFCA) was signed in March 1991 between DOE-SR and EPA Region IV (Alabama, Florida, Georgia, Kentucky, Mississippi, North Carolina, South Carolina, and Tennessee). The goal of the FFCA was to address SRS mixed waste compliance with LDRs. The FFCA was terminated September 29, 1995, when the STP Consent Order became effective.

As required by the STP Consent Order, SRS issued an annual update to the STP by April 30,1998. The update called for changes in the mixed waste treatment status, including the addition of new mixed waste streams. Information for STP updates was supplied in part from a Mixed Waste Inventory Report completed in January 1998. STP updates will 
continue to be produced annually unless the consent order is modified.

Treatability variances are an option available to facilities for particular waste streams that either cannot be treated at the level specified in regulations-the appropriate treatment technology may not be available - or for which the treatment technology is inappropriate for the waste. SRS has identified certain mixed waste streams that are potential candidates for a treatability variance. One variance-for in-tank precipitation filters-was granted in October 1993 by EPA Region IV. The STP references three additional treatability variances for mixed wastes with special problems that prevent treatment according to LDR standards. Two of the three variances, completed and sent to EPA headquarters in September 1997, were for tritiated water with mercury and for silver saddles (silver nitrate-coated ceramic devices designed to take up iodine gas). The third variance, for plastic/lead/cadmium Raschig rings (packing material spacers used for criticality control), is required by the STP to be submitted by September 30, 1999.

\section{Notices of Violation (RCRA)}

SRS received two NOVs from SCDHEC during 1998 for RCRA storage deficiencies.

The first NOV, issued to WSRC March 6, stated that DOE and WSRC had stored benzene waste in the Organic Waste Storage Tank (OWST) beyond the one-year storage prohibition and that 15 containers of hazardous waste at the Consolidated Incineration Facility (CIF) had exceeded the 90-day accumulation period. After negotiations, SRS entered a consent order with SCDHEC that closed the NOV. Under the consent order, WSRC had until November 30, 1998, to empty the OWST; this was completed October 30 (a month early), thereby meeting the RCRA "empty tank" requirement. The storage deficiency for the 15 drums was corrected, and WSRC paid a $\$ 6,000$ civil penalty for exceeding the 90-day storage limit at the CIF staging area.

SCDHEC issued the second NOV to DOE and the Savannah River Ecology Lab (SREL) June 23 for an SREL satellite area deficiency that exceeded the 55 -gallon limit. The deficiency was corrected and the NOV closed-without any fines.

\section{Underground Storage Tanks}

Underground storage tanks at SRS house petroleum products-such as gasoline and diesel fuel一and hazardous substances, as defined by the Comprehensive Environmental Response,
Compensation, and Liability Act (CERCLA). All such tanks -20 of which were in operation at SRS during 1998-are regulated under Subtitle I of RCRA.

Underground storage tank regulations promulgated (legally issued) in the late 1980s required that all regulated existing tanks be closed or upgraded to meet or comply with "new" tank standards by December 22, 1998. WSRC closed four tanks in 1998; the closure method included filling the tanks with concrete. SCDHEC inspected 19 WSRC tanks November 16-17 and one tank belonging to Wackenhut Services, Inc. (WSI), the company's security contractor, November 30 . Tightness tests were performed on the tanks and their connective piping. All 19 WSRC tanks passed, and SCDHEC issued certificates verifying that the tanks and lines complied with the new tank standards. The WSI tank was found to comply with the new tank standards, but the tightness tests on the piping did not pass. Corrective actions to repair the connective piping were to be completed by February 1999.

The underground storage tank regulations set standards for upgrading existing tanks based on their age. In areas where underground tanks are still needed, WSRC has upgraded the leak/spill/overfill detection systems. All 20 of the operational tanks at SRS met the new tank standards in 1998.

\section{High-Level Radioactive Waste Tank Closure}

The primary regulatory goal of SRS's waste tank closure process at the F-Area and $\mathrm{H}$-Area high-level tank farms is to close the tank systems in a way that protects public health and the environment in accordance with South Carolina Regulation R.61-82, "Proper Closeout of Wastewater Treatment Facilities." This must be accomplished in compliance with the requirements of RCRA and CERCLA, under which any releases to the environment from the high-level waste tank "farms" will be addressed. A general tank closure plan presents the environmental regulatory standards and guidelines pertinent to closure of the waste tanks and describes the process for evaluating and selecting the closure configuration (the residual source term and method of stabilizing the tanks' residual waste material). The plan also describes the integration of existing commitments with high-level waste farm closure activities. These commitments involve removal of waste from the tanks before closure and remediation of the entire area (including soils and groundwater) surrounding the tank farms.

Tank 20F, a 1.3-million-gallon, single-shelled, carbon steel vessel, and tank 17F, with the same capacity, 
were closed in 1997. Prior to the initiation of closure activities, all but approximately 1000-2000 gallons of waste were removed from each tank and further processed.

The assessment of soils and groundwater around the waste tanks will be deferred until complete closure of a geographical grouping of tank systems and their associated support services. The tank $17 \mathrm{~F}$ and tank $20 \mathrm{~F}$ systems cannot be isolated practically from other operational systems for the purpose of assessing potential releases to the environment.

A revised waste removal plan and schedule called for SCDHEC and EPA approval in 1998. SCDHEC had requested a revised waste removal plan and schedule that was consistent with the three-party consensus tank closure strategy outlined in the high-level waste tank closure program plan. Appendix $C$ of this plan is used by SRS as a tool for managing high-level waste tank system closures. DOE submitted a revised waste removal plan and schedule to SCDHEC January 15. The plan and schedule were approved February 26 by SCDHEC and June 22 by EPA. They supersede the original waste removal plan and schedule, submitted to SCDHEC and EPA in November 1993.

DOE determined October 30, 1998, that SRS should perform a tank closure Environmental Impact Statement (EIS) before conducting any further closure activities. A Record of Decision (ROD) on this action has been forecast for December 1999. The EIS process is not expected to impact the commitments in the revised waste removal plan and schedule.

\section{RCRA 3004(u) Program}

The hazardous waste permit issued to SRS in September 1987 requires that the site institute a program for investigating and, if necessary, performing corrective actions at solid waste management units under RCRA 3004(u). The RCRA 3004(u) requirements have been integrated with CERCLA requirements in the Federal Facility Agreement (FFA). The integration of RCRA and CERCLA regulatory requirements is expected to provide a more cost-effective and focused investigation and remediation process. The RCRA/CERCLA program status is detailed under the CERCLA section of this chapter.

\section{Waste Minimization Program}

The SRS Waste Minimization Program is part of a broad, ongoing effort to prevent pollution and minimize waste on site. The program is designed to meet the requirements of RCRA, of DOE orders, and of applicable executive orders. More information on the site's pollution prevention activities-including specific programs such as Waste Minimization-can be found in chapter 3, "Environmental Program Information," page 50, and chapter 4, page 63.

\section{Comprehensive Environmental Response, Compensation, and Liability Act}

SRS was placed on the National Priority List in December 1989, under the legislative authority of CERCLA (Public Law 96-510), as amended by the Superfund Amendments and Reauthorization Act of 1986 (SARA, Public Law 99-499). CERCLA assigns liability and provides for compensation, cleanup, and emergency response for hazardous substances released to the environment.

In accordance with Section 120 of CERCLA, DOE, EPA Region IV, and SCDHEC entered into the FFA, which became effective August 16, 1993. Declaration of the effective date results in the FFA being an enforceable agreement. The FFA, which sets the milestones for environmental remediation at SRS, consolidates site cleanup activities into one comprehensive strategy.

The FFA also identifies about 300 site evaluation units for which investigations are required. Site evaluation reports were submitted to EPA and SCDHEC for 28 areas in 1994 and for 24 areas each year from 1995 to 1997 . Twenty site evaluation reports-encompassing many areas of potential releases-were submitted to EPA and SCDHEC in 1998.

Releases or potential releases from RCRA/CERCLA waste management units are evaluated under the FFA. Work plans detailing the proposed investigations for the RCRA/CERCLA units must be approved by both EPA and SCDHEC prior to implementation.

Remediation under CERCLA imposes requirements in addition to existing RCRA requirements. CERCLA requires remedial decisions to be based on the results of a baseline risk assessment, which examines present and future risk to human health and the environment from the waste unit, using conservative, EPA-approved exposure scenarios.

CERCLA also requires public participation in the selection of remediation alternatives. A significant step in this process is the development of a Proposed Plan, which highlights key aspects of the remedial investigation and feasibility study. The plan also provides a brief analysis of remedial alternatives that were considered, identifies the preferred alternatives, and tells the public how it can participate in the 
remedy selection process. After consideration of public comments and further analysis, decisions are made and documented in a ROD, which presents the selected remedy and provides the rationale for that selection. Also included in this process is the establishment of an administrative record file that documents the remediation alternatives and provides for public review of them.

SRS's 1998 environmental restoration activities included the submittal to EPA and SCDHEC of

- five signed RODs

- 20 site evaluation reports

- eight field starts

Also, six RODS (the five from 1998 and one from 1997) were signed by EPA and SCDHEC. Other 1998 activities included (1) the beginning, in August, of remedial action at the L-Area oil and chemical basin; (2) the completion, in October, of the removal of more than 1,300 batteries and contaminated soil from the L-Area burning/rubble pit, rubble pile, and gas cylinder disposal facility; and (3) the continuation of TNX groundwater remediation and of Old Radioactive Burial Ground remedial action.

Table 2-8 ("RCRA and RCRA/CERCLA Units at SRS"), beginning on page 37, includes

- a listing of approximately 470 waste units and potential waste units at SRS

- units that are RCRA-regulated and for which interim-action or final RODs have been issued

\section{Emergency Planning and Community Right-to-Know Act}

Within a period of 4 years, two related federal acts were enacted to help protect the public and the environment. The Emergency Planning and Community Right-to-Know Act (EPCRA) of 1986 was enacted as a freestanding provision of SARA. EPCRA requires facilities to notify state and local emergency planning entities about their hazardous chemical inventories and to report releases of hazardous chemicals. The Pollution Prevention Act of 1990 expanded the Toxic Chemical Release Inventory report to include source reduction and recycling activities.

\section{Tier II Inventory Report}

Under Section 312 of EPCRA, SRS completes an annual Tier II Inventory Report for all hazardous chemicals present at the site in excess of specified quantities during the calendar year. Hazardous chemical storage information is submitted to state and local authorities by March 1 for the previous calendar year.

\section{Toxic Chemical Release Inventory Report}

Under Section 313 of EPCRA, SRS must file an annual Toxic Chemical Release Inventory report by July 1 . SRS calculates chemical releases to the environment for each regulated chemical that exceeds its established threshold and reports the release values to EPA on Form $R$ of the report. The release values include chemical releases to air, water, land, underground injection, and offsite transfers. EPA treats offsite transfers as releases to the environment for reporting purposes. The transfers actually are shipments of waste to EPA-approved facilities for further treatment, storage, disposal, or recycling.

Form R for 1997 was submitted to EPA in June 1998. Seven chemicals, with releases totaling 280,649 pounds, were reported to EPA for 1997. This compares with seven chemicals $(31,582$ pounds of releases) reported for 1996 and six chemicals $(66,967$ pounds of releases) for 1995 . For the 10-year period from 1988 through 1997, reportable releases of quantities declined by 90 percent (from 2,762,007 pounds in 1988 to 280,649 pounds in 1997).

However, the remediation of an old waste site and the resulting transfer of contaminated soil to an offsite treatment facility led to an increase in the total release value for 1997. Figure 2-1 shows the overall reduction in total toxic chemical releases at SRS for the period 1988-1997. Several factors have contributed to this reduction. Pollution prevention programs have supported declines in the use and release of toxic chemicals, resulting in significant decreases for chemicals such as chlorine, lead, Freon 113, and 1,1,1-trichloroethane. Two primary reasons for the dramatic decline in reported totals during the late 1980s were as follows:

- EPA initially identified chemicals for reporting that did not meet the toxic criteria later developed for EPCRA Section 313. For example, EPA delisted nontoxic chemicals such as sodium sulfate; this resulted in a decline in reported releases for SRS.

- DOE curtailed nuclear production operations at SRS in 1989.

A breakdown of the comparison of toxic chemical releases from 1995 through 1997 is presented in table $2-1$. Significant changes were made in the 1995 and 1996 totals because of the discovery in 1998 of previously unaccounted-for lead releases.

Toluene represented 86 percent of the reported releases for 1997-largely due to the transfer of 240,833 pounds of toluene in soil from an old waste 


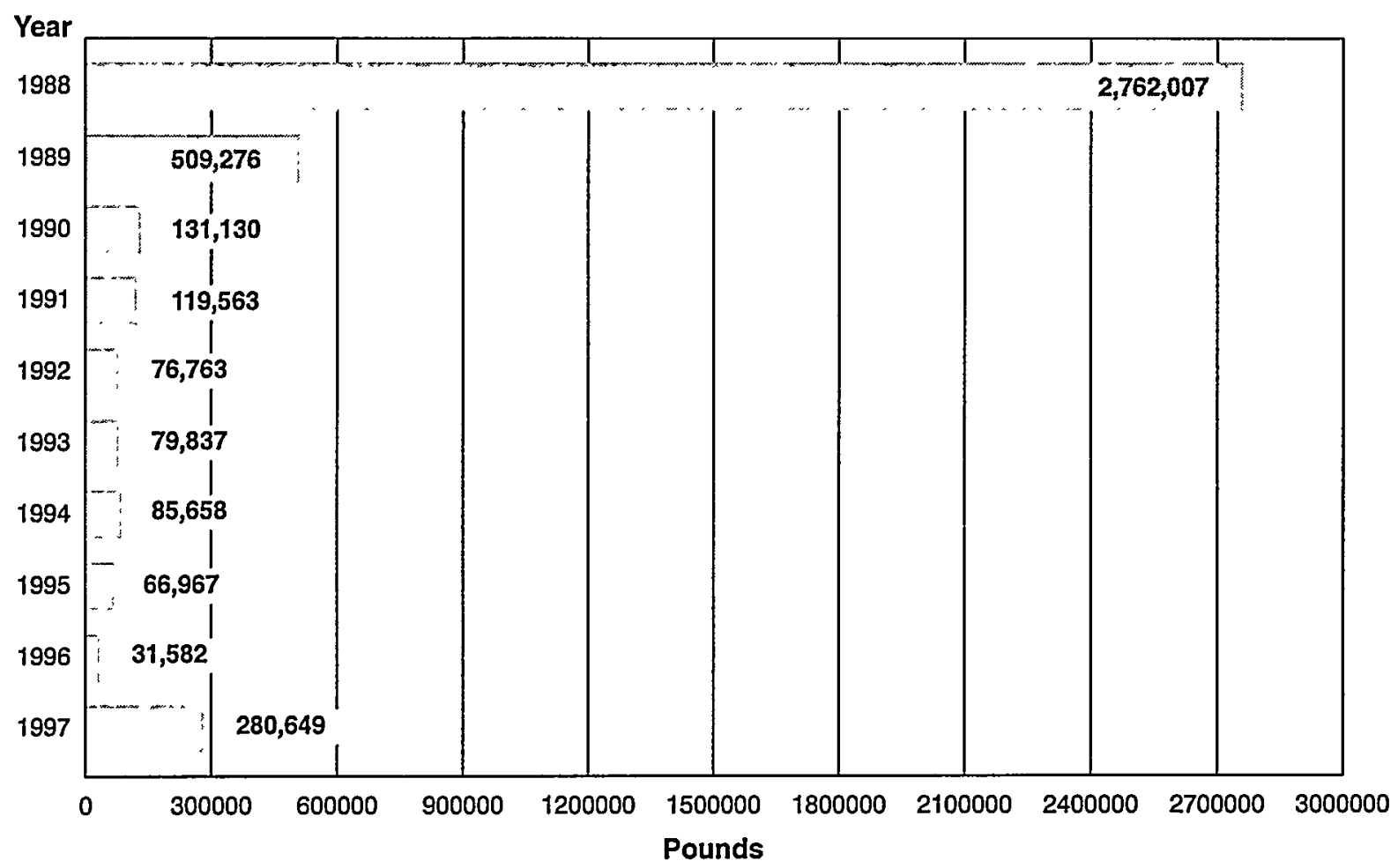

Ileaf Graphic

Figure 2-1 Total Toxic Chemical Releases at SRS, 1988-1997

Through 1997, total toxic chemical releases had been reduced by about 90 percent when compared to 1988 . The sharpest drop occurred between 1988 and 1989, when EPA delisted nontoxic chemicals that did not meet toxic criteria for EPCRA Section 313. The decline between 1989 and 1990 represented curtailed nuclear production. The increase from 1996 to 1997 reflects active remediation of old waste sites by SRS and the transfer of contaminated soil to an EPA offsite treatment facility, both of which are considered "releases."

site to a RCRA treatment facility. Nitrate compounds released to water made the largest 1996 contribution to the site total. Some nitrate compounds may be exempt under EPCRA reporting requirements, but all nitrate compounds detected in water sampling results were reported. Reasons for increased nitrate compounds have been speculative, but variable factors include amounts of rainfall and sources (locations) of samples. Lead represented a significant portion of the 1995 total, as indicated in the table; its share of the 1996 total, however, was considerably smaller. The reported totals for lead deserve special attention because 87 percent of the lead reported for 1995 was sent off site for recycling or disposal and was identified as an offsite transfer on Form $R$.

\section{3/50 Pollution Prevention Program}

In September 1992, DOE became the first federal agency to agree formally to participate in EPA's 33/50 Pollution Prevention Program. Under the agreement, DOE voluntarily adopted program goals that are expected to reduce the use and release of 17 priority chemicals. The first goal, which called for a 50 -percent reduction by the end of 1995, applied to SRS and other contractor-operated facilities that already were reporting the releases under EPCRA in 1992. The second goal, which called for a 33-percent reduction by the end of 1997, applied to the other contractor-operated facilities that met the reporting criteria in 1992 but had not previously reported the releases under EPCRA.

By 1993, the DOE complex already had met its 50 -percent reduction goals. With this achievement of the $33 / 50$ goals, the complex began to focus on reducing all toxic chemical releases, as identified in Executive Order 12856.

More about pollution prevention programs can be found in chapter 3, page 49.

\section{Executive Order 12856}

Executive Order 12856 requires that all federal facilities comply with right-to-know laws and pollution prevention requirements. The order requires that federal facilities meet EPCRA reporting 
Table 2-1 Releases and Offsite Transfers of Toxic Chemicals (in Pounds) by SRS During 1995, 1996, and 1997 Reporting Years (Reported Under EPCRA Section 313)

\begin{tabular}{|c|c|c|c|c|c|}
\hline Chemical & $\begin{array}{l}\text { Air } \\
\text { Emissions }\end{array}$ & $\begin{array}{l}\text { Water } \\
\text { Discharges }\end{array}$ & $\begin{array}{l}\text { Land } \\
\text { Disposal }\end{array}$ & $\begin{array}{l}\text { Offsite } \\
\text { Transfers }\end{array}$ & Total \\
\hline Benzene & 7,600 & 0 & 0 & 1,724 & 9,324 \\
\hline Formic acid & 33 & 0 & 0 & 0 & 33 \\
\hline Lead & $5^{a}$ & 13 & $6,700^{a}$ & 43,426 & 50,144 \\
\hline Nitrate compounds & 2 & 7,240 & 0 & 0 & 7,242 \\
\hline Nitric acid & 224 & 0 & 0 & 0 & 224 \\
\hline Sodium nitrite ${ }^{b}$ & 0 & 0 & 0 & 0 & 0 \\
\hline Totals & 7,864 & 7,253 & 6,700 & 45,150 & 66,967 \\
\hline \multicolumn{6}{|l|}{1996} \\
\hline Chemical & $\begin{array}{l}\text { Air } \\
\text { Emissions }\end{array}$ & $\begin{array}{l}\text { Water } \\
\text { Discharges }\end{array}$ & $\begin{array}{l}\text { Land } \\
\text { Disposal }\end{array}$ & $\begin{array}{l}\text { Offsite } \\
\text { Transfers }\end{array}$ & Total \\
\hline Formic acid & 56 & 0 & 0 & 0 & 56 \\
\hline Lead & $9^{a}$ & 83 & $7,100^{a}$ & 234 & 7,426 \\
\hline Naphthalene & 50 & 0 & 0 & 192 & 242 \\
\hline $\mathrm{n}$-Hexane & 54 & 0 & 0 & 96 & 150 \\
\hline Nitrate compounds & 12 & 20,768 & 0 & 50 & 20,830 \\
\hline Nitric acid & 2,840 & 0 & 4 & 0 & 2,844 \\
\hline Sodium nitrite & 0 & 0 & 9 & 25 & 34 \\
\hline Totals & 3,021 & 20,851 & 7,113 & 597 & 31,582 \\
\hline \multicolumn{6}{|l|}{1997} \\
\hline Chemical & $\begin{array}{l}\text { Air } \\
\text { Emissions }\end{array}$ & $\begin{array}{l}\text { Water } \\
\text { Discharges }\end{array}$ & $\begin{array}{l}\text { Land } \\
\text { Disposal }\end{array}$ & $\begin{array}{l}\text { Offsite } \\
\text { Transfers }\end{array}$ & Total \\
\hline Formic acid & 60 & 0 & 0 & 0 & 60 \\
\hline Lead & 11 & 27 & 5,700 & 2,670 & 8,408 \\
\hline Nitrate compounds & 25 & 25,157 & 0 & 1 & 25,183 \\
\hline Nitric acid & 2,573 & 0 & 0 & 0 & 2,573 \\
\hline Sodium nitrite & 2 & 0 & 0 & 12 & 14 \\
\hline Toluene & 891 & 0 & 2 & 240,833 & 241,726 \\
\hline Xylene & 1,937 & 0 & 8 & 740 & 2,685 \\
\hline Totals & 5,499 & 25,184 & 5,710 & 244,256 & $\overline{280,649}$ \\
\hline
\end{tabular}

a Revised value submitted to EPA in 1998 because additional information made available

b Reporting criteria met; however, no releases to environment

requirements and develop voluntary goals to reduce releases of toxic chemicals 50 percent on a DOE complexwide basis by the end of 1999. SRS complies with the applicable reporting requirements for EPCRA, as indicated in table 2-2, and the site incorporates the toxic chemicals on the Toxic
Chemical Release Inventory report into its pollution prevention efforts.

\section{National Environmental Policy Act}

The National Environmental Policy Act (NEPA) establishes policies and goals for the protection, 
Table 2-2 1998 SRS Reporting Compliance with Executive Order 12856

\begin{tabular}{llc}
\hline $\begin{array}{l}\text { EPCRA } \\
\text { Citation }\end{array}$ & $\begin{array}{l}\text { Activity } \\
\text { Regulated }\end{array}$ & $\begin{array}{l}\text { Reported per } \\
\text { Applicable } \\
\text { Requirement }\end{array}$ \\
\hline $302-303$ & Planning Notification & Not Requireda \\
304 & $\begin{array}{l}\text { Extremely Hazardous Substances } \\
\text { Release Notification } \\
311-312\end{array}$ & $\begin{array}{l}\text { Material Safety Data Sheet/ } \\
\text { Chemical Inventory }\end{array}$ \\
313 & Toxic Release Inventory Reporting & Yes
\end{tabular}

a Not required to report under provisions of "Executive Order 12856 and SARA Title III Reporting Requirements"

maintenance, and enhancement of the human environment in the United States. NEPA's purpose is to provide the federal government with a process for implementing these goals. The act requires consideration of environmental factors during the planning process for all major federal activities that could significantly affect the quality of the environment. In practice, NEPA provides a means to evaluate the potential environmental impact of such proposed activities and to examine alternatives to those actions. In 1998, 235 reviews of newly proposed actions were conducted at SRS and formally documented through Categorical Exclusions (CXs), notifications of previous NEPA coverage, Environmental Assessments (EAs), NEPA Values Impact Assessments (VIAs), or EISs. Supplemental Environmental Impact Statements (SEISs) and Programmatic Environmental Impact Statements (PEISs) also were prepared.

The types and numbers of NEPA activities conducted at SRS during 1998 are presented in table 2-3. Among the specific activities were the following:

- The final EA and Finding of No Significant Impact (FONSI) on the Tritium Facility Modernization and Consolidation Project at SRS were issued January 7. This EA assessed the potential impacts associated with the proposed upgrade of the existing SRS tritium facilities to improve safety and productivity, reduce future operating costs, and reduce the impacts to the environment.
- The final EA and FONSI for the proposed Waste Segregation Facility at SRS were issued January 9. This facility would be used to sort, shred, and compact low-level radioactive waste to reduce the number of B-25 low-level radioactive waste storage containers used at the site.

- On January 23 and August 5, DOE issued first and second RODs, respectively, related to the final PEIS on DOE Waste Management. The first ROD dealt with transuranic waste management decisions, while the second involved disposal of nonradioactive hazardous waste within the DOE complex. Additional RODs for other waste types

Table 2-3 Types/Quantity of NEPA Activities at SRS During 1998

Type of NEPA Documentation Number

Categorical Exclusion (CX) 194

Tiered by Previous NEPA Documentation 22

Environmental Assessment (EA) 7

Values Impact Assessment 1

Environmental Impact Statement (EIS) 8

Supplemental Environmental

Impact Statement (SEIS) 1

Programmatic Environmental

Impact Statement (PEIS)

Total 
addressed in this programmatic document are expected to be issued in 1999.

- The transuranic waste disposal phase ROD for the Waste Isolation Pilot Plant SEIS was issued January 23 . The proposed action would encompass the disposal of transuranic waste accumulated in aboveground storage in the DOE complex since 1970 and additional waste volumes projected to be generated over approximately the next 35 years. The existing waste volumes include transuranic waste currently stored at SRS.

- The final EA and FONSI on the Reuse of TNX as a Multipurpose Pilot Plant Campus at SRS were issued April 24. The EA assessed the potential environmental and safety impacts associated with DOE planning to allow asset reuse of the TNX facilities and equipment. The proposed action would include providing a Centers of Excellence location at or adjacent to SRS and entering into a cooperative agreement to market the resources in the TNX Area at SRS.

- The final VIA for the remediation of the SRS chemicals, metals, and pesticides pit was issued August 31 . This document was incorporated into the draft CERCLA interim action proposed plan regarding the waste site.

- The final EA and FONSI on the constructed wetlands project to treat effluent discharged from the A-01 outfall at SRS were issued October 7. The proposed action would include installation of a subsurface-flow wetland and an associated detention basin to receive flow from the various substreams that contribute to the A-01 outfall.

- The ROD for the Management of Certain Plutonium Residues and Scrub Alloy Stored at the Rocky Flats Environmental Technology Site final EIS was issued December 1. This ROD-the first of two that will be issued for that EIS-covers the decision to implement the preferred alternative for nine of the material categories covered in the EIS. Included in this decision were approximately $3,377 \mathrm{~kg}$ of ash and plutonium fluoride residues and approximately $700 \mathrm{~kg}$ of scrub alloy-all of which will be packaged and shipped to SRS. These materials will be stabilized in F Canyon and placed in safe and secure storage until DOE has made final decisions on the disposition of the separated plutonium.

Table 2-4 contains a complete list of NEPA documentation activities conducted at SRS during 1998.
Eight new department NEPA coordinators completed the SRS certification program during 1998 , bringing the current total to 31 certified department NEPA coordinators within the various contractor organizations on site.

In 1998, DOE-HQ required that the NEPA level (CX, EA, EIS) determinations at all sites within the complex be approved by the site NEPA compliance officer. This decision eliminated the sitewide CXs at SRS that could be approved at the department NEPA coordinator level. To ensure the rapid turnaround time that had been realized with sitewide CXs, this new approval process utilizes a computerized database with sitewide access. It includes electronic signature capability for both the contractor and the DOE-SR NEPA compliance officer. The average approval turnaround time within this process at SRS currently is less than two days.

The SRS NEPA Program continues to improve the sitewide computerized NEPA database/tracking system, which was developed for reporting and analysis purposes. An SRS NEPA home page is now available to offsite computer users by means of the Internet at the following address:

http://www.srs.gov/general/sci-tech/nepa/nepa.html. The home page contains electronic copies of SRS EAs and EISs, monthly NEPA reports, and hot links to other NEPA web sites.

In 1998, SRS received the NEPA Presidential Excellence Award for integrating NEPA compliance with the site's CERCLA processes. The National Association of Environmental Professionals recognized the WSRC/DOE team for developing an integration document that complies with both NEPA and CERCLA regulatory requirements. The integration guidance (1) combines public participation processes, (2) eliminates redundancy in environmental sampling and in impact analysis, and (3) reduces document preparation efforts. This cuts the time and cost for developing NEPA documentation in half where CERCLA action is involved. The SRS integrated process uses a new type of NEPA document called a VIA to demonstrate that NEPA values have been properly addressed, rather than preparing an EA or EIS toward fulfilling compliance with NEPA. The first NEPA VIA to be completed at SRS (and the first in the DOE complex) addressed the impacts associated with the environmental remediation of the chemicals, metals, and pesticides pit site. The General Accounting Office is making the SRS NEPA/CERCLA Integration Guidance available at its Internet site to all federal agencies. 
Table 2-4 SRS Project NEPA Documentation Activities During 1998

Project Name

Level of NEPA

Documentation

DOE Waste Management

PEIS

Surplus Plutonium Disposition

PEIS

Accelerator for the Production of Tritium at SRS

EIS

DWPF Salt Disposition Technology

SEIS

Geologic Repository for the Disposal of Spent Nuclear Fuel and High-Level

Radioactive Waste at Yucca Mountain, Nye County, Nevada

EIS

High-Level Waste Tank Closure at SRS

EIS

Management of Certain Plutonium Residues and Scrub Alloy Stored.

at the Rocky Flats Environmental Technology Site

EIS

Shutdown of the SRS River Water System

EIS

SRS Spent Nuclear Fuel

EIS

Tritium Extraction Facility at SRS

EIS

Disposal of Transuranic Waste at the Waste Isolation Pilot Plant

SEIS

A-01 Outfall Constructed Wetlands Project at SRS

EA

Construction, Operation, and Decommissioning of the Waste Segregation Facility EA

Implementation of the SRS Wetland Mitigation Bank Program

EA

Offsite Transportation of CIF Ash and Environmental Restoration Waste for Disposal

EA

Pond B Dam Repair Project at SRS

EA

Reuse of TNX as a Multipurpose Pilot Plant Campus at SRS

EA

Tritium Facility Modernization and Consolidation Project at SRS

EA

Remediation of the Chemicals, Metals, and Pesticides Pit at SRS

VIA

SRS continues to be recognized as having one of the most schedule-efficient and cost-effective NEPA programs in the DOE complex. At the request of senior management at DOE's West Valley

Demonstration Site in upstate New York, WSRC NEPA representatives advised West Valley NEPA personnel in March 1998 on ways to streamline their program by increasing its efficiency and cost-effectiveness.

\section{Safe Drinking Water Act}

The federal Safe Drinking Water Act (SDWA)—enacted in 1974 to protect public drinking water supplies-was amended in 1980, 1986, and 1996. SRS drinking water is supplied by 18 separate systems, all of which utilize groundwater sources. The number of drinking water systems at the site was reduced from 27 to 18 in 1997 by a project that consolidated 12 major drinking water systems into three: A-Area, D-Area, and K-Area. These three systems are actively regulated by SCDHEC and are classified as nonpersistent/noncommunity systems because each serves more than 25 people. The remaining 15 site water systems, each of which serves fewer than 25 people, receive a lesser degree of regulatory oversight.

During 1998, lead and copper compliance sampling was performed under an ultraprecise monitoring plan, approved by SCDHEC, for the A-Area consolidated system. This system did not exceed the lead and copper action levels in the 90th percentile during 1998. SDWA and SCDHEC regulations specify that treatment technique requirements are triggered by exceedances of the lead and copper action levels 


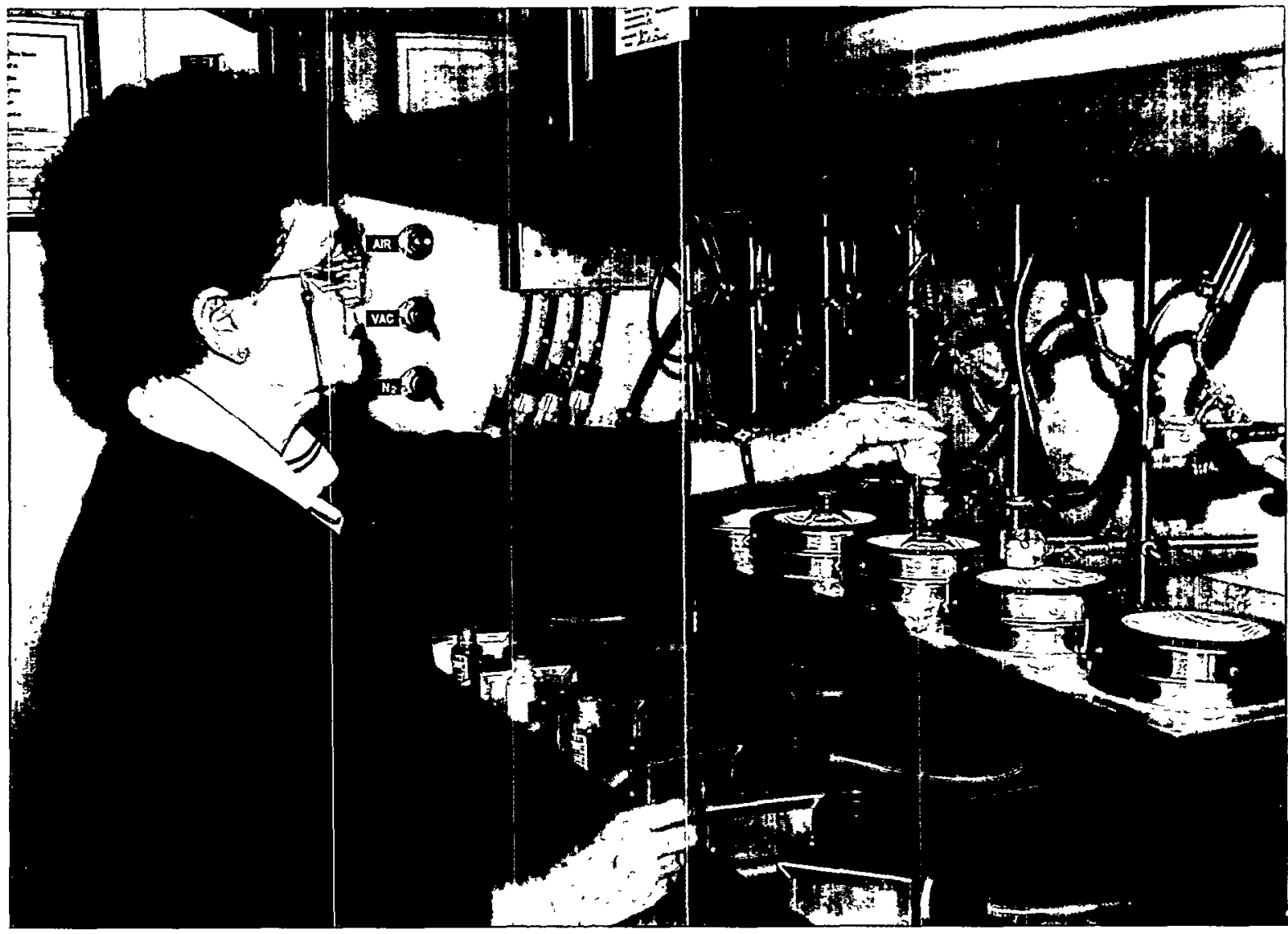

Al Mamatey Photo (99X00118.04)

Compliance with drinking water regulations requires various analyses, including radiological. Here, a WSRC laboratory technician pours a drinking water sample into a boiling flask for distillation and subsequent tritium analysis.

measured in the 90th percentile. As a result, lead and copper sampling will not be required for this system again until 2001.

The D-Area and K-Area consolidated water systems qualified in 1997 for an ultrareduced monitoring plan and are not required to resample for lead and copper until the year 2000 .

The A-Area consolidated water system was nominated by SCDHEC to EPA Region IV as South Carolina's representative in the "Large Ground Water System" category for the "1998 Public Water System SDWA Excellence Award." This system was judged against the other nominees in this category within Region IV. The award program is intended to highlight effective operations and maintenance programs as well as the commitment by local administration and plant personnel to maintaining and protecting drinking water and public water supplies.

SCDHEC executed a Memorandum of Agreement in 1998 that allows SRS to oversee and monitor seven of its smaller domestic water systems. These systems serve fewer than 15 service connections or regularly serve an average of fewer than 25 individuals daily.

No NOVs were issued to SRS in 1998 under the SDWA.

\section{Clean Water Act}

\section{National Pollutant Discharge Elimination System}

The CWA of 1972 created the NPDES program, which is administered by SCDHEC under EPA authority. The program is designed to protect surface waters by limiting releases of nonradiological effluents into streams, reservoirs, and wetlands. Radiological effluents are limited under DOE orders. Discharge limits are set for each facility to ensure that SRS operations do not adversely impact water quality.

SRS had four NPDES permits in 1998, as follows:

- One permit for industrial wastewater discharge (SC0000175)-SRS received a modification of 
this permit from SCDHEC January 1, 1998. The modification removed outfalls P-13, P-14, P-19, and $K-08$, added outfall $X-19$, and changed the sampling requirements at several other outfalls.

- One general permit for utility water discharge (SCG250162) - Under this permit, outfall 001 discharged once during 1998.

- Two general permits for stormwater discharge (SCR000000 for industrial and SCRI00000 for construction) - New stormwater permits were issued January 15, 1998, and became effective February 1.

More information about the NPDES permits can be found in chapter 8, "Nonradiological Effluent Monitoring."

All results of monitoring for compliance with the industrial wastewater discharge permit and the general permit for utility water discharge were reported to SCDHEC in the monthly Discharge Monitoring Reports, as required by the permits.

In October 1998, SCDHEC personnel conducted a 2-week audit in which SRS wastewater facilities were inspected and the permitted NPDES outfalls were sampled. All the facilities passed the operations/maintenance part of the audit, and no significant findings were noted at the audit closeout meeting.

All monitoring for compliance with the industrial stormwater discharge permit was evaluated and recorded in the pollution prevention plan for each outfall, as required by that permit. The individual outfall pollution prevention plans were combined to form a site pollution prevention plan, which was developed and implemented in 1993 and updated in 1996 for identified stormwater outfalls. Effective in 1998, individual outfall pollution prevention plans are kept at specific operations facilities, where they can be updated as needed. They are submitted to EPD annually. Each plan identifies facility areas where "best management practices" and/or "best available technology" should be implemented to prevent or mitigate the release of pollutants with stormwater runoff. (More about pollution prevention programs can be found in chapter 3, page 49.)

The outfalls covered by the new industrial stormwater permit (SCR000000) were reevaluated in 1998. This resulted in the development of a new sampling plan, which will be implemented in 1999.

All construction activity that would result in a land disturbance of 5 or more acres must be permitted. The five land areas associated with industrial activity from construction are permitted as required under permit SCR100000. One project in this category was closed in 1998. The pollution prevention plan for this permit also requires a sediment reduction and erosion control plan.

Under the Code of Federal Regulations (CFR) Oil Pollution Prevention regulation (40 CFR 112), SRS must report petroleum product discharges of 1,000 gallons or more into or upon the navigable waters of the United States, or petroleum product discharges in harmful quantities that result in oil sheens. No such incidents occurred at the site during 1998.

SRS has an agreement with SCDHEC to report petroleum product discharges of 25 gallons or more to the environment. Two such incidents in this category occurred at the site during 1998 and were reported appropriately.

\section{Notices of Violation (NPDES)}

SRS's 1998 compliance rate for NPDES under the CWA was 99.3 percent. The site did receive one NPDES-related NOV from SCDHEC in 1998. SCDHEC issued the NOV to WSRC September 28 for violation of the monitoring and reporting requirements of permit $\mathrm{SC} 0000175$. The agency cited 13 violations, which occurred from January through July 1998. These violations involved flow, total suspended solids, fecal coliform, and copper. Corrective actions were implemented in all the cases except the one involving copper, which occurred at the $\mathrm{H}-12$ outfall. The problem was still being investigated at the end of 1998 in an effort to determine the source of the copper.

A list of exceedances-including outfall locations, probable causes, and corrective actions-can be found in chapter 8 (table 8-5).

\section{Dredge and Fill; Rivers and Harbors}

The CWA, Section 404, "Dredge and Fill Permitting," as amended, and the Rivers and Harbors Act, Sections 9 and 10, "Construction Over and Obstruction of Navigable Waters of the United States," protect U.S. waters from dredging and filling and construction activities by the permitting of such projects. Dredge and fill operations in U.S. waters are defined, permitted, and controlled through implementation of federal regulations in 33 CFR (U.S. Army Corps of Engineers) and 40 CFR (EPA). In 1998, SRS conducted the following activities under one individual 404 permit and six nationwide permits issued under the nationwide permits (NWP) program:

- Work was completed under Section 404 and Section 10 permits to widen the boat ramp at river mile 157.8 on the Savannah River to allow 
a barge to dock and offload steam generators for Chem-Nuclear Systems (operator of a low-level waste disposal facility near Barnwell, South Carolina).

- Work continued under NWP 26, "Headwaters and Isolated Waters Discharges," at the area used for access to a bridge over Lower Three Runs Creek at Road B, which is being used by Chem-Nuclear Systems to transport the steam generators.

- Repair of a culvert and a road shoulder on the North Bypass near Road 3 was completed under NWP 3, "Maintenance."

- Work continued under NWP 3 on the repair and maintenance of the spillway and dam at Skinface Pond.

- Replacement of the Road 2-1 bridge over Tinker Creek was completed under NWP 3.

- Replacement of the bridges at Road C and Road F over Upper Three Runs Creek was completed under NWP 3.

- Replacement of the bridges at Road 8-1 and Road 2-1 over Upper Three Runs Creek was completed under NWP 3.

\section{Construction in Navigable Waters}

SCDHEC Regulation 19-450, "Permit for Construction in Navigable Waters," protects the state's navigable waters through the permitting of any dredging, filling, construction, or alteration activity in, on, or over state navigable waters, in or on the beds of state navigable waters, or in or on land or waters subject to a public navigational servitude. The only state navigable waters at SRS are Upper Three Runs Creek (through the entire site) and Lower Three Runs Creek (upstream to the base of the PAR Pond Dam).

In 1998, work was conducted on four SRS projects permitted under Regulation 19-450, as follows:

- The boat ramp widening project at Savannah River mile 157.8

- The Road B bridge project on Lower Three Runs Creek

- The Road 2-1 and 8-1 bridge replacement work over Upper Three Runs Creek.

- The Road $\mathrm{C}$ and Road $\mathrm{F}$ bridge replacement work over Upper Three Runs Creek

\section{Federal Insecticide, Fungicide, and Rodenticide Act}

The Federal Insecticide, Fungicide, and Rodenticide Act restricts the application of pesticides through a state-administered certification program. SRS's pesticide procedure provides guidelines for pesticide use and requires that applicators be state certified. A pesticide-use task group evaluates planned pesticide programs to ensure that they are acceptable and that appropriate pesticides are used, so that any impact on the environment is minimal. The task group also

- maintains records of pest control activities

- assists in disseminating pesticide-use information to site contractors

SRS pesticide programs typically include such activities as the maintenance of roadways, gravel areas, and fence lines through the use of herbicides.

EPA Region IV and South Carolina Department of Pesticide Regulation personnel conducted an inspection of the SRS pesticide program December 14-15, 1998. The regulators gave the program high marks and did not identify any violations from their evaluation of pesticide storage areas, records, and application sites managed by WSRC and the U.S. Department of Agriculture Forest Service's Savannah River Natural Resource Management and Research Institute (SRI).

\section{Clean Air Act}

\section{Regulation, Delegation, and Permits}

The CAA provides the basis for protecting and maintaining air quality. Some types of SRS air emissions, such as radioactive sources and ozone-depleting substances (ODSs), are regulated by EPA, but most are regulated by SCDHEC, which must ensure that its air pollution regulations are at least as stringent as the CAA's. This is accomplished through SCDHEC Regulation 61-62, "Air Pollution Control Regulations and Standards."

Under the CAA, and as defined in federal regulations, SRS is classified as a "major source" and, as such, is assigned one permit number (0080-0041) by SCDHEC. In this permit, each emission source is identified by the area designation, by a point identification number, and by a source description. SRS holds operating and construction permits from SCDHEC's Bureau of Air Quality, which regulates nonradioactive toxic and criteria pollutant emissions from approximately 208 point sources, several of which have specific emission limits. As of May 1994, SCDHEC had completed renewal of all SRS operating permits, which are valid for 5 years. During 
1998, four of SRS's current operating permits were due to expire. However, because of ongoing work on the Title V permit, SCDHEC granted an extension of the four operating permits until the new Title $V$ permit is issued. Of the 208 point sources, 157 operated in some capacity during 1998 . The remaining 51 either were under construction or were being maintained in a "cold standby" status.

During 1998, SCDHEC conducted compliance inspections of 59 permitted sources at SRS, reviewing 176 permitted parameters. The inspections included

- biennial stack tests

- initial operation inspections following completion of construction

- annual compliance inspections

As indicated earlier, the site achieved a compliance rate of 100 percent-and received no NOVs-under the CAA in 1998.

\section{National Emission Standards for Hazardous Air Pollutants}

The National Emission Standards for Hazardous Air Pollutants (NESHAP) is a CAA-implementing regulation that sets air quality standards for air emissions containing hazardous air pollutants, such as radionuclides, benzene, and asbestos. The NESHAP regulations found in $40 \mathrm{CFR} 61$ are divided into subparts based on specific hazardous pollutant categories, such as Subpart $\mathrm{H}$ for radionuclides and Subpart $M$ for asbestos. The Clean Air Act Amendments (CAAA) of 1990 revised the original list of hazardous air pollutants. The revised list of 189 air pollutants includes all radionuclides as a single item. Regulation of these pollutants, except for radionuclides, has been delegated to SCDHEC; EPA Region IV regulates radionuclides.

SRS, like most South Carolina industrial complexes, uses a number of chemicals identified by SCDHEC as toxic air pollutants and by EPA as hazardous air pollutants. These include many common consumer products-e.g., off-the-shelf bug sprays, correction fluids, paints, sealers, janitorial cleaning supplies, gasoline for vehicles-as well as a number of typical industrial chemicals, such as degreasers, solvents, metals, batteries, and diesel fuel. But SRS has at least one category, radionuclides, not found in typical industrial settings. During the course of normal operations, some radionuclides are released to the air.

NESHAP Radionuclide Program The SRS NESHAP radionuclide program continues to change to incorporate sampling, monitoring, and dose assessment practices that meet or exceed the requirements of $40 \mathrm{CFR} 61$, Subpart $\mathrm{H}$. This radionuclide subpart for the FFCA was signed October 31, 1991. An amendment to the subpart-signed by EPA Region IV August 16, 1993-provided SRS an extension of the original FFCA through February 10, 1995, to accomplish monitoring equipment upgrades to several additional sources. These upgrades were completed on time, and the FFCA was officially closed by EPA Region IV May 10, 1995.

During 1998, the maximally exposed individual effective dose equivalent, calculated using the NESHAP-required CAP88 computer code, was estimated to be $0.08 \mathrm{mrem}(0.08 \mathrm{mSv})$, which is 0.8 percent of the 10-mrem-per-year (0.10-mSv-per-year) EPA standard (chapter 7, "Potential Radiation Doses").

NESHAP Nonradionuclide Program SRS uses many chemicals identified as toxic or hazardous air pollutants, but most of these chemicals are not regulated under the CAA or under federal NESHAP regulations. Except for asbestos, SRS facilities and operations do not fall into any of the "categories" listed in the subparts. Under Title III of the federal CAAA of 1990, EPA in December 1993 issued a final list of hazardous air pollutant-emitting source categories potentially subject to maximum achievable control technology standards. These standards are being developed and issued over a 10-year period that will end in the year 2000, based on a schedule arranged according to

- the effects of each pollutant

- the industry group source category

- the abatement technology available

In an attempt to regulate hazardous or toxic air pollutants in South Carolina, SCDHEC established Air Pollution Control Regulation 61-62.5, Standard No. 8, "Toxic Air Pollutants," in June 1991. To demonstrate compliance with this standard, SRS completed and submitted an air emissions inventory and air dispersion modeling data for all site sources in 1993. The submitted data demonstrated compliance by computer modeling the accumulated ambient concentration of individual toxic air pollutants at the boundary line and comparing them to the Standard No. 8 maximum allowable concentrations. To ensure continued compliance with Standard No. 8, new sources of toxic air pollutants must be permitted, which requires submittal of appropriate air permit applications and air dispersion modeling. Sources with emissions below a threshold of 1,000 pounds per month of any single toxic air pollutant may be 
exempted from permitting requirements. During 1998,15 sources of toxic air pollutants either were issued a construction permit or exempted from permitting requirements.

NESHAP Asbestos Abatement Program Asbestos is a naturally occurring mineral. Because of its availability, low cost, and unique properties, the U.S. construction industry used asbestos extensively from after World War II through the mid 1970s. The construction of SRS began in the early 1950s, and asbestos-containing material can be found throughout the site. The danger from exposure to airborne asbestos fibers was virtually unknown during the early years at the site. Today, however, it is well established that unprotected exposure to airborne asbestos fibers can lead to asbestosis, lung cancer, mesothelioma, and other diseases.

SRS began an asbestos abatement program in 1988 and continues to manage asbestos-containing material by "best management practices." Site compliance in asbestos abatement, as well as demolitions, falls under South Carolina and federal regulations, including SCDHEC Regulation R.61-86.1 ("Standards of Performance for Asbestos Projects") and 40 CFR 61, Subpart M ("National Emission Standards for Asbestos").

Asbestos-containing material is managed at SRS through the following control options:

- an operations and maintenance program

- enclosure

- encapsulation

- repair

- removal

Many site demolition, renovation, and maintenance projects require the removal of asbestos-containing material. During 1998, SRS personnel removed and disposed of an estimated 1,525 square feet and 885 linear feet of regulated asbestos-containing material and demolished four regulated structures. In addition, contractors removed and disposed of an estimated 8,940 square feet and 3,775 linear feet of regulated asbestos-containing material and demolished 17 regulated structures.

Radiological asbestos waste, removed by SRS personnel and contractors who are not permanent SRS employees, was disposed of at the SRS Low-Level Burial Ground. Nonradiological asbestos waste removed by SRS personnel was disposed of in the Hickory Hill Landfill, located near Ridgeland, South Carolina. Nonradiological asbestos waste removed by contractors was disposed of at SCDHEC-approved offsite landfills.

Other CAA Requirements Only a few of the major sections of the CAA and its 1990 amendments and regulations have had-or are expected to have-a significant impact on SRS sources and facilities. These include Title V, "Permits," and Title VI, "Stratospheric Ozone Protection." The other regulations impacting SRS facilities are implemented primarily in SCDHEC Regulation 61-62 and in existing operating or construction permits.

Air Emissions Inventory SCDHEC Regulation 61-62.1, Section III ("Emissions Inventory"), requires compilation of an air emissions inventory for the purpose of locating all sources of air pollution and defining and characterizing the various types and amounts of pollutants. To demonstrate compliance, SRS personnel conducted the 1993 comprehensive air emissions inventory, compiling source information from as far back as 1985 . Guidelines and procedures were written to

- ensure that all radiological and nonradiological sources had been accounted for

- ensure documentation of all vents and stacks for each building

- better characterize emission points from site processes

- calculate emissions based on design capacity, maximum potential emissions, and actual emissions for a selected period of time

- provide consistency in recording appropriate data

The inventory identified approximately 5,300 radiological and nonradiological air emission sources. Source operating data and calculated emissions from 1990 were used to establish the SRS baseline emissions and to provide data for air dispersion modeling. This modeling was required to demonstrate sitewide compliance with Regulation 61-62.5, Standard No. 2, "Ambient Air Quality Standards," and Standard No. 8.

Regulation 61-62.1, Section III, requires that inventory data be updated and recorded annually but only reported every even calendar year. Calendar year 1997 operating data for permitted and other significant sources were reported to SCDHEC in 1998. Because data collection for all SRS sources begins in January and requires up to 6 months to complete, this report provides emissions data for calendar year 1997 (table 8-4 of this document for criteria pollutants and table 53, SRS Environmental Data for 1998, WSRC-TR-98-00314, for toxic/hazardous air pollutants). Compilation of 1998 
data will be completed in 1999 and reported in the SRS Environmental Report for 1999.

Title V Operating Permit Program As previously indicated, the CAAA of 1990 also include, under Title V, a major new permitting section expected to have a significant impact on the site. The primary purpose of this permitting program is to establish federally enforceable operating permits for major sources of air emissions. The implementation plan for this program was submitted to EPA in 1993 by the State of South Carolina and subsequently approved by EPA in June 1995 . SRS then submitted an extensive application package for site air emission sources by the March 15, 1996, deadline set forth in the implementation plan, Regulation 62.70, "Title V Operating Permit Program."

SRS and SCDHEC have been developing the Title V (Regulation 62.70) operating air permit since 1996. In September 1998, SRS received a draft Part 70 permit from SCDHEC and subsequently submitted comments back to SCDHEC on October 1 . At the end of the year, the site still was awaiting SCDHEC's disposition of those comments and issuance of a final draft permit, which will then undergo a 30-day public comment period and a 45-day EPA comment period.

Ozone-Depleting Substances Title $V$ of the CAAA of 1990 addresses stratospheric ozone protection. This law requires that EPA establish a number of regulations to phase out the production and consumption of ODSs. The substances commonly are used as refrigerants in air conditioning and cooling systems; as degreasers and cleaners; as spray can propellants; as fire suppressants (Halon); as laboratory extractions; and in many other common consumer products.

Several sections of Title VI of the CAAA of 1990, along with recently established EPA regulations, apply to the site. The ODSs are regulated in three general categories, as follows:

- Class I substances - chlorofluorocarbons (CFCs), Halon, carbon tetrachloride, methyl chloroform, methyl bromide, and hydrobromofluorocarbons ( $\mathrm{HBFCs}$ )

- Class II substances - hydrochlorofluorocarbons (HCFCs)

\section{- Substitute substances}

Class I ODSs are about 10 times more ozone-depleting than HCFCs and thus are more strictly regulated. As required by the CAAA of 1990 , most Class I Halon was phased out of production by January 1, 1994, and other Class I ODSs were phased out by January 1,1996 . This means that several very important refrigerants (CFC-11, $-12,-114$, and -502 ) used on site essentially may become unavailable for purchase. Many of the large chillers on site that use these refrigerants are being scheduled for total replacement or for retrofits that will use HCFCs or other chemical substitutes. The site also is scheduling fire suppression (Halon) system replacements. Many common degreasers are Class I ODSs and have been targeted for replacement. Most major degreasing applications already have been eliminated or replaced with non-ODSs. Smaller ODS-degreasing applications, such as those used in maintenance and electrical shops, are being targeted for phaseout. ODSs used in laboratory extraction procedures will be replaced when EPA approves newly developed processes that use non-ODSs.

The SRS CAAA of 1990 Title V operating air permit application includes ODS emission sources. All large (greater than or equal to 50-pound charge) heating, ventilation, and air conditioning/chiller systems for which there are recordkeeping requirements are included as fugitive emission sources.

In 1994, the site formed a CFC steering committee of participants from all the major users of these substances to provide initial direction in the phaseout of Class I ODSs on the site. A number of technical subcommittees also were initiated at that time to address particular applications, such as refrigeration, fire suppression, degreasers, laboratory applications, and environmental compliance. The ODS

Subcommittee of the Central Environmental Committee was created in 1995 to communicate to site organizations-through field representatives-any changes in Title VI regulations that could affect established programs. The "Savannah River Site Refrigerant Management Plan," completed and issued in September 1994, provides guidance to assist SRS and DOE in the phaseout of CFC refrigerants and equipment.

The site has

- purchased certified recycling equipment

- trained and certified technicians where required

- implemented required recordkeeping and leak-tracking for large cooling systems

- implemented proper labeling and other recordkeeping requirements

In 1996, SRS let a subcontract for the offsite reclamation of used refrigerants. The site also eliminated the use of CFC-114 by completing replacement of the 789-A chiller plant with a new plant that uses a non-CFC refrigerant. Plans are to 
sell the 55,000 pounds of CFC-114 as part of a decontamination and decommissioning contract. Additionally, Executive Order 12856 requires a 50-percent reduction in CFC usage by the end of 1999, based on 1993 data. SRS surpassed the 21,116-pound 1999 goal in 1996 by reducing CFC refrigerant usage to 12,570 pounds, but incurred a 1997 increase to 12,930 pounds-still surpassing the goal set in the executive order. In 1998, the site cut CFC usage sharply, to 6,430 pounds. This achievement exceeded the federal goal by 35 percent- and did so a year ahead of schedule. The SRS reduction in CFC usage, based on 1993 data, was 85 percent by 1998 , compared to the federal goal of 50 percent by 1999 .

CFC refrigerant system replacement projects that were in various stages of implementation during 1998 included the following:

- H-Canyon and 299-H system upgrades

- tritium facility system replacement

- HB-Line system replacement

- 221-S system replacement

- new source recovery facility system upgrades

- a central system for F-Canyon and associated support labs

\section{- 235-F refrigerant system upgrade}

The H-Canyon and 299-H upgrades were completed in 1998, as was the second phase of the tritium project-which involved the replacement of eight chillers at 232-H, 234-H, 234-4H, and 238-1H with four chillers at a central location in $218-\mathrm{H}$ and 218-1H (A third phase, in which two chillers are to be replaced at $249-\mathrm{H}$, is scheduled for completion in 1999.) Work continued on the 235-F and F-Canyon projects in 1998; the HB-Line and 221-5 replacements and the new source recovery facility upgrades, meanwhile, are new projects initiated during the year.

\section{Toxic Substances Control Act}

The Toxic Substances Control Act (TSCA) gives EPA comprehensive authority to identify and control chemical substances manufactured, imported, processed, used, or distributed in commerce in the United States. Reporting and recordkeeping are mandated for new chemicals and for any chemical that may present a substantial risk of injury to human health or the environment. EPD and Industrial Hygiene personnel coordinate reporting and recordkeeping requirements under TSCA.
Polychlorinated biphenyl (PCB) chemicals have been used in various SRS processes. The use, storage, and disposal of these organic chemicals are specifically regulated under 40 CFR 761 of TSCA, which is administered by EPA. SRS has a well-structured PCB program that complies with the TSCA regulation, DOE orders, and WSRC policies. The 1997 PCB Annual Document Log was completed prior to the July 1, 1998, deadline in full compliance with these requirements. The disposal of PCBs routinely generated at SRS is conducted at EPA-approved facilities within the regulatory time frame. In 1998, extensive revisions were made to the $\mathrm{PCB}$ regulations. SRS has revised its compliance program to conform to the new provisions.

In August 1993, PCBs were confirmed to be present as a component of dense nonaqueous phase liquids in samples from two groundwater monitoring wells around the M-Area hazardous waste management facility. Regulators were notified, and a modification to the RCRA Part B Permit Application to address the discovery of PCBs was submitted to SCDHEC in December 1993. Any waste generated was handled in accordance with the appropriate TSCA and RCRA requirements. Savannah River Technology Center personnel (SRTC) continue to study ways to remediate the dense nonaqueous phase liquids.

Certain PCB waste generated by SRS during the late 1970 s and early 1980 s was radioactively contaminated. Most of the radioactively contaminated waste resulted from a 1978 spill of PCBs from a failed electrical capacitor inside a nuclear materials processing area. TSCA regulations call for annual disposal of PCB waste, but there is insufficient capacity for offsite disposal of radioactive $\mathrm{PCB}$ waste. A request to conduct a treatability study on this waste was approved by EPA in 1995, and work continued on the study from late that year until mid-1996. The study included the evaluation of three chemical dechlorination technologies and one thermal desorption/vacuum extraction technology. The chemical dechlorination technologies were unsuccessful in treating the waste below TSCA thresholds. The test of the thermal desorption/vacuum extraction process was terminated prior to its conclusion because of vendor equipment malfunction and the shutdown of the vendor facility. The residuals from the study subsequently were returned to SRS for storage. Shipment of the waste to DOE's Oak Ridge TSCA incinerator is not expected to be completed until 1999.

In 1996, PCBs were detected in certain painted surfaces and electrical cables at the Heavy Water Components Test Reactor. The materials were analyzed as part of the predemolition characterization 
of the building. Subsequently, varying amounts of PCBs were detected in painted surfaces in two other site facilities. Prior to this discovery, the use of PCBs in paints and other solid items at SRS was unrecognized.

In 1997, the issue of $\mathrm{PCBs}$ in painted surfaces was the highest priority TSCA/PCB compliance issue at SRS, which conducted extensive research on the use of PCBs in solids-particularly in coatings used prior to the passage of TSCA. The site learned that PCBs had been used for certain coating products formulated for special purposes such as waterproofing and chemical and fire resistance. PCBs also were used in certain pigments, although these are not believed to be a major PCB contributor to most paints. SRS tested numerous painted surfaces for PCBs during 1997. The testing included measures of transferable PCB surface contamination, during which it was consistently demonstrated that PCBs in dried paint remained bound up in the coating and did not leach. It was concluded, therefore, that these PCBs did not pose a dermal exposure hazard to employees or to others who came into contact with them.

As discoveries of $\mathrm{PCBs}$ in paints were made, SRS worked closely with EPA on related TSCA compliance issues. Current TSCA regulations prohibit the use and distribution in commerce of PCBs in solids other than paints that contain more than 2 parts per million (ppm) of PCBs. In 1997, however, EPA granted an SRS request to consider painted iterns to be "excluded PCB products" under TSCA regulations; as a result, painted items at concentrations of greater than 2 ppm but less than $50 \mathrm{ppm}$ now may be used and distributed in commerce-not only by SRS, but nationwide. EPA considered revisions to fully authorize the use of PCBs in dried paints and other nonliquids-and formulated a rule related to this effort in August 1998.

SRS obtained an Enforcement Discretion Letter from EPA in 1997 that allowed the site to sell some excess metal-working equipment considered critical to the startup of a new manufacturing plant expected to employ 1,000 people. SRS will continue to work with EPA as related compliance issues arise.

As a result of site evaluation work completed in early 1997, PCBs greater than $50 \mathrm{ppm}$ were discovered in an underground tank that collected wastewater from the Ford Building in N-Area [WSRC 1997]. The building had been shut down for a number of years, and the tank no longer was being used. Its removal, via the CERCLA program, was completed in September 1998.

Also, PCBs were detected in 1997 inside the Ford Building on some old machinery and on the floor near the machinery. SRS notified EPA and began evaluating cleanup options for this facility. The cleanup got under way in 1998.

\section{Endangered Species Act}

The Endangered Species Act of 1973, as amended, provides for the designation and protection of wildlife, fish, and plants in danger of becoming extinct. The act also protects and conserves the ecosystems on which such species depend.

Several threatened and endangered species exist at SRS. The site conducts research on the wood stork, the red-cockaded woodpecker, the bald eagle, the shortnose sturgeon, and the smooth purple coneflower. Programs designed to enhance the habitat of such species are in place.

NEPA documentation was prepared and reviewed for several new projects at SRS in 1998 to ensure protection of threatened and endangered species. Biological assessments were conducted to evaluate potential impacts of future activities at

- the proposed Accelerator for the Production of Tritium

- the A-01 outfall project

- the Central Shops burning/rubble pit

- the C-Reactor seepage basin

- the CMP pits near Pen Branch

- the P-Area burning/rubble pit

- the Road A chemical basin

- the Ford Building seepage basin

- the L-Area rubble pits and piles

None of these activities was found to have had any significant potential impact on threatened and endangered species.

A biological assessment for the river water system shutdown EIS concluded in 1996 that the proposed action could affect the bald eagle, the alligator, and the wood stork. Subsequent consultations conducted by SRS in 1996-97 with U.S. Fish and Wildlife Service personnel (as pursuant to Section 7 , "Interagency Cooperation," of the Endangered Species Act) resulted in a cooperative agreement between SRS and the Service to perform studies on the bald eagle. 


\section{National Historic Preservation Act}

The National Historic Preservation Act (NHPA) of 1966, Section 106, governs the protection and preservation of archaeological and historical resources. SRS ensures that the site is in compliance with this act through the site-use process. All sites being considered for activities such as construction are evaluated by the University of South Carolina's Savannah River Archaeological Research Program group to ensure that archaeological or historic sites are not impacted. Reviews of timber compartment prescriptions include surveying for archaeological concerns and documenting areas of importance with regard to historic and prehistoric significance.

The archaeology group reviewed 37 site-use packages during 1998 in support of SRS project activities. Nine of these resulted in surveys being conducted due to potential for land altering in 1998. Most were found to have no activities of significant impact in terms of the NHPA. However, one of the reviews in 1997 had determined that the proposed Plutonium Immobilization Plant location included a site that could be subject to such impact. The proposed location subsequently was changed, but it was determined by a 1998 review that the new location still included a site that could be subject to such impact. Evaluation of this site had not been completed by the end of 1998 .

The archaeology group also supported forestry activities on site by surveying 1,823 acres in 1998; this resulted in the investigations of 29 new and existing sites for cultural resources.

\section{Floodplains and Wetlands}

Under DOE General Provisions, 10 CFR, Part 1022 ("Compliance with Floodplains/Wetlands Environmental Review Requirements"), establishes policies and procedures for implementing DOE's responsibilities in terms of compliance with Executive Orders 11988 ("Floodplain Management") and 11990 ("Protection of Wetlands"). Part 1022 includes DOE policies regarding the consideration of floodplains/wetlands factors in planning and decision making. It also includes DOE procedures for identifying proposed actions involving floodplains/wetlands, providing early public reviews of such proposed actions, preparing floodplains/wetlands assessments, and issuing statements of findings for actions in floodplains.

\section{Executive Order 11988,} "Floodplain Management"

Executive Order 11988, "Floodplain Management," was established to avoid long- and short-term impacts associated with the occupancy and modification of floodplains. The evaluation of impacts to SRS floodplains is ensured through the NEPA Evaluation Checklist and the site-use system. Site-use applications are reviewed for potential impacts by WSRC, DOE-SR, the Savannah River Natural Resource Management and Research Institute (SRI, formerly the Savannah River Forest Station), and the Savannah River Ecology Laboratory (SREL), as well as by professionals from other organizations. NEPA reviews of new projects at SRS in 1998 found no activities of significant impact with respect to Executive Order 11988.

\section{Executive Order 11990, "Protection of Wetlands"}

Executive Order 11990, "Protection of Wetlands," was established to mitigate adverse impacts to wetlands caused by the destruction and modification of wetlands and to avoid new construction in wetlands wherever possible. Avoidance of impact to SRS wetlands is ensured through the site-use process, various departmental procedures and checklists, and project reviews by the SRS Wetlands Task Group. Many groups and individuals, including scientists at SRTC, SREL, and EPD, review site-use applications to ensure that proposed projects do not impact wetlands. NEPA reviews of new projects at SRS in 1998 found no activities of significant impact with respect to Executive Order 11990.

Floodplain/wetland assessments were conducted on the $A-01$ outfall project and the CMP pits near Pen Branch.

\section{Environmental Release Response and Reporting}

\section{Response to Unplanned Releases}

Environmental Monitoring Section (EMS) personnel respond to unplanned environmental releases-both radiological and nonradiological—upon request by area operations personnel.

A number of unplanned environmental releases occurred in 1998, but area operations personnel did not require the sampling and analysis services of EMS. If the services of EMS personnel are requested, the samples collected are given priority in preparation and, if radiological in nature, priority in the counting room. Data are validated, and a determination is made as to whether there has been an actual release. 
Table 2-5

CERCLA Releases Reported to Regulatory Agencies in 1998

\begin{tabular}{llll}
\hline Date & $\begin{array}{l}\text { Applicable Regulation/ } \\
\text { Reason for Notification }\end{array}$ & $\begin{array}{l}\text { Agencies } \\
\text { Notified }\end{array}$ & Description \\
\hline May 4 & Exceeded RQ of 10 pounds & EPASCDHEC & $\begin{array}{l}\text { About 15 gallons of F006 wastewater } \\
\text { spilled during the melter process in } \\
\text { M-Area. }\end{array}$ \\
\hline
\end{tabular}

If there has been, then consequences to the public and the environment are determined.

\section{Occurrences Reported to Regulatory Agencies}

"Federally permitted" releases comply with legally enforceable licenses, permits, regulations, or orders. Under the Atomic Energy Act, for example, releases of SRS radionuclides are federally permitted as long as public dose standards in DOE orders are not exceeded.

If a nonpermitted release to the environment of a reportable quantity (RQ) or more of a hazardous substance (including radionuclides) occurs, CERCLA requires notification of the National Response Center. Also, the CWA requires that the National Response Center be notified if an oil spill causes a "sheen" on navigable waters, such as rivers, lakes, or streams. Oil spill reporting was reinforced with liability provisions in CERCLA's National Contingency Plan.

Other CERCLA provisions allow exemptions from reporting a release of an $\mathrm{RQ}$ or more of a hazardous substance if the release is federally permitted or covered by a continuous-release notification. A continuous-release notification provides an exemption from reporting each release of a specific hazardous substance greater than an RQ. The site submitted two continuous-release notifications in 1992--for ethylene glycol and for asbestos, each of which had a statutory RQ of 1 pound. SRS withdrew the request for continuous-release notification status for ethylene glycol in 1995, when EPA made an adjustment to that $R Q$. The asbestos continuous-release notification request is still active.

During 1998, SRS notified regulatory agencies of one CERCLA reportable release, which is described in table 2-5. This performance compares with three such releases reported during 1997, two during 1996, and four during 1995.

Seven other notifications-not required by CERCLA - were made by the site to regulatory agencies during 1998. Four of these were made to inform the agencies, principally SCDHEC, of events such as permit exceedances. The other three were the result of an agreement to notify SCDHEC about sewage and petroleum product releases. The agreement requires reporting of sewage releases "equal to or greater than 100 gallons" and of petroleum product releases "equal to or greater than 25 gallons" unless the releases come in contact with "waters of the state." In these cases, releases in any amount are to be reported-whether for sewage or for petroleum products. All three of the agreement-based notifications were for sewage releases.

EPCRA (40 CFR 355.40) requires that reportable releases of extremely hazardous substances or CERCLA hazardous substances be reported to any local emergency planning committees and state emergency response commissions likely to be affected by the release. No EPCRA reportable releases occurred in 1998.

It is SRS policy to notify SCDHEC and the Georgia Department of Natural Resources (GDNR) of any occurrence that may interest state regulatory agencies. Although not required by law, these "courtesy notifications" enhance environmental protection objectives. In 1997, SRS expanded the plan for the courtesy notifications in response to a request by local governments. The expanded notification plan includes such occurrences as shelter alarms and stack monitoring alarms, even though they may be false alarms.

\section{Site Item Reportability and Issues Management Program}

The Site Item Reportability and Issues Management (SIRIM) program, mandated by DOE Order 232.1A (which superceded DOE Order 232.1), "Occurrence Reporting and Processing of Operations Information," is designed to "... establish a system for reporting of operations information related to DOE-owned or operated facilities and processing of that information to provide for appropriate corrective action...." It is the intent of the order that DOE be “... kept fully and currently informed of all events which could: (1) affect the health and safety of the 
Table 2-6

Environmentally Related Unusual Occurrences Reported Through SIRIM in 1998

\begin{tabular}{llll}
\hline $\begin{array}{l}\text { Discovery } \\
\text { Date }\end{array}$ & Occurrence & $\begin{array}{l}\text { Report No. } \\
\text { (SR-WSRC-) }\end{array}$ & Cause/Explanationa \\
\hline May 4 & $\begin{array}{l}\text { About 15 gallons of F006 } \\
\text { wastewater spilled during the } \\
\text { melter process in M-Area }\end{array}$ & RMAT-1998-0003 & Spill caused by a line break \\
\hline
\end{tabular}

a SRS takes followup corrective actions to minimize the impact on the environment.

public; (2) seriously impact the intended purpose of DOE facilities; (3) have a noticeable adverse effect on the environment; or (4) endanger the health and safety of workers."

The SIRIM program at SRS is designed to meet the requirements of DOE Order 232.1A by ensuring that

- all occurrences specified are identified in a timely manner, categorized, and reported

- proper corrective actions are taken in a timely manner

- all reportable occurrences are reviewed to assess significance and root causes

- occurrence reports to DOE operations are disseminated to prevent the recurrence of similar events

All SIRIM events are classified in one of the following categories: (1) facility condition; (2) environmental; (3) personnel safety; (4) personnel radiation protection; (5) safeguards and security; (6) transportation; (7) value-based reporting; (8) facility status; (9) nuclear explosive safety (not applicable at SRS); or (10) cross-group items. The impact-or the anticipated impact - of each event is categorized as follows (based on criteria in site procedures):

- Emergency - the most serious event; requires increased alert status for onsite and, in specific cases, offsite authorities

- Unusual occurrence - a nonemergency event that has significant impact or potential for impact on safety, environment, health, security, or operations

- Off-normal occurrence - an abnormal or unplanned event or condition that deviates from established standards or specifications

In 1998, of the 561 SIRIM-reportable events, 24 were categorized as primarily environmental. Of these 24 , none were classified as emergencies, one was classified as an unusual occurrence, and 23 were classified as off-normal occurrences. Table 2-6 lists the one unusual occurrences reported through SIRIM in 1998.

\section{Assessments/lnspections}

The SRS environmental program is overseen by a number of organizations, both outside and within the DOE complex. In 1998, the WSRC environmental appraisal program consisted of self and independent assessments. The program employs total-quality management concepts that support the site's four imperatives of safety, disciplined operations, continuous improvement, and cost effectiveness. It also ensures recognition of noteworthy practices, identification of performance deficiencies, and initiation and tracking of associated corrective actions until they are satisfactorily completed. The primary objectives of the WSRC assessment program are to ensure compliance with regulatory requirements and to foster continuous improvement. WSRC conducted 16 self assessments in 1998. These covered such areas as surface and domestic water quality, toxic and chemical materials, waste management, environmental radiation protection, environmental quality assurance, air quality protection, and facility permitting.

An improvement initiative jointly entered into by WSRC and DOE will combine the development and execution of the site environmental program self-assessment plan activities as an integrated effort. This process, piloted late in the 1997 program self-assessment cycle, was implemented in 1998.

During 1998, personnel from DOE-SR's Environmental Quality \& Management Division performed direct oversight and evaluation of WSRC's self-assessment program to ensure that it continues to meet the needs and expectations of DOE Order 5482.1B, "Environment, Safety, and Health Appraisal Program"; Savannah River Implementation Procedure (SRIP) 200, Chapter 223.4, "SR Technical Assessment Program"; and SRIP 450.1, "SR Environmental Protection Program." Completed 
assessments have met with positive results; routine assessments promoted improvement and helped ensure the adequacy of environmental programs and operations at SRS.

SCDHEC also inspects the SRS environmental program for regulatory compliance. Agency representatives performed three comprehensive compliance inspections in 1998, as follows:

- During the period April 13 to May 7, annual air compliance inspections were conducted for 54 of the site's 157 operating permitted air emission sources. The air emission sources were in compliance.

- The 1998 Comprehensive Monitoring Evaluation (a RCRA inspection) of SRS was conducted May $11-20$ by SCDHEC. Approximately 130 areas were visited during the evaluation, which is aimed at ensuring compliance with state solid and hazardous waste management regulations. During a closeout meeting, SCDHEC termed the site's performance in this area "excellent" and made no findings or observations. At a hearing with SCDHEC following the meeting, a warning was issued for maintenance of greater than 55 gallons of waste in an SREL satellite area (self reported by SRS in May 1998), but no deficiencies were cited-either during the hearing or in SCDHEC's final report, which was issued June 11.

- During the period October 12-22, annual CWA/NPDES operation and maintenance inspections were performed at SRS wastewater treatment facilities, and grab and composite samples were collected at site NPDES discharge points. No deficiencies were noted at the time of the inspection, but SCDHEC is expected to issue a final report-including category ratings-in early 1999.

SCDHEC also performed monthly compliance inspections during the year, with no deficiencies noted.

\section{Environmental Permits}

SRS has 697 construction and operating permits that specify operating levels for each permitted source. This compares with 675 such permits in 1997, 668 in 1996,643 in 1995, and 608 in 1994. Table 2-7 summarizes the permits held by the site during the past 5 years. These numbers reflect only permits obtained by WSRC for itself and for other SRS contractors that requested assistance in obtaining permits.

\section{Environmental Training}

The site's environmental training program identifies training activities to teach job-specific skills that protect the employee and the environment while satisfying regulatory training requirements. Chapter 3 contains more information about the training program.

\section{Facility Decommissioning}

With the rapidly declining need for a large nuclear weapons stockpile, many SRS facilities no longer are needed to produce or process nuclear materials. They have become surplus and must be dispositioned safely and economically. Many of them are large and complex and contain materials that, if improperly handled or stored, could be hazardous. SRS faces a major task in the cleanup, reuse, safe storage, and demolition of these facilities. The Facilities Decommissioning Division was established in 1996 to meet this challenge. The site's 1998 deactivation and decommissioning activities are discussed in chapter 4 .

\section{Other Major Environmental Issues and Actions}

DOE-SR signed a ROD December 23, 1997, on the final EIS for the SRS river water system shutdown. Based on the environmental information found in the EIS, and on economic and regulatory considerations, DOE-SR has decided to continue to operate and maintain the river water system for the immediate future. This means that the water in L-Lake-a 1,000-acre, manmade lake created in 1985 to disperse and cool water from L-Reactor-will be maintained at its current level. PAR Pond-a 2,640-acre lake created in 1958 to disperse and cool water from P-Reactor and R-Reactor-also is supplied by the river water system, but its level is adequately maintained through rainfall and groundwater seepage.

The river water system was constructed in the late 1950 s to pump cooling water from the Savannah River to the site's five nuclear material production reactors. At the reactor areas, the water passed through heat exchangers to absorb heat from the reactor cores. Though the reactors no longer are operational, the river water system continues to be used to support fire protection efforts and the sanitary waste treatment plant and to maintain L-Lake's water level.

The EIS process was initiated to study cost savings and environmental impacts associated with operation and maintenance of the river water system. The EIS evaluated three options: 
Table 2-7

SRS Construction and Operating Permits, 1994-1998

\begin{tabular}{lrrrrr}
\hline Type of Permit & \multicolumn{5}{c}{ Number of Permits } \\
\hline & 1994 & 1995 & 1996 & 1997 & 1998 \\
Air & 189 & 200 & 196 & 198 & 202 \\
U.S. Army Corps of Engineers 404 & 1 & 0 & 0 & 1 & 1 \\
Army Corps of Engineers Nationwide Permit & $\mathrm{a}$ & $\mathrm{a}$ & 8 & 6 & 6 \\
Domestic Water & 152 & 165 & 178 & 186 & 194 \\
Industrial Wastewater & 83 & 90 & 87 & 84 & 83 \\
NPDES-Discharge & 2 & 2 & 2 & 1 & 1 \\
NPDES-General Utility & 0 & 0 & 0 & 1 & 1 \\
NPDES-No Discharge & 1 & 1 & 1 & 1 & 1 \\
NPDES-Stormwater & 2 & 2 & 2 & 2 & 2 \\
RCRA & 1 & 1 & 1 & 1 & 1 \\
Sanitary Wastewater & 133 & 133 & 135 & 137 & 139 \\
SCDHEC 401 & 1 & 1 & 1 & 2 & 2 \\
SCDHEC Navigable Waters & $\mathrm{a}$ & $\mathrm{a}$ & 4 & 4 & 4 \\
Solid Waste & 6 & 6 & 6 & 5 & 5 \\
Underground Injection Control & 7 & 13 & 18 & 17 & 31 \\
Underground Storage Tanks & $31^{\mathrm{b}}$ & $29 \mathrm{~b}$ & 29 & 29 & 24 \\
\cline { 2 - 6 } & 608 & 643 & 668 & 675 & 697
\end{tabular}

a Formal tracking of these permits was initiated in 1996.

b Additional underground storage tank permits not previously reported were identified in 1996, so numbers from 1995 and years prior have been changed accordingly.

- continuing operation of the system

- shutting down the system but maintaining it for potential restart

- shutting down and deactivating the system, with no maintenance for potential restart

Shutting down the system eventually would have lowered the level of L-Lake.

The river water system has continued to operate while DOE-SR conducts a characterization of L-Lake under CERCLA; the characterization work is expected to begin by the year 2000. DOE has an agreement with EPA and SCDHEC that provides a commitment and schedule for the comprehensive remediation of contamination at SRS, including that at site streams and lakes. Sediments that contain low-level radionuclides remain under the lake-primarily in the former Steel Creek stream bed. The contaminated sediments were deposited prior to creation of the lake.

Continued operation of the river water system while the characterization efforts are being completed is expected to enable DOE-SR to determine the best ultimate course of action for the system. 
Table 2-8 RCRA and RCRA/CERCLA Units at SRS - 1998

Page 1 of 5

\begin{tabular}{|c|c|c|}
\hline Unit and Location & $\begin{array}{l}\text { Building or Identification } \\
\text { Number(s) }\end{array}$ & Additional Information \\
\hline \multicolumn{3}{|l|}{ A-Area and M-Area } \\
\hline A-Area Burning/Rubble Pits & $731-\ddot{A},-1 A,-2 A$ & Field start initiated 6/28/94 \\
\hline A-Area Coal Pile Runoff Basin & $788-3 A$ & \\
\hline A-Area Miscellaneous Rubble Pile & $731-6 \mathrm{~A}$ & \\
\hline A-Area Stormwater Outfalls & $\mathrm{A}-001,-002,-024, \mathrm{~A}-013$ & \\
\hline 716-A Motor Shop Seepage Basin & $904-101 G$ & Final ROD issued 9/17/98 \\
\hline $\begin{array}{l}\text { M-Area Hazardous Waste } \\
\text { Management Facility (HWMF), } \\
\text { including }\end{array}$ & $904-51 G, 904-112 G$ & RCRA-regulated \\
\hline AM Groundwater Portion & $904-110$ & $\begin{array}{l}\text { RCRA-regulated; } \\
\text { interim-action ROD issued }\end{array}$ \\
\hline $\begin{array}{l}\text { M-Area HWMF Settling Basin } \\
\text { Inactive Process Sewers to } \\
\text { Manhole } 1\end{array}$ & $081-\mathrm{M}$ & RCRA-regulated \\
\hline M-Area HWMF Vadose Zone & & $\begin{array}{l}\text { RCRA-regulated; } \\
\text { interim-action ROD issued }\end{array}$ \\
\hline M-Area West & $631-21 G$ & Final ROD issued 9/29/95 \\
\hline Met Lab Basin/Carolina Bay & $904-110$ & $\begin{array}{l}\text { RCRA-regulated; } \\
\text { interim-action ROD issued }\end{array}$ \\
\hline $\begin{array}{l}\text { Miscellaneous Chemical Basin/ } \\
\text { Metals Burning Pits }\end{array}$ & $731-4 A,-5 A$ & Field start initiated $8 / 26 / 94$ \\
\hline Silverton Road Waste Site & $731-3 A$ & Final ROD issued $4 / 22 / 97$ \\
\hline SRL Seepage Basins & $904-53 G 1,-53 G 2,-54 G,-55 G$ & Field start initiated 9/25/96 \\
\hline SRL 904-A Process Trench & $904-A$ & $\begin{array}{l}\text { Time-critical removal initiated } \\
\text { in fiscal year } 1997\end{array}$ \\
\hline \multicolumn{3}{|l|}{ C-Area } \\
\hline C-Area Burning/Rubble Pit & $131-C$ & Field start initiated 8/22/95 \\
\hline C-Area Coal Pile Runoff Basin & $189-C$ & Final ROD issued 11/10/98 \\
\hline C-Area Reactor Seepage Basins & $904-066 \mathrm{G},-067 \mathrm{G},-068 \mathrm{G}$ & Field start initiated 6/25/98 \\
\hline C-Area Stormwater Outfall & $\mathrm{C}-004$ & \\
\hline Tank 105-C & & $\begin{array}{l}\text { RCRA-regulated; final ROD } \\
\text { issued 9/23/94 }\end{array}$ \\
\hline \multicolumn{3}{|l|}{$\begin{array}{l}\text { General Separations and Waste } \\
\text { Management Areas (E-, F-, H-, S-, Y-, and } \\
\text { Z-) }\end{array}$} \\
\hline \multicolumn{3}{|l|}{ Burial Ground Complex comprised of } \\
\hline $\begin{array}{l}\text { Low Level Radioactive Waste } \\
\text { Disposal Facility (nonhazardous } \\
\text { portion) }\end{array}$ & 643-7E & RCRA-regulated \\
\hline
\end{tabular}


Table 2-8 RCRA and RCRA/CERCLA Units at SRS - 1998

Page 2 of 5

\begin{tabular}{|c|c|c|}
\hline Unit and Location & $\begin{array}{l}\text { Building or Identification } \\
\text { Number(s) }\end{array}$ & Additional Information \\
\hline Mixed Waste Management Facility & $643-28 E$ & $\begin{array}{l}\text { RCRA-regulated; final ROD } \\
\text { issued } 9 / 23 / 93\end{array}$ \\
\hline $\begin{array}{l}\text { Old Radioactive Waste Burial } \\
\text { Ground }\end{array}$ & $643-E$ & $\begin{array}{l}\text { Interim-action ROD issued } \\
5 / 30 / 96\end{array}$ \\
\hline \multicolumn{3}{|l|}{ Solvent Tanks S01-S22 } \\
\hline \multicolumn{3}{|l|}{ Burial Ground Complex Groundwater } \\
\hline Burma Road Rubble Pit & $231-4 F$ & Final ROD issued $7 / 8 / 96$ \\
\hline 211-FB Pu-239 Release & $081-F$ & \\
\hline F-Area Acid/Caustic Basin & $904-47 G$ & RCRA-regulated \\
\hline F-Area Burning/Rubble Pits & $231-F,-1 F,-2 F$ & Final ROD issued 4/22/97 \\
\hline \multicolumn{3}{|l|}{ F-Area Canyon Groundwater } \\
\hline F-Area Coal Pile Runoff Basin & $289-F$ & Final ROD issued 11/10/98 \\
\hline \multicolumn{3}{|l|}{ F-Area Groundwater } \\
\hline $\begin{array}{l}\text { F-Area Hazardous Waste Management } \\
\text { Facility }\end{array}$ & $904-41 G,-42 G,-43 G$ & $\begin{array}{l}\text { RCRA-regulated; final ROD } \\
\text { issued }\end{array}$ \\
\hline $\begin{array}{l}\text { F-Area Inactive Process Sewer Lines } \\
\text { from Building to Security Fence }\end{array}$ & $081-1 F$ & \\
\hline F-Area Retention Basin & $281-3 F$ & Final ROD issued 10/19/98 \\
\hline $\begin{array}{l}\text { F-Area Seepage Basin Groundwater } \\
\text { Operable Unit }\end{array}$ & $904-44 \mathrm{~F}$ & $\begin{array}{l}\text { RCRA-regulated; } \\
\text { interim-action ROD issued }\end{array}$ \\
\hline \multicolumn{3}{|l|}{$\begin{array}{l}\text { F-Area Tank Farm Groundwater } \\
\text { Operable Unit }\end{array}$} \\
\hline H-Area Acid/Caustic Basin & $904-75 G$ & RCRA-regulated \\
\hline H-Area Coal Pile Runoff Basin & 289-H & \\
\hline $\mathrm{H}$-Area Ditch to Outfall $\mathrm{H}-012$ & $\mathrm{H}-012$ & \\
\hline \multicolumn{3}{|l|}{ H-Area Groundwater } \\
\hline $\begin{array}{l}\text { H-Area Hazardous Waste Management } \\
\text { Facility }\end{array}$ & $904-44 G,-45 G,-46 G,-59 G$ & $\begin{array}{l}\text { RCRA-regulated; final ROD } \\
\text { issued }\end{array}$ \\
\hline $\begin{array}{l}\text { H-Area Inactive Process Sewer Lines } \\
\text { from Building to the Security Fence }\end{array}$ & $081-H$ & \\
\hline H-Area Retention Basin & $281-3 \mathrm{H}$ & $\begin{array}{l}\text { RCRA permit modification } \\
\text { not required }\end{array}$ \\
\hline $\begin{array}{l}\text { H-Area Seepage Basin Groundwater } \\
\text { Operable Unit }\end{array}$ & & $\begin{array}{l}\text { RCRA-regulated; } \\
\text { interim-action ROD issued }\end{array}$ \\
\hline H-Area Stormwater Outfall H-013 & $\mathrm{H}-013$ & \\
\hline \multicolumn{3}{|l|}{$\begin{array}{l}\text { H-Area Tank Farm Groundwater } \\
\text { Operable Unit }\end{array}$} \\
\hline Old F-Area Seepage Basin & $904-49 G$ & Final ROD issued 6/19/97 \\
\hline
\end{tabular}


Table 2-8 RCRA and RCRA/CERCLA Units at SRS - 1998

Page 3 of 5

\begin{tabular}{cll}
\hline Unit and Location & $\begin{array}{l}\text { Building or Identification } \\
\text { Number(s) }\end{array}$ & Additional Information \\
\hline Warner's Pond & $685-23 \mathrm{G}$ & $\begin{array}{c}\text { RCRA permit modification } \\
\text { not required }\end{array}$
\end{tabular}

K-Area

K-Area Acid/Caustic Basin

K-Area Bingham Pump Outage Pit

K-Area Burning/Rubble Pit

K-Area Coal Pile Runoff Basin

K-Area Reactor Seepage Basin

K-Area Rubble Pile

K-Area Sludge Land Application Site

K-Area Stormwater Outfall

K-Area Tritium Anomaly

L-Area

Chemicals, Metals, and Pesticides Pits

Gas Cylinder Disposal Facility

L-Area Bingham Pump Outage Pits

L-Area Buming/Rubble Pits

L-Area Hot Shop

L-Area Oil/Chemical Basin and L-Area Acid/Caustic Basin

L-Area Rubble Pits

L-Area Southern Groundwater

L-Area Stormwater Outfall

$\mathrm{N}$-Area (Central Shops)

Central Shops Burning/Rubble Pits

Central Shops Burning/Rubble Pits

Central Shops Sludge Lagoon

P-Area

P-Area Acid/Caustic Basin
904-080G

643-1G

$131-K$

$189-K$

904-65G

631-20G

761-4G

$\mathrm{K}-011$
RCRA-regulated

Final ROD issued 4/14/98

Final ROD issued 11/10/98

RCRA permit modification not required

RCRA permit modification not required

080-17G, $-17.1 \mathrm{G},-18 \mathrm{G},-19 \mathrm{G}$, Field start initiated 9/29/94 $-18.1 G,-18.2 G,-18.3 G$

Final ROD planned for fiscal year 1998

$131-2 L$

$643-2 G,-3 G$

$131-L,-3 L$

Time-critical removal initiated in fiscal year 1997

Final ROD planned for fiscal year 1998

Field start initiated 11/3/97

Time-critical removal initiated in fiscal year 1997

$717-G$

904-83G, $-77 G$

Final ROD issued 1/5/98; remedial action initiated $8 / 31 / 98$

$131-1 L,-4 L$

$L-012$

$631-G,-3 G,-5 G$

631-6G

Final ROD issued 6/19/97

080-24G

Field start initiated 12/21/98

RCRA-regulated 
Table 2-8 RCRA and RCRA/CERCLA Units at SRS - 1998

Page 4 of 5

\section{Unit and Location}

P-Area Bingham Pump Outage Pits

P-Area Burning/Rubble Pit

P-Area Coal Pile Runoff Basin

P-Area Stormwater Outfall

R-Area

Overflow Basin

PAR Pond (including pre-cooler ponds and canals)

PAR Pond Sludge Land Application Site

R-Area Acid/Caustic Basin

R-Area Bingham Pump Outage Pits

R-Area Burning/Rubble Pits

R-Area Reactor Seepage Basins

R-Area Rubble Pile

Sanitary Landfill

Sanitary Landfill

Sanitary Landfill Groundwater

TNX and D-Areas

D-Area Oil Seepage Basin

D-Area Ash Basin

D-Area Burning/Rubble Pits

D-Area Coal Pile Runoff Basin

D-Area Waste Oil Facility

New TNX Seepage Basin

Old TNX Seepage Basin

TNX Burying Ground

TNX Groundwater

West of SREL "Georgia Fields" Site Other

Fire Department Hose Training Facility

\section{Building or Identification} Number(s)

643-G

$131-P$

189-P

$\mathrm{P}-010$

$108-4 R$

$685-G$

$761-5 G$

904-79G

$643-8 G,-9 G,-10 G$

131-R, $-1 R$

904-57G, -58G, -59G, -60G $-103 G,-104 G$

631-25G

$740-G$

$631-G$

488-D

431-D, -1D

489-D

484-D

904-102G

904-076G

643-5G

$082-G$

631-19G

\section{Additional Information}

RCRA permit modification not required

Final ROD planned for fiscal year 1998

Field start initiated 3/25/98

Final ROD issued 11/10/98

Field start initiated 9/28/95

Interim-action ROD issued 2/16/95

Final ROD planned for fiscal year 1998

Final ROD planned for fiscal year 1998

Portions RCRA-regulated

RCRA-regulated

Interim-action ROD issued 2/16/95; final ROD submitted 8/28/98

Field start initiated 9/29/98

Final ROD issued 4/22/97

Field start initiated 9/29/98

Interim-action ROD issued 11/16/94

Final ROD issued 9/17/98 
Table 2-8 RCRA and RCRA/CERCLA Units at SRS - 1998

Page 5 of 5

\section{Unit and Location}

Ford Building Seepage Basin

Ford Building Waste Site

Fourmile Branch Integrator Operable Unit

G-Area Oil Seepage Basin

Grace Road Site

Gunsite 113 Access Road

Gunsite 218 Rubble Pile

Gunsite 720 Rubble Pit

Hydrofluoric Acid Spill

\section{Building or Identification Number(s)}

904-91G

643-11G

761-13G

631-22G

$631-24 G$

$631-23 G$

631-16G

$631-4 G$

\section{Additional Information}

Time-critical removal completed in fiscal year 1997

Final ROD issued 4/22/97

Final ROD issued 4/22/97

Final ROD planned for fiscal year 2012

Final ROD issued 4/22/97

RCRA permit modification not required

Lower Three Runs Integrator Operable Unit

Pen Branch Integrator Operable Unit

Road A Chemical Basin

904-111G

Savannah River Integrator Operable Unit

Savannah River Floodplain Swamp Integrator Operable Unit

SRL Oil Test Site

080-16G

Steel Creek Integrator Operable Unit

Steel Pond

Upper Three Runs Integrator Operable Unit

X-001 Outfall Drainage Ditch

$x-001$

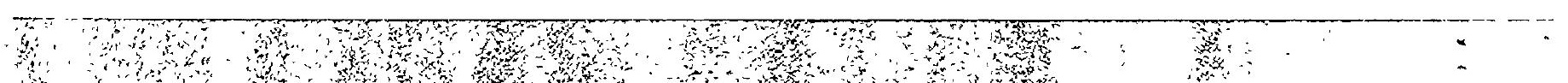


Program

\section{Information}

\author{
Mary Dodgen and Greg Peterson \\ Environmental Protection Department
}

ISO 14001 ..................... 44

Environmental Monitoring ........... 44

Dose Reconstruction Study ............ 49

Pollution Prevention .................. 49

Public Involvement ................. 51

Employee Training .............. 53

Information Exchange............. 54

Public Outreach ................ 54

\section{Highlights}

- SRS maintained its ISO 14001 certification as the result of the annual surveillance by a third-party registrar conducted in February 1998. The SRS Environmental Management Systems Policy provides the basis for environmental programs and emphasizes vigilance in protecting human health and ecological or natural resources.

- The Enhanced Tritium Monitoring program, designed to provide sufficient warning to the downstream water authorities in the event of an abnormal tritium release from site facilities, was implemented in October.

- Solid waste generators identified more than 130 waste reduction initiatives with potential to reduce forecasted waste generation by more than 35,000 cubic feet over a 12 -month period. These initiatives represent part of an approximate 70 percent reduction in radioactive and hazardous solid waste generation rates achieved from 1991 to 1998. The decrease is attributed largely to waste minimization efforts, but also to changing site missions.

- In fiscal year 1998 , almost 4,400 tons of nonradioactive, nonhazardous materials were recycled at SRS, including 995 tons of paper, cardboard, and aluminum cans-as well as approximately 3,400 tons of recyclable materials through WSRC's Salvage Operations group.

- Each year, WSRC employees are involved in many programs designed to bring science and mathematics to local teachers and students. For the 1997-1998 school year, an estimated 50,000 contacts were made with students in surrounding communities through these programs. One educational initiative was the Research Intern Program, which placed 143 students, teachers, and faculty members in research intern positions in fiscal year 1998. The School-to-Work Program provided 119 high school and postsecondary students with work-based learning experiences at SRS in fiscal year 1998.

$\mathrm{B}$ eginning with preconstruction in the early 1950s, the Savannah River Site (SRS) has been concerned with stewardship of the environment as shown through its policies, procedures, and performance. Through the years, environmental programs have evolved to complement site missions. Policies related to these programs were formalized in recent years in the SRS Environmental Management System Policy, which emphasizes vigilance in protecting human health and ecological or natural resources. The full text of this policy is provided in appendix A, "Applicable Guidelines, Standards, and Regulations."

The 1998 Environmental Management System senior management review resulted in no substantive change to the site policy. (Updating the signatories-due to top management position changes-was required.) Senior management determined that the policy continued to apply to their philosophy of environmental stewardship, pollution prevention, regulatory compliance, and continual improvement. These fundamental commitments continued during 1998.

Information in this chapter exemplifies SRS's adherence to this policy. Included are

- particulars about the International Organization for Standardization (ISO) 14000 series and SRS's ISO 14001 Environmental Management System Standard certification within the 14000 series.

- a general overview of environmental programs, including monitoring. Two goals of the environmental monitoring program are to measure concentration or quantity of contaminants (both radiological and nonradiological) released from site operations and to provide a technical basis for any needed corrective action. Also, the data generated provide evidence as to whether or not applicable federal, state, and local standards, as well as U.S. 
Department of Energy (DOE) orders, are being met.

- an overview of the SRS Dose Reconstruction Study, which is an evaluation of historical monitoring data and other site records. An objective of this study is to provide an independent assessment of potential human health risk to populations exposed to radioactive materials and chemicals released into the surrounding environment since site operations began in the 1950s.

- a description of the site's pollution prevention program. The goal of this program is to reduce the impact of site operations on the environment by focusing on source reduction, on recycling, and on increasing employee awareness of-and participation in-waste minimization.

- an account of public involvement activities, a fundamental part of DOE's decision-making process. Included in this section is a summary of the SRS Citizens Advisory Board (CAB) stakeholder functions and its recommendations.

- descriptions of activities-such as employee training, information exchange, and public outreach-that offer ways to provide job-related knowledge and develop job-related skills; to share information about site operations, programs, and objectives; and to address public concerns.

Various site organizations have lead responsibility for the environmental programs. These groups are Westinghouse Savannah River Company's (WSRC) Environmental Protection Department (EPD); Safety and Health Operations (S\&HO); Savannah River Technology Center (SRTC); Savannah River Ecology Laboratory (SREL); Savannah River Natural Resource Management and Research Institute (SRI); and Savannah River Archaeological Research Program (SRARP). SRTC, SREL, SRI, and SRARP are discussed briefly in chapter 1 , "Introduction."
However, the education outreach programs of SREL, SRI, and SRARP, as well as that of WSRC, are discussed in this chapter.

\section{ISO 14001}

The ISO is composed of standards groups from 120 member countries. Founded in 1947, ISO has set international standards for things as varied as paper sizes and automotive parts.

ISO 14000 is a family of voluntary environmental management standards and guidelines. ISO 14001 is the Environmental Management System Standard within the 14000 series. Application of the ISO 14001 environmental management principles increases cost effectiveness and environmental compliance efficiency.

ISO 14001 certification provides evidence to stakeholders that SRS is committed to an environmentally safe site, to pollution prevention, to environmental compliance, and to continual improvement. SRS is the largest multiorganizational and multifunctional operating nuclear site in the United States to achieve ISO 14001 certification. SRS was initially registered in conformance with ISO 14001 in September 1997. The site maintained its ISO 14001 certification as the result of the annual surveillance by a third-party registrar conducted in February 1998.

\section{Environmental Monitoring}

SRS environmental monitoring, which includes both onsite and offsite activities, is the responsibility of EPD's Environmental Monitoring Section (EMS). Also, the Division of Environmental Research of the Academy of Natural Sciences of Philadelphia has performed biological and water quality surveys of the Savannah River since 1951.

The two components of environmental monitoring are effluent monitoring and environmental

\section{Effluent Monitoring and Environmental Surveillance}

Per DOE Order 5400.5, "Radiation Protection of the Public and the Environment":

Effluent monitoring is the collection and analysis of samples or measurements of liquid and gaseous effluents for purposes of characterizing and quantifying contaminants, assessing radiation exposure to members of the public, and demonstrating compliance with applicable standards.

Environmental surveillance is the collection and analysis of samples of air, water, soil, foodstuffs, biota, and other media from DOE sites and their environs and the measurement of external radiation for purposes of demonstrating compliance with applicable standards, assessing radiation exposures to members of the public, and assessing the effects, if any, on the local environment.

Monitoring occurs at the point of discharge, such as an air stack or drainage pipe; surveillance involves looking for contaminants in the environment. 


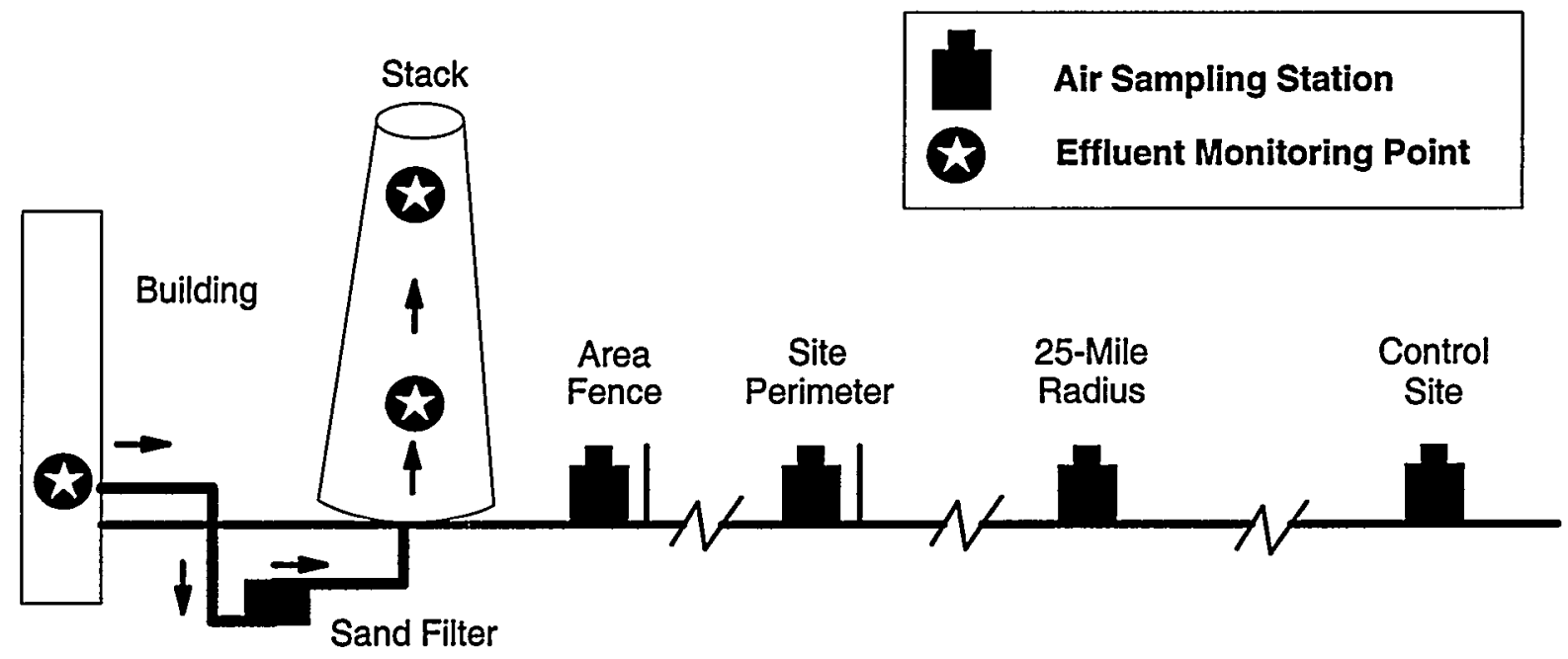

9700407.01.AlL (modified)

Figure 3-1 Typical Airborne Effluent Monitoring and Environmental Surveillance Effluents are monitored at points of discharge. Released materials of concern are tracked in the environment.

surveillance. Additional environmental monitoring information in this report is provided in chapters dealing specifically with

- radiological effluent monitoring (chapter 5)

- radiological environmental surveillance (chapter 6)

- nonradiological effluent monitoring (chapter 8)

- nonradiological environmental surveillance (chapter 9)

- groundwater monitoring (chapter 10)

- special surveys and projects (chapter 12)

\section{Effluent Monitoring}

Effluent monitoring is conducted by collecting and analyzing onsite samples of liquid and airborne effluents taken at or very near their points of discharge to the environment. Radiological effluent monitoring meets regulatory requirements and provides source terms for calculating potential offsite radiation doses. More information about these calculations can be found in chapter 7, "Potential Radiation Doses." In 1998, approximately 4,200 radiological samples were taken at 79 points of discharge.

S\&HO and EMS share the responsibility for radiological effluent monitoring. S\&HO collects and screens air and liquid samples from regulated (radiologically controlled) areas and maintains monitoring equipment on stacks and at some liquid effluent discharge points. EMS collects and analyzes most liquid effluent samples. Following validation, results of these analyses are recorded in a monthly radioactive releases report. Data from the monthly reports are summarized in an annual data publication (in 1998, SRS Environmental Data for 1998, WSRC-TR-98-00314).

SRS handles plutonium, tritium, and other special nuclear materials. Therefore, one focus of the environmental program is to detect possible releases of these radioactive materials from routine operations. This is done by collecting and analyzing samples of airborne and liquid effluents. A typical setup for airborne effluent monitoring is illustrated in figure 3-1. As shown, radioactive materials are monitored at their points of discharge, and air monitoring stations are located strategically to track - and to quantify - the dispersion of any released material into the surrounding environment. Monitoring may be performed at any or all of the identified locations as determined by the rationale discussed on page 47 .

The major nonradiological airborne emissions of concern from SRS stacks include-but are not limited to-sulfur dioxide, oxides of nitrogen, particulate matter, and toxic air pollutants such as trichloroethylene, perchloroethylene, benzene, and hydrochloric acid. Data generated from monitoring nonradioactive contaminants in airborne effluents at SRS provide evidence as to whether or not requirements of permits issued by the South Carolina Department of Health and Environmental Control (SCDHEC) are being met. These permits are 
discussed further in chapter 2, "Environmental Compliance."

As part of a network associated with the federal Clean Air Act, Georgia and South Carolina environmental agencies maintain several monitoring stations near SRS. These stations monitor ambient air to ensure state compliance with federal ambient air quality standards and-because of their proximity to SRS-demonstrate site compliance as well.

Nonradioactive liquid effluents generally are sampled at National Pollutant Discharge Elimination System (NPDES) outfalls (points of discharge) and reported to SCDHEC in a monthly discharge monitoring report, as required by the Clean Water Act. Monitoring requirements for liquids may vary at each outfall, depending on the type of facility and the known characteristics of the wastewater. A typical setup for liquid effluent monitoring is shown in figure 3-2.

\section{Environmental Surveillance}

Environmental surveillance is conducted by collecting and analyzing onsite and offsite samples taken at various distances from points of discharge. In 1998 , approximately 10,000 radiological analyses were performed on approximately 5,000 samples (not including groundwater). In 1998, 34,801 radiological analyses were performed on groundwater samples collected from 1,133 monitoring wells.

Data from radiological environmental surveillance are evaluated to

- detect and characterize contaminants that could adversely affect the environment

- provide a way to verify dose calculations and predictions from mathematical models

Because most contaminants are released in such small amounts that they cannot be readily measured in environmental samples, SRS uses mathematical models to estimate contaminant concentrations in environmental media. The data obtained at the point of discharge (e.g., stack, pipe, or outfall)—where the concentration would be highest if a contaminant were present-is used to calculate the estimated contaminant concentration in sampled media, such as water, soil, or vegetation. More information about modeling can be found in chapter 7 .

Nonradiological environmental surveillance is conducted by collecting and analyzing samples from site streams and the Savannah River to verify the outfall sampling data and to ensure the detection and characterization of materials that could adversely affect the environment. Adverse conditions resulting from the presence of such materials are identified and evaluated to provide a basis for corrective action.

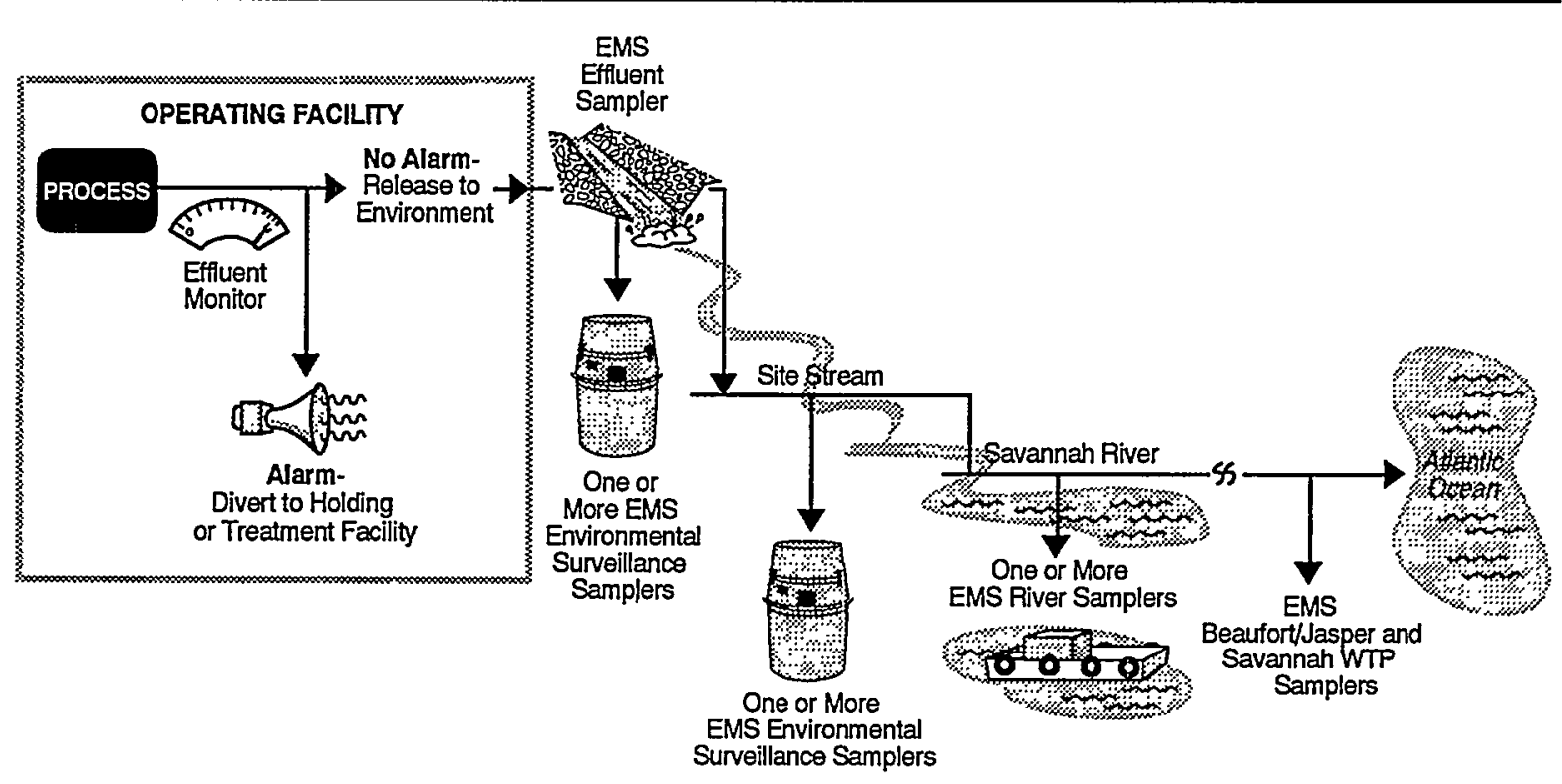

94X06608.57.AIL

Figure 3-2 Typical Liquid Effluent Monitoring and Environmental Surveillance

Effluents are monitored at points of discharge. Released materials of concern are tracked in the environment from discharge to site stream to river to water treatment plants at Beaufort/Jasper and Savannah. 
In 1998, approximately 6,300 nonradiological analyses for specific chemicals and metals were performed on about 1,200 samples, not including groundwater. In 1998, 172,249 nonradiological analyses were performed on groundwater samples collected from 1,133 monitoring wells.

\section{Policy}

SRS policy requires an environmental monitoring program designed to

- establish effluent and ambient levels of radionuclides and other discharges

- determine trends in these releases

- provide a basis for assessment of dose to humans and the environment

- provide information needed to detect and correct problems

SRS is committed to sharing this information with the public and its representatives.

\section{Objectives}

One purpose of environmental regulations is to protect human health and the environment. In support of this purpose, the SRS environmental monitoring

objectives are to

- assess actual or potential exposures of radioactive and nonradioactive materials to critical groups and populations from normal site operations or from accidents

- demonstrate compliance with authorized limits and regulatory requirements or need for corrective action

- verify the adequacy of each facility in containing radioactivity and controlling effluents

- notify appropriate officials of unusual or unforeseen conditions and, if necessary, activate a special environmental monitoring program

- communicate accurate and effective EMS monitoring results to $\mathrm{DOE}$, to other government agencies, and to the general public

- maintain an accurate and continuous record of the effects of SRS operations on the environment

- determine concentrations of radioactive and nonradioactive contaminants in environmental media for the purpose of assessing the immediate and long-term consequences of normal and accidental releases

- distinguish between environmental contamination and effects from SRS operations and those from other sources
- evaluate and revise the environmental monitoring program in response to changing conditions in transport pathways and to the site's changing mission ( the site's change in mission is discussed in chapter 1, page 4).

- provide site-specific data for risk assessment and uncertainty analyses for human populations near SRS

- assess the validity and effectiveness of models used to predict the concentration of pollutants in the environment

- conduct scientific studies on the transport pathways of radioactive and nonradioactive contaminants in the environment

These objectives incorporate the recommendations of the International Commission on Radiological Protection ("Principles of Monitoring for the Radiation Protection of the Public," ICRP Publication 43), of DOE Order 5400.1 ("General Environmental Protection Program"), and of DOE/EH-0173T ("Environmental Regulatory Guide for Radiological Effluent Monitoring and Environmental Surveillance").

As a result of the environmental monitoring program, SRS seeks to

- determine any long-term buildup of - and predict environmental trends from-site-released contaminants

- establish baselines of environmental quality so that trends in the physical, chemical, and biological condition of environmental media can be characterized

- identify and quantify new or existing environmental quality problems, then assess the need for corrective actions or mitigation measures

- pinpoint exposure pathways in which contaminants are accumulated and transmitted to the public

\section{Rationale}

Many factors are considered in the determination of monitoring activities at SRS, including responsible environmental stewardship. Sampling locations, sample media, sampling frequency, and types of analysis are selected on the basis of environmental regulations, exposure pathways, public concerns, and measurement capabilities. More detailed information about the site's environmental monitoring program is documented in sections 1101-1111 (SRS EM Program) of the SRS Environmental Monitoring Section Plans and Procedures, WSRC-3Q1-2, Volume 1 . This document is reviewed annually and updated every 3 years. 
Figure 3-3 Some Potential Exposure Pathways

Airborne and liquid materials released from SRS operations can reach people in a variety of ways. These ways, or routes, are called exposure pathways. 98X00342.01.AlL

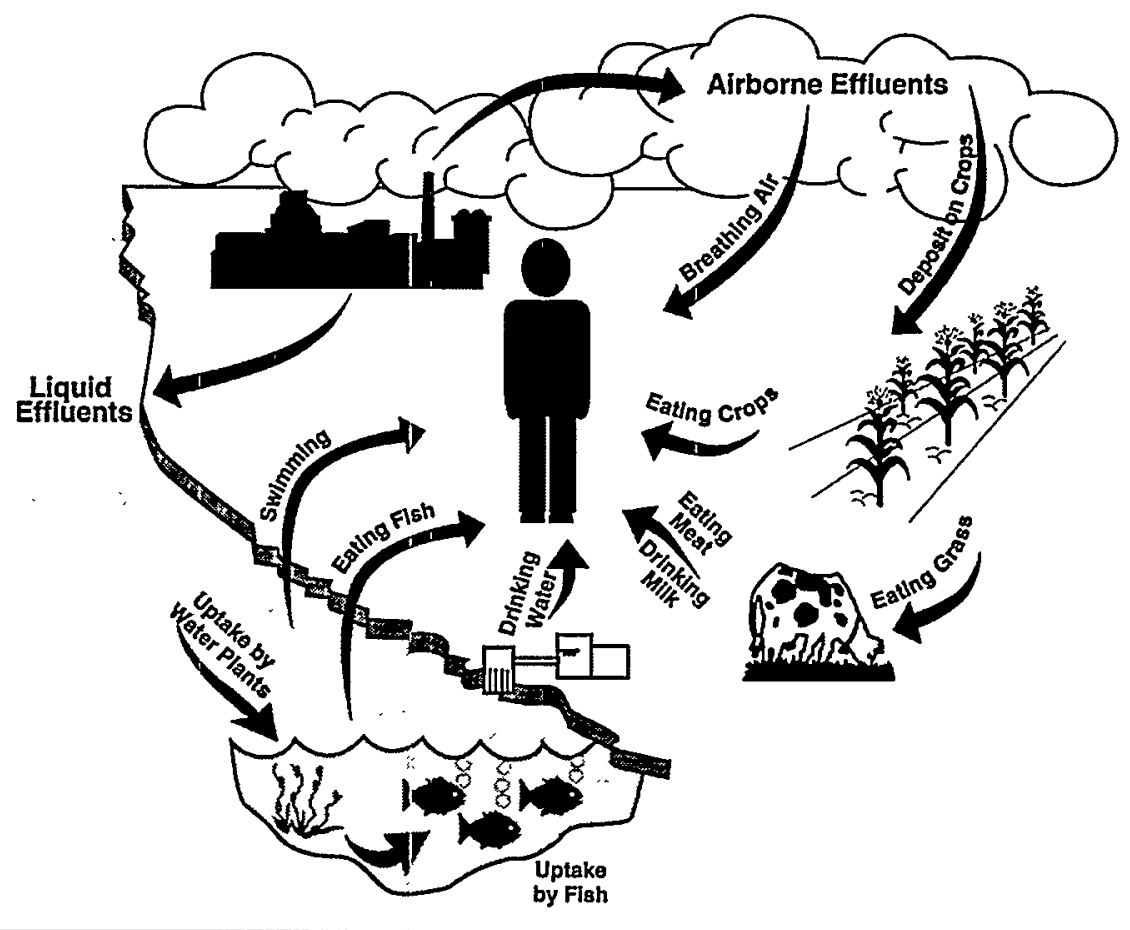

\section{Environmental Regulations}

Environmental monitoring at SRS is designed to meet state and federal regulatory requirements for radiological and nonradiological programs. These requirements are stated in DOE orders 5400.1 and 5400.5 ("Radiation Protection of the Public and the Environment"); in the Clean Air Act-for example, National Emission Standards for Hazardous Air Pollutants (NESHAP); in the Comprehensive Environmental Response, Compensation, and Liability Act (CERCLA-also known as the Superfund); in the Resource Conservation and Recovery Act (RCRA); and in the Clean Water Act-for example, NPDES. SCDHEC, the U.S. Environmental Protection Agency (EPA), and DOE conduct audits to verify that the site complies with environmental regulations. Chapter 2 summarizes the site's compliance status for 1998.

\section{Exposure Pathways}

Materials released from SRS reach the environment and people in a variety of ways. The routes that materials follow to get from an SRS facility to the environment and then to people are called exposure pathways. Some potential exposure pathways are illustrated in figure $3-3$, which shows that materials released into the air may be taken into a human body when a person breathes air or eats food grown near the site-for example, vegetables or beef products. Similarly, materials released into site streams may be taken into the body if a person drinks Savannah River water or eats fish taken from the river. However, the released amounts of radioactive and nonradioactive materials from SRS meet-and are significantly below-all regulatory standards. Thus, they present no known danger to the environment, to site workers, or to the public.

The method used to determine exposure pathways is called a critical pathways analysis. A thorough critical pathways analysis for radioactive materials released from SRS operations was done in 1997 by SRTC's Environmental Analysis Section [Jannik, 1997]. The analysis identified tritium and cesium-137 as the primary contributors to offsite exposures. As expected, potential exposure pathways for tritium released into air were through breathing air and eating food, whereas potential exposure pathways for tritium and cesium- 137 released into site streams were through drinking river water and eating fish from the river.

Critical pathway analyses conducted in late 1996 and in 1997 for nonradioactive materials released from SRS operations identified arsenic and benzene as the primary potential contributors to offsite exposure.

Critical pathways analysis results are used as part of the site's environmental monitoring activities to make decisions about sampling locations, sample media, and sampling frequency. Results from modeling exposure pathways can help

- verify that sampling programs perform as required 
- make the best use of sampling and analysis resources

\section{Public Concerns}

Public concerns influence the site's environmental monitoring activities. The public wants to know about releases and their potential health effects. All aspects of the environmental monitoring program are designed and implemented with public concerns in mind. Some examples include (1) offsite monitoring at air surveillance and population centers with thermoluminescent dosimeters (TLDs) - devices used to measure external gamma radiation that provide a quick, reliable method of determining the dose from gamma-emitting radionuclides in the event of an unplanned release of radioactive material; (2) public drinking water supply monitoring; and (3) fish monitoring in the Savannah River.

\section{Measurement Capabilities}

Many materials released from SRS exist in such low concentrations in the environment that they cannot be readily measured. Thus, the ability to measure low levels of concentrations becomes a significant factor in the rationale for monitoring certain materials. In these cases, modeling with nationally accepted computer programs is used to predict or estimate concentration levels. More information on modeling can be found in chapter 7, and more on measurement capabilities can be found in tables 1-3 in SRS Environmental Data for 1998.

\section{Program Changes}

The types, frequencies, and locations of environmental measurements are reviewed annually to determine how best to continue an effective monitoring program. If a clear rationale for a measurement no longer exists, the measurement is deleted from the program. Likewise, as new sampling/analytical methods evolve or additional needs are identified, new measurements are added to the program.

To address the public's concerns regarding consumption of Savannah River water by the downstream population, SRS implemented the Enhanced Tritium Monitoring program in October 1998. This program was designed to provide sufficient warning to the downstream water authorities in the event of an abnormal tritium release from site facilities.

In 1997, following completion of the critical pathways analysis for radioactive materials released from SRS operations (described on page 48), EMS undertook a comprehensive review of environmental monitoring programs to validate program integrity and ensure best use of sampling and analysis resources. Specific programmatic changes made in 1998 are detailed in subsequent chapters of this report. Additional changes based on the critical pathways analysis will be implemented in 1999.

\section{Dose Reconstruction Study}

SRS has conducted environmental monitoring of radioactive materials and chemicals released to the environment since the beginning of site operations in the early 1950 s. Historical data from this environmental monitoring and from site operations are being evaluated independently by the federal Centers for Disease Control and Prevention (CDC) in Atlanta, Georgia, as part of the SRS Dose Reconstruction Study, to determine the effects these materials may have had on people living near the site.

Phase I of the study-the location and review of records-was completed in 1995 and is discussed briefly in the SRS Environmental Report for 1996 (WSRC-TR-97-0171) and the SRS Environmental Report for 1997 (WSRC-TR-97-00322). Phase II of the study-the source term calculation-was completed in 1998. In phase II, the CDC reconstructed the historical releases of radioactive materials and chemicals to calculate the total amounts and types released from the site to the environment. The phase II results and reports are expected to be released to the public by the CDC in 1999.

Inquiries can be made about the study by writing to Centers for Disease Control and Prevention, 4770 Buford Highway NE, MS F35, Atlanta, GA 30341-3724; by calling 770-488-7040; or by faxing 770-488-7044.

\section{Pollution Prevention}

Pollution prevention at SRS is designed to reduce the impact of site operations on the environment, reduce operational costs, and reduce employee exposure to hazardous materials. Pollution prevention at the site includes

- $\quad$ source reduction activities

- recycling of potential wastes and pollutants

- reduction in the use of materials, energy, water, and other resources

- protection of human health and of natural resources through conservation or more efficient use

- disposal of waste in an environmentally safe manner

Pollution prevention programs are a major focus of many activities, organizations, and implementation 
teams. Improvements in the coordination of and communication between these program areas are ongoing, and employee awareness of-and management emphasis on-pollution prevention is increasing. Highlights of some of the 1998 SRS pollution prevention activities are discussed in the following paragraphs. Certain aspects of pollution prevention also are discussed in chapter 2, pages 19 and 25 .

\section{Waste Minimization}

The SRS Waste Minimization Program continued in 1998 to reduce the generation of solid wastes that require costly treatment, storage, and disposal. The annualized radioactive and hazardous solid waste generation volumes decreased by about 70 percent, or almost 715,000 cubic feet, from 1991 to 1998 . (In calendar year 1991, 972,751 cubic feet of radioactive and hazardous solid waste was generated; in fiscal year 1998, 255,000 cubic feet of radioactive and hazardous solid waste was generated.)

The decrease is attributed largely to waste minimization efforts initiated as a site program in 1991. In 1998, solid waste generators identified more than 130 waste reduction initiatives with potential to reduce forecasted waste generation by more than 35,000 cubic feet over a 12 -month period. Key initiatives included incorporation of commercial radioactive waste reduction practices; emphasis on reduction in the size of radioactive contamination areas; increased use of recyclable-versus disposable-materials for radioactive jobs; and the surveying, decontaminating, and subsequent free-release of previously contaminated materials.

More about waste minimization can be found in chapter 4, "Environmental Management" (page 63).

\section{Solid Waste Recycling}

SRS began using the North Augusta Material

Recovery Facility in July; this increased the amount of routine sanitary waste recovered for recycling. In fiscal year 1998, almost 4,400 tons of nonradioactive, nonhazardous materials were recycled at SRS, including 995 tons of paper, cardboard, and aluminum cans-as well as approximately 3,400 tons of recyclable materials through WSRC's Salvage Operations group. The total number of tons recycled in fiscal year 1998 was about double that recycled in fiscal year 1997 ( 2,445 tons).

Also in fiscal year 1998, SRS recycled more than 40 tons of other potentially hazardous materials, such as lead, fluorescent light bulbs, and photographic silver fixative.

\section{Energy Conservation}

Reducing site demand for energy in turn reduces emissions and conserves resources (e.g., coal) associated with energy production. A comprehensive energy conservation program and site mission changes - that resulted in secession of river water pumphouse operations and shutdowns of facilities (i.e., reactors, power houses)-helped drive down facility energy consumption in British Thermal Units (BTU) per gross square foot by more than 70 percent from 1985 (baseline year) through 1998.

The primary focus during 1998 was the sitewide Energy Savings Performance Contract. Under this contracting mechanism, an Energy Services Company (ESCO) incurs the cost of implementing energy savings measures, including-but not limited to-performing energy audits and studies; designing, acquiring, and installing equipment; and training personnel. The ESCO is required by federal law to guarantee a minimum cost savings resulting directly from implementation of such measures during the term of the contract and is at risk to ensure that this minimum guarantee is achieved. In exchange for providing these services, the ESCO receives a percentage of the cost savings.

In March, a contract was awarded to determine energy conservation opportunities at SRS. In April, the contracted company began an aggressive auditing campaign of 21 administrative buildings in the main administrative area of the site. Recommendations for energy conservation were made to the DOE-Savannah River Operations Office (DOE-SR) in the first draft delivery order issued September 30. The preliminary proposal for Task Order \#1 includes lighting retrofits; redistribution of area heating, ventilation, and air conditioning loads to the more efficient central chilled water loop; application of variable frequency drives; installation of smaller motors in some air handling units; and incorporation of energy management systems to minimize the amount of energy required to meet operational needs. Final review and acceptance of this proposal is anticipated during 1999.

\section{Reduction of Chemical Releases}

Under Section 313 of the Emergency Planning and Community Right-to-Know Act (EPCRA), SRS has filed Toxic Chemical Release Inventory reports annually since 1987 . The site calculates chemical releases to the environment and reports aggregate quantities for each regulated chemical that exceeds threshold amounts. More about Toxic Chemical Release Inventory reports, including summary data results, can be found in chapter 2, page 18 . 


\section{Affirmative Procurement of Recycled Products}

The SRS Affirmative Procurement Program -implemented as part of federal Executive Order 12873, "Federal Acquisition, Recycling and Waste Prevention," and RCRA Section 6002-promotes the purchase of products made from recycled materials to help conserve natural resources. The program is based on DOE guidelines for implementing affirmative procurement requirements at federal facilities. The fiscal year 1998 program continued to expand recycled product purchasing in several areas, including paper, re-refined oil, retread tires, office supplies, and construction and building materials.

\section{Excess-Chemical Management}

The Chemical Commodity Management Center was created and staffed in 1994 to ensure environmentally sound, safe, and cost-effective acquisition, distribution, and reuse of chemicals/excess chemical products for the site. An "excess chemical product" is defined as any reusable material that can be sold, donated, or redistributed on site, that requires a material safety data sheet, and that is in its original form and concentration as received as a stock supply item from a supplier. Some accomplishments included implementing reviews of all chemical procurement requests prior to purchase, coordinating the site's annual EPCRA Tier II chemical inventory (chapter 2), and developing a sitewide chemical management program. In 1998, the excess chemical transfer program (how chemicals are physically transferred to the center) was streamlined, and the number of sales avenues for chemicals was increased. In addition, all hazardous chemical procurement requests were reviewed to identify substitution opportunities and decrease potential RCRA waste.

During 1998, the Chemical Commodity Management Center received 60,000 pounds of excess chemicals but disbursed more than 74,000 pounds of excess chemicals from its total inventory. The disbursements were made to offsite institutions as part of the site's excess chemical sales, recycling, and donation programs. Excess chemical disbursements resulted in the receipt of usable products by offsite institutions and the avoidance of substantial waste disposal costs by the site.

\section{Ozone-Depleting Substances}

The Clean Air Act Amendments of 1990 require that EPA publish a number of regulations to phase out the production and consumption of ozone-depleting substances. SRS has produced an internal guidance document designed to assist the site in the phaseout of these substances. The main objective of the plan is to reduce the use of chlorofluorocarbon (CFC) refrigerants by (1) replacement and retrofit of CFC equipment, (2) sound refrigerant containment practices (such as reducing leaks), and (3) controlling distribution of refrigerants from inventories.

More about ozone-depleting substances can be found in chapter 2, page 29.

\section{Public Involvement}

DOE considers public involvement a fundamental component in program operations, planning activities, and decision making in DOE. The public is encouraged to play a role in $\mathrm{DOE}$ decision making. Public involvement is a major focus in every operational division at SRS and is established annually as one of the major goals in the site's strategic plan.

Stakeholder involvement at SRS follows the legal requirements of the National Environmental Policy Act (NEPA), RCRA, and CERCLA, but also reaches beyond to provide opportunities on the site's budget, future-use activities, and complex-wide issues.

The site's public involvement program offers a comprehensive approach to citizen participation as suggested by DOE policy. The ultimate goal is that the program be dynamic and accessible to any person or organization wishing to have a voice in site activities.

\section{Environmental Restoration}

Within the environmental restoration program, the public is consulted frequently about decisions on closure of waste sites. In 1998, approximately 30 participation opportunities were provided.

Public notices and comments were provided for remedial and limited actions and for no action waste units. Public comment periods were held also for sections of the Federal Facility Agreement- and CERCLA-proposed plans for several SRS operable units. Notices of Availability for three Records of Decision and two Removal Actions were provided in area newspapers, using both display and legal advertisements.

A public workshop was held to discuss remedial options at the Old Radioactive Waste Burial Ground. This workshop was followed by a more intensive public involvement effort- $a$ focus group established by the SRS CAB (more about the $C A B$ can be found on page 52) in November. Additionally, DOE, EPA, 
and SCDHEC cosponsored information exchanges in Barnwell, South Carolina, and Augusta, Georgia, to better inform citizens of timely environmental issues.

\section{National Environmental Policy Act Activities}

Stakeholders participated in many NEPA events regarding future tritium production and storage, stabilization, and disposition of legacy defense nuclear materials. In 1998, SRS supported public involvement in various NEPA Environmental Impact Statement (EIS) activities and the distribution of documents, including

- Accelerator Production of Tritium draft EIS

- Commercial Light Water draft EIS

- Tritium Extraction Facility draft EIS

- Surplus Plutonium draft EIS

- SRS Spent Nuclear Fuel Management draft EIS

- High-Level Waste Tank Closures EIS

\section{Material and Facility Stabilization}

Stakeholders throughout Georgia and South Carolina were encouraged to attend the American Nuclear Society's Third Annual Topical Meeting on DOE Spent Nuclear Fuel and Fissile Material Management held in Charleston, South Carolina.

International experts and top DOE decisions makers provided presentations at the meeting. Additionally, the SRS CAB (next column) was a cosponsor and provided a display for this national conference.

\section{Accelerated Cleanup Plan: Paths to Closure and Savannah River Site Budget Activities}

More than 12 meetings were held on the SRS budget and the draft Accelerating Cleanup: Paths to Closure (ACPC) document. More than 600 stakeholders received copies of the ACPC document, and approximately 70 comments helped to shape its June 1998 release.

Public involvement in the ACPC will be a continual process. The document is updated about every six months to reflect changes in DOE's strategic goals and the national budget.

\section{Risk Communication Activities}

To better inform the public of the potential risks of eating fish from the Savannah River, SRS joined EPA, SCDHEC, and the Georgia Department of
Natural Resources (GDNR) in developing and distributing a fact sheet to Georgia and South Carolina stakeholders. The intense effort to reach subsistence fishermen involved careful development of an understandable fact sheet and distribution of the fact sheet to people living along the river, to SRS employees, to the media, and to health care organizations. Copies of the fact sheet can be obtained by calling the SRS CAB administrator at 1-800-249-8155.

\section{Citizens Advisory Board}

The $C A B$ is an independent organization officially chartered by DOE to provide recommendations and stakeholder insight on site activities to DOE, EPA, and SCDHEC. It provides SRS with ongoing counsel to help guide decisions consistent with stakeholder values and opinions. Thus, it complements regulatory and program stakeholder input. The $\mathrm{CAB}$ is composed of 25 South Carolina and Georgia individuals who reflect the cultural diversity of the population affected by SRS. Membership applications are accepted year-round from stakeholders living in an area ranging from the Central Savannah River Area (CSRA) to Georgia and South Carolina coastal communities downriver of SRS. Applications are placed in membership categories representing labor, environmental, political, educational, and minority groups as well as public officials and the general public. Voting by ballot is held once a year at a full board meeting. Members serve a two-year term. They can serve two additional terms (six consecutive years) if elected.

\section{Recommendations to Federal Agencies}

The citizens group, nationally recognized as being one of the most productive site-specific advisory boards in the DOE complex, provided 27 recommendations to the agencies in late 1997 and 1998. Many of the recommendations for the environmental restoration program focused on disposal of contaminated vegetation at the Savannah River Laboratory Seepage Basins and the issue of disposing of CERCLA wastes at an SRS disposal facility. The $\mathrm{CAB}$ also recommended remedial solutions at the F-Area Retention Basin and the D-Area Oil Seepage Basin.

Recommendations developed by the CAB Nuclear Material Management subcommittee and approved by the full board supported SRS for stabilization of plutonium residues and scrub alloy from the Rocky Flats Environmental Technology Site in Golden, Colorado, and also supported SRS as the preferred location for managing DOE's surplus plutonium disposition program. The $\mathrm{CAB}$ recommended that 
Nuclear Regulatory Commission regulation of DOE facilities be carefully addressed to weigh the benefits and disadvantages thereof. The $\mathrm{CAB}$ continued to emphasize repeatedly that chemical processing should be evaluated fairly against other new and proven technologies for stabilizing spent fuel and nuclear materials.

Several members of the CAB Nuclear Material Management subcommittee served as active participants in DOE studies dealing with research reactor spent nuclear fuel, Nuclear Regulatory Commission oversight of DOE facilities, and the use of SRS's F-Canyon and H-Canyon to stabilize nuclear materials from across the complex.

In its comments on the local and national ACPC, the $\mathrm{CAB}$ included concerns that the documents were neither planning nor budget documents and that they were too long and detailed to be considered strategy documents. The $\mathrm{CAB}$ also expressed concern that facility decontamination and decommission costs were excluded, as well as the cost of landlord responsibility beyond 2028 . The $C A B$ continued to be concerned that SRS funding is less than required.

More information about the CAB's 1998 recommendations can be obtained by calling the SRS $\mathrm{CAB}$ administrator at $1-800-249-8155$ or by visiting the $\mathrm{CAB}$ website at www.srs.gov.

\section{Other Activities}

$\mathrm{CAB}$ activities other than recommendation development during 1998 included the formation of a Risk Working Group to analyze and understand risk management at SRS. This group, divided into four teams, is reviewing the differences in risk assessments funded by various DOE programs and how they roll up into the SRS Integrated Priority List. The group also plans to

- address the issue of compliance versus risk and how risk is communicated to the public

- develop recommendations on how SRS can improve its risk management process and communication methods

In April-when it was determined that in-tank precipitation, a chemical process for removing cesium-137 from the salt solution in the high-level waste tanks, was not working properly-the $\mathrm{CAB}$ formed a focus group to evaluate the process used by SRS to select alternatives to the in-tank precipitation process and to examine in detail the final alternatives chosen.
A final report, issued in October, concluded that efforts by the Salt Disposition Team appeared to be comprehensive in scope and detail and reflected a mature appreciation and use of a "system engineering approach" for evaluation of candidate alternatives. The focus group also provided observations on the final alternatives considered for salt disposition.

During 1998 , the $C A B$ participated in several national stakeholder meetings and increased emphasis on environmental management integration. Board members attended national intersite workshops, a low-level waste seminar, and site-specific advisory board meetings. The $C A B$ hosted visitors from citizens advisory boards from the Nevada Test Site; Oak Ridge Reservation at Oak Ridge, Tennessee; and Pantex Plant at Amarillo, Texas.

\section{Employee Training}

SRS environmental training programs help achieve environmental goals at the site. SRS is committed, as a matter of policy, to maintaining its facilities and conducting its operations in full compliance with all applicable laws and regulations for the protection of the environment and of the health and safety of its employees and the general public. The training program identifies training activities to teach job-specific skills that protect the environment and satisfy regulatory requirements.

Environmental training at SRS addresses good environmental stewardship, which includes compliance with federal and state regulations. The focus is on required training and recommended education courses for employees (based on responsibility) involved with environmental oversight, hazardous materials, and waste management at the site.

DOE-SR and WSRC are working closely with the National Environmental Training Office to determine and/or develop "best-in-class" environmental training courses while reducing costs. These will be made available to SRS environmental professionals and others within the DOE complex.

Environmental training activities in 1998 included the following:

- Site environmental protection coordinators (14) were trained in responsibilities for reporting occurrences having environmental consequences. Training also was provided for DOE and environmental coordinator representatives.

- Site workers (550) received and/or maintained water/wastewater certification.

- More than 50 persons attended environmental training through subcontracted courses. 
- Site workers (670) attended Hazardous Waste Operations courses (29 CFR 1910.120), which provide health and safety training in hazardous-waste cleanup activities and in working at RCRA treatment, storage, and disposal facilities.

- Site workers $(1,398)$ attended RCRA training. (SRS identified isolated incidences of workers who had failed to obtain initial RCRA training within the required time period and who had not taken the required annual RCRA update training. Measures were implemented to help prevent reoccurrences.)

- More than 14,200 site workers took the Consolidated Annual Training course to meet general training requirements, including some environmental training and information about the ISO 14001 program implemented at SRS.

- More than 250 persons attended a variety of environmental training courses dealing with topics such as asbestos, laws/regulations, and occurrence reporting.

\section{Information Exchange}

SRS has opened several avenues of exchange with state and federal regulators, other government-owned, contractor-operated (GOCO) facilities, and scientists to improve and update its environmental monitoring and research programs.

DOE-SR representatives attend technical information exchange workshops sponsored by DOE

Headquarters (DOE-HQ), which provide a way to enhance the exchange of technical information among DOE sites.

Environmental awareness and information exchange tours are conducted for many special-interest groups, including environmental activists and representatives of other GOCOs, DOE-HQ, Westinghouse Electric Corporation, EPA, and SCDHEC. Tours are designed to meet the needs of a particular group. For example, EPA and SCDHEC tours might focus on regulatory issues, while tours for other GOCOs might cover activities applicable to their programs.

Initiated in 1996, the Interagency Information Exchanges are public forums that enable state and federal regulators and SRS to address environmental compliance issues. At these forums, EPA, SCDHEC, and SRS representatives discuss cleanup plans and draft RCRA permit changes while soliciting public comments. Public input is considered by the agencies and used to develop final remedial approaches.
The SRS CAB provides recommendations to DOE, EPA, and SCDHEC on environmental remediation, waste management, and related issues. More information about the $\mathrm{CAB}$ and its 1998 recommendations can be found on page 52 .

The Environmental Advisory Committee, which is comprised of nationally recognized consultants from the fields of biology, ecology, hydrogeology, health physics, environmental restoration, and economics, meets quarterly to review site environmental programs and make recommendations. In 1998, this group formally reviewed the SRS Environmental Report for 1997 and SRS Environmental Data for 1997 (WSRC-TR-97-00324).

The CSRA Radiological Environmental Monitoring Program is a data exchange program involving representatives of SCDHEC, GDNR, Georgia Power Company, Chem-Nuclear Systems, DOE, and WSRC. This group has met semiannually since 1987 to share technical environmental program information and data. These meetings provide an open forum in which to review and possibly improve each organization's monitoring program.

\section{Public Outreach}

\section{Communications}

SRS public outreach activities-such as public meetings, the Visitors Program, and the Speakers Bureau,-provide communication channels between the site and the public. Local newspaper, television, and radio advertisements also inform the public about environmental activities. More information can be obtained by contacting the WSRC Public Relations group at 803-725-0193.

When topics involve unusually complex issues, DOE may conduct workshops that give special-interest groups or citizens the opportunity to meet with site representatives.

\section{Environmental Justice}

Environmental justice principles set forth in Executive Order 12898, "Environmental Justice Strategy," are incorporated in the design of community-specific risk communication programs and their delivery to the targeted audience.

In carrying out these programs, DOE-HQ and EPA provided funding through SRS to continue a grant for the Savannah (Georgia)-based Citizens for Environmental Justice activities through fiscal year 1999. This project provides a tool to strengthen the capacity of communities to interface with the government (DOE and EPA) in environmental 
decision making and environmental monitoring associated with federal facilities. The Citizens for Environmental Justice will apply monies toward community workshops, informational literature on radiation and health effects, radio programs, newsletters, and EIS workshops on spent nuclear fuel. Savannah State University will apply this grant toward improving academic programming in environmental studies. Savannah State will submit a final report to DOE by September 30, 1999.

Additional information on SRS environmental justice activities can be obtained by calling the DOE-SR

Office of Environmental Programs at 803-725-5351.

\section{Public Notice Requirements}

Various regulations require that SRS notify the public of its environmental plans and activities. RCRA, CERCLA, NEPA, and the Clean Water Act have public notice and/or meeting requirements. SRS meets these requirements by using various community involvement tools, including public meetings for certain RCRA permit application modification requests and notices to contiguous landowners, media, local and state government agencies, and any other interested stakeholders. Such notices-and the status of documentation-typically are sent in a monthly newsletter called the Environmental Bulletin and in separate mailings, as required. NEPA documentation generated by SRS and various construction and operating permits held by SRS are available to the public. Chapter 2 lists 1998 SRS project NEPA documentation activities.

\section{Education}

\section{Westinghouse Savannah River Company}

WSRC assists in conducting competitions such as the CSRA Science and Engineering Fair and the DOE Savannah River Regional Science Bowl to encourage student interest in engineering, science, and mathematics. In partnership with the Ruth Patrick Science Education Center, WSRC offers the Traveling Science Demonstration Program, which provides hands-on science kits demonstrated by working scientists and engineers to local elementary, middle, and high schools. Other education initiatives include the Research Intern Program, which placed 143 students, teachers, and faculty members in research intern positions in fiscal year 1998, and the School-to-Work Program, which provided 119 high school and postsecondary students with work-based learning experiences at SRS in fiscal year 1998. During the year, WSRC was instrumental in forming the CSRA Environmental Science Education
Cooperative, a partnership with private and public organizations committed to environmental education outreach in the CSRA. Tabulations on the 1997-98 school year show that WSRC programs had more than 50,000 contacts with students in the surrounding communities through various programs and events in science and mathematics. WSRC received a State Board of Education Business Award for its contributions to public education.

\section{Savannah River Natural Resource Management and Research Institute}

SRI made more than 40,000 contacts with people through outreach programs in 1998, including about 25,000 contacts made through community events and participation in the Visitors Program mentioned on page 54. Other outreach activities include the following:

- The Natural Resources Science, Math, and Engineering Education Program allows students in grades 3 through 12 from throughout the CSRA to have an opportunity to learn science, mathematics, and engineering principles in a hands-on setting. In 1998, the program had almost 15,000 student-visits. The program also sponsors teacher workshops, summer camps, and a graduate course for teachers.

- The Savannah River Environmental Sciences Field Station provides hands-on, field-oriented experiences for undergraduates from 25 historically black colleges and universities and other schools in the region.

- SRI provides natural resource research opportunities for federal and state agencies, universities, industrial/private landowners, and conservation organizations from throughout the region.

- The fire management program helps local communities control wildland fires, provides help to other states during the summer fire season, brings Smokey Bear's fire prevention message to about 1,900 children in South Carolina, and has responded to numerous natural disasters in the region, such as hurricanes and floods.

- SRI provides several training classes and workshops for both onsite and offsite groups on a variety of topics, including erosion control technologies, constructed wetlands, ecosystem management, GPS/GIS (Global Positioning System/Geographic Information System), and controlled burning and wildfire suppression.

- SRI administers U.S. Department of Agriculture Natural Resource Conservation Education grants to local schools to defray the costs of curriculum development, supplies, and teacher training. 


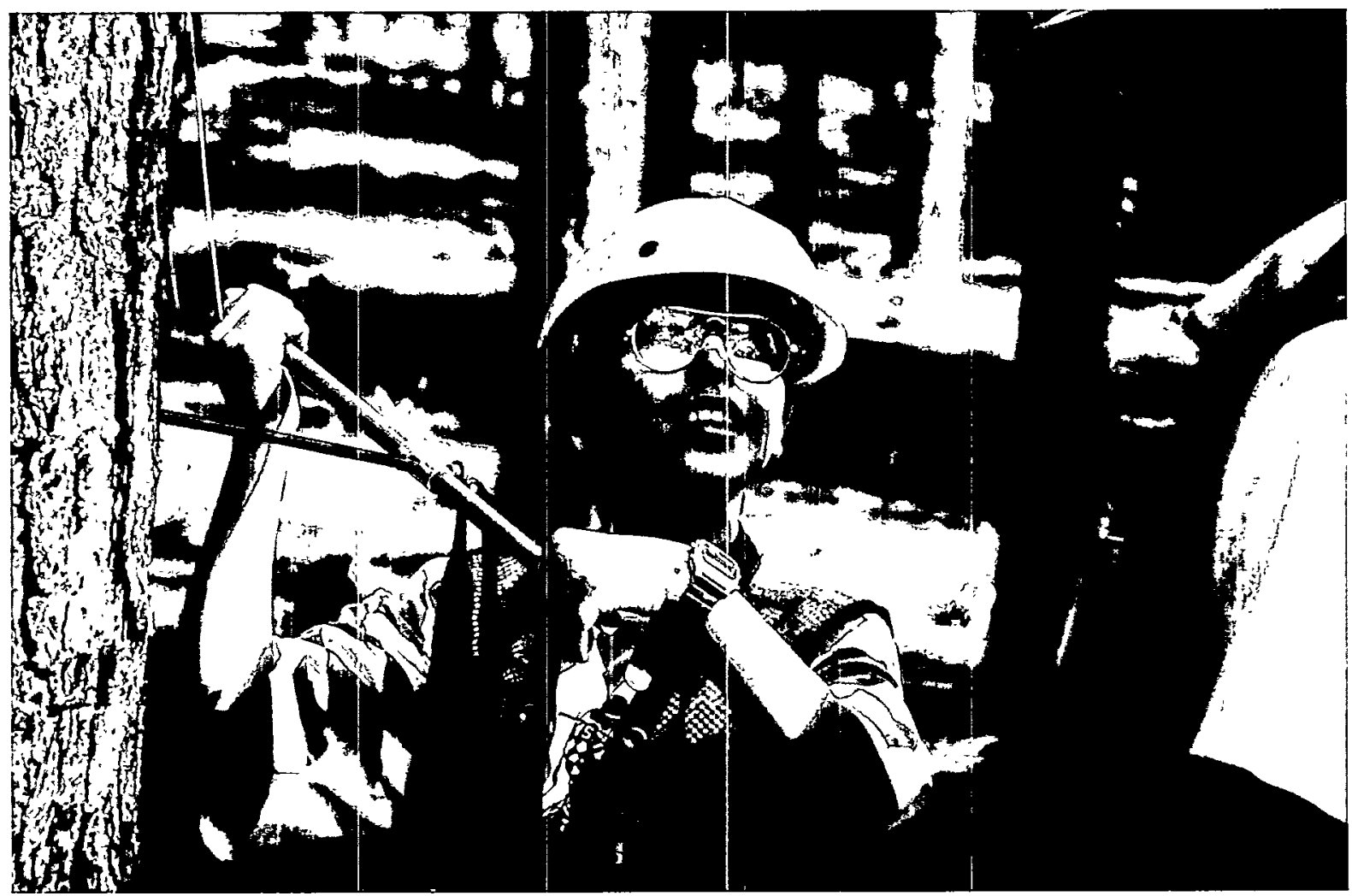

Steve Lenzo Photo (WSAC-98-0313901)

Learning about nature through education programs sponsored by SRI reinforces mathematics and science principles. Here, a student undergoes hands-on learning by taking a core sample from a tree. The rings in the tree can be counted using the sample of wood pulled from the tree with the long tube.

- SRI provides planning and other assistance to local rural communities to develop natural resource assets.

More information about SRI outreach can be obtained by calling $803-725-0237$.

\section{Savannah River Ecology Laboratory}

SREL's Environmental Outreach and Education Program educated people through an estimated 75,000 contacts during 1998 . The program emphasizes the importance of environmental awareness in decision making regarding ecological problems. Environmental awareness is promoted through tours of the laboratory; lectures to students and civic and special interest groups; teacher workshops; and various exhibits. Presentation topics include animal ecology, outdoor safety, plants and wetlands, the environment, conservation, and careers in ecology and research. More information can be obtained by contacting SREL at 803-725-0156.

\section{Savannah River Archaeological Research Program}

SRARP continued its heritage education activities in 1998 with a full schedule of classroom education, public outreach, and onsite tours. Volunteer excavations at SRS's George Bush historical site were conducted with the Augusta Archaeological Society and other avocational groups participating, while offsite excavations provided a variety of opportunities for field experience.

Two open houses were held, with participants touring the SRARP facility and hearing presentations on archaeological compliance. Some 70 presentations, displays, and tours were provided for schools, historical societies, civic groups, and environmental and historical awareness day celebrations; an estimated 10,000 individuals took part in these outreach activities. "Discovering Archaeology" and "Classroom Dig," two outreach programs with public schools, brought methods and practices of archaeology to the classroom in a hands-on approach. More information can be obtained by contacting SRARP at 803-725-3623. 


\title{
Environmental Management
}

\author{
Steve Bingham \\ Environmental Restoration Division \\ Dean Campbell \\ Public Relations Department \\ Albert R. Mamatey \\ Environmental Protection Department \\ Craig McMullin \\ Facilities Decommissioning Division \\ Judy Spencer \\ Public Relations Department
}

\section{Highlights}

- More than 1,300 zinc-mercury and lead-acid batteries were discovered at the L-Area burning/rubble pit in April and subsequently removed and packaged for metals recycling at approved offsite disposal facilities.

- Under the site's hazardous waste program, 244 cubic meters of legacy waste and 43 cubic meters of newly generated waste were shipped off site. Overall, the inventory of waste in the Hazardous Waste Storage Facility declined more than 25 percent (from 1,018 cubic meters to 740 cubic meters).

- DWPF produced 249 canisters of immobilized high-level waste, bringing the total to 536 canisters since radioactive processing began in March 1996. The facility reached a milestone in November, when it marked the production of its 2-millionth pound of glass from high-level waste sludge.

- An independent team completed field evaluations of SRS's top 10 inactive facilities for at-risk conditions. The 10 were in a group of 130 process-related and support facilities evaluated for the potential of structural condition, occupancy, industrial safety, and radiological and hazardous material conditions to adversely affect workers, the public, and the environment.

$\mathrm{E}$ NVIRONMENTAL restoration, waste management, and facility disposition at the Savannah River Site (SRS) are part of the U.S. Department of Energy's (DOE) Environmental Management program, which was established in 1989 to address the environmental legacy of nuclear weapons production and other sources of potential pollutants, such as nuclear research. Considerable progress was made in all three areas in terms of environmental cleanup during 1998. This chapter provides a brief overview of the programs that guide these activities and describes some of their major 1998 milestones. These programs reflect the site's ongoing efforts to ensure the safety of its workers, the public, and the surrounding environment.

"Environmental restoration" involves the assessment and cleanup of inactive waste units and groundwater (remediation). "Cleanup" means actions taken to deal with the release or potential release of hazardous substances. This may refer to complete removal of a substance, or it may mean stabilizing, containing, or otherwise treating the substance so it will not affect human health or the environment [DOE EM, 1991]. Determining the most environmentally sound methods of cleaning up waste units is a major focus of the SRS environmental restoration program.

"Waste management" refers to the safe, effective management of various kinds of nonhazardous, hazardous, and radioactive waste generated on site. Identifying the need for appropriate waste management facilities and ensuring their availability have been major components of the SRS waste management program.

"Facility disposition" encompasses the management of SRS excess facilities-from completion of operations shutdown through final disposition-in a way that minimizes facility life cycle costs without compromising health, safety, or environmental quality. 


\section{Regulatory Compliance}

Applicable environmental management guidelines can be found in appendix A, "Applicable Guidelines, Standards, and Regulations."

\section{Environmental Restoration}

SRS began its remediation program in 1981, before many of the regulations requiring environmental restoration were written. However, the site's current environmental restoration program was not officially established and developed until 1990. Through 1998, 477 inactive waste and contaminated groundwater sites had been identified.

The Environmental Restoration Division (ERD) reached 111 enforceable agreement milestones, such as remedial action startups and Records of Decision, in 1998.

\section{Accomplishments}

ERD accomplishments in 1998 included the following field remediation projects:

- geosynthetic capping of 25 acres at the radioactive burial ground

- removal of 1,300 batteries from the L-Area burning/rubble pit for recycling

- removal and safe storage of a 6,000-gallon radioactive underground retention tank

- extraction of 115,000 pounds of solvent from soil and groundwater

- installation of nine new recirculation wells and a second GeoSiphon Cell for the additional removal of solvent

Final Records of Decision were completed for nine waste sites and No Further Action decisions for 61 additional waste sites.

\section{Upper Three Runs}

The removal of solvents from soil and groundwater continued to be a priority of the Upper Three Runs Project in 1998. Approximately 360 million gallons of groundwater were remediated and 118,000 pounds of solvents removed in 1998, bringing the total since the work began in 1983 to more than 3 billion gallons of groundwater treated and approximately 700,000 pounds of solvent removed. Emphasis continued to be placed on increasing the efficiency of existing groundwater treatment systems and using improved cleanup technologies. Progress achieved to date in cleaning up the contaminated groundwater has allowed the shutdown of two of the Upper Three
Runs area's six soil-vapor extraction units, since the effectiveness of these units was decreasing with time. This is the first step toward switching over to the passive BaroBall treatment method, which is expected to complete the groundwater cleanup in this area more cost-effectively.

Another accomplishment at Upper Three Runs was the installation of 12 recirculation wells in the southern sector. Recirculation well technology performs in situ stripping of contaminants by using air lift pumping in a concentric well configuration (figure 4-1). This remediation is conducted at about half the cost of conventional aboveground air strippers.

\section{Central Savannah Watershed}

Central Savannah Watershed Project achievements in 1998 included the following:

\section{Successful Modification of the GeoSiphon Cell}

The GeoSiphon cell is a passive treatment technology using granular cast iron as the treatment medium to clean up solvent-contaminated groundwater. Phase II testing of the first cell, which was installed in 1997, began in 1998 to determine an acceptable siphon flow rate and the required cell spacing. A second cell was installed in September, approximately 50 feet south of the initial cell. Dual cell testing will begin in 1999 to evaluate the effectiveness of the two cells working in tandem.

\section{Removal of the Ford Building Tank in $\mathbf{N}$-Area (Central Shops)}

Located in N-Area, the Ford Building was used to refurbish reactor heat exchanger units and other processing equipment. From 1964 to 1984 , wastewater generated during these operations was piped to a 6,000-gallon underground retention tank and analyzed for radionuclides. A removal action was deemed necessary in 1997 when it was discovered that approximately 4,500 gallons of low-level radioactive water and nearly 150 gallons of low-level radioactive sludge remained in the tank. The project team completed safe removal of the tank in September 1998.

\section{Beginning of D-Ash Basin Sampling Work}

The $488 \mathrm{D}$-Ash Basin was put into operation in 1951 and received ash-sluice water from the D-Area powerhouse until 1952. After 1952, the basin received dry ash and reject material, while ash-sluice water was channeled to other basins. The $488 \mathrm{D}$-Ash Basin is inactive today and receives no waste material. It is adjacent to a wetland approximately 


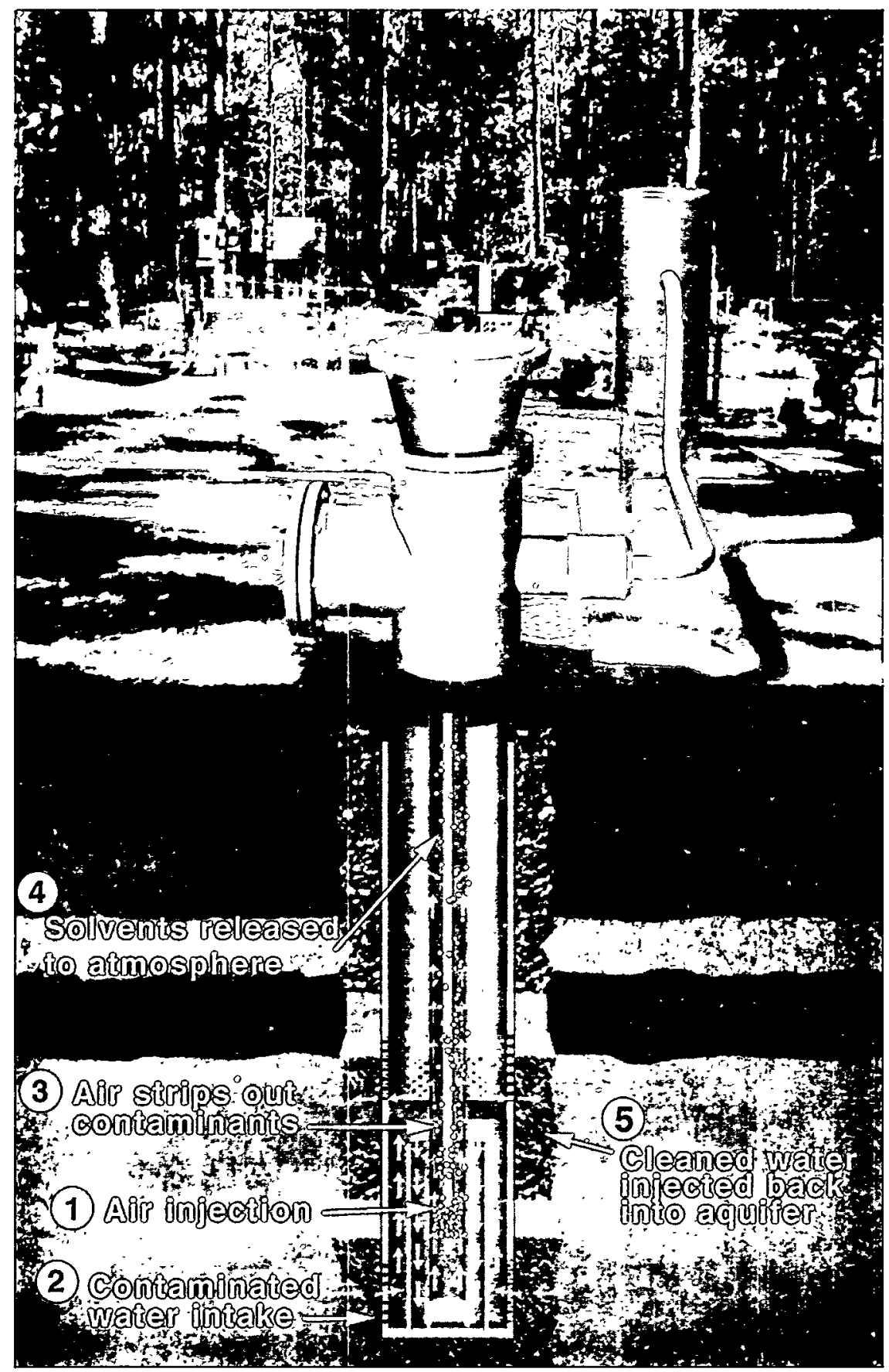

Figure 4-1

Recirculation Well Technology

The installation of 12 recirculation wells in the Upper Three Runs area was completed in 1998 to perform in situ stripping of solvent contaminants from the groundwater. Air is pumped down the center well, then travels upward in the outer well while stripping the solvents from the contaminated groundwater. The solvents then are exhausted into the atmosphere while the clean water is returned to the aquifer.

Ed Landry Graphic
1,250 feet long and 100 to 300 feet wide, however, and runoff to this area has caused some concern because of the low $\mathrm{pH}$ and possible constituents of the leachate. Full characterization of the ash basin and adjacent wetlands area began in September.

\section{General Separations}

Within the General Separations Project area are the Burial Ground Complex, the F-Area and H-Area Groundwater Treatment Facilities, and the Old
F-Area Seepage Basin. The Burial Ground Complex occupies approximately 194 acres in the central section of SRS between F-Area and H-Area separations facilities. During 1998, approximately 95 percent of the inactive portions of the Burial Ground Complex were capped. Geosynthetic capping of more than 25 acres at the Low-Level Radioactive Waste Disposal Facility was completed in December. Geosynthetic capping is faster and less costly than other capping methods, and its use greatly reduces the possibility of further groundwater contamination 
because it provides excellent protection from rainwater infiltration.

From 1958 to 1988 , seven unlined basins covering 22 acres were used to dispose of radioactive wastewater from SRS separations facilities in F-Area and H-Area. All the basins were closed and remediated with protective closure caps in 1991. However, contaminants already had reached the groundwater in these areas, so two water treatment facilities and 30 extraction wells were installed in 1997. These remediation systems remove heavy metals, nitrates, and radionuclides to meet groundwater protection standards and control tritium migration.

During 1998, project engineers replaced or modified many of the components in the systems to increase groundwater contaminant removal capacity. The F-Area and H-Area groundwater treatment units began full operation after these modifications (in July) to enhance system performance.

Soil solidification remedial action at the Old F-Area Seepage Basin began in September. The basin will be grouted to help prevent the spread of contamination to the groundwater, and a low-permeability cap will be installed. The project is expected to be completed by late 1999 .

\section{Reactor Areas}

ERD reactor area achievements in 1998 included the following:

\section{Development of a Regional Groundwater Model}

A regional groundwater flow model, which incorporates historical and recent field characterization data, was developed for the areas around K-Reactor, R-Reactor, P-Reactor, and C-Reactor-a first at SRS. The model is being used to improve characterization activities and to analyze the movement of contaminants through groundwater plumes.

\section{Completion of Removal Actions}

Approximately 1,300 zinc-mercury and lead-acid batteries were removed from the L-Area burning/rubble pit (131-L). The batteries-discovered during waste unit sampling-will be shipped to approved offsite disposal facilities for metals recycling. Twenty-nine hazardous gas cylinders were removed from the L-Area gas cylinder disposal facility in February 1998, after it was verified that they had been vented of hazardous gases during their disposal in the 1970s. Contaminated vegetation from within the K-Reactor and C-Reactor seepage basins was removed in conjunction with the "rollback" (decontamination) of the basins; this allowed their redesignation from "Contamination Area" to a less serious "Soil Contamination Area."

\section{Federal Facility Agreement Milestone}

A major Federal Facility Agreement milestone was achieved with the beginning of remediation work at the L-Area oil and chemical basin in August. The basin had received radioactive and hazardous wastewater from the early 1960 s to the 1970 s. The entire basin will be filled with grout, safely stabilizing any remaining contaminants, and a low-permeability soil cover will be placed over it.

\section{Solid Waste Management}

SRS solid waste management facilities host a number of important waste management and environmental restoration efforts on site.

\section{Accomplishments}

The activities of Solid Waste Division (SWD) personnel during 1998 included

- an increase-from 25 percent to approximately 60 percent-in the amount of material recycled from SRS's compactible sanitary waste

- the successful design, construction, and startup of a low-level waste sorting facility to prepare waste for volume reduction prior to disposal

- the shipment of about 500 cubic meters of hazardous waste off site for disposal

- the retrieval, venting, and purging of more than 3,300 transuranic waste drums

- the successful rollback of more than 118,000 square feet of contaminated operating areas

The SRS solid waste program continues to support the site's transition from production to cleanup activities by managing large volumes of backlog wastes at various site facilities. Proper handling of the waste requires that the waste be categorized as sanitary, low-level, transuranic, hazardous, mixed, or high-level (high-level waste discussion begins on page 64).

\section{Sanitary Waste}

Sanitary waste includes office waste, food, garbage, refuse, and other solid wastes that can be disposed of in landfills. SRS has privatized the collection, hauling, and disposal of its sanitary waste, which consists primarily of food and office wastes. 


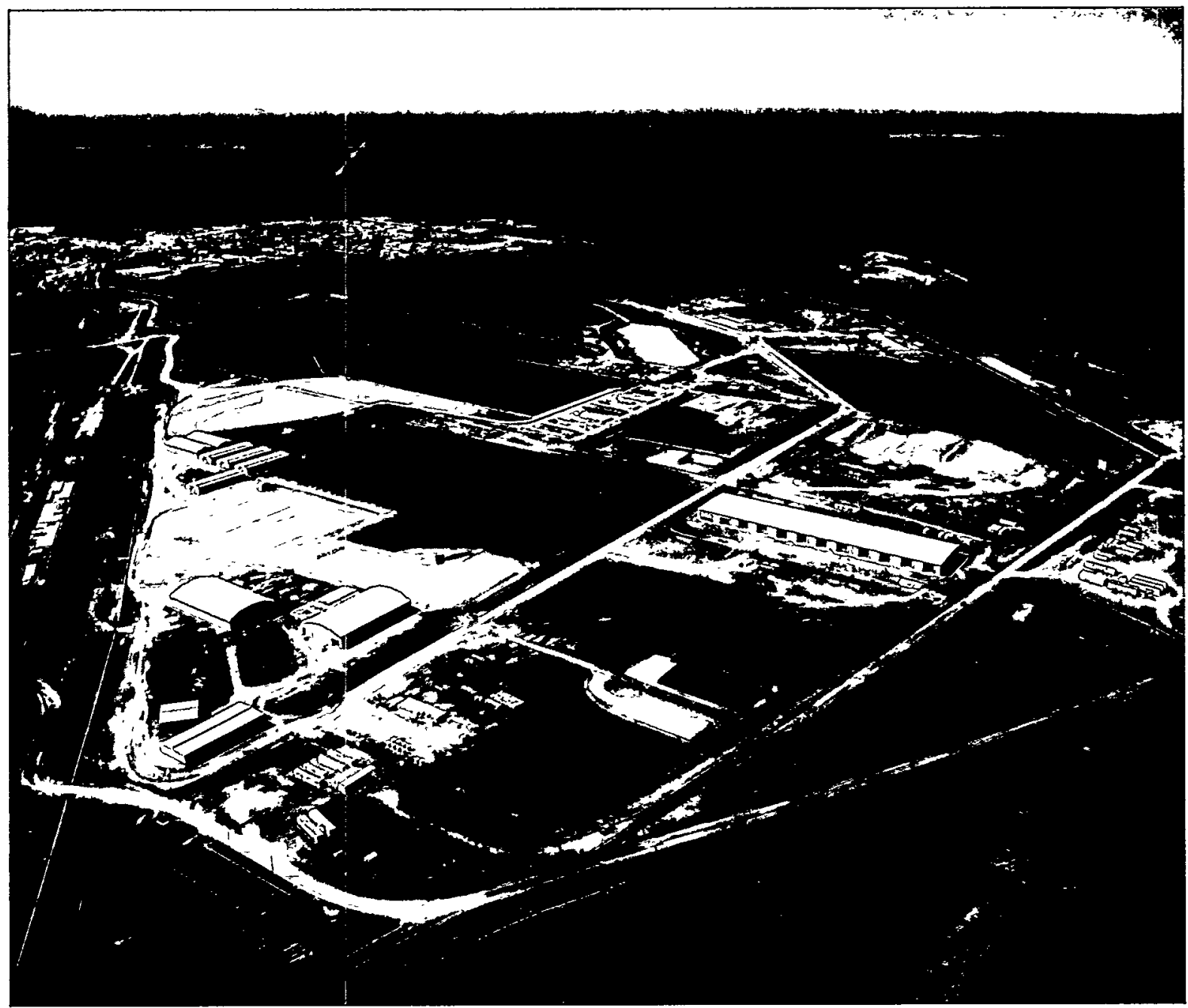

Steve Ashe Photo (98-1063-1E)

Many of SRS's solid waste management operations are located in E-Area, including the E-Area vaults, the transuranic storage and retrieval facilities, mixed-waste permitted storage facilities, and a number of environmental restoration closure sites.

In July 1998, SRS began shipping the compactible portion of its municipal solid waste to the City of North Augusta (South Carolina) Material Recovery Facility, which recovers recyclable materials, including white office paper, newspapers and magazines, cardboard, plastic, steel cans, aluminum cans, and glass. By using the North Augusta facility, the site was able to increase-from 25 percent to approximately 60 percent--the amount of material recycled from its compactible sanitary waste.

\section{Low-Level Waste}

Low-level waste is any radioactive waste not classified as high-level or transuranic waste.

Examples of SRS low-level wastes include protective clothing, job control waste, equipment, tools, filters, rags, and papers. Most wastes certified as low-level are stored or disposed of in the E-Area Vaults.

Programs focusing on waste minimization, waste volume reduction, segregation, and release of clean waste were implemented in 1998. This is expected to extend the utilization period for existing disposal vaults by at least 10 years, thereby delaying or possibly eliminating the need for new vault construction.

The volume reduction program includes sorting wastes for compaction and incineration. During 1998, SWD completed the design, construction, and startup of the Waste Sort Facility. Located in E-Area, the facility sorts and segregates low-level waste to reduce volume. 


\section{Hazardous Waste}

According to RCRA, hazardous waste is any toxic, corrosive, reactive, or ignitable material that could damage the environment or negatively affect human health. Examples of SRS hazardous wastes include oils, solvents, acids, metals, and pesticides.

Under the site's hazardous waste program in 1998, 244 cubic meters of legacy waste and 43 cubic meters of newly generated waste were shipped off site. Overall, the inventory of waste in the Hazardous Waste Storage Facility declined more than 25 percent (from 1,018 cubic meters to 740 cubic meters).

\section{Mixed Waste}

Mixed waste is both radioactive and hazardous and is subject to regulations governing both waste types. During 1998, all mixed low-level waste program Site Treatment Plan (STP) commitments were met. The STP represents an agreement between SWD, DOE's Savannah River Operations (DOE-SR), and the South Carolina Department of Health and Environmental Control (SCDHEC) to properly treat SRS's mixed waste on a specific schedule. Accomplishments included the following:

- External and internal surfaces of lead-acid batteries (previously stored and managed as mixed waste) were tested and determined to be nonradioactive. The batteries subsequently were reclassified and recycled as conventional batteries, which eliminated the need for treatment and disposal of the batteries as mixed waste.

- Onsite personnel were used to decontaminate elemental lead items instead of using an offsite commercial vendor as planned. This allowed the lead decontamination operation to begin in December 1998, about 18 months sooner than originally scheduled.

- Waste sampling and characterization efforts were completed on site paints and thinners and mixed waste oil and on the old solvent storage trailer. Uranium chromium solutions and "waste and spill site" soils were x-rayed in support of characterization, a step that must be taken before treatment of these wastes.

- Generator application documentation was submitted to personnel affiliated with the East Tennessee Technology Park Toxic Substances Control Act Incinerator at Oak Ridge. Once approved, this documentation will allow SRS to ship radioactively contaminated polychlorinated biphenyls for treatment.
Also, 389 cubic meters of mixed waste that had been prepared in 1997 were treated at the Consolidated Incineration Facility (CIF).

\section{Transuranic Waste}

Transuranic waste is radioactive waste contaminated with certain isotopes that have decay rates and activities exceeding defined levels. It contains manmade elements that are heavier than uranium, some of which decay slowly, thus requiring thousands of years of isolation. At SRS, transuranic wastes can include contaminated equipment, protective clothing, and tools.

The site stored 11,289 unvented transuranic waste drums $-8,809$ under earthen cover and 2,480 under weather cover-at the Solid Waste Management Facility from the early 1970s until 1996, when it was determined that they would be vented and purged. In 1998,

- 3,750 drums were retrieved from earthen cover

- 3,469 drums retrieved from earthen cover (some in 1998, others in previous years) and 16 drums under weather cover underwent the vent-and-purge process

This moved the transuranic waste to a safer storage configuration and a step closer to being shipped to the New Mexico Waste Isolation Pilot Plant for disposal.

At the end of 1998, 2,884 earth covered drums and 1,355 weather covered drums remained to be vented and purged. Plans call for completion of the vent-and-purge process by December 1999.

\section{Consolidated Incineration Facility}

The CIF met its major STP commitment in 1998 by treating over 50 percent of SRS's non-PUREX (plutonium/uranium extraction) backlogged mixed waste. The primary wastes treated were filter paper takeup rolls and solvent rags.

The CIF processed approximately 750,000 pounds of solid waste and 250,000 pounds of liquid waste in 1998 - about three times the amount processed in 1997.

\section{Effluent Treatment Facility}

The Effluent Treatment Facility (ETF) collects and processes low-level radioactive and chemically contaminated wastewater from the high-level waste tank farm evaporator overheads and from reprocessing facility evaporators. The ETF process, utilizing microfiltration, organic removal, ion exchange, and reverse osmosis, allows approximately 95 percent of the water collected to be released to the 


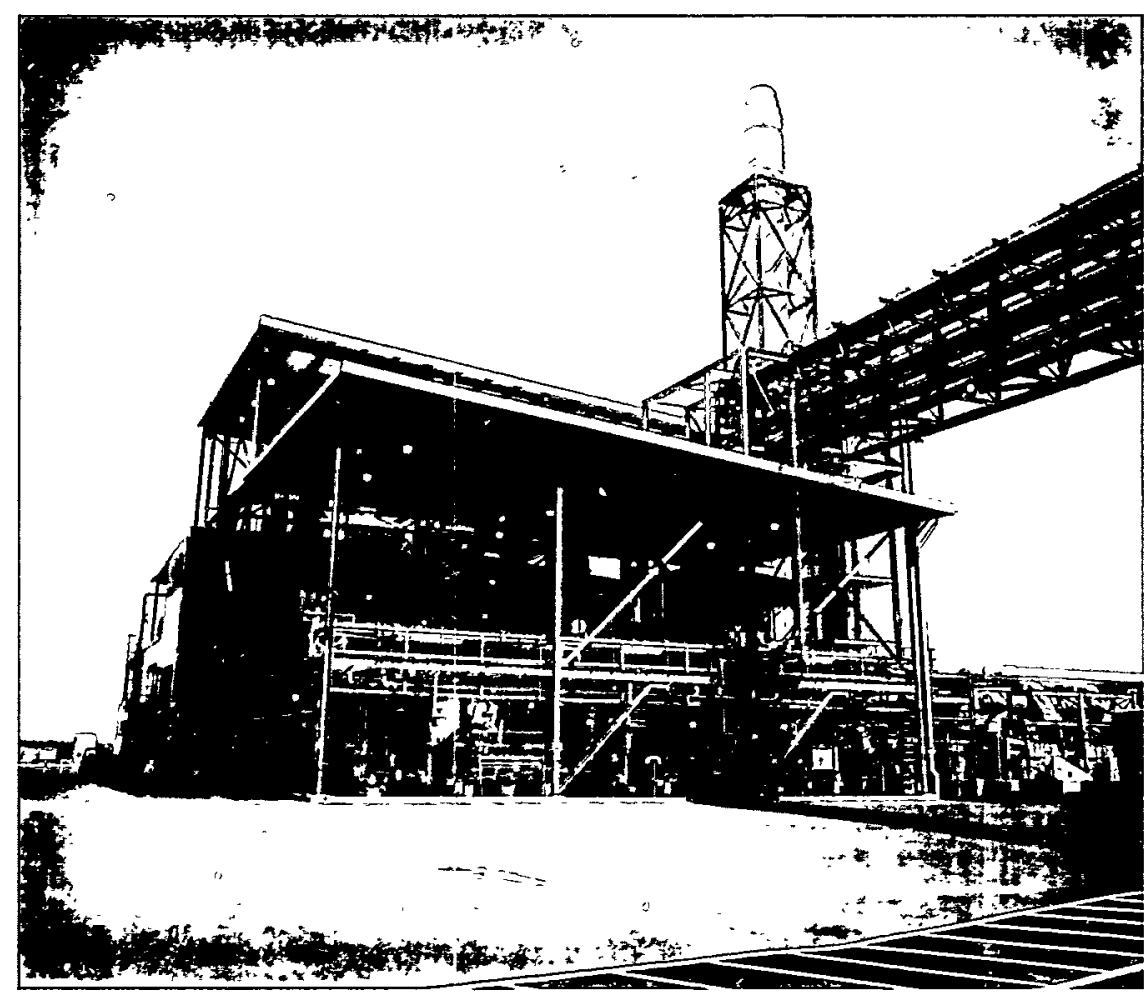

SRS operates the CIF to treat and reduce the volume of certain solid and liquid incinerable low-level radioactive, hazardous and mixed (both hazardous and radioactive) wastes. Located adjacent to $\mathrm{H}$-Area, the CIF is an integral part of the site's waste management program. Facility design started in the late 1980s, and construction began in 1992. Testing was completed in early 1997, and the incinerator began processing mixed waste in April of that year.

Hugh Smith Photo (97-1140-4E)

environment through a National Pollutant Discharge Elimination System (NPDES)-permitted outfall. The remaining 5 percent represents concentrates removed from the bulk of the liquid. Processed through ETF evaporators, this material is being transferred to a storage tank at the In-Tank Precipitation Facility (ITPF) for eventual disposal at the Saltstone Facility.

In 1998, ETF processed and released more than 25 million gallons of wastewater - the highest single-year total since the facility began operations in 1988. A "normal" total in any given year would be 18 million gallons.

\section{Saltstone Facility}

The Saltstone Facility treats and disposes of low-level radioactive salt solutions that are the byproduct of the high-level waste treatment process at SRS.

After the salt solutions are received at the facility, they are mixed with cement, fly ash, and furnace slag to form a grout, which then is pumped into a large concrete vault divided into sections, or cells. There, it cures into a stable form called "saltstone." After it is filled, the vault will be capped with clean grout to isolate it from rain and weathering. Final closure of the vault disposal area will include covering each vault with a clay cap and backfilling it with earth.
Radioactive operations began at the Saltstone Facility in June 1990; since that time, the facility has processed approximately 2.5 million gallons of salt solutions (including 300,000 gallons in 1998), creating more than 4 million gallons of "saltstone." The facility was placed in "standby" mode in September 1998, pending completion of a review of SRS's treatment of high-level waste precipitates.

\section{Pollution Prevention/Waste Minimization}

During 1998, SRS waste generators implemented more than 130 projects that helped curb the generation of approximately 36,000 cubic feet of radioactive and hazardous solid waste.

Contamination area rollbacks continued to reduce low-level waste generation and employee hazards while increasing productivity. This involved the reclamation of areas that had been radiologically contaminated by past operations. During 1998, SWD reduced the hazard of contamination area space; this eliminated more than 20,000 cubic feet of low-level waste.

More about pollution prevention/waste minimization can be found in chapter 2 ("Environmental Compliance"), pages 17 and 25 , and chapter 3 , ('Environmental Program Information"), pages 49-50. 


\section{High-Level Waste Management}

"High-level waste" is highly radioactive waste material that results primarily from the reprocessing of spent nuclear fuel. It contains liquid waste produced directly in reprocessing, any solid waste derived from that liquid, and both transuranic waste and fission products in concentrations requiring permanent isolation from the environment.

High-level waste from the F-Area and H-Area canyons is segregated according to radionuclide and heat content. High-heat waste, generated primarily during the first extraction cycle in these canyons, contains a major portion of the radioactivity. Low-heat waste is generated primarily from the second and subsequent canyon extraction cycles.

SRS continues to manage approximately 34 million gallons of high-level liquid radioactive waste (about 498 million curies), which is stored in 49 massive storage tanks grouped into two "tank farms." Twenty-nine tanks are located in the H-Area Tank Farm and 20 in the F-Area Tank Farm. All SRS tanks are built of carbon steel inside reinforced concrete containment vaults.

The major waste streams in the F-Area and H-Area tank farms include transfers from the canyons, receipts from the Receiving Basin for Offsite Fuels, and a recycle stream from the Defense Waste Processing Facility (DWPF).

\section{High-Level Waste Facilities}

Each tank farm has one operating evaporator system used to concentrate (1) high-level waste received from the canyons and (2) dilute waste streams from other facilities. These evaporators, which reduce the waste to 10-33 percent of its original volume, reclaimed about 3 million gallons of tank space in 1998. SRS has successfully conducted this space reclamation operation in the tank farms since 1960, when the first evaporator facilities began operation. More than 100 million gallons of space have been reclaimed during this time.

Without these evaporator systems, SRS would have required 85 additional waste storage tanks-at $\$ 50$ million apiece-to store waste produced over the site's lifetime. Construction continued in 1998 on the replacement high-level waste evaporator, which will enable the tank farms to process future waste loads. The new evaporator, expected to begin operations in September 1999, will have twice the processing capacity of the two existing evaporators.
The Extended Sludge Processing Facility, one of two DWPF pretreatment operations in the High Level Waste Division, washes sludge (unsettled insoluble waste) to reduce the concentration of sodium salts and dissolves and removes aluminum to ensure glass quality for DWPF. In 1998, the facility completed preparation of the second of 10 sludge batches that will be needed to vitrify all the high-level waste sludge. Three million gallons of sludge must be pretreated in this manner.

The washed and decanted sludge is transferred to DWPF as part of "sludge only" vitrification operations. DWPF then treats the sludge from the original waste and the highly radioactive material removed from the salt cake by combining them with glass. The mixture is heated until it melts and then is poured into stainless steel canisters to cool. The glass-like solid that forms contains the highly radioactive material and seals it off from the environment. Another word for this process is "vitrification." The glass will be kept in the sealed canisters and will be stored at SRS until a federal repository is established.

The ITPF, the second pretreatment operation for DWPF, was expected to process the "liquid salt" waste in tanks. The work was suspended in February 1998, however, to address safety issues arising from the excess generation of benzene during the process. In March, a team began evaluating options for redirection of the ITPF design and configuration. A systems engineering review of approximately 140 options has narrowed the salt processing technologies to three viable alternatives, as follows:

- small tank precipitation

- crystalline silicotitanate ion exchange

- cesium encapsulation in grout

Precipitation and ion exchange split the salt stream into two streams. In precipitation, the highly radioactive portion, called "precipitate," would go to DWPF for vitrification, while the remainder, called "filtrate" (about 90 percent of the salt waste), would be low-level waste to be grouted into a solid form at the Saltstone Facility.

In ion exchange, the crystalline silicotitanate required to remove the highly radioactive portion would go to DWPF, while the resulting lower level waste stream would be sent for grouting at the Saltstone Facility.

In the cesium encapsulation method, cesium and low-level waste are separated from high-level waste, then bound in grout and sent directly into a permitted facility for storage. 
Research and development of the three options will continue in 1999, with a decision on which new approach to use expected late in the year.

\section{Accomplishments}

SRS continued to manage its high-level waste facilities in support of the integrated high-level waste removal program in 1998.

\section{Tank Farms}

The tank farm evaporators recovered more than 2.7 million gallons of tank space in 1998 through evaporation of the watery "supernate" that floats atop the sludge in the tanks. The $242-16 \mathrm{H}$ evaporator system recovered more than 2 million gallons while the $242-16 \mathrm{~F}$ evaporator system recovered more than 700,000 gallons. The key to this achievement was an interarea line used to transfer waste from $\mathrm{H}$-Area to F-Area via a 2-mile underground system. Approximately 500,000 gallons of radioactive waste were transferred via the interarea line during 1998.

Modifications to the evaporator systems and tank farms continued in 1998 to enhance safe operations without affecting productivity.

\section{DWPF}

The successful processing of radioactive sludge continued during 1998. DWPF produced 249 canisters of immobilized high-level waste during the year, bringing the total to 536 canisters since radioactive processing began in March 1996. A milestone was reached in November, when the facility marked the production of its 2-millionth pound of glass from high-level waste sludge since it began radioactive operations in March 1996.

DWPF will continue processing sludge until the "precipitate" from one of the salt processing alternatives is available. Approximately 200 canisters of glass are expected to be produced in fiscal year 1999.

\section{Facility Deactivation and Decommissioning}

With the declining need for a large nuclear weapons stockpile, many SRS facilities are no longer needed to produce or process nuclear materials. They pose a challenge to the site in terms of how to maintain them safely and economically storage until final disposition. Many of them are large and complex, and they are spread throughout the site. Many also contain residual materials that, if improperly handled or stored, could be hazardous to workers, the public, and the environment. SRS faces an enormous task in the cleanup, reuse, surveillance, maintenance, and disposition of these surplus facilities.

The Facilities Decommissioning Division (FDD) manages excess facilities after completion of operations shutdown through final disposition in a manner that considers facility life cycle costs without compromising either the health and safety of the workers and the public or the quality of the environment.

FDD must bring all formerly used SRS nuclear and associated support facilities to a safe, deactivated, and nontime-critical status. The safety of deactivated facilities will be ensured through continued surveillance and maintenance programs until ultimate decommissioning can be completed. Facilities and structures that cannot be safely and cost effectively maintained in this long-term surveillance and maintenance state will be decommissioned.

\section{Accomplishments}

\section{Inactive Facilities Risk Ranking and Prioritization}

Beginning in 1997, databases were developed for inactive facilities risk ranking and for prioritization. This led to the identification of 130 process-related and support facilities considered inactive (figure 4-2). Facility custodians evaluated each facility's structural condition, occupancy, industrial safety, and radiological and hazardous material conditions for the potential to adversely affect workers, the public, and the environment. The top 35 risk-ranked facilities then were further evaluated based on regulatory compliance, mission impact, mortgage reduction, social-economic impact, and overall facility management concerns. The overall scores from the risk ranking and prioritization databases were averaged to provide an overall Prioritized Risk Ranked Listing. In 1998, an independent team completed field evaluations of the top 10 facilities for at-risk conditions. The team identified and recorded facility hazards and deficiencies related to the control of chemicals, combustible fire loading, asbestos contamination, and Occupational Safety and Health Administration safety requirements. The findings were prioritized and are being resolved as funding and schedules permit.

\section{Decontamination Facility}

The primary objective of the Decontamination Facility in C-Area is to perform decontamination and waste handling activities for FDD's excess facilities as well as the division's disposition projects. These activities are an integral part of deactivation and 
decommissioning projects, which are performed at SRS to reduce surveillance and maintenance requirements. The facility's secondary objective is to perform resource recovery and waste reduction work for other Westinghouse Savannah River Company (WSRC) divisions.

In 1998, the Decontamination Facility

- $\quad$ processed 46,273 cubic feet of material

- second-sorted 130 B-25 boxes (11,571 cubic feet) for SWD

- "rolled back" (decontaminated) 53,484 cubic feet of contaminated areas

- installed a large-span metal modular hut, plastic blaster, dry/wet stainless steel huts, and a material shredder.

\section{Large-Scale Demonstration and Deployment Project}

The large-scale demonstration and deployment project at the 321-M Fuel Fabrication Facility began in April 1998. The project's purpose is to demonstrate new and innovative deactivation and

decommissioning technologies alongside competing baseline technologies. Successfully demonstrated technologies are available for the remaining portions of particular problems within the project, as well as for similar problems throughout the DOE complex.

Five technologies were identified that will support a full-scale demonstration and are expected to benefit the 321-M project. The technologies

- address defined problems and needs at the 321-M facility

- $\quad$ are widely applicable across the DOE complex

- $\quad$ are potentially applicable to the commercial sector

Demonstrations of two of the five technologies-(1) the assessment of six strippable coatings and (2) the long-range alpha detection method for component monitoring-were initiated in 1998, and were applied at the 321-M facility. Subcontracts for the other three

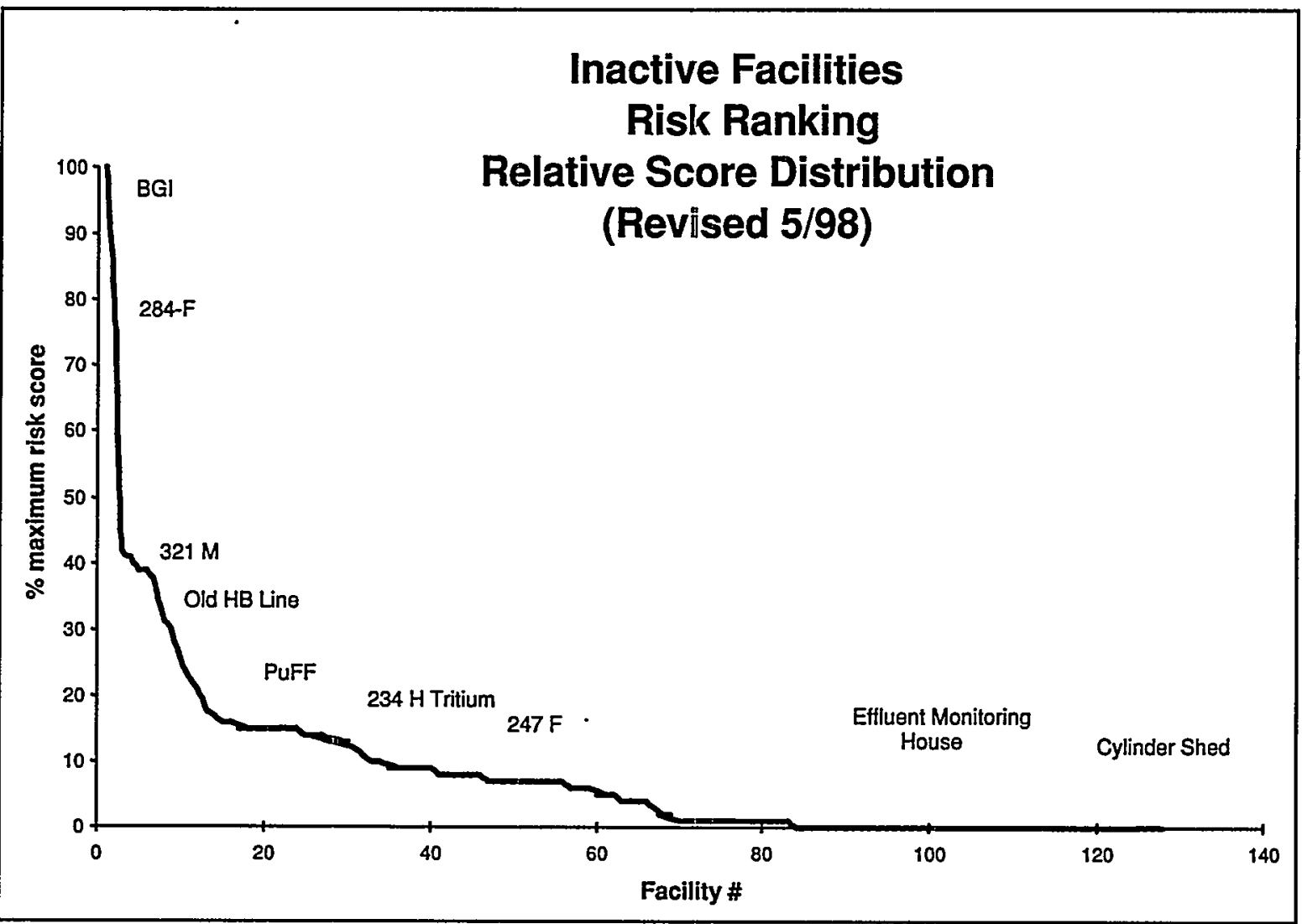

Figure 4-2 Ranking the Risk

Databases have been developed to identify the risk ranking of 130 SRS facilities. A series of weighting factors was used to determine a numerical risk score for each facility. Facilities are listed here in decreasing order of relative risk score. The distribution chart represents initial results of the hazard ranking for the 130 facilities. 


\section{Workers from the C-Area Decontamination Facility spray "Instacote" on a tank at the H-Area Tank Farm. The epoxy-like, polymer-based substance, which can be used to stabilize contamination on a wide range of surfaces, comes in both removable and permanent varieties.}

Byron Williams Photo (98-1120-4E)

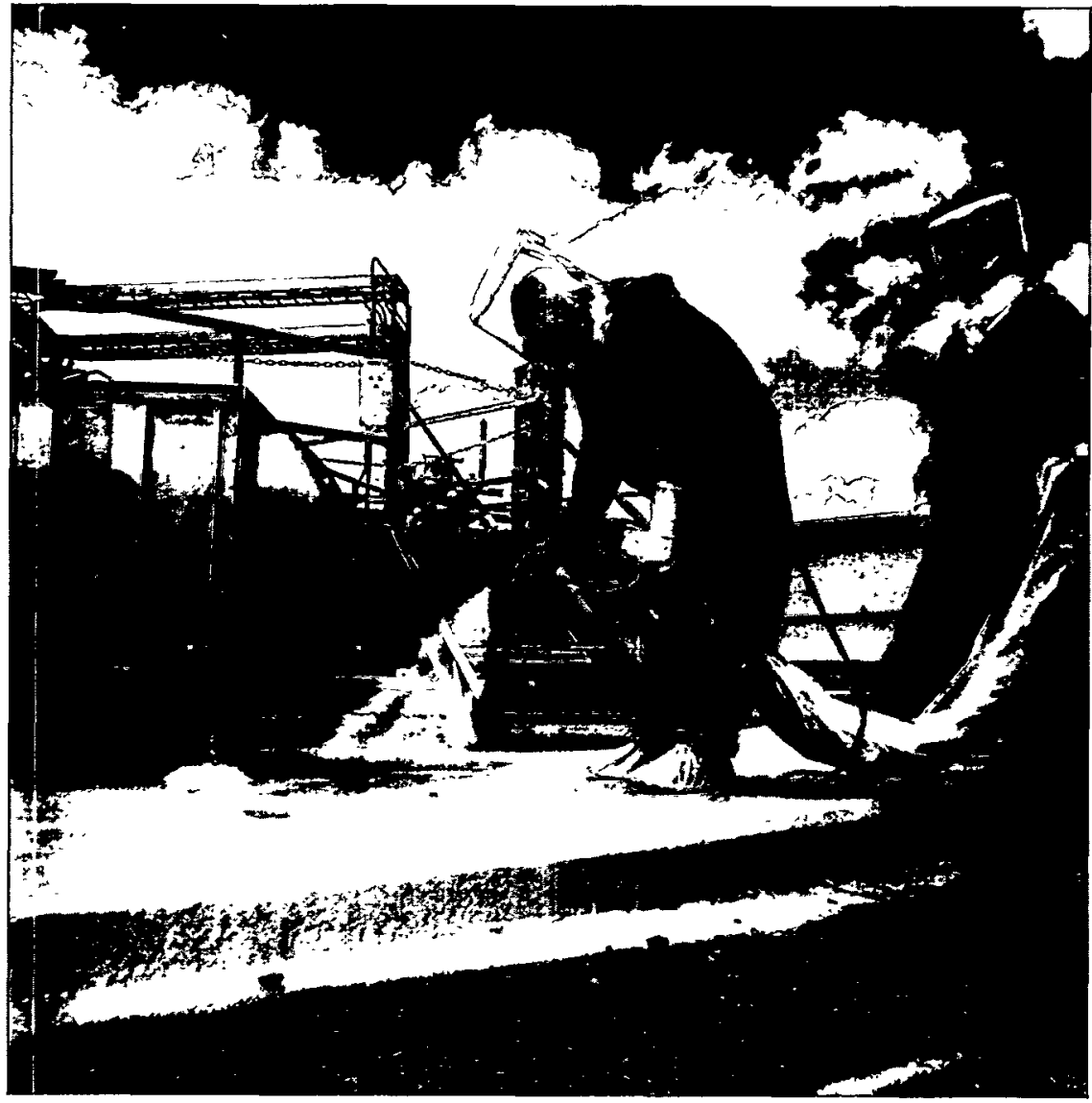

technologies were still being prepared at the end of the year.

\section{Assets for Services}

Disposing of surplus assets for services is a way to exchange the value of the assets for demolition and removal services. FDD instituted an assets-for-services pilot program in 1998 to dispose of preselected M-Area assets for demolition and removal services in the same area. Only government property that had been declared surplus through the government property screening and donation processes, as required by federal and DOE regulations and site procedures, was included.

WSRC planning and implementation activities for recently issued DOE Order 430.1A, "Life Cycle Asset Management," identified two opportunities related to cost-effective management of surplus government property-(1) to dispose of an increasing amount of surplus property that should be identified at SRS and (2) to speed the resolution of safety concerns and potential risks associated with surplus facilities, given recognized funding limitations.
The assets-for-services program successfully exploits both these opportunities in a timely manner. First, it provides an alternative that disposes of surplus property with a minimal quantity of site resources and expense; and second, it offsets the cost of services to mitigate or eliminate potential risks associated with surplus facilities at SRS. The program also

- reduces the expenditure of site resources and costs to decontaminate, remove, and stage surplus equipment for other "sales" alternatives

- supports the site's facility disposition program

FDD completed the dismantlement and removal of buildings, structures, and equipment at various M-Area locations in December 1998. The concept of exchanging assets for services saved $\$ 295,000$ in field costs during this project, providing $\mathrm{DOE}$ a 19-percent return on its investment.

\section{Dismantlement of 704-R}

The dismantling in September 1998 of the 704-R administration and maintenance building exemplifies the effective use of specialized equipment to perform a job quickly, efficiently, and safely. The L-shaped building, composed of a metal frame with a concrete 
A hydraulic power shear was used to dismantle the 704-R facility in September 1998. Use of this special equipment greatly reduced the time and resources required to complete the project. The facility had been an administration and maintenance building during the operation of R-Reactor.

Joe Trahan Photo (NFN)

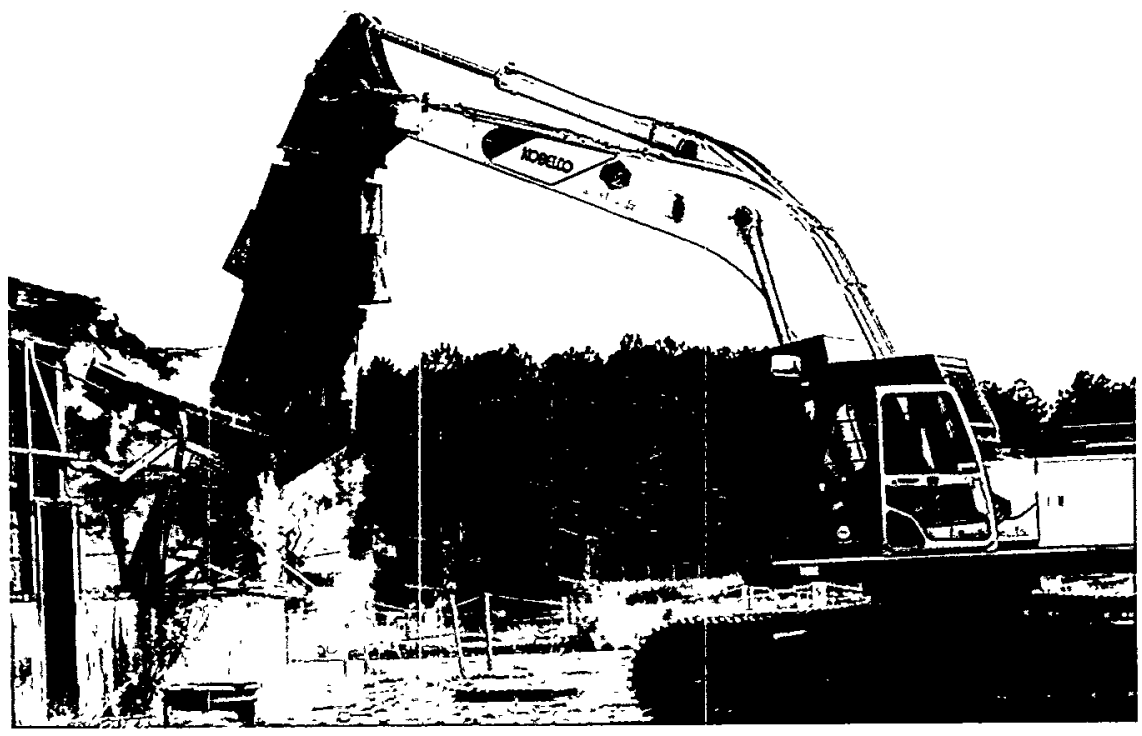

slab roof measuring approximately 18,600 square feet, was built in 1953. The structure was almost entirely enclosed in asbestos material, with transite exterior panels. Interior walls, floor tile, mastic, roofing, and insulation materials also contained asbestos. Used for a time as a radioactive material storage area, the facility was decontaminated in 1998 and "released as a clean facility."

Because of insect infestation and the poor condition of exits and egress paths, the 704-R facility had become a safety hazard. To eliminate the hazard and provide a storage area for future activities at R-Reactor, the facility was scheduled for dismantlement and removal.

The construction crew responsible for the project accomplished the job by using a larger model of a hydraulic power shear that had previously been used on the Rotunda Building in B-Area and to dismantle the old bridge at the cloverleaf intersection of $\mathrm{C} \mathrm{Road}$ and $\operatorname{Road} 2$.

By using the larger power shear, the construction crew reduced manpower requirements by half and saved approximately 3 months of work (the time required for using a torch and pulling down the building with a piece of heavy equipment).

\section{Deactivation of the Heavy Water Components Test Reactor}

Deactivation of the Heavy Water Components Test Reactor was completed in September 1998. The facility was placed in a safe and stable condition following the removal of hazardous and radioactive materials to minimize the long-term cost of surveillance and maintenance activities. As part of this deactivation project, the following activities were completed:

- demolition of the 735-U Health Physics Building

- removal of the exhaust stack and other system exterior components

- removal of the exhaust system fans

- removal of the 904-1U underground waste storage tank

- removal of the fence enclosing the Heavy Water Components Test Reactor compound

- welding closed the entrances to the reactor dome

- removal of the underground steam line

\section{Disposition of Abandoned Powerhouses}

Demolition of two former reactor area powerhouses was completed in 1998. WSRC proposed use of the assets-for-services program in this project-that is, trading the equipment within the facilities for demolition services. As a result, the powerhouses, located in C-Area and P-Area, were packaged together for sale in exchange for the dismantlement and removal services. A contractor subsequently negotiated with domestic and foreign manufacturers for component re-use, paid WSRC for the two powerhouses, and disposed of all the related components, systems, and structures. The project was completed in September 1998. This type of initiative enables DOE to remove surplus powerhouses at little or no cost. Also, the contractor receives valuable assets, and the end user gets reliable equipment at reasonable prices. 


\section{Other Accomplishments}

The following paragraphs describe some of the activities involved in other accomplishments by FDD during 1998.

GTS Duratek, Inc., successfully completed the treatment of some 580,000 gallons of mixed-waste sludge (equivalent to about 2,500 drums) during 1998. The subcontractor had installed a new melter and resumed radioactive operations in December 1997 at its M-Area Vendor Treatment Facility. A number of adjustments were made to the overall system during the restart to achieve optimum performance. By the end of 1998, the hazardous component of the sludge had been stabilized, and FDD was awaiting a response from SCDHEC on its petition to have the waste reclassified and disposed of a low-level radioactive waste.

Fifteen drums holding 1,910 containers of enriched lithium were successfully loaded and shipped to a plant at the Oak Ridge (Tennessee) National Laboratory for dispositioning.
A memorandum of understanding was completed for the transfer of building $690-\mathrm{N}$ (the Ford Building) to FDD from the Spent Fuel Storage Division. This transfers management of the building and 48 100-ton excess heat exchangers to FDD. The heat exchangers potentially present several opportunities to decontaminate and recycle contaminated stainless steel.

Facility deactivation plans were completed for three M-Area facilities: the 320-M Chemical Laboratory, the 321-M Fuel Fabrication Facility, and the 322-M Metallurgical Laboratory. This approach adopted the "end-point determination" method outlined in DOE's Facility Deactivation Guide. The deactivation will place each facility in a passive state in which existing conditions can be monitored over an extended period of time at minimal surveillance and maintenance costs.

FDD supported the development of the 232-H tritium facility deactivation plan. This deactivation will occur in phases over the next several years. In 1998, the team developed an overall plan strategy, which included the transition report, the overall end-point vision, and end-point visions for each phase. 
Chapter 5

Radiological

Effluent

Monitoring

\author{
Mary Dodgen, Pete Fledderman, \\ and Phillip Miller \\ Environmental Protection Department
}

Timothy Jannik

Savannah River Technology Center
To Read About ... See Page...

Airborne Emissions ................ 72

Liquid Discharges ................. 74

Transport of Actinides in Streams . . . . . . 80

\section{Highlights}

- Of the approximately 4,200 radiological effluent samples scheduled to be collected and analyzed during 1998, three ( 0.07 percent) were either not collected or not analyzed because of sampling equipment failure or inadvertent loss of the sample media. The radioactive releases attributed to these samples were accounted for in the annual release totals by using historic process knowledge.

- Tritium in elemental and oxide forms accounted for most of the total radioactivity released to the atmosphere from SRS operations. About $82,700 \mathrm{Ci}(3.06 \mathrm{E}+15 \mathrm{~Bq})$ of tritium was released from SRS, compared to about $58,000 \mathrm{Ci}(2.15 \mathrm{E}+15 \mathrm{~Bq})$ in 1997.

- Tritium also accounted for most of the radioactivity released to the Savannah River from the site. About $10,555 \mathrm{Ci}(3.91 \mathrm{E}+14 \mathrm{~Bq})$ of tritium, compared to about $8,350 \mathrm{Ci}(3.09 \mathrm{E}+14 \mathrm{~Bq})$ in 1997 , were released to the Savannah River. Of the 1998 amount, $1,092 \mathrm{Ci}(4.04 \mathrm{E}+13 \mathrm{~Bq})$ were directly released from process areas, compared to $1,570 \mathrm{Ci}(5.81 \mathrm{E}+13 \mathrm{~Bq})$ for 1997 .

$\mathrm{T}$ - HIS chapter describes the Savannah River Site (SRS) radiological effluent monitoring program and summarizes the 1998 effluent monitoring data results. Objectives and rationale for the SRS radiological effluent monitoring program are discussed in chapter 3, "Environmental Program Information."

Radiological effluent monitoring results are a major component in determining compliance with applicable dose standards, which can be found in chapter 7, "Potential Radiation Doses," and in appendix A, "Applicable Guidelines, Standards, and Regulations." Also, SRS management philosophy is that potential exposures to members of the public be kept as far below regulatory standards as is reasonably achievable. This philosophy is known as the "as low as reasonably achievable" (ALARA) concept.

SRS airborne and liquid effluents that potentially contain radionuclides are monitored at their points of discharge by a combination of direct measurement and/or sample extraction and analysis. Each operating facility maintains ownership of and is responsible for its radiological effluents. However, Safety and Health Operations (S\&HO) and the Environmental Protection Department's Environmental Monitoring Section (EMS) perform most of the radiological effluent monitoring functions. S\&HO personnel collect and screen air and liquid samples from regulated (radiologically controlled) areas and maintain monitoring equipment on stacks and at some liquid effluent discharge points. EMS personnel collect and analyze most liquid effluent samples and analyze most of the airborne effluent samples. Results of these analyses are compiled and reported in monthly radioactive releases reports.

Of the approximately 4,200 radiological effluent samples scheduled to be collected and analyzed during 1998 , three ( 0.07 percent) were either not collected or not analyzed because of sampling equipment failure or inadvertent loss of the sample media. The radioactive releases attributed to these samples were accounted for in the annual release totals by using historical process knowledge.

A complete description of the EMS sampling and analytical procedures used for radiological effluent monitoring can be found in sections 1102 and 1103 of 
the Savannah River Site Environmental Monitoring Section Plans and Procedures, WSRC-3Q1-2, Volume 1 (SRS EM Program). A summary of data results is presented in this chapter; however, more detailed data can be found in SRS Environmental Data for 1998 (WSRC-TR-98-00314).

\section{Airborne Emissions}

Process area stacks that release or have the potential to release radioactive materials are monitored continuously by applicable online monitoring and/or sampling systems [SRS EM Program, 1995]. Filter paper samples, used to collect radioactive particles, generally are gathered daily and screened initially for radioactivity by $S \& H O$ personnel. Charcoal canisters, used to collect radioiodines, are gathered weekly at some locations and monthly at locations with lower potential for release. S\&HO personnel routinely transfer the filter paper samples and charcoal canisters weekly to EMS sampling personnel for transport to, and analysis in, the EMS laboratories.

Depending on the processes involved, discharge stacks also may be monitored with "real-time" instrumentation by area operations and/or S\&HO personnel to determine instantaneous and cumulative atmospheric releases to the environment. Tritium is one of the radionuclides monitored with continuous real-time instrumentation.

\section{Description of Monitoring Program}

\section{Sample Collection Systems}

Sample collection systems vary from facility to facility, depending on the nature of the radionuclides being discharged. Generally, S\&HO personnel are responsible for ensuring that the sampling systems are maintained and for collecting the filter papers and charcoal filter samples.

The following effluent sampling and monitoring changes were made during 1998:

- Air effluent sampling of the 105-C Crane Maintenance Decontamination Exhaust began in March.

- Air effluent sampling at 241-81H ETF (Effluent Treatment Facility) Process Stack and 241-84H ETF Lab Stack was discontinued in September.

- Air effluent sampling at the 313-M Stack was discontinued in January. Ventilation in the facility was turned off in July, and the stack was capped in December.

- Effective in April, the sampling frequency at the four 250-S Glass Waste Buildings (\#1488,
$\# 1509$, \#3928, and \#3940) was changed from weekly to monthly. The reported monthly releases were based on a 24-hour sample taken during the month.

- Air effluent sampling at $210-Z$ and $704-Z$ was discontinued in October.

\section{Continuous Monitoring Systems}

SRS reactor and tritium facilities use real-time instrumentation to determine instantaneous and cumulative atmospheric releases of tritium and noble gas radioisotopes. All other monitored radionuclides are sampled using filter papers, charcoal filters, or other air effluent sampling media.

\section{Laboratory Analysis}

EMS provides most of the necessary radioanalytical laboratory services required to conduct the site airborne effluent monitoring program. However, tritium in airborne effluents is measured at each applicable operating facility.

\section{Effluent Flow Rates}

Stack effluent flows generally are determined with hot-wire anemometers, Pitot tubes, or fan capacity calculations. Sample line flow rates usually are determined with in-line rotameters or hot-wire anemometers. Flow rates are used to determine the total quantity of radioactive materials released.

\section{Diffuse and Fugitive Sources}

Estimates of radionuclide releases from unmonitored diffuse and fugitive sources also are included in the $\mathrm{SRS}$ radioactive release totals. These unmonitored sources include ponds, contaminated land areas, and structures without ventilation-or with ventilation but without well-defined release points.

Diffuse and fugitive releases are calculated using the U.S. Environmental Protection Agency (EPA)'s recommended methods. They are conservative estimates that have large unknown uncertainness. However, for consistency with other reported data, the estimates are reported to three significant figures.

For 1998, because of their very short half-lives, iodine-131, zirconium-85, praseodymium- $144 \mathrm{~m}$, and neptunium-239 were not included in the diffuse and fugitive releases totals.

Also, rhodium-106, barium-137m, praseodymium-144, lead-212, thorium-234, and protactinium-234 are short-lived progeny of long-lived parent radionuclides. Their reported release totals were added to the parent radionuclides-ruthenium-106, cesium-137, 
cerium-144, thorium-238, and uranium-238 (for thorium-234 and protactinium-234), respectively.

\section{Monitoring Results}

The total amount of radioactive material released to the environment is quantified by using data obtained from continuously monitored airborne effluent releases points and estimates of diffuse and fugitive sources in conjunction with calculated release estimates of unmonitored radionuclides from the separations areas. These unmonitored radionuclides are fission product tritium, carbon-14, and krypton- 85 . Because these radionuclides cannot be measured readily in the effluent streams, the values are calculated on an annual basis. In addition, during 1998, iodine-129 was not measured by EMS but was calculated based on historical releases and operations in the separations areas. Total SRS atmospheric releases for 1998 are shown by source in table 5-1, page 81 (and in table 4, SRS Environmental Data for 1998).

The data in table 5-1 are a major component in the determination of offsite dose estimations from SRS operations. The calculated individual and collective doses from atmospheric releases are presented in chapter 7, as is a comparison of these offsite doses to EPA and the U.S. Department of Energy (DOE) dose standards.

\section{Beta- and Alpha-Emitting Radionuclides}

For dose calculation purposes, values for unidentified beta- and alpha-emitting radionuclides in airborne releases are summed with the values reported for strontium-89,90 and plutonium-239, respectively. Accounting for the unidentified beta- and alpha-emitting radionuclides in this way, a conservative approach, generates an overestimated dose attributable to releases from SRS because

- strontium-89,90 and plutonium-239 have the highest dose factors among the common betaand alpha-emitting radionuclides

- a part of the unidentified activity probably is not from SRS operations but is from naturally occurring radionuclides, such as potassium -40 and radon progeny

In 1998 , because this methodology was used, unidentified beta-emitting radionuclides accounted for 99 percent of the reported total strontium- 89,90 and unidentified alpha-emitting radionuclides accounted for 96 percent of the reported total plutonium-239.

\section{Tritium}

Tritium in elemental and oxide forms accounts for most of the total radioactivity released to the atmosphere from SRS operations. As an isotope of hydrogen, tritium acts the same as hydrogen chemically and physically and thus is extremely difficult to remove from air effluent streams. During 1998 , about $82,700 \mathrm{Ci}(3.06 \mathrm{E}+15 \mathrm{~Bq})$ of tritium was released from SRS, compared to about $58,000 \mathrm{Ci}$ $(2.15 \mathrm{E}+15 \mathrm{~Bq})$ in 1997 . This 43 percent increase was due mainly to increases in operations in P-Area, where a part of the site's moderator consolidation effort was performed. This effort, which removed all of the stored tritiated moderator (heavy water) from P-Area and placed it in drums that are stored in $\mathrm{K}$-Area, began in May and was completed in August.

Because of improvements in facilities, processes, and operations and because of changes in the site's mission, the amount of tritium (and other atmospheric radionuclides) released has been reduced throughout the history of SRS. During the early years at SRS, large quantities of tritium were discharged to the atmosphere. The maximum yearly release of 2.4 million $\mathrm{Ci}(8.9 \mathrm{E}+16 \mathrm{~Bq})$ of tritium occurred during 1958. From 1989 through 1992, the amount of tritium released from SRS decreased approximately 20 percent per year (figure 5-1). In recent years, because of the changes in the site's missions and the existence of the Replacement Tritium Facility, the total amount of tritium released has remained less than $100,000 \mathrm{Ci}$ per year.

\section{Comparison of Average Concentrations in Airborne Emissions to DOE Derived Concentration Guides}

Average concentrations of radionuclides in airborne emissions are calculated by dividing the yearly release total of each radionuclide from each stack by the yearly stack flow quantities. These average concentrations then can be compared to the DOE derived concentration guides (DCGs), which are found in DOE Order 5400.5, "Radiation Protection of the Public and the Environment," for each radionuclide.

DCGs are used as reference concentrations for conducting environmental protection programs at all DOE sites. Based on a 100-mrem exposure, DCGs are applicable at the point of discharge (prior to dilution or dispersion) under conditions of continuous exposure (assumed to be an average inhalation rate of 8,400 cubic meters per year). This means that the DOE DCGs are based on the highly conservative assumption that a member of the public has direct access to-and continuously breathes, or is immersed 


\section{Curies}

400000

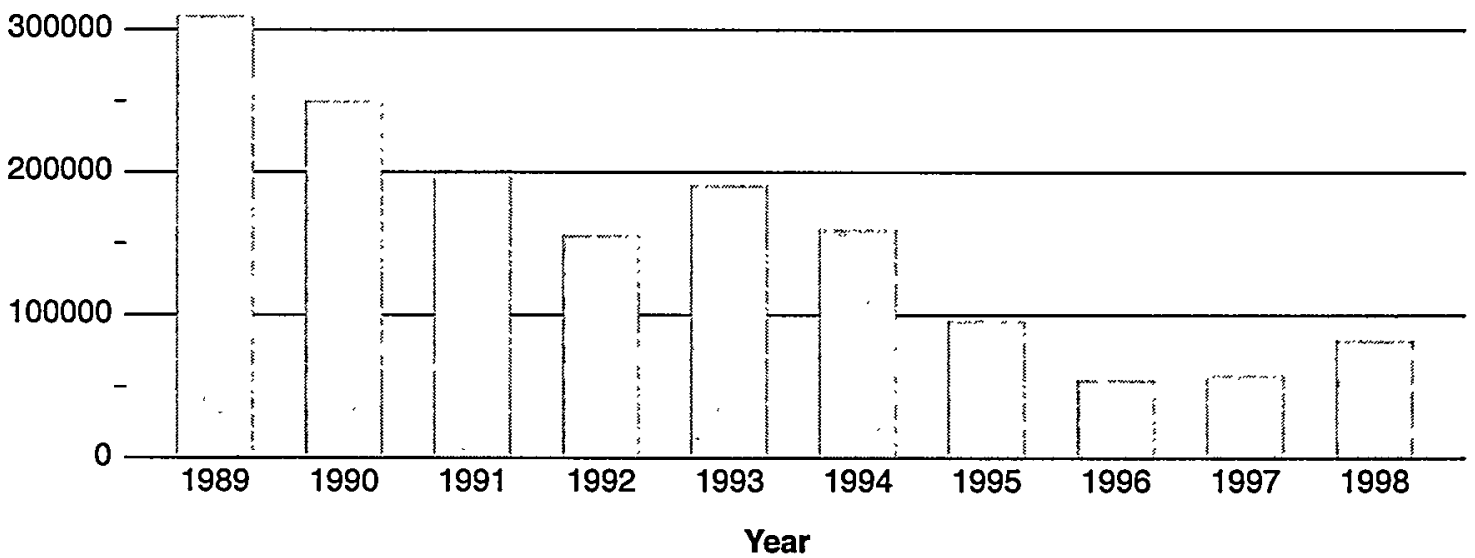

lleaf Graphic

Figure 5-1 Ten-Year History of SRS Annual Atmospheric Tritium Releases

in - the actual air effluent 24 hours a day, 365 days a year. However, because of the distance between most SRS operating facilities and the site boundary, and because the wind rose at SRS shows no strong prevalence (chapter 7), this scenario is improbable.

Average annual radionuclide concentrations in SRS air effluents can be referenced to DOE DCGs as a screening method to determine if existing effluent treatment systems are proper and effective. The 1998 atmospheric effluent 12-month average concentrations, their comparisons against the $\mathrm{DOE}$ DCGs, and the quantities of radionuclides released are provided, by discharge point, in table 5, SRS Environmental Data for 1998.

Most of the SRS radiological stacks/facilities release small quantities of radionuclides at concentrations below the DOE DCGs. However, certain radionuclides-tritium (in the oxide form) from the heavy water rework facilities, the reactor facilities, and the tritium facilities; americium-241 in F-Area from 6.1 and 6.4 dissolvers; plutonium-238 and plutonium-239 in H-Area from 261-H (off gas); uranium-234 in M-Area from 321-M machining room stack; and uranium-232, uranium-234, and uranium-238 from M-Area VTF-were emitted at concentration levels above the DCGs. Because of the extreme difficulty involved in removing tritium and because of current facility designs, site missions, and operational considerations, this situation is unavoidable. However, the offsite dose consequences from all atmospheric releases during 1998 remained well below the DOE and EPA annual atmospheric pathway dose standard of $10 \mathrm{mrem}(0.1 \mathrm{mSv})$ (chapter 7).

\section{Liquid Discharges}

Each process area liquid effluent discharge point that releases or has potential to release radioactive materials is sampled routinely and analyzed for radioactivity [SRS EM Program, 1995]. The radiological liquid effluent sampling locations at SRS are shown, along with the surface water surveillance sampling locations, in chapter 6 , "Radiological Environmental Surveillance" (page 92, figure 6-4).

Site streams also are sampled upstream and downstream of seepage basins to obtain data to calculate the amount of radioactivity migrating from the basins. These results are important in calculating the total amount of radioactivity released to the Savannah River as a result of SRS operations.

\section{Description of Monitoring Program}

\section{Sample Collection Systems}

Liquid effluents are sampled continuously by automatic samplers at, or very near, their points of discharge to the receiving streams. EMS personnel normally collect the liquid effluent samples weekly and transport them to the EMS laboratory for analysis. 
During 1998, C-Canal, McQueen Branch at Road F, $\mathrm{P}-013 \mathrm{~A}$, and $\mathrm{P}-019$ were discontinued as liquid effluent monitoring points (effective January 1).

\section{Continuous Monitoring Systems}

Depending on the processes involved, liquid effluents also may be monitored by area operations and/or S\&HO personnel with real-time instrumentation to ensure that instantaneous releases stay within established limits. However, because of instrumentation detection capabilities, on-line monitoring systems are not used to quantify liquid radioactive releases from SRS.

\section{Laboratory Analysis}

EMS provides most of the necessary radioanalytical laboratory services required to conduct the site liquid effluent monitoring program. However, specific low-level analyses for iodine- 129 have not been performed at SRS since 1996. For 1998 dose calculations, the iodine-129 value measured in 1996 was used. This value is reported in table 5-2 on page 84 of this chapter and in tables 6 and $8, S R S$ Environmental Data for 1998.

\section{Flow Rate Measurements}

Liquid effluent flows generally are determined by one of three methods: U.S. Geological Survey flow stations, commercial flow meters, or pump capacity calculations. Effluent flow rates are used to determine the total radioactivity released.

\section{Monitoring Results}

Data from continuously monitored liquid effluent discharge points are used in conjunction with site seepage basin and Solid Waste Disposal Facility (SWDF) migration release estimates to quantify the total radioactive material released to the Savannah River from SRS operations. SRS liquid radioactive releases for 1998 are shown by source in table 5-2, page 84, and in table 6, SRS Environmental Data for 1998).

The data in this table are a major component in the determination of offsite dose consequences from SRS operations. The calculated individual and collective doses from site liquid releases are presented in chapter 7, as is a comparison of these offsite doses to EPA and DOE dose standards.

\section{Beta- and Alpha-Emitting Radionuclides}

As with airborne releases, values for unidentified beta- and alpha-emitting radionuclides in liquid discharges are summed with the values reported for strontium-89,90 and plutonium-239, respectively.
In 1998, because this methodology was used, unidentified beta-emitting radionuclides accounted for about 12 percent of the reported total strontium-89,90 and unidentified alpha-emitting radionuclides accounted for more than 99 percent of the reported total plutonium-239.

\section{Direct Discharges of Liquid Effluents}

Direct discharges of liquid effluents are quantified at the point-of-release to the receiving stream, prior to dilution by the stream. The release totals are based on measured concentrations and flow rates.

The quantities of radionuclides released during 1998 are provided, by discharge point, in table 7, SRS Environmental Data for 1998.

Tritium accounts for most of the radioactivity discharged in SRS liquid effluents. The total amount of tritium released directly from process areas (i.e., reactor, separations, heavy water rework) to site streams during 1998 was $1,092 \mathrm{Ci}(4.04 \mathrm{E}+13 \mathrm{~Bq})$, which was 30 percent less than the 1997 total of $1,570 \mathrm{Ci}(5.81 \mathrm{E}+13 \mathrm{~Bq})$.

Direct releases of tritium to site streams for the years 1989-1998 are shown in figure 5-2.

\section{Comparison of Average Concentrations in Liquid Releases to DOE Derived Concentration Guides}

In addition to dose standards, DOE Order 5400.5 imposes other control considerations on liquid releases. These considerations are applicable to direct discharges but not to seepage basin and SWDF migration discharges. The DOE order lists DCG values for most radionuclides. DCGs are used as reference concentrations for conducting environmental protection programs at all DOE sites. These DCG values are not release limits but screening values for "best available technology" investigations and for determining whether existing effluent treatment systems are proper and effective.

According to DOE Order 5400.5, exceedance of the DCGs at any discharge point may require an investigation of "best available technology" waste treatment for the liquid effluents. Tritium in liquid effluents is specifically excluded from "best available technology" requirements; however, it is not excluded from other ALARA considerations. DOE DCG compliance is demonstrated when the sum of the fractional DCG values for all radionuclides detectable in the effluent is less than 1.00 , based on consecutive 12 -month average concentrations.

DCGs, based on a 100-mrem exposure, are applicable at the point of discharge from the effluent conduit to 
the environment (prior to dilution or dispersion). They are based on the highly conservative assumption that a member of the public has continuous direct access to the actual liquid effluent and consumes 2 liters of the effluent every day, 365 days a year. However, because of security controls and the distance between most SRS operating facilities and the site boundary, this scenario is improbable.

For each site facility that releases radioactivity, EMS compares the monthly liquid effluent concentrations and 12-month average concentrations against the DOE DCGs. The 1998 liquid effluent 12-month average concentrations, their comparisons against the DOE DCGs, and the quantities of radionuclides released are provided, by discharge point, in table 7 , SRS Environmental Data for 1998.

The data show that the U3R-2A ETF outfall at the Road C discharge point exceeded the DCG guide for 12-month average tritium concentrations during 1998. However, as noted previously, DOE Order 5400.5 specifically exempts tritium from "best available technology" waste treatment investigation requirements. This is because there is no practical technology available for removing tritium from dilute liquid waste streams. In 1992, in consideration of ALARA principles for tritium discharges and while reviewing, analyzing, and modifying the process for controlling liquid releases of radioactive effluents, SRS identified several options and alternatives to continuing with these discharges at the U3R-2A ETF outfall. None of these alternatives was considered viable on a cost/benefit basis. No other discharge points exceeded the DOE DCGs during 1998.

\section{Seepage Basin and Solid Waste Disposal Facility Migration}

To incorporate the migration of radioactivity to site streams into total radioactive release quantities, EMS monitors and quantifies the migration of radioactivity from site seepage basins and the SWDF. During 1998, tritium, strontium-89,90, and cesium-137 were detected in migration releases (table 8, SRS Environmental Data for 1998). As noted previously, measured iodine-129 results were not available from EMS and the value measured in 1996 was used for

\section{Curies}

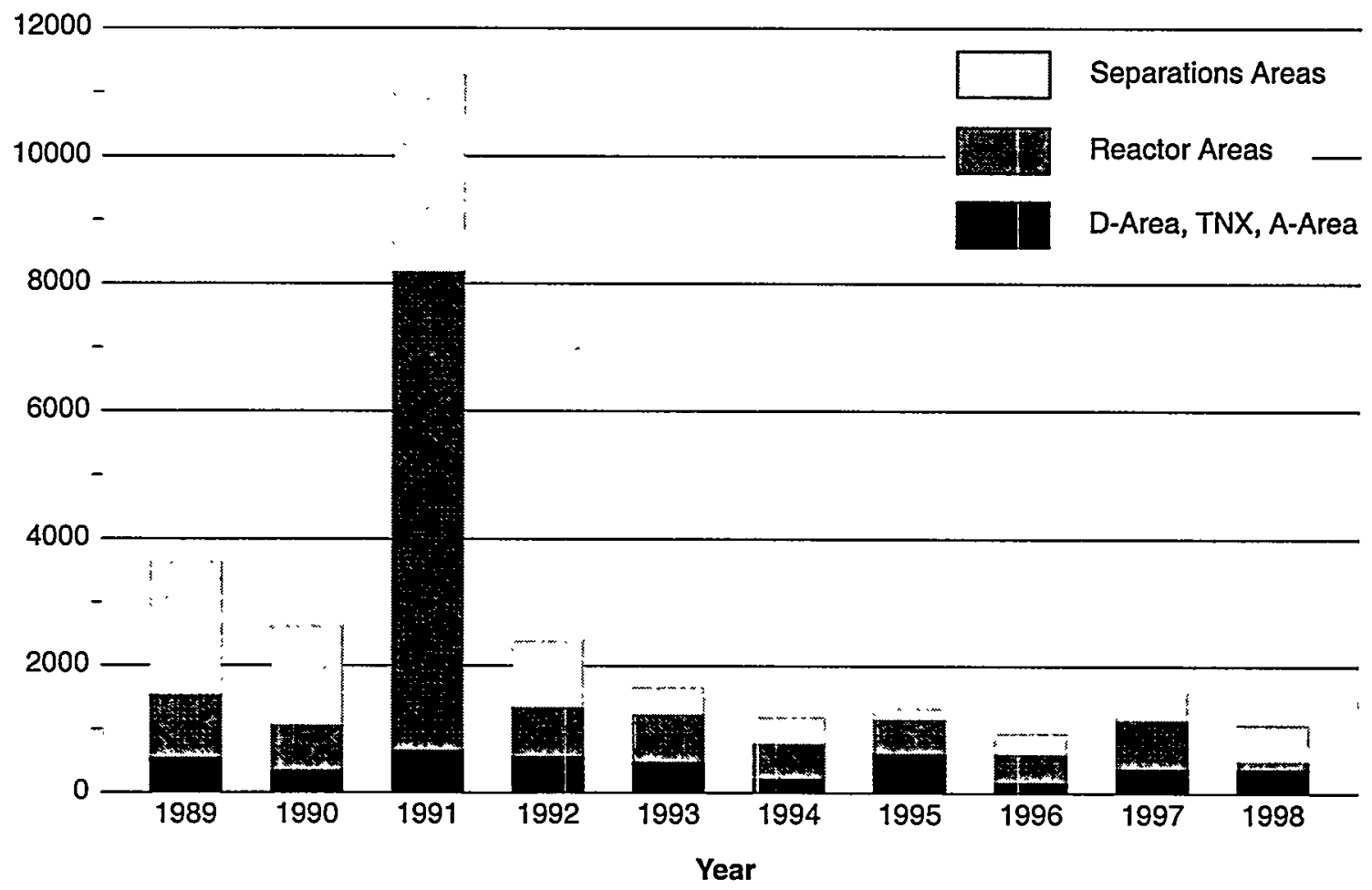

Figure 5-2 Direct Releases of Tritium to SRS Streams, 1989-1998

Ileaf Graphic

The 1991 total includes an accidental release in December of 5,700 Ci from K-Reactor. 


\section{Curies}

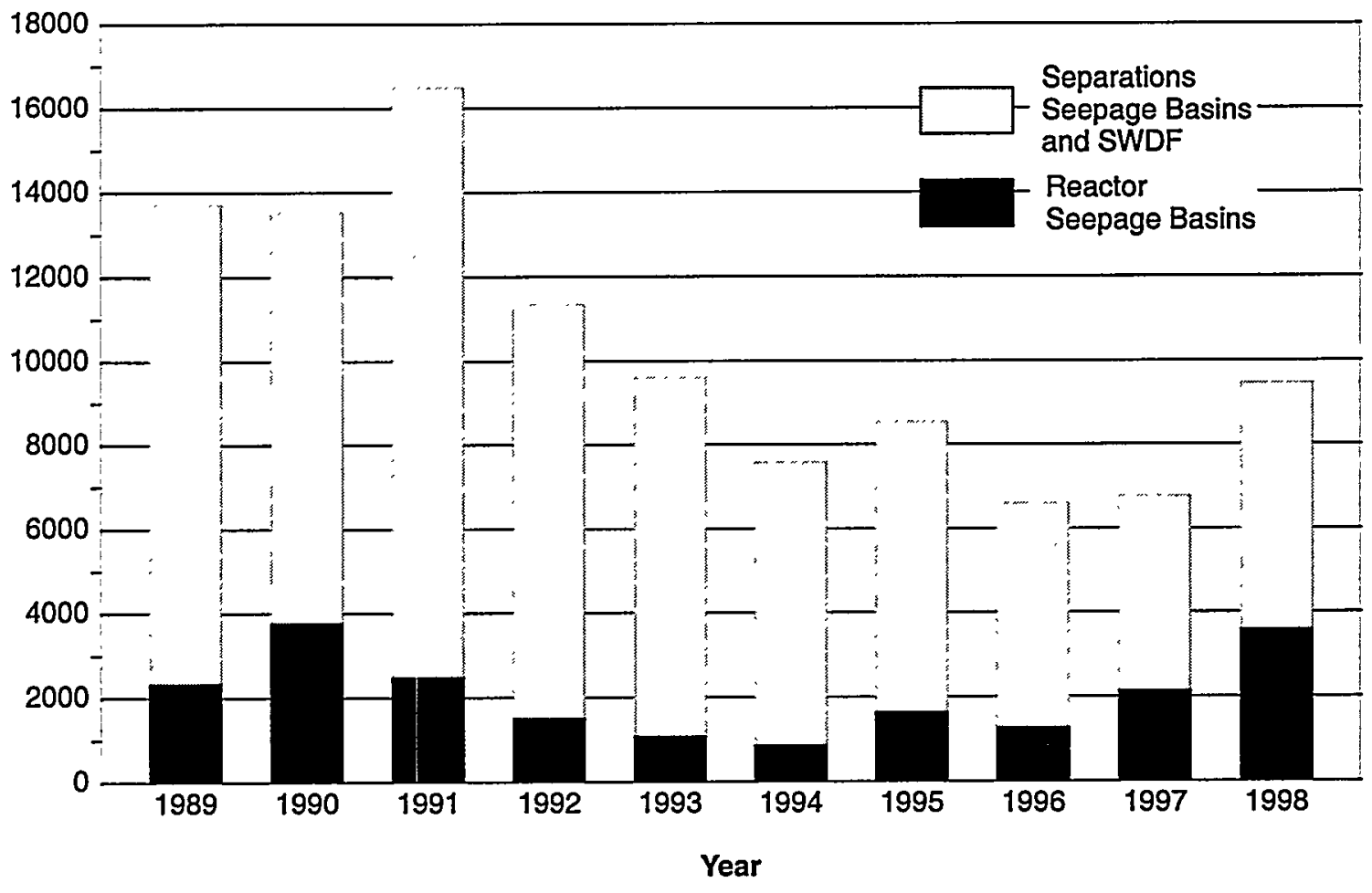

lleaf Graphic

Figure 5-3 Tritium Migration from Seepage Basins and SWDF to SRS Streams, 1989-1998

dose calculation. This value is reported in table 5-2 on page 84 of this chapter and in tables 6 and $8, S R S$ Environmental Data for 1998.

Figure 5-3 is a graphical representation of releases of tritium via migration to site streams for the years 1989-1998. During 1998, the total quantity of tritium migrating from the seepage basins and SWDF was about $9,463 \mathrm{Ci}(3.50 \mathrm{E}+14 \mathrm{~Bq})$, compared to $6,780 \mathrm{Ci}$ $(2.51 \mathrm{E}+14 \mathrm{~Bq})$ in 1997.

The total combined tritium releases in 1998 (direct discharges and migration from seepage basins and SWDF) were about $10,555 \mathrm{Ci}(3.91 \mathrm{E}+14 \mathrm{~Bq})$, compared to about 8,350 $\mathrm{Ci}(3.09 \mathrm{E}+14 \mathrm{~Bq})$ in 1997 (table 9, SRS Environmental Data for 1998). The cause of this 26 percent increase is not known, but increases in tritium migration may be attributed to increased rainfall at the site from late 1997 through the spring of 1998. Figure 5-4 shows 1989-1998 total combined tritium releases.

In calculating dose (chapter 7), the slightly higher stream transport value of $10,588 \mathrm{Ci}(3.92 \mathrm{E}+14 \mathrm{~Bq})$ was used instead of the total combined tritium release figure. SRS tritium transport data for 1960-1998 are summarized in chapter 6 (page 97, figure 6-6).
F-Area and $\mathrm{H}$-Area Seepage Basins and SWDF Radioactivity previously deposited in the F-Area and H-Area seepage basins and SWDF continues to migrate via the groundwater and to outcrop into Four Mile Creek (also known as Fourmile Branch) and into Upper Three Runs.

Groundwater migration from the F-Area seepage basins enters Four Mile Creek between sampling locations FM-3A, FM-2B, and FM-A7. Most of the outcropping from $\mathrm{H}$-Area seepage basins 1,2 , and 3 occurs between FM-1C and FM-2B. Outcropping from $H$-Area seepage basin 4 and part of SWDF occurs between FM-3 and FM-3A. Radioactivity from H-Area seepage basin 4 and SWDF mixes during groundwater migration to Four Mile Creek. Therefore, radioactivity from the two sources cannot be distinguished at the outcrop point. Four Mile Creek sampling locations are shown in chapter 6 , (page 92, figure 6-4).

Measured migration of tritium from F-Area seepage basins was $1,477 \mathrm{Ci}(5.46 \mathrm{E}+13 \mathrm{~Bq})$ in 1998 . This is nearly a 48 percent increase from the 1997 total of $1,000 \mathrm{Ci}(3.70 \mathrm{E}+13 \mathrm{~Bq})$. The measured migration from $\mathrm{H}$-Area seepage basin 4 and SWDF was 3,490 Ci (1.29E+14 Bq), a 18-percent increase from 


\section{Curies}

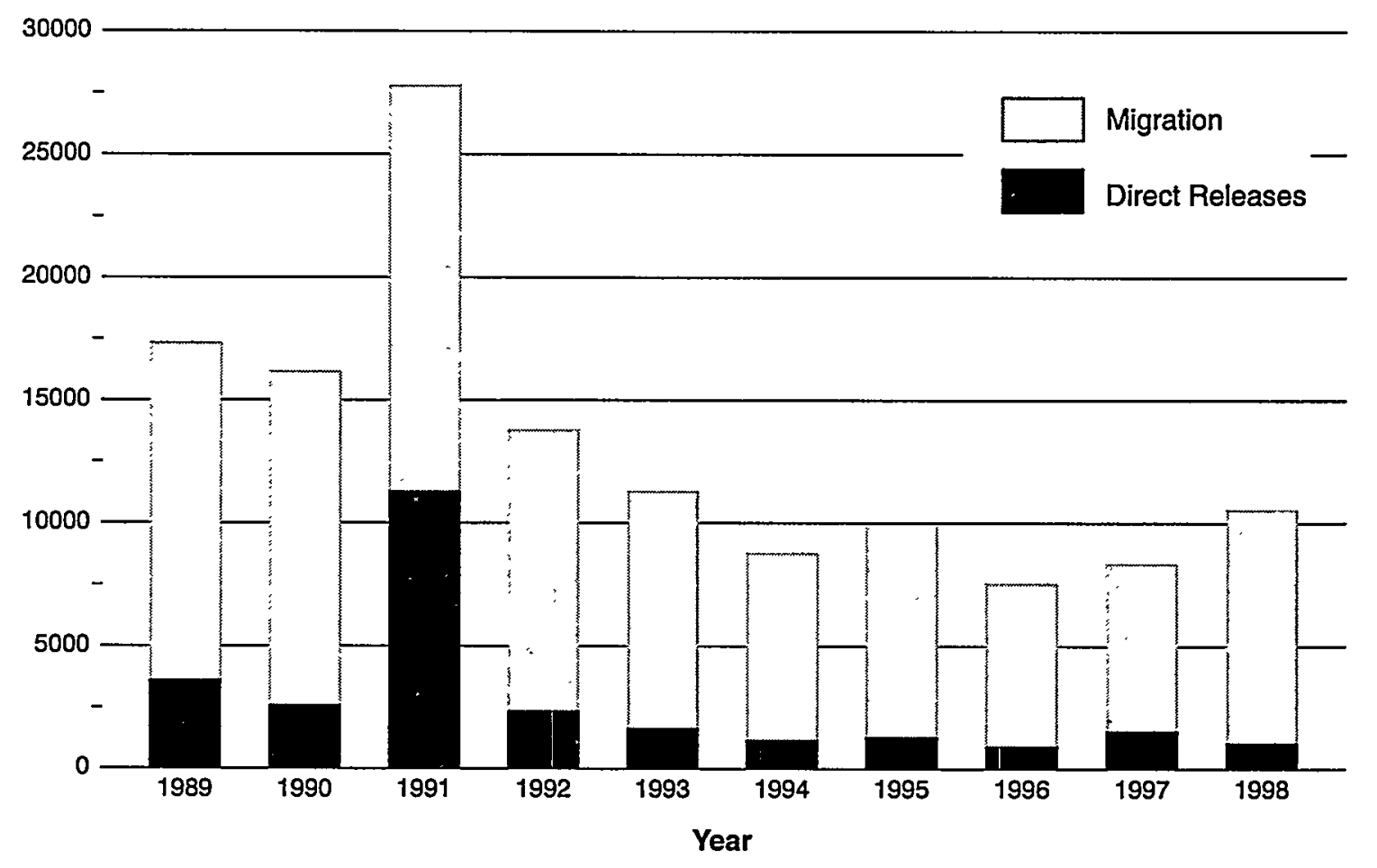

lleaf Graphic

Figure 5-4 Total Tritium Releases to SRS Streams (Direct Discharges and Migration), 1989-1998, Based on Point-of-Release Concentrations and Flow Rates

the 1997 total of $2,960 \mathrm{Ci}(1.10 \mathrm{E}+14 \mathrm{~Bq})$. The measured migration from $\mathrm{H}$-Area seepage basins 1,2 , and 3 was $515 \mathrm{Ci}(1.91 \mathrm{E}+13 \mathrm{~Bq})$, a 29 -percent increase from the 1997 total of $400 \mathrm{Ci}$ $(1.48 \mathrm{E}+13 \mathrm{~Bq})$.

Past, current, and projected tritium migration releases from the F-Area and H-Area seepage basins and SWDF into Four Mile Creek are shown in figure 5-5. Migration releases during 1998 were slightly less than the projected amount.

Generally, tritium migration from the F-Area and H-Area seepage basins, which were closed in 1988, has been declining and is projected to continue to decline [Looney, 1993]. Tritium migration from SWDF has fluctuated between 3,000 and 6,500 curies during the past 10 years. Based on recent assessments of the operational history of SWDF and the geology and hydrology of the site, it is anticipated that, with no corrective actions, SWDF tritium migration into Four Mile Creek is expected to continue, but slowly decrease for the next 20 to 25 years [Flach, 1996].
In 1998, EMS began accounting for tritium migration into Upper Three Runs. This migration is quantified by subtracting direct discharges (principally from the Effluent Treatment Facility) to Upper Three Runs from the stream transport location U3R-4. In the past, these migration releases were included in the stream transport total for Upper Three Runs. The measured migration from the north side of SWDF and the General Separations Area (GSA) into Upper Three Runs was $386 \mathrm{Ci}(1.43 \mathrm{E}+13 \mathrm{~Bq})$, a 45-percent increase from the 1997 total of $267 \mathrm{Ci}$ $(9.88 \mathrm{E}+12 \mathrm{~Bq})$. (The GSA is in the central part of SRS and contains all waste disposal facilities, chemical separations facilities, associated high-level waste storage facilities, and numerous other sources of radioactive material.)

A ten-year history of tritium migration releases into Upper Three Runs is shown in figure 5-6. Except for the years 1989 through 1991, tritium migration into Upper Three Runs has remained between 150 and $500 \mathrm{Ci}$ per year. However, a recent computer-modeled groundwater migration study predicts increased tritium migration to Upper Three Runs during the next 20 years [Cook, 1997]. This 
analysis assumes all current and future tritium inventories will migrate relatively fast without considering past migration releases or potential corrective actions; these assumptions are considered to be very conservative. A complete and thorough assessment of tritium migration into Upper Three Runs that is based on measured groundwater concentrations and movement has not yet been completed.

As required by the Resource Conservation and Recovery Act (RCRA) Part B Permit, SRS is developing SWDF groundwater corrective action plans for South Carolina Department of Health and Environmental Control (SCDHEC) approval. Portions of SWDF also are regulated under the Comprehensive Environmental Response, Compensation, and Liability Act (CERCLA). CERCLA characterization and assessment continued in 1998. Reduction of tritium migration releases is one of the factors being considered during the development of these RCRA/CERCLA groundwater corrective action plans. Low-permeability caps, waste form stabilization, groundwater barriers, groundwater pump-treat-reinjection, and other technologies are under consideration, or are currently being implemented, as components of SWDF remediation. Remediation is discussed in chapter 4, "Environmental Management."

The total amount of strontium- 89,90 entering Four Mile Creek from the GSA seepage basins and SWDF during 1998 was estimated to be $130 \mathrm{mCi}$ $(4.81 \mathrm{E}+09 \mathrm{~Bq})$. This was a 24-percent increase from the 1997 level of $105 \mathrm{mCi}(3.89 \mathrm{E}+09 \mathrm{~Bq})$.

In addition, a total of $55.5 \mathrm{mCi}(2.05 \mathrm{E}+09 \mathrm{~Bq})$ of cesium-137 was estimated to have migrated from the GSA seepage basins and SWDF in 1998. As discussed previously, iodine-129 was not measured in Four Mile Creek water samples during 1998. It was assumed that $78.2 \mathrm{mCi}(2.89 \mathrm{E}+09 \mathrm{~Bq})$ migrated from the GSA seepage basins in 1998. This was the amount last measured (during 1996).

K-Area Drain Field and Seepage Basin Liquid purges from the $\mathrm{K}$-Area disassembly basin were released to the K-Area seepage basin in 1959 and 1960. Since 1960, purges from the K-Area disassembly basin have been discharged to a percolation field below the $\mathrm{K}$-Area retention basin. A total tritium migration of $3,090 \mathrm{Ci}(1.14 \mathrm{E}+14 \mathrm{~Bq})$

\section{Curies}

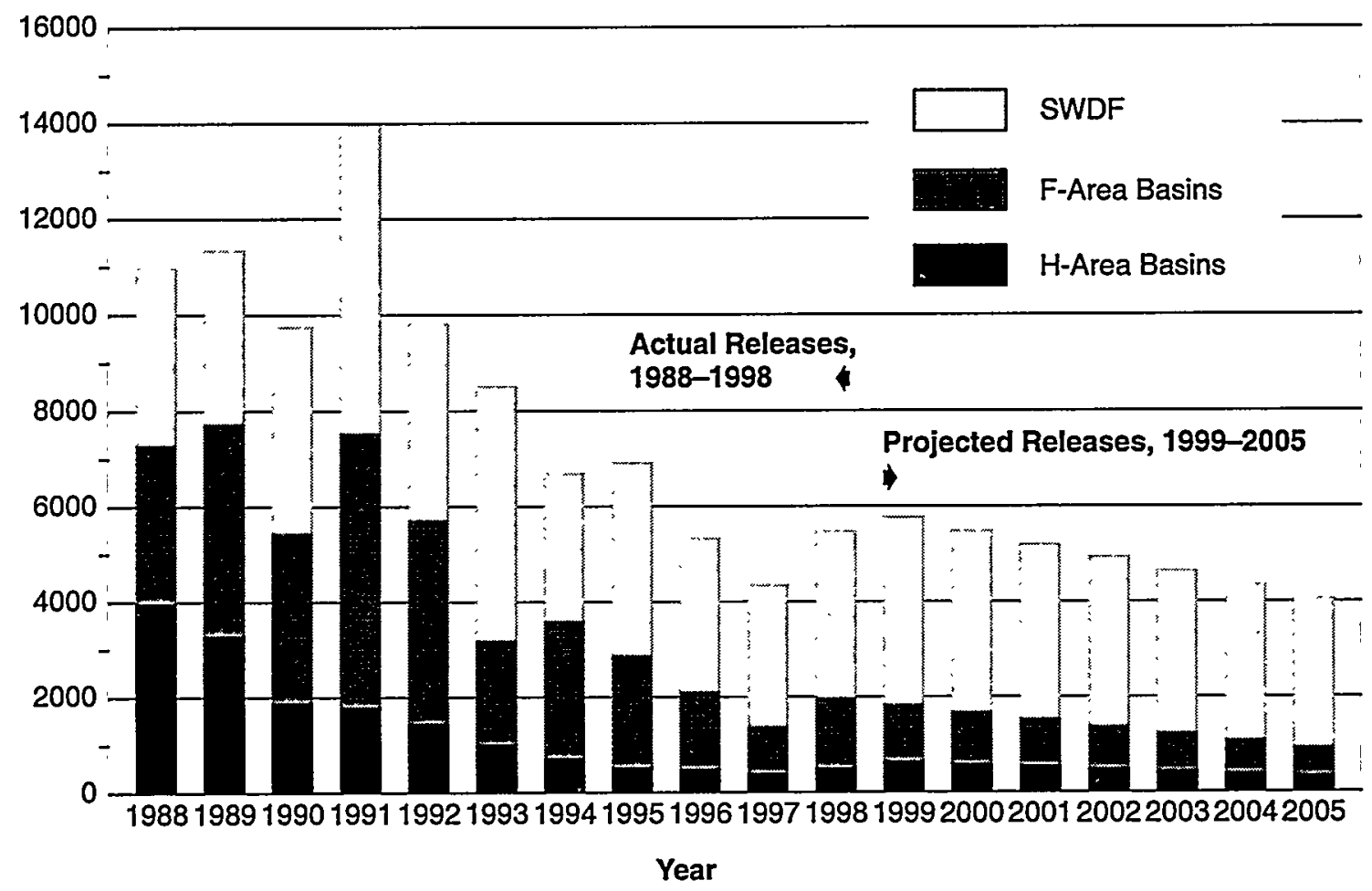

Ileaf Graphic

Figure 5-5 Past, Current, and Projected Tritium Migration Releases to Four Mile Creek from the F-Area and H-Area Seepage Basins and SWDF 


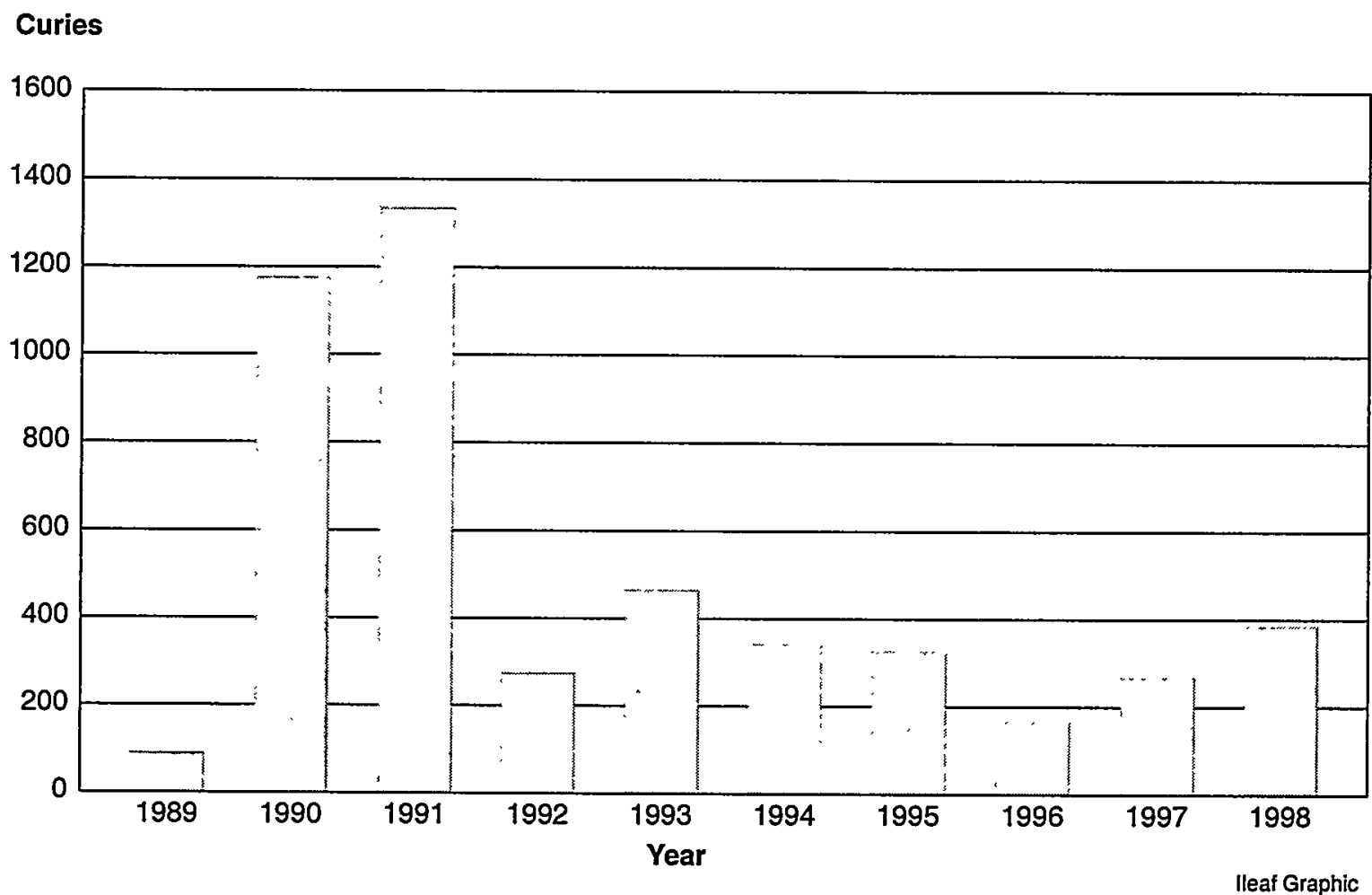

Figure 5-6 Tritium Migration Releases to Upper Three Runs from the General Separations Area and SWDF, 1989-1998

was measured in Pen Branch during 1998. The sample location used to determine tritium migration from the K-Area seepage basin was changed in 1997 to $\mathrm{PB}-3$. This location was determined to be the best location for capturing all migration from K-Area. The 1998 migration total represents a 44-percent increase from the $2,150 \mathrm{Ci}(7.96 \mathrm{E}+13 \mathrm{~Bq})$ recorded in 1997.

\section{P-Area, C-Area, and L-Area Seepage Basins}

Liquid purges from the P-Area, L-Area, and C-Area disassembly basins were released periodically to their respective seepage basins from the 1950s until 1970 . Purge water was released to the seepage basins to allow a significant part of the tritium to decay before the water outcropped to surface streams and flowed into the Savannah River. The delaying action of the basins reduced the dose that users of water from downriver water treatment plants received from SRS tritium releases. Between 1970 and 1978, disassembly basin purge water was released directly to SRS streams. However, the earlier experience with seepage basins indicated that the extent of radioactive decay during the holdup was sufficient to recommend that the basins be used again in P-Area, L-Area, and $\mathrm{C}$-Area, and the periodic release of liquid purges to the seepage basins was resumed. Because of SRS mission changes, however, these basins are no longer in service for receiving liquid purges from disassembly basins.

No radionuclide migration was attributed to the C-Area seepage basin in 1998. The failure of the Twin Lakes Dam in 1991 made the determination of migration more difficult in this area. Results from a sampler installed on Steel Creek above L-Lake indicated that $507 \mathrm{Ci}(1.88 \mathrm{E}+13 \mathrm{~Bq})$ of tritium migrated from the P-Area seepage basin during 1998 , 29 percent more than the $393 \mathrm{Ci}(1.45 \mathrm{E}+13 \mathrm{~Bq})$ of tritium in 1997. No migration of radionuclides from the L-Area seepage basin was detected in site streams.

\section{Transport of Actinides in Streams}

In 1996, a new and more sensitive actinide method was implemented for the analysis of uranium, plutonium, americium, and curium. As a result of the increased sensitivity, trace amounts of uranium and plutonium were detected at the stream transport locations FM-6, PB-3, L3R-2, and U3R-4.

Consequently, these small amounts were incorporated into the source term used for the calculation of the annual dose. Results (1996 through 1998) can be found in table 10, SRS Environmental Data for 1998. 
Table 5-1 Radioactive Atmospheric Releases by Source

Page 1 of 3

\begin{tabular}{|c|c|c|c|c|c|c|c|}
\hline \multirow[b]{2}{*}{$\begin{array}{l}\text { Radio- } \\
\text { nuclide }\end{array}$} & \multicolumn{7}{|c|}{ Curies $^{a}$} \\
\hline & Reactors & $\begin{array}{l}\text { Separa- } \\
\text { tions }^{b}\end{array}$ & $\begin{array}{l}\text { Reactor } \\
\text { Materials }\end{array}$ & $\begin{array}{l}\text { Heavy } \\
\text { Water }\end{array}$ & SRTCC & $\begin{array}{c}\text { Diffuse } \\
\text { and } \\
\text { Fugitive }^{d}\end{array}$ & Total \\
\hline Note: $\quad B l c$ & \multicolumn{7}{|c|}{ Blank spaces indicate no quantifiable activity. } \\
\hline \multicolumn{8}{|c|}{ GASES AND VAPORS } \\
\hline$H-3$ (oxide) & $2.28 E+04$ & $3.45 \mathrm{E}+04$ & & $4.04 E+02$ & & $9.31 E+02$ & $5.86 \mathrm{E}+04$ \\
\hline $\mathrm{H}-3$ (elem.) & & $2.41 E+04$ & & & & & $2.41 E+04$ \\
\hline H-3 Total & $2.28 E+04$ & $5.86 \mathrm{E}+04$ & & $4.04 E+02$ & & $9.31 E+02$ & $8.27 E+04$ \\
\hline C-14 & & 7.01E-02 & & & & $9.68 \mathrm{E}-05$ & 7.02E-02 \\
\hline $\mathrm{Kr}-85$ & & $1.70 E+04$ & & & & & $1.70 E+04$ \\
\hline Xe-135 & & 4.95E-02 & & & & & 4.95E-02 \\
\hline $1-129$ & & $1.25 \mathrm{E}-02$ & & & & $1.29 E-05$ & $1.25 E-02$ \\
\hline $1-131$ & & $5.92 E-05$ & & & $8.29 E-06$ & & $6.75 E-05$ \\
\hline $\mid-133$ & & & & & $1.59 E-04$ & & $1.59 E-04$ \\
\hline \multicolumn{8}{|c|}{ PARTICULATES } \\
\hline $\mathrm{Na}-22$ & & & & & & $7.76 E-11$ & $7.76 E-11$ \\
\hline $\mathrm{Cr}-51$ & & & & & & $1.21 E-04$ & $1.21 E-04$ \\
\hline $\mathrm{Fe}-55$ & & & & & & $3.90 E-04$ & $3.90 E-04$ \\
\hline Co-57 & & & & & & $9.40 E-11$ & $9.40 E-11$ \\
\hline Co-58 & & & & & & 1.27E-04 & 1.27E-04 \\
\hline Co-60 & & & & & $2.65 E-07$ & $1.38 E-04$ & $1.38 E-04$ \\
\hline $\mathrm{Ni}-59$ & & & & & & 8.33E-13 & 8.33E-13 \\
\hline $\mathrm{Ni}-63$ & & & & & & $8.21 E-06$ & 8.21E-06 \\
\hline$Z n-65$ & & & & & & $2.23 E-05$ & $2.23 E-05$ \\
\hline $\mathrm{Se}-79$ & & & & & & $1.85 E-11$ & $1.85 E-11$ \\
\hline $\mathrm{Sr}-89,90^{\ominus}$ & $1.62 E-03$ & $3.23 E-04$ & $5.05 E-04$ & $2.61 E-04$ & $2.66 \mathrm{E}-05$ & $2.58 \mathrm{E}-02$ & $2.85 E-02$ \\
\hline $\mathrm{Zr}-95$ & & & & & & $1.71 E-05$ & $1.71 E-05$ \\
\hline $\mathrm{Nb}-95$ & & & & & & $1.13 E-04$ & $1.13 E-04$ \\
\hline Tc-99 & & & & & & $2.82 E-05$ & $2.82 E-05$ \\
\hline$R u-103$ & & & & & & $2.26 \mathrm{E}-05$ & $2.26 \mathrm{E}-05$ \\
\hline$R u-106$ & & $1.08 \mathrm{E}-05$ & & & & $2.26 \mathrm{E}-05$ & $3.34 \mathrm{E}-05$ \\
\hline$S n-126$ & & & & & & $1.29 \mathrm{E}-13$ & $1.29 \mathrm{E}-13$ \\
\hline $\mathrm{Sb}-125$ & & $1.79 E-07$ & & & & 5.27E-05 & $5.29 E-05$ \\
\hline
\end{tabular}

a One curie equals $3.7 \mathrm{E}+10$ Becquerels.

b Includes separations, waste management, and tritium facilities

c Savannah River Technology Center

d Estimated releases from minor unmonitored diffuse and fugitive sources

$\theta$ Includes unidentified beta emissions 
Table 5-1 Radioactive Atmospheric Releases by Source

Page 2 of 3

\begin{tabular}{|c|c|c|c|c|c|c|c|}
\hline \multirow[b]{2}{*}{$\begin{array}{l}\text { Radio- } \\
\text { nuclide }\end{array}$} & \multicolumn{7}{|c|}{ Curies $^{a}$} \\
\hline & Reactors & $\begin{array}{l}\text { Separa- } \\
\text { tions }\end{array}$ & $\begin{array}{c}\text { Reactor } \\
\text { Materials }\end{array}$ & $\begin{array}{l}\text { Heavy } \\
\text { Water }\end{array}$ & SRTCC & $\begin{array}{c}\text { Diffuse } \\
\text { and } \\
\text { Fugitived }\end{array}$ & Total \\
\hline Cs-134 & & $2.32 \mathrm{E}-07$ & & & & $1.31 E-04$ & $1.31 E-04$ \\
\hline Cs-137 & $3.50 E-05$ & $3.77 E-04$ & & & $2.30 E-06$ & $4.89 E-03$ & $5.30 E-03$ \\
\hline $\mathrm{Ce}-141$ & & & & & & $4.16 \mathrm{E}-05$ & 4.16E-05 \\
\hline $\mathrm{Ce}-144$ & & & & & & $1.45 E-04$ & $1.45 E-04$ \\
\hline Pm-147 & & & & & & $9.79 E-10$ & $9.79 E-10$ \\
\hline Eu-152 & & & & & & 4.19E-08 & $4.19 E-08$ \\
\hline$E u-154$ & & & & & & $5.74 \mathrm{E}-06$ & $5.74 E-06$ \\
\hline Eu-155 & & & & & & 1.10E-06 & $1.10 E-06$ \\
\hline $\mathrm{Ra}-226$ & & & & & & $8.64 E-06$ & $8.64 E-06$ \\
\hline $\mathrm{Ra}-228$ & & & & & & $2.13 E-05$ & $2.13 E-05$ \\
\hline Th-228 & & & & & & $9.44 \mathrm{E}-06$ & $9.44 \mathrm{E}-06$ \\
\hline Th-230 & & & & & & $1.02 E-05$ & $1.02 E-05$ \\
\hline Th-232 & & & & & & $7.51 E-07$ & $7.51 E-07$ \\
\hline $\mathrm{Pa}-231$ & & & & & & $1.00 E-09$ & $1.00 E-09$ \\
\hline$U-232$ & & & $1.20 E-06$ & & & & $1.20 E-06$ \\
\hline $\mathrm{U}-233$ & & & & & & 2.35E-06 & $2.35 E-06$ \\
\hline$U-234$ & & $2.62 E-05$ & $3.39 E-05$ & & & $1.83 E-05$ & $7.84 \mathrm{E}-05$ \\
\hline$U-235$ & & 1.57E-06 & $6.21 E-06$ & & & $2.10 E-06$ & $9.88 E-06$ \\
\hline$U-236$ & & & & & & 2.39E-09 & $2.39 E-09$ \\
\hline$U-238$ & & $6.92 E-05$ & 6.32E-05 & & & $5.12 E-05$ & $1.84 \mathrm{E}-04$ \\
\hline $\mathrm{Np}-237$ & & & & & & $1.01 E-09$ & $1.01 E-09$ \\
\hline $\mathrm{Pu}-238$ & & $1.15 \mathrm{E}-04$ & 4.76E-08 & & & $3.28 E-04$ & 4.43E-04 \\
\hline$P u-239 e$ & $2.19 \mathrm{E}-04$ & $1.12 E-04$ & $5.09 \mathrm{E}-05$ & $2.98 E-05$ & 6.71E-06 & $1.41 E-03$ & $1.83 E-03$ \\
\hline$P u-240$ & & & & & & $1.12 E-06$ & $1.12 E-06$ \\
\hline$P u-241$ & & & & & & $6.02 E-05$ & $6.02 E-05$ \\
\hline$P u-242$ & & & & & & $1.59 E-07$ & $1.59 E-07$ \\
\hline Am-241 & & $3.31 \mathrm{E}-05$ & $2.17 E-08$ & & & $5.75 E-06$ & $3.89 E-05$ \\
\hline$A m-243$ & & & & & & 1.89E-05 & $1.89 E-05$ \\
\hline $\mathrm{Cm}-242$ & & & & & & $1.58 E-07$ & $1.58 \mathrm{E}-07$ \\
\hline $\mathrm{Cm}-244$ & & 3.67E-06 & 4.90E-09 & & & $1.30 E-04$ & $1.34 E-04$ \\
\hline
\end{tabular}

One curie equals $3.7 \mathrm{E}+10$ Becquerels.

Includes separations, waste management, and tritium facilities

Savannah River Technology Center

Estimated releases from minor unmonitored diffuse and fugitive sources

includes unidentified alpha emissions 
Table 5-1 Radioactive Atmospheric Releases by Source

Page 3 of 3

\begin{tabular}{|c|c|c|c|c|c|c|c|}
\hline \multirow[b]{2}{*}{$\begin{array}{l}\text { Radio- } \\
\text { nuclide }\end{array}$} & \multicolumn{7}{|c|}{ Curies $^{a}$} \\
\hline & Reactors & $\begin{array}{c}\text { Separa- } \\
\text { tions }^{\mathbf{b}}\end{array}$ & $\begin{array}{c}\text { Reactor } \\
\text { Materials }\end{array}$ & $\begin{array}{l}\text { Heavy } \\
\text { Water }\end{array}$ & SRTC & $\begin{array}{c}\text { Diffuse } \\
\text { and } \\
\text { Fugitive }^{\text {d }}\end{array}$ & Total \\
\hline $\mathrm{Cm}-245$ & & & & & & $2.08 \mathrm{E}-13$ & $2.08 E-13$ \\
\hline $\mathrm{Cm}-246$ & & & & & & 9.37E-07 & 9.37E-07 \\
\hline Cf-249 & & & & & & 5.27E-16 & 5.27E-16 \\
\hline Cf-251 & & & & & & $2.17 \mathrm{E}-14$ & 2.17E-14 \\
\hline
\end{tabular}

a One curie equals $3.7 \mathrm{E}+10$ Becquerels.

Includes separations, waste management, and tritium facilities

Savannah River Technology Center

Estimated releases from minor unmonitored diffuse and fugitive sources 
Table 5-2 Radioactive Liquid Releases by Source

(Including Direct and Seepage Basin Migration Releases)

Page 1 of 1

\begin{tabular}{|c|c|c|c|c|c|c|}
\hline \multirow[b]{2}{*}{$\begin{array}{l}\text { Radio- } \\
\text { nuclide }\end{array}$} & \multicolumn{6}{|c|}{ Curies $^{a}$} \\
\hline & Reactors & Separations ${ }^{b}$ & $\begin{array}{l}\text { Reactor } \\
\text { Materials }\end{array}$ & $\begin{array}{c}\text { Heavy } \\
\text { Water/TNX }\end{array}$ & $\begin{array}{c}\text { Savannah } \\
\text { River } \\
\text { Technology } \\
\text { Center }\end{array}$ & Total \\
\hline \multicolumn{7}{|c|}{ Blank spaces indicate no quantifiable activity. } \\
\hline H-3 (oxide) & $3.44 \mathrm{E}+03$ & $6.75 \mathrm{E}+03$ & & $3.98 E+02$ & $1.52 E+00$ & $1.06 E+04$ \\
\hline Sr-89,90c & $2.21 E-02$ & 2.70E-01 & $3.25 \mathrm{E}-03$ & $3.22 E-03$ & $4.24 \mathrm{E}-03$ & $3.03 E-01$ \\
\hline $1-129$ & & $7.82 E-02$ & & & & $7.82 E-02^{d}$ \\
\hline Cs-134 & & $1.01 \mathrm{E}-04$ & & & & $1.01 E-04$ \\
\hline Cs-137 & $1.16 \mathrm{E}-02$ & $1.82 E-01$ & & & & $1.93 E-01$ \\
\hline $\mathrm{U}-234$ & $6.70 E-03$ & $3.99 E-02$ & $7.02 E-06$ & $9.20 \mathrm{E}-06$ & $8.48 E-05$ & 4.67E-02 \\
\hline U-235 & $7.16 \mathrm{E}-05$ & $1.70 \mathrm{E}-03$ & 4.17E-06 & $4.30 \mathrm{E}-07$ & $2.83 E-06$ & $1.78 \mathrm{E}-03$ \\
\hline U-238 & $5.09 \mathrm{E}-03$ & $4.78 E-02$ & $5.38 \mathrm{E}-05$ & $2.39 E-05$ & $7.83 E-05$ & $5.30 \mathrm{E}-02$ \\
\hline Pu-238 & $4.90 E-04$ & $9.80 \mathrm{E}-04$ & $3.19 \mathrm{E}-06$ & $2.59 E-06$ & 1.47E-05 & $1.49 \mathrm{E}-03$ \\
\hline Pu-239e & $1.36 \mathrm{E}-03$ & 2.77E-02 & $2.38 \mathrm{E}-03$ & $1.70 E-03$ & 4.41E-03 & $3.76 \mathrm{E}-02$ \\
\hline Am-241 & & $3.93 E-06$ & $1.34 \mathrm{E}-05$ & & & $1.73 E-05$ \\
\hline $\mathrm{Cm}-244$ & & 2.36E-06 & & & & $2.36 E-06$ \\
\hline
\end{tabular}

\footnotetext{
One curie equals $3.7 \mathrm{E}+10$ Becquerels.

Includes separations, waste management, and tritium facilities

Includes unidentified beta emissions

Measured iodine-129 results were not available for 1997 and 1998 from the Savannah River Technology Laboratory.

This value was measured in 1996.

e Includes unidentified alpha emissions
} 
To Read About ... $\quad$ See Page...

Mary Dodgen, Pete Fledderman, Bill Littrell, Phillip Miller, and Stuart Stinson

Environmental Protection Department
Air........................ 86

Rainwater .................... 88

Gamma Radiation ................. 89

Seepage Basins ................. 90

Site Streams .................... 91

Savannah River ..................... 95

Drinking Water . . . . . . . . . . . . . . . 98

Terrestrial Food Products . . . . . . . . . . . . 98

Aquatic Food Products . . . . . . . . . . . . 100

Deer and Hogs . . . . . . . . . . . . . . . . . 102

Turkeys ................... 103

Beavers ... . . . . . . . . . . . . . . . . . 104

Soil . . . . . . . . . . . . . . . . . . . . . . . 104

Sediment.... . . . . . . . . . . . . . . . . . 104

Grassy Vegetation ................ 106

\section{Highlights}

- As in previous years, tritium-in-air values were highest near the center of the site and at D-Area. This is consistent with the operations at these facilities. The tritium concentration in air rapidly decreases as a function of distance from the source.

- Tritium is the predominant radionuclide detected above background levels in the Savannah River. The average concentration at RM-120, located at U.S. Highway 301 below SRS, was $948 \mathrm{pCi} / \mathrm{L}$-less than 5 percent of the 20,000-pCi/L derived drinking water standard set by EPA for tritium in drinking water.

- No drinking water samples collected and analyzed by EMS exceeded the 20,000-pCi/L EPA derived drinking water standard for tritium. The average tritium concentration in finished water at Beaufort-Jasper, $728 \mathrm{pCi} / \mathrm{L}$, was approximately 4 percent of the EPA derived drinking water limit, as was the average tritium concentration at Port Wentworth, $829 \mathrm{pCi} / \mathrm{L}$.

- A total of 1,293 deer and 61 feral hogs were taken from SRS during 12 hunts as part of the site's controlled hunt program. This compares with 1,363 deer and 85 feral hogs taken during 14 hunts in 1997 . The hunts are conducted to control the site's deer and hog populations and to reduce the number of animal-vehicle collisions.

$\mathrm{T}$ HE Savannah River Site (SRS) radiological environmental surveillance program is designed to survey and quantify any effects that routine and nonroutine operations might have on the site and on the surrounding area and population. The program represented an extensive network in 1998 that covered approximately 2,000 square miles and extended up to 25 miles from the site. In conjunction with the radiological effluent monitoring program (chapter 5, "Radiological Effluent Monitoring"), the program enables SRS to monitor ambient radiological conditions and determine site contributions of radioactive materials to the environment.

Routine radiological surveillance activities are performed by the Environmental Protection Department's Environmental Monitoring Section (EMS) and by the Savannah River Technology Center (SRTC). The Savannah River also is monitored by other groups, including the South Carolina Department of Health and Environmental Control (SCDHEC) and the Georgia Department of Natural Resources (GDNR).

As part of the radiological surveillance program, routine surveillance of all radiation exposure pathways (ingestion, inhalation, immersion, and submersion) is performed on all environmental media that may lead to a measurable annual dose at the site boundary. This chapter summarizes surveillance results of the atmosphere (air and rainwater), surface water (seepage basins, site streams, and the Savannah River), drinking water, food products (terrestrial and aquatic), wildlife, soil, sediment, and vegetation. Also summarized are results of extensive monitoring of ambient gamma radiation levels performed on site, at the site boundary, and in population centers (surrounding communities). A description of the surveillance program and 1998 results for 
groundwater can be found in chapter 10, "Groundwater."

Analytical results for 1998 appear in SRS

Environmental Data for 1998. Nominal lower limits of detection (LLDs) for the types of analyses being performed on the various environmental surveillance media can be found in table 2 of SRS Environmental Data for 1998 (WSRC-TR-98-00314). Information on the rationale for the radiological environmental surveillance program can be found in chapter 3 , "Environmental Program Information." Data from earlier years can be found in previous SRS environmental reports and data publications.

A complete description of the SRS radiological environmental surveillance program can be found in section 1105 of the Savannah River Site Environmental Monitoring Section Plans and Procedures, WSRC-3Q1-2, Volume 1 (SRS EM Program).

\section{Air}

\section{Description of Surveillance Program}

EMS maintains an extensive network of 17 sampling stations in and around SRS to monitor the concentration of radioactive materials in the air. As a result of an EMS critical contaminant/critical pathway analysis completed in 1997, the number of air surveillance program locations was reduced from 23 to 17 in 1998. These locations are divided into four subgroups, as follows:

- onsite

- site perimeter

- a control location at 25 miles

- selected major population centers at 25 and 100 miles

Figure 6-1 shows all the sampling locations except the 25- and 100-mile stations.

The air surveillance program helps determine the impact (if any) of site operations on the environment and evaluates trends in airborne radionuclide concentrations. The program also is used to verify atmospheric transport models and to support emergency response activities in the event of an unplanned release of radioactive material to the atmosphere.

\section{Surveillance Results}

Chapter 5 details the types and quantity of radioactive material released to the environment from SRS

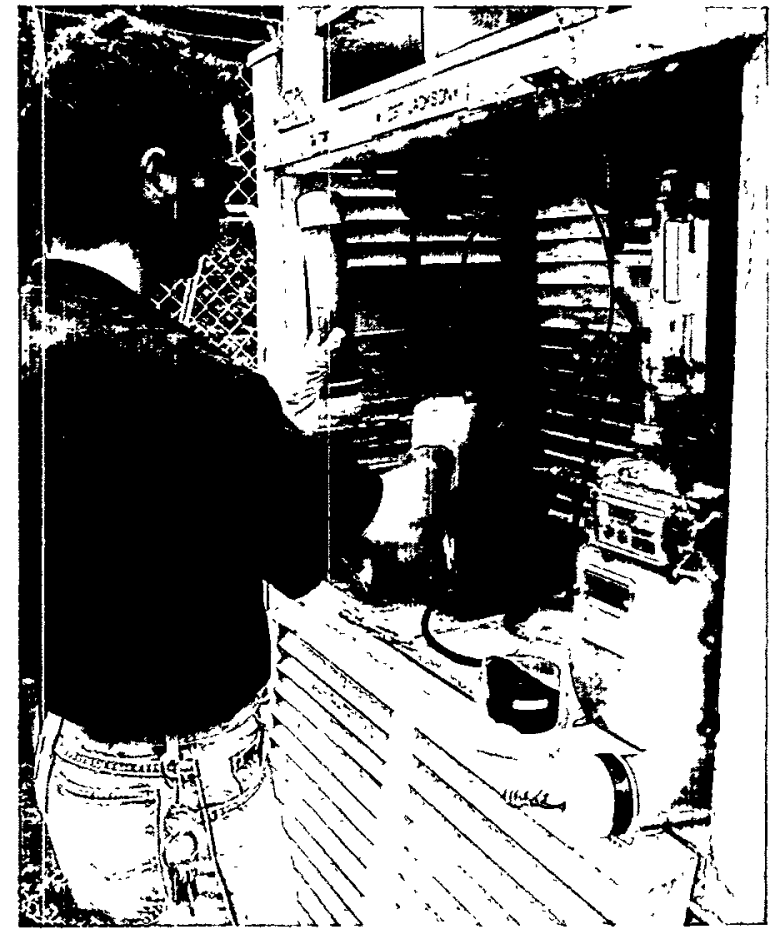

Al Mamatey Photo (98X03269.10)

An EMS technician exchanges a silica gel collection column in one of SRS's air surveillance stations. The stations are serviced every week, with silica gel columns exchanged on a biweekly basis.

activities in 1998. Except for tritium, specific radionuclides were not routinely detectable at the site perimeter. Both onsite and offsite activity concentrations were similar to levels observed in previous years (table 11, SRS Environmental Data for 1998).

\section{Gross Alpha and Gross Beta}

Gross alpha and gross beta activity analyses are performed on glass fiber filter papers. Although they cannot provide concentrations of specific radionuclides, these measurements are useful in providing information for trending of the total activity in an air sample or in screening samples:

A summary of the monitoring results from 1994-1998 is presented in table 6-1. Both the average onsite gross alpha and average onsite gross beta results are slightly lower than-but still consistent with-the 1997 results. Results from the site perimeter and 25-mile-radius stations are slightly higher than - but also still consistent with-the 1997 results. The Savannah, Georgia, location was not sampled in 1998 because of lease and electric power 


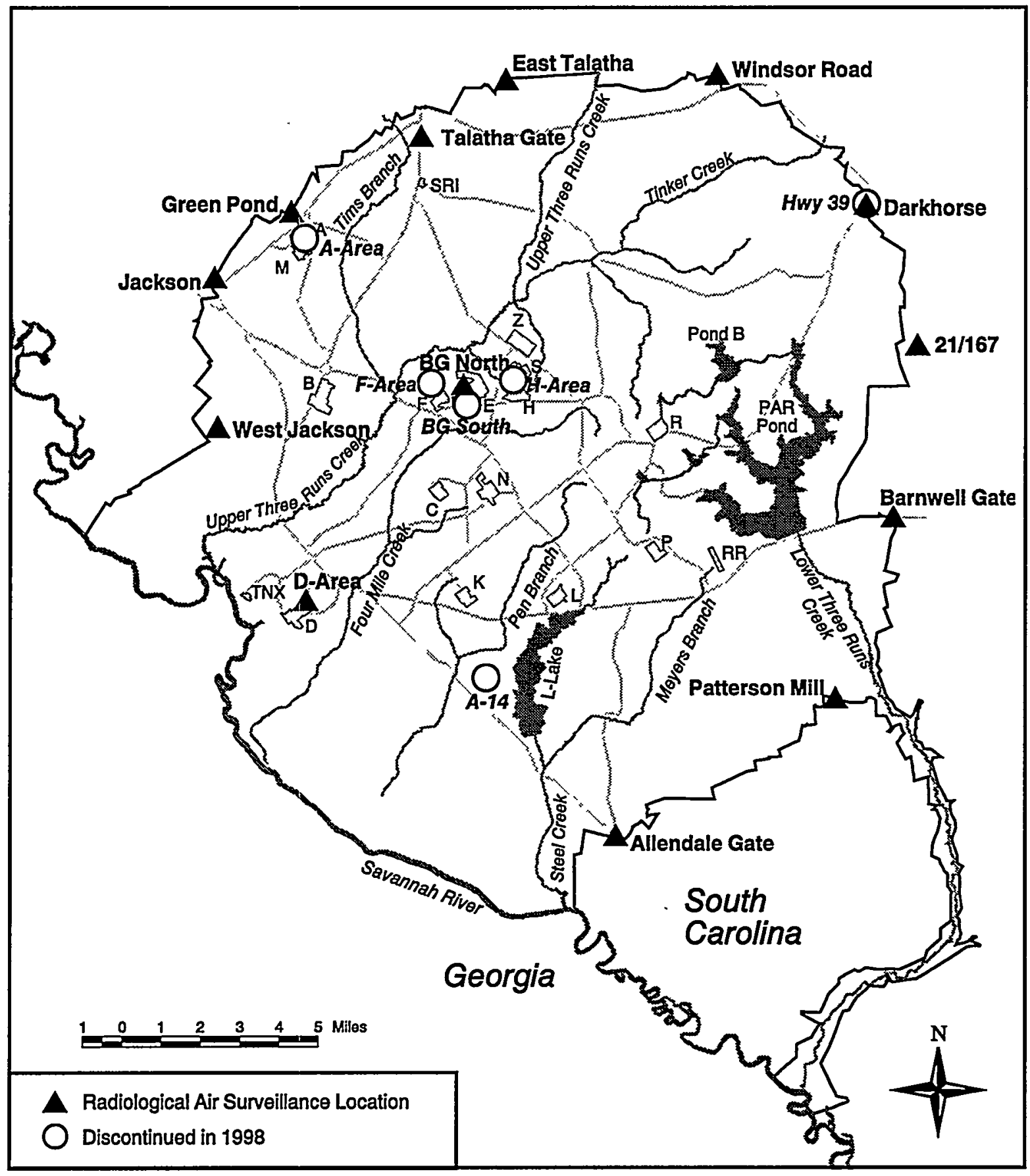

EPD/GIS Map

Figure 6-1 Radiological Air Surveillance Sampling Locations

The SRS air surveillance program consists of 13 stations (down from 19 in 1997) located on site or along the site perimeter, as well as (not shown) three stations approximately 25 miles from the site perimeter (located near the Highway 301 Bridge over the Savannah River, the Augusta Lock and Dam, and the Aiken airport) and one approximately 100 miles from the site perimeter (at Savannah, Georgia).

problems. In summary, the results observed are consistent with historical trends. As in previous years, no significant difference was seen between the average concentration measured on site near the operating facilities and the average concentration observed at the site perimeter. 
Table 6-1

Average Gross Alpha and Gross Beta Measured in Air (pCi/m³ $)$, 1994-1998

\begin{tabular}{|c|c|c|c|c|c|}
\hline \multicolumn{6}{|c|}{ Average Gross Alpha } \\
\hline Locations & 1994 & 1995 & 1996 & 1997 & 1998 \\
\hline On site & $1.4 E-3$ & $1.5 \mathrm{E}-3$ & $1.1 E-3$ & $1.2 E-3$ & $1.1 E-3$ \\
\hline Site perimeter & $1.4 \mathrm{E}-3$ & $1.4 \mathrm{E}-3$ & $1.0 \mathrm{E}-3$ & $9.8 \mathrm{E}-4$ & $1.4 \mathrm{E}-3$ \\
\hline 25 -mile radius & $1.4 \mathrm{E}-3$ & $1.4 \mathrm{E}-3$ & $1.0 \mathrm{E}-3$ & $1.0 \mathrm{E}-3$ & $1.5 E-3$ \\
\hline 100 -mile radius & $1.8 E-3$ & $1.6 \mathrm{E}-3$ & $9.4 \mathrm{E}-4$ & $1.1 E-3$ & a \\
\hline \multicolumn{6}{|c|}{ Average Gross Beta } \\
\hline Locations & 1994 & 1995 & 1996 & 1997 & 1998 \\
\hline On site & 1.7E-2 & $1.8 \mathrm{E}-2$ & $1.5 \mathrm{E}-2$ & 1.7E-2 & $1.6 \mathrm{E}-2$ \\
\hline Site perimeter & $1.8 \mathrm{E}-2$ & $1.8 \mathrm{E}-2$ & $1.5 \mathrm{E}-2$ & $1.5 \mathrm{E}-2$ & $1.8 \mathrm{E}-2$ \\
\hline 25-mile radius & $1.8 \mathrm{E}-2$ & $1.8 \mathrm{E}-2$ & $1.6 \mathrm{E}-2$ & $1.6 \mathrm{E}-2$ & $1.9 E-2$ \\
\hline 100 -mile radius & $1.8 \mathrm{E}-2$ & $1.8 \mathrm{E}-2$ & $1.4 E-2$ & $1.1 \mathrm{E}-2$ & a \\
\hline a Not sampled & & & & & \\
\hline
\end{tabular}

\section{Gamma-Emitting Radionuclides}

Glass fiber filters and activated charcoal canisters are collected weekly. Program changes implemented in 1998 eliminated routine analysis of activated charcoal canisters and changed analytical protocols for glass fiber filters by eliminating composites. No manmade gamma-emitting radionuclides were observed n 1998. These results are consistent with historical results, which indicate a small number of samples with detectable activity.

\section{Tritium}

Tritium-in-air analyses are conducted on biweekly silica gel samples. Tritium is released as part of routine SRS operations and becomes part of the natural environment. Monitoring ensures that it poses no health risk to the surrounding population. Consistent with the SRS source term, tritium concentrations generally decrease with increasing distance from the tritium facilities near the center of the site. In addition, the analytical results generally agree with the predictions of the SRS transport and dose assessment model, as detailed in chapter 7, "Potential Radiation Doses."

\section{Plutonium and Strontium}

Glass fiber filters are composited either weekly or monthly and analyzed for plutonium isotopes (plutonium-238 and plutonium-239) and total strontium (strontium-89,90). These radionuclides are released in small quantities as part of routine site operations-primarily from the separations areas. The observed concentrations of the radionuclides in 1998 were similar to historical levels; all locations were below the nominal LLDs. Because of these levels, no distribution pattern or difference between onsite and offsite locations was observed.

\section{Rainwater}

SRS maintains a network of rainwater sampling sites as part of the air surveillance program. These stations are used to measure deposition of radioactive materials.

\section{Description of Surveillance Program}

Rainwater collection pans are located at each routine air surveillance station (figure 6-1). Program modifications-as explained in the "Air" section of this chapter-reduced the number of rain ion column sites in 1998 from 10 to seven and the number of rainwater sites from 23 to 17 . Ion-exchange resin columns are placed at seven of these locations. At each of these locations, rain passes through the column and into a collection bottle. Both the ion-exchange resin column and the collected liquid are returned to the laboratory for analysis. The column is analyzed weekly for gamma-emitting radionuclides, gross alpha, and gross beta and annually for plutonium-238, plutonium-239, and strontium- 89,90 , while the rainwater is analyzed for. tritium. At all other locations, the collected rainwater is returned to the laboratory and analyzed for tritium only. Ion-exchange column sampling is performed 


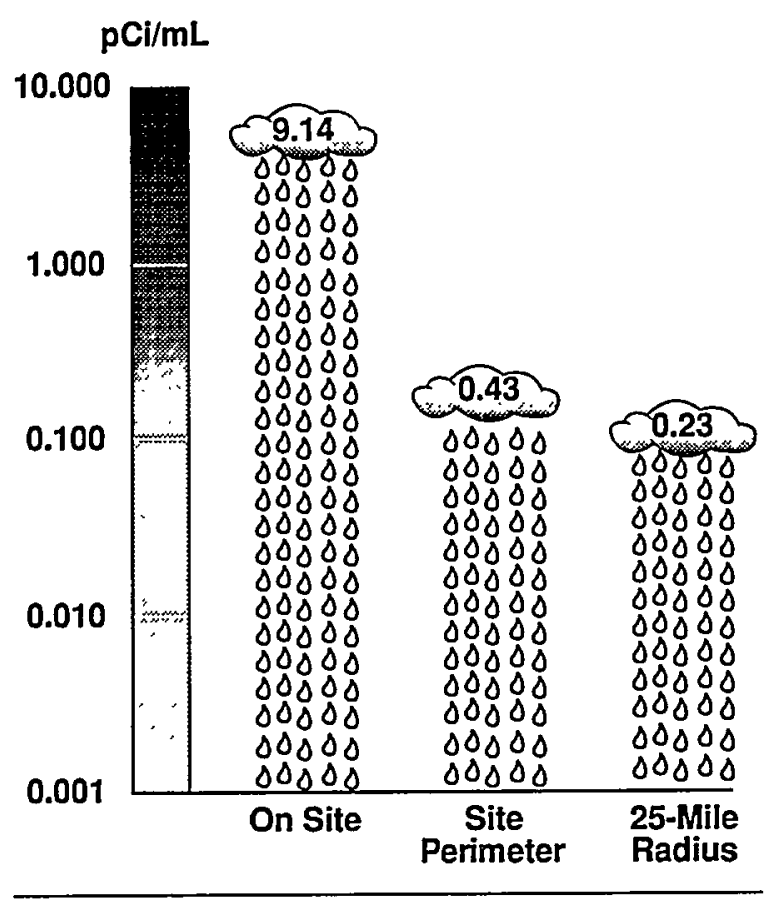

99X00886.01 (modified)

Figure 6-2 Average Concentration of Tritium in Rainwater

Tritium concentrations in rainwater (shown here in $\mathrm{pCi} / \mathrm{mL}$ ), generally decrease as the distance from the site increases.

monthly, while rainwater sampling is performed biweekly.

\section{Surveillance Results}

Detailed results of rainwater analyses can be found in tables 12 and 13 of SRS Environmental Data for 1998.

\section{Gamma-Emitting Radionuclides}

As in 1997, no detectable manmade gamma-emitting radionuclides were observed in rainwater samples during 1998.

\section{Gross Alpha and Gross Beta}

The gross alpha and gross beta results were consistent with those of 1997; no increasing or decreasing trend was evident. This implies that the observed values are natural background and does not indicate any contribution directly attributable to SRS.

\section{Plutonium}

No detectable levels of plutonium-238 or plutonium-239 were observed in rainwater samples during 1998. This generally is consistent with 1997 results, in which plutonium was quantified twice at levels slightly above detection-once in a sample collected 25 miles from the site and once in a sample collected 100 miles from the site.

\section{Strontium}

As in 1997, no detectable levels of strontium-89,90 were observed in rainwater samples during 1998.

\section{Tritium}

As in previous years, tritium-in-rain values were highest at those locations near the center of the site and at D-Area. This is consistent with the D-Area and H-Area effluent release points that routinely release tritium. As with tritium in air, concentrations generally decreased as distance from the effluent release point increased (figure 6-2); this observation also is consistent with the source term and with atmospheric transport.

\section{Gamma Radiation}

\section{Description of Surveillance Program}

Ambient gamma exposure rates in and around SRS are monitored by an extensive network of dosimeters. The site uses the thermoluminescent dosimeter (TLD) to quantify integrated gamma exposure on a quarterly basis. The TLD performs this function accurately, reliably, and relatively inexpensively.

SRS has been monitoring ambient environmental gamma exposure rates with TLDs since 1965. The information provided by this program is used primarily to determine the impact (if any) of site operations on the gamma exposure environment and to evaluate trends in environmental exposure levels. Other potential uses include

- support of routine and emergency response dose calculation models

- assistance in determining protective action recommendations in the event of an unplanned release of gamma-emitting radionuclides

- confirmatory accident assessment

The SRS ambient gamma radiation monitoring program is divided into four subprograms, as follows: site perimeter stations, population centers, air surveillance stations, and Vogtle (stations that monitor potential exposures from Georgia Power's Vogtle Electric Generating Plant). All TLDs are exchanged quarterly. Program modifications were implemented during 1998 as a result of the 1997 EMS critical contaminant/critical pathway analysis. These modifications eliminated all monitoring around SRS operating areas and, in conjunction with air 


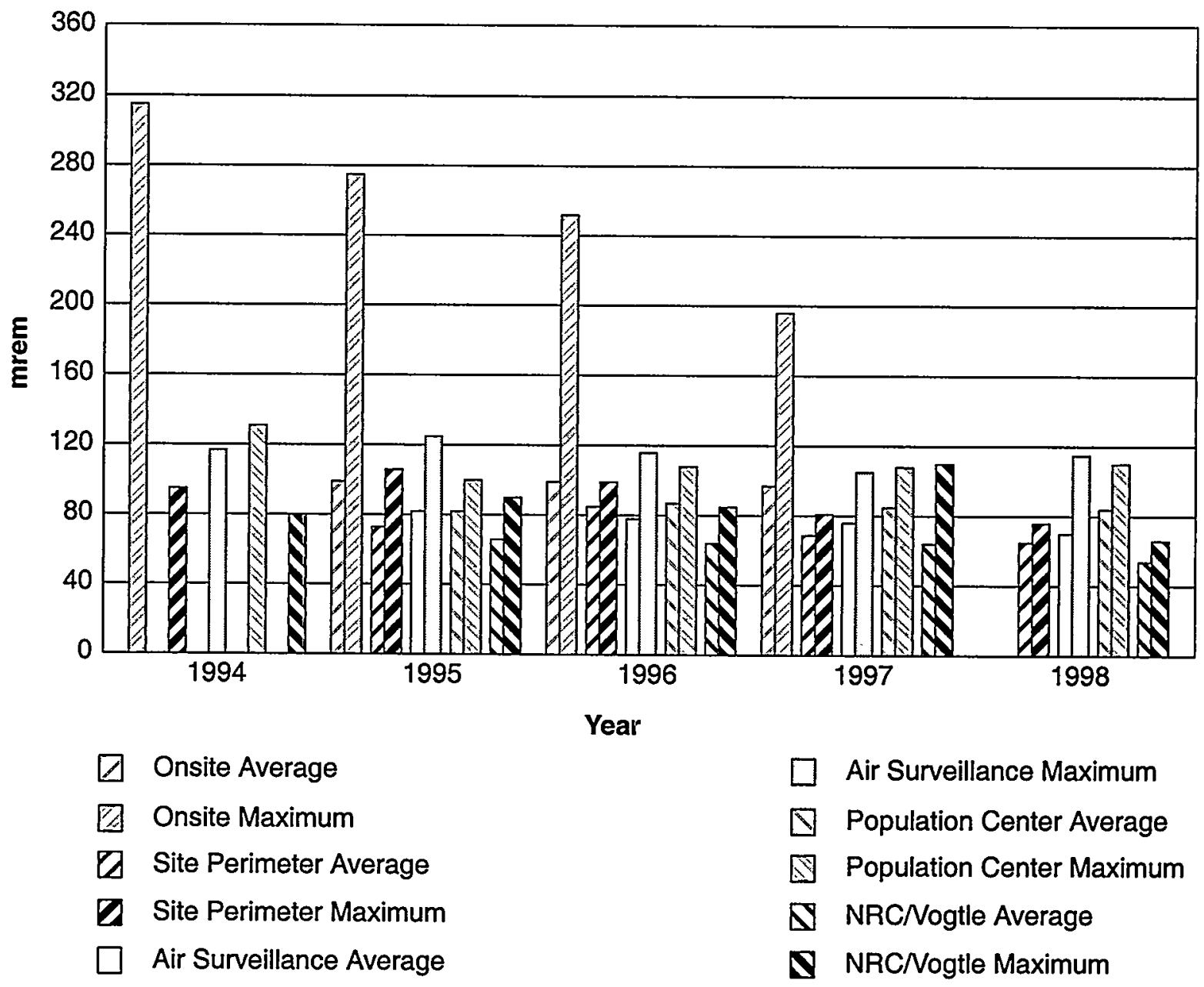

Nleal Graphic

Figure 6-3 Annual Average and Maximum Gamma Exposure Grouped by Program Element Natural background gamma exposure levels remain fairly constant with time. With the exception of a few locations, onsite gamma exposure levels at SRS are similar to regional background levels.

surveillance program changes, reduced the number of air surveillance locations from 23 to 17.

Most gamma exposure monitoring is conducted on site and at the site perimeter. Monitoring continues to be conducted in population centers within approximately 9 miles $(15 \mathrm{~km})$ of the site boundary, but only limited monitoring is conducted beyond this distance and at the 25-and 100-mile air surveillance stations.

\section{Surveillance Results}

Only two quarters of ambient gamma radiation monitoring results could be obtained in 1998 because of analytical difficulties. In general, the 1998 results indicated gamma exposure rates consistent with those observed at the same locations in 1997. Site perimeter and offsite locations were consistent with previously published historical results, as indicated in figure 6-3.

Exposures at all TLD monitoring locations show some variation based on normal site-to-site and year-to-year differences in the components of natural ambient gamma exposure levels. Generally, this phenomena also is observed at both onsite and offsite locations. Table 6-2 summarizes the 1998 surveillance results. Detailed analytical results from the TLD monitoring program can be found in tables 14, 15, 16, 17, and 18 of SRS Environmental Data for 1998.

\section{Seepage Basins}

During previous years of operation, SRS discharged liquid effluent to seepage basins to allow for the decay and natural removal of radioactivity in the 
Table 6-2

TLD Surveillance Results Summary for 1998

\begin{tabular}{lccc}
\hline $\begin{array}{l}\text { Monitoring } \\
\text { Subprogram }\end{array}$ & $\begin{array}{l}\text { Mean Exposure } \\
\text { (mrem per year) }\end{array}$ & $\begin{array}{l}\text { Maximum Exposure } \\
\text { (mrem per year) }\end{array}$ & $\begin{array}{l}\text { Maximum-Exposure } \\
\text { Location }\end{array}$ \\
\hline On site & & & \\
Site perimeter & 65 & 76 & Perimeter \#65-D \\
Air surveillance & 70 & 115 & Burial Ground North \\
Population centers & 84 & 110 & Girard, GA \\
NRCNogtle & 54 & 66 & GA Power \#4 High \\
& & & \\
\hline D Discontinued in 1998 & & & \\
\hline
\end{tabular}

water before it reached onsite streams. The practice of discharging water to the seepage basins was discontinued in 1988, but water accumulating in the basins from other sources continues to be monitored by EMS because of potential contamination from the basin soil.

\section{Description of Surveillance Program}

Seepage basin water is analyzed for gross alpha, gross beta, tritium, strontium, and gamma-emitting radionuclides. Analyses for specific radionuclides are determined by the makeup of previous releases to the basins.

In 1998, aqueous samples were scheduled to be collected annually from the TNX seepage basin, quarterly from A-Area, C-Area, L-Area, and P-Area seepage basins, and monthly from E-Area basins. Because of dry conditions, samples could be obtained only from three E-Area basins in 1998.

\section{Surveillance Results}

Because there are no active discharges to site seepage basins, the primary contributor to seepage basin water is from rainwater. As a result, there has been little variation in seepage basin results in recent years (table 19, SRS Environmental Data for 1998). In 1998, the highest mean tritium concentration, $(1.16 \pm 0.69) \mathrm{E}+04 \mathrm{pCi} / \mathrm{L}$, was found in the SWDF Basin North (E-002). This represents only a slight increase from the highest 1997 mean concentration, $(9.34 \pm 9.50) \mathrm{E}+03 \mathrm{pCi} / \mathrm{L}$, found in the SWDF Basin South (E-001), and is not an indication of significantly increasing tritium levels. Mean cobalt-60, cesium-137, gross alpha, and gross beta concentrations all were below the nominal LLD for rainwater.

\section{Site Streams}

Continuous surveillance is used on several SRS streams (figure 6-4), including Tims Branch, Upper Three Runs Creek, Four Mile Creek (also known as Fourmile Branch), Pen Branch, Steel Creek, and Lower Three Runs Creek. Stream water sampling locations that monitor below process areas serve to detect and quantify levels of radioactivity in liquid effluents that are being transported to the Savannah River. In 1998, 24 samplers on SRS streams served as environmental surveillance points.

\section{Description of Surveillance Program}

Stream samples were collected every other week during 1998 and analyzed as either biweekly or monthly composites. Frequency and types of analyses performed on each sample are based on the potential quantity and type of radionuclides likely to be present in the water at the surveillance station. Generally, tritium determinations, gamma and alpha spectroscopy, and gross alpha and gross beta screening are performed on stream water. Monthly composites also are analyzed for strontium-89,90-another likely byproduct of SRS operations. Analytical schemes for particular stream locations are documented in the SRS EM Program. The site implemented a new sample reporting regime in 1996 that requires the laboratory to report all gamma spectroscopy results for cobalt- 60 and cesium-137 and all alpha spectroscopy results for uranium-234, 235, and 238 and plutonium-238 and 239 , even though the results may be below the 


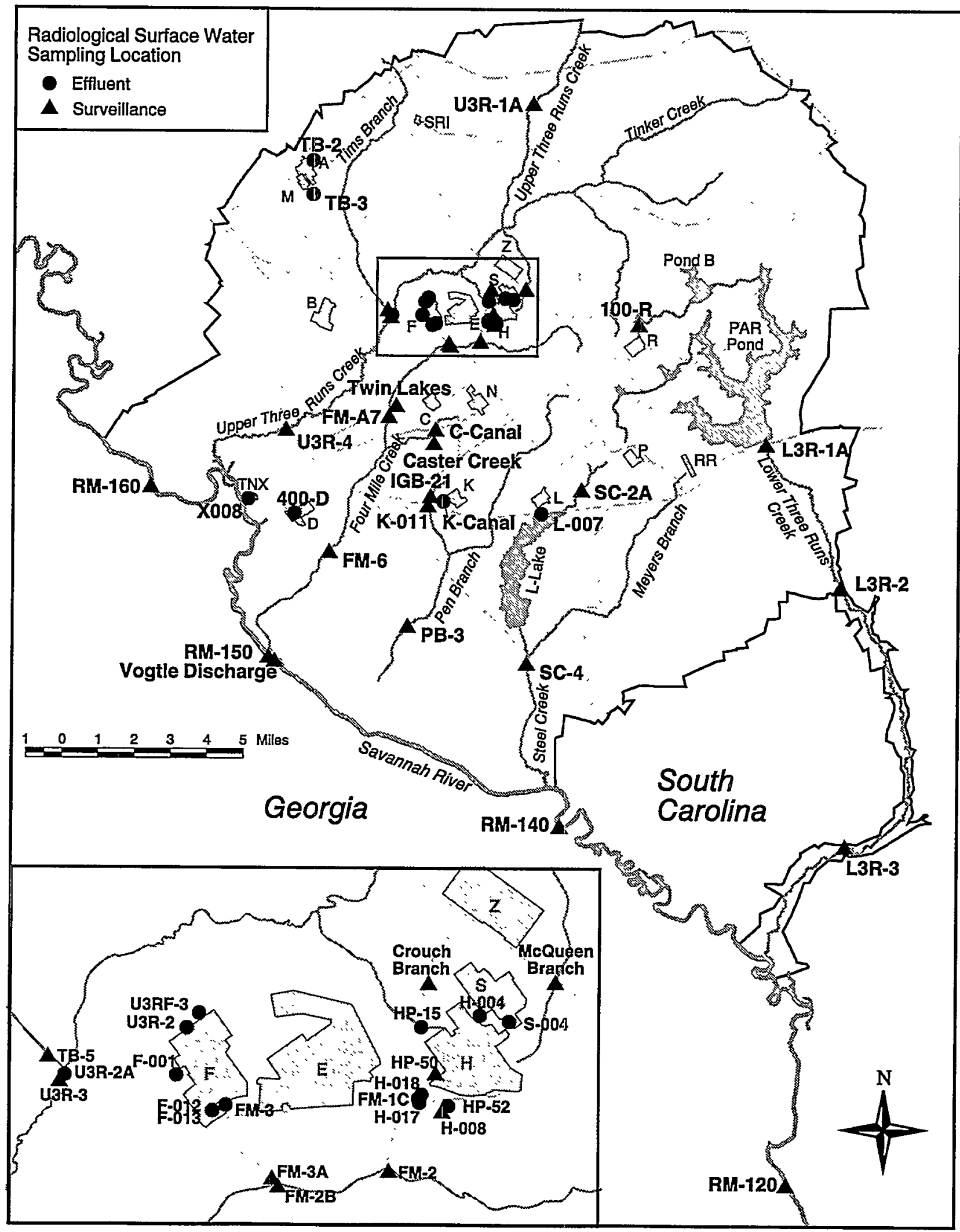

EPD/GIS Map

Figure 6-4 Radiological Surface Water Sampling Locations

Surveillance and effluent sampling points are at SRS seepage basins and streams and on the Savannah River. 
approximate LLDs listed in table 2 of $S R S$

Environmental Data for 1998.

\section{Surveillance Results}

The average gross alpha, gross beta, and tritium concentrations at downstream locations near the creek mouths are presented in table 6-3. A graph showing the average tritium concentration over a 10 -year period is presented in figure $6-5$. The locations of these stations, well below all points at which radioactivity is introduced into the respective streams, ensure that adequate mixing has taken place and that a representative sample is being analyzed. Concentrations at surveillance station U3R-1A (above process effluents and runoff locations on Upper Three Runs Creek) are listed for comparison purposes in table 6-3. Detailed results of stream water analyses appear in table 20 of SRS Environmental Data for 1998. The following sections contain discussions of surveillance results from each of the major SRS streams.

\section{Tims Branch}

A tributary of Upper Three Runs Creek, Tims Branch receives effluents from $M$-Area and SRTC. A surveillance point on Tims Branch, TB-5, is located downstream of all release points and before entry into Upper Three Runs Creek. The average tritium value at TB-5 in 1998 was below the nominal short-count LLD. The maximum recorded level of tritium, $(1.47 \pm 0.26) \mathrm{E}+03 \mathrm{pCi} / \mathrm{L}$, was slightly higher than the LLD. The 1998 gross alpha results were slightly above the nominal LLD, but all values were less than the values recorded at the U3R-1A sampling location, which is located above all SRS discharge points. The 1998 average gross beta results also were slightly above the nominal LLD and slightly higher, but still comparable, to the values recorded at the U3R-1A sampling location.

\section{Upper Three Runs Creek}

Upper Three Runs Creek receives discharges from the Effluent Treatment Facility (ETF), flow from Tims Branch, effluent from the Naval Fuels Facility, and stormwater runoff from $\mathrm{F}$-Area and $\mathrm{H}$-Area. Tritium, the predominant radionuclide detected in Upper Three Runs Creek, is discharged primarily from the ETF. The average concentration of tritium in 1998 at U3R-4, located on SRS Road A and the downstream point nearest to the Savannah River, was $(4.26 \pm 3.36) \mathrm{E}+03 \mathrm{pCi} / \mathrm{L}$, or 16.8 percent of the 2.00E+04-pCi/L EPA drinking water standard for tritium - virtually identical to 1997 levels. The mean gross alpha concentration at U3R-4 was $(2.48 \pm 1.37) \mathrm{E}+00 \mathrm{pCi} / \mathrm{L}$, or 16.5 percent of the 15-pCi/L EPA drinking water standard for gross alpha-down from 18.9 percent in 1997. Mean concentrations for uranium-234 and 238 were slightly higher than the nominal LLD, but the total activity from all uranium and plutonium isotopes, including uranium-234, 235, and 238 and plutonium-238 and 239 , was only $0.13 \mathrm{pCi} / \mathrm{L}$-less than 1 percent of the 15-pCi/L EPA drinking water standard for gross alpha activity. The mean gross beta activity was $(1.43 \pm 0.91) \mathrm{E}+00 \mathrm{pCi} / \mathrm{L}$ - slightly above the nominal LLD but still lower than the mean activity level found at the U3R-1A upstream location. Mean cobalt- 60 and cesium-137 activities were less than the nominal LLDs.

Table 6-3

Average 1998 Concentration of Radioactivity in SRS and Surveillance Station Waters (pCi/L)

$\begin{array}{lc}\begin{array}{l}\text { Locationa } \\ \text { Onsite Downstream Locations }\end{array} & \text { Gross Alpha } \\ \text { Tims Branch (TB-5) } & (4.08 \pm 3.27) \mathrm{E}+00 \\ \text { Upper Three Runs (U3R-4) } & (2.48 \pm 1.37) \mathrm{E}+00 \\ \text { Four Mile Creek (FMC-6) } & (4.33 \pm 4.83) \mathrm{E}+00 \\ \text { Pen Branch (PB-3) } & (5.64 \pm 5.23) \mathrm{E}-01 \\ \text { Steel Creek (SC-4) } & (0.98 \pm 1.14) \mathrm{E}+00 \\ \text { Lower Three Runs (L3R-2) } & (1.07 \pm 0.72) \mathrm{E}+00\end{array}$

Gross Beta

$(2.39 \pm 1.52) \mathrm{E}+00$

$(1.43 \pm 0.91) \mathrm{E}+00$

$(1.60 \pm 0.94) \mathrm{E}+01$

$(9.52 \pm 6.94) \mathrm{E}+01$

$(1.43 \pm 0.88) \mathrm{E}+00$

$(2.02 \pm 0.71) E+00$
Tritium

$(8.15 \pm 3.33) \mathrm{E}+02$

$(4.26 \pm 3.36) \mathrm{E}+03$

$(1.90 \pm 0.47) \mathrm{E}+05$

$(1.17 \pm 0.28) \mathrm{E}+05$

$(5.24 \pm 1.19) \mathrm{E}+04$

$(1.58 \pm 0.58) \mathrm{E}+03$

Onsite Surveillance Station (for comparison purposes)

Upper Three Runs (U3R-1A) $\quad(3.81 \pm 1.58) E+00$

$(1.75 \pm 0.87) E+00$

$(5.12 \pm 3.52) \mathrm{E}+02$

a Site surveillance locations are near mouths of streams. 


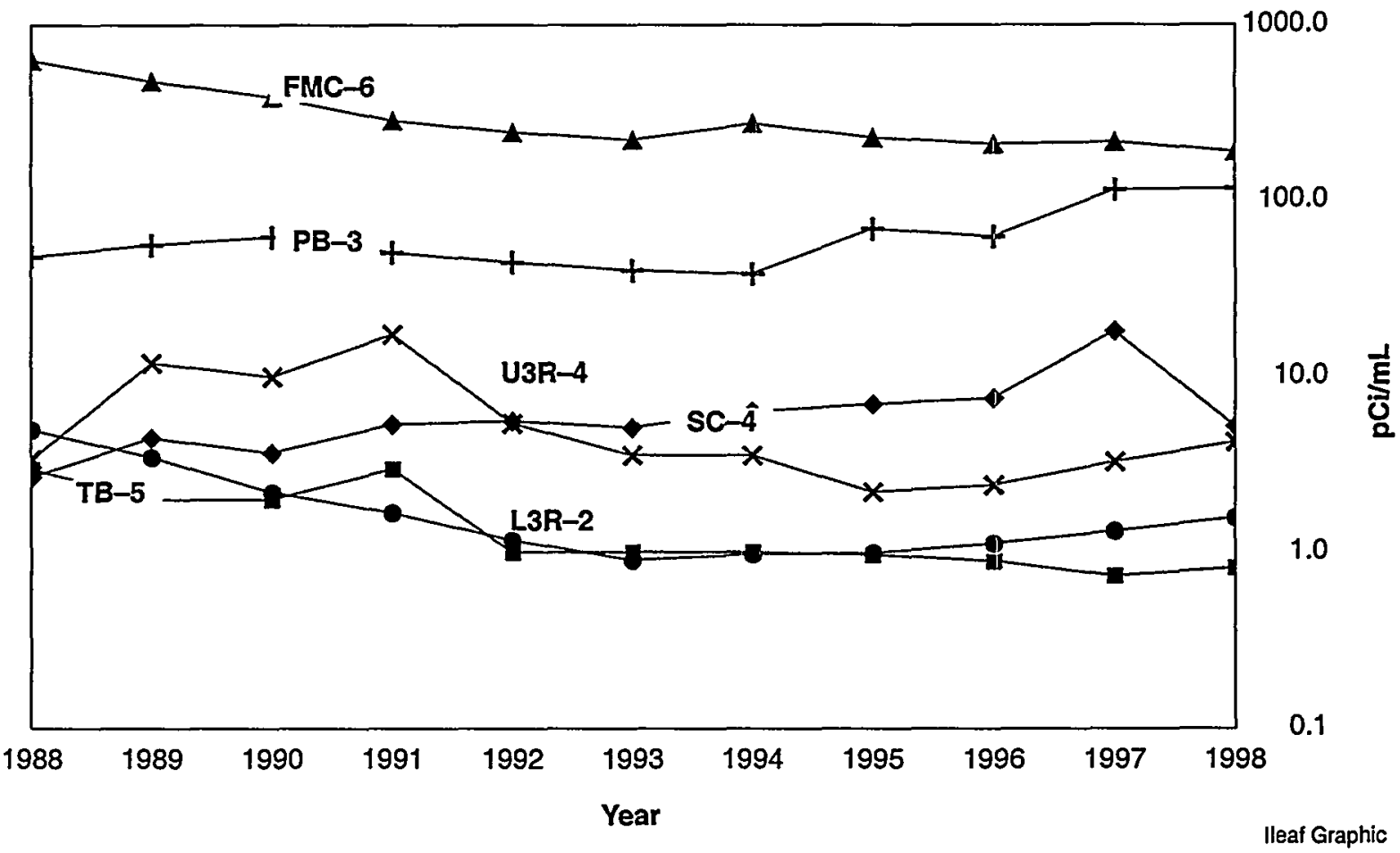

Figure 6-5 Average Tritium Concentration in SRS Streams, 1988-1998

Stream water analysis shows an increase in tritium concentration in two SRS streams.

\section{Four Mile Creek}

Four Mile Creek receives effluents from F-Area, $\mathrm{H}$-Area, and C-Area, as well as from water that has migrated from seepage basins and is outcropping into the stream. Four Mile Creek transported the majority of radioactivity present in SRS streams in 1998-mostly in the form of gross beta-gamma activity and tritium. The gross beta-gamma is made up of strontium-89,90 (outcropping from retired seepage basins) and cesium- 137 (from direct releases and resuspension of activity deposited in the streambed). The amount of tritium transported in Four Mile Creek was approximately 54.7 percent of the total amount reaching the Savannah River in 1998. Because the highest tritium concentrations are present at surveillance points along Four Mile Creek, and not at the stations monitoring direct releases, most of the tritium transport is due to outcropping activity from retired seepage basins and from the SWDF. This activity has decreased significantly since the F-Area and $\mathrm{H}$-Area seepage basins were closed in 1988 (figure 6-5).

\section{Pen Branch}

Pen Branch receives discharges from K-Area and flow from a tributary, Indian Grave Branch. Because K-Reactor has not operated since 1992, tritium detected in Pen Branch is due to water entering from Indian Grave Branch, which carries tritium outcropping from the K-Area percolation field and seepage basins. A 1996 investigation identified a previously unmonitored groundwater tritium migration source that enters the stream above PB-3. With continued tritium migration into Pen Branch, the tritium level at $\mathrm{PB}-3$ increased from $(3.83 \pm 0.34) \mathrm{E}+04 \mathrm{pCi} / \mathrm{L}$ in 1994 to $(1.17 \pm 0.28) \mathrm{E}+05 \mathrm{pCi} / \mathrm{L}$ in 1998 . Mean cobalt 60 and cesium- 137 concentrations were less than the nominal LLDs. Detectable amounts of uranium-234 and 238 were found at PB-3; however, the total concentration for all alpha-emitting isotopes, including uranium-234, 235, and 238 and plutonium-238 and 239 , was only $0.11 \mathrm{pCi} / \mathrm{L}$, or less than 1 percent of the $15-\mathrm{pCi} / \mathrm{L}$ EPA drinking water limit for alpha activity. The strontium level at PB-3 was $(2.73 \pm 2.14) \mathrm{E}-01 \mathrm{pCi} / \mathrm{L}$, or 3.4 percent of the most restrictive EPA drinking water limit (8E+00 $\mathrm{pCi} / \mathrm{L}$ for strontium-90) for isotopes of strontium. Mean gross alpha and beta, cobalt-60, and cesium-137 activities were less than the nominal LLDs.

\section{Steel Creek}

Steel Creek receives releases from L-Area effluents and tritium migration from P-Area seepage basins. 
When P-Area diverts water away from PAR Pond to Steel Creek, the area's discharges are transported to the stream. All releases enter L-Lake, water from which overflows into Steel Creek and is monitored at $\mathrm{SC}-4$. The mean tritium level at $\mathrm{SC}-4$ in 1998 was $(5.24 \pm 1.19) \mathrm{E}+03 \mathrm{pCi} / \mathrm{L}$. The mean tritium level in $1997,(1.81 \pm 4.45) \mathrm{E}+04 \mathrm{pCi} / \mathrm{L}$, had been considerably higher than the 1996 level of $(7.54 \pm 0.86) \mathrm{E}+03 \mathrm{pCi} / \mathrm{L}$; this increase was attributed to an analytical result that was higher than historical values at SC-4. An investigation indicated that the 1997 sample either was mislabeled or contaminated and was not a reflection of higher tritium levels at SC-4.

The 1998 mean tritium level was consistent with historical levels and slightly less than the 1996 level. Because the highest 1998 mean tritium concentration, $(1.94 \pm 0.71) \mathrm{E}+05 \mathrm{pCi} / \mathrm{L}$, was measured at the surveillance station at $\mathrm{SC}-2 \mathrm{~A}$ - and not at the direct-release monitoring stations in L-Area and P-Area-activity being transported in Steel Creek is attributed to outcropping from the P-Area seepage basins. The mean gross alpha concentration at $\mathrm{SC}-4$ was $(9.80 \pm 1.14) \mathrm{E}-01 \mathrm{pCi} / \mathrm{L}$, or 6.5 percent of the EPA drinking water limit for alpha activity-down from 10.9 percent in 1997. The mean gross beta activity at $\mathrm{SC}-4$ was $(1.43 \pm 0.88) \mathrm{E}+00$ pCi/L-slightly above the nominal LLD and below the 1998 mean activity level of $(2.93 \pm 3.31) \mathrm{E}+00$ $\mathrm{pCi} / \mathrm{L}$. The mean concentrations for gross alpha, gross beta, and strontium-89,90 were less than the nominal LLDs.

\section{Lower Three Runs Creek}

Lower Three Runs Creek receives overflow from PAR Pond, a manmade pond that receives discharges from P-Area. The mean gross beta concentration at L3R-3 in $1998,(1.58 \pm 0.51) \mathrm{E}+00 \mathrm{pCi} / \mathrm{L}$, was slightly above the nominal LLD. This is attributable to low concentrations of cesium-137 from previous releases during P-Area and R-Area operations. Mean concentrations for gross alpha, tritium, cobalt- 60 , and cesium-137 at L3R-3 all were below the nominal LLDs.

\section{Savannah River}

Continuous surveillance is performed along the Savannah River at points above and below SRS and below the point at which Plant Vogtle liquid discharges enter the river. In 1998, five locations along the river served as environmental surveillance points. River sampling locations are shown in figure $6-4$.

\section{Description of Surveillance Program}

The Savannah River, which provides SRS its western boundary for a 35-mile stretch, is analyzed to determine what effects, if any, the site's effluents have on the river water. Gross screening for alpha and beta emitters, along with determinations of specific radionuclides, such as tritium and gamma emitters, is performed on biweekly composites.

\section{Surveillance Results}

Detailed results of Savannah River water analyses can be found in table 21 of SRS Environmental Data for 1998.

\section{Gross Alpha, Gross Beta, and Tritium}

The average concentrations of gross alpha, gross beta, and tritium at river locations are presented in table 6-4. The order of the locations begins at RM (river mile)-160, above the site, and ends at RM-120, after all site streams enter the Savannah River. Samplers situated between RM-160 and RM-120 are located at regular intervals along the SRS boundary and where Plant Vogtle's discharges feed into the river.

Tritium is the predominant radionuclide detected above background levels in the Savannah River. The highest average concentration in 1998, $(0.38 \pm 1.27) \mathrm{E}+04 \mathrm{pCi} / \mathrm{L}$, was measured in November at the Vogtle discharge location. This corresponded

Table 6-4

Average 1998 Concentration of Radioactivity in the Savannah River (pCi/L)

\begin{tabular}{llcc}
\hline Location & Gross Alpha & Gross Beta & Tritium \\
\hline RM-120 & $(1.55 \pm 2.20) E-01$ & $(1.60 \pm 0.49) \mathrm{E}+00$ & $(9.48 \pm 4.63) \mathrm{E}+02$ \\
$\mathrm{RM}-140$ & $(2.19 \pm 2.74) \mathrm{E}-01$ & $(1.78 \pm 0.55) \mathrm{E}+00$ & $(9.15 \pm 6.14) \mathrm{E}+02$ \\
$\mathrm{RM}-150$ & $(1.90 \pm 2.38) \mathrm{E}-01$ & $(1.58 \pm 0.49) \mathrm{E}+00$ & $(1.06 \pm 0.81) \mathrm{E}+03$ \\
$\mathrm{RM}-160$ & $(1.29 \pm 2.67) \mathrm{E}-01$ & $(1.72 \pm 0.49) \mathrm{E}+00$ & $(0.92 \pm 1.36) \mathrm{E}+02$ \\
Vogtle discharge & $(2.31 \pm 3.13) \mathrm{E}-01$ & $(1.82 \pm 0.89) \mathrm{E}+00$ & $(0.38 \pm 1.27) \mathrm{E}+04$ \\
\hline
\end{tabular}


Heavy rains during the winter and spring of 1998 raised the Savannah River to its highest levels in recent years. This prompted the U.S. Army Corps of Engineers, on February 5, to open all 23 spillway gates at the Strom Thurmond dam-the first time they had done so since 1964. The river remained in flood stage from late December 1997 until early June 1998. Photographs made at SRS's D-Area boat ramp during the early spring of the year (top), and then during the fall, clearly show the dramatic difference in the river between when it was near its maximum and after it had receded to a more "normal" level.

Al Mamatey Photos
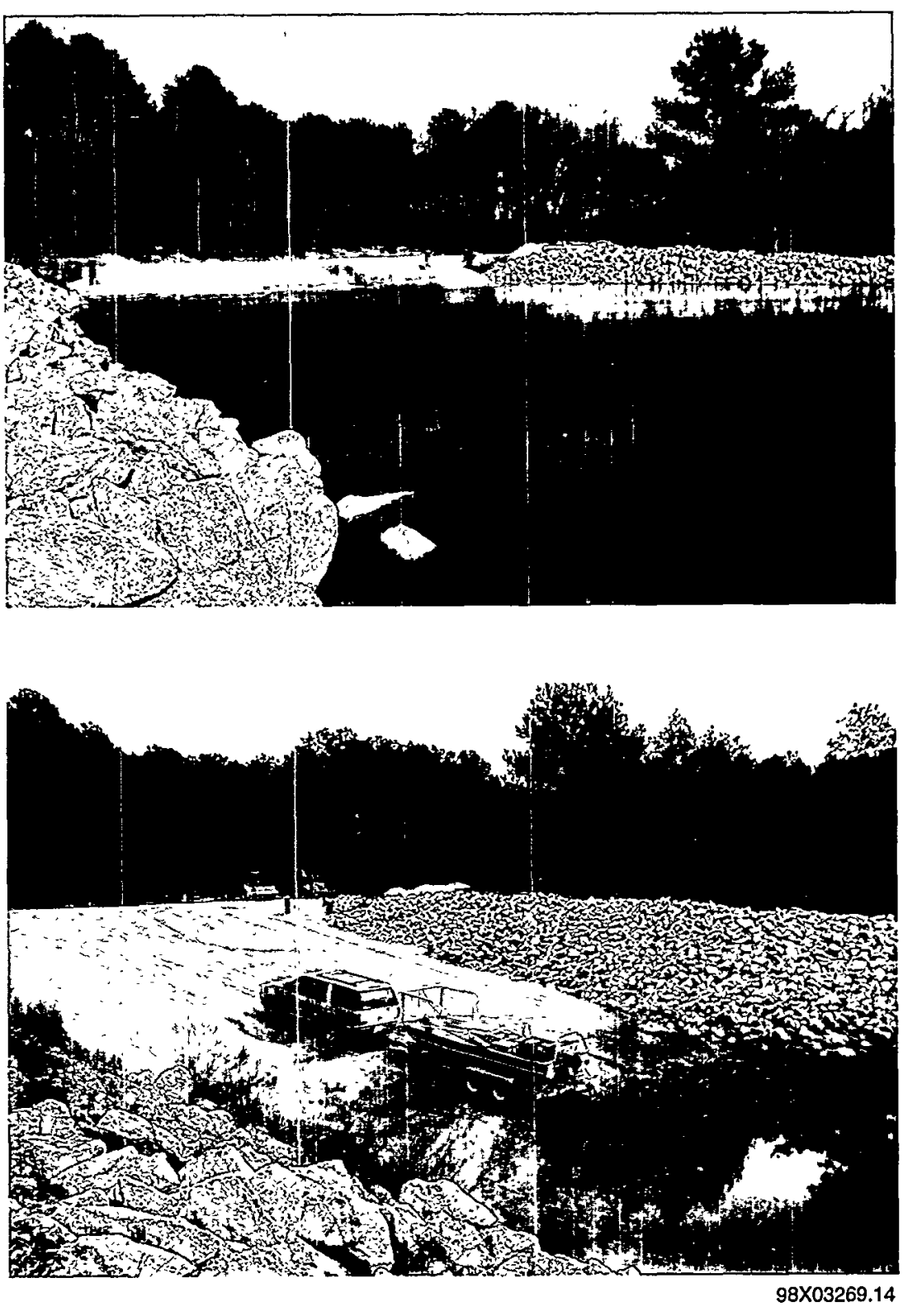

with operations at Plant Vogtle that resulted in a discharge of approximately 165 curies of tritium. Tritium concentrations at downstream locations (RM-140 and RM-120), which are affected by dilution, also were at their highest 1998 levels during this time frame. The maximum tritium concentration at $\mathrm{RM}-120$, the farthest downstream river location, was $(2.54 \pm 4.63) \mathrm{E}+03 \mathrm{pCi} / \mathrm{L}$-approximately 12.7 percent of the $2.00 \mathrm{E}+04-\mathrm{pCi} / \mathrm{L}$ drinking water standard set by EPA for tritium in drinking water. The annual mean tritium concentration at RM-120 was (9.48 \pm 4.63$) \mathrm{E}+02 \mathrm{pCi} / \mathrm{L}-$ less than 5 percent of the drinking water standard.

The mean gross alpha concentration at each river location was below the nominal LLD in 1998, which demonstrates the absence of significant alpha-emitting radionuclides in the river. The maximum concentrations of cesium-137, $(2.72 \pm 1.19) \mathrm{E}+00 \mathrm{pCi} / \mathrm{L}$, and cobalt -60 , $(2.86 \pm 1.17) \mathrm{E}+00 \mathrm{pCi} / \mathrm{L}$, were observed at $\mathrm{RM}-140$; these values are slightly above the nominal LLD. The mean concentrations for cesium-137 and cobalt- 60 were below the nominal LLD at all river locations. Mean gross beta concentrations were slightly above the nominal LLD at all river locations, and all were virtually equal to the concentration at the control location (RM-160). The maximum gross beta concentration, $(5.91 \pm 0.47) \mathrm{E}+00 \mathrm{pCi} / \mathrm{L}$, was found at the Vogtle discharge location. The 1998 mean and yearly maximum concentrations of these 
radionuclides do not indicate significant impact to the river.

\section{Tritium Transport in Streams and River}

Tritium is introduced into SRS streams and the Savannah River from production areas on site. Because of the mobility of tritium in water and the quantity of the radionuclide released during the years of SRS operations, a tritium balance has been performed annually since 1960 (table 22, SRS Environmental Data for 1998). The balance is evaluated among the following alternative methods of calculation:

- tritium releases from effluent release points and calculated seepage basin and SWDF migration (direct releases)

- tritium transport in SRS streams and the last sampling point before entry into the Savannah River (stream transport)
- $\quad$ tritium transport in the Savannah River downriver of SRS after subtraction of any measured contribution above the site (river transport)

Figure 6-6 shows graphic and numeric summaries of the last 39 years of direct releases, stream transport, and river transport determined by EMS.

Direct releases decreased 30 percent in 1998 (to 1,092 curies from 1,570 curies in 1997), while indirect releases increased 40 percent (to 9,463 curies from 6,780 curies in 1997). Total tritium transport increased approximately 25 percent for direct-releases-plus-migration, stream-transport, and river-transport methods. Excessive rainfall was the primary cause of the increased tritium transport. Estimated tritium releases in SRS streams and the Savannah River can be found in table 9 of SRS Environmental Data for 1998. Detailed discussions of these occurrences can be found in chapter 5 , "Radiological Effluent Monitoring."

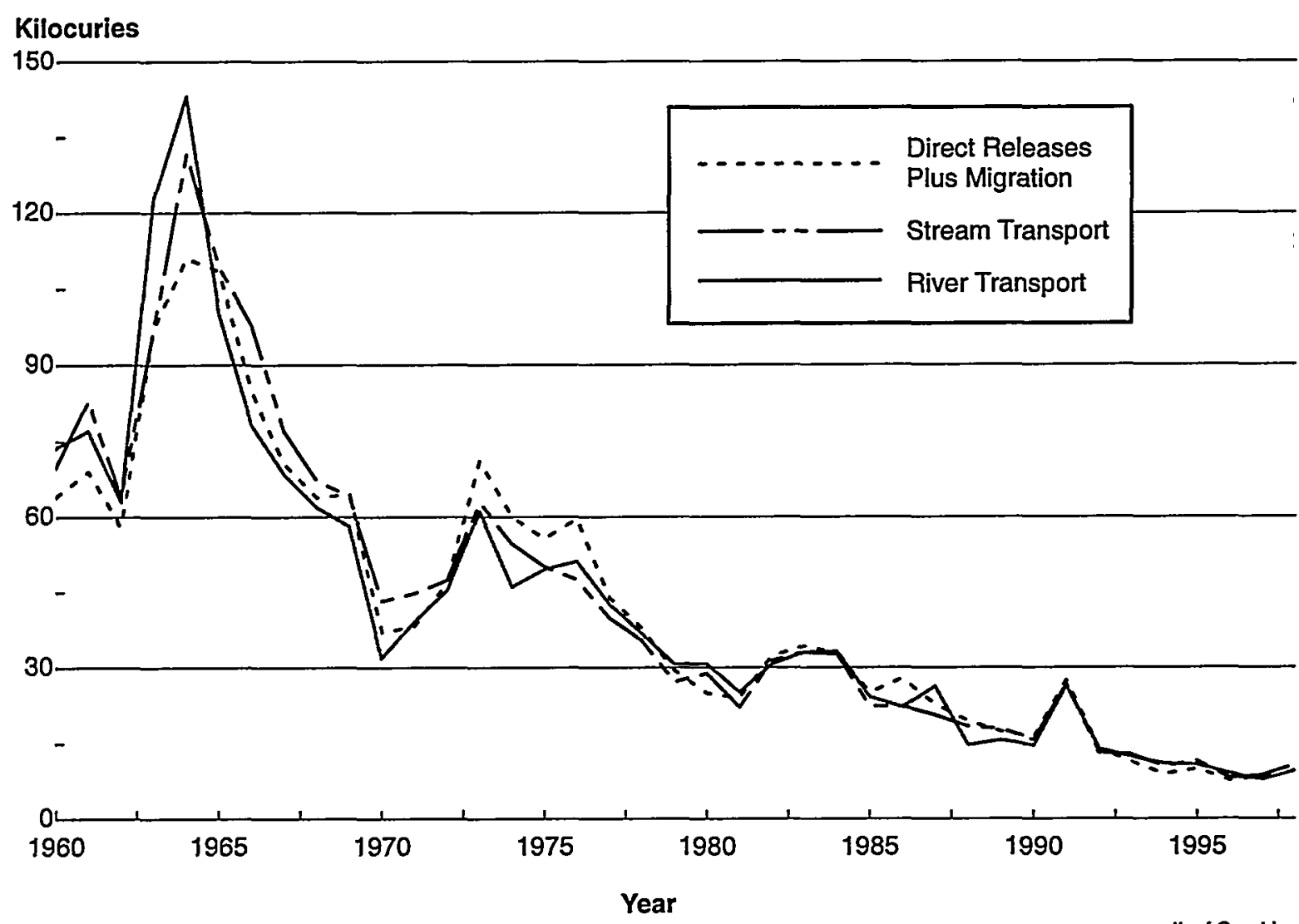

Figure 6-6 SRS Tritium Transport Summary, 1960-1998

SRS has maintained a tritium balance of direct releases plus migration, stream transport, and river transport since 1960 in an effort to account for and trend tritium releases in liquid effluents from the site. The general downward slope over time indicates that tritium transport has decreased as production has slowed and effluent controls have been developed. 
General agreement between the three calculational methods of annual tritium transport-measurements at the source, stream transport, and river transport-serves to validate SRS sampling schemes and counting results. Differences between the various methods can be attributed to uncertainties arising in the collection and analytical processes, including determinations of water flows and varying transport times. For conservatism, the highest of the results obtained from the three methods is used in annual environmental dose calculations (chapter 7).

\section{Drinking Water}

EMS collects drinking water samples from locations at SRS and at water treatment facilities that use Savannah River water. Potable water is analyzed at offsite treatment facilities to ensure that SRS operations are not adversely affecting the water supply and to provide voluntary assurance that drinking water does not exceed EPA drinking water standards for radionuclides.

\section{Description of Surveillance Program}

Sampling on site consists of quarterly (down from monthly in 1997 as a result of the EMS critical contaminant/critical pathway analysis) grab samples at large treatment plants in A-Area, D-Area, and $\mathrm{K}$-Area and annual (down from quarterly) grab samples at wells and small systems. Collected monthly off site are composite samples from

- two water treatment plants downriver of SRS that supply treated Savannah River water to Beaufort and Jasper counties in South Carolina and to Port Wentworth, Georgia

- the North Augusta (South Carolina) Water Treatment Plant

At all the offsite facilities, raw and finished water samples are collected daily and composited for analysis by EMS. All drinking water samples are screened for alpha, beta, and gamma emitters and analyzed specifically for tritium. The onsite samples also are analyzed once a year for strontium-89,90.

\section{Surveillance Results}

\section{Gross Alpha and Gross Beta}

All drinking water samples collected by EMS are screened for gross alpha and gross beta concentrations to determine if activity levels warrant further analysis (table 23, SRS Environmental Data for 1998). No samples collected in 1998 exceeded EPA's $1.50 \mathrm{E}+01-\mathrm{pCi} / \mathrm{L}$ alpha activity limit or 5.00E $+01-\mathrm{pCi} / \mathrm{L}$ beta activity limit. In 1998 , the highest alpha concentration in SRS drinking water was $(1.01 \pm 2.21) \mathrm{E}+01-\mathrm{pCi} / \mathrm{L}$-at the 701-5G Aiken Barricade (Talatha Gate). Although this sample was not analyzed for radium-226, previous studies have indicated that alpha activity in site drinking water is at least partially the result of the presence of radium-226. For human consumption, a separate source (bottled water) was used at the Aiken barricade location in 1998. No sample exceeded $8.00 \mathrm{E}+00 \mathrm{pCi} / \mathrm{L}$ of beta activity- the EPA limit for strontium-90, which is the most restrictive beta-emitting radionuclide.

\section{Strontium}

No drinking water samples collected and analyzed by EMS for strontium-89,90 exceeded the $1.90 \mathrm{E}+00-\mathrm{pCi} / \mathrm{L}$ nominal LLD. This limit is approximately 25 percent of the EPA drinking water standard for strontium-90.

\section{Tritium}

No onsite or offsite drinking water samples collected and analyzed by EMS in 1998 exceeded the $2.00 \mathrm{E}+04-\mathrm{pCi} / \mathrm{L}$ EPA tritium limit. The highest level observed was $(2.43 \pm 0.15) \mathrm{E}+03 \mathrm{pCi} / \mathrm{L}$-at $701-13 \mathrm{G}$ (Patrol Gate 6). Detectable levels of tritium were present in the drinking water samples collected monthly from the Beaufort-Jasper and Port Wentworth water treatment facilities. These levels reflect the introduction of tritium from SRS operations into the Savannah River. The average tritium concentration in finished water at Beaufort-Jasper in $1998,(7.28 \pm 2.67) \mathrm{E}+02 \mathrm{pCi} / \mathrm{L}$, was 3.6 percent of the EPA drinking water limit. The average tritium concentration at Port Wentworth, $(8.29 \pm 2.95) \mathrm{E}+02 \mathrm{pCi} / \mathrm{L}$, was 4.1 percent of the EPA drinking water limit. The levels of tritium at both treatment facilities were about one-percent lower than those measured in 1997.

\section{Terrestrial Food Products}

The terrestrial food products surveillance program consists of radiological analyses of food product samples typically found in the Central Savannah River Area (CSRA). Because radioactive materials can be transported to man through the consumption of milk and other food products containing radioactivity, food product samples are analyzed to determine what effects, if any, SRS operations have on them. Data from the food product surveillance program are not used to show direct compliance with any dose standard; however, the data can be used as required to verify dose models and determine environmental trends. 


\section{Description of Surveillance Program}

\section{Meat, Fruit, and Greens}

The food products surveillance program divides the area that surrounds the SRS, approximately 9 miles $(15 \mathrm{~km})$ beyond its perimeter, into four quadrants: northeast, southeast, southwest, and northwest. Samples of food-including meat (beef or chicken), fruit (peaches or melons), and green vegetables (collards)-are collected from one location within each of the quadrants and from a control location within an extended (to 25 miles beyond the perimeter) southeast quadrant. All food samples are collected annually except milk, which is collected monthly for the analysis of tritium and gamma-emitting radionuclides and quarterly for the analysis of strontium- 90 .

Food samples are analyzed for gamma-emitting radionuclides, tritium, strontium-89,90, plutonium-238, and plutonium 239.

\section{Milk}

During 1998, EMS collected milk samples at five dairies within a 25-mile radius of SRS and from locally produced inventories of a major distributor.

Milk samples are analyzed for tritium and gamma-emitting radionuclides, primarily cesium-137 and iodine-131. Additional milk samples are collected quarterly and analyzed for strontium-90.

\section{Surveillance Results}

Two samples of beef and one of milk were not available for collection during the scheduled time frame in 1998. Detailed results of all food sample analyses can be found in tables 24 and 25 in SRS Environmental Data for 1998.

\section{Gamma-Emitting Radionuclides}

The only manmade gamma-emitting radionuclide detected in food products, excluding milk, was cesium-137. The maximum concentration, $(1.36 \pm 0.46) \mathrm{E}-02 \mathrm{pCi} / \mathrm{g}$, was measured in greens from the 0-10-mile southeast quadrant. Generally, concentrations of cesium- 137 in indicator samples were similar to those measured at the control location. These concentrations were similar to those observed in previous years.

Cesium-137 also was the only manmade gamma-emitting radionuclide detected in milk samples during 1998. Measured average concentrations ranged from a high of
$(7.78 \pm 2.26) \mathrm{E}+00 \mathrm{pCi} / \mathrm{L}$ at the Denmark, South Carolina, location to lows below the nominal LLD at several locations. The mean concentrations measured in 1998 were similar to those measured in 1997.

Iodine-131 was not detected in any 1998 milk samples. Because of its short physical half-life ( 8 days), iodine-131 generally is not detected, except

- shortly after tests of nuclear weapons

- in the wake of events such as the Chernobyl incident

- during reactor operations

- when processing fresh fuel

- when the isotope is used medically, industrially, or for research.

\section{Tritium}

Tritium in milk and other samples is attributed to releases from SRS. Tritium concentrations in food products, excluding milk, ranged from a high of $(1.63 \pm 0.35) \mathrm{E}-01 \mathrm{pCi} / \mathrm{g}$, measured in beef from the 0-10-mile southwest quadrant, to lows below the nominal LLD in several samples. The concentrations were similar to those measured in 1997.

Milk from two dairies showed detectable concentrations of tritium at some point during 1998. The maximum concentration, $(4.81 \pm 0.08) \mathrm{E}+03 \mathrm{pCi} / \mathrm{L}$, was measured at the Waynesboro, Georgia, location. The minimum concentration was below the nominal LLD at several locations. Tritium concentrations measured in milk in 1998 were slightly higher than those in 1997 and generally reflected atmospheric releases from the site.

\section{Strontium}

The highest strontium- 89,90 concentration detected in food products, excluding milk, during 1998 was $(2.97 \pm 0.41) \mathrm{E}-01 \mathrm{pCi} / \mathrm{g}$-found in greens from the northeast quadrant; the lowest was below the nominal LLD at several locations. Strontium-89,90 levels generally were within the ranges observed during past years.

Strontium-90 analysis was performed on milk from all six sampling locations during 1998. None of the samples collected showed detectable concentrations.

\section{Plutonium}

Concentrations of plutonium-238 and plutonium-239 in food products, excluding milk, during 1998 were below the nominal LLD at all five sampling locations and were similar to the 1997 concentrations. 


\section{Aquatic Food Products}

\section{Description of Surveillance Program}

The aquatic food product surveillance program includes both fish (freshwater and saltwater) and shellfish. To determine the potential dose and risk to the public from consumption of these fish, both are sampled.

Nine surveillance points for the collection of freshwater fish are located on the Savannah River (figure 6-7). These points are at

- the New Savannah Bluff Lock and Dam area (the control location, formerly the Augusta Lock and Dam), above the site

- five areas where site streams enter the Savannah River

- the U.S. Highway 301 bridge area, below the site

- Stokes Bluff Landing, below the site

- the U.S. Highway 17 bridge area, below the site

Nine surveillance points for freshwater fish collection also are located within the SRS boundary. These points are at PAR Pond, L-Lake, Pond B, Lower Three Runs Creek, Upper Three Runs Creek, Beaver Dam Creek, Pen Branch, Steel Creek, and Four Mile Creek. Freshwater fish are grouped into one of three categories: bass, panfish (bream), or catfish.

Saltwater fish, collected from the U.S. Highway 17 bridge area, also are grouped into one of three categories: predatory fish, filter feeders, or bottom-dwelling fish. Sea trout and red drum (spottail bass) are placed in the predatory group; mullet in the filter feeder group; and catfish and flounder in the bottom-dwelling group. The fish are selected for sampling because they are the most sought-after fish in the Savannah River, according to the latest creel survey conducted by the Fisheries Management Section of GDNR's Wildlife Resources Division.

For analysis purposes, five fish from each category at each collection location are combined to create a composite. Composites are divided into edible (meat fillet only) and nonedible (scales, skin, head, fins, viscera, bone) portions. Analyses are conducted for gross alpha and gross beta on edible portions for all locations and on nonedible portions for all offsite locations except those at Stokes Bluff Landing and at the U.S. Highway 17 bridge area. Freshwater fish collected from the New Savannah Bluff Lock and Dam location downstream through the U.S. Highway 301 bridge area also are analyzed for strontium-89,90; plutonium-238 and plutonium-239 and tritium (edible portions only); and gamma-emitting radionuclides. Freshwater fish (edible portions only) from river locations at Stokes Bluff Landing and the U.S. Highway 17 bridge area and from onsite streams and ponds are analyzed for gross alpha, gross beta, and gamma-emitting radionuclides.

A one-time special sample of bowfin and sucker, requested by DOE's Savannah River Operations Office (DOE-SR) to determine the levels of radionuclides in those fish, was conducted at four locations during the year: the U.S. Highway 301 bridge area, the mouths of Steel Creek and Four Mile Creek, and the New Savannah Bluff Lock and Dam. Fifteen fish of each type were collected at each location and analyzed the same way as the standard fish from that location. (Data from this collection were summarized with the routine data, whose analysis results appear in the next section.)

Saltwater fish (edible portions only) also are analyzed for gross alpha, gross beta, and gamma-emitting radionuclides.

In the shellfish surveillance program, samples of oysters and crabs are collected on the coast near Savannah. The shellfish are analyzed for gross alpha, gross beta, strontium-89,90, and gamma-emitting radionuclides.

Calculations of risk from the consumption of fish from the Savannah River can be found in chapter 7 .

\section{Surveillance Results}

In the following surveillance results discussion, uncertainty values are provided because most measurements were at or near the LLDs.

\section{Freshwater Fish}

Detailed analytical results from freshwater fish composites can be found in table 26 of SRS Environmental Data for 1998.

Savannah River All categories of freshwater fish from all nine Savannah River locations were collected during 1998, including the DOE-SR special samples.

Gross alpha activity in Savannah River edible composites was below the LLD at all nine sampling locations, and gross alpha activity in river nonedible composites was below the LLD at all seven sampling locations.

Gross beta activity in Savannah River edible composites was detectable at all nine locations and was attributed primarily to the naturally occurring 


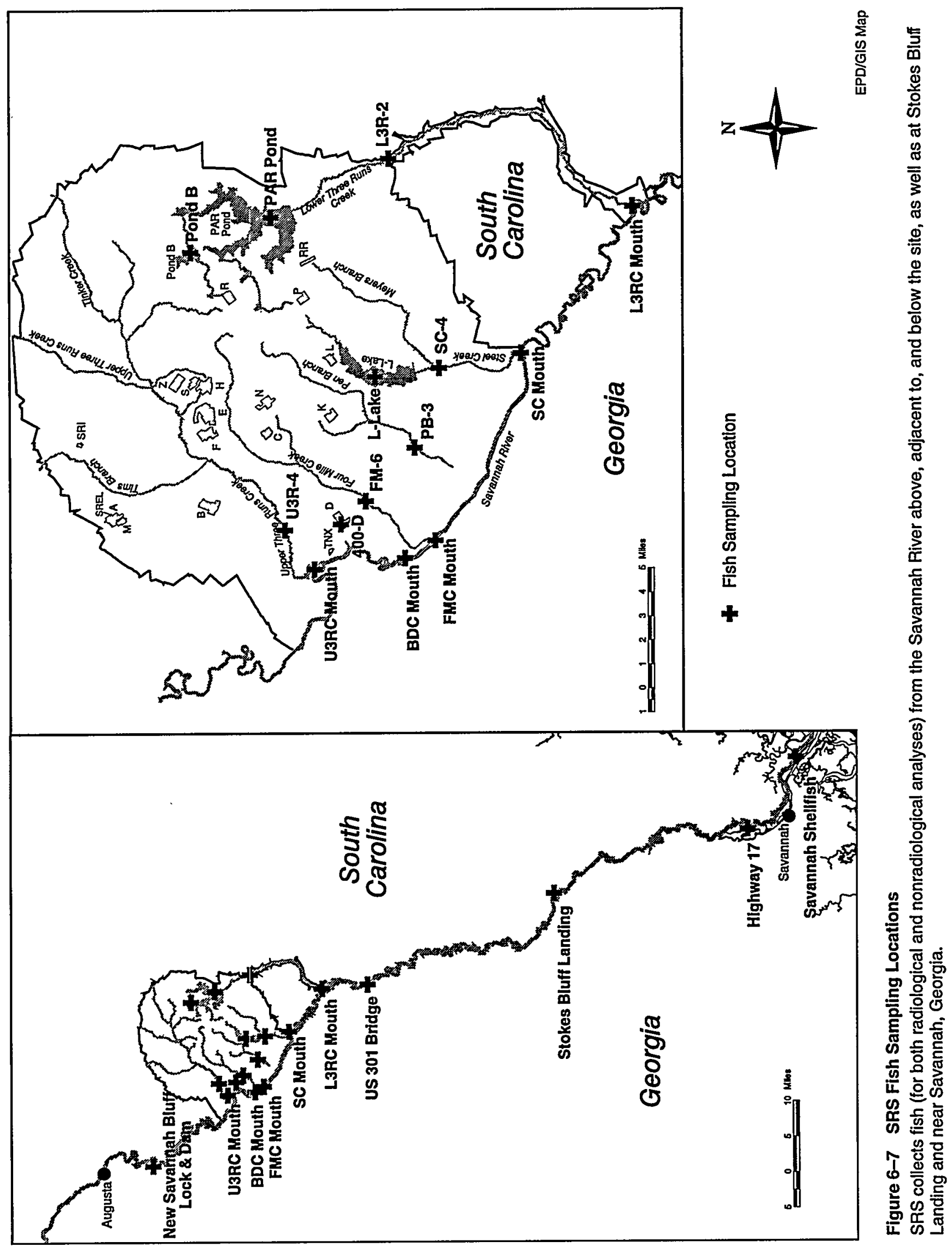


radionuclide potassium- 40 . The values ranged from a high of $(3.85 \pm 0.46) \mathrm{E}+00 \mathrm{pCi} / \mathrm{g}$ in catfish from the mouth of Four Mile Creek to a low of $(5.63 \pm 2.98) \mathrm{E}-01 \mathrm{pCi} / \mathrm{g}$ in bass from the mouth of Upper Three Runs Creek. Gross beta activity in river nonedible composites was detectable at five of seven locations, ranging from a high of $(5.53 \pm 1.34) \mathrm{E}+00$ $\mathrm{pCi} / \mathrm{g}$ in bass from the mouth of Four Mile Creek to lows below the LLD in several composites.

Cesium- 137 was the only manmade, gamma-emitting radionuclide detected in 1998 fish composites. Cesium-137 activity in Savannah River edible composites was detectable at all nine sampling locations, ranging from a high of $(2.52 \pm 0.13) \mathrm{E}+00 \mathrm{pCi} / \mathrm{g}$ in bass from the mouth of Steel Creek to lows below the LLD in several composites. Cesium-137 activity in river nonedible composites was detectable at all seven sampling locations, ranging from a high of $(1.20 \pm 0.05) \mathrm{E}+00 \mathrm{pCi} / \mathrm{g}$ in bass from the mouth of Steel Creek to lows below the LLD in several composites.

Strontium-89,90 activity in Savannah River edible fish in 1998 was detectable at six of seven sampling locations, ranging from a high of $(3.51 \pm 1.33) \mathrm{E}-02 \mathrm{pCi} / \mathrm{g}$ in bream from the mouth of Four Mile Creek to lows below the LLD in several composites. Strontium-89,90 in river nonedible composites was detectable at all seven sampling locations, ranging from a high of $(2.20 \pm 0.07) \mathrm{E}+00$ $\mathrm{pCi} / \mathrm{g}$ in bass from the mouth of Four Mile Creek to a low of $(5.87 \pm 3.70) \mathrm{E}-02 \mathrm{pCi} / \mathrm{g}$ in catfish from the New Savannah Bluff Lock and Dam location.

Tritium activity in Savannah River edible composites in 1998 was detectable at all of the seven sampling locations and ranged from a high of $(1.06 \pm 0.01) \mathrm{E}+01 \mathrm{pCi} / \mathrm{g}$ in bass from the mouth of Four Mile Creek to lows below the LLD in several composites.

Onsite Streams and Ponds Not enough fish could be collected from onsite streams and ponds in 1998 for any composite samples (five from the same category per location) from Four Mile Creek and Pen Branch.

Gross alpha activity in fish composites (edible portions only) from onsite streams and ponds was below the LLD at all of the seven sampled locations except for bass at Pond $B$, which had a level of $(1.45 \pm 0.49) \mathrm{E}+00 \mathrm{pCi} / \mathrm{g}$. Gross beta activity, on the other hand, was detectable at all of these locations and ranged from a high of $(7.17 \pm 0.16) \mathrm{E}+01 \mathrm{pCi} / \mathrm{g}$ in bass from Pond $B$ to a low of $(7.35 \pm 3.39) E-00$ $\mathrm{pCi} / \mathrm{g}$ in bream from PAR Pond.

Cesium-137-the only manmade, gamma-emitting radionuclide found in 1998 fish composites from onsite streams and ponds-was detectable at all seven sampled locations. The activity ranged from a high of $(1.13 \pm 0.04) \mathrm{E}+02 \mathrm{pCi} / \mathrm{g}$ in bass from Pond $\mathrm{B}$ to $\mathrm{a}$ low of $(1.02 \pm 1.37) \mathrm{E}-02 \mathrm{pCi} / \mathrm{g}$ in bream from Beaver Dam Creek.

\section{Saltwater Fish}

In the saltwater fish category, red drum (spottail bass) and mullet were collected in 1998 from the U.S. Highway 17 bridge area. All gross alpha concentrations measured in saltwater fish composites during 1998 were below the LLD. Gross beta concentrations, however, were detectable in all five composites collected and ranged from a high of $(3.07 \pm 0.43) \mathrm{E}+00 \mathrm{pCi} / \mathrm{g}$ in spottail bass to a low of $(2.16 \pm 0.39) \mathrm{E}+00 \mathrm{pCi} / \mathrm{g}$, also in spottail bass.

Cesium-137 was the only manmade, gamma-emitting radionuclide detected in 1998 saltwater fish composites. Cesium-137 activity in edible saltwater fish composites ranged from a high of $(6.04 \pm 1.81) \mathrm{E}-02 \mathrm{pCi} / \mathrm{g}$ in mullet to lows below the LLD.

Detailed analytical results from saltwater fish composites can be found in table 27 of SRS Environmental Data for 1998.

\section{Shellfish}

A sample of oysters and a sample of crabs-both from near the mouth of the Savannah River-were collected in 1998. Analytical results showed that no manmade radionuclides above the LLDs were present in these samples (table 28, SRS Environmental Data for 1998).

\section{Deer and Hogs}

\section{Description of Surveillance Program}

Annual hunts, open to members of the general public, are conducted at SRS to control the site's deer and feral hog populations and to reduce animal-vehicle accidents. Before any animal is released to a hunter, EMS uses portable sodium iodide detectors to perform field analysis for cesium-137. The dose resulting from consumption is calculated for each animal, and each hunter's cumulative total is tracked to ensure compliance with the DOE dose limit for the general public. Media samples (muscle and/or bone) are collected periodically for laboratory analysis based on a set frequency, on cesium-137 levels, and/or on exposure limit considerations. 


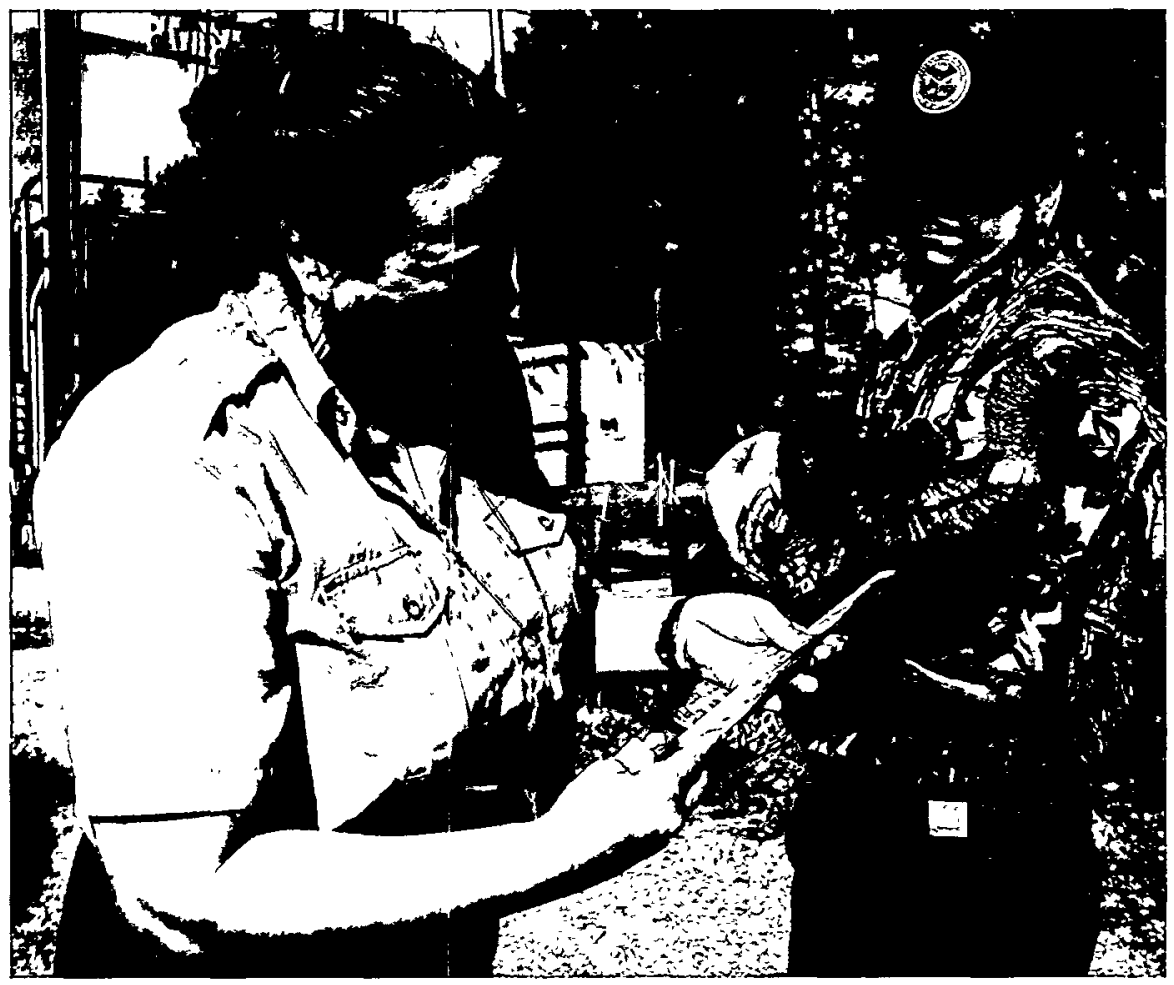

South Carolina

Wildlife and Marine

Resources

Department

employees check the

beard length on a

turkey trapped at SRS.

The agency has

trapped approximately

1,000 turkeys on site

since a program was

begun in 1976 to

capture the birds and

use them to

repopulate other

areas. The turkeys are

weighed-adult

gobblers may reach

21 pounds-and

monitored for

cesium-137. They

have been shipped as

far away as Texas and

Maryland.

Al Mamatey Photo (99X00497.02)

\section{Surveillance Results}

During 1998, 1,293 deer and 61 feral hogs were taken from the site as part of the controlled hunt program. This compares with 1,363 deer and 85 feral hogs taken during the 1997 hunts. The number of hunts, which is determined each year by site safety and wildlife management concerns, was reduced from 14 to 12 in 1998.

\section{Gamma-Emitting Radionuclides}

In 1998, the maximum field measurement of cesium-137 in deer muscle was approximately 77 $\mathrm{pCi} / \mathrm{g}$, while the mean cesium-137 concentration was approximately $4 \mathrm{pCi} / \mathrm{g}$. In feral hogs, the maximum field measurement of cesium-137 in muscle was approximately $12 \mathrm{pCi} / \mathrm{g}$, while the mean concentration was approximately $4 \mathrm{pCi} / \mathrm{g}$.

Each animal is monitored prior to release, and the field measurements are supplemented by laboratory analyses. Samples are collected from approximately 10 percent of the animals processed, including every 10 th animal monitored and any animal that results in a hunter's annual dose exceeding $25 \mathrm{mrem}$ (approximately 25 percent of the DOE limit)-either alone or in combination with previous animals killed by the hunter. In 1998, 152 samples from 129 animals were collected and analyzed for gamma-emitting radionuclides.
As observed during previous hunts, cesium- 137 was the only manmade gamma-emitting radionuclide detected during laboratory analysis. Generally, the cesium- 137 concentrations measured by the field and lab methods were comparable. Field measurements ranged from approximately $1 \mathrm{pCi} / \mathrm{g}$ to $77 \mathrm{pCi} / \mathrm{g}$, while lab measurements ranged from approximately $1 \mathrm{pCi} / \mathrm{g}$ to $76 \mathrm{pCi} / \mathrm{g}$.

\section{Strontium}

Strontium levels are determined in some of the animals analyzed for cesium-137. Typically, muscle and bone samples are collected for analysis from the same animals checked for cesium-137, and the samples are analyzed for strontium-89,90.

In 1998, 42 muscle samples from 29 animals and 13 bone samples from 13 animals were collected for strontium-89,90 analysis. However, because of laboratory backlog, these samples were not analyzed.

\section{Turkeys}

\section{Description of Surveillance Program}

Wild turkeys are trapped on site by the South Carolina Wildlife and Marine Resources Department and used to repopulate game areas in South Carolina and other states. All turkeys are monitored for cesium-137 with portable sodium iodide detectors before leaving SRS. No turkey with a reading above $25 \mathrm{pCi} / \mathrm{g}$ is released off site. 


\section{Surveillance Results}

EMS monitored 36 turkeys in 1998. Concentrations of cesium-137 generally were similar to those measured in the past, with all results $5.0 \mathrm{pCi} / \mathrm{g}$ or less. This compares to maximum concentrations in 1997 of $6.0 \mathrm{pCi} / \mathrm{g}$, in 1996 of $5.0 \mathrm{pCi} / \mathrm{g}$, and in 1995 of 1.0 $\mathrm{pCi} / \mathrm{g}$. All concentrations below the LLD are assigned a value of $1.0 \mathrm{pCi} / \mathrm{g}$.

\section{Beavers}

\section{Description of Surveillance Program}

The U.S. Forest Service administers a contract for the trapping of beavers in selected areas within the SRS perimeter. The purpose of this trapping is to reduce the beaver population in specific areas of the site and thereby minimize dam-building activities that can result in flood damage to timber stands, to primary and secondary roads, and to railroad beds. All beavers are monitored for cesium- 137 with portable sodium iodide detectors and disposed of in the SRS sanitary landfill.

\section{Surveillance Results}

EMS monitored 11 beavers in 1998. The cesium-137 concentration in all the beavers was less than 1.0 $\mathrm{pCi} / \mathrm{g}$. These results compare with maximums of 12.5 in $1997,10.5 \mathrm{pCi} / \mathrm{g}$ in 1995 and 1996 , and $22 \mathrm{pCi} / \mathrm{g}$ in 1994.

\section{Soil}

The SRS soil monitoring program provides

- data for long-term trending of radioactivity deposited from the atmosphere (both wet and dry deposition)

- information on the concentrations of radioactive materials in the environment

Routine and nonroutine SRS atmospheric releases, as well as worldwide fallout, are monitored in this program. The concentrations of radionuclides in soil vary greatly among locations because of differences in rainfall patterns and in the mechanics of retention and transport in different types of soils. Because of this program's design, a direct comparison of data from year to year is not appropriate.

\section{Description of Surveillance Program}

Soil samples were collected in 1998 from four uncultivated and undisturbed locations in E-Area (burial ground), F-Area, H-Area, and Z-Area-one sample from each area-and from one control location (off site) near the U.S. Highway 301 bridge over the Savannah River, as shown in figure 6-8. One location approximately 100 miles from SRS-at Savannah-also was sampled.

Hand augers or other similar devices are used in sample collection to a depth of 3 inches. The samples are analyzed for gamma-emitting radionuclides, strontium-89,90, plutonium-238, and plutonium-239. The rationale for each sampling site is explained in the SRS EM Program.

\section{Surveillance Results}

Detailed analytical results from soil samples collected during 1998 can be found in table 29, SRS Environmental Data for 1998.

\section{Gamma-Emitting Radionuclides}

Cesium-137 was observed at levels above the nominal LLD in 1998 at both offsite locations and three of the onsite ones. The highest concentration detected, $(3.66 \pm 0.30) \mathrm{E}-01 \mathrm{pCi} / \mathrm{g}$, was in a sample taken from H-Area, and the lowest was below the nominal LLD. The highest offsite concentration was $(3.16 \pm 0.40) \mathrm{E}-01 \mathrm{pCi} / \mathrm{g}$, at the U.S. Highway 301 bridge area.

\section{Plutonium}

Three of the four onsite soil sampling locations showed a concentration of plutonium-238 above the nominal LLD. The highest was F-Areas, at $(1.26 \pm 0.23) \mathrm{E}-02 \mathrm{pCi} / \mathrm{g}$. Three of the locations had concentrations of plutonium-239 above the nominal LLD-F-Area at $(1.49 \pm 0.26) \mathrm{E}-02 \mathrm{pCi} / \mathrm{g}, \mathrm{H}$-Area at $(2.05 \pm 0.21) \mathrm{E}-02 \mathrm{pCi} / \mathrm{g}$, and Z-Area at $(3.26 \pm 0.34) \mathrm{E}-02 \mathrm{pCi} / \mathrm{g}$.

\section{Strontium}

Soil samples from all locations were analyzed for strontium-89,90, and all results were below the nominal LLD.

\section{Sediment}

Sediment sample analysis measures the movement, deposition, and accumulation of long-lived radionuclides in stream beds and in the Savannah River bed. Significant year-to-year differences may be evident because of the continuous deposition and remobilization occurring in the stream and river beds, but the data obtained can be used to observe long-term environmental trends.

\section{Description of Surveillance Program}

Sediment samples (annual) were collected at 23 locations in 1998-eight in the Savannah River and 

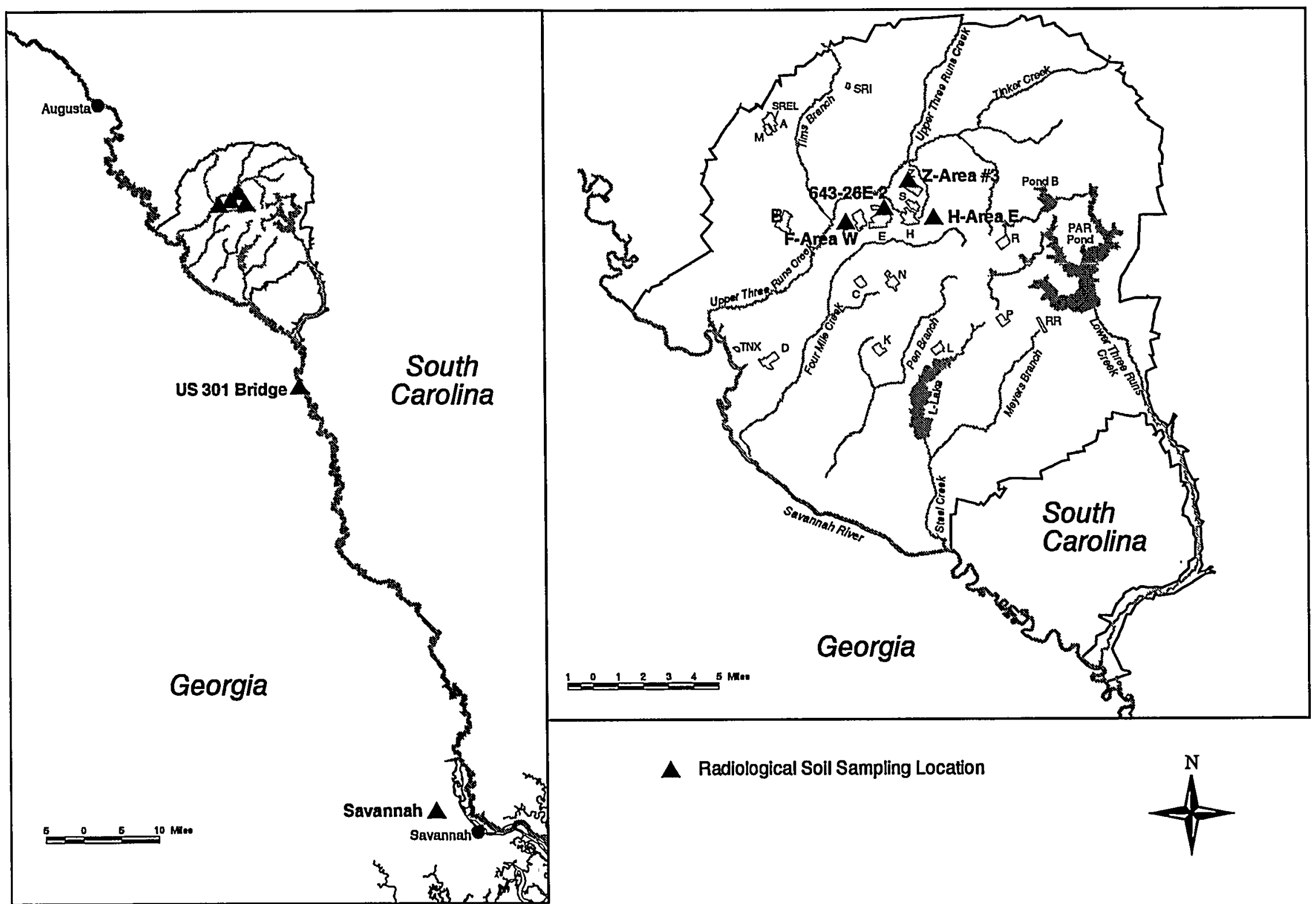

A Radiological Soil Sampling Location

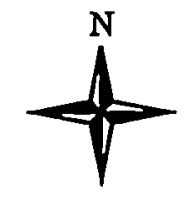

EPD/GIS Map

Figure 6-8 Radiological Soil Sampling Locations

SRS collected soil samples in 1998 from four onsite locations and two offsite locations-one near the U.S. Highway 301 bridge over the Savannah River and one near Savannah, Georgia. 
15 in site streams (figure 6-9). Samples are obtained with a Ponar dredge or an Emery pipe dredge and analyzed for gamma-emitting fission and activation products, strontium- 89,90 , plutonium- 238 , and plutonium-239.

\section{Surveillance Results}

Concentrations of radionuclides in river sediment during 1998 were similar to those of past years. Detailed analytical results from all sediment samples collected during the year can be found in table 30, SRS Environmental Data for 1998.

\section{Gamma-Emitting Radionuclides}

Cesium- 137 and Cobalt- 60 were the only manmade gamma-emitting radionuclides observed in river and stream sediments during 1998.

The highest cesium-137 concentration in streams, $(4.80 \pm 0.15) \mathrm{E}+01 \mathrm{pCi} / \mathrm{g}$, was detected in sediment from R-Area Downstream of R-1; the lowest concentrations were below the nominal LLD at two locations. The highest level found on the river, $(2.15 \pm 0.16) \mathrm{E}+00 \mathrm{pCi} / \mathrm{g}$, was at the mouth of Upper Three Runs Creek; the lowest levels were below the nominal LLD at several locations. Generally, cesium-137 concentrations were slightly higher in stream sediments than in river sediments. This is to be expected because the streams receive radionuclide-containing liquid effluents from the site. Most radionuclides settle out and deposit on the stream beds or at the streams' entrances to the swamp areas along the river.

Cobalt- 60 was detected above the nominal LLD in sediment from the following locations:

- Four Mile 2

- Four Mile A-7A

- Four Mile Creek Swamp Discharge

- Pen Branch Swamp Discharge

- Steel Creek 4

- R-Area Downstream of R-1

- River Mile 118.7 (Highway 301 crossing)

The highest Cobalt -60 concentration, $(2.30 \pm 0.19) \mathrm{E}-01 \mathrm{pCi} / \mathrm{g}$, was measured at Steel Creek 4; concentrations at the other 16 sediment sampling locations were below the nominal LLD.

\section{Plutonium}

Concentrations of plutonium-238 in sediment ranged from a high of $(7.34 \pm 0.49) \mathrm{E}-01 \mathrm{pCi} / \mathrm{g}$ at the Four Mile 2 location to lows below the nominal LLD at several locations. Concentrations of plutonium-239 ranged from a high of $(8.56 \pm 0.87) \mathrm{E}-02$-at the R-Area Downstream of R-1 location-to lows below the nominal LLD at several locations. As expected, concentrations of these isotopes in streams generally were higher than concentrations in the river. Differences observed when these data are compared to those of previous years probably are attributable to the effects of resuspension and deposition, which occur constantly in sediment media.

\section{Strontium}

Strontium 89,90 was detected above the nominal LLD in 1998 at six of the 15 site stream sediment sampling locations. The maximum strontium $-89,90$ concentration, $(1.45 \pm 0.18) \mathrm{E}-01 \mathrm{pCi} / \mathrm{g}$, which occurred at the Four Mile 2 location, is higher than in 1997. The change probably is due to the year-to-year variations cited earlier.

\section{Grassy Vegetation}

The radiological program for grassy vegetation is designed to collect and analyze samples from onsite and offsite locations to determine radionuclide concentrations. Vegetation samples are obtained to complement the soil and sediment samples in order to determine the environmental accumulation of radionuclides and help confirm the dose models used by SRS. The program also provides information that can be used to determine the effects, if any, of various radioactive material operations on the surrounding vegetation.

Typically, grasses are collected for vegetation because of their year-round availability. Bermuda grass is preferred because of its importance as a pasture grass for dairy herds.

\section{Description of Surveillance Program}

Vegetation samples are obtained from

- locations containing soil radionuclide concentrations that are expected to be higher than normal background levels

- locations receiving water that may have been contaminated

As a result of the 1997 EMS critical contaminant/critical pathway analysis, site perimeter and onsite sampling locations in the vegetation surveillance program were reduced from 100 to five for 1998; offsite locations were increased from one to two; and the analysis of samples was expanded to include actinides. The changes also eliminated the collection of samples from the chemical, retention, and seepage basins and from the Solid Waste 


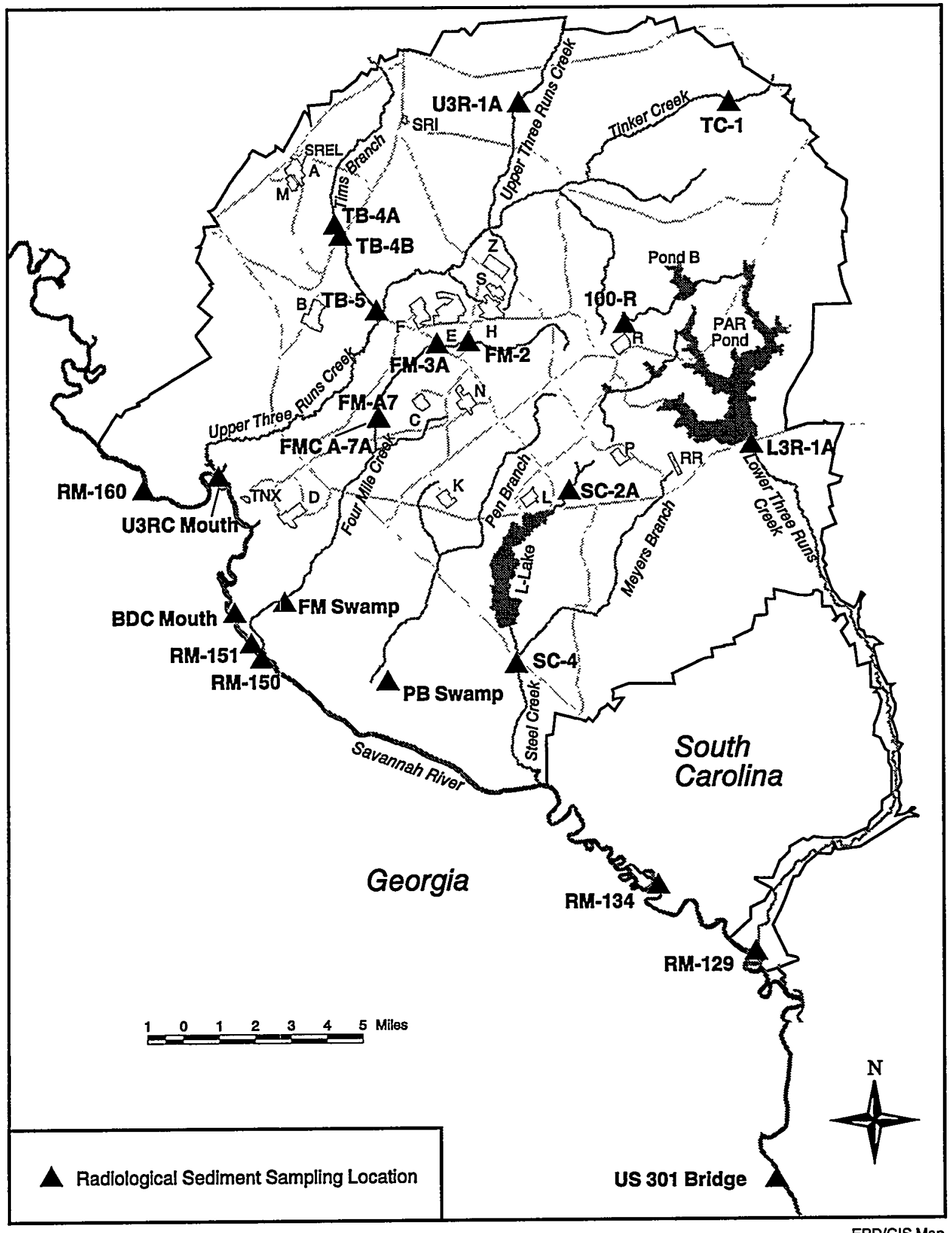

Figure 6-9 Radiological Sediment Sampling Locations

Sediment samples were collected in 1998 at eight Savannah River locations-upriver of, adjacent to, and downriver of the site-and 15 site stream locations. 


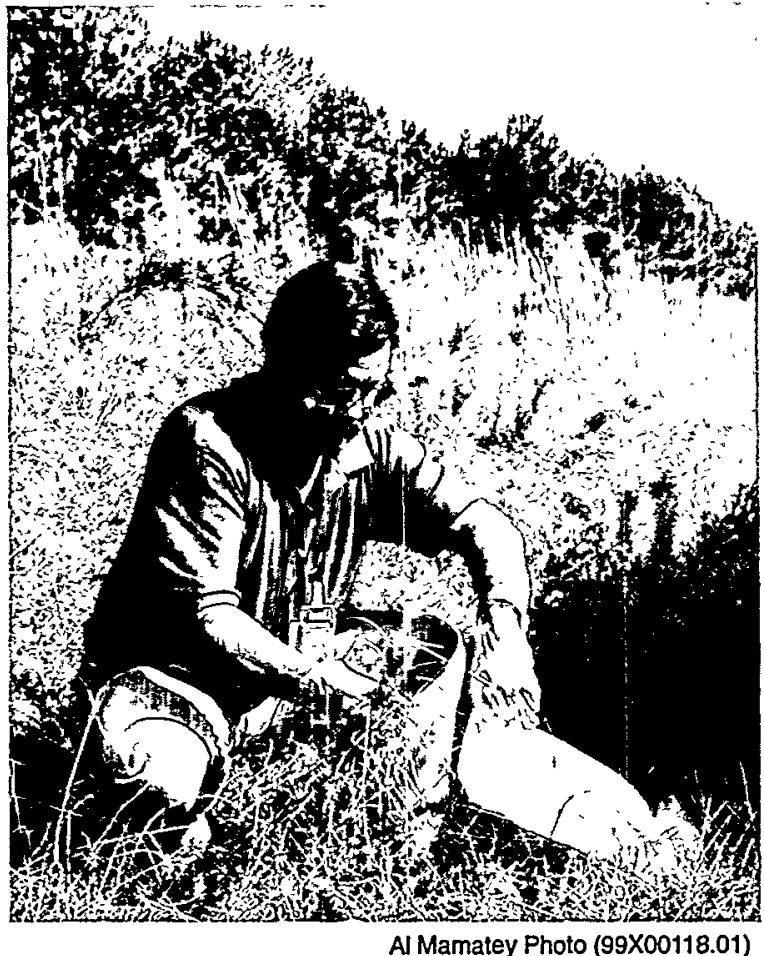

An EMS technician collects a grass sample as part of the SRS radiological program for grassy vegetation. Grasses-gathered at on-and offsite locations-are preferred because of their availability all year long.

Disposal Facility. The onsite location is near the geographical center of the site, and the four perimeter locations are situated near air monitoring stations that provide sampling within each 30-degree sector around the site boundary. Selected as control sites, the two offsite locations are in the vicinity of the environmental air monitoring stations at the U.S. Highway 301 bridge over the Savannah River and near the city of Savannah. All the vegetation locations, which continue to be sampled annually, are shown in figure 6-10.

In addition to actinides, vegetation samples are analyzed for gross alpha and gross beta, gamma-emitting radionuclides, tritium, and strontium. Vegetation can be contaminated externally by the deposition of airborne radioactive contaminants (i.e., from fallout) and internally by uptake, from soil or water, by the roots. While the vegetation surveillance program makes no attempt to differentiate between contributions of the external and internal contaminations, contributions can be approximated when radionuclide concentrations in local soils are known.

The sampling and analysis programs for grassy vegetation are documented in WSRC-3Q1-2, Volume 1, Section 1105.3.10.2. Operational details of sample collection are in procedure manual WSRC-3Q1-3, while analytical procedures are in WSRC-3Q1-4 and WSRC-3Q1-6.

\section{Surveillance Results}

All surveillance results are based on dry weight. The 1998 grassy vegetation results showed tritium, cesium, strontium, and americium activity near or slightly above minimum detectable concentrations at several locations. Also, naturally occurring uranium isotopes were detected at several locations. Gross beta activity was detected at all locations but was attributed primarily to the naturally occurring radionuclide potassium- 40 . Detailed analytical results from vegetation samples collected during 1998 can be found in table 31 of SRS Environmental Data for 1998. 


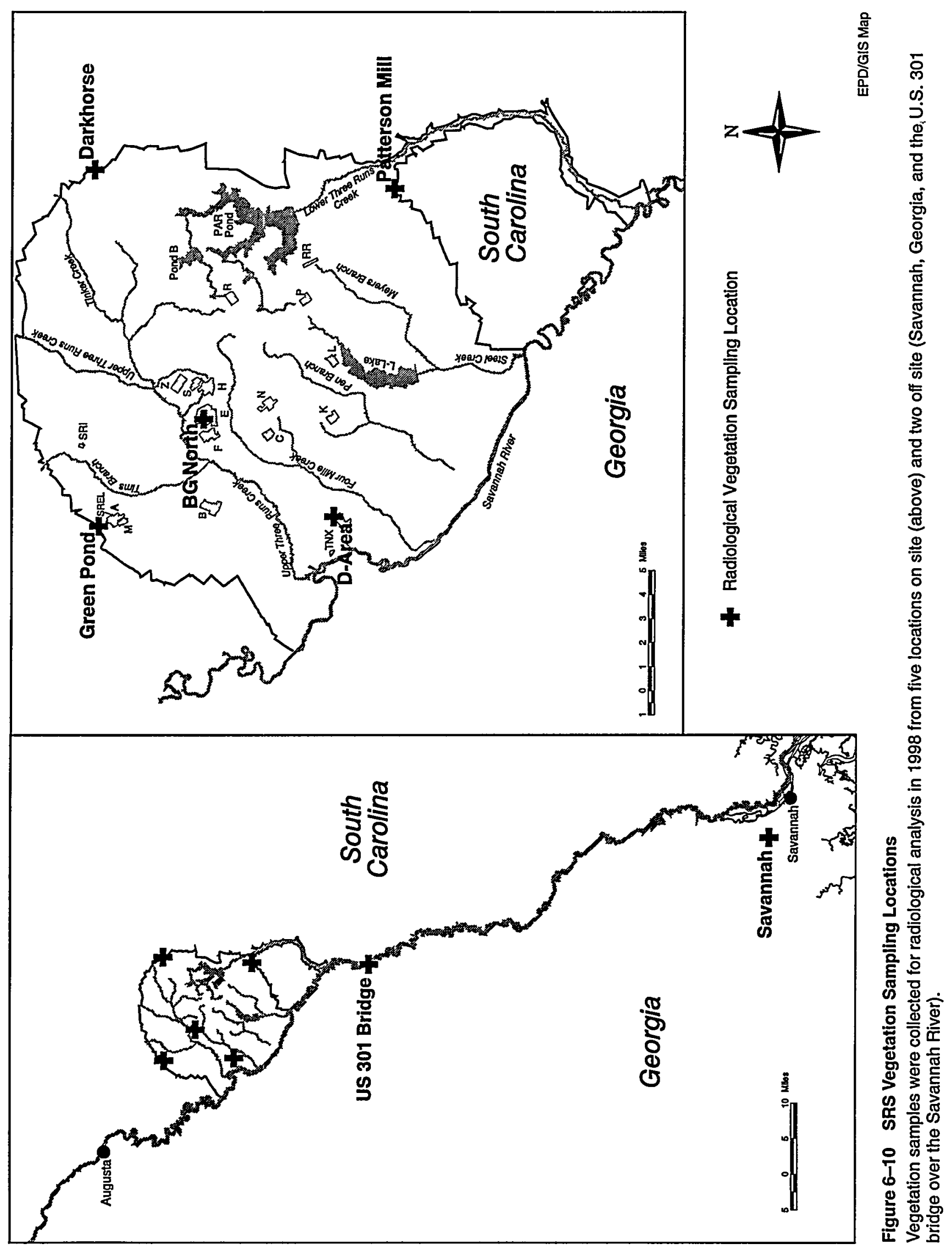


. 
Calculating Dose ................. 112

\title{
Radiation
}

Dose Calculation Results ............ 116

Potential Risk from Consumption

of SRS Creek Mouth Fish ............ 126

Doses

Radiological Assessment Program ..... 129

\author{
Bill Cariton and Timothy Jannik \\ Savannah River Technology Center
}

\section{Highlights}

- Using conservative methods, the calculated potential radiation doses from the site were well below all applicable standards of radiation exposure to humans and aquatic organisms.

- The potential dose to the maximally exposed individual from liquid releases in 1998 was estimated at 0.12 mrem $(0.0012 \mathrm{mSv}$ ). This dose is 0.12 percent of DOE's 100 -mrem all-pathway dose standard for annual exposure. The dose is about 8 percent less than the 1997 dose.

- The estimated dose to the maximally exposed individual from airborne releases was $0.07 \mathrm{mrem}(0.0007 \mathrm{mSv})$. This dose is 0.7 percent of DOE's 10-mrem air pathway dose standard for annual exposure. The 1998 dose was 40 percent more than the 1997 dose-primarily because of increased moderator consolidation operations in P-Area.

- The potential maximally exposed individual all-pathway dose was $0.19 \mathrm{mrem}(0.0019 \mathrm{mSv})-0.07 \mathrm{mrem}$ from the airborne pathway plus $0.12 \mathrm{mrem}$ from the liquid pathway. This dose is 6 percent more than the 1997 all-pathway dose of $0.18(0.0018 \mathrm{mSv})$.

- The potential maximum dose that could have been received by an onsite hunter was estimated at 56 mrem $(0.56 \mathrm{mSv})$, or 56 percent of DOE's $100-\mathrm{mrem}$ all-pathway dose. This hunter harvested five animals, and it was assumed that he personally consumed the entire edible portion (242 pounds) of all of them.

- The potential maximum dose for a recreational fisherman was based on the consumption of $19 \mathrm{~kg}$ (42 pounds) of Savannah River fish having the highest measured concentrations of radionuclides. Bass caught at the mouth of Steel Creek had the highest concentrations in 1998. Consumption of these bass could have resulted in a dose of $1.6 \mathrm{mrem}(0.016 \mathrm{mSv})$, or 1.6 percent of DOE's 100-mrem all-pathway dose.

$\mathrm{T}$ HIS chapter presents the potential doses to offsite individuals and the surrounding population from 1998 Savannah River Site

(SRS) atmospheric and liquid radioactive releases. Additionally, potential doses from special-case exposure scenarios-such as deer meat, fish, and goat milk consumption and crops irrigated with Savannah River water-are documented.

Unless otherwise noted, the generic term "dose" used in this report includes both the committed effective dose equivalent (50-year committed dose) from internal deposition of radionuclides and the effective dose equivalent attributable to sources external to the body. Use of the effective dose equivalent allows doses from different types of radiation and to different parts of the body to be expressed on the same relative basis.

Many parameters-such as radioactive release quantities, population distribution, meteorological conditions, radionuclide dose factors, human consumption rates of food and water, and environmental dispersion-are considered in the dose models used to estimate offsite doses at SRS.

Descriptions of the effluent monitoring and environmental surveillance programs discussed in this chapter can be found in chapter 5 , "Radiological Effluent Monitoring," and chapter 6, "Radiological Environmental Surveillance." A complete description of how potential doses are calculated can be found in section 1108 of the Savannah River Site Environmental Monitoring Section Plans and Procedures, WSRC-3Q1-2, Volume 1 (SRS EM Program). Tables containing all potential dose calculation results are presented in SRS Environmental Data for 1998 (WSRC-TR-98-00314).

Applicable dose regulations can be found in appendix A, "Applicable Guidelines, Standards, and Regulations," of this document. 


\section{Calculating Dose}

Potential offsite doses from SRS effluent releases of radioactive materials (atmospheric and liquid) are calculated for the following scenarios:

- maximally exposed individual

- 80-kilometer (50-mile) population

Because the U.S. Department of Energy (DOE) has adopted dose factors only for adults, SRS calculates maximally exposed individual and collective doses as if the entire 80-kilometer population consisted of adults [DOE, 1988].

The International Commission on Radiological Protection (ICRP), in its Publications \#56 and \#67, has established age-specific dose factors for six age groups, ranging from 3-month-old infants to adults. However, dose factors for only a select group of radioisotopes were published, and these are applicable to only the ingestion pathway. In general, for most radioisotopes, the dose to an infant is more than to an adult. For the radioisotopes that constitute most of SRS's radioactive releases (i.e., tritium and cesium-137), the dose to infants would be approximately two to three times more than to adults. The dose to older children becomes progressively closer to the adult dose.

When the ICRP completes age-specific dose factors for all radioisotopes and develops an age-specific lung model for inhalation, and when DOE adopts these factors and models, doses will be calculated for the various age groups.

SRS also uses adult consumption rates for food and drinking water and adult usage parameters to estimate intakes of radionuclides (tables 36 and 38, SRS
Environmental Data for 1998). These intake values and parameters were developed specifically for SRS based on an intensive regional survey [Hamby, 1991]. The survey includes data on agricultural production (table 34, SRS Environmental Data for 1998), consumption rates for food products, and use of the Savannah River for drinking water and recreational purposes.

\section{Dose Calculation Models}

To calculate annual offsite doses, SRS uses radiation transport and dose models developed for the commercial nuclear industry [NRC, 1977]. The models are implemented at SRS in the following computer programs [SRS EM Program, 1996]:

- MAXIGASP: calculates maximum and average doses to offsite individuals from atmospheric releases.

- POPGASP: calculates collective doses from atmospheric releases.

- LADTAPII: calculates maximum and average doses to offsite individuals and the population from liquid releases.

- CAP88: calculates doses to offsite individuals from atmospheric releases to demonstrate compliance with the National Emission Standards for Hazardous Air Pollutants (NESHAP) under the Clean Air Act.

The CAP88 computer code is required under the Clean Air Act to calculate offsite doses from atmospheric releases from existing and proposed facilities. SRS uses the CAP88 dose estimates to show NESHAP compliance, but not for routine dose calculations. Both the CAP88 and the MAXIGASP codes use modeling based on U.S. Nuclear Regulatory Commission Regulatory Guide 1.109.

\section{Dose to the Maximally Exposed Individual}

When calculating radiation doses to the public, SRS uses the concept of the maximally exposed individual; however, because of the conservative lifestyle assumptions used in the dose models, no such person is known to exist. The parameters used for the dose calculations are

For airborne releases: Someone who lives at the SRS boundary 365 days per year and consumes large amounts of milk, meat, and vegetables produced at that location

For liquid releases: Someone who lives downriver of SRS (near River Mile 120) 365 days per year, drinks 2 liters of untreated water per day from the Savannah River, consumes a large amount of Savannah River fish, and spends the majority of time on or near the river

To demonstrate compliance with the DOE Order 5400.5 all-pathway dose standard of 100 mrem per year, SRS conservatively combines the airborne pathway and liquid pathway dose estimates, even though the two doses are calculated for hypothetical individuals residing at different geographic locations. 


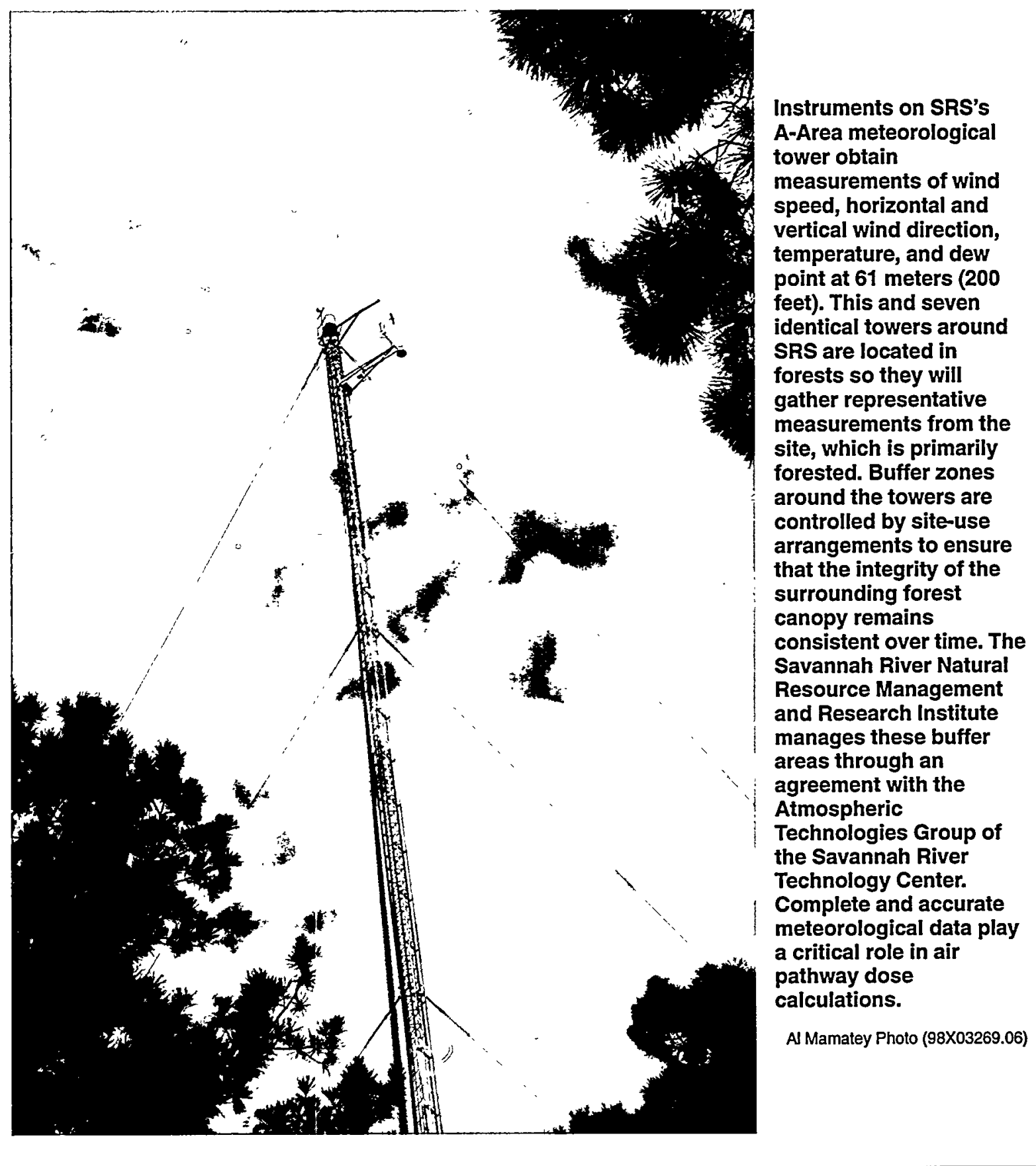

\section{Meteorological Database}

Meteorological data are used as input for the atmospheric transport and dose models.

For 1998, all potential offsite doses from releases of radioactivity to the atmosphere were calculated with quality-assured meteorological data for A-Area (used for A-Area and M-Area releases), D-Area (used for D-Area releases), and $\mathrm{H}$-Area (used for releases from all other areas). The meteorological databases used were for the years 1992-1996, reflecting the most recent 5-year compilation period (table 32, SRS Environmental Data for 1998). Five-year average databases are used instead of the actual annual data because of the difficulty of compiling, inputting, and validating all the data in time to be used for the current-year dose calculations.

The wind rose developed from the 1992-1996 H-Area database is provided in figure 7-1. As shown, there is no prevailing wind at SRS, which is typical for the lower midlands of South Carolina. The maximum frequency that the wind blew in any one 


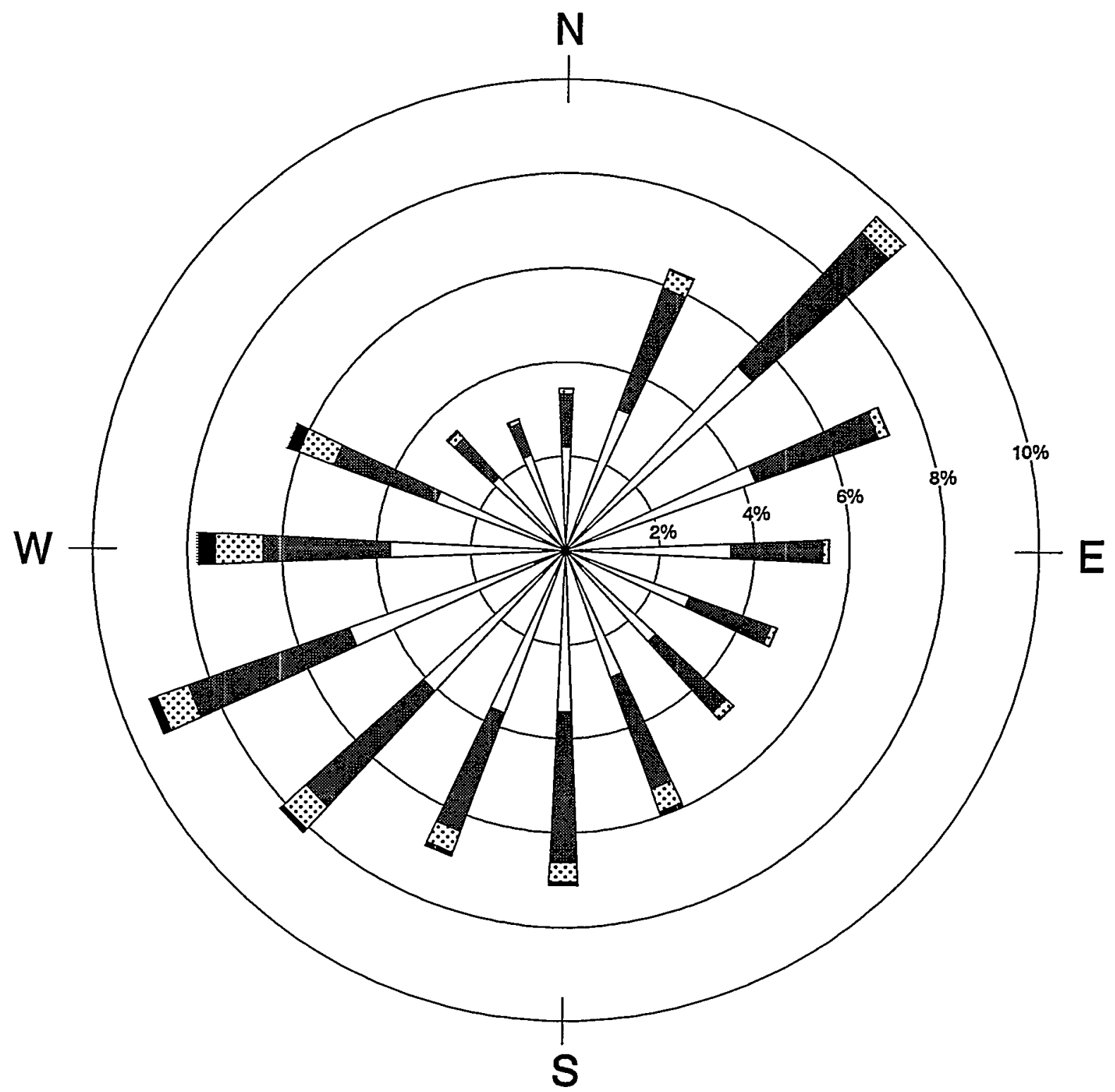

\section{$\begin{array}{llllll}0.0 & 2.0 & 4.0 & 6.0 & 8.0 & 12.0\end{array}$ \\ Wind Speed Class Boundaries (Meters/Second)}

Figure 7-1 Wind Rose for SRS, 1992-1996

This wind rose graphically depicts the percent of occurrence frequencies of six wind speed categories by 16 cardinal wind direction sectors at SRS. The wind speed categories are defined on the plot; direction is defined as the sector from which the wind blows. The data used to generate the wind rose consist of hourly averages of wind speed and direction at the H-Area meteorological tower for the 5-year period 1992-1996; measurements were taken 200 feet above the ground. 
direction was 9.7 percent of the time, which occurred toward the southwest direction.

The meteorological measurements include all dispersion conditions observed during the 5-year period, ranging from unstable (considerable turbulence, which leads to rapid dispersion) to very stable (very little turbulence, which produces a narrow, undispersed plume). The data for 1992-1996 indicate that the SRS area experiences stable conditions (atmospheric stability classes E, F, G) about 18.4 percent of the time.

\section{Population Database and Distribution}

Collective, or population, doses from atmospheric releases are calculated for the population within a 80-kilometer (50-mile) radius of SRS.

For 1998 dose calculations, the 1990 population. database prepared by the University of South Carolina was used. This database distributes the population into a grid of cells one-second latitude by one-second longitude. This database is transformed by the POPGASP Code into polar coordinates of 16 compass sectors and varying radial distances out to 80 kilometers. The POPGASP Code can prepare a polar coordinate database for any release point put into the code in polar coordinates. A separate, fixed-polar-coordinate database was prepared for use with the CAP 88 Code, which does not have the capability of transforming the grid into polar coordinates. The population database generated by the POPGASP Code is centered on the geographical center of SRS (table 33, SRS Environmental Data for 1998).

Within the 80-kilometer radius, the total population for 1990 was 620,100 , compared to 555,200 for 1980 , a 12-percent population growth in 10 years.

Some of the collective doses resulting from SRS liquid releases are calculated for the populations served by the City of Savannah Industrial and Domestic Water Supply Plant (formerly Cherokee Hill Water Treatment Plant), near Port Wentworth, Georgia, and by the Beaufort-Jasper Water Treatment Plant, near Beaufort, South Carolina. According to the treatment plant operators, the population served by the Port Wentworth facility is approximately 10,000 persons, and the population served by the Beaufort-Jasper facility is approximately 60,000 persons.

\section{River Flow Rate Data}

Offsite dose from liquid effluents varies each year with the amount of radioactivity released and the amount of dilution (flow rate) in the Savannah River.
Although flow rates are recorded at U.S. Geological Survey (USGS) gauging stations at the SRS boat dock and near River Mile 120 (U.S. Highway 301 bridge), these data are not used directly in dose calculations. This is because weekly river flow rates fluctuate widely (i.e., short-term dilution varies from week to week). Used instead are "effective" flow rates, which are based on measured concentrations of tritium in Savannah River water and measured concentrations in water used at the downstream water treatment plants. However, the USGS-measured flow rates are used for comparison to these calculated values.

For 1998, the River Mile 120 calculated (effective) flow rate of 12,500 cubic feet per second was used in determining doses to maximally exposed individuals, population doses from recreation and fish consumption, and potential doses from crops irrigated with river water. This flow rate was 44 percent more than the 1997 effective flow rate of 8,700 cubic feet per second. For comparison, during 1998 the USGS-measured flow rate at River Mile 120 was 16,300 cubic feet per second, which was about 55 percent more than the 1997 measured rate of 10,500 cubic feet per second. Therefore, the calculated value is more conservative because it accounts for less dilution.

The 1998 calculated (effective) flow rate for the Beaufort-Jasper facility was 16,300 cubic feet per second, which was about 57 percent more than the 1997 rate of 10,400 cubic feet per second.

The 1998 calculated (effective) flow rate for the Port Wentworth facility was 14,300 cubic feet per second, which was about 44 percent more than the 1997 rate of 9,910 cubic feet per second.

The 1998 calculated Savannah River estuary flow rate (18,000 cubic feet per second) was used only for calculation of dose from consumption of salt water invertebrates.

In figure 7-2, the annual average Savannah River flow rates, measured by the USGS at River Mile 120, are provided for the years of SRS operations (1954 to 1998). As indicated, the 1998 rate of 16,300 cubic feet per second was the second highest measured during this 45 -year period.

\section{Uncertainty in Dose Calculations}

Radiation doses are calculated using the best available data. If adequate data are unavailable, then site-specific parameters are selected that would result in a conservative estimate of the maximum dose.

All radiation data and input parameters have an uncertainty associated with them, which causes 


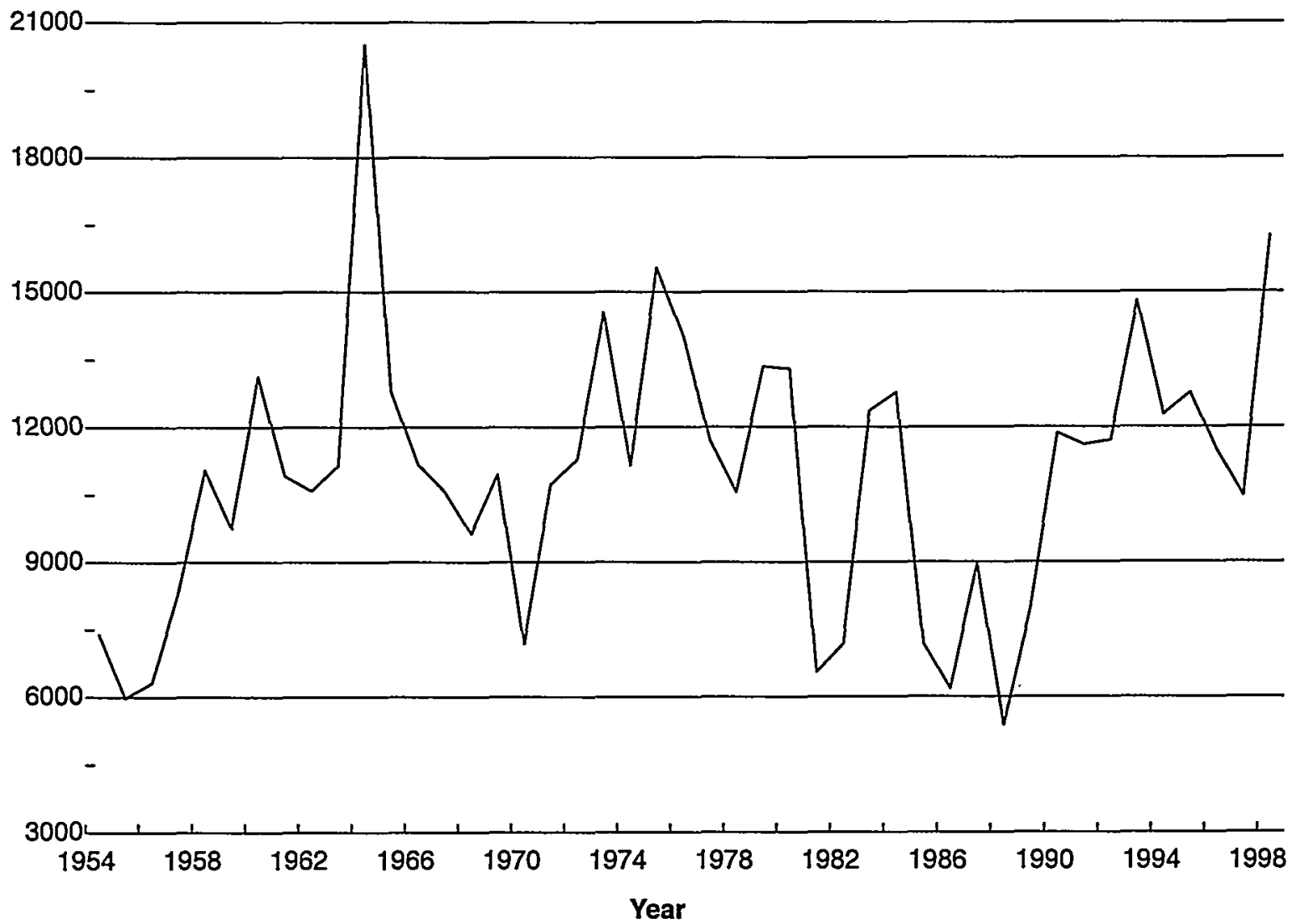

Ileaf Graphic

Figure 7-2 Savannah River Mile 120 Annual Average Flow Rates, 1954-1998

The 1998 River Mile 120 flow rate of 16,200 cubic feet per second was the second highest measured during the 45-year operating history of SRS. River Mile 120 flow rates were not measured for the years 1971-1981; mean flow rates for those years are based on rates measured near Augusta, Georgia.

uncertainty in the dose determinations. For example, there is uncertainty in the assumption that an individual eats $81 \mathrm{~kg}$ (179 pounds) of meat each year. Obviously, a few people will eat more than $81 \mathrm{~kg}$, but most probably will eat less. Uncertainties can be combined mathematically to create a distribution of doses rather than a single number. While the concept is simple, the calculation is quite difficult. A detailed technical discussion of the method of estimating uncertainty at SRS was published in the July 1993 issue of Health Physics [Hamby, 1993].

\section{Dose Calculation Results}

Liquid and air pathway doses are calculated for the maximally exposed individual and for the surrounding population. In addition, a sportsman dose is calculated separately for consumption of fish, deer, and feral hogs, which are nontypical exposure pathways. Finally, a dose is calculated for the aquatic biota found in SRS streams.

\section{Liquid Pathway}

This section contains information on liquid release quantities used as source terms in SRS dose calculations, including a discussion about radionuclide concentrations in Savannah River fish. The calculated dose to the maximally exposed individual, the calculated collective (population) dose, and the potential dose from agricultural irrigation are presented.

\section{Liquid Release Source Terms}

The 1998 radioactive liquid release quantities used as source terms in SRS dose calculations are presented in chapter 5 and summarized by radionuclide in table 7-1. In order to maintain conservatism, the stream transport tritium release total of $10,600 \mathrm{Ci}$ $(3.92 \mathrm{E}+14 \mathrm{~Bq})$, which was the highest value of the 
three alternative tritium release calculation methods employed at SRS (chapter 6), was used in the dose calculations.

As discussed in chapter 5 , for dose calculations, releases of unidentified beta-gamma emitters were summed with strontium- 89,90 releases, and unidentified alpha emitters were summed with releases of plutonium- 239 .

For use in dose determinations and model comparisons, the concentrations of tritium in Savannah River water and cesium-137 in Savannah River fish are measured at several locations along the river. The amounts of all other radionuclides released from SRS are so small that they cannot be detected in the environment using standard analytical techniques.

The measured concentrations of tritium in the Savannah River near River Mile 120 and at the Beaufort-Jasper and Port Wentworth water treatment facilities are shown in table 7-1, as are the LADTAPII computer code-determined concentrations for the other released radionuclides.
The 12-month average tritium concentrations measured in the Savannah River near River Mile 120 $(0.948 \mathrm{pCi} / \mathrm{mL})$, and at the Beaufort-Jasper $(0.728 \mathrm{pCi} / \mathrm{mL})$ and Port Wentworth $(0.829 \mathrm{pCi} / \mathrm{mL})$ water treatment plants, remained below the U.S. Environmental Protection Agency (EPA) and DOE concentration standards of $20 \mathrm{pCi} / \mathrm{mL}$ and $80 \mathrm{pCi} / \mathrm{mL}$, respectively.

The 1998 River Mile 120 concentration was 14 percent less than the 1997 concentration of $1.10 \mathrm{pCi} / \mathrm{mL}$. This occurred-even though the amount of tritium released to the Savannah River during 1998 (10,600 curies) was 24 percent more than during 1997 (8,550 curies)-because the 1998 River Mile 120 flow rate (16,200 cubic feet per second) was 54 percent more than the 1997 flow rate ( 10,500 cubic feet per second), which resulted in increased dilution.

Annual average tritium concentrations measured during the period 1989-1998 at River Mile 120 and at the Beaufort-Jasper and Port Wentworth facilities are compared to the EPA standard in figure 7-3. The data for Beaufort-Jasper and Port Wentworth are the

Table 7-1

1998 Radioactive Liquid Release Source Term and 12-Month Average Downriver Radionuclide Concentrations (Calculated Concentrations Are Based on Effective River Flow Rates)

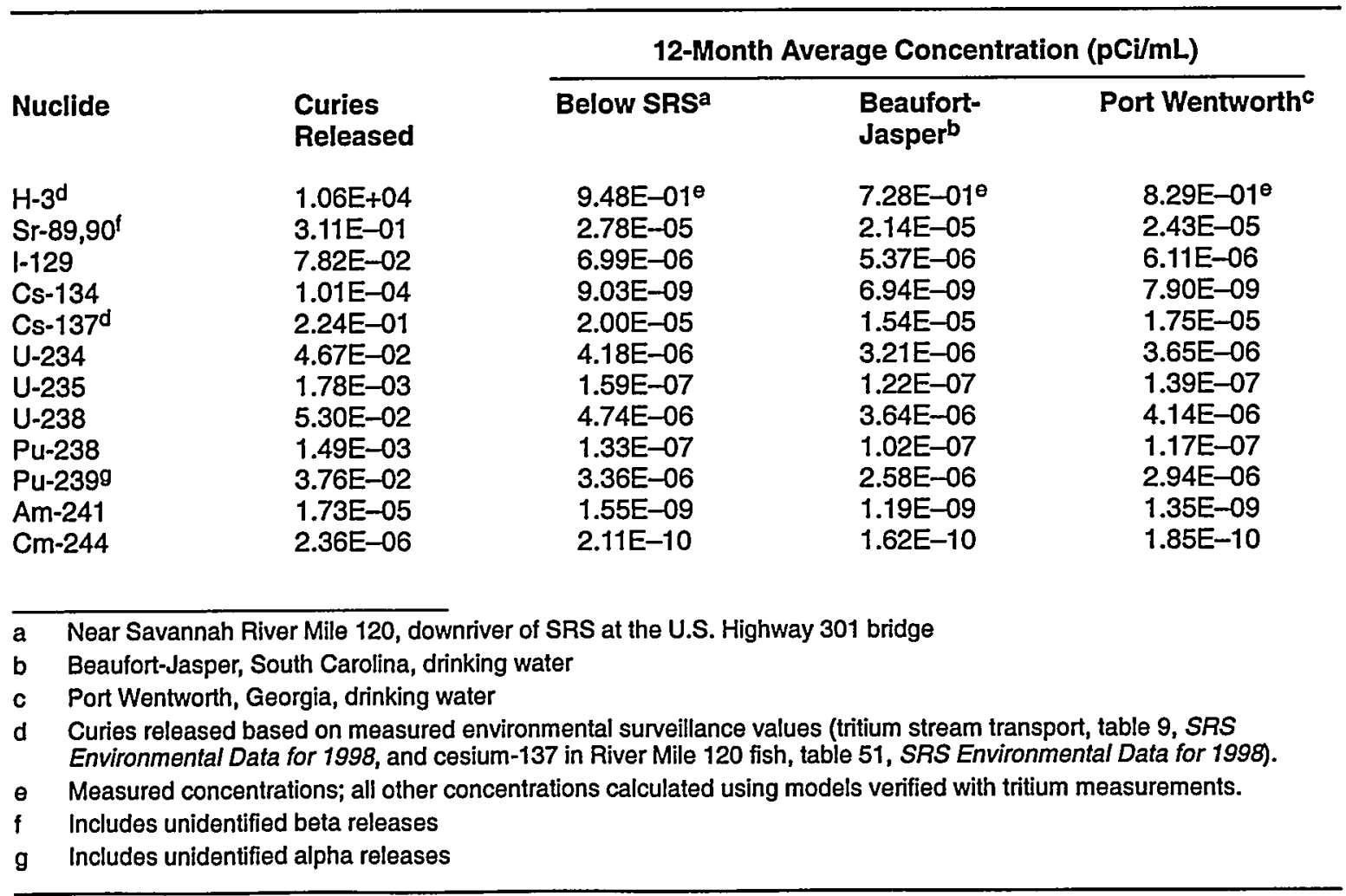


tritium concentrations measured in the finished drinking water at each facility.

Radionuclide Concentrations in River Fish At SRS, an important dose pathway for the maximally exposed individual is from the consumption of fish.

Fish exhibit a high degree of bioaccumulation for certain elements. For the element cesium (including radioactive isotopes of cesium), the bioaccumulation factor for Savannah River fish is approximately 3,000 . That is, the concentration of cesium found in fish flesh is about 3,000 times more than the concentration of cesium found in the water in which the fish live.

Because of this high bioaccumulation factor, cesium-137 is more easily detected in fish flesh than in river water. Therefore, the fish pathway dose from cesium-137 is based directly on the radioanalysis of the fish collected near Savannah River Mile 120, which is the assumed location of the hypothetical maximally exposed individual (table 51, SRS Environmental Data for 1998). The fish pathway dose from all other radionuclides is based on the calculated concentrations determined by the LADTAPII code. A consumption rate of $19 \mathrm{~kg}$
(42 pounds) of fish per year is used in the maximally exposed individual dose calculation [Hamby, 1991]. Some fraction of this estimated dose is due to cesium-137 from worldwide fallout and from neighboring Vogtle Electric Generating Plant; however, that amount is difficult to determine and is not subtracted from the total.

The dose determinations are accomplished in the LADTAPII code by substituting a cesium- 137 release value that would result in the measured concentration in river fish, assuming the site-specific bioaccumulation factor of 3,000. A weighted average concentration (based on the number of fish in each composite analyzed) of cesium-137 in River Mile 120 fish was used for maximally exposed individual and population dose determinations. Using the above factors, the cesium- 137 release value used for LADTAPII input was 2.24E-01 Ci (8.29 E+09 Bq), which is more conservative than the measured effluent release value of $1.93 \mathrm{E}-01 \mathrm{Ci}(7.14 \mathrm{E}+09 \mathrm{~Bq})$ and was about 79 percent more than the 1997 value of $1.25 \mathrm{E}-01 \mathrm{Ci}(4.63 \mathrm{E}+09 \mathrm{~Bq})$.

\section{Dose to the Maximally Exposed Individual}

The potential liquid pathway dose to the hypothetical maximally exposed individual living downriver of

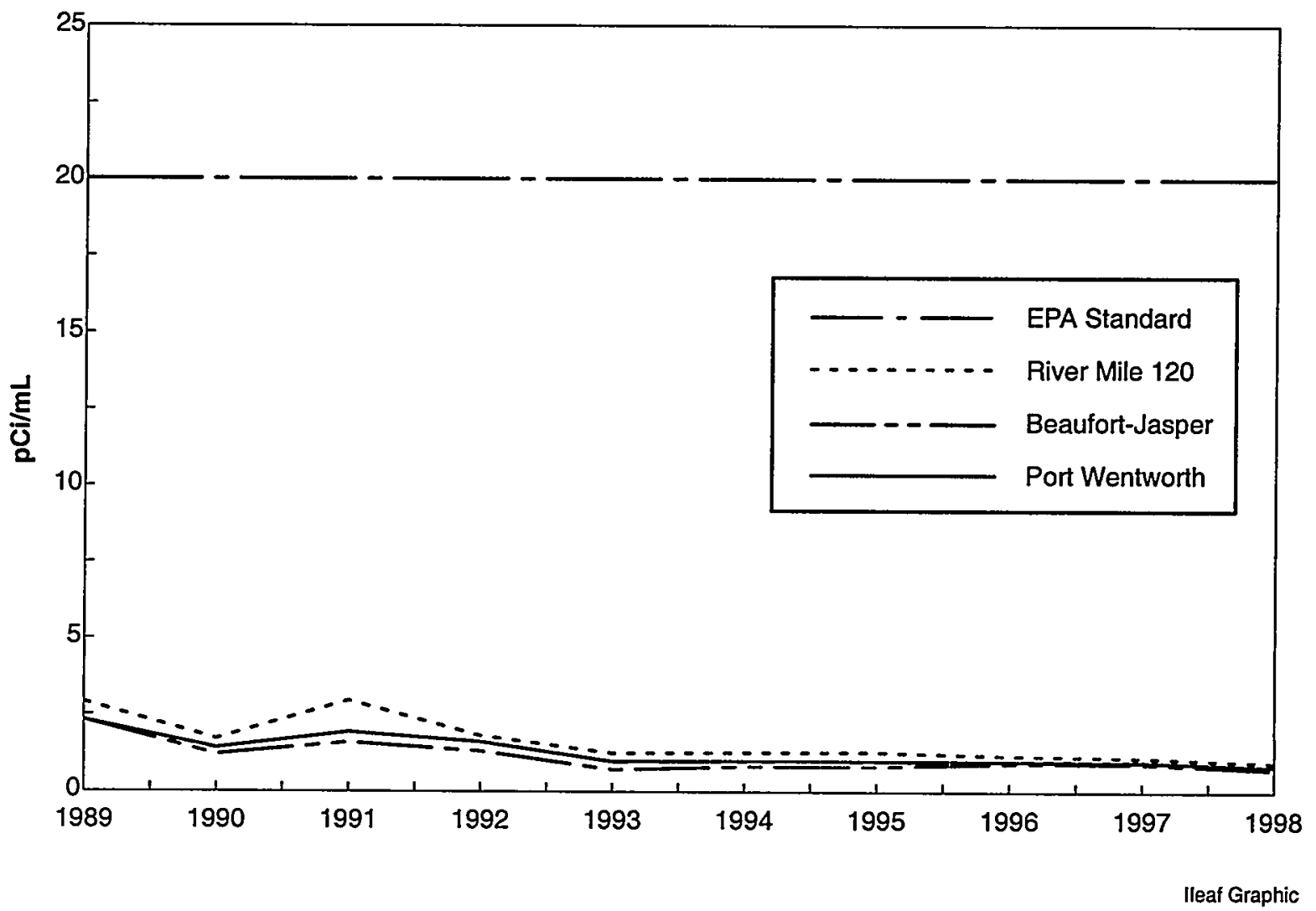

Figure 7-3 Annual Average Tritium Concentrations at River Mile 120, Beaufort-Jasper, and Port Wentworth (1989-1998) Compared to EPA Standard of $20 \mathrm{pCi} / \mathrm{mL}$. 
Table 7-2

Potential Dose to the Maximally Exposed Individual from SRS Liquid Releases in 1998

\begin{tabular}{|c|c|c|c|}
\hline & $\begin{array}{l}\text { Committed } \\
\text { Dose }\end{array}$ & $\begin{array}{l}\text { Applicable } \\
\text { Standard }\end{array}$ & $\begin{array}{l}\text { Percent } \\
\text { of Standard }\end{array}$ \\
\hline \multicolumn{4}{|c|}{ Maximally Exposed Individual } \\
\hline $\begin{array}{l}\text { At Site Boundary } \\
\text { (untreated river water) }\end{array}$ & $0.12 \mathrm{mrem}$ & 100 mrem $^{a}$ & 0.12 \\
\hline $\begin{array}{l}\text { At Port Wentworth } \\
\text { (public water supply only) }\end{array}$ & 0.05 mrem & 4 mrem $^{b}$ & 1.25 \\
\hline $\begin{array}{l}\text { At Beaufort-Jasper } \\
\text { (public water supply only) }\end{array}$ & 0.05 mrem & 4 mrem $^{b}$ & 1.25 \\
\hline a Mil"padinway unse stalic & rem per year ( $\mathrm{D}$ & & \\
\hline b Drinking water pathways & 4 mrem per yea & 0.5 and EPA, 1975) & \\
\hline
\end{tabular}

SRS, near River Mile 120, was determined based on adult intake and usage parameters discussed earlier in this chapter and on other site-specific physical parameters (table 39, SRS Environmental Data for 1998).

As shown in table 7-2, the highest potential dose to the maximally exposed individual from liquid releases in 1998 was estimated at 0.12 mrem $(0.0012 \mathrm{mSv})$. This dose is 0.12 percent of DOE's 100-mrem all-pathway dose standard for annual exposure.

The 1998 potential maximally exposed individual dose was about 8 percent less than the 1997 dose of $0.13 \mathrm{mrem}(0.0013 \mathrm{mSv})$ - primarily because the 54-percent increase in the Savannah River flow rate resulted in more dilution.

Approximately 47 percent of the dose to the maximally exposed individual at the site perimeter resulted from the ingestion of cesium-137, mainly from the consumption of fish, and about 36 percent resulted from the ingestion (via drinking water) of tritium (table 46, SRS Environmental Data for 1998). More than 9 percent of the liquid pathway maximally exposed individual dose was attributed to unidentified alpha emitters, which are conservatively accounted for as plutonium-239 releases in the dose calculations (chapter 5, "Radiological Effluent Monitoring").

Drinking Water Pathway Persons downriver of SRS may receive a radiation dose by consuming drinking water that contains radioactivity as a result of liquid releases from the site. In 1998, tritium in downriver drinking water represented the majority of the dose (about 72 percent) received by persons at downriver water treatment plants.

The calculated doses to maximally exposed individuals whose entire daily intake of water is supplied by the Beaufort-Jasper and Port Wentworth water treatment facilities, located downriver of SRS, were determined for maximum ( 2 liters per day for a year) water consumption rates.

The maximum potential dose during 1998 was $0.05 \mathrm{mrem}(0.0005 \mathrm{mSv})$ at both the Beaufort-Jasper Water Treatment Plant and the City of Savannah Industrial and Domestic Water Supply Plant (Port Wentworth) (tables 47 and 48, SRS Environmental Data for 1998).

As shown in table 7-2, the maximum dose of $0.05 \mathrm{mrem}(0.0005 \mathrm{mSv})$ is 1.25 percent of the DOE and EPA standard of 4 mrem per year from public water supplies. The 1998 maximum potential drinking water dose was 29 percent less than the 1997 maximum dose of $0.07 \mathrm{mrem}(0.0007 \mathrm{mSv})$. This decrease in dose is attributed to the 54-percent increase in the Savannah River flow rate.

\section{Collective (Population) Dose}

The collective drinking water consumption dose is calculated for the discrete population groups at Beaufort-Jasper and Port Wentworth. The collective dose from other pathways is calculated for a diffuse population that makes use of the Savannah River. However, it cannot be described as being in a specific geographical location.

Potential collective doses were calculated, by pathway and radionuclide, using the LADTAPII 
computer code (table 49, SRS Environmental Data for 1998). In 1998, the collective dose from SRS liquid releases was estimated at 1.8 person-rem (0.018 person-Sv). This was less than the 1997 collective dose of 2.4 person-rem ( 0.022 person-Sv) -again because the 54-percent increase in the Savannah River flow rate resulted in more dilution.

\section{Potential Dose from Agricultural Irrigation}

The 1990 update of land- and water-use parameters [Hamby, 1991] revealed that there is no known use of river water downstream of SRS for agricultural irrigation purposes. However, in response to public concerns, potential doses from this pathway are calculated for information purposes only and are not included in calculations of the official maximally exposed individual or collective doses.

For 1998, a potential offsite dose of $0.09 \mathrm{mrem}$ $(0.0009 \mathrm{mSv})$ to the maximally exposed individual and a collective dose of 6.6 person-rem ( 0.066 person-Sv) were estimated for this exposure pathway.

As in previous years, collective doses from agricultural irrigation were calculated for 1,000 acres of land devoted to each of four major food types-vegetation, leafy vegetation, milk, and meat (table 50, SRS Environmental Data for 1998). It is assumed that all the food produced on the 1,000-acre parcels is consumed by the 80 -kilometer population of 620,100 .

\section{Air Pathway}

This section describes the atmospherio source term and concentrations used for dose determinations and presents the calculated dose to the maximally exposed individual, as well as the calculated collective (population) dose. Also included is a discussion about how SRS demonstrates NESHAP compliance.

\section{Atmospheric Source Terms}

The 1998 radioactive atmospheric release quantities used as the source term in SRS dose calculations are presented in chapter 5 . For dose calculation purposes, releases of unidentified beta emitters were summed with strontium- 89,90 releases and releases of unidentified alpha emitters were summed with plutonium-239 releases (table 4, SRS Environmental Data for 1998).

Tritium, in its elemental and oxide form, accounts for the majority of the radioactivity released to the atmosphere from SRS. It should be noted that tritium in its gaseous elemental form (HT or $\mathrm{T}^{2}$ ) is of much less concern in terms of human health than tritium in its oxide, or tritiated water, form ( $\mathrm{HTO}$ or $\mathrm{T}^{2} \mathrm{O}$ ). This is because the physically and chemically stable elemental form of tritium is

- not readily absorbed by the human body

- much less (about 25,000 times less) radiotoxic than the oxide form [NCRP, 1979]

- not readily converted to the oxide form

- quickly dispersed in the atmosphere

Estimates of unmonitored diffuse and fugitive sources were considered, as required for demonstrating compliance with NESHAP regulations. Most of the estimated diffuse and fugitive releases occurred at the separations areas, the reactor areas, and the Solid Waste Disposal Facility.

Airborne effluents are grouped by major release points for dose calculations. For the MAXIGASP code, five release locations with specific release heights were used (table 35, SRS Environmental Data for 1998).

The CAP88 code can calculate doses from collocated release heights but cannot combine calculations for releases at different geographical locations.

Therefore, for CAP88 calculations, airborne effluents were grouped for elevated releases (61 meters) and ground-level releases ( 0 meters), and the geographical center of the site was used as the release location for both (table 37, SRS Environmental Data for 1998).

\section{Atmospheric Concentrations}

The MAXIGASP and CAP88 codes calculate average and maximum concentrations of all released radionuclides at the site perimeter. These calculated concentrations are used for dose determinations instead of measured concentrations. This is because most radionuclides released from SRS cannot be measured, using standard methods, in the air samples collected at the site perimeter and offsite locations. However, the concentrations of tritium oxide at the site perimeter locations usually can be measured and are compared with calculated concentrations as a verification of the dose models.

In table 7-3, the average 1989-1998 tritium oxide concentrations in air-measured near the center of the site and at locations along the site perimeter-are compared to the average concentrations calculated for the site perimeter, using the MAXIGASP code. These data show that the calculated site-perimeter tritium oxide concentrations consistently and reasonably approximate the measured values and therefore are appropriate for use in dose determinations. 
Table 7-3

Ten-Year History of SRS Atmospheric Tritium and Tritium Oxide Releases and Average Measured Tritium Oxide Concentrations in Air Compared to Calculated Concentrations in Air

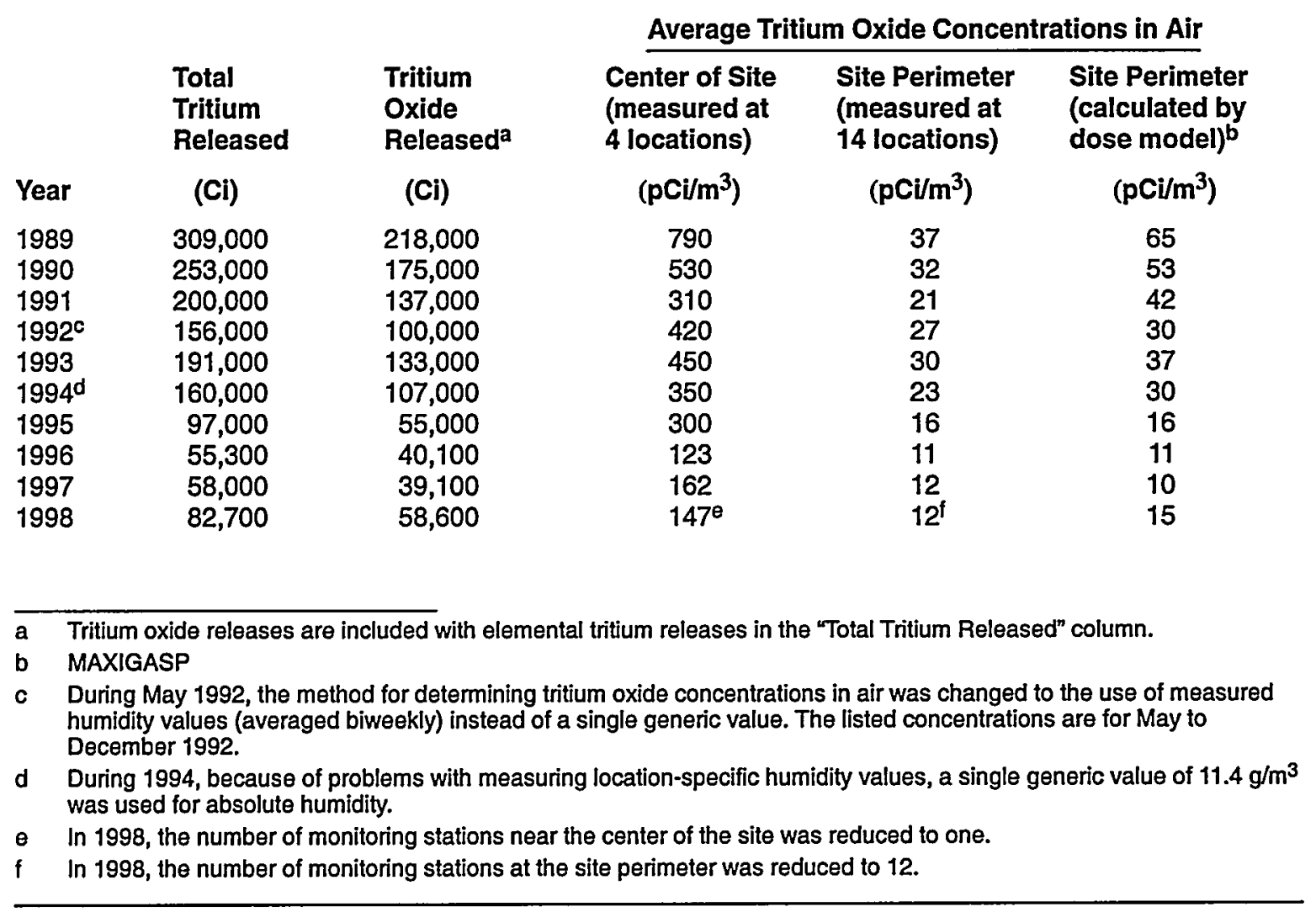

The average tritium oxide concentration in air measured at the 12 site perimeter locations during 1998 was $12 \mathrm{pCi} / \mathrm{m}^{3}\left(0.44 \mathrm{~Bq} / \mathrm{m}^{3}\right)$, which was the same as in 1997. The 1998 measured value is less than, but compares favorably with, the MAXIGASP computer code value of $15 \mathrm{pCi} / \mathrm{m}^{3}\left(0.55 \mathrm{~Bq} / \mathrm{m}^{3}\right)$.

The maximum tritium oxide concentration measured in air at the site perimeter was $18 \mathrm{pCi} / \mathrm{m}^{3}$

$\left(0.67 \mathrm{~Bq} / \mathrm{m}^{3}\right)$, which occurred at the D-Area location. This value is less than, but compares favorably with, the MAXIGASP calculated value of $29 \mathrm{pCi} / \mathrm{m}^{3}$ $\left(1.07 \mathrm{~Bq} / \mathrm{m}^{3}\right)$.

The CAP88 code calculated a maximum site perimeter concentration of $21 \mathrm{pCi} / \mathrm{m}^{3}\left(0.78 \mathrm{~Bq} / \mathrm{m}^{3}\right)$. This value is less than the MAXIGASP code value because the CAP88 code assumes that all releases occurred from only one point, which is located at the center of the site.

\section{Dose to the Maximally Exposed Individual}

The potential air pathway dose to a hypothetical maximally exposed individual located at the site perimeter was determined using the MAXIGASP computer code. The adult consumption and usage parameters used for the calculations were discussed earlier in this chapter.

In 1998, the estimated dose to the maximally exposed individual was $0.07 \mathrm{mrem}(0.0007 \mathrm{mSv})$, which is about 0.7 percent of the DOE Order 5400.5 ("Radiation Protection of the Public and the Environment") standard of 10 mrem per year. This dose is 40 percent more than the 1997 dose of $0.05 \mathrm{mrem}(0.0005 \mathrm{mSv})$. The increase is attributed to the 50-percent increase in tritium oxide releases from the site-caused by moderator consolidation operations in P-Area (chapter 5). Tritium oxide releases accounted for about 67 percent of the dose to the maximally exposed individual. Table 7-4 
compares the maximally exposed individual's dose with the DOE standard.

For 1998, the MAXIGASP code determined that the southwest and west-southwest sectors of the site were the locations of the highest maximally exposed individual dose. Figure 7-4 shows the potential dose to the maximally exposed individual residing at the site boundary for each of the 16 major compass point directions around SRS.

The major pathways contributing to the dose to the maximally exposed individual from atmospheric releases were from inhalation (43 percent) and from consumption of vegetation ( 42 percent), cow milk (10 percent), and meat ( 4 percent) (table $40, S R S$ Environmental Data for 1998).

Additional calculations of the dose to the maximally exposed individual were performed substituting goat milk for the customary cow milk pathway. The potential dose using the goat milk pathway was estimated at 0.08 mrem $(0.0008 \mathrm{mSv})$, which is slightly more than the cow milk pathway dose (table 41, SRS Environmental Data for 1998).

Most of this difference is from tritium oxide because the transfer factor (fraction of the daily intake of the nuclide that appears in each liter of milk) for tritium is 17 times higher for goat milk than for cow milk [NRC, 1977]. However, because goat milk consumption is less common, the dose calculated from cow milk consumption will continue to be the primary dose used for demonstrating compliance with dose standards.

\section{Collective (Population) Dose}

Potential doses also were calculated, by pathway and radionuclide, using the POPGASP computer code for the population $(620,100$ people) residing within
80 kilometers of the center of SRS (table 33, SRS Environmental Data for 1998).

In 1998, the collective dose was estimated at 3.5. person-rem (0.035 person-Sv)-less than 0.01 percent of the collective dose received from natural sources of radiation (about 186,000 person-rem) (table 42, SRS Environmental Data for 1998).

Tritium oxide releases, which increased about 50 percent during 1998, accounted for 77 percent of the collective dose. Primarily because of the increased amount of tritium oxide released, the 1998 collective dose was approximately 59 percent more than the 1997 collective dose of 2.2 person-rem (0.022 person-Sv).

\section{NESHAP Compliance}

To demonstrate compliance with NESHAP (Clean Air Act, 40 CFR 61, Subpart $H$ ) regulations, maximally exposed individual and collective doses were calculated, and a percentage of dose contribution from each radionuclide was determined using the CAP88 computer code.

The dose to the maximally exposed individual, calculated with CAP88, was estimated at 0.08 mrem $(0.0008 \mathrm{mSv})$, which is 0.8 percent of the 10-mrem-per-year EPA standard, as shown in table 7-4. Tritium oxide releases accounted for almost 94 percent of this dose (tables 43 and 44, SRS Environmental Data for 1998).

The CAP88 collective dose was estimated at 8.1 person-rem ( 0.081 person-Sv). Tritium oxide releases accounted for about 95 percent of this dose (table 45, SRS Environmental Data for 1998).

As the data in tables 44 and 45 show, the CAP88 code estimates a higher dose than do the MAXIGASP and POPGASP codes.

Most of the differences occur in the tritium dose estimated from food consumption. The major cause

Table 7-4

Potential Dose to the Maximally Exposed Individual from SRS Atmospheric Releases in 1998

\begin{tabular}{lll}
\hline & MAXIGASP & CAP88 (NESHAP) \\
\cline { 2 - 3 } Calculated dose & $0.07 \mathrm{mrem}$ & $0.08 \mathrm{mrem}^{-}$ \\
Applicable standard & $10 \mathrm{mrem} \mathrm{m}^{\mathrm{a}}$ & $10 \mathrm{mrem}^{\mathrm{b}}$ \\
Percent of standard & 0.7 & 0.8 \\
& & \\
\hline a DOE: DOE Order 5400.5, February 8, 1990 & & \\
b EPA: (NESHAP) 40 CFR 61 Subpart H, December 15, 1989 & \\
\hline
\end{tabular}


Figure 7-4 Sector-Specific Adult Maximally Exposed Individual Air Pathway Doses (in mrem) for 1998

Maximally exposed individual site boundary doses from airborne releases are shown for each of the 16 major compass point directions surrounding SRS. For 1998, the southwest and west-southwest sectors were the locations of the highest maximally exposed individual dose (0.07 mrem).

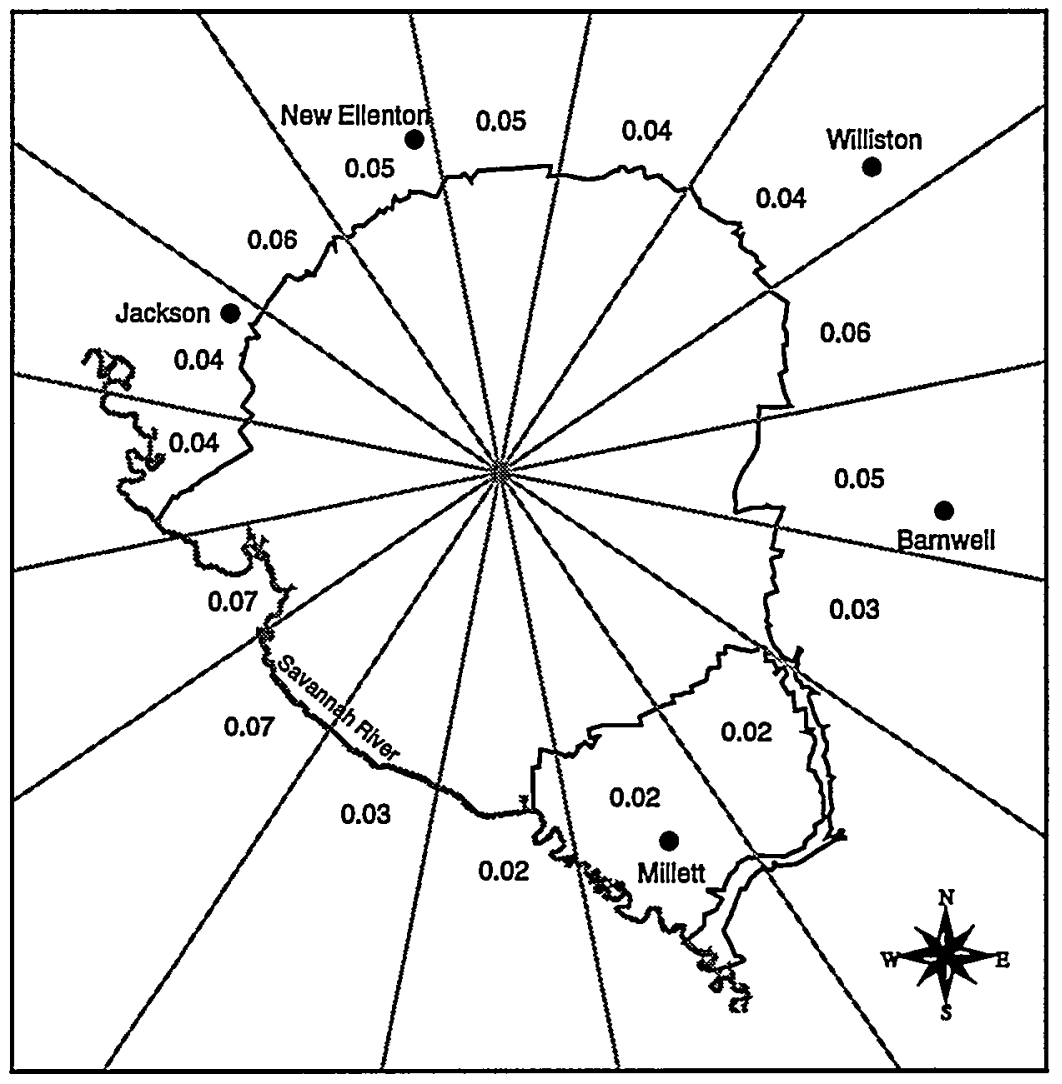

of this difference is the CAP88 code's use of 100-percent equilibrium between tritium in air moisture and tritium in food moisture, whereas the MAXIGASP and POPGASP codes use 50-percent equilibrium values, as recommended by the Nuclear Regulatory Commission [NRC, 1977]. A recent publication indicates that the 50-percent value is correct for the atmospheric conditions at SRS [Hamby and Bauer, 1994].

Because tritium oxide dominates the doses determined using the CAP88 code, and because the CAP88 code is limited to a single, center-of-site release location, other radionuclides (such as iodine-129, plutonium-239, and ruthenium-106) are less important-on a percentage-of-dose basis-for the CAP88 doses than for the MAXIGASP and POPGASP doses.

\section{All-Pathway Dose}

To demonstrate compliance with the DOE Order 5400.5 all-pathway dose standard of $100 \mathrm{mrem}$ per year (1.0 mSv per year), SRS conservatively combines the maximally exposed individual airborne pathway and liquid pathway dose estimates, even though the two doses are calculated for hypothetical individuals residing at different geographic locations.
Figure 7-5 shows a 10-year history of SRS's all-pathway doses (airborne pathway plus liquid pathway doses to the maximally exposed individual).

For 1998, the potential maximally exposed individual all-pathway dose was $0.19 \mathrm{mrem}$ $(0.0019 \mathrm{mSv})-0.07 \mathrm{mrem}$ from airborne pathway plus $0.12 \mathrm{mrem}$ from liquid pathway. This dose is 6 percent more than the 1997 all-pathway dose of $0.18 \mathrm{mrem}(0.0018 \mathrm{mSv})$.

Figure 7-6 shows a comparison of the 1998 maximum potential all-pathway dose attributable to SRS operations ( $0.19 \mathrm{mrem})$ with the average annual radiation dose received by a typical Central Savannah River Area (CSRA) resident from natural and manmade sources of radiation (360 mrem).

As shown in table 7-5, the 1998 potential all-pathway dose of $0.19 \mathrm{mrem}(0.0019 \mathrm{mSv})$ is 0.19 percent of the 100-mrem-per-year DOE dose standard.

\section{Sportsman Dose}

DOE Order 5400.5 specifies radiation dose standards for individual members of the public. The dose standard of 100 mrem per year includes doses a person receives from routine DOE operations through all exposure pathways. Nontypical exposure pathways, not included in the standard calculations of 


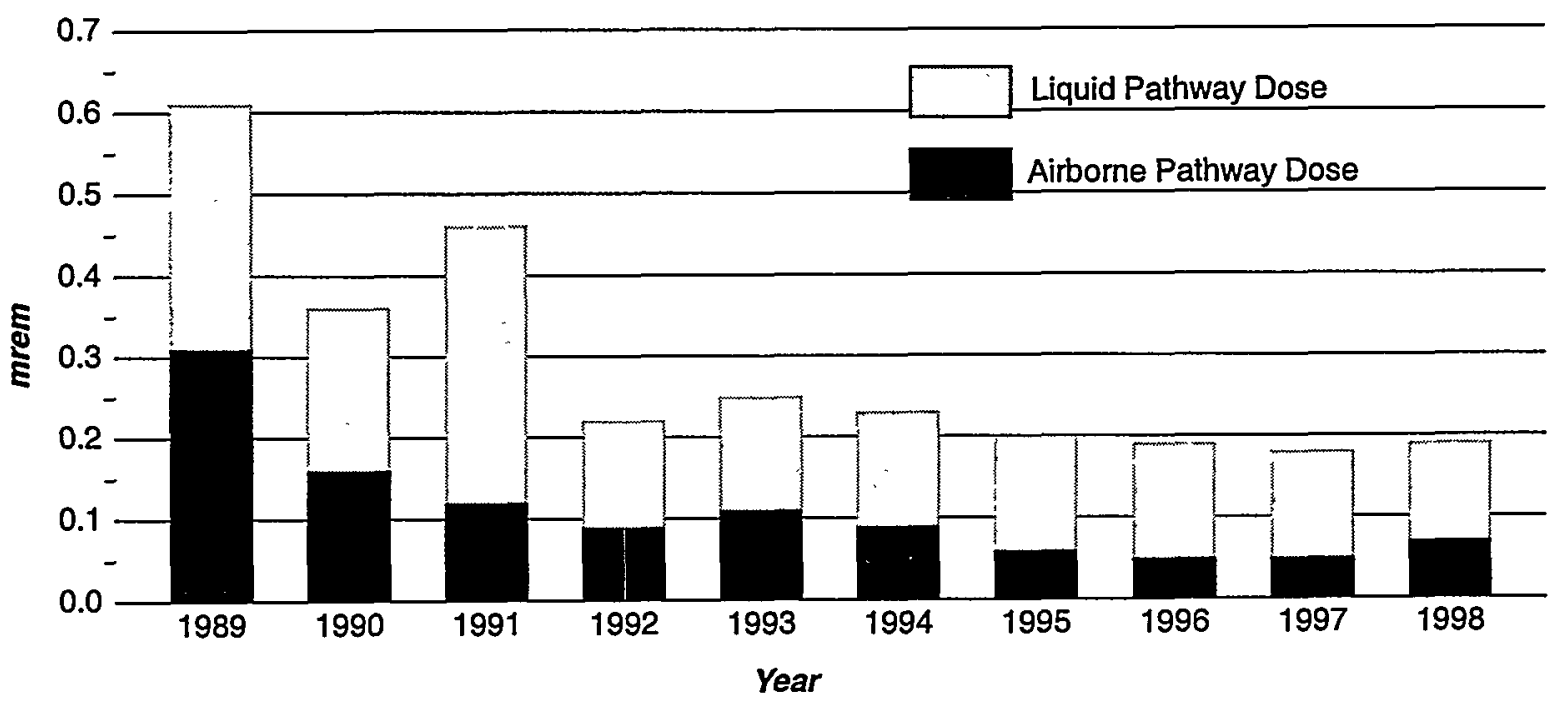

lleaf Graphic

Figure 7-5 Ten-Year History of SRS Potential All-Pathway Doses to the Maximally Exposed Individual (Airborne plus Liquid Pathways)

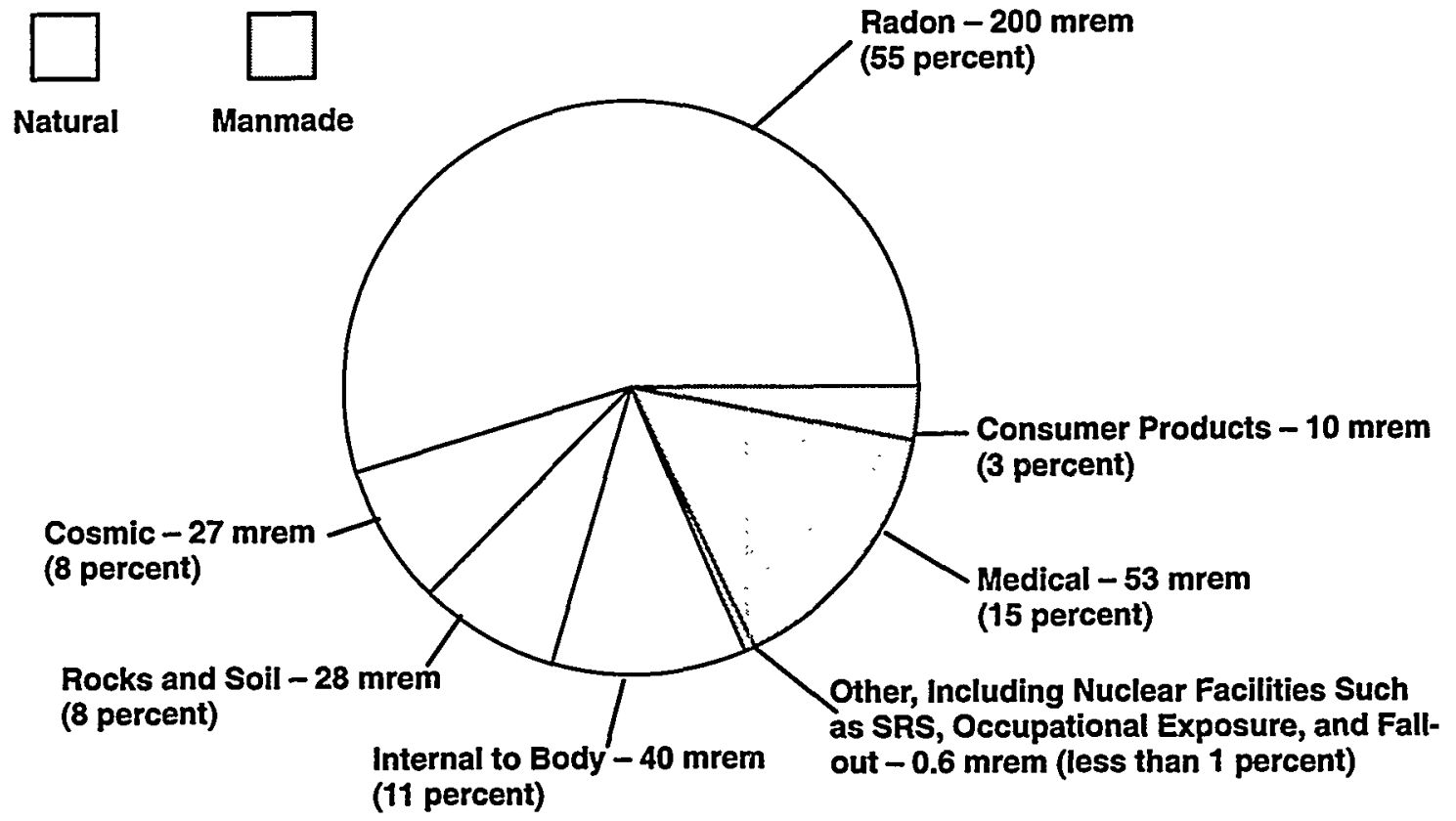

lleaf Graphic

Figure 7-6 Contributions to the U.S. Average Individual Dose

The major contributor to the annual average individual dose in the United States, including residents of the CSRA, is naturally occurring radiation (about $300 \mathrm{mrem}$ ) [NCRP, 1987]. During 1998, SRS operations potentially contributed a maximum individual dose of $0.19 \mathrm{mrem}$, which is less than 0.05 percent of the 360-mrem total annual average dose (natural plus manmade sources of radiation). 
Table 7-5

1998 Maximum Potential All-Pathway and Sportsman Doses Compared to the DOE All-Pathway Dose Standard

\begin{tabular}{lccc}
\hline & $\begin{array}{l}\text { Committed } \\
\text { Dose (mrem) }\end{array}$ & $\begin{array}{l}\text { Applicable } \\
\text { Standarda (mrem) }\end{array}$ & $\begin{array}{c}\text { Percent } \\
\text { of Standard }\end{array}$ \\
\cline { 2 - 4 } $\begin{array}{l}\text { Maximally Exposed Individual Dose } \\
\quad \begin{array}{l}\text { All-Pathway } \\
\text { (Liquid Plus Airborne Pathway) }\end{array}\end{array}$ & 0.19 & 100 & 0.19 \\
$\begin{array}{l}\text { Sportsman Doses } \\
\quad \text { Creek Mouth Fisherman } \\
\quad \text { Onsite Hunter } \\
\text { Offsite Hunter }\end{array}$ & 1.6 & 100 & 1.6 \\
\hline a All-pathway dose standard: 100 mrem per year (DOE Order 5400.5) & 56 & 100 & 56 \\
\hline
\end{tabular}

the doses to the maximally exposed individual, are considered and quantified separately. This is because they apply to low-probability scenarios, such as consumption of fish caught exclusively from the mouths of SRS streams, or to unique scenarios, such as volunteer deer hunters.

\section{Deer and Hog Consumption Pathway}

For approximately 6 weeks each year, controlled hunts of deer and feral hogs are conducted at SRS. Hunt participants are volunteers. Before any harvested animal is released to a hunter, SRS personnel perform a field analysis for cesium-137 on the deer and hogs at the hunt site, using portable sodium iodide detectors. Like fish, deer and hogs have a high bioaccumulation factor for cesium.

The estimated dose from consumption of the harvested deer or hog meat is determined for each hunter. During 1998, the maximum potential dose that could have been received by a hunter was estimated at $56 \mathrm{mrem}(0.56 \mathrm{mSv})$, or 56 percent of DOE's 100-mrem all-pathway dose standard (table 7-5). This dose was determined for a prolific hunter who had harvested five animals during the 1998 hunts. The hunter-dose calculation is based on the conservative assumption that the hunter individually consumed the entire edible portion-approximately $110 \mathrm{~kg}$ (242 pounds) - of the animals he harvested from SRS.

An additional deer meat consumption pathway considered was for a hypothetical offsite individual whose entire intake of meat during the year was deer meat. It was assumed that this individual harvested deer that had resided on SRS, but then moved off site. The estimated dose was based on the maximum annual meat consumption rate for an adult of $81 \mathrm{~kg}$ per year [Hamby, 1991].

Based on these low-probability assumptions and on the gross average concentration of cesium-137

$(3,85 \mathrm{pCi} / \mathrm{g})$ in deer harvested from SRS during 1998 , the potential maximum dose from this pathway was estimated at $12 \mathrm{mrem}(0.12 \mathrm{mSv})$. An average $80-\mathrm{km}$ background cesium- 137 concentration of $1 \mathrm{pCi} / \mathrm{g}$ is subtracted from the onsite gross average concentration before calculating the dose. The $80-\mathrm{km}$ background concentration is based on previous studies performed at SRS (table 33, SRS

Environmental Data for 1994, WSRC-TR-95-077).

As shown in table 7-5, the 1998 offsite hunter potential dose is 12 percent of DOE's 100 -mrem all-pathway dose standard. This dose was 14 percent less than the 1997 dose of 14 mrem (0.14 mSv).

\section{Fish Consumption Pathway}

For 1998, analyses were conducted of fish taken from the mouths of five SRS streams, and the subsequent estimated doses from the maximum consumption of $19 \mathrm{~kg}$ (42 pounds) per year [Hamby, 1991] of these fish were determined (table 51, SRS Environmental Data for 1998). Fish flesh was composited by species for each location and analyzed for tritium, strontium-90, cesium-137, plutonium-238, and plutonium-239.

As shown in table 7-5, the maximum potential dose from this pathway was estimated at $1.6 \mathrm{mrem}$ $(0.016 \mathrm{mSv})$ from the consumption of bass collected 
at the mouth of Steel Creek. This hypothetical dose is based on the low-probability scenario that, during 1998, a fisherman consumed $19 \mathrm{~kg}$ of bass caught exclusively from the mouth of Steel Creek. More than 97 percent of this potential dose was from cesium-137. Again, some fraction of this cesium-137 is from worldwide fallout and from neighboring Vogtle Electric Generating Plant effluent discharges; however, that amount is difficult to determine and is not subtracted from the total.

\section{Potential Risk from Consumption of SRS Creek Mouth Fish}

During 1991 and 1992, in response to a U.S. House of Representative Appropriations Committee request for a plan to evaluate risk to the public from fish collected from the Savannah River, SRS developed-in conjunction with EPA, the Georgia Department of Natural Resources (GDNR), and the South Carolina Department of Health and Environmental Control (SCDHEC)-and implemented the Westinghouse Savannah River Company/Environmental Monitoring Section Fish Monitoring Plan [SRS EM Program, 1996]. Part of the reporting requirements of this plan are to perform an assessment of radiological risk from the consumption of Savannah River fish, and to summarize the results in the annual SRS Environmental Report. The following sections discuss the potential radiological risks from the consumption of Savannah River fish, using SRS-published data from 1993 through 1998. Potential radiological risks are determined using both the ICRP-60 [ICRP, 1990] and the EPA [EPA, 1991] methods.

Exposure Scenario In EPA's risk assessment guidance document [EPA, 1991], two fish consumption pathways are considered-the recreational fisherman scenario and the subsistence fisherman scenario. Because of SRS's relatively remote location, the recreational fisherman scenario-as opposed to the subsistence fisherman scenario-is considered the more reasonable exposure scenario and is used in this assessment.

It is assumed that a recreational fisherman fishes for a single species of fish-either panfish, such as bream; predators, such as bass; or bottom dwellers, such as catfish-from the mouth of the worst-case SRS stream. Access to upstream portions of SRS streams is prohibited by postings, fencing (where possible), and periodic patrols.

Per EPA guidance [EPA, 1991], the maximum consumption rate that should be used for determining risk to the recreational fisherman is 19 kilograms (42 pounds) per year. This is the same as the consumption rate used by SRS for demonstrating maximally exposed individual dose compliance [Hamby, 1991].

The EPA guidance document requires that critical subpopulations and fish species be considered in risk assessments. Currently, there are no known sensitive subpopulations (e.g., Native Americans) in the immediate SRS region who are known to regularly consume whole fish (edible and nonedible portions) as part of their typical diet. Also, there are no known species of fish, such as smelt, in the SRS region of the Savannah River that are commonly eaten whole. Therefore, it is reasonably assumed that the recreational fisherman consumes only the edible (fillet only) portion of the fish caught.

Risk Factors For the EPA method, estimates of potential risk are calculated directly by multiplying the amount of each radionuclide ingested by the appropriate risk (slope) factors provided in EPA's Health Effects Assessment Summary Tables (HEAST) [EPA, 1996]. The HEAST ingestion slope factors are best estimates of potential, age-averaged, lifetime excess cancer incidence (fatal and nonfatal) risk per unit of activity ingested.

For the ICRP-60 method, estimates of potential risk are determined first by calculating a radiation dose attributable to the amount of radionuclides ingested and then multiplying that dose by the ICRP- 60 coefficient of risk of severe detriment of 7.3E-07 per mrem [ICRP, 1990]. Stated another way, if a group of $10,000,000$ people each received a radiation dose of $1 \mathrm{mrem}$, during their collective lifetimes there would theoretically be 7.3 additional severe detrimental incidences (fatal/nonfatal cancer or severe hereditary effects), which is small compared to the $2,000,000$ or more expected fatal cancer incidences from other causes during their lifetimes [BEIR V, 1990].

The ICRP-60 risk coefficient includes factors for

- fatal cancers (5.0E-07 per mrem)

- nonfatal cancers (1.0E-07 per mrem)

- hereditary effects (1.3E-07 per mrem)

It should be noted that all radiological risk factors are based on observed and documented health effects to actual people who have received high doses (more than 100,000 mrem) of radiation, such as the Japanese atomic bomb survivors. Radiological risks at low doses (less than 10,000 mrem) are theoretical and are estimated by extrapolating the observed health effects at high doses to the low-dose region by using a linear, no-threshold model. However, cancer and other health effects have not been observed consistently at low radiation doses because the health 
Table 7-6

Potential Lifetime Risks from the Consumption of Savannah River Fish Compared to Dose Standards (1993-1998)

\begin{tabular}{|c|c|c|c|}
\hline & $\begin{array}{l}\text { Committed } \\
\text { Dose (mrem) }\end{array}$ & $\begin{array}{l}\text { ICRP-60 } \\
\text { Risk Method }\end{array}$ & $\begin{array}{l}\text { EPA/CERCLA } \\
\text { Risk Method }\end{array}$ \\
\hline \multicolumn{4}{|c|}{1998 Savannah River Fish } \\
\hline 1-Year Exposure & 1.6 & $1.2 E-06$ & $1.0 \mathrm{E}-06$ \\
\hline 30-Year Exposure & 48 & $3.5 E-05$ & $3.0 \mathrm{E}-05$ \\
\hline 50-Year Exposure & 80 & $5.8 E-05$ & $5.0 E-05$ \\
\hline \multicolumn{4}{|c|}{1997 Savannah River Fish } \\
\hline 1-Year Exposure & 0.65 & $4.8 \mathrm{E}-07$ & $4.1 E-07$ \\
\hline 30-Year Exposure & 20 & $1.4 E-05$ & $1.2 E-05$ \\
\hline 50-Year Exposure & 33 & $2.4 E-05$ & $2.1 E-05$ \\
\hline \multicolumn{4}{|c|}{1996 Savannah River Fish } \\
\hline 1-Year Exposure & 1.7 & $1.2 E-06$ & $1.1 E-06$ \\
\hline 30-Year Exposure & 51 & 3.7E-05 & 3.3E-05 \\
\hline 50-Year Exposure & 85 & $6.2 E-05$ & $5.5 E-05$ \\
\hline \multicolumn{4}{|c|}{1995 Savannah River Fish } \\
\hline 1-Year Exposure & 1.2 & $8.8 E-07$ & $7.4 E-07$ \\
\hline 30-Year Exposure & 36 & $2.6 E-05$ & $2.2 E-05$ \\
\hline 50-Year Exposure & 60 & $4.4 \mathrm{E}-05$ & 3.7E-05 \\
\hline \multicolumn{4}{|c|}{1994 Savannah River Fish } \\
\hline 1-Year Exposure & 1.3 & $9.5 E-07$ & 8.2E-07 \\
\hline 30-Year Exposure & 39 & $2.8 E-05$ & 2.5E-05 \\
\hline 50-Year Exposure & 65 & $4.7 E-05$ & 4.1E-05 \\
\hline \multicolumn{4}{|c|}{1993 Savannah River Fish } \\
\hline 1-Year Exposure & 1.3 & $9.5 E-07$ & $7.9 E-07$ \\
\hline 30-Year Exposure & 39 & $2.8 \mathrm{E}-05$ & $2.4 E-05$ \\
\hline 50-Year Exposure & 65 & 4.7E-05 & $4.0 \mathrm{E}-05$ \\
\hline \multicolumn{4}{|l|}{ Dose Standard } \\
\hline \multicolumn{4}{|c|}{ 100-mrem/year All Pathway } \\
\hline 1-Year Exposure & 100 & $7.3 E-05$ & $6.3 \mathrm{E}-05$ \\
\hline 30-Year Exposure & 3,000 & $2.2 E-03$ & $1.9 E-03$ \\
\hline 50-Year Exposure & 5,000 & $3.7 E-03$ & $3.2 E-03$ \\
\hline
\end{tabular}

risks either do not exist or are so low that they are undetectable by current scientific methods.

Exposure Duration According to EPA guidance, the upper bound value of 30 years can be used for exposure duration when calculating reasonable maximum residential exposures. This assessment compares the potential risks of exposure durations of 1 year, 30 years, and 50 years. The 30 -year and 50-year exposure duration risks are simply 30 times and 50 times the 1-year exposure duration risk, respectively.

Risk Comparisons The maximum potential radiation doses and lifetime risks from the consumption of SRS creek mouth fish for 1-year, 30-year, and 50-year exposure durations are shown in table 7-6 and are compared to the radiation risks associated with the DOE Order 5400.5 all-pathway dose standard of $100 \mathrm{mrem}(1.0 \mathrm{mSv})$ per year. 


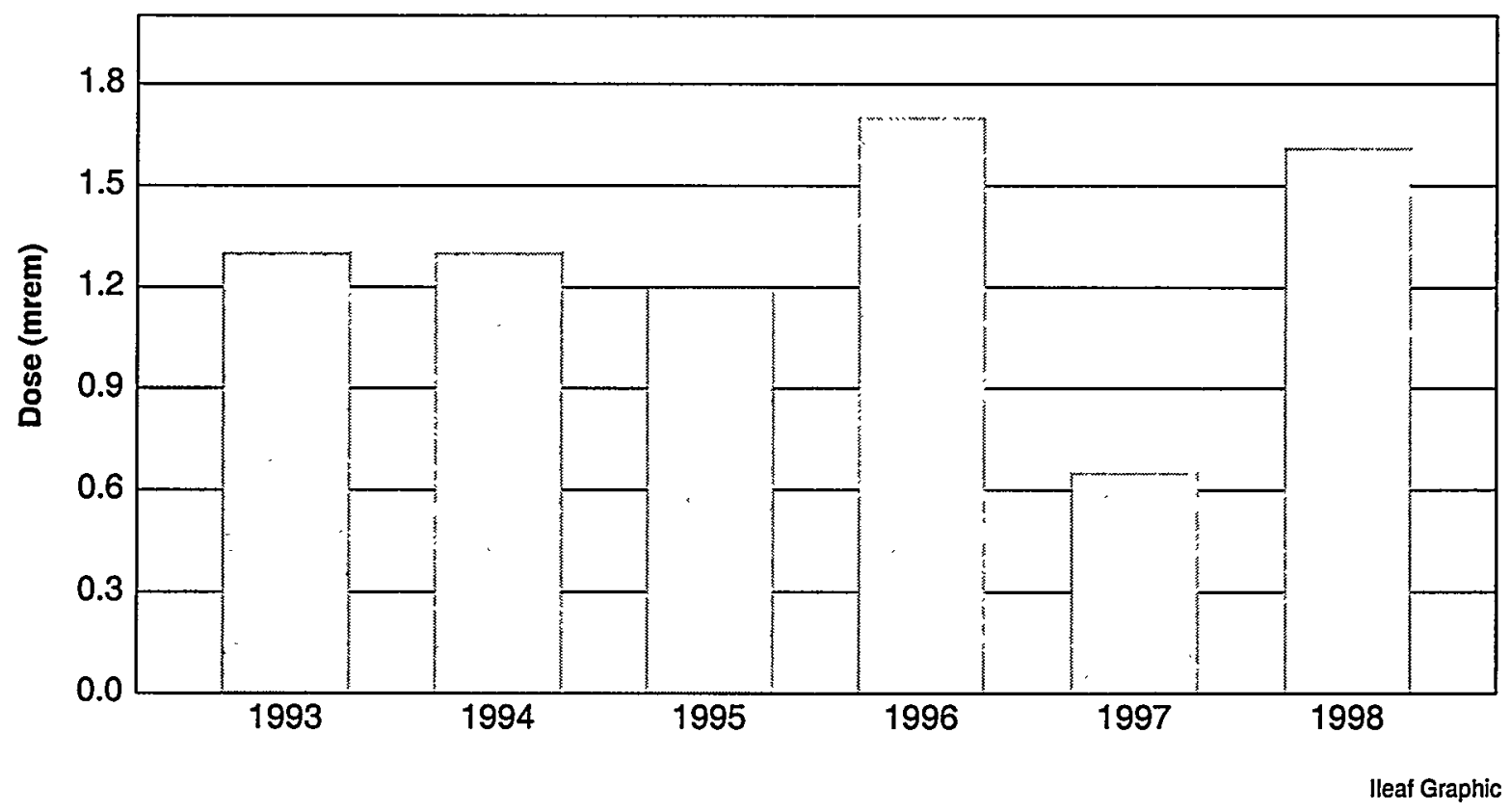

Figure 7-7 Annual Potential Radiation Doses from Consumption of Savannah River Fish (1993-1998)

For each year, the maximum recreational fisherman dose was caused by the consumption of bass collected at the mouth of Steel Creek. More than 97 percent of the doses are attributable to cesium-137.

Figure 7-7 shows a 5-year history of the annual potential radiation doses from consumption of Savannah River fish. As yet, no apparent trends can be discerned from the data. This is because there is large variability in the annual cesium-137 concentrations measured in fish from the same location due to differences in (1) the size of the fish collected each year, (2) their mobility and location within the stream mouth from which they are collected, and (3) the time of year they are collected.

Also, it should be noted that most of the cesium-137 that exists in SRS stream watersheds is legacy contamination left from relatively large liquid releases that occurred during the early years of operations at SRS (1954-1963) and is not from current direct operational releases [Carlton et al., 1994]. Therefore, there is large annual variability in the amount of cesium- 137 available in the water and sediments at the site stream mouths; this is caused by annual changes in stream flow rates (turbulence) and water chemistry.

As indicated in table 7-6, the 50-year maximum potential lifetime risks from consumption of SRS creek mouth fish range between $2.4 \mathrm{E}-05$ and $6.2 \mathrm{E}-05$, which are below the 50-year risk associated with the 100-mrem-per-year dose standard.
According to EPA practice, if a potential risk is calculated to be less than 1.0E-06 (i.e., one additional case of cancer over what would be expected in a group of $1,000,000$ people), then the risk is considered minimal and the corresponding contaminant concentrations are considered negligible. If a calculated risk is more than 1.0E-04 (one additional case of cancer in a population of 10,000 ), then some form of corrective action or remediation usually is required. However, if a calculated risk falls between $1.0 \mathrm{E}-04$ and $1.0 \mathrm{E}-06$, which is the case with the maximum potential lifetime risks from the consumption of Savannah River fish, then the risks are considered acceptable if they are kept as low as reasonably achievable (ALARA).

At SRS, the following programs are in place to ensure that the potential risk from site radioactive liquid effluents (and, therefore, from consumption of Savannah River fish) are kept ALARA:

- radiological liquid effluent monitoring program (chapter 5)

- radiological environmental surveillance program (chapter 6)

- environmental ALARA program [SRS EM Program, 1996]

\section{Dose to Aquatic Animal Organisms}

DOE Order 5400.5 establishes an interim dose standard for protection of native aquatic animal organisms. The absorbed dose limit to these 
organisms is 1 rad per day ( 0.01 Gy per day) from exposure to radioactive material in liquid effluents released to natural waterways.

Hypothetical doses to aquatic biota in SRS streams are calculated annually to demonstrate compliance with this 1-rad-per-day (0.01-Gy-per-day) dose standard. Upper-limit doses are calculated with measured radioactivity transport and minimum flow rates for each surface stream. Flow rates are chosen to maximize the biota dose. Source terms (stream transport) are provided by the site's Environmental Monitoring Section (table 52. SRS Environmental Data for 1998).

The CRITR computer code [Soldat et al., 1974], incorporated as part of the LADTAPII code, calculates internal and external doses to aquatic biota and to higher trophic levels that depend on aquatic biota for food. The CRITR Code is one of the three aquatic biota dose codes recommended by DOE [DOE, 1991]. External doses are calculated with the same external dose factors used for man [DOE, 1988]. Internal doses are based on the physical size of the biota (effective radius) and on effective energies provided for each radionuclide for each radius. The maximum dose to biota was estimated at $0.029 \mathrm{rad}$ per day ( 0.00029 Gy per day), which occurred in ducks in Four Mile Creek. This is 2.9 percent of the 1-rad-per-day (0.01-mGy-per-day) DOE dose limit.

\section{Radiological Assessment Program}

The preparation of documents describing the effects of SRS operations on the environment began in 1988. The format chosen was a separate document for each major radionuclide or group of similar radionuclides. The documents describe the operating history of the site with respect to the production, storage, and release of each radionuclide. The transport of the radionuclide in air, surface water, and groundwater is explained, and a calculation of the dose estimate to individuals and the population surrounding SRS is presented. As of December 31, 1998, the following documents had been published ${ }^{\mathrm{a}}$ :

- Assessment of Tritium in the Savannah River Site Environment, WSRC-TR-93-214

- Cesium in the Savannah River Site Environment, WSRC-RP-92-250

- Uranium in the Savannah River Site Environment, WSRC-RP-92-315

- Radioiodine in the Savannah River Site Environment, WSRC-RP-90-424-2

- Assessment of Radiocarbon in the Savannah River Site Environment, WSRC-TR-93-215

- Assessment of Technetium in the Savannah River Site Environment, WSRC-TR-93-217

- Assessment of Strontium in the Savannah River Site Environment, WSRC-RP-92-984

- Plutonium in the Savannah River Site Environment, WSRC-RP-92-879, Rev. 1

- Assessment of Mercury in the Savannah River Site Environment, WSRC-TR-94-0218ET

- Assessment of Noble Gases in the Savannah River Site Environment, WSRC-TR-95-0219

- Assessment of Activation Products in the Savannah River Site Environment, WSRC-TR-95-0422

- Assessment of Selected Fission Products in the SRS Environment, WSRC-TR-96-0220

- Assessment of Neptunium, Americium, and Curium in the Savannah River Site Environment, WSRC-TR-97-00266

- Assessment of Radionuclides in the Savannah River Site Environment-Summary, WSRC-TR-98-00162

No additional documents are scheduled for publication in 1999, although some revisions may be issued.

a Copies of these documents can be obtained from the National Technical Information Service, U.S. Department of Commerce, 5285 Port Royal Road, Springfield, VA 22161. 


\title{
Nonradiological Effluent Monitoring
}

To Read About... See Page...

Airborne Emissions ............... 131

Liquid Discharges ................ 134

History of NPDES Exceedances ........ 138

1998 NPDES Exceedances ........... 139

\author{
Carl Cook, Larry Eldridge, \\ and Stuart Stinson \\ Environmental Protection Department
}

\section{Highlights}

- At SRS, there are 208 permitted/exempted nonradiological air emission sources, 157 of which were in operation to some capacity in 1998. Thirty-seven of the SRS permitted sources are permitted for toxic air pollutants; 18 of these were operated during the year.

- SRS conducts no onsite monitoring for ambient air quality; however, the site is required to show compliance with various air quality standards. This is accomplished by using air dispersion modeling techniques. Modeling analysis for new sources permitted at SRS in 1998 showed that the site was in compliance with all applicable ambient air quality standards.

- SRS monitors nonradioactive releases to surface water through NPDES. The site discharged water into site streams and the Savannah River under four NPDES permits in 1998.

- Thirty-two of the site's 33 permitted outfalls discharged; the other was not in service. Results from 42 of the 5,790 discharge-sample analyses exceeded limits because of process upsets; however, the site was able to achieve a 99.3-percent compliance rate. DOE has mandated a 98-percent compliance rate.

$\mathrm{N}$ ONRADIOACTIVE air emissions originating at Savannah River Site (SRS) facilities are monitored at their points of discharge by direct measurement, sample extraction and measurement, or process knowledge. Air monitoring is used to determine whether all emissions and ambient concentrations are within applicable regulatory standards.

Nonradiological liquid effluent monitoring encompasses sampling and analysis and is performed by the Environmental Protection Department's Environmental Monitoring Section (EMS) and the Savannah River Technology Center.

A complete description of EMS sampling and analytical procedures used for nonradiological monitoring can be found in sections 1101-1111 (SRS EM Program) of the Savannah River Site Environmental Monitoring Section Plans and Procedures, WSRC-3Q1-2, Volume 1. A summary of data results is presented in this chapter; more complete data can be found in SRS Environmental Data for 1998 (WSRC-TR-98-00314).

\section{Airborne Emissions}

The South Carolina Department of Health and Environmental Control (SCDHEC) regulates nonradioactive air emissions-both criteria pollutants and toxic air pollutants-from SRS sources. Each source of air emissions is permitted or exempted by SCDHEC, with specific limitations identified. The bases for the limitations are outlined in various South Carolina and federal air pollution control regulations and standards. Many of the applicable standards are source dependent, i.e., applicable to certain types of industry, processes, or equipment. However, some standards govern all sources for criteria and toxic air pollutants and ambient air quality. Air pollution control regulations and standards applicable to SRS sources are discussed briefly in appendix $A$, "Applicable Guidelines, Standards, and Regulations." The SCDHEC air standards for toxic air pollutants are listed in appendix C, "Standard No. 8 Toxic Air Pollutants."

At SRS, there are 208 permitted/exempted nonradiological air emission sources, 157 of which were in operation in some capacity during. 1998 . The 
remaining 51 sources either were being maintained in a "cold standby" status or were under construction.

\section{Description of Monitoring Program}

Major nonradiological emissions of concern from stacks at SRS facilities include sulfur dioxide, carbon monoxide, oxides of nitrogen, particulate matter smaller than 10 microns, volatile organic compounds, and toxic air pollutants. Facilities that have such emissions include diesel engine-powered equipment, package No. 2 fuel oil steam generators, powerhouse coal-fired boilers, the Defense Waste Processing Facility, the in-tank precipitation process, groundwater air strippers, and various other process facilities. Emissions from SRS sources are determined during an annual emissions inventory from calculations using source operating parameters such as fuel oil consumption rates, total hours of operation, and the emission factors provided in the U.S. Environmental Protection Agency (EPA) "Compilation of Air Pollution Emission Factors," AP-42. The calculation for boiler sulfur dioxide emissions also uses the average sulfur content of the coal and assumes 100-percent liberation of sulfur and 100-percent conversion to sulfur dioxide. Most of the processes at SRS are unique sources requiring nonstandard, complex calculations that use process chemical or material throughputs, hours of operation, chemical properties, etc., to determine actual emissions. In addition to the annual emissions inventory, compliance with various standards is determined in several ways, as follows:

At the SRS powerhouses, stack compliance tests are performed every 2 years for each boiler by airborne emission specialists under contract to SRS. The tests include

- sampling of the boiler exhaust gases to determine particulate emission rates and carbon dioxide and oxygen concentrations

- laboratory analysis of coal for sulfur content, ash content, moisture content, and British Thermal Unit (BTU) output

Sulfur content and BTU output are used to calculate sulfur dioxide emissions. SCDHEC also conducts visible-emissions observations during the tests to verify compliance with opacity standards. The day-to-day control of particulate matter smaller than 10 microns is demonstrated by opacity meters in all SRS powerhouse stacks.

For the package steam generating boilers in K-Area and for two portable units, compliance with sulfur dioxide standards is determined by analysis of the fuel oil purchased from the offsite vendor. The percent of sulfur in the fuel oil must be below 0.5 and is reported to SCDHEC each quarter. Compliance with particulate emission standards initially was demonstrated by mass-balance calculations rather than stack emission tests.

Compliance by SRS diesel engines and other process stacks is determined during annual compliance inspections by the local SCDHEC district air manager. These inspections include a review of operating parameters, hours of operation recorded in logbooks, an examination of continuous-emission monitors (where required for process or boiler stacks), and a visible-emissions observation for opacity.

Compliance by all toxic air pollutant and criteria pollutant sources also is determined by using EPA-approved air dispersion models. Air dispersion modeling is extremely conservative unless refined models are used. The Industrial Source Complex Version No. 3 model was used to predict maximum ground-level concentrations occurring at or beyond the site boundary for new sources permitted during 1998. Some site sources of toxic air pollutants also are required to be stack tested every 2 years.

\section{Monitoring Results}

As noted earlier, emissions are calculated each year as part of an annual emissions inventory. In 1998, operating data were compiled and emissions were calculated for 1997 operations for all site air emission sources (table 53, SRS Environmental Data for 1998). Because this process, which begins in January, requires up to 6 months to complete, this report will provide a more comprehensive examination of total 1997 emissions, with only limited discussion of available 1998 monitoring results. Actual emissions for 1998 will be compiled and reported in depth in the SRS Environmental Report for 1999.

Two power plants with five coal-fired boilers are operated by Westinghouse Savannah River Company (WSRC) at SRS. These boilers are used to generate steam, which is used for facility heating systems and, where required, as process steam. The location, number of boilers, and capacity of each boiler for these plants are listed in table 8-1. The A-Area and $\mathrm{H}$-Area boilers are overfeed stoker fed and use coal as their only fuel. Stack testing was conducted during 1998 for both boilers in A-Area and for the No. 1 and No. 3 boilers in H-Area. The No. 2 boiler in H-Area has been placed in cold standby status and will be 
Table 8-1

SRS Power Plant Boiler Capacities

\begin{tabular}{lcc}
\hline Location & $\begin{array}{l}\text { Number of } \\
\text { Boilers }\end{array}$ & $\begin{array}{c}\text { Capacity } \\
\text { (BTU/hr) }\end{array}$ \\
A-Area & 2 & $71.7 \mathrm{E}+06$ \\
H-Area & 3 & $71.1 \mathrm{E}+06$ \\
\hline
\end{tabular}

tested upon being restarted. Results of the boiler stack tests conducted during 1998 are shown in table 8-2.

SRS also has four package steam generating boilers fired by No. 2 fuel oil. The steam from these boilers is used primarily to heat buildings during cold weather, but also for process steam. The location, number of boilers, and capacity of each boiler are shown in table 8-3. During 1998, only the 76.8- and 38.0-million BTU/hr boilers were operated. The percent of sulfur in the fuel oil burned during the year was certified by the vendor to meet the requirements of the permit.

At SRS, 127 permitted and exempted sources, both portable and stationary, are powered by internal combustion diesel engines. These sources include portable air compressors, diesel generators, emergency cooling water pumps, and fire water pumps ranging in size from 15 to 205 kilowatts for generators and 20 to 52 horsepower for air compressor and pump engines. Fuel oil consumption for the diesel engines operated in 1997 was 589,100 gallons. Total fuel consumption for 1998 will be included in the report for calendar year 1999.

Another significant source of criteria pollutant emissions at SRS is the burning of forestry areas

Table 8-2

Boiler Stack Test Results (A-Area, H-Area)

\begin{tabular}{|c|c|c|c|}
\hline \multirow[t]{2}{*}{ Boiler } & \multirow[t]{2}{*}{ Pollutant } & \multicolumn{2}{|c|}{ Emission Rates } \\
\hline & & $\mathrm{lb} / 10^{6} \mathrm{BTU}$ & $\mathrm{lb} / \mathrm{hr}$ \\
\hline A\#1 & $\begin{array}{l}\text { Particulates } \\
\text { Sulfur dioxide }\end{array}$ & $\begin{array}{l}0.60 \\
1.30\end{array}$ & $\begin{array}{l}51.93 \\
\mathrm{NC}^{\mathrm{a}}\end{array}$ \\
\hline$A \# 2$ & $\begin{array}{l}\text { Particulates } \\
\text { Sulfur dioxide }\end{array}$ & $\begin{array}{l}0.27 \\
0.99\end{array}$ & $\begin{array}{l}71.13 \\
\mathrm{NCa}^{\mathrm{a}}\end{array}$ \\
\hline$H \# 1$ & $\begin{array}{l}\text { Particulates } \\
\text { Sulfur dioxide }\end{array}$ & $\begin{array}{l}0.31 \\
1.19\end{array}$ & $\begin{array}{l}23.60 \\
\mathrm{NC}^{\mathrm{a}}\end{array}$ \\
\hline $\mathrm{H} \# 3$ & $\begin{array}{l}\text { Particulates } \\
\text { Sulfur Dioxide }\end{array}$ & $\begin{array}{l}0.40 \\
1.13\end{array}$ & $\begin{array}{l}34.20 \\
\mathrm{NC}^{\mathrm{a}}\end{array}$ \\
\hline $\mathrm{No}$ & ated & & \\
\hline
\end{tabular}

Table 8-3

SRS Package Steam Boiler Capacities

\begin{tabular}{lcl}
\hline Location & $\begin{array}{c}\text { Number of } \\
\text { Boilers }\end{array}$ & $\begin{array}{l}\text { Capacity } \\
\text { (BTU/hr) }\end{array}$ \\
K-Area & 1 & $76.8 \mathrm{E}+06$ \\
K-Area & 1 & $38.0 \mathrm{E}+06$ \\
Portable & 2 & $17.0 \mathrm{E}+06$ \\
\hline
\end{tabular}

across the site. The Savannah River Forest Station (SRFS), a unit of the U.S. Department of Agriculture Forest Service, periodically conducts controlled burning of vegetation and undergrowth as a means of preventing uncontrolled forest fires. During 1997, SRFS personnel burned a total of 19,753 acres across the site.

Other sources of criteria pollutants at SRS are too numerous to discuss here by type. Table $8-4$ provides the 1997 atmospheric emissions results for all SRS sources, as determined by the air emissions inventory conducted in 1998. All calculated emissions were within applicable SCDHEC standards and permit limitations during 1997.

Thirty-seven of the SRS permitted sources are permitted for toxic air pollutants; 18 of these were operated during 1998. Several of the toxic air pollutant sources-specifically, the catalytic oxidation units-are required to be stack tested following startup to verify initial compliance with their respective permitted emission rates. Subsequent test requirements will be specified in their respective operating permits when the permits are issued. No operating permits were issued for these units in 1998, no additional testing requirements were identified, and no sources of toxic air pollutants were tested. As

\section{Table 8-4 \\ 1997 Criteria Pollutant Air Emissions}

$\begin{array}{lr}\text { Pollutant Name } & \begin{array}{r}\text { Actual Emissions } \\ \text { (Tons/Year) }\end{array} \\ \text { Sulfur dioxide (SOX) } & 4.85 \mathrm{E}+02 \\ \text { Total suspended particulates } & 1.98 \mathrm{E}+03 \\ \mathrm{PM}_{10} \text { (particulate matter 10 microns) } & 1.54 \mathrm{E}+03 \\ \text { Carbon monoxide } & 5.20 \mathrm{E}+03 \\ \text { Ozone (volatile organic compounds) } & 2.88 \mathrm{E}+02 \\ \text { Gaseous fluorides (as hydrogen fluoride) } & 1.96 \mathrm{E}-01 \\ \text { Nitrogen dioxide (NOX) } & 4.33 \mathrm{E}+02 \\ \text { Lead } & 1.88 \mathrm{E}-02\end{array}$

a From all SRS sources (permitted and nonpermitted) 
indicated in the 1997 environmental report, the Consolidated Incineration Facility was stack tested in 1997; however, a final review by SCDHEC was not completed in time for inclusion in the report. SCDHEC completed its review of the Consolidated Incineration Facility stack test results in 1998 and has determined that the facility was being operated in compliance with all permit conditions and air emission rates.

Total toxic air pollutant emissions at SRS are determined annually in tons per year for each pollutant (table 53, SRS Environmental Data for 1998). It should be noted that some toxic air pollutants (e.g., benzene) regulated by SCDHEC also are, by nature, volatile organic compounds (VOCs). As such, the total for VOCs in table 8-4 includes toxic air pollutant emissions.

\section{Ambient Air Quality}

Under existing regulations, SRS is not required to conduct onsite monitoring for ambient air quality; however, the site is required to show compliance with various air quality standards. To accomplish this, air dispersion modeling was conducted during 1998 for new emission sources as part of the sources' construction permitting process. The modeling analysis showed that SRS air emission sources were in compliance with applicable regulations. Also in 1998 , SRS conducted a complete modeling analysis using 1996 emissions data and new source information to

- show compliance with SCDHEC Air Pollution Control Regulation 61-62.5, Standard No. 2 (for criteria pollutants) and Standard No. 8 (for toxic air pollutants)

- establish emission rates for the SRS Title V (Part 70) operating permit

South Carolina and Georgia continue to monitor ambient air quality near SRS as part of the network associated with the Clean Air Act. Resulting data are available to the public through (1) the South Carolina Bureau of Air Quality and (2) the Georgia Department of Natural Resources, Environmental Protection Division, Air Protection Branch.

\section{Liquid Discharges}

\section{Description of Monitoring Program}

SRS monitors nonradioactive releases to surface waters through the National Pollutant Discharge Elimination System (NPDES). As required by EPA and SCDHEC, SRS has NPDES permits for discharges to the waters of the United States and South Carolina. These permits require that SRS test water discharged from the site for pollutants. Also mandated are specific sites to be monitored, parameters to be tested, and monitoring frequency - as well as analytical, reporting, and collection methods. Detailed requirements for each permitted discharge point-including parameters sampled for, permit limits for each parameter, sampling frequency, and method for collecting each sample - can be found in the individual permits, which are available to the public through SCDHEC's Freedom of Information office at (803) 734-5376.

In 1998, SRS discharged water into site streams and the Savannah River under four NPDES permits: one for industrial wastewater (SC0000175), one for general utility water discharges (SCG250162), and two for stormwater runoff-SCR00000 (industrial discharge) and SCR10000 (construction discharge). A fifth permit, ND0072125, is a "no discharge" water pollution control land application permit that regulates sludge sampling at onsite sanitary wastewater treatment facilities.

Permit SC0000175 regulated 33 industrial wastewater outfalls in 1998 (figure 8-1). Effective January 1, the permit was modified, with the removal of outfalls $\mathrm{K}-08, \mathrm{P}-13, \mathrm{P}-14$, and $\mathrm{P}-19$ and the addition of outfall X-19. Permit SCG250162 requires sampling at only one utility water discharge location. That location, outfall 001 , discharged only once during 1998. Permits SCR000000 and SCR 100000 were issued January 15 and became effective February 1. Permit SCR000000 regulated 46 stormwater outfalls sorted into 11 groups. Samples were obtained from 13 locations in 1998 to provide representative sampling of all the groups. Permit SCR 100000 does not require sampling unless requested by SCDHEC to address specific discharge issues at a given construction site; SCDHEC did not request such sampling in 1998.

NPDES samples are preserved in the field according to 40 CFR 136, the federal document that lists specific sample collection, preservation, and analytical methods acceptable for the type of pollutant to be analyzed. Chain-of-custody procedures are followed after collection and during transport to the analytical laboratory. The samples then are accepted by the laboratory and analyzed according to procedures listed in 40 CFR 136 for the parameters required by the permit.

The effectiveness of the NPDES monitoring program is documented by a surveillance program involving chemical and biological evaluation of the waters to which effluents have been discharged. More monitoring information can be found in chapters 9 , 


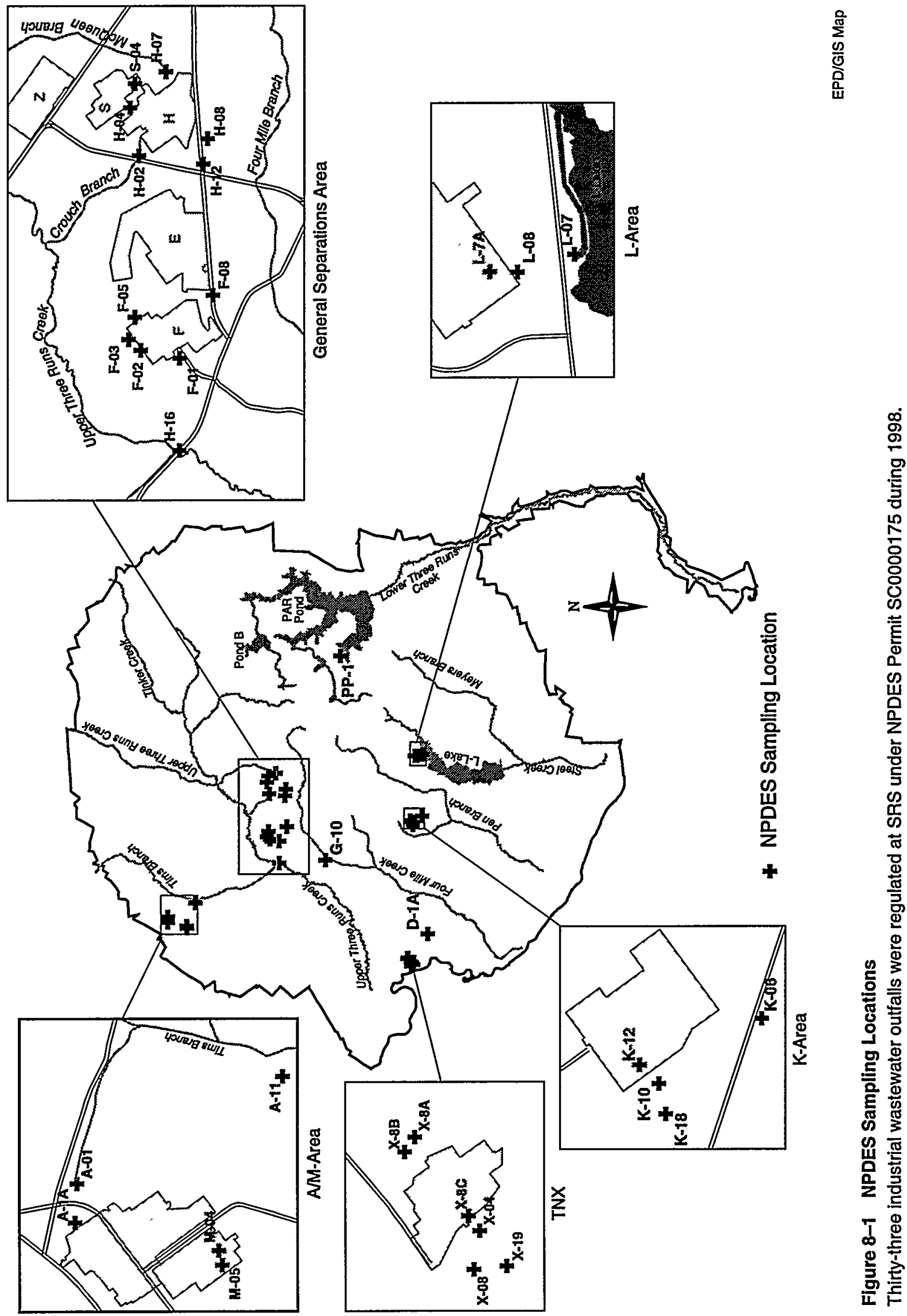


An EMS sampling technician obtains a water sample from one of SRS's 33 NPDES discharge locations. Within 15 minutes of sampling, the technician will add required preservatives (before the sample is sent to the laboratory). The site's NPDES permit specifies analytical parameters, based on discharge potential, at each outfall.

Al Mamatey Photo (98X03269.11)

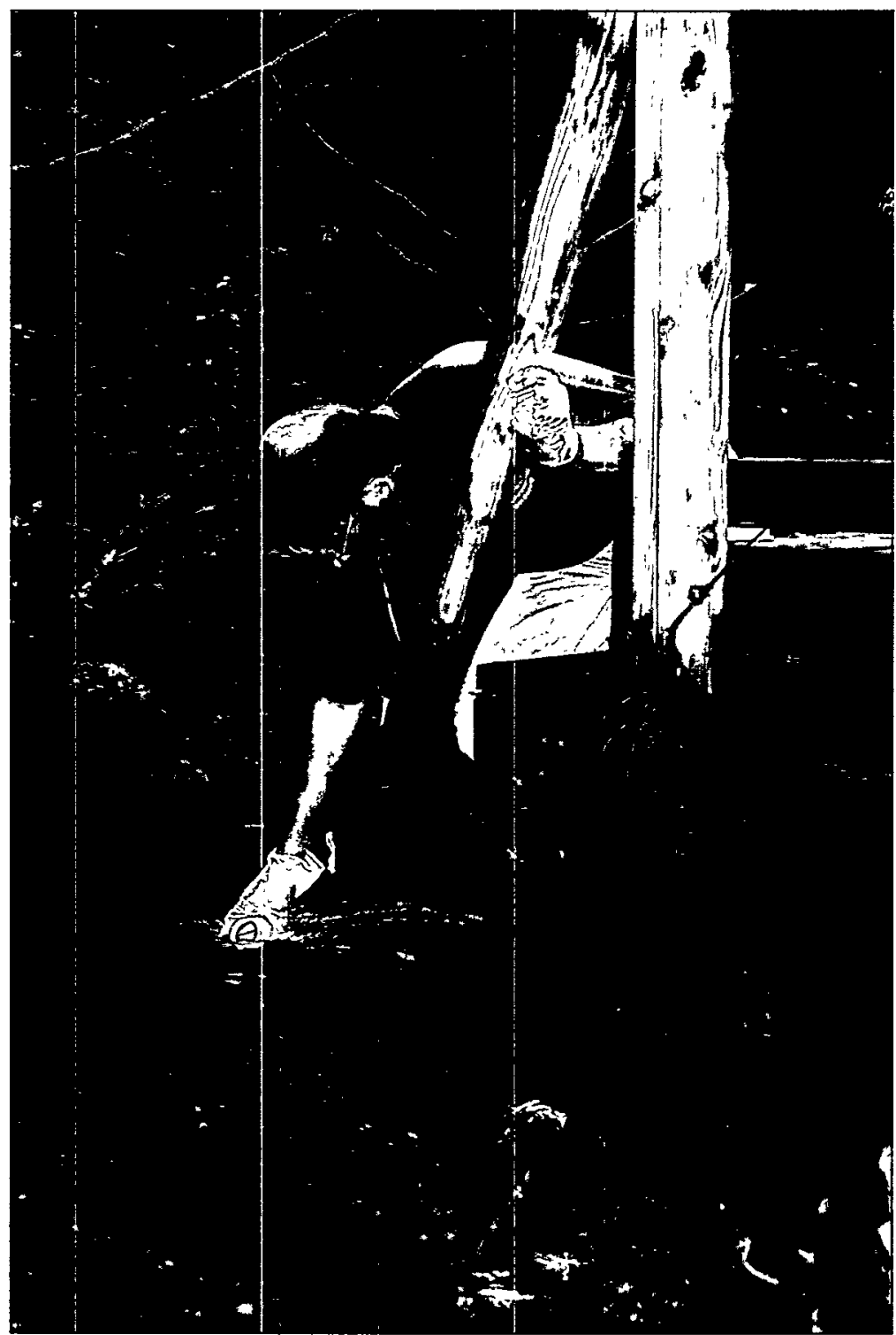

"Nonradiological Environmental Surveillance," and 12, "Special Surveys and Projects."

\section{Monitoring Results}

SRS reports analytical results to SCDHEC through a monthly discharge monitoring report, which includes an explanation concerning any analytical measurements outside permit limits and a summary of all analyses performed at each permitted outfall. Complete results from 1998 NPDES industrial discharges (permit SC0000175) can be found in tables 54 and 55, SRS Environmental Data for 1998.

Of the 33 outfalls permitted by SC0000175 in 1998, 32 discharged and one was not in service. Results from 42 of the 5,790 discharge sample analyses performed during the year exceeded permit limits because of process upsets, such as the sanitary system at the $\mathrm{D}-1 \mathrm{~A}$ outfall being inundated by heavy rains.

The 1998 exceedance total of 42 represents a significant increase from previous years. Repeat exceedances at outfalls D-1A, H-12, G-10, and A-11 accounted for 29 of the 42 exceedances. Excessive flow, caused by ongoing heavy rainfall that caused groundwater levels to rise significantly at the D-1A outfall, was responsible for 18 of the exceedances. D-Area is low lying, and an older portion of the collection system became submerged because of the raised groundwater levels. This part of the system, which took on a large amount of infiltration with each additional rain event, 
subsequently was decommissioned. Outfall $\mathrm{H}-12$ had three exceedances for $\mathrm{pH}$ and three for copper. The $\mathrm{pH}$ exceedances were due to raw well water being pumped to the outfall. The well water was a drinking water source prior to installation of a central drinking water system and still is used as makeup water for various processes. A proposed solution, awaiting SCDHEC approval at the end of 1998, was to combine well water with retention basin water. The source of the copper exceedances was unknown but under active investigation and the end of 1998. Outfall G-10, the Central Sanitary Facility discharge site, had two exceedances for fecal coliform. This has been a recurring problem but usually is corrected by cleaning the ultraviolet lights, which kill organisms in the water. A contributing factor is suspected to be the growth of a colonial Bryozoan in the clarifier and ultraviolet channel; the Bryozoan provides surface areas where fecal coliform organisms can escape the ultraviolet lights and regenerate prior to discharge. Outfall A-11 failed in October, November, and December for chronic toxicity, which had been identified previously. An ongoing toxicity identification evaluation has determined the cause to be metals in the wastewater, but further evaluation will be required before final corrective actions can be taken. The remaining exceedances were single instances that did not indicate chronic or systematic problems.

SRS still achieved a 99.3-percent compliance rate-higher than the 98 percent rate mandated by DOE. On September 28, the site received one Notice of Violation from SCDHEC for violation of the monitoring and reporting requirements of permit SC0000175. SCDHEC cited 13 violations, which occurred from January through July 1998. These included flow, total suspended solids, fecal coliform, and copper. Corrective actions were implemented in all cases except at the $\mathrm{H}-12$ outfall.
A list of 1998 NPDES exceedances appears in table 8-5. Figure 8-2 shows the NPDES exceedances at SRS from 1986 through 1998, along with the site's compliance rate for each year. Complete results of 1998 industrial wastewater sample analyses can be found in table 54, SRS Environmental Data for 1998.

An ongoing problem has been identified at the NPDES A-01 outfall, where discharge water has been found to be toxic to test organisms. This outfall failed 14 of 16 analyses for chronic toxicity during 1998. The failures have been attributed to elevated levels of copper in the discharge stream. SRS is actively pursuing a plan to eliminate the problem. A similar problem has been identified at NPDES outfall A-11, which failed 10 of 14 analyses for chronic toxicity. SRS was still investigating the cause of the failures at the end of 1998. A summary of toxicity results from 1998 can be found in table 55, SRS Environmental Data for 1998.

A total of 506 analyses were performed during 1998 on stormwater discharge samples. SCDHEC has not mandated permit limits for stormwater outfalls. Complete results of 1998 NPDES stormwater sample analyses can be found in table 56, SRS Environmental Data for 1998.

A total of 101 analyses were performed during 1998 on sanitary sludge samples. All results were within permit specifications. Results from all the land application analyses can be found in table 57, SRS Environmental Data for 1998.

Outfall 001, permitted by SCG250162, did not flow for the majority of 1998. Only one sample was obtained, with five analyses performed-all of which were within permit specifications. Complete results of 1998 utility water discharge sample analyses can be found in table 54, SRS Environmental Data for 1998. 
Number

of Exceedances

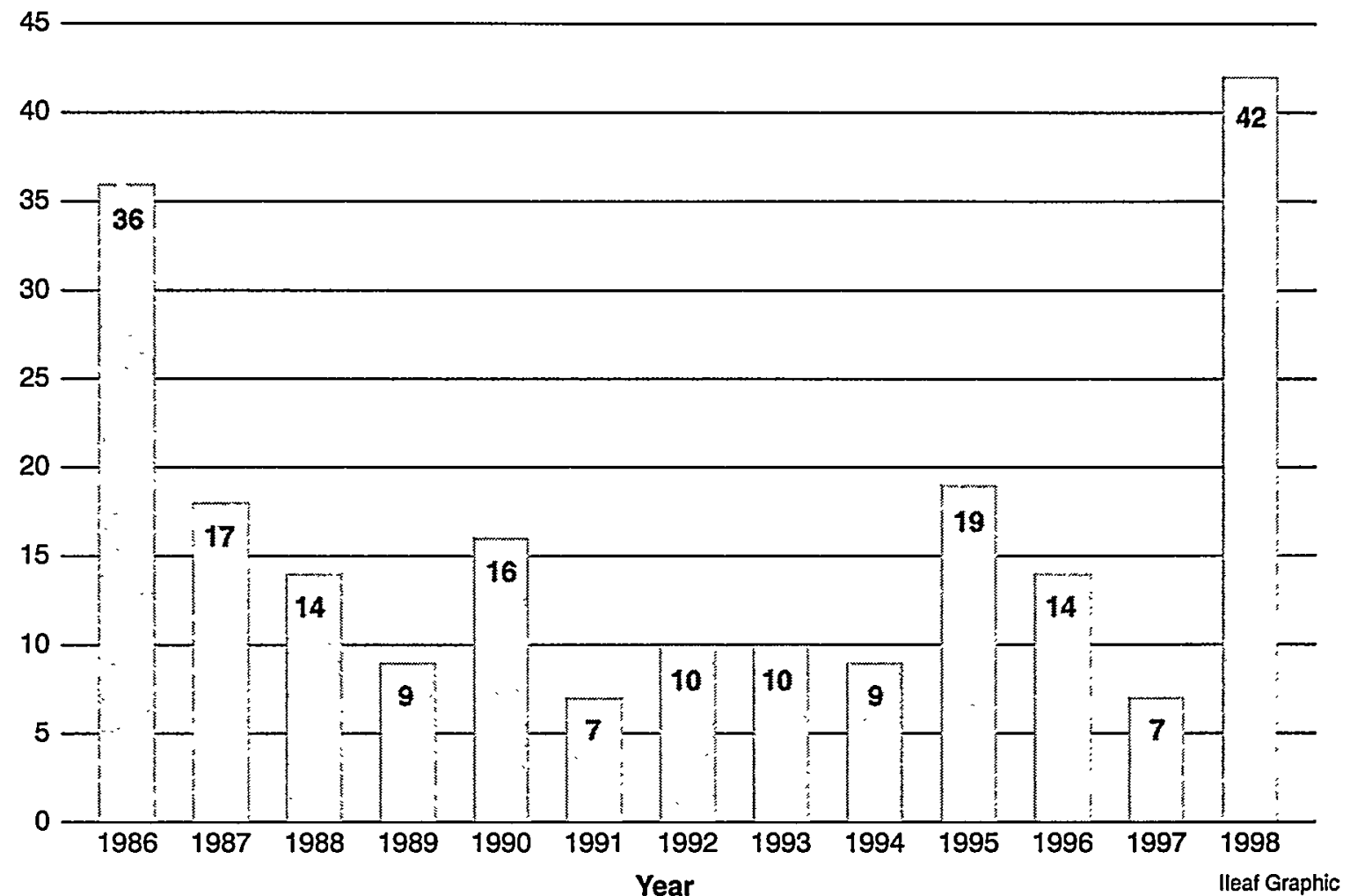

Year

Number of Analyses

Compliance Rate

\begin{tabular}{|c|c|c|}
\hline 1986 & 6,240 & $99.4 \%$ \\
\hline 1987. & 6,560 & $99.7 \%$ \\
\hline 1988. & 6,250 & $99.8 \%$ \\
\hline 1989. & 6,859 & $99.9 \%$ \\
\hline 1990. & 6,810 & $99.8 \%$ \\
\hline 1991. & 8,329 & $99.9 \%$ \\
\hline 1992. & 7,729 & $99.9 \%$ \\
\hline 1993. & 8,000 & $99.9 \%$ \\
\hline 1994. & 7,568 & $99.9 \%$ \\
\hline 1995. & 7,515 & $99.8 \%$ \\
\hline 1996. & 5,737 & $99.8 \%$ \\
\hline 1997. & 5,758 & $99.9 \%$ \\
\hline 1998. & 5,790 & $99.3 \%$ \\
\hline
\end{tabular}

Figure 8-2 History of NPDES Exceedances at SRS, and Site's Compliance Rate, 1986-1998

The chart and table provide historical information about NPDES exceedances from SRS liquid discharges to South Carolina waters, including the number of exceedances-and the site's compliance rate-for each year from 1986 to 1998. To determine the compliance rate, the number of analyses not exceeding limits for a given year is divided by the total number of analyses. For example, 5,790 analyses were performed in 1998 , with 42 exceedances. To calculate the compliance rate for that year, divide $5,694(5,790$ minus 42$)$ by 5,790 for a quotient of .9927 - or 99.3 percent. 
Table 8-5

1998 Exceedances of SCDHEC-Issued NPDES Permit Liquid Discharge Limits at SRS

Page 1 of 2

\begin{tabular}{|c|c|c|c|c|c|c|}
\hline Department & Outfall & Date & $\begin{array}{l}\text { Parameter } \\
\text { Exceeded }\end{array}$ & Result & Possible Cause & Corrective Action \\
\hline Separations & $F-01$ & Jan. 15 & TSS & $54 \mathrm{mg} / \mathrm{L}$ & $\begin{array}{l}\text { Collected during } \\
\text { rain event }\end{array}$ & None \\
\hline Separations & $\mathrm{F}-02$ & Jan. 15 & TSS & $223 \mathrm{mg} / \mathrm{L}$ & $\begin{array}{l}\text { Collected during } \\
\text { rain event }\end{array}$ & None \\
\hline Separations & $\mathrm{F}-02$ & Feb. 11 & $\mathrm{pH}$ & $9.54 \mathrm{SU}(\max )$ & $\begin{array}{l}\text { Caustic residue } \\
\text { in ground }\end{array}$ & $\begin{array}{l}\text { Area capped with } \\
\text { asphalt }\end{array}$ \\
\hline Separations & $\mathrm{H}-12$ & $\begin{array}{l}\text { Aug. } 20 \\
\text { Aug. } 31 \\
\text { Oct. } 12\end{array}$ & $\mathrm{pH}$ & $\begin{array}{l}4.55 \mathrm{SU} \text { (min) } \\
3.79 \mathrm{SU} \text { (min) } \\
3.65 \mathrm{SU} \text { (min) }\end{array}$ & Unknown & Under investigation \\
\hline Separations & $\mathrm{H}-12$ & $\begin{array}{l}\text { May } 7 \\
\text { July } 1 \\
\text { Sept. } 8\end{array}$ & Copper & $\begin{array}{l}0.431 \mathrm{mg} / \mathrm{L} \\
0.149 \mathrm{mg} / \mathrm{L} \\
0.093 \mathrm{mg} / \mathrm{L}\end{array}$ & $\begin{array}{l}\text { Well } 905-87 \mathrm{H} \\
\text { flushing directly } \\
\text { to outfall }\end{array}$ & Under investigation \\
\hline SUD & $D-1 A$ & $\begin{array}{l}\text { Jan. } 23 \\
\text { Jan. } 27 \\
\text { Jan. } 28 \\
\text { Feb. } 3 \\
\text { Feb. } 4 \\
\text { Feb. } 5 \\
\text { Feb. } 6 \\
\text { Feb. } 17 \\
\text { Feb. } 18 \\
\text { Feb. } 21 \\
\text { Feb. } 22 \\
\text { Feb. } 23 \\
\text { Feb. } 24 \\
\text { Feb. } 25 \\
\text { Feb. } 26 \\
\text { March } 8 \\
\text { March } 9 \\
\text { Sept. } 3\end{array}$ & Flow & $\begin{array}{l}0.026797 \text { MGD } \\
0.025024 \text { MGD } \\
0.024621 \text { MGD } \\
0.026904 \text { MGD } \\
0.032388 \text { MGD } \\
0.031014 \text { MGD } \\
0.029185 \text { MGD } \\
0.025958 \text { MGD } \\
0.023421 \text { MGD } \\
0.047833 \text { MGD } \\
0.026101 \text { MGD } \\
0.026503 \text { MGD } \\
0.026016 \text { MGD } \\
0.024761 \text { MGD } \\
0.023463 \text { MGD } \\
0.035063 \text { MGD } \\
0.023550 \text { MGD } \\
0.028781 \text { MGD }\end{array}$ & $\begin{array}{l}\text { System } \\
\text { inundated by } \\
\text { heavy rains }\end{array}$ & $\begin{array}{l}\text { Problem areas } \\
\text { isolated/repaired }\end{array}$ \\
\hline SUD & $L-7 A$ & Sept. 3 & Flow & 0.058244 MGD & $\begin{array}{l}\text { System } \\
\text { inundated by } \\
\text { heavy rains }\end{array}$ & $\begin{array}{l}\text { Two manholes ele- } \\
\text { vated; storm drain } \\
\text { disconnected }\end{array}$ \\
\hline SUD & $\mathrm{G}-10$ & Jan. 22 & Fec Col & $440 \mathrm{col} / 10 \mathrm{~mL}$ & $\begin{array}{l}\text { UV bulbs needed } \\
\text { cleaning }\end{array}$ & UV bulbs cleaned \\
\hline SUD & $\mathrm{G}-10$ & Aug. 26 & Fec Col & $800 \mathrm{col} / 10 \mathrm{~mL}$ & $\begin{array}{l}\text { UV bulbs needed } \\
\text { cleaning }\end{array}$ & UV bulbs cleaned \\
\hline SUD & $G-10$ & Aug. 4 & C-TOX & Fail & $\begin{array}{l}\text { Unable to } \\
\text { determine }\end{array}$ & None \\
\hline SUD & $G-10$ & Aug. 28 & A-TOX & Fail & $\begin{array}{l}\text { Unable to } \\
\text { determine }\end{array}$ & None \\
\hline
\end{tabular}


Table 8-5

1998 Exceedances of SCDHEC-Issued NPDES Permit Liquid Discharge Limits at SRS

Page 2 of 2

\begin{tabular}{lllllll}
\hline Department & Outfall & Date & $\begin{array}{l}\text { Parameter } \\
\text { Exceeded }\end{array}$ & Result & Possible Cause & Corrective Action \\
\hline SUD & X-8A & Sept. 29 & Fec Col & $>88$ col/100mL & $\begin{array}{l}\text { Underloaded } \\
\text { plant caused } \\
\text { stagnation in } \\
\text { stilling basin; test } \\
\text { analysis invalid }\end{array}$ & $\begin{array}{l}\text { Water added to } \\
\text { relieve stagnation; } \\
\text { analysts retrained }\end{array}$ \\
on procedure
\end{tabular}

\footnotetext{
Key: $\quad$ A-TOX-Acute Toxicity

C-TOX - Chronic Toxicity

Fec Col - Fecal Coliform

SU-Standard Units

TCE - Trichloroethylene

TSS - Total Suspended Solids

UV-Ultraviolet
} 


\title{
Nonradiological Environmental Surveillance
}

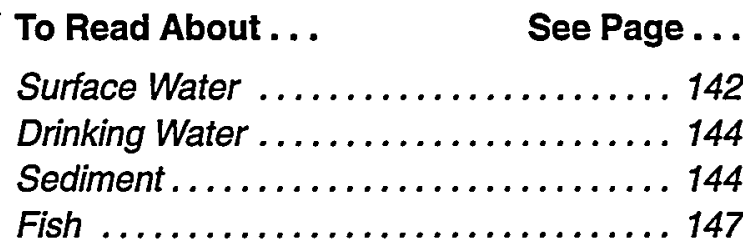

\author{
Bill Littrell and Phillip Miller \\ Environmental Protection Department
}

Robert Turner
Engineering Services Department

\section{Highlights}

- Analysis of the nonradiological environmental surveillance data indicated that SRS discharges are not significantly affecting the water quality of the streams or the Savannah River.

- All samples collected from SRS drinking water systems were in compliance with SCDHEC and EPA water quality limits.

- No pesticides or herbicides were found in sediment samples to be above the practical quantitation limits. All analyses of pesticides/herbicides were below the detection limits of EPA analytical procedures used.

m From year to year, most metals in sediment vary from nondetectable levels to low levels. This was true in 1998.

- Individual fish analysis results indicated that bass contained the highest levels of mercury, followed in order by bowtin, catfish, bream, and sucker.

$\mathrm{N}$ ONRADIOACTIVE environmental surveillance at the Savannah River Site (SRS) involves the sampling and analysis of surface water (six onsite streams and the Savannah River), drinking water, sediment, groundwater, and fish. Surface water, drinking water, sediment, and fish surveillance programs are discussed in this chapter. However, a description of the surveillance program and 1998 results for groundwater can be found in chapter 10, "Groundwater."

The Environmental Protection Department's Environmental Monitoring Section (EMS) and the Savannah River Technology Center (SRTC) perform nonradiological surveillance activities. The Savannah River also is monitored by other groups, including the South Carolina Department of Health and Environmental Control (SCDHEC) and the Georgia Department of Natural Resources (GDNR). In addition, the Academy of Natural Sciences of Philadelphia conducts special environmental surveys on the Savannah River through a program that began in 1951. The academy's studies are discussed in chapter 12, "Special Surveys and Projects."

A complete description of the EMS sample collection and analytical procedures used for nonradiological surveillance can be found in section 1105 of the Savannah River Site Environmental Monitoring Section Plans and Procedures, WSRC-3Q1-2, Volume 1 (SRS EM Program). A summary of analytical results is presented in this chapter; however, more complete data can be found in SRS Environmental Data for 1998 (WSRC-TR-98-00314). Information on the rationale for the nonradiological environmental surveillance program can be found in chapter 3 , "Environmental Program Information."

In 1998, approximately 6,300 nonradiological analyses for specific chemicals and metals were performed on about 1,200 samples, not including groundwater.

SRS currently does not conduct onsite surveillance for ambient air quality. However, to ensure compliance with SCDHEC air quality regulations and standards, SRTC conducted air dispersion modeling for all site sources of criteria and toxic air pollutants in 1993. This modeling indicated that all SRS sources were in compliance with air quality regulations and standards. Since that time, additional modeling conducted for new sources of criteria and toxic air pollutants has demonstrated continued compliance by the site with these regulations and 
standards. The states of South Carolina and Georgia continue to monitor ambient air quality near the site as part of a network associated with the federal Clean Air Act.

\section{Surface Water}

SRS streams and the Savannah River are classified as "Freshwaters" by SCDHEC. Freshwaters are defined as surface water suitable for

- primary-and secondary-contact recreation and as a drinking water source after conventional treatment in accordance with SCDHEC requirements

- fishing and survival and propagation of a balanced indigenous aquatic community of fauna and flora

- industrial and agricultural uses

Appendix A, "Applicable Guidelines, Standards, and Regulations," provides some of the specific guides used in water quality surveillance, but because some of these guides are not quantifiable, they are not tracked (i.e., amount of garbage found).

\section{Description of Surveillance Program}

SRS stream and Savannah River nonradiological surveillance is conducted for any evident degradation that could be attributed to the water discharges regulated by the site National Pollutant Discharge Elimination System (NPDES) permits and materials that may be released inadvertently from sources other than routine release points. In the surveillance program, site streams and the Savannah River are sampled monthly for various physical and chemical properties. Surface water sampling locations are shown in figure 9-1.

Each SRS stream receives varying amounts of treated wastewater and rainwater runoff from site facilities. Stream locations are sampled for water quality at monthly and quarterly frequencies by the conventional grab-collection technique. Each grab sample shows the water quality at the time of sampling only.

River sampling sites are located upriver of, adjacent to, and downriver of the site to compare the SRS contribution of pollutants with background levels of chemicals from natural sources and from contaminants produced by municipal sewage plants, medical facilities, and other upriver industrial facilities. Nonradiological surveillance of the river also checks for any degradation that could be attributed to the water discharges regulated by site NPDES permits.
To monitor the quality of water coming onto and leaving the site, field measurements for conductivity, dissolved oxygen, $\mathrm{pH}$, and temperature are taken monthly and laboratory analyses are conducted for other water quality parameters, such as metals, pesticides/herbicides (quarterly), and other physical properties. Comparison of the results from upstream and downstream locations (locations that are below process areas or at points where the water leaves the site) indicates any impact the site may have had on the water.

The natural chemical and physical parameters measured monthly on each stream and in the river vary to some extent throughout the year. This natural variation can be trended on a month-to-month basis. When results diverge greatly from the historical norm, an abnormal discharge event or occurrence in the environment may be indicated. An investigation is held to determine if a release has occurred.

\section{Surveillance Results}

Results can be found in table 58, SRS Environmental Data for 1998.

The December sample data for dissolved oxygen at the Lower Three Runs Creek-2 location inadvertently were not recorded and thus were not reported. In addition, the June herbicides and pesticides data from the Pen Branch 3 location were contaminated in the laboratory and also were not reported.

Comparison of the upstream and downstream locations where available (Upper Three Runs Creek) and month-to-month trends for each of these stations indicated normal trends for a southern pine forest stream. The upstream $\mathrm{pH}$ varied within a range of 4.0 to 6.9 , while the conductivity ranged from a low of $15 \mu \mathrm{hmos} / \mathrm{cm}$ at the Upper Three Runs Creek-1A location to a high of $71 \mu \mathrm{hmos} / \mathrm{cm}$ at Tinker Creek-1. The downstream station at Upper Three Runs Creek -4 had a pH range of 4.6 to 6.4 and a conductivity range of 19 to $26 \mu \mathrm{hmos} / \mathrm{cm}$.

Nitrate levels for the river and most stream locations usually ranged below $0.50 \mathrm{mg} / \mathrm{L}$. Four Mile Creek-6 had the highest nitrate concentration of all the streams (between 1 and $2 \mathrm{mg} / \mathrm{L}$ ). This was due to discharges into Four Mile Creek from the waste treatment facility above the sampling location.

Phosphate levels were typically higher in the Savannah River than on site. The highest phosphate level, $1.4 \mathrm{mg} / \mathrm{L}$, was seen at River Mile-120. The next location upstream (River Mile-129, below the Lower Three Runs Creek mouth) had a phosphate 


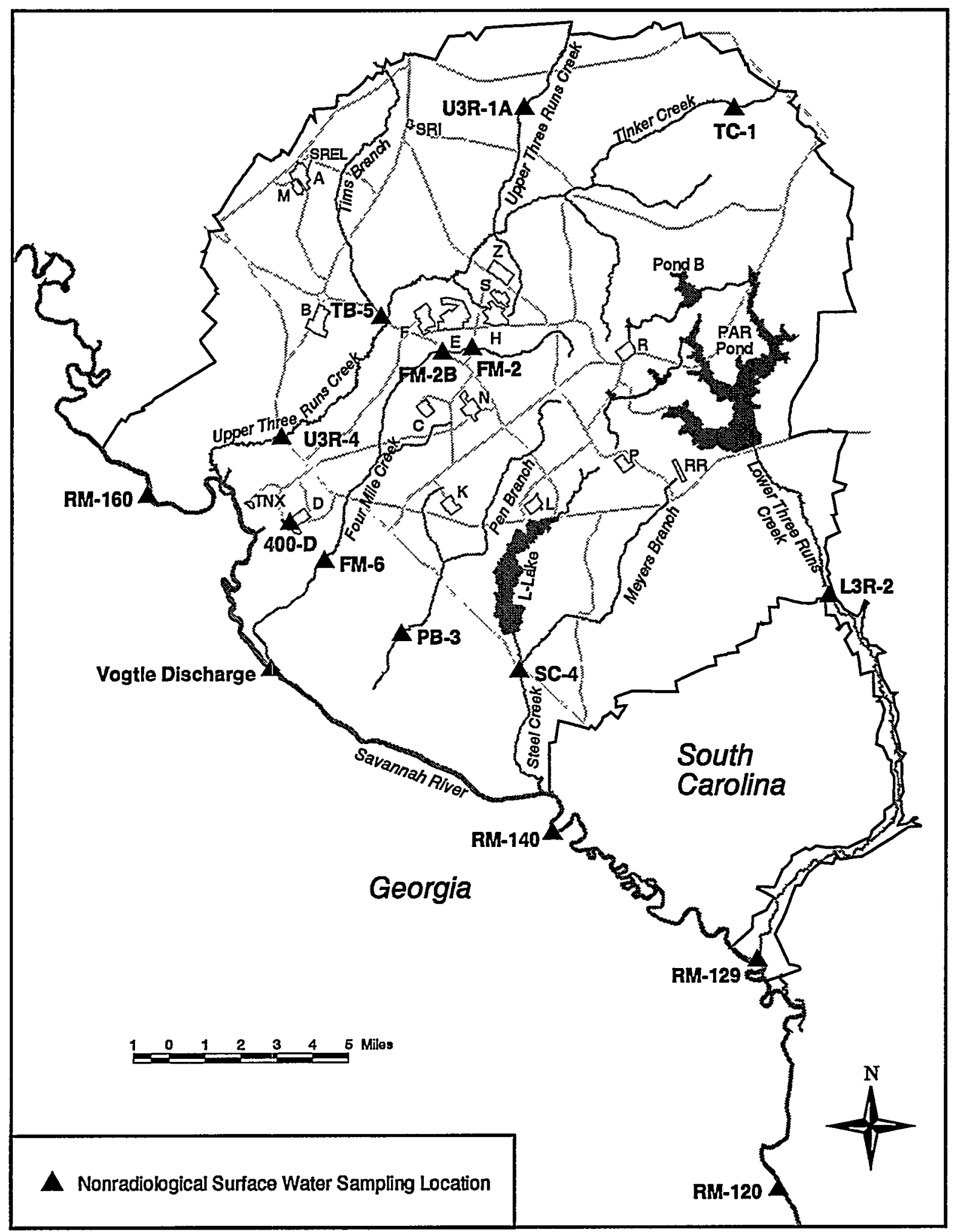

EPD/GIS Map

Figure 9-1 Nonradiological Surface Water Sampling Locations

Surface water samples are collected from five Savannah River and eleven SRS stream locations and are analyzed for various chemical and physical properties. 
level of $0.312 \mathrm{mg} / \mathrm{L}$. River Mile-160, the uppermost river location, had a phosphate range from "not detected" in some months to a high of $0.249 \mathrm{mg} / \mathrm{L}$ in December. The November phosphate level at Upper Three Runs Creek-1A ( $0.46 \mathrm{mg} / \mathrm{L}$ ) was higher than in previous months. Tinker Creek-1 also showed a higher level $(0.319 \mathrm{mg} / \mathrm{L})$ than in previous months. The downstream station at Upper Three Runs Creek-4 reflected these higher phosphate numbers at $0.718 \mathrm{mg} / \mathrm{L}$.

Metals across the site generally reflected the values found in the soils. May data indicated low levels of lead at several locations. Closer inspection of the raw data and contact with the laboratory indicated no laboratory problems. However, a duplicate sample at one location indicated a low level of detection while the other duplicate sample at that location detected no lead. Therefore, the lead data were suspect. Analyses of the data generally indicated that SRS discharges are not significantly affecting the water quality of the streams or the river.

\section{Drinking Water}

Most of the drinking water at SRS is supplied by three systems that have treatment plants in A-Area, $\mathrm{B}$-Area, and K-Area. The site also has 15 small drinking water facilities at remote security barricades, field laboratories, and field offices that serve populations of fewer than 25 persons (figure 9-2).

Well water from the McBean, Congaree, Black Creek, and Middendorf aquifers is utilized for the 18 drinking water systems. Many of these well water supplies require treatment to ensure that SCDHEC and U.S. Environmental Protection Agency (EPA) drinking water quality standards are maintained. Treatment processes include aeration to remove dissolved gases; filtration to remove iron; and addition of potable water treatment chemicals to adjust $\mathrm{pH}$, prevent piping corrosion, and prevent bacterial growth.

\section{Description of Surveillance Program}

SRS drinking water supplies are tested routinely by site personnel and by SCDHEC to ensure compliance with SCDHEC and EPA drinking water standards (the drinking water standards can be found in appendix B) and monitoring requirements. This testing includes

- daily testing to monitor concentration of any potable water treatment chemicals added
- monthly or quarterly testing to confirm that bacteria are not present

- periodic testing for metals, organic and inorganic chemicals, and radionuclides

\section{Surveillance Results}

All samples collected from SRS drinking water systems during 1998 were in compliance with SCDHEC and EPA water quality limits.

As in past surveillance, analytical results from volatile organic samples (collected from onsite drinking water systems by EMS personnel) were less than the method detection limit of $2 \mu \mathrm{g} / \mathrm{L}$. The last volatile organic samples were taken by mid-February. The program was closed out by the second quarter.

\section{Sediment}

EMS's nonradiological sediment surveillance program provides a method of determining the deposition, movement, and accumulation of nonradiological contaminants in stream systems.

\section{Description of Surveillance Program}

The nonradiological sediment program consists of the collection of sediment samples at eight onsite stream locations and three Savannah River locations (figure 9-3). Collection is made by either a Ponar sediment sampler or an Emery pipe dredge sampler. The samples are analyzed for various inorganic contaminants (metals) and pesticides/herbicides by the Toxicity Characteristic Leaching Procedure (TCLP) method. This method analyzes for the soluble constituents in sediment. The program is designed to check for the existence and possible buildup of the inorganic contaminants as well as for pesticides/herbicides.

\section{Surveillance Results}

Sediment results can be found in table 59, SRS Environmental Data for 1998.

As in the previous two years, no pesticides or herbicides were found in sediment samples to be above the practical quantitation limits in 1998. All pesticide/herbicide results were below the detection limits of EPA analytical procedures used.

Aluminum, barium, magnesium, manganese, and zinc were seen in sediment at all river and stream locations. Levels for these metals were consistent with those seen in soil samples. From year to year, most metals vary from nondetectable levels to very low levels. 


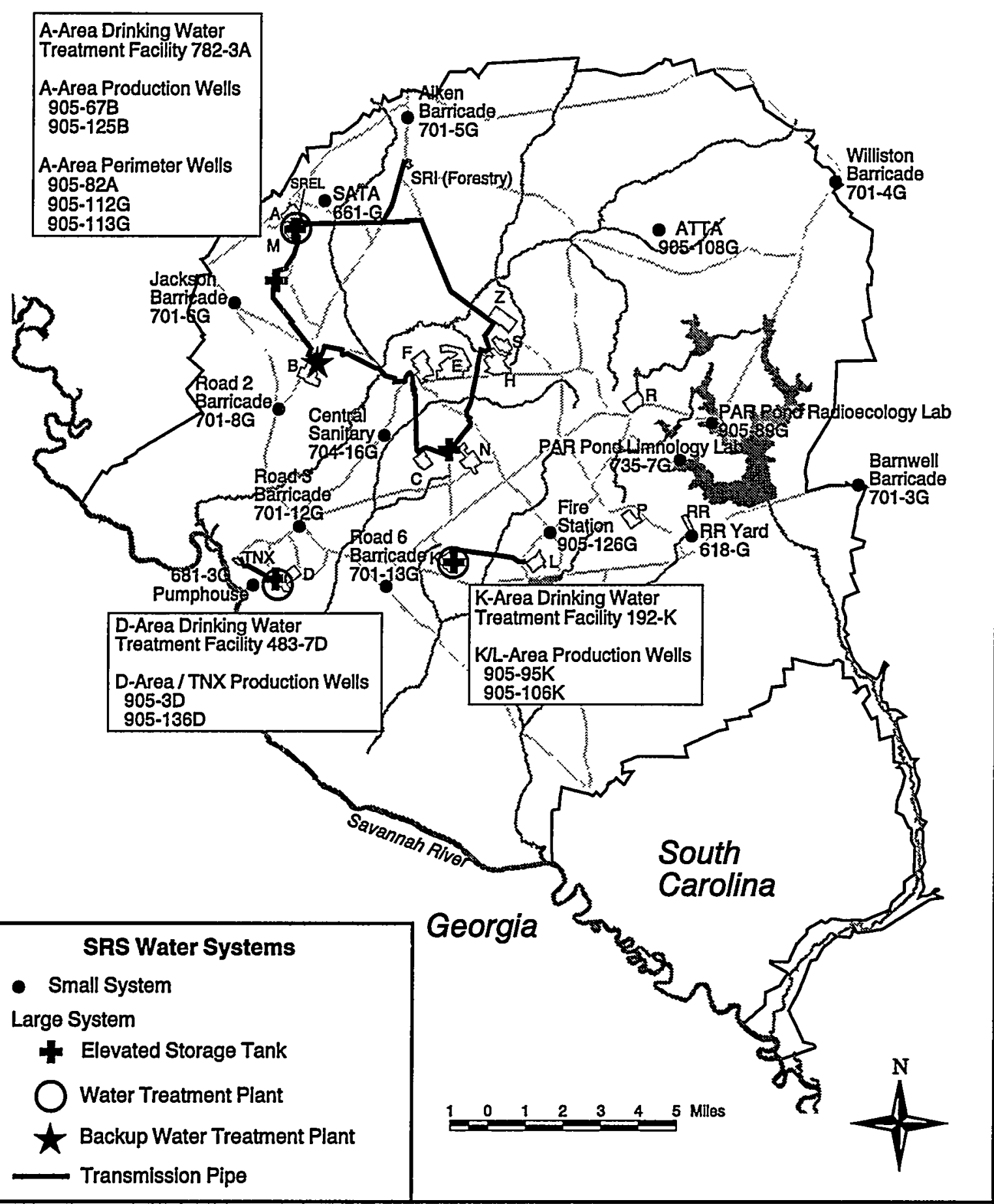

EPD/GIS Map

Figure 9-2 Drinking Water Systems

Most of the drinking water at SRS is supplied by three systems. The site also has 15 small drinking water facilities that serve populations of fewer than 25 persons. The three larger systems are depicted by transmission pipes, elevated storage tanks, water treatment plants, and a backup water treatment plant.

In 1998, copper was found at all onsite locations and was consistently between 0.03 and $0.04 \mathrm{mg} / \mathrm{L}$. For the previous three years, it had ranged as high as
$0.103 \mathrm{mg} / \mathrm{L}$ at Tinker Creek-1 (control location) to below the lower limit of detection (LLD) at several locations as well as Tinker Creek-1. 


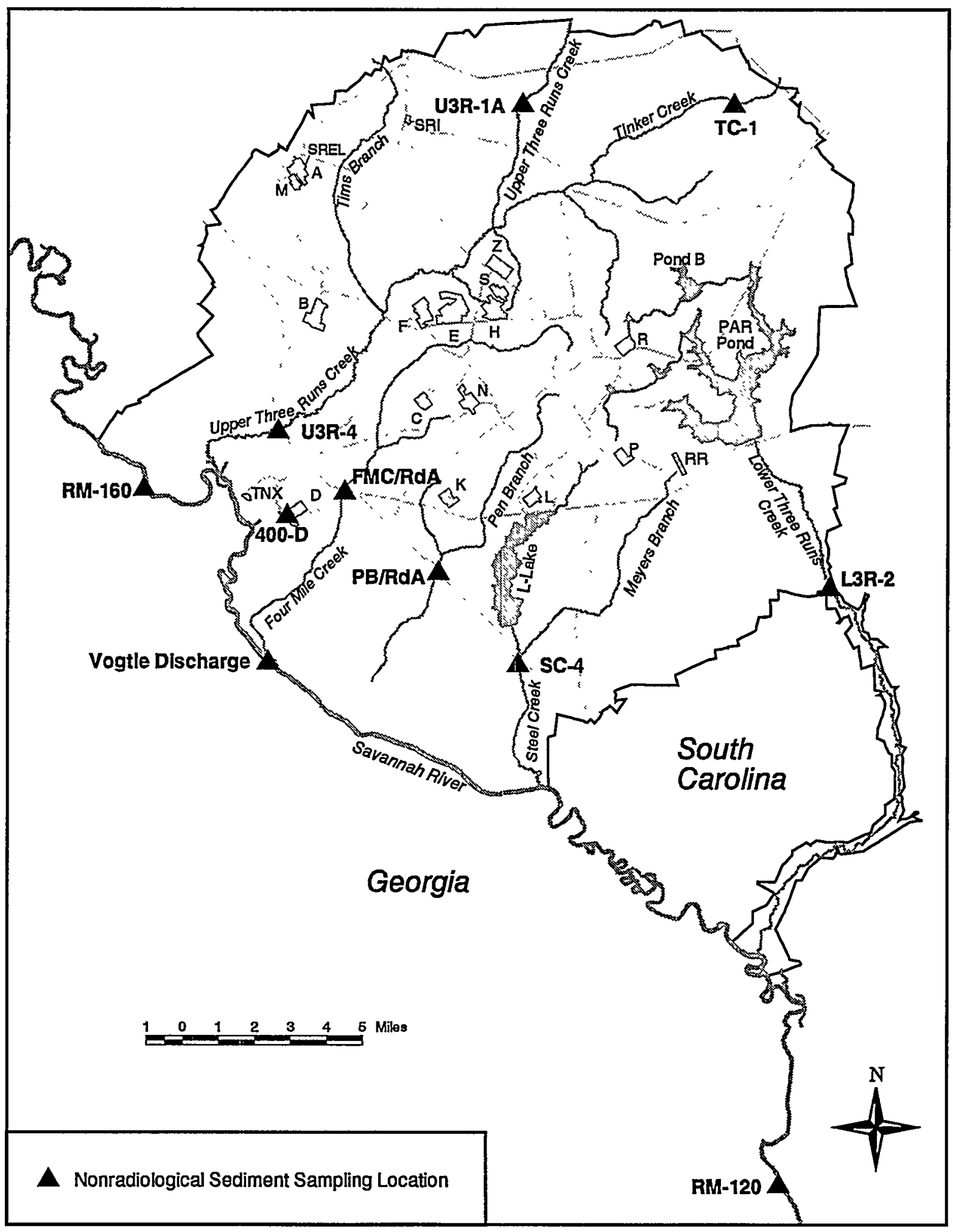

EPD/GIS Map

Figure 9-3 Nonradiological Sediment Sampling Locations

Sediment samples are collected at eight onsite stream locations and three Savannah River locations. The samples are analyzed for various inorganic contaminants (metals) and pesticides/herbicides. 
In 1998, Tinker Creek-1 showed $0.0003 \mathrm{mg} / \mathrm{L}$ of mercury for the first time. No other sites showed mercury in 1998. Also, for the two years previous to 1998, no mercury was detected at any site. The 1998 level at Tinker Creek-1 was slightly above detection.

Lead was detected at three locations-Upper Three Runs Creek-1A, Upper Three Runs Creek-4, and Beaver Dam Creek (400-D). The levels ranged from 0.005 to $0.008 \mathrm{mg} / \mathrm{L}$. In 1997 , lead was found at the Steel Creek-4 location only. No significant trends could be found for the metals in the Savannah River or on site.

\section{Fish}

Mercury is a naturally occurring metal that cycles between land, water, and air. The major sources of atmospheric mercury are as follows:

- Natural-Degassing of the earth's crust generates 2,700 to 6,000 tons of mercury per year [WHO, 1990].

- Manmade-Burning of fossil fuels releases an estimated 5,000 tons of mercury per year [Klaassen et al., 1986]; industrial and other discharges account for an undetermined amount.

As mercury enters streams and rivers through rainfall, runoff, and discharges, it is converted to the
An EMS laboratory technician prepares a fish for mercury analysis. EMS examines the flesh of fish caught from onsite streams and ponds and from the Savannah River. In 1998, bass, bream, catfish, red drum, mullet, bowfin, and sucker were analyzed.

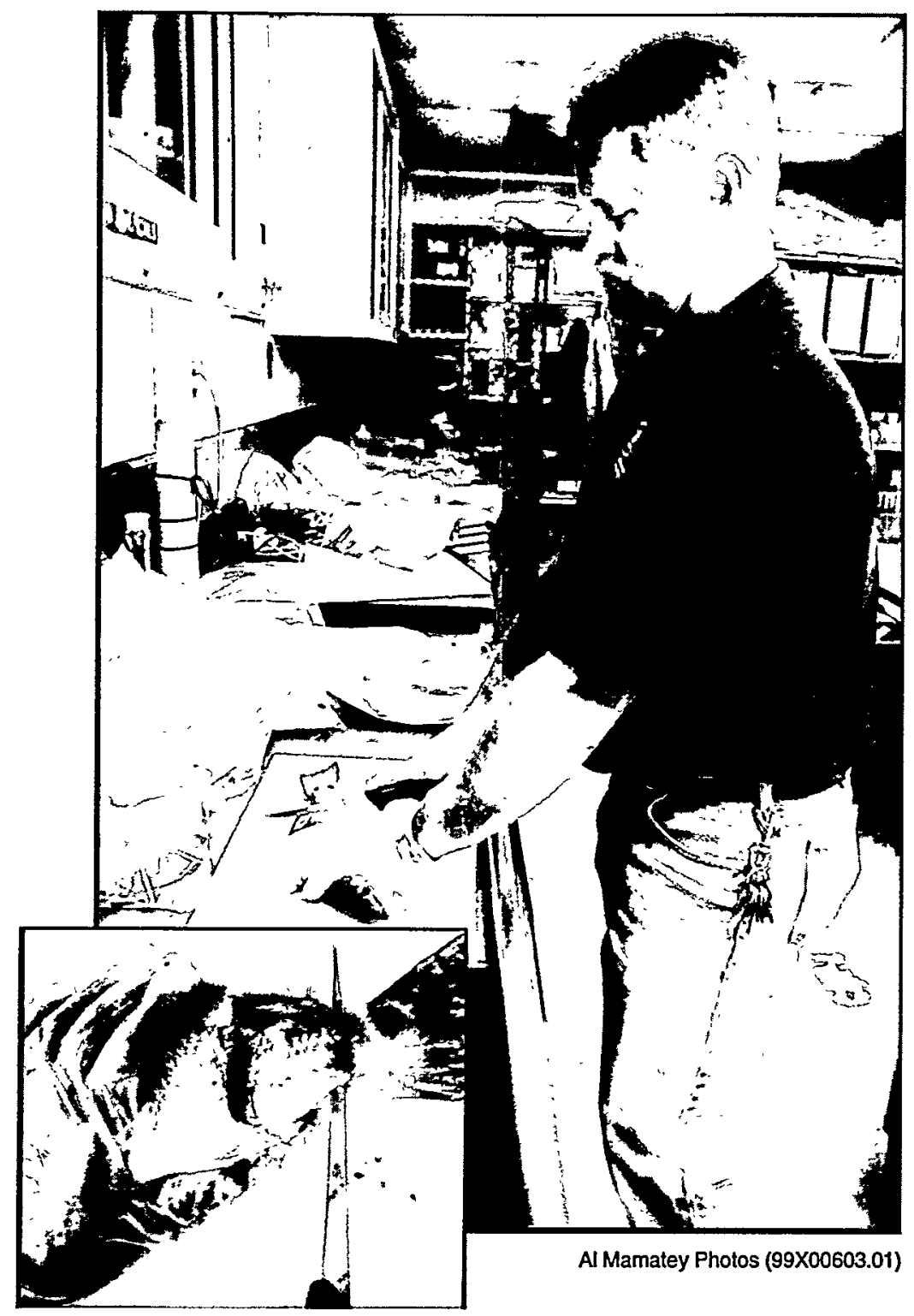


chemical compound methylmercury by bacterial and other processes. As part of the natural cycling, some mercury is absorbed by plants and animals into their tissues. Fish absorb methylmercury from food they ingest and from water as it passes over their gills; the methylmercury then is bound in their tissues. Consumption by people of fish containing methylmercury then completes the mercury pathway to humans. The amount of fish that can be eaten safely varies with (1) the concentration of methylmercury, (2) the amount consumed, and (3) the frequency of consumption. These factors are the basis of calculations performed during "risk analysis," a method to determine how much fish can be consumed safely.

State and federal regulatory agencies calculate the health risk associated with the consumption of fish, then recommend consumption guidelines based on that risk. Adherence to these guidelines can effectively control one's exposure to methylmercury. A list of fish advisories and/or recommended consumption limits can be obtained from state environmental agencies. EPA criteria taken from "Guidance For Assessing Chemical Contaminant Data For Use In Fish Advisories, Volume II Risk Assessment And Fish Consumption Limits" (EPA 823-B-94-004, June 1994), gives the monthly consumption limits for chronic systemic health endpoint for the general population.

\section{Description of Surveillance Program}

EMS analyzes the flesh of fish caught from onsite streams and ponds and from the Savannah River to determine concentrations of mercury in the fish [SRS EM Program, 1995]. The fish analyzed represent the most common edible species of fish in the Central Savannah River Area (CSRA), an 18-county area in Georgia and South Carolina that surrounds Augusta, Georgia, and includes SRS. (Sampling locations for fish are depicted in a map in chapter 6, "Radiological Environmental Surveillance," page 101.)

\section{Surveillance Results}

In 1998, 260 fish from SRS streams and ponds and the Savannah River were caught and analyzed for mercury. No fish were caught from the Pen Branch-3 and Four Mile Creek-6 locations.
The mercury concentrations in fish analyzed from onsite waters ranged from a high of $1.83 \mu \mathrm{g} / \mathrm{g}$ in bass from PAR Pond and Pond $B$ to values less than the reporting limit $(0.33 \mu \mathrm{g} / \mathrm{g})$ at several locations. Mercury concentrations in offsite fish ranged from a high of $1.30 \mu \mathrm{g} / \mathrm{g}$ in a bass from the Beaver Dam Creek Mouth to values less than the reporting limit $(0.33 \mu \mathrm{g} / \mathrm{g})$ at several locations (table $60, S R S$ Environmental Data for 1998). Eight special samples (one each of bowfin and sucker at four locations) were collected in the Savannah River at the request of the Department of Energy (DOE). The eight samples were taken at the Four Mile Creek Mouth, Steel Creek Mouth, New Savannah Lock and Dam (formerly the Augusta Lock and Dam), and Highway 301 locations. Overall individual results indicated that bass contained the highest levels of mercury, followed in order by bowfin, catfish, bream, and sucker.

Table 3-57 in the EPA publication mentioned in the previous column indicates that the recommended monthly consumption limit for fish collected at the highest offsite location for 1998 (Beaver Dam Creek Mouth) would be between one and two 8-ounce servings per month.

\section{Perspective on Mercury}

Mercury in the environment can come from natural sources, such as volcanoes and venting of the earth's crust, and from manmade sources and processes, such as fungicides and fossil fuel combustion byproducts and the manufacture of chlorine, sodium hydroxide, plastics, and electrical apparatus.

An important source in the SRS region may be in releases upriver of the site. Much of the mercury detected in SRS fish has been attributed to offsite sources, such as Savannah River water [Davis et al., 1989]. Savannah River water is pumped onto the site to support fire protection efforts and the sanitary waste treatment plant and to maintain L-Lake's water level. The water subsequently is released into site streams and lakes. 
Groundwater at SRS.............. 149

Description of Groundwater

Monitoring Program .............. 153

\author{
Drew Cobb, Laurie Tyler, and Jen Williams \\ Exploration Resources, Inc.
}

Groundwater Monitoring Program

Changes During 1998 .............. 157

Groundwater Monitoring Results ....... 157

\title{
1998 Highlights
}

- Most analytical results from groundwater monitoring were similar to those of recent years. However, the results show that ongoing remediation efforts at A-Area and M-Area have slowed the spread of contamination (primarily organics and metals) and reduced the impact of operations in those areas on the groundwater.

- In most of the reactor areas (K-Area, L-Area, and P-Area), tritium is the most widespread contaminant. Trichloroethylene is the most widespread contaminant in C-Area, and tritium is significantly elevated there as well. Organics are present in groundwater near the burning/rubble pits in these areas and near the chemicals, metals, and pesticides pits just north of L-Area. Metals are present near the reactor seepage basins in P-Area and near the chemicals, metals, and pesticides pits. No metals are present in K-Area, and no evidence of tritium exists in R-Area, but other radionuclides and metals are present in the groundwater, based on current and previous years' sampling.

- D-Area shows continued contamination associated with activities at the coal-fired power plant and related facilities and with organics and metals near the oil disposal basin. The contaminant plume in the TNX area indicated the presence of organics, metals, radionuclides, and other constituents near disposal sites.

- In the general separations and waste management areas (E-Area, F-Area, and H-Area), the groundwater contamination plumes include tritium, radionuclides, metals, organics, and other constituents. Metals, organics, and radionuclides are present in N-Area. Stabilization and closure programs are ongoing in these areas. Radionuclides were detected in one well in Z-Area. S-Area shows evidence of groundwater contamination in the vicinity of the vitrification building.

- Organics, metals, tritium, and other radionuclides are present in the groundwater near the sanitary landfill, while tritium was identified in two wells and gross alpha in a single well in B-Area.

$\mathrm{G}$ roundwater beneath an estimated five to 10 percent of the Savannah River Site (SRS) has been contaminated by industrial solvents, tritium, metals, or other constituents used or generated by operations at SRS. Groundwater in areas indicated on figure 10-1 contains one or more of these constituents at or above the levels of the Safe Drinking Water Act primary drinking water standards (DWS) of the U.S. Environmental Protection Agency (EPA).

This chapter summarizes the groundwater monitoring results for 1,133 wells in 101 locations (figure 10-1) within designated areas at SRS. Only results exceeding the DWS are presented in figures and tables in this report. Most constituents are compared to the final federal primary DWS. In some cases, comparison is to the proposed primary DWS or the interim final primary DWS. (See appendix A, "Applicable Guidelines, Standards, and Regulations," for additional information about applicable monitoring standards, and appendix B, "Drinking Water Standards," for the DWS.) Some information about additional constituents is discussed in the text of this chapter.

Detailed groundwater monitoring results are presented in the following public documents: The Savannah River Site's Groundwater Monitoring Program, First Quarter 1998 (ESH-EMS-98-0568);

The Savannah River Site's Groundwater Monitoring

Program, Second Quarter 1998

(ESH-EMS-98-0569); The Savannah River Site's Groundwater Monitoring Program, Third Quarter 1998 (ESH-EMS-98-0570); and The Savannah River Site's Groundwater Monitoring Program, Fourth Quarter 1998 (ESH-EMS-98-0571). Full results for each well sampled during a quarter are presented alphabetically in the quarterly reports.

Another public document, the Environmental Protection Department's Well Inventory

(ESH-EMS-98-0590), contains detailed maps of the wells at each monitored location.

\section{Groundwater at SRS}

When rain falls, part of the rainwater runs off of the surface of the earth into streams, and part of it soaks 


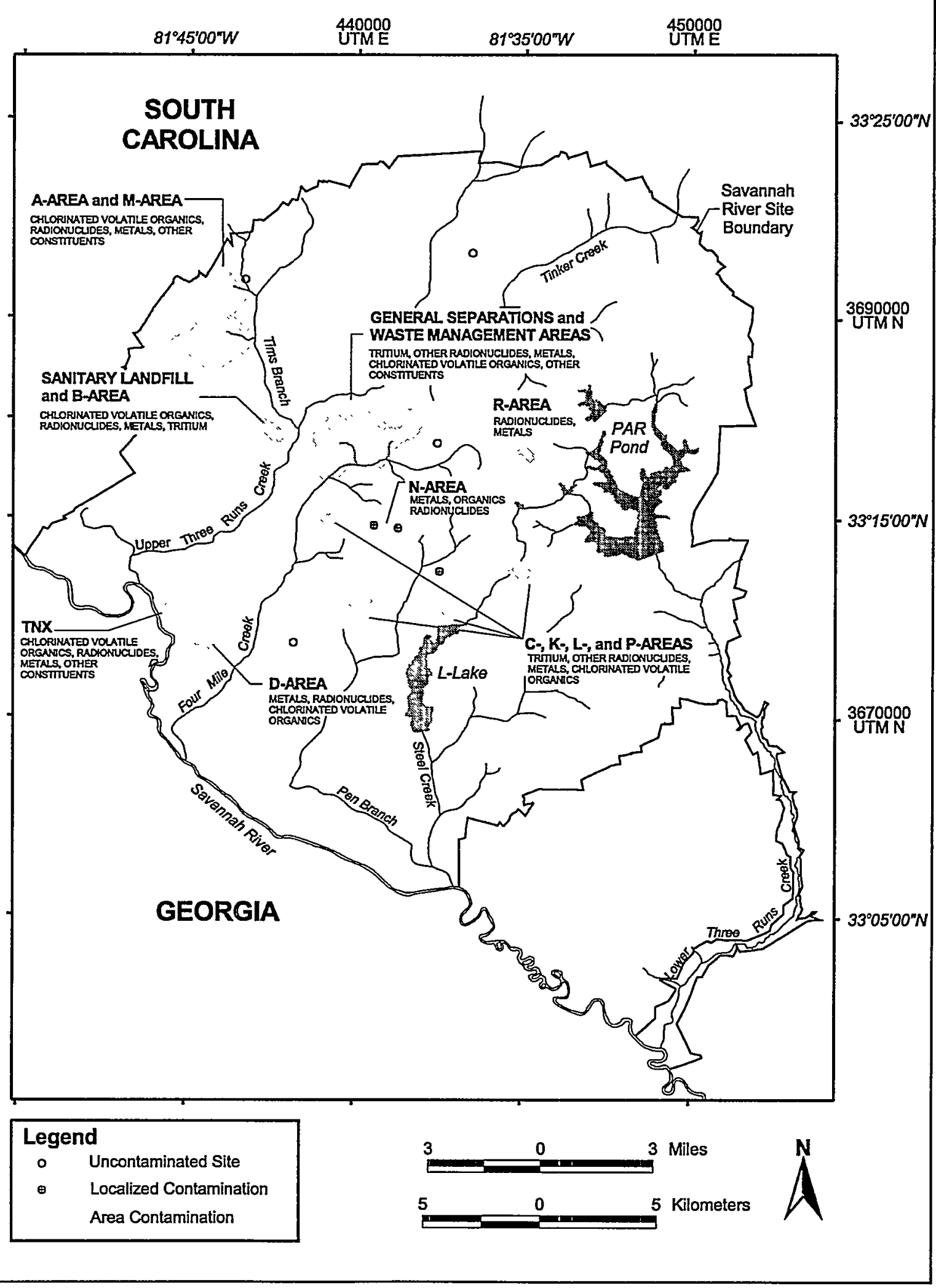

Exploration Resources, Inc.

Figure 10-1 Facilities Monitored by the SRS Monitoring Well Network, Including Areas Having Constituents Exceeding Drinking Water Standards in 1998 


\section{A-Area and M-Area}

- A-Area and M-Area Recovery Well Network

- A-Area Background Well Near Firing Range

- A-Area Burning/Rubble Pits and A-Area Ash Pile

- A-Area Coal Pile Runoff Containment Basin

- A-Area Metals Burning Pits

- M-Area Hazardous Waste Management Facility and M-Area Plume Definition

- Metallurgical Laboratory Seepage Basin

- Miscellaneous Chemical Basin

- Motor Shop Oil Basin

- Savannah River Laboratory Seepage Basins

- Silverton Road Waste Site

General Separations and Waste Management Areas (E-Area, F-Area, H-Area, S-Area, and Z-Ärea)

- Burial Ground Expansion (E-Area Vaults)

- Burial Grounds Perimeter

- Burma Road Rubble Pit

- E-Areas Hazardous Waste/Mixed Waste Disposal Facility

- F-Area Ash Basin

- F-Area Burning/Rubble Pits

- F-Area Canyon Building and A-Line Uranium Recovery Facility

- F-Area Coal Pile Runoff Containment Basin

- F-Area Effluent Treatment Cooling Water Basin

- F-Area Retention Basins

- F-Area Sanitary Sludge Land Application Site

- F-Area Seepage Basins and Inactive Process Sewer Line

- F-Area Seepage Basins Remediation Extraction Wells and Tank

- F-Area Seepage Basins Remediation Injection Tank

- F-Area Tank Farm

- H-Area Auxiliary Pump Pit

- H-Area Canyon Building

- H-Area Coal Pile Runoff Containment Basin

- H-Area Effluent Treatment Cooling Water Basin

- H-Area Retention Basins

- H-Area Seepage Basins and Inactive Process Sewer Line

- $\quad$ H-Area Seepage Basins Remediation Extraction Tank

- H-Area Seepage Basins Remediation Injection Tank

- H-Area Tank Farm and Tank Farm Groundwater Operable Unit

- HP-52 Outfall and Wamer's Pond Area

- Old Burial Ground

- Old F-Area Seepage Basin

- Old H-Area Retention Basin

- S-Area Defense Waste Processing Facility Vitrification Building

- S-Area Low-Point Pump Pit

- Waste Solidification and Disposal Facility

- Wells Between the F-Area Canyon Building and the Naval Fuel Material Facility

- Z-Area Low-Point Drain Tank

- Z-Area Saltstone Facility Background Wells

C-Area

- 108-3C Bioremediation Facility

- C-Area Burning/Rubble Pit

- C-Area Coal Pile Runoff Containment Basin

- C-Area Disassembly Basin

- C-Area Reactor Seepage Basins

\section{K-Area}

- K-Area Ash Basin

- K-Area Bingham Pump Outage Pit

- K-Area Buming/Rubble Pit

- K-Area Coal Pile Runoff Containment Basin

- K-Area Disassembly Basin

- K-Area Reactor Seepage Basin

- K-Area Retention Basin

- K-Area Tritium Sump

\section{L-Area}

- 108-3L Bioremediation Facility

- L-Area Acid/Caustic Basin and L-Area Oil and Chemical Basin

- L-Area Bingham Pump Outage Pits

- L-Area Buming/Rubble Pit

- L-Area Disassembly Basin

- L-Area Reactor Seepage Basin

- L-Area Research Wells

\section{P.Area}

- P-Area Bingham Pump Outage Pit

- P-Area Buming/Rubble Pit

- P-Area Coal Pile Runoff Containment Basin

- P-Area Disassembly Basin

- P-Area Reactor Seepage Basins

R-Area

- R-Area Acid/Caustic Basin

- R-Area Bingham Pump Outage Pit

- R-Area Buming/Rubble Pits

- R-Area Coal Pile

- R-Area Disassembly Basin

- R-Area Reactor Seepage Basins

Sanitary Landfill and B-Area

- B-Area Microbiology Wells

- Sanitary Landfill and Interim Sanitary Landfill

Central Shops (N-Area)

- Ford Building Seepage Basin

- Hazardous Waste Storage Facility

- Hydrofluoric Acid Spill

- N-Area Diesel Spill

- N-Area Burning/Rubble Pits

- N-Area Fire Department Training Facility

\section{D-Area and TNX}

- D-Area Buming/Rubble Pits

- D-Area Oil Seepage Basin

- D-Area Coal Pile, Coal Pile Runoff Containment Basin, and Ash Basins

- New TNX Seepage Basin

- Old TNX Seepage Basin

- Road A Chemical Basin (Baxley Road)

- TNX-Area Assessment Wells

- TNX-Area Background Wells

- TNX-Area Operable Unit Wells

- TNX-Area Recovery Wells

- TNX Burying Ground

- TNX Intrinsic Remediation Piezometers

\section{Other Sites}

- Accelerator for Production of Tritium Area

- Chemicals, Metals, and Pesticides Pits

- Savannah River Ecology Laboratory Flowing Springs Site 


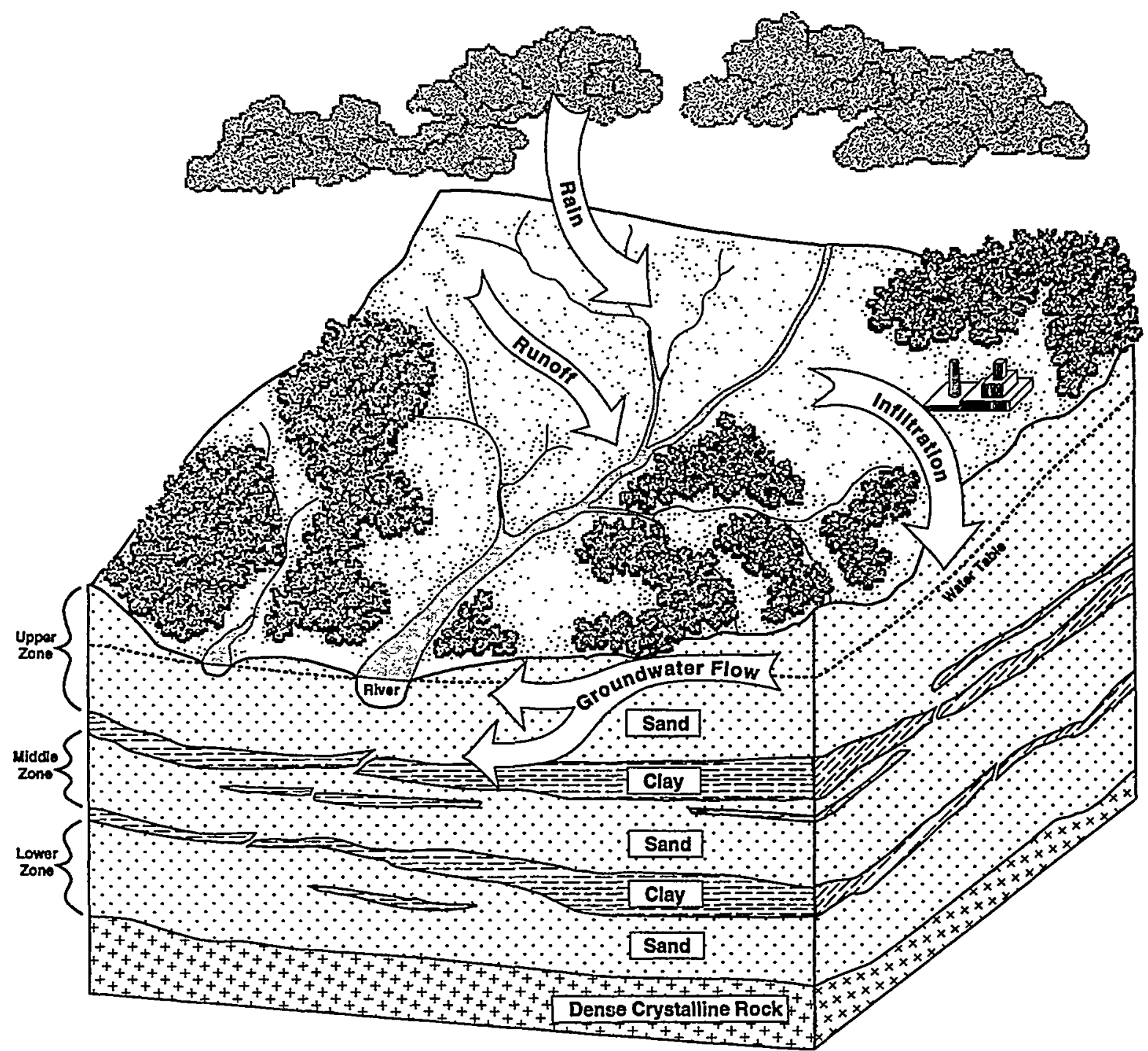

Exploration Resources, Inc.

Figure 10-2 Groundwater at SRS

into the soil (figure 10-2). The water that runs off is called direct runoff, and the water that soaks in and infiltrates the soil is called groundwater. Groundwater moves through the soil and eventually reappears at the surface in springs, swamps, or rivers. Potentially hazardous substances in the soil may dissolve as the groundwater infiltrates and moves down through the soil to the water table. In this way, contaminants in the soil can move with the groundwater and may become a health risk.

SRS is built on a 700-1,200-foot stack of sediments composed of sand, clayey sand, and clay, with a small amount of limestone. Dense crystalline rock lies under the sediments. The groundwater in the vicinity moves through the sediments, mostly in the sand layers. The clay layers allow very little groundwater to flow through them; therefore, their presence between sand layers helps direct the flow of groundwater and contaminants.

At SRS, groundwater moves in several sandy zones that are separated by less permeable clay layers. The upper zone comprises the rainwater that moves down from the surface. Water in this zone moves either laterally to discharge or downward into lower zones. Beneath the upper zone is a clay layer that retards the water moving downward into the lower zones. In some areas of SRS, this clay layer is thick and undisturbed and is effective in preventing the upper zone of groundwater from moving downward. In other areas, this clay layer is thin, broken, or missing, 
and the groundwater from the top zone can move readily into lower zones.

Below the upper zone is another zone of sand where the water moves relatively freely. Water in this middle zone is used for domestic water supplies. Below the middle zone is another clay layer and then a lower zone of groundwater. The lowest zone is the most important aquifer in the region and supplies water to domestic and industrial users.

Groundwater beneath SRS flows slowly-at rates ranging from inches to several hundred feet per year-toward streams and swamps on site and into the Savannah River. Figures $10-3$ and 10-4 illustrate the potentiometric contours and horizontal-flow directions of the middle and lower zones beneath SRS. Similar to contour lines on a weather map that connect points of equal barometric pressure, the figures' potentiometric surface contour lines connect below-ground regions of equal hydraulic head (elevation of the water in a well or piezometer). Horizontal-flow directions of groundwater within these zones are indicated on figures $10-3$ and 10-4 by bold arrows perpendicular to the contour lines. In both zones, the direction of flow beneath monitored waste sites generally is toward the Savannah River, the Savannah River Swamp, Upper Three Runs Creek, or Lower Three Runs Creek. Surface water in the swamp and creeks eventually flows into the Savannah River.

The upper zone is the most affected in general by activity at SRS. The middle zone is known to be contaminated in several areas. Contamination in the lowest zone has been identified only in A-Area and M-Area.

Monitoring wells are used extensively at SRS to assess the effect of site activities on groundwater quality. Most of the wells monitor the highest groundwater zone, although wells in lower zones are present at the sites with the larger groundwater contamination plumes.

\section{Description of the Groundwater Monitoring Program}

The groundwater monitoring program at SRS gathers information to determine the effect of site operations on groundwater quality. The program is designed to

- assist SRS in complying with environmental regulations and U.S. Department of Energy (DOE) directives

- provide data to identify and monitor constituents in the groundwater
- permit characterization of new facility locations to ensure that they are suitable for the intended facilities

- support basic and applied research projects

The groundwater monitoring program at SRS is conducted by the Environmental Geochemistry Group (EGG) of the Environmental Protection Department/Environmental Monitoring Section (EPD/EMS) of Westinghouse Savannah River Company (WSRC). To assist other departments in meeting their responsibilities, EGG provides the services for installing monitoring wells, collecting and analyzing samples, and reporting results.

The Savannah River Site Environmental Monitoring Plan (WSRC-3Q1-2, Section 2000) provides details about the following aspects of the groundwater monitoring program:

- well siting, construction, maintenance, and abandonment

- sample planning

- sample collection and field measurements

- analysis

- data management

- related publications, files, and databases

The next four sections of this chapter present overviews of several of these topics, along with information specific to 1998 .

\section{Sample Scheduling and Collection}

EMS schedules groundwater sampling either in response to specific requests from SRS personnel or as part of its ongoing groundwater monitoring program. These groundwater samples provide data for reports required by federal and state regulations and for internal reports and research projects. The groundwater monitoring program schedules wells to be sampled at intervals ranging from quarterly to triennially.

- Groundwater from new wells added to the program is analyzed for environmental-screening constituents (table 10-1) for 4 consecutive quarters for only the wells identified in the Savannah River Site Screening Program Wells (ESH-EMS-98-0152).

- Environmental-screening analyses are conducted once every 3 years for only the wells identified in the Savannah River Site Screening Program Wells (ESH-EMS-98-0152).

- If their environmental-screening constituent concentrations are above certain limits, wells 


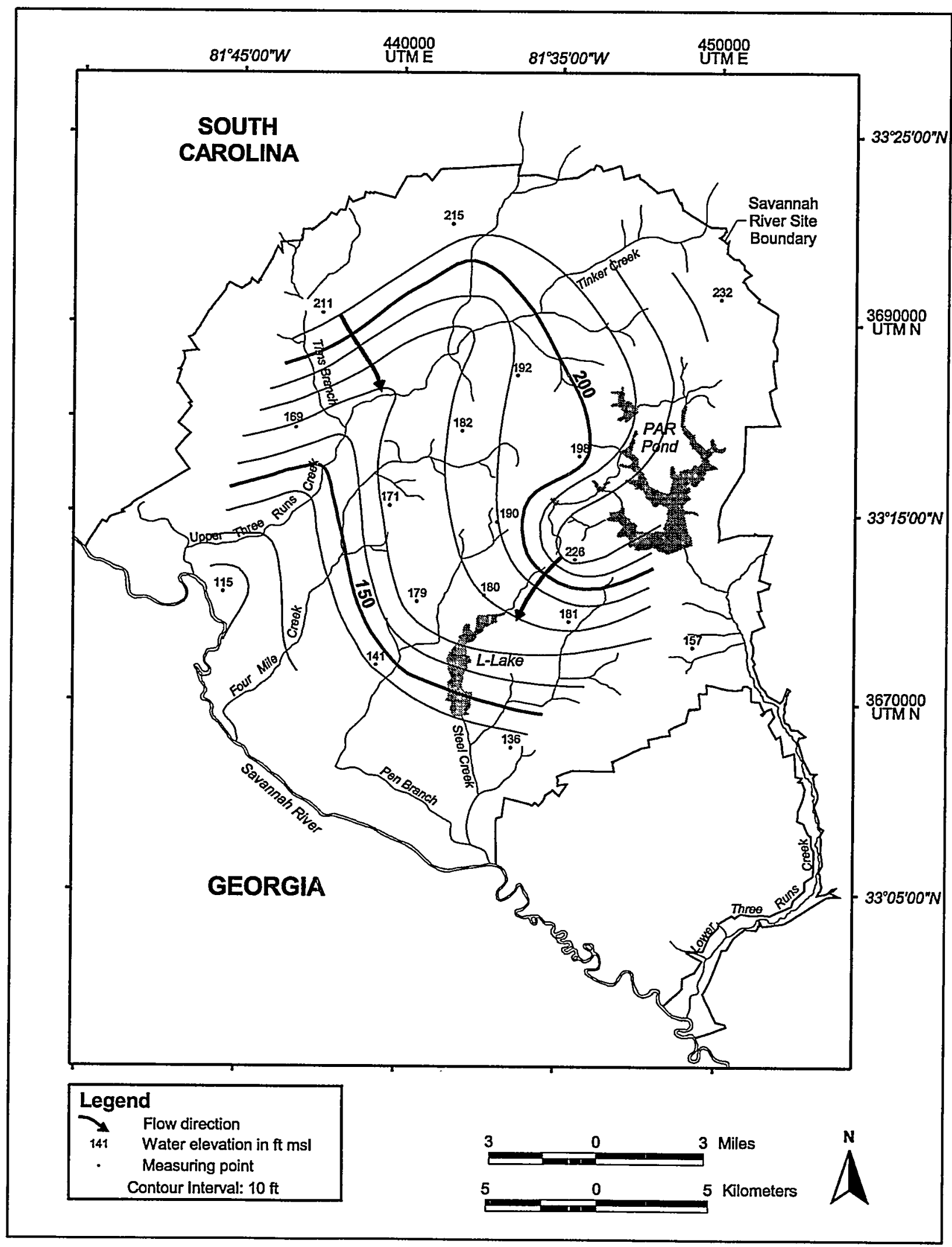

Exploration Resources, Inc.

Figure 10-3 Potentiometric Surface and Horizontal Groundwater Flow Directions of the Middle Zone at SRS During the First Quarter of 1998 


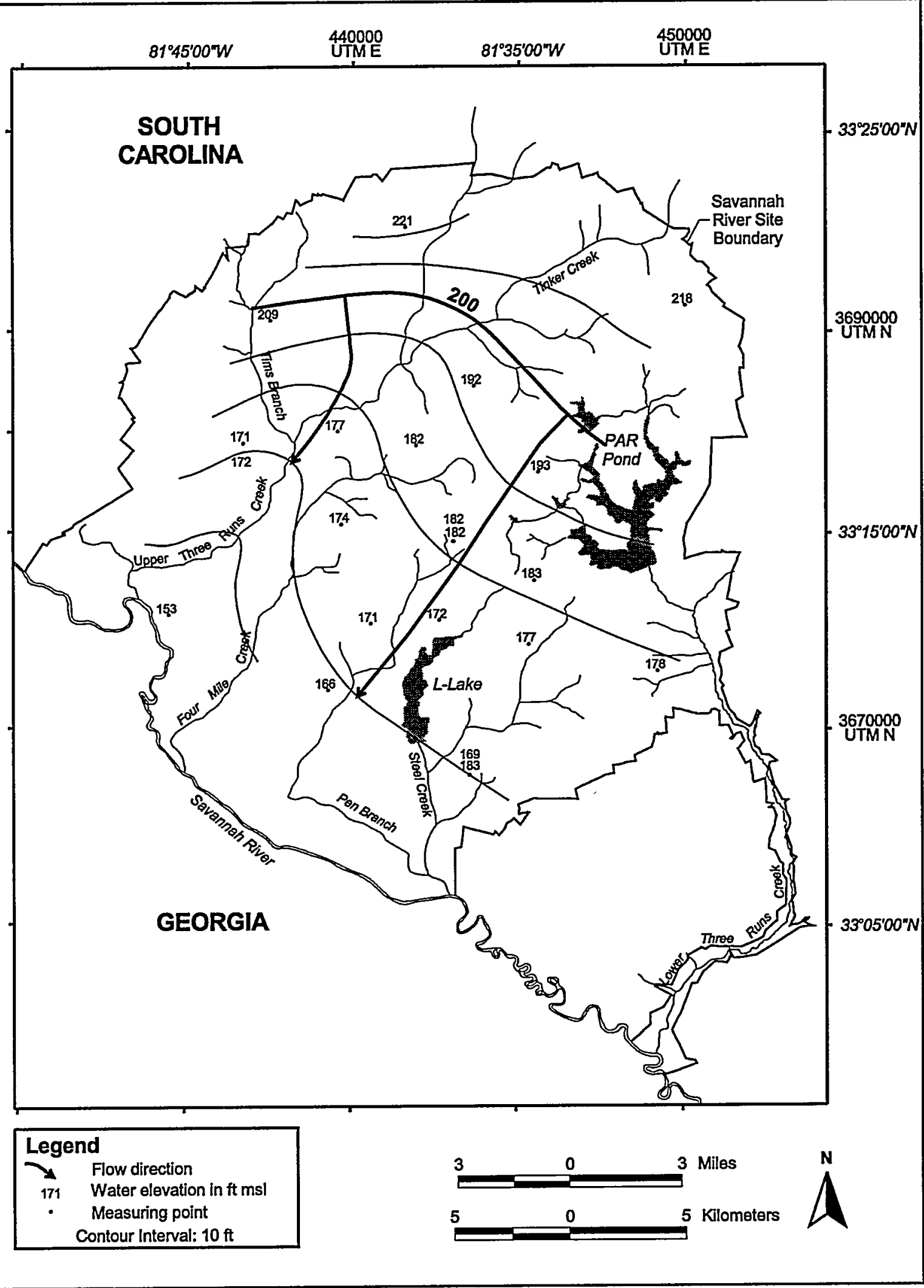

Exploration Resources, Inc.

Figure 10-4 Potentiometric Surface and Horizontal Groundwater Flow Directions of the Lower Zone at SRS During the First Quarter of 1998 
Table 10-1 Environmental-Screening Constituents

Aluminum
Arsenic
Barium
Boron
Cadmium
Calcium
Chloride
Chromium
Fluoride
Gross alpha
Iron
Lead
Lithium
Magnesium
Manganese
Mercury
Nitrate-nitrite as nitrogen
Nonvolatile beta
Potassium
Selenium
Silica
Silver
Sodium
Sulfate
Total dissolved solids
Total organic carbon
Total organic halogens
Total phosphates (as P)
Tritium

identified in the Savannah River Site Screening Program Wells (ESH-EMS-98-0152) are sampled annually.

Personnel outside EMS may request sample collection as often as weekly. In addition to environmental-screening constituents, constituents that may be analyzed by request include suites of herbicides, pesticides, additional metals, volatile organics, and others. Radioactive constituents that may be analyzed by request include gamma emitters, iodine- 129 , strontium-90, radium-228, uranium isotopes, and other alpha and beta emitters.

Groundwater samples are collected from monitoring wells, generally with either pumps or bailers dedicated to the well to prevent cross-contamination among wells. Occasionally, portable sampling equipment is used; this equipment is decontaminated between wells.

Sampling and shipping equipment and procedures are consistent with EPA, South Carolina Department of Health and Environmental Control (SCDHEC), and U.S. Department of Transportation guidelines.
EPA-recommended preservatives and sample-handling techniques are used during sample storage and transportation to both onsite and offsite analytical laboratories. Potentially radioactive samples are screened for total activity (alpha and beta emitters) prior to shipment to determine appropriate packaging and labeling requirements.

Deviations (caused by dry wells, inoperative pumps, etc.) from scheduled sampling and analysis for 1998 are enumerated in the SRS quarterly groundwater monitoring reports cited on the first page of this chapter.

In $1998,34,801$ radiological analyses and 172,249 nonradiological analyses were performed on groundwater samples collected from 1,133 monitoring wells.

\section{Analytical Procedures}

In 1998, General Engineering Laboratories of Charleston, South Carolina; Recra LabNet Philadelphia of Lionville, Pennsylvania; and EMAX Laboratories, Inc., of Torrance, California, performed most of the groundwater analyses. QST

Environmental, Inc., of Gainesville, Florida, and Gulf Coast of Chicago, Illinois, also performed groundwater analyses. The contracted laboratories are certified by SCDHEC to perform specified analyses.

The EMS radiological laboratory at SRS screened potentially radioactive samples for total activity prior to shipment. Environmental Physics, Inc., of Charleston subcontracted radiological analyses from General Engineering Laboratories; Thermo NUtech of Oak Ridge, Tennessee, and Quanterra Incorporated of Richland, Washington, subcontracted radiological analyses from Recra LabNet Philadelphia.

Full lists of constituents analyzed, analytical methods used, and the laboratories' estimated quantitation limits are given in the SRS quarterly groundwater reports referenced earlier.

\section{Evaluation of Groundwater Data}

EMS receives analytical results and field measurements as reports and as ASCI files that are loaded into databases at SRS. Logbooks track receipt and transfer of data to the Geochemical Information Management System (GIMS) database, and computer programs present the data in a format that can be validated.

Quality control practices include the following:

- verification of well names and sample dates for field and analytical data

- verification that all analyses requested on the chain-of-custody forms were completed by each laboratory 
- identification of data entry problems (e.g., duplicate records, incorrect units)

- comparison of analytical data to historical data and review of the data for transcription, instrument, or calculation errors

- comparison of blind replicates and laboratory in-house duplicates for inconsistencies

- identification of laboratory blanks and blind blanks with elevated concentrations

Possible transcription errors and suspect results are documented and submitted to the appropriate laboratory for verification or correction. No changes are made to the database until the laboratory documents the problem and solution. Changes to the database are recorded in a logbook.

The quarterly groundwater monitoring reports identify queried results verified by the laboratory and list groundwater samples associated with blanks having elevated results. These reports also present the results of intralaboratory and interlaboratory quality assurance comparisons (chapter 11, "Quality Assurance").

\section{Changes to the Groundwater Monitoring Program during 1998}

\section{Well Abandonments and Additions; Changes to the Sampling Schedule}

During 1998, three wells were abandoned in the L-Area oil and chemical basin because their 30-foot screens went through a confining unit. The well casings were removed and the shafts filled with soil.

The following 91 wells, piezometers, and tanks were monitored for the first time in 1998:

- One new well was installed in the A-Area rubble pile for Resource Conservation and Recovery Act (RCRA) Facility Investigation/Remedial Investigation (RFI/RI) characterization.

- Eight wells were sampled at the accelerator for production of tritium site to support site characterization.

- Twenty-four new wells were installed in the old burial ground for compliance monitoring to support the 1992 Mixed Waste Management Facility RCRA Part B permit application.

- Four new wells were installed in the C-Area reactor seepage basins to support the RFI/RI investigation.

- Ten new wells were installed in the F.Area burning/rubble pits in conjunction with the RFI/RI project.
- Eleven wells were sampled for the first time in conjunction with the F-Area groundwater remediation system.

- One new well and four new piezometers were installed in the H-Area retention basins in support of RFI/RI characterization.

- Four new wells were installed in the Interim Sanitary Landfill to comply with Subtitle D of the SCDHEC Municipal Solid Waste permit.

- Two new wells were installed in the K-Area burning/rubble pit to support the RFI/RI investigation.

- Two new wells were installed in the L-Area burning/rubble pit to support RFI/RI characterization.

- Three new wells were installed in the miscellaneous chemical basin for sampling in conjunction with the RFI/RI project.

- Thirteen new wells were installed in the N-Area (Central Shops) burning/rubble pits for RFI/RI characterization.

- One new well was installed at the P-Area burning/rubble pit to support RFI/RI characterization.

- One new well was installed in the R-Area Bingham pump outage pit to be sampled in compliance with RFI/RI requirements.

- Two water treatment unit extraction tanks, one in F-Area and one in $\mathrm{H}$-Area, were monitored in 1998, as required for the first time by SCDHEC.

\section{Groundwater Monitoring Results at SRS}

This section summarizes groundwater monitoring results during 1998 for each of the following areas at SRS:

- A-Area and M-Area

- C-Area

- D-Area and TNX

- General separations and waste management areas (E-Area, F-Area, H-Area, S-Area, and Z-Area)

- K-Area

- L-Area and chemicals, metals, and pesticides pits

- N-Area

- P-Area

- R-Area

- Sanitary Landfill and B-Area

Groundwater monitoring results for each area in the above list are (1) illustrated with a figure showing the 
extent of contamination, (2) described in the text, and (3) summarized with a table.

A figure (from each area) shows facilities of interest at or near the site and illustrates areas of notable contamination above DWS. The figures do not specify every contaminant identified through groundwater monitoring, but they illustrate contamination above DWS.

Each figure is accompanied by a brief description of the sites and facilities of interest in the area, an explanation of groundwater flow, and the nature of contamination in the area.

The description of contamination at each area concludes with a table that summarizes the following information:
- major groups of constituents

- percent of wells sampled (for 1996 through 1998) that contained constituents above drinking water standards

- number of wells sampled (for 1996 through 1998) for each constituent group

- sources of contamination

Substantial areas of contamination identified in the tables are illustrated in more detail, in some cases, in the accompanying figures. For example, a table may identify metals contamination, and the figure may show that most of that contamination is lead. 


\section{Groundwater Contamination at A-Area and M-Area}

\section{Location and Facilities}

The administration and manufacturing areas, A-Area and M-Area, are located in the northwest portion of SRS. A-Area houses administrative and research facilities, including the Savannah River Technology Center (SRTC). M-Area was used for production of nuclear fuels, targets, and other reactor components.

A-Area and M-Area include the following facilities and sites associated with the groundwater monitoring program:

- A-Area ash pile

- A-Area burning/rubble pits

- A-Area coal pile runoff containment basin

- A-Area metals burning pit

- M-Area Hazardous Waste Management Facility

- M-Area settling basin

- Metallurgical Laboratory seepage basin

- Miscellaneous chemical basin

- Motor Shop oil basin

- Savannah River Laboratory seepage basins

- Silverton Road waste site

\section{Nature of Contamination}

Surface drainage in A-Area and M-Area is toward Tims Branch, approximately to the east, and toward valleys to the northwest and southwest that lead to the Savannah River. The water table in this vicinity slopes to the southeast, south, and southwest toward Tims Branch and other discharge points. Most of the water of the upper saturated zone migrates downward into lower water-bearing zones.

Figure 10-5 shows the extent of contamination and the location of the various contaminant groups at A-Area and M-Area. There is a large groundwater contamination plume under and downgradient of A-Area and M-Area. Organic constituents-the primary contaminants-are found throughout the area and account for the largest percentage of contaminated wells. Trichloroethylene, tetrachloroethylene, and other organic compounds were used as degreasers during manufacturing and research. After use, organic wastes, metals, and other contaminants were placed into unlined basins, from which they slowly seeped into the groundwater. Contaminants also entered the groundwater as the result of spills or leaking pipes.
The highest concentrations of organics and metals generally are found beneath seepage and settling basins in central and southern portions of the area. The entire contaminant plume covers approximately 3 square miles and is approximately one-third mile from the SRS boundary.

Because of the chemical nature of trichloroethylene and tetrachloroethylene and the groundwater conditions in the upper aquifer zone, the contaminant movement generally is downward into deeper aquifers. Once in the deeper aquifers, these contaminants may be moved horizontally by faster groundwater flow rates.

The ASB 6 well cluster monitors the contaminant plume just west of the Savannah River Laboratory seepage basins. Figure 10-6 illustrates the concentration of trichloroethylene in these wells since January 1992. The trichloroethylene concentration is highest in well ASB 6AA, which monitors an aquifer zone below those monitored by wells ASB 6A and ASB 6C. Trichloroethylene concentrations also are notable in well ASB 6TA, which monitors the Crouch Branch Aquifer Zone, the deepest aquifer zone monitored in A-Area and M-Area.

Trending data for trichloroethylene and tetrachloroethylene contamination in A-Area and M-Area indicate that all wells on the southern extent of the central portion of the areas show an upward trend for concentrations. All other recovery wells show downward trends or no overall trends. Trending data for the selected monitoring wells show no clear indication of localized plume movement or removal. Table 10-2 summarizes 1996-1998 groundwater monitoring results for A-Area and M-Area.

\section{Remediation}

Ongoing remediation efforts have substantially altered the groundwater and contaminant flow patterns in the upper, middle, and lower aquifer zones beneath A-Area and M-Area. These efforts include capping the basins and extracting and processing volatile organics from the groundwater. About 377,000 pounds of volatile organics were removed from the groundwater from 1985 through the end of 1998. Remediation efforts also included pumping contaminated air to six soil vacuum-extraction units, where the volatile organic compounds were destroyed. These units destroyed approximately 356,000 pounds of degreaser solvent from 1994 through the end of 1998. While ongoing remediation never will clean up contaminated groundwater zones completely, it can slow the spread of contamination and minimize the impact to the environment. 


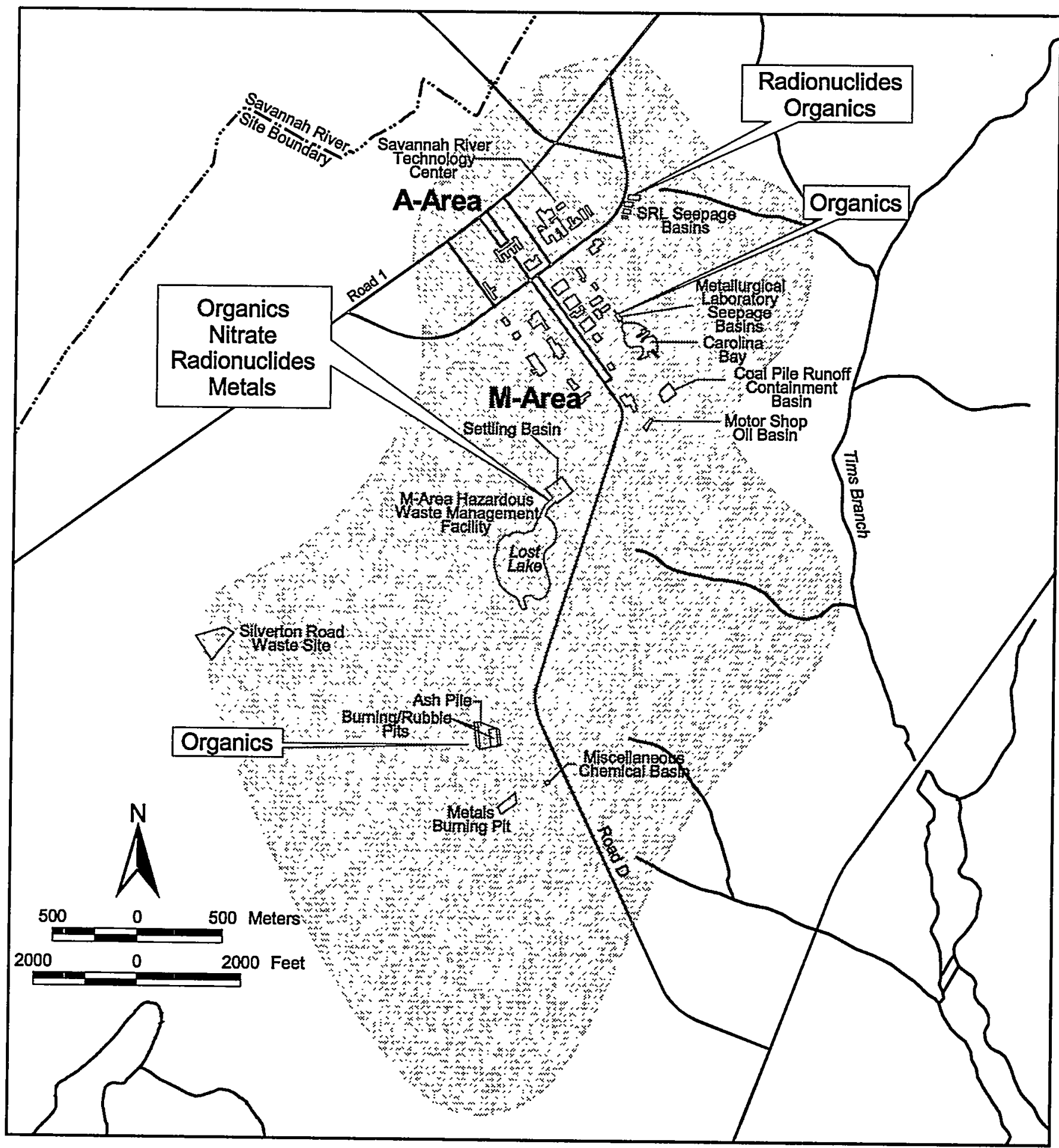

Exploration Resources, Inc. Figure 10-5 Extent of Groundwater Contamination Beneath A-Area and M-Area in 1998 and Location of Noteworthy
Sources of Contamination Exceeding Drinking Water Standards 
Trichloroethylene Concentrations Well Cluster ASB 6

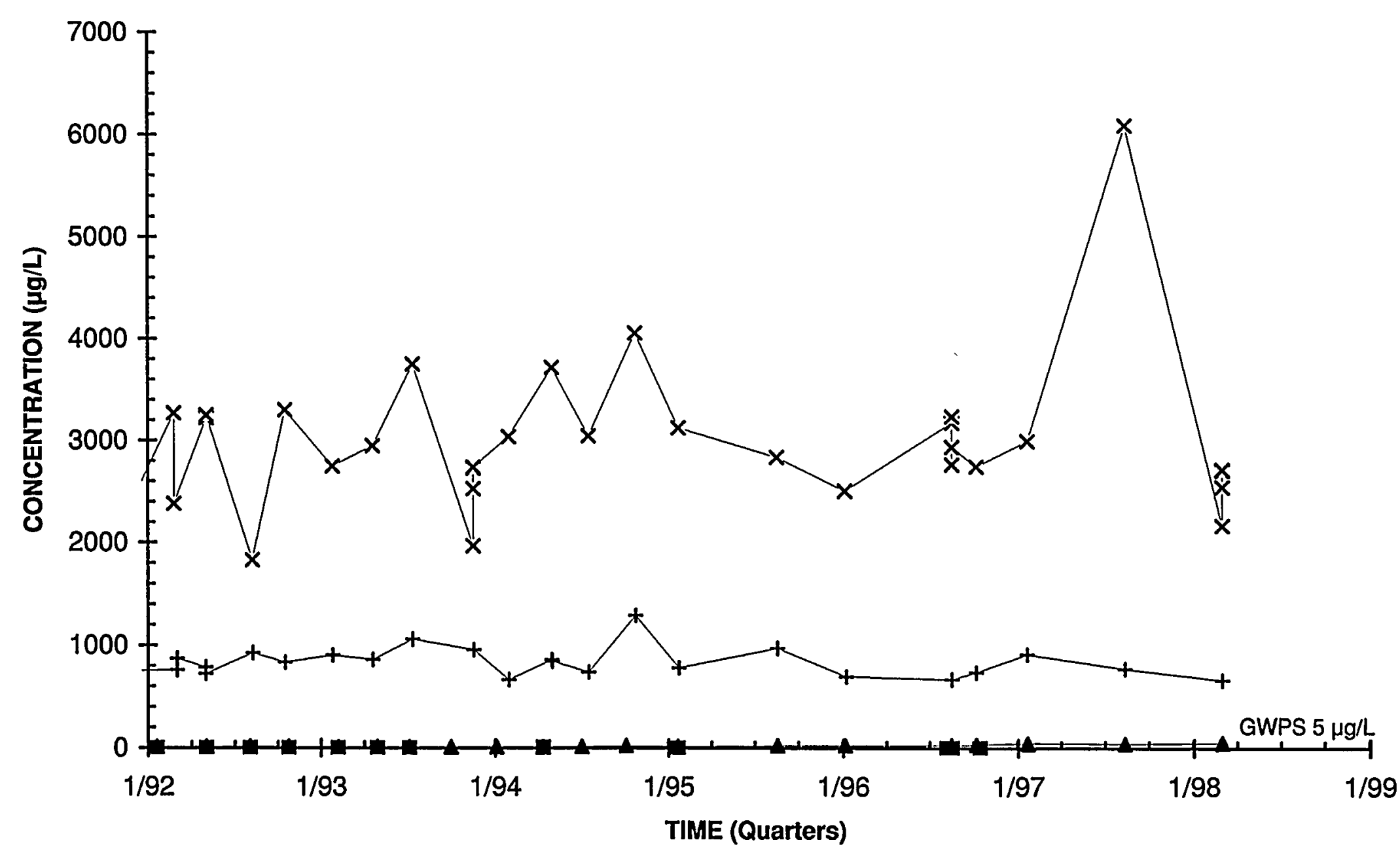

$\rightarrow$ ASB 6A (M) - - ASB 6C (LL) -X-ASB 6AA (MCBC) -ASB 6TA (CBA)

Note: $M=M$ Area: $L L=L o w e r$ Lost Lake: $M C B C=$ Middle Sand: $C B A=$ Crouch

Figure 10-6 Trichloroethylene Concentrations in Well Cluster ASB 6

Exploration Resources, Inc. 
Table 10-2 Constituent Groups Above Drinking Water Standards at A-Area and M-Area, 1996-1998

\begin{tabular}{lccc|ccccl}
\hline & \multicolumn{4}{l}{$\begin{array}{l}\text { Percent of Wells } \\
\text { With Results }\end{array}$} \\
Constituent Groups & \multicolumn{3}{l}{$\begin{array}{l}\text { Number of } \\
\text { Abolls Sampled }\end{array}$} & Sources of Contamination \\
\hline & 1996 & 1997 & 1998 & 1996 & 1997 & 1998 & \\
\hline Dioxins/furans & $0 \%$ & $0 \%$ & $0 \%$ & 14 & 13 & 14 & None \\
Metals & $7 \%$ & $2 \%$ & $5 \%$ & 294 & 288 & 271 & $\begin{array}{l}\text { HWMF, Motor Shop oil basin, settling } \\
\text { basin, Silverton Road waste site }\end{array}$ \\
Organics & $57 \%$ & $54 \%$ & $58 \%$ & 296 & 288 & 273 & $\begin{array}{l}\text { Burning/rubble pits, HWMF, metals burn- } \\
\text { ing pit, Met Lab seepage basin, SRL } \\
\text { seepage basins }\end{array}$ \\
Pesticides/PCBs & $0 \%$ & $5 \%$ & $0 \%$ & 73 & 43 & 49 & None \\
Tritium & $2 \%$ & $0 \%$ & $0 \%$ & 52 & 41 & 1 & None \\
Other radionuclides & $4 \%$ & $24 \%$ & $10 \%$ & 295 & 271 & 261 & HWMF, SRL seepage basins \\
Other constituents & $7 \%$ & $7 \%$ & $5 \%$ & 289 & 276 & 267 & HWMF \\
\hline
\end{tabular}

Note: Drinking Water Standards refer to federal final primary DWS, proposed primary DWS, and interim final primary DWS. 


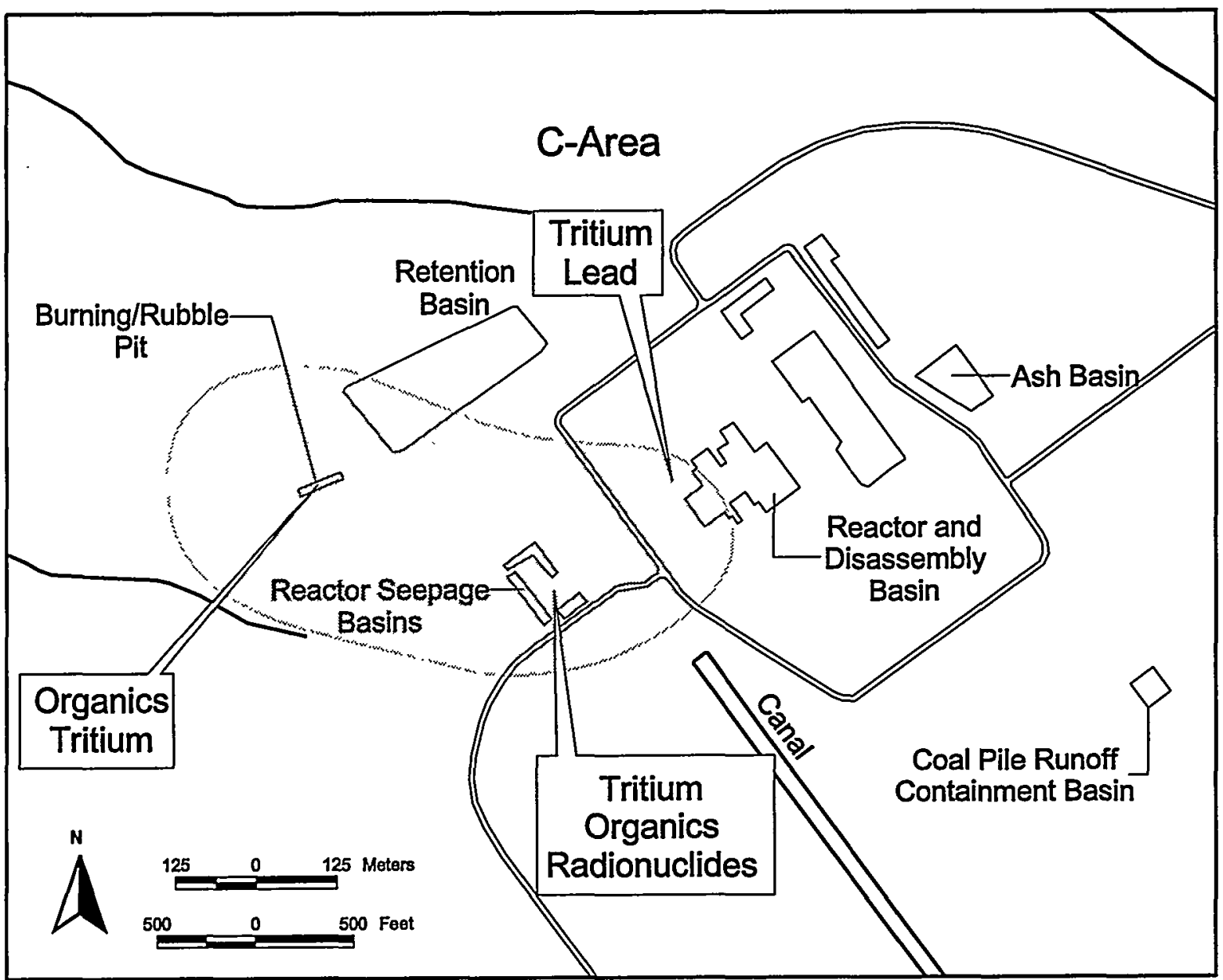

Exploration Resources, Inc.

Figure 10-7 Extent of Groundwater Contamination Beneath C-Area in 1998 and Location of Noteworthy Sources of Contamination Exceeding Drinking Water Standards

\section{Groundwater Contamination at C-Area}

\section{Location and Facilities}

C-Area, which is in the west-central part of SRS, contains the C-Area reactor. The C-Area reactor achieved criticality in March 1955 and was shut down in 1985 for maintenance. It was placed on cold standby in 1987 , followed by cold shutdown.

C-Area includes the following facilities associated with the groundwater monitoring program:

- C-Area bioremediation facility

- C-Area ash basin

- C-Area burning/rubble pit

- C-Area coal pile runoff containment basin

- C-Area disassembly basin
- C-Area reactor

- C-Area reactor seepage basins

- C-Area retention basin

\section{Nature of Contamination}

Groundwater flow beneath C-Area tends to be toward incised creeks near the area. Horizontal flow generally is west toward Four Mile Creek (also known as Fourmile Branch), and surface drainage is predominantly west toward a tributary of Four Mile Creek.

During routine reactor operations, the radioactivity level from tritium built up in the disassembly basins that held activated target rods. Periodically, the water from these basins was purged to limit worker exposure. During different time periods, the water was discharged to the reactor seepage basins or to surface streams. Tritium also escaped from the disassembly basins. 
The C-Area burning/rubble pit and basins also received materials that could cause groundwater contamination.

Figure 10-7 shows the extent of contamination and the location of the various contaminant groups at C-Area. Consistent with results from previous years, trichloroethylene is the most widespread contaminant. Tritium and other radionuclides are also elevated in several wells in the vicinity of the seepage basins and the reactor disassembly basin.

Table 10-3 shows the tritium concentrations in selected C-Area wells from 1995 to 1998. Previous years' sampling has shown that thallium is present in wells near the burning/rubble pit and reactor seepage basins, and other constituents are elevated in a few wells. Monitoring results from 1998 are consistent with those of previous years. Table 10-4 summarizes 1996-98 groundwater monitoring results for C-Area.

Table 10-3 Tritium Concentrations (in $\mu \mathrm{Ci} / \mathrm{mL}$ ) in Selected C-Area Wells, 1995-1998

\begin{tabular}{lllll}
\hline Well & 1995 & 1996 & 1997 & 1998 \\
\hline CRP 1 & $2.0 \mathrm{E}-05$ & $2.11 \mathrm{E}-05$ & NA & $2.73 \mathrm{E}-05$ \\
CRP 3D & $1.2 \mathrm{E}-05$ & $1.16 \mathrm{E}-05$ & $1.06 \mathrm{E}-05$ & $1.33 \mathrm{E}-05$ \\
CRP 5D & NA & $1.94 \mathrm{E}-05$ & $1.24 \mathrm{E}-05$ & $1.15 \mathrm{E}-05$ \\
CRP 10D & NA & NA & $8.86 \mathrm{E}-06$ & $1.42 \mathrm{E}-05$ \\
CRP 11D & NA & NA & NA & $1.24 \mathrm{E}-05$ \\
\hline
\end{tabular}

Notes: $\mathrm{NA}=$ not analyzed. Well CRP 5D went dry before it could be sampled for tritium in 1995. Wells CRP 10D and CRP 11D were not installed until mid-1997. Wells CRP 1 and 11D were not sampled for tritium in 1997.

Data for wells are from fourth quarter for 1995, first quarter for 1996 and 1998, and first quarter for 1997-oxcept for well CRP 10D, which is from third quarter.

The federal final primary DWS for tritium is $2.0 \mathrm{E}-05 \mu \mathrm{Ci} / \mathrm{mL}$.

Table 10-4 Constituent Groups Above Drinking Water Standards at C-Area, 1996-1998

\begin{tabular}{|c|c|c|c|c|c|c|c|}
\hline \multirow[t]{2}{*}{ Constituent Groups } & \multicolumn{3}{|c|}{$\begin{array}{l}\text { Percent of Wells } \\
\text { With Results } \\
\text { Above Standards }\end{array}$} & \multicolumn{3}{|c|}{$\begin{array}{l}\text { Number of } \\
\text { Wells Sampled }\end{array}$} & \multirow[t]{2}{*}{ Sources of Contamination } \\
\hline & 1996 & 1997 & 1998 & 1996 & 1997 & 1998 & \\
\hline Dioxins/furans & - & - & - & - & - & - & \\
\hline Metals & $63 \%$ & $60 \%$ & $0 \%$ & 19 & 15 & 5 & None \\
\hline Organics & $56 \%$ & $67 \%$ & $33 \%$ & 18 & 18 & 6 & $\begin{array}{l}\text { Burning/rubble pit, reactor seepage ba- } \\
\text { sins }\end{array}$ \\
\hline Pesticides/PCBs & $0 \%$ & $0 \%$ & $0 \%$ & 12 & 6 & 4 & None \\
\hline Tritium & $56 \%$ & $58 \%$ & $22 \%$ & 18 & 12 & 9 & $\begin{array}{l}\text { Disassembly basin, reactor seepage ba- } \\
\text { sins, burning/rubble pit }\end{array}$ \\
\hline Other radionuclides & $9 \%$ & $36 \%$ & $60 \%$ & 11 & 11 & 5 & Reactor seepage basins \\
\hline Other constituents & $0 \%$ & $0 \%$ & $0 \%$ & 12 & 17 & 5 & None \\
\hline
\end{tabular}

Notes: Drinking Water Standards refer to federal final primary DWS, proposed primary DWS, and interim final primary DWS.

Dioxins/furans were not sampled at C-Area during 1996, 1997, and 1998. 


\section{Groundwater Contamination at D-Area and TNX}

\section{Location and Facilities}

D-Area, located in the southwest part of SRS, includes a large coal-fired power plant and the inactive heavy-water facilities.

D-Area includes the following facilities associated with the groundwater monitoring program:

- D-Area burning/rubble pits

- D-Area coal pile, coal pile runoff containment basin, and ash basins

- D-Area oil disposal basin

- Road A chemical basin (Baxley Road)

TNX, also located in the southwest part of SRS-and operated by SRTC - tests equipment prior to installation and develops new designs. The nearest SRS boundary is the Savannah River, approximately one-quarter mile to the west.

Facilities in TNX include the following:

- New TNX seepage basin

- Old TNX seepage basin

- TNX burying ground

\section{Nature of Contamination}

The water table in D-Area discharges to the Savannah River and to a nearby swamp along Beaver Dam Creek. The water table surface in the vicinity of the coal pile runoff containment basin in D-Area is very close to the ground surface and drains to Beaver Dam Creek, which flows into the Savannah River Swamp.

Figure 10-8 shows the extent of contamination and the location of the various contaminant groups at D-Area and TNX. There is substantial contamination of the groundwater near the coal pile runoff containment basin. The water is characterized by high conductivity and total dissolved solids. Elevated levels of metals, alpha-emitting radionuclides, and volatile organics are present. The contamination is consistent with the leaching of coal and coal ash. During past years, high levels of nickel were detected in several D-Area wells, with the highest concentrations found in well DCB 1A. Nickel analyses were not requested for 1998.

A separate plume of contaminated groundwater is present near the D-Area oil disposal basin. Volatile organics and lead have been detected above DWS. Table 10-5 shows tetrachloroethylene and trichloroethylene concentrations in selected D-Area wells from 1994 to 1998.

The water table in TNX discharges to the Savannah River and the nearby Savannah River Swamp.

There is a plume of contaminated groundwater underneath much of TNX and downgradient into the Savannah River Swamp. Volatile organic compounds and nitrate are the most widely distributed contaminants. Metals also are present near the known disposal sites. Table 10-6 summarizes 1996-1998 groundwater monitoring results for D-Area and TNX. 


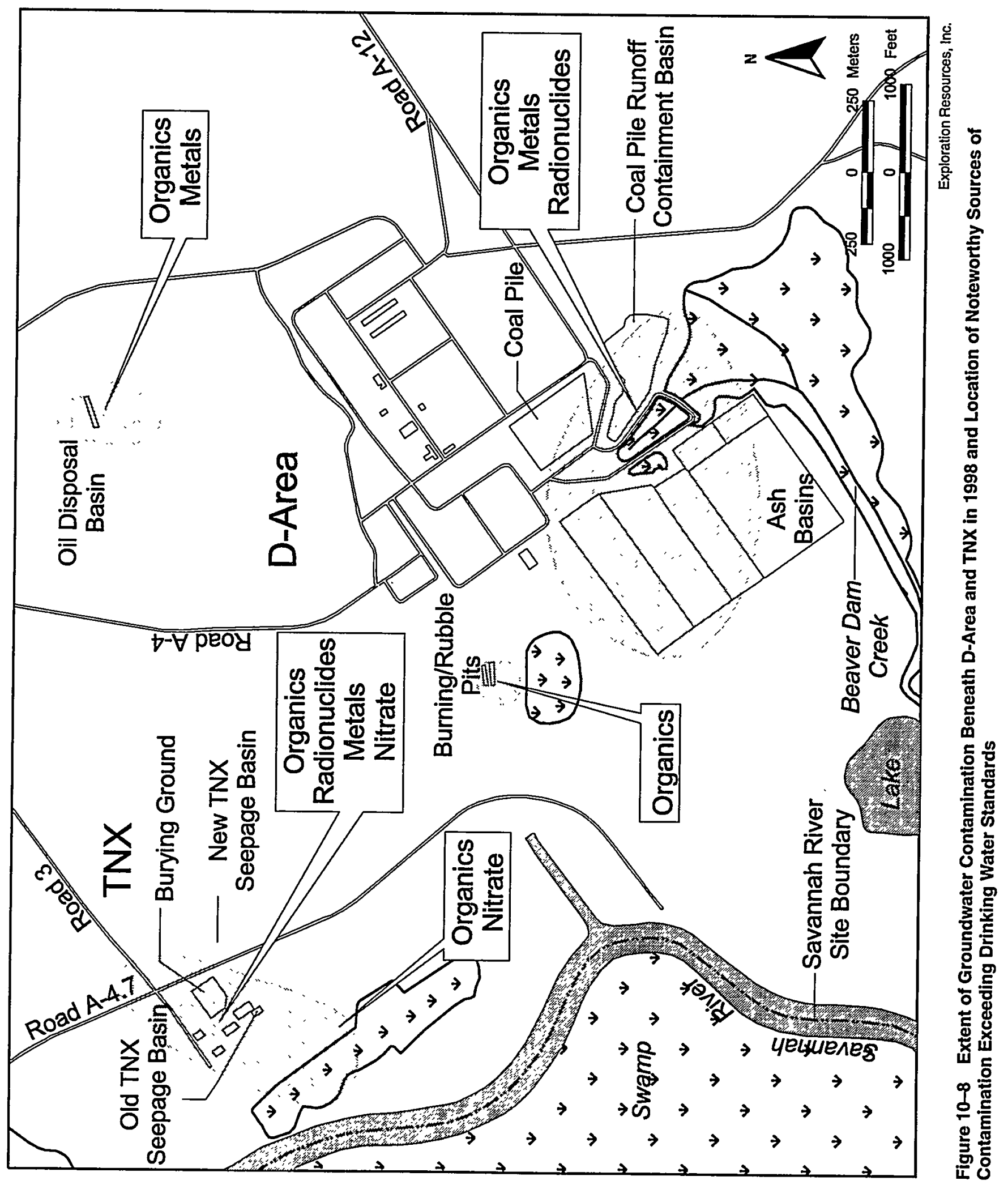


Table 10-5 Tetrachloroethylene and Trichloroethylene Concentrations (in $\mu \mathrm{g} / \mathrm{L}$ ) in Selected D-Area Wells, 1994-1998

\begin{tabular}{lllllll}
\hline Well & Contaminant & 1994 & 1995 & 1996 & 1997 & 1998 \\
\hline DOB 1 & Tetrachloroethylene & 22 & 12 & 14.6 & 0.495 & 3.45 \\
& Trichloroethylene & 83 & 53 & 87.7 & 0.762 & $<5.00$ \\
DOB 2 & Tetrachloroethylene & $<1.0$ & $<2.0$ & $<5.00$ & 2.59 & $<5.00$ \\
& Trichloroethylene & $<1.0$ & $<2.0$ & $<5.00$ & 21.6 & $<5.00$ \\
DOB 7 & Tetrachloroethylene & NA & NA & 18.5 & 3.02 & 8.07 \\
& Trichloroethylene & NA & NA & 118 & 3.96 & $<5.00$ \\
DOB 8 & Tetrachloroethylene & NA & NA & 7.64 & $<1.00$ & 7.60 \\
& Trichloroethylene & NA & NA & 0.650 & $<1.00$ & $<5.00$ \\
DOB 10 & Tetrachloroethylene & NA & NA & $<5.00$ & 7.34 & $<5.00$ \\
& Trichloroethylene & NA & NA & $<5.00$ & 39.1 & $<5.00$ \\
DOB 12 & Tetrachloroethylene & NA & 13 & 1.82 & 9.12 & 1.29 \\
& Trichloroethylene & NA & 34 & 3.61 & 8.14 & 2.54
\end{tabular}

Notes: $N A=$ not analyzed. Wells DOB 7 and 10 were not installed until September 1994. Well DOB 12 was not installed until December 1995. Wells DOB 7, 8, and 10 were not sampled in 1995.

Data for 1994 are from third quarter. Data for 1995 are from third quarter, except for well DOB 12, which is from fourth quarter. Data for 1996 and 1998 are from second quarter. Data for 1997 are from fourth quarter.

The federal final primary DWS for tetrachloroethylene is $5 \mu \mathrm{g} / \mathrm{mL}$. The federal primary DWS for trichloroethylene is $5 \mu \mathrm{g} / \mathrm{mL}$.

Table 10-6 Constituent Groups Above Drinking Water Standards at D-Area and TNX, 1996-1998

\begin{tabular}{|c|c|c|c|c|c|c|c|}
\hline \multirow[t]{2}{*}{ Constituent Groups } & \multicolumn{3}{|c|}{$\begin{array}{l}\text { Percent of Wells } \\
\text { With Results } \\
\text { Above Standards }\end{array}$} & \multicolumn{3}{|c|}{$\begin{array}{l}\text { Number of } \\
\text { Wells Sampled }\end{array}$} & \multirow[t]{2}{*}{ Sources of Contamination } \\
\hline & 1996 & 1997 & 1998 & 1996 & 1997 & 1998 & \\
\hline Dioxins/furans & $0 \%$ & $0 \%$ & $0 \%$ & 8 & 31 & 30 & None \\
\hline Metals & $20 \%$ & $36 \%$ & $16 \%$ & 76 & 107 & 43 & $\begin{array}{l}\text { Coal facilities, oil disposal basin, old } \\
\text { TNX seepage basin, TNX burying } \\
\text { ground }\end{array}$ \\
\hline Organics & $40 \%$ & $41 \%$ & $52 \%$ & 75 & 108 & 44 & $\begin{array}{l}\text { Coal facilities, oil disposal basin, old } \\
\text { TNX seepage basin, TNX burying } \\
\text { ground, burning/rubble pit }\end{array}$ \\
\hline Pesticides/PCBs & $0 \%$ & $0 \%$ & $0 \%$ & 59 & 80 & 30 & None \\
\hline Tritium & $0 \%$ & $2 \%$ & $0 \%$ & 60 & 99 & 7 & None \\
\hline Other radionuclides & $12 \%$ & $29 \%$ & $18 \%$ & 60 & 99 & 37 & Coal facilities, TNX burying ground \\
\hline Other constituents & $15 \%$ & $16 \%$ & $23 \%$ & 73 & 104 & 37 & $\begin{array}{l}\text { Old TNX seepage basin, TNX burying } \\
\text { ground }\end{array}$ \\
\hline
\end{tabular}

Notes: Drinking Water Standards refer to federal final primary DWS, proposed primary DWS, and interim final primary DWS. 


\section{Groundwater Contamination at the General Separations and Waste Management Areas}

\section{Location and Facilities}

The separations and waste management areas, which include E-Area, F-Area, H-Area, S-Area, and Z-Area, are located in the central part of SRS.

Reactor-produced materials are processed in the chemical separations plants in F-Area and H-Area, where uranium, plutonium-238, and plutonium-239 are separated from each other and from fission products. These areas also have facilities for purification and packaging of tritium and for storage of fission wastes.

The separations and waste management areas include the following facilities associated with the groundwater monitoring program:

\section{E-Area}

- Burial Ground expansion (E-Area Vaults)

- Burial Grounds perimeter

- E-Area Hazardous Waste/Mixed Waste Disposal Facility

- Old Burial Ground

- Radioactive Waste Burial Ground (also known as Solid Waste Disposal Facility)

\section{F-Area}

- F-Area acid/caustic basin

- F-Area Burma Road rubble pit

- F-Area burning/rubble pits

- F-Area canyon building and A-Line Uranium Recovery Facility

- F-Area coal pile runoff containment basin and ash basins

- F-Area effluent treatment cooling water basin

- F-Area sanitary sludge land application site

- F-Area seepage basins and inactive process sewer line

- F-Area tank farm

- New F-Area retention basin

- Old F-Area retention basin

- Old F-Area seepage basin

\section{H-Area}

- H-Area acid/caustic basin
- H-Area auxiliary pump pit

- H-Area canyon building

- H-Area coal pile runoff containment basin and ash basin

- H-Area effluent treatment cooling water basin

- H-Area sanitary sludge land application site

- H-Area retention basin

- H-Area seepage basins and inactive process sewer line

- H-Area tank farm

- New H-Area retention basin

- Old H-Area retention basin

S-Area

- Defense Waste Processing Facility Vitrification Building

- S-Area auxiliary pump pit

- S-Area low-point pump pit

Z-Area

- Z-Area low-point drain tank

- Z-Area Saltstone Disposal Facility

- Waste Solidification and Disposal Facility

\section{Nature of Contamination}

Surface drainage in these areas of SRS is to Four Mile Creek to the south and Upper Three Runs Creek and its tributaries to the north and west.

E-Area, F-Area, and H-Area are located on the groundwater divide between Four Mile Creek and Upper Three Runs Creek. Near-surface groundwater in the southern portions of these areas discharges to Four Mile Creek and its tributaries. Near-surface groundwater in the northern portions of these areas discharges to Upper Three Runs Creek and its tributaries to the north.

S-Area and Z-Area are located on the groundwater divide between Upper Three Runs Creek and its tributaries to the west.

Figure 10-9 shows the extent of contamination and the location of the various contaminant groups at the general separations areas. The facilities at E-Area, F-Area, and H-Area have been sources of substantial groundwater pollution. In the past, the seepage and retention basins in F-Area and $\mathrm{H}$-Area have been used to dispose of liquids containing radionuclides, metals, organics, and nitrates. Radioactive liquids have leaked into the groundwater below the tank farms. Tritium and metals have leached from 
materials buried in E-Area. Several stabilization and closure programs have been implemented to reduce the impact of the sources of groundwater contamination. Radionuclides were detected in one well in Z-Area during 1998, and contamination was found in the vicinity of the vitrification building in Z-Area.

Many groundwater contamination plumes overlap in the area. Plumes from the Old Burial Ground and the F-Area and $\mathrm{H}$-Area seepage basins discharge radionuclides, metals, nitrates, and tritium into Four Mile Creek. An extensive tritium plume is migrating north from the Solid Waste Disposal Facility. Other plumes are under the buildings, tank farms, and other waste disposal areas.

The F-Area Hazardous Waste Management Facility well network monitors three distinct hydrostratigraphic units in the uppermost aquifer beneath the facility. Figure 10-10 illustrates the concentration of gross alpha in well cluster FSB 95 since January 1992. The gross alpha concentration is higher in well FSB 95DR but is also notable in FSB 95CR. Groundwater flow in Water Table and Barnwell/McBean aquifer zones generally are south or southwest toward Four Mile Creek. Table 10-7 summarizes 1996-1998 groundwater monitoring results for the general separations and waste management areas.

Table 10-7 Constituent Groups Above Drinking Water Standards at the General Separations and Waste Management Areas, 1996-1998

\begin{tabular}{|c|c|c|c|c|c|c|c|}
\hline \multirow[t]{2}{*}{ Constituent Groups } & \multicolumn{3}{|c|}{$\begin{array}{l}\text { Percent of Wells } \\
\text { With Results } \\
\text { Above Standards }\end{array}$} & \multicolumn{3}{|c|}{$\begin{array}{l}\text { Number of } \\
\text { Wells Sampled }\end{array}$} & \multirow[t]{2}{*}{ Sources of Contamination } \\
\hline & 1996 & 1997 & 1998 & 1996 & 1997 & 1998 & \\
\hline Dioxins/furans & $0 \%$ & $0 \%$ & $0 \%$ & 14 & 14 & 14 & None \\
\hline Metals & $24 \%$ & $16 \%$ & $21 \%$ & 414 & 520 & 334 & $\begin{array}{l}\text { Canyon buildings, tank farms, seepage } \\
\text { basins, Burial Grounds }\end{array}$ \\
\hline Organics & $12 \%$ & $8 \%$ & $10 \%$ & 376 & 384 & 371 & $\begin{array}{l}\text { Burial Grounds, burning/rubble pit, can- } \\
\text { yon buildings, F-Area seepage basins }\end{array}$ \\
\hline Pesticides/PCBs & $0 \%$ & $0 \%$ & $0 \%$ & 31 & 38 & 21 & None \\
\hline Tritium & $54 \%$ & $48 \%$ & $51 \%$ & 435 & 432 & 426 & $\begin{array}{l}\text { Burial Grounds, canyon buildings, tank } \\
\text { farms, seepage basins }\end{array}$ \\
\hline Other radionuclides & $39 \%$ & $37 \%$ & $43 \%$ & 422 & 441 & 412 & $\begin{array}{l}\text { Burial Grounds, seepage basins, tank } \\
\text { farms, saltstone disposal facility }\end{array}$ \\
\hline Other constituents & $28 \%$ & $25 \%$ & $28 \%$ & 339 & 365 & 322 & Seepage basins, burning/rubble pit \\
\hline
\end{tabular}

Notes: Drinking Water Standards refer to federal final primary DWS, proposed primary DWS, and interim final primary DWS. 


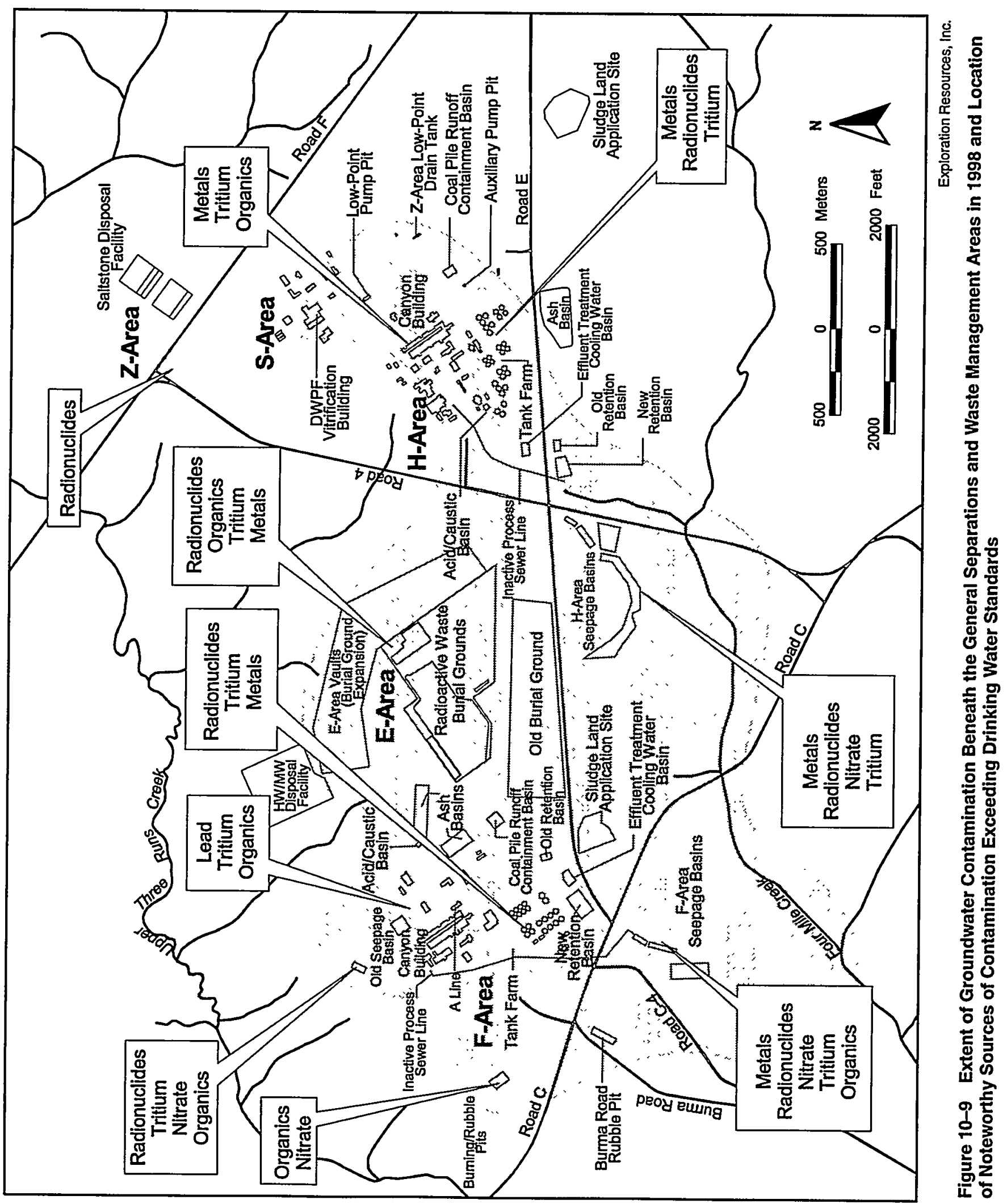



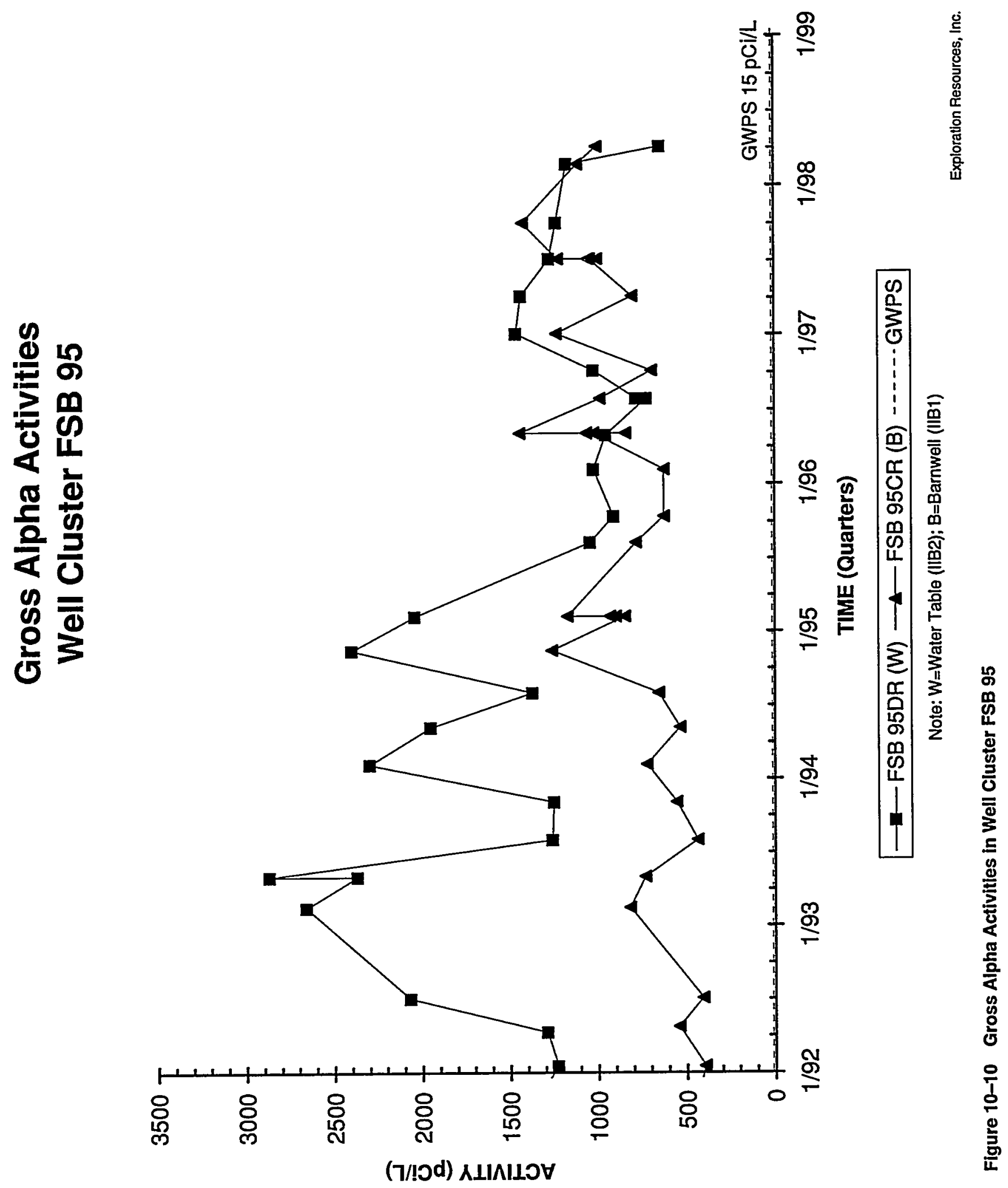


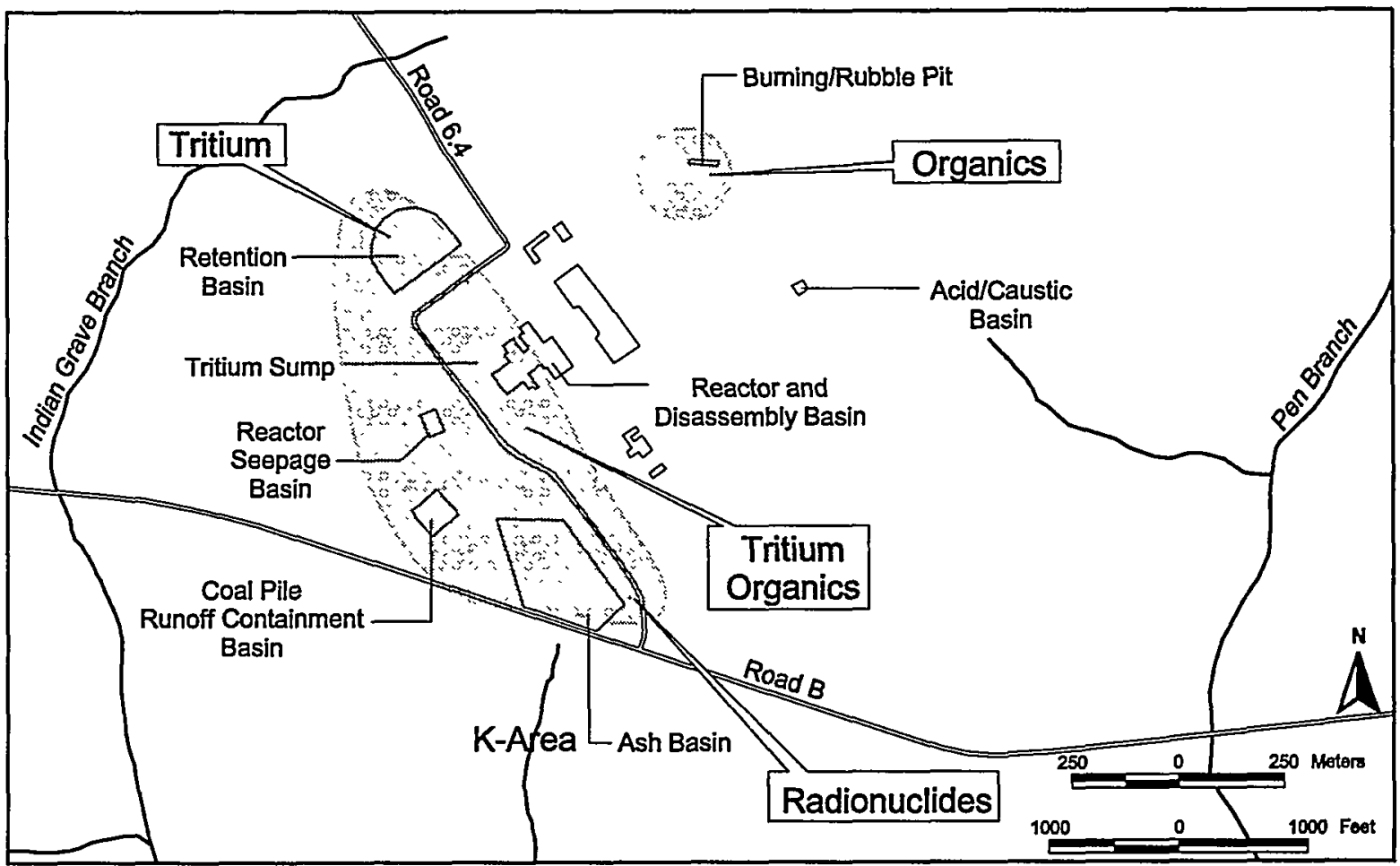

Exploration Resources, Inc.

Figure 10-11 Extent of Groundwater Contamination Beneath K-Area in 1998 and Location of Noteworthy Sources of Contamination Exceeding Drinking Water Standards

\section{Groundwater Contamination at K-Area}

Location and Facilities

$\mathrm{K}$-Area is in the south-central part of SRS and contains the K-Area reactor, which achieved criticality in 1954 and was shut down in 1988 for maintenance. The reactor was placed in cold shutdown in February 1996.

$\mathrm{K}$-Area includes the following facilities associated with the groundwater monitoring program:

- $\mathrm{K}$-Area ash basin

- K-Area Bingham pump outage pit

- K-Area burning/rubble pit

- K-Area coal pile runoff containment basin

- K-Area diesel tank spill

- K-Area disassembly basin

- K-Area reactor

- K-Area reactor seepage basin

- K-Area retention basin

- $\quad \mathrm{K}$-Area tritium sump

\section{Nature of Contamination}

The bisection of Pen Branch and Indian Grave Branch isolates the near-surface groundwater. Deeper groundwater flows toward the Savannah River.

Figure 10-11 shows the extent of contamination and the location of the various contaminant groups in $\mathrm{K}$-Area. Several plumes of contaminated groundwater exist at $\mathrm{K}$-Area. The largest plume consists of tritium-contaminated water around the disassembly basin, the reactor seepage basin, and the retention basin. As described in the C-Area discussion, these sites are known sources of tritium. Low levels of volatile organics are detected in some wells that monitor this plume.

Table 10-8 shows tritium concentrations in selected K-Area wells from 1994 to 1998.

Some groundwater under and near the ash basin and the coal pile runoff containment basin has gross-alpha contamination. This is a typical contaminant leached from coal and coal ash.

The groundwater underneath the burning/rubble pit is contaminated with tetrachloroethylene.

Table 10-9 summarizes 1996-1998 groundwater monitoring results for K-Area. 
Table 10-8 Tritium Concentrations (in $\mu \mathrm{Ci} / \mathrm{mL}$ ) in Selected K-Area Wells, 1994-1998

\begin{tabular}{llllll}
\hline Well & 1994 & 1995 & 1996 & 1997 & 1998 \\
\hline KDB 1 & $1.5 \mathrm{E}-03$ & $3.0 \mathrm{E}-04$ & $7.3 \mathrm{E}-05$ & $7.0 \mathrm{E}-05$ & $1.2 \mathrm{E}-04$ \\
KDB 2 & $5.0 \mathrm{E}-03$ & $5.2 \mathrm{E}-03$ & $5.8 \mathrm{E}-03$ & $7.8 \mathrm{E}-03$ & $3.0 \mathrm{E}-03$ \\
KDB 3 & $4.3 \mathrm{E}-05$ & $5.2 \mathrm{E}-05$ & $5.2 \mathrm{E}-05$ & $3.8 \mathrm{E}-05$ & $6.2 \mathrm{E}-05$ \\
KDB 4 & $\mathrm{NA}$ & $1.6 \mathrm{E}-04$ & $2.1 \mathrm{E}-04$ & $3.2 \mathrm{E}-04$ & $6.3 \mathrm{E}-04$ \\
KDB 5 & $\mathrm{NA}$ & $4.5 \mathrm{E}-03$ & $2.5 \mathrm{E}-04$ & $3.4 \mathrm{E}-05$ & $3.5 \mathrm{E}-04$ \\
\hline
\end{tabular}

Notes: $\mathrm{NA}=$ not analyzed. Wells KDB 4 and 5 were not installed until January 1995.

All data are from third quarter of the respective years, except for 1995 data for wells KDB 1 and 2. These data are from first quarter because these wells were not sampled for tritium during third quarter 1995.

The federal final primary DWS for tritium is $2.0 \mathrm{E}-05 \mu \mathrm{Ci} / \mathrm{mL}$.

Table 10-9 Constituent Groups Above Drinking Water Standards at K-Area, 1996-1998

\begin{tabular}{|c|c|c|c|c|c|c|c|}
\hline \multirow[t]{2}{*}{ Constituent Groups } & \multicolumn{3}{|c|}{$\begin{array}{l}\text { Percent of Wells } \\
\text { With Results } \\
\text { Above Standards }\end{array}$} & \multicolumn{3}{|c|}{$\begin{array}{l}\text { Number of } \\
\text { Wells Sampled }\end{array}$} & \multirow[t]{2}{*}{ Sources of Contamination } \\
\hline & 1996 & 1997 & 1998 & 1996 & 1997 & 1998 & \\
\hline Dioxins/furans & 一 & - & - & 一 & - & - & \\
\hline Metals & $18 \%$ & $0 \%$ & $0 \%$ & 33 & 15 & 13 & None \\
\hline Organics & $31 \%$ & $57 \%$ & $38 \%$ & 16 & 7 & 8 & $\begin{array}{l}\text { Burning/rubble pit, disassembly basin, } \\
\text { reactor seepage basin }\end{array}$ \\
\hline Pesticides/PCBs & $0 \%$ & - & $0 \%$ & 5 & - & 6 & None \\
\hline Tritium & $63 \%$ & $87 \%$ & $60 \%$ & 24 & 15 & 10 & $\begin{array}{l}\text { Disassembly basin, reactor seepage ba- } \\
\text { sin, retention basin }\end{array}$ \\
\hline Other radionuclides & $4 \%$ & $18 \%$ & $17 \%$ & 27 & 17 & 12 & $\begin{array}{l}\text { Ash basin, coal pile runoff containment } \\
\text { basin }\end{array}$ \\
\hline Other constituents & $0 \%$ & $0 \%$ & $0 \%$ & 16 & 11 & 8 & None \\
\hline
\end{tabular}

Notes: Drinking Water Standards refer to federal final primary DWS, proposed primary DWS, and interim final primary DWS.

Dioxins/furans were not sampled at K-Area during 1996, 1997, and 1998. Pesticides/PCBs were not sampled at K-Area during 1997. 


\section{Groundwater Contamination at L-Area and the Chemicals, Metals, and Pesticides Pits}

\section{Location and Facilities}

L-Area is in the south-central part of SRS and contains the L-Area reactor, which achieved criticality in 1954 and continued production until 1968 , when it was placed in warm standby. It subsequently operated from 1985 until 1988, when it was shut down for maintenance. It was placed in warm standby in December 1991 to be put into operation as a backup to K-Reactor, if necessary, but since has been placed in cold shutdown.

L-Area includes the following facilities associated with the groundwater monitoring program:

- 108-3L Bioremediation facility

- L-Area acid/caustic basin

- L-Area Bingham pump outage pits

- L-Area burning/rubble pits

- L-Area disassembly basin

- L-Area oil and chemical basin

- L-Area reactor

- L-Area reactor seepage basin

The chemicals, metals, and pesticides (CMP) pits are near the head of Pen Branch. The pits were used from 1971 to 1979 to dispose of waste consisting of drummed oil, organic solvents, and small amounts of pesticides and metals. In 1984, the pits were excavated to form two trenches, backfilled, and capped. During excavation, most of the contaminated material was removed to the Hazardous Waste Storage Facility.

\section{Nature of Contamination}

Figure 10-12 shows the extent of contamination and the location of the various contaminant groups at L-Area and the CMP pits. There is a plume of contaminated groundwater downgradient between the L-Area reactor buildings and L-Lake. Tritium is the most extensive contaminant, and results from current and previous years show that lead, nitrate, and tetrachloroethylene are present in low concentrations. Tritium activity in a monitoring well about 1,000 feet southwest of the reactor building has increased substantially since 1994 . Tetrachloroethylene and nitrate are present near the disassembly basin and the oil and chemical basin.

Several small tributaries of Steel Creek receive surface drainage from L-Area. The near-surface groundwater discharges to Steel Creek and Pen Branch.

A plume of groundwater beneath the CMP pits is contaminated with volatile organics and metals. Monitoring results from 1998 were similar to those of previous years.

Surface drainage at the CMP pits is to the north toward Pen Branch and to the south toward a tributary of Pen Branch. Groundwater flows downward and horizontally away from the pits.

Table 10-10 summarizes 1996-1998 groundwater monitoring results for L-Area and the CMP pits. 


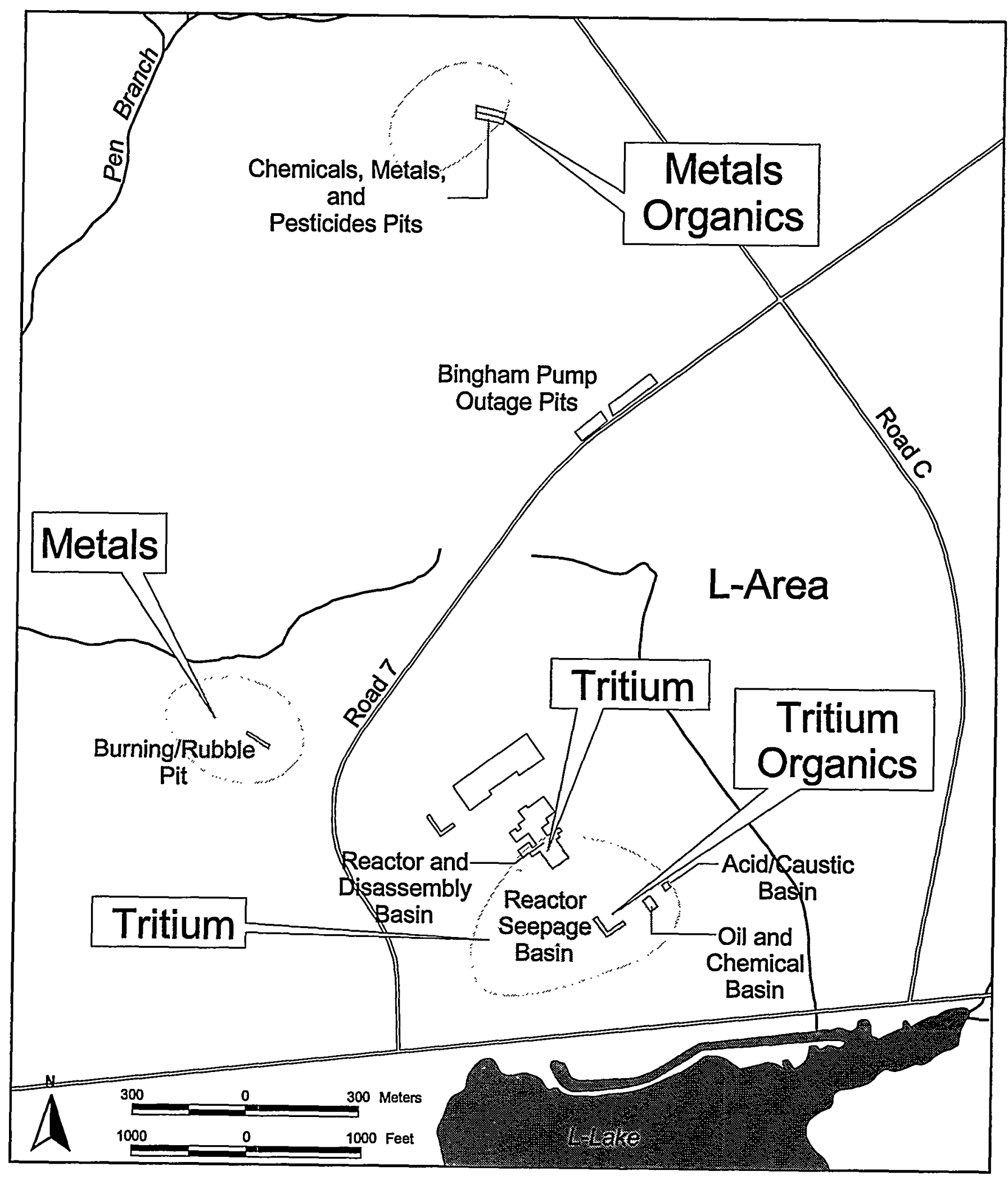

Exploration Resources, Inc.

Figure 10-12 Extent of Groundwater Contamination Beneath L-Area and the Chemicals, Metals, and Pesticides Pits in 1998 and Location of Noteworthy Sources of Contamination Exceeding Drinking Water Standards 
Table 10-10 Constituent Groups Above Drinking Water Standards at L-Area and the Chemicals, Metals, and Pesticides Pits, 1996-1998

\begin{tabular}{|c|c|c|c|c|c|c|c|}
\hline \multirow[t]{2}{*}{ Constituent Groups } & \multicolumn{3}{|c|}{$\begin{array}{l}\text { Percent of Wells } \\
\text { With Results } \\
\text { Above Standards }\end{array}$} & \multicolumn{3}{|c|}{$\begin{array}{l}\text { Number of } \\
\text { Wells Sampled }\end{array}$} & \multirow[t]{2}{*}{ Sources of Contamination } \\
\hline & 1996 & 1997 & 1998 & 1996 & 1997 & 1998 & \\
\hline Dioxins/furans & - & - & - & - & - & - & \\
\hline Metals & $19 \%$ & $9 \%$ & $23 \%$ & 26 & 22 & 13 & CMP pits, burning/rubble pit \\
\hline Organics & $25 \%$ & $27 \%$ & $8 \%$ & 20 & 159 & 12 & CMP pits, oil and chemical basin \\
\hline Pesticides/PCBs & $0 \%$ & $0 \%$ & $0 \%$ & 13 & 7 & 6 & None \\
\hline Tritium & $25 \%$ & $30 \%$ & $36 \%$ & 24 & 20 & 14 & $\begin{array}{l}\text { Disassembly basin, oil and chemical ba- } \\
\text { sin, reactor seepage basin }\end{array}$ \\
\hline Other radionuclides & $0 \%$ & $5 \%$ & $0 \%$ & 18 & 19 & 9 & None \\
\hline Other constituents & $0 \%$ & $6 \%$ & $0 \%$ & 13 & 18 & 10 & None \\
\hline
\end{tabular}

Notes: Drinking Water Standards refer to federal final primary DWS, proposed primary DWS, and interim final primary DWS.

Dioxins/furans were not sampled at L-Area or the CMP pits during 1996, 1997, and 1998. 


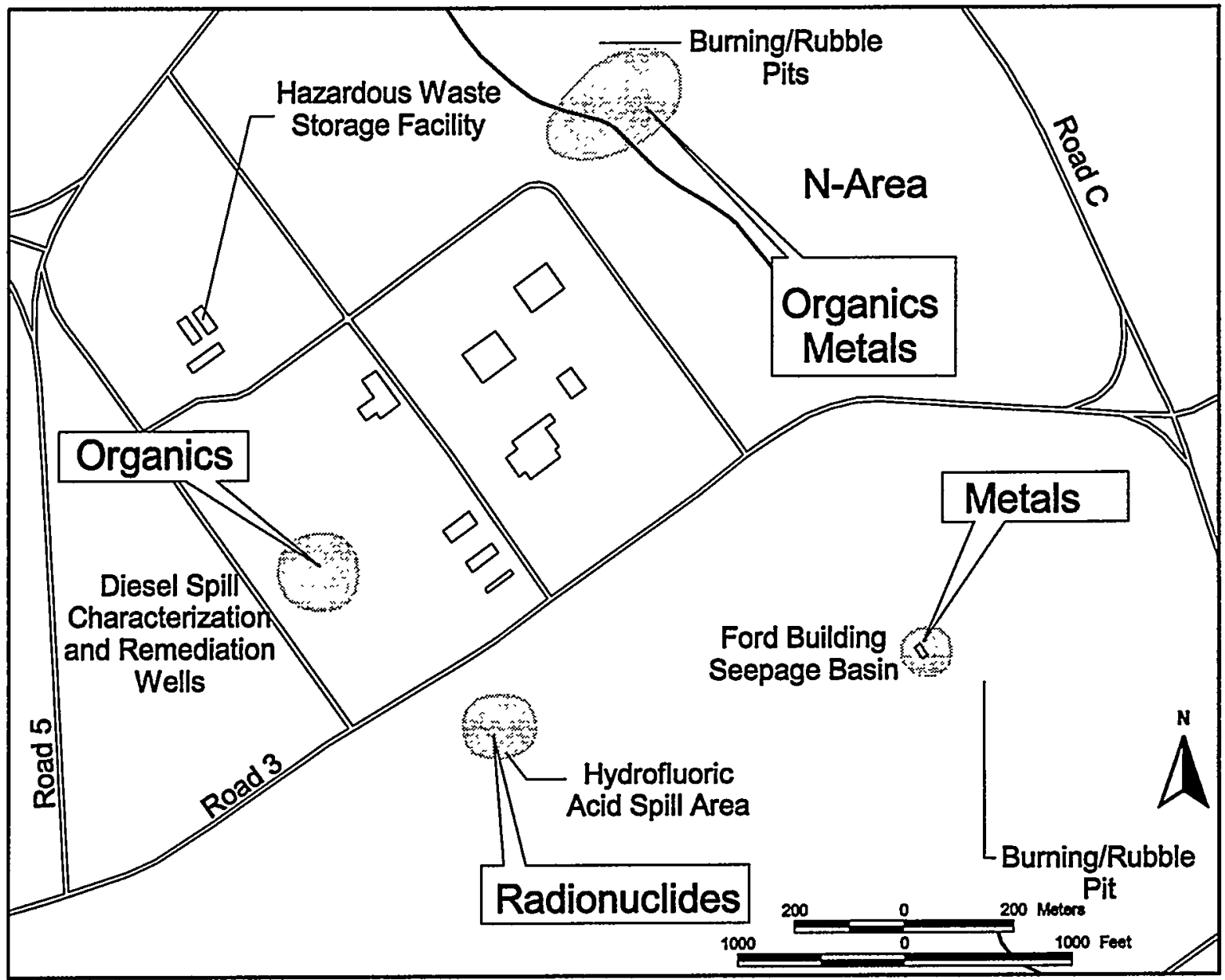

Exploration Resources, Inc.

Figure 10-13 Extent of Groundwater Contamination Beneath N-Area in 1998 and Location of Noteworthy Sources of Contamination Exceeding Drinking Water Standards

\section{Groundwater Contamination at N-Area}

\section{Location and Facilities}

N-Area, also called the Central Shops area, is located in the central part of SRS and provides supply, maintenance, and other support services for the site.

$\mathrm{N}$-Area includes the following facilities associated with the groundwater monitoring program:

- Ford Building seepage basin

- Hazardous Waste Storage Facility

- Hydrofluoric acid spill
- N-Area burning/rubble pits

- N-Area diesel spill

- N-Area Fire Department Training Facility

Figure 10-13 shows the extent of contamination and the location of the various contaminant groups in $\mathrm{N}$-Area. Surface drainage in $\mathrm{N}$-Area is to tributaries of Four Mile Creek to the north, west, and south and to tributaries of Pen Branch to the east. Four Mile Creek, Upper Three Runs Creek, and several other incised creeks are located between $\mathrm{N}$-Area and the SRS boundary and are areas of groundwater discharge. Figure 10-1 shows the locations of these streams. Table 10-11 summarizes 1996-1998 groundwater monitoring results for $\mathrm{N}$-Area. 
Table 10-11 Constituent Groups Above Drinking Water Standards at N-Area, 1996-1998

\begin{tabular}{|c|c|c|c|c|c|c|c|}
\hline \multirow[t]{2}{*}{ Constituent Groups } & \multicolumn{3}{|c|}{$\begin{array}{l}\text { Percent of Wells } \\
\text { With Results } \\
\text { Above Standards }\end{array}$} & \multicolumn{3}{|c|}{$\begin{array}{l}\text { Number of } \\
\text { Wells Sampled }\end{array}$} & \multirow[t]{2}{*}{ Sources of Contamination } \\
\hline & 1996 & 1997 & 1998 & 1996 & 1997 & 1998 & \\
\hline Dioxins/furans & - & - & $0 \%$ & - & - & 3 & None \\
\hline Metals & $0 \%$ & $9 \%$ & $11 \%$ & 8 & 11 & 10 & $\begin{array}{l}\text { Ford Building seepage basin, burning/ } \\
\text { rubble pits }\end{array}$ \\
\hline Organics & $0 \%$ & $33 \%$ & $11 \%$ & 1 & 3 & 10 & Diesel spill, burning/rubble pits \\
\hline Pesticides/PCBs & - & $0 \%$ & $0 \%$ & 一 & 1 & 10 & None \\
\hline Tritium & $0 \%$ & $0 \%$ & $0 \%$ & 6 & 8 & 7 & None \\
\hline Other radionuclides & $0 \%$ & $0 \%$ & $14 \%$ & 3 & 8 & 7 & Hydrofluoric acid spill area \\
\hline Other constituents & $0 \%$ & $0 \%$ & $0 \%$ & 3 & 10 & 10 & None \\
\hline \multicolumn{8}{|c|}{$\begin{array}{l}\text { Notes: Drinking Water Standards refer to federal final primary DWS, proposed primary DWS, and interim } \\
\text { final primary DWS. }\end{array}$} \\
\hline \multicolumn{8}{|c|}{$\begin{array}{l}\text { Dioxins/furans were not sampled at N-Area during } 1996 \text { and 1997. Pesticides/PCBs were not sampled at } \\
\text { N-Area during } 1996 .\end{array}$} \\
\hline
\end{tabular}




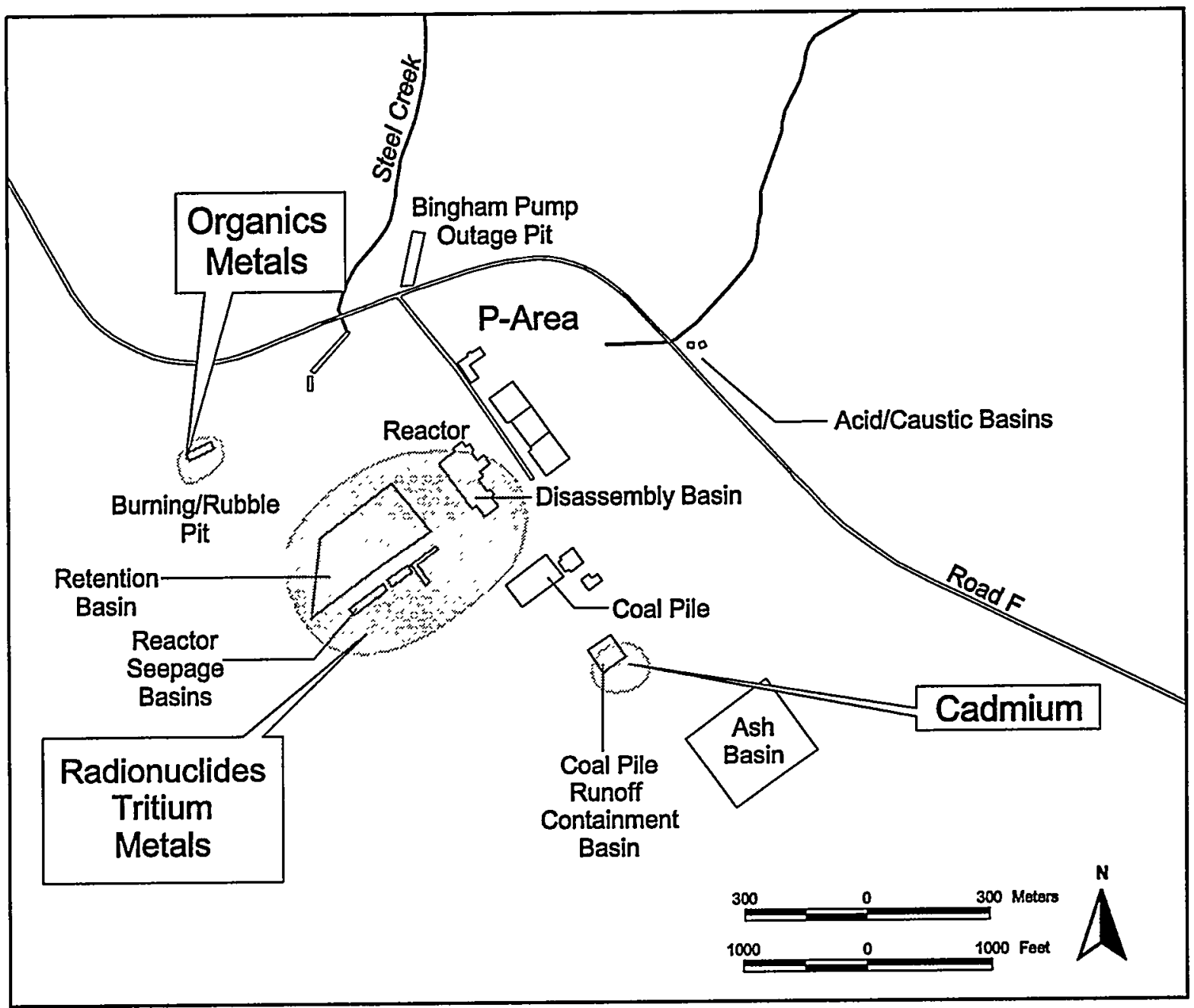

Exploration Resources, Inc.

Figure 10-14 Extent of Groundwater Contamination Beneath P-Area in 1998 and Location of Noteworthy Sources of Contamination Exceeding Drinking Water Standards

\section{Groundwater Contamination at P-Area}

\section{Location and Facilities}

P-Area, located in the south-central part of SRS, houses the P-Area reactor, which achieved criticality in 1954, was shut down for maintenance in 1987, and has since been placed in cold shutdown.

P-Area includes the following facilities associated with the groundwater monitoring program:

- P-Area acid/caustic basins

- P-Area ash basin

- P-Area Bingham pump outage pit

- P-Area burning/rubble pit
- P-Area coal pile and coal pile runoff containment basin

- P-Area disassembly basin

- P-Area reactor

- P-Area reactor seepage basins

- P-Area retention basin

\section{Nature of Contamination}

Lower Three Runs Creek to the east, Steel Creek to the southwest, and Meyers Branch to the south and east isolate the near-surface groundwater in P-Area. Figure 10-1 shows the locations of these streams. The horizontal hydraulic gradients vary across P-Area and increase near a tributary to PAR Pond. The horizontal gradients also increase near a tributary to Steel Creek to the southeast.

Figure 10-14 shows the extent of contamination and the location of various contaminant groups at P-Area. 
The largest plume of contaminated groundwater in P-Area historically has consisted of tritium contamination near the disassembly basin and the reactor seepage basins. The sampling of previous years shows that lead is elevated in a few wells near the seepage basins. The available results are consistent with those of past years and are expected, based on the tritium disposal at these sites.

As in the past, low levels of trichloroethylene were detected in the groundwater near the burning/rubble pits.

Table 10-12 summarizes 1996-1998 groundwater monitoring results for $\mathrm{P}$-Area.

Table 10-12 Constituent Groups Above Drinking Water Standards at P-Area, 1996-1998

\begin{tabular}{lccc|cccc}
\hline & \multicolumn{2}{l}{$\begin{array}{l}\text { Percent of Wells } \\
\text { With Results } \\
\text { Constituent Groups }\end{array}$} & $\begin{array}{l}\text { Number of } \\
\text { Above Standards }\end{array}$ & Wells Sampled & Sources of Contamination \\
\hline & 1996 & 1997 & 1998 & 1996 & 1997 & 1998 & \\
\hline Dioxins/furans & - & - & - & - & - & - & \\
Metals & $20 \%$ & $23 \%$ & $14 \%$ & 20 & 22 & 7 & $\begin{array}{l}\text { Burning/rubble pit, coal pile runoff con- } \\
\text { tainment basin, reactor seepage basins }\end{array}$ \\
Organics & $25 \%$ & $13 \%$ & $25 \%$ & 4 & 15 & 4 & Burning/rubble pit \\
Pesticides/PCBs & - & $0 \%$ & $0 \%$ & - & 13 & 4 & None \\
Tritium & $67 \%$ & $67 \%$ & $0 \%$ & 15 & 15 & 7 & None \\
Other radionuclides & $0 \%$ & $10 \%$ & $7 \%$ & 6 & 20 & 14 & Reactor seepage basins \\
Other constituents & $0 \%$ & $0 \%$ & $0 \%$ & 13 & 19 & 7 & None \\
\hline
\end{tabular}

Notes: Drinking Water Standards refer to federal final primary DWS, proposed primary DWS, and interim final primary DWS.

Dioxins/furans were not sampled at P-Area during 1996, 1997, and 1998. Pesticides/PCBs were not sampled at P-Area during 1996. Tritium was not sampled in all the P-Area wells during 1998. 


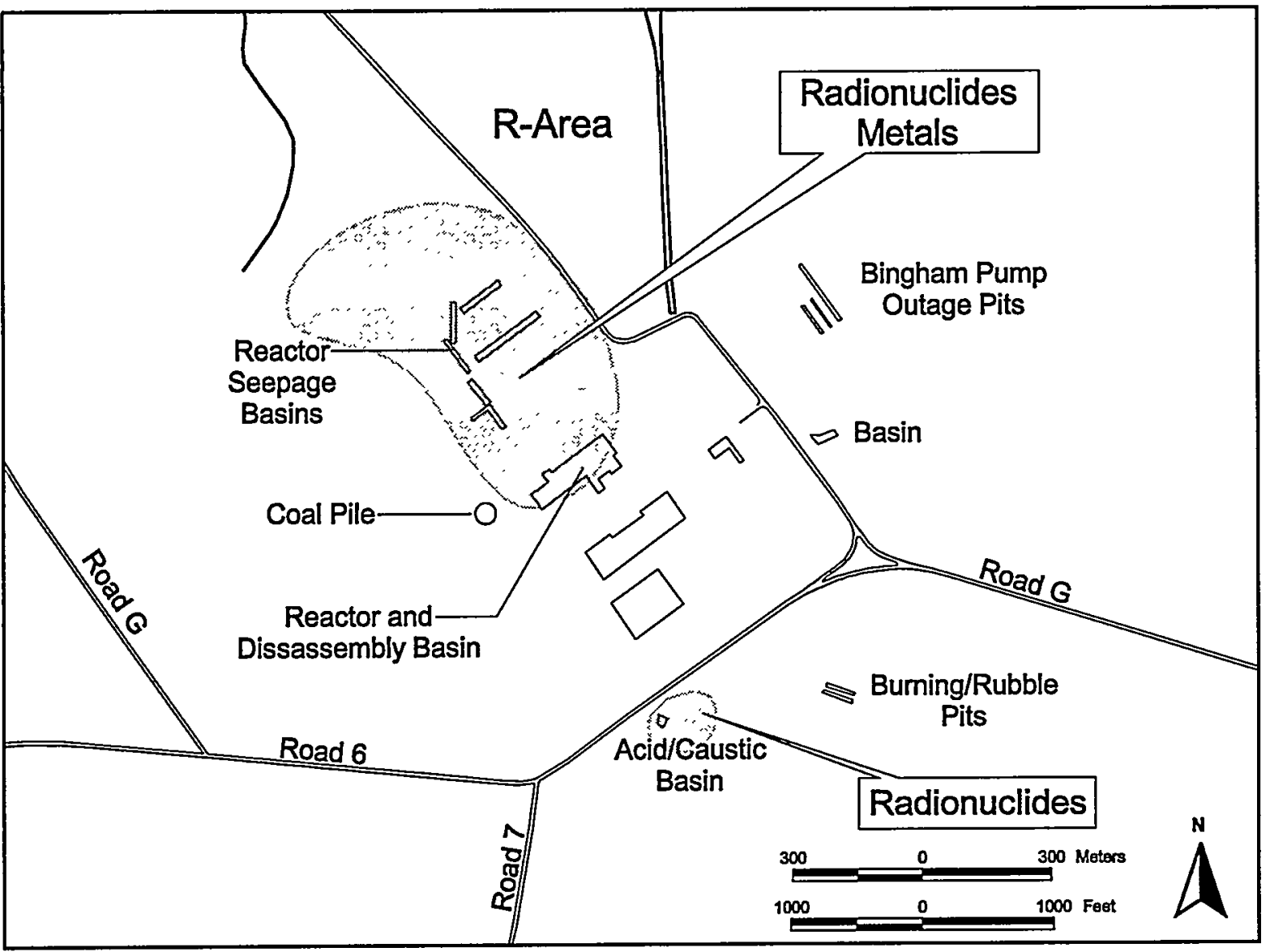

Exploration Resources, Inc.

Figure 10-15 Extent of Groundwater Contamination Beneath R-Area in 1998 and Location of Noteworthy Sources of Contamination Exceeding Drinking Water Standards

\section{Groundwater Contamination at R-Area}

\section{Location and Facilities}

R-Area, located in the east-central part of SRS, houses the R-Reactor, which achieved criticality in 1953 and was shut down permanently in 1964.

R-Area includes the following facilities associated with the groundwater monitoring program:

- R-Area acid/caustic basin

- R-Area Bingham pump outage pit

- R-Area burning/rubble pits

- R-Area coal pile

- R-Area disassembly basin

- R-Area reactor

- R-Area reactor seepage basins

\section{Nature of Contamination}

Surface drainage in R-Area is to the northwest and northeast toward Mill Creek and Pond $A$ and to the southeast and southwest toward tributaries of Pond 2 and Pond 4. Figure 10-1 shows the locations of these streams.

Incised tributaries and streams and PAR Pond separate near-surface groundwater at R-Area from the site boundary to the east. R-Area is near a groundwater divide between Mill Creek and PAR Pond. The groundwater just north of R-Area naturally discharges to Mill Creek to the northwest and to the R-Area Canal of Pond A to the northeast. The groundwater from the southern part of R-Area naturally discharges to a tributary of Pond 4 south of R-Area.

Figure 10-15 shows the extent of contamination and the location of various contaminant groups at $R$-Area. The only substantial groundwater contamination found at R-Area during 1998 consists of radionuclides surrounding the reactor disassembly 
basin and the seepage basins. Sampling from previous years shows that elevated levels of lead and other metals also are present. This contamination is consistent with that of previous years and with the history of the site.

On November 8, 1957, an experimental fuel element failed during a calorimeter test in the emergency section of the R-Area disassembly basin. Following this incident, the original seepage basin received approximately $2,700 \mathrm{Ci}$ of gross beta activity, including strontium-90 and cesium-137, each of which has a half-life of about 30 years. Much of the released radioactivity was contained in that basin, which was backfilled in December 1957. Five more basins were placed in operation in 1957 and 1958 to assist in containing the radioactivity.

Table 10-13 summarizes 1996-1998 groundwater monitoring results for $\mathrm{R}$-Area.

Table 10-13 Constituent Groups Above Drinking Water Standards at R-Area, 1996-1998

\begin{tabular}{lccc|cccl}
\hline & \multicolumn{3}{l}{$\begin{array}{l}\text { Percent of Wells } \\
\text { With Results } \\
\text { Above Standards }\end{array}$} & $\begin{array}{l}\text { Number of } \\
\text { Wells Sampled }\end{array}$ & Sources of Contamination \\
\hline & 1996 & 1997 & 1998 & 1996 & 1997 & 1998 & \\
\hline Dioxins/furans & - & - & - & - & - & - & \\
Metals & $25 \%$ & $30 \%$ & $0 \%$ & 16 & 27 & 7 & None \\
Organics & $0 \%$ & $0 \%$ & $0 \%$ & 6 & 3 & 7 & None \\
Pesticides/PCBs & $0 \%$ & $0 \%$ & $0 \%$ & 6 & 3 & 4 & None \\
Tritium & $0 \%$ & $0 \%$ & $0 \%$ & 13 & 12 & 8 & None \\
Other radionuclides & $18 \%$ & $25 \%$ & $14 \%$ & 17 & 24 & 35 & Reactor seepage basins, acid/caustic \\
& & & & & & & basins \\
Other constituents & $8 \%$ & $0 \%$ & $0 \%$ & 13 & 18 & 7 & None \\
\hline
\end{tabular}

Notes: Drinking Water Standards refer to federal final primary DWS, proposed primary DWS, and interim final primary DWS.

Dioxins/furans were not sampled at R-Area during 1996, 1997, and 1998. 


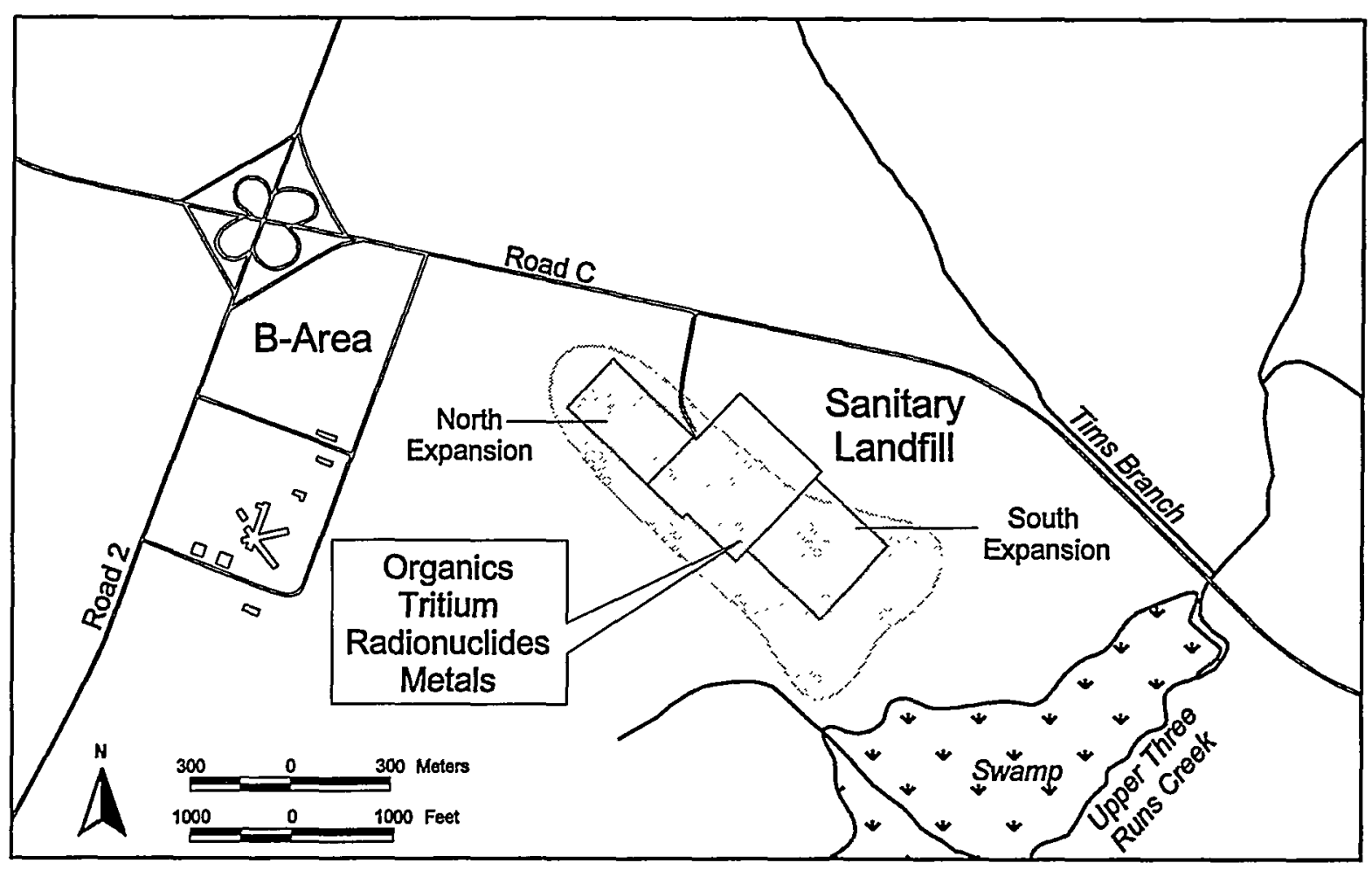

Exploration Resources, Inc.

Figure 10-16 Extent of Groundwater Contamination Beneath the Sanitary Landfill and B-Area in 1998 and Location of Noteworthy Sources of Contamination Exceeding Drinking Water Standards

\section{Groundwater Contamination at the Sanitary Landfill and B-Area}

\section{Location and Facilities}

The Sanitary Landfill is south of Road C, about midway down the slope from the Aiken Plateau to Upper Three Runs Creek.

The Sanitary Landfill began receiving waste from office, cafeteria, and industrial activities during 1974. Materials such as paper, plastics, rubber, wood, cardboard, rags, metal debris, pesticide bags, empty cans, carcasses, asbestos in bags, and sludge from SRS's wastewater treatment plant were placed in unlined trenches and covered daily with soil or a fabric substitute. The original section of the landfill and its southern expansion, with a total area of approximately 54 acres, have been filled. The portion of approximately 16 acres known as the northern expansion, or the interim sanitary landfill, ceased operations in November 1994.

\section{Nature of Contamination}

Surface drainage at the Sanitary Landfill is to the south-southeast, toward Upper Three Runs Creek.
Horizontal groundwater flow is to the southeast, toward Upper Three Runs Creek.

Sanitary landfills are intended to receive only nonradioactive, nonhazardous waste. However, until October 1992, some hazardous wastes (specifically, solvent-laden rags and wipes used for cleaning, decontamination, and instrument calibration) were buried in portions of the original 32-acre landfill and its southern expansion.

Figure 10-16 shows the extent of contamination and the location of various contaminant groups at the Sanitary Landfill and near B-Area. There is a substantial plume of contaminated groundwater under and downgradient of the Sanitary Landfill. Organic compounds are the most widespread contaminants, but metals, tritium, and other radionuclides also are present.

Tritium was detected in two wells above DWS near the Sanitary Landfill in 1998. Gross alpha was elevated in one well near the landfill.

Table 10-14 summarizes the 1996-1998 groundwater monitoring results for the Sanitary Landfill and B-Area. 
Table 10-14 Constituent Groups Above Drinking Water Standards at the Sanitary Landfill and B-Area, 1996-1998

\begin{tabular}{|c|c|c|c|c|c|c|c|}
\hline \multirow[t]{2}{*}{ Constituent Groups } & \multicolumn{3}{|c|}{$\begin{array}{l}\text { Percent of Wells } \\
\text { With Results } \\
\text { Above Standards }\end{array}$} & \multicolumn{3}{|c|}{$\begin{array}{l}\text { Number of } \\
\text { Wells Sampled }\end{array}$} & \multirow[t]{2}{*}{ Sources of Contamination } \\
\hline & 1996 & 1997 & 1998 & 1996 & 1997 & 1998 & \\
\hline Dioxins/furans & $0 \%$ & - & - & 4 & - & - & \\
\hline Metals & $10 \%$ & $13 \%$ & $6 \%$ & 51 & 48 & 50 & Sanitary Landfill \\
\hline Organics & $21 \%$ & $37 \%$ & $30 \%$ & 61 & 51 & 50 & Sanitary Landfill \\
\hline Pesticides/PCBs & $0 \%$ & $0 \%$ & $0 \%$ & 45 & 8 & 15 & None \\
\hline Tritium & $11 \%$ & $4 \%$ & $4 \%$ & 45 & 49 & 50 & Sanitary Landfill \\
\hline Other radionuclides & $7 \%$ & $2 \%$ & $3 \%$ & 45 & 42 & 38 & Sanitary Landfill \\
\hline Other constituents & $2 \%$ & $0 \%$ & $0 \%$ & 47 & 4 & 8 & None \\
\hline
\end{tabular}

Notes: Drinking Water Standards refer to federal final primary DWS, proposed primary DWS, and interim final primary DWS.

Dioxins/furans were not sampled in the Sanitary Landfill or B-Area during 1997 and 1998. 


\section{Chapter 11 \\ Quality Assurance}

\author{
Bob Henderson, Moheb Khalil, \\ Walt Kubilius, and Stuart Stinson \\ Environmental Protection Department
}

To Read About ... S See Page...

QAVQC for EMS Laboratories . . . . . . . . 186

Training for Personnel ............ 186

Intemal QA Program ............... 187

External QA Program .............. 188

QAVQC for Subcontracted Laboratories . 189

Nonradiological Liquid Effluents ........ 189

Stream and River Water Quality ....... 191

Groundwater ................... 191

Soil/Sediment..................... 192

Detailed Data Reviews . . . . . . . . . . . . 193

\section{Highlights}

- An EMS training plan was completed for analysts in the section's Environmental Sampling and Reporting and Environmental Chemistry and Analysis groups.

- In the blind sample program routinely conducted by EMS to assess the quality and reliability of pH field data, $\mathrm{pH}$ measurements were taken on 24 samples. All field pH measurements were well within EPA's suggested acceptable control limit.

- Twelve blind samples were analyzed for tritium by the EMS laboratory. All tritium data were within the control limits. The results of these blind samples were used to validate analytical work in the chemistry and counting laboratory.

- The EMS laboratory participated in two interlaboratory comparison programs to track performance accuracy. These program are run by DOE and EPA. In general, EMS's performance in these interlaboratory comparison program demonstrated a high level of accuracy.

$\mathrm{T}$ HE Environmental Monitoring Section (EMS) of the Savannah River Site's (SRS) Environmental Protection Department (EPD) maintains a quality assurance (QA) program to continuously verify the integrity of data generated by its own environmental monitoring program and by its subcontracted laboratories.

Various definitions have been suggested for $\mathrm{QA}$ and quality control (QC). Frequently, the terms are used interchangeably. In the EMS program, QA consists of the system whereby the laboratory can assure clients and other outside entities, such as government agencies and accrediting bodies, that the laboratory is generating data of proven and known quality. QC refers to those operations undertaken in the laboratory to ensure that the data produced are generated within known probability limits of accuracy and precision.

Although QC represents the core activity in a QA program, the latter encompasses much more than the technical operations of controlling quality. Another QA component is quality assessment, which refers to the evaluation activities that provide assurance that the $\mathrm{QC}$ job is being done effectively.
Each aspect of the environmental monitoring program, from sample collection to data reporting, must address QC and quality assessment standards defined in the Savannah River Site Environmental Monitoring Program Quality Assurance Plan, section 8000 , WSRC-3Q1-2.

This chapter summarizes the QA program. Tables containing the 1998 QA/QC data can be found in SRS Environmental Data for 1998 ,

WSRC-TR-98-00314. A more complete description of the EMS QA program can be found in section 1110 of the Savannah River Site Environmental Monitoring Section Plans and Procedures, WSRC-3Q1-2, Volume 1 (SRS EM Program).

Guidelines and applicable standards for the QA environmental monitoring program are referenced in appendix A, "Applicable Guidelines, Standards, and Regulations," of this document. Detailed information about federal, state, and local QA regulations and standards can be found in the SRS EM Program. Figure 11-1 illustrates the hierarchy of relevant guidance documents that support the EMS QA/QC program. 


\section{Quality Assurance/Quality Control for Environmental Monitoring Section Laboratories}

General objectives of the QA/QC program include validity, traceability, and reproducibility of reported results; comparability of results within databases; representativeness of each sample to the population or condition being measured; and accuracy and precision.

\section{Training for Personnel}

EMS personnel are responsible for understanding and complying with all requirements applicable to the activities with which they are involved. Consequently, appropriate training courses are provided to assist them in fulfilling their responsibilities. Courses include training on applicable QA procedures, Occupational Safety and Health Administration-mandated training, and General Employee Training. Regulations and

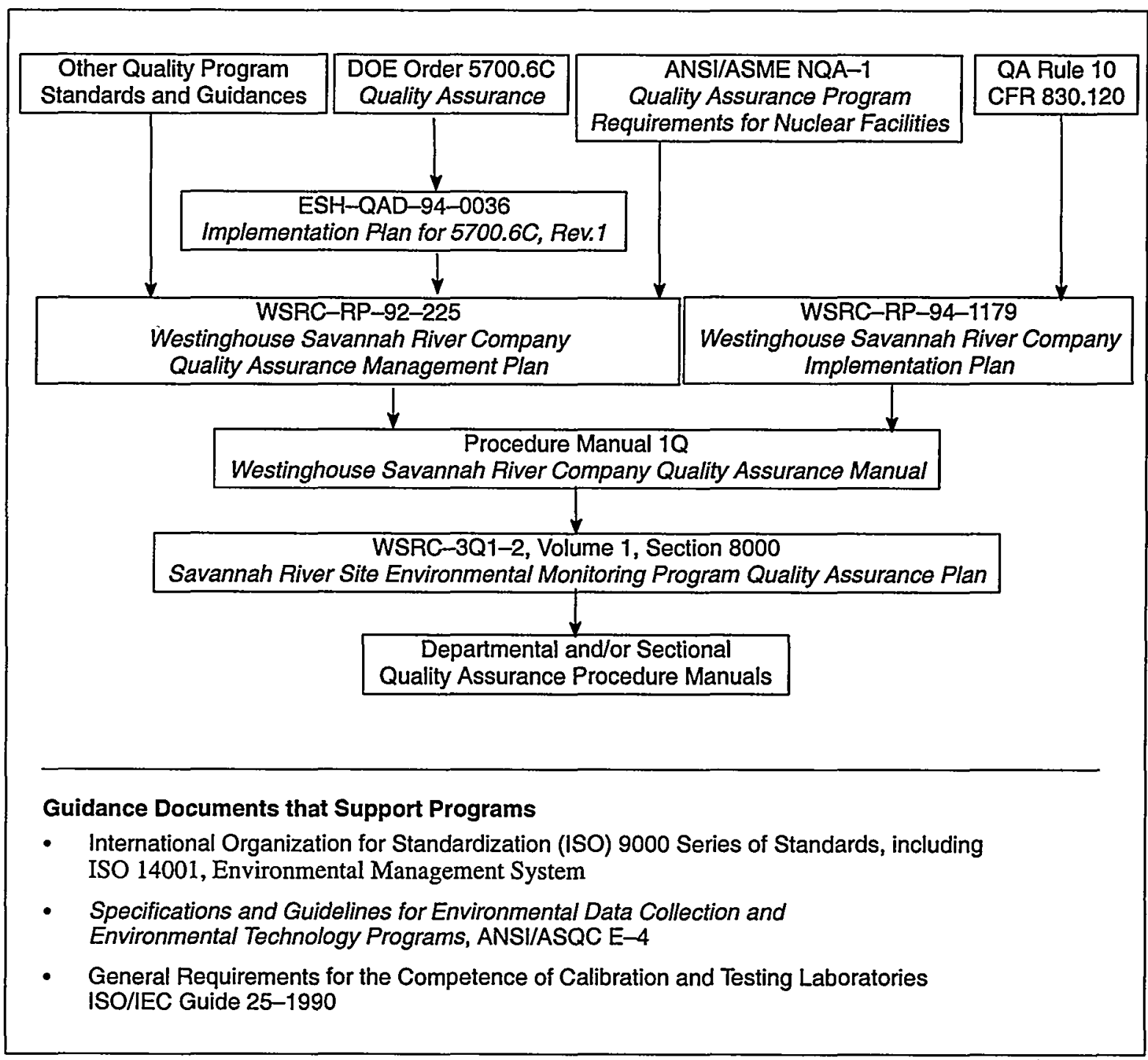

Figure 11-1 SRS EM Program QA/QC Document Hierarchy of Relevant Guidance Documents and Supporting Guidance Documents

Note: DOE Order 414.1, "Quality Assurance," which was approved in November 1998, will supercede DOE Order 5700.6C. Implementation of the new order at SRS should take place in 1999, after WSRC issues a directive. 


\section{Statistical Terms}

coefficient of variation measure of precision calculated as the standard deviation divided by the average of a set of values; usually multiplied by 100 to be expressed as a percentage

mean measurement of central tendency, commonly called the average

mean relative difference measure

of reproducibility of identical chemical analyses

median middle value of a set of data when the data are ranked in increasing or decreasing order percent difference measure of accuracy used to compare "known" values with laboratory measurements; represents the absolute difference between the known and measured value divided by the known value; usually multiplied by 100 to be expressed as a percentage

standard deviation indication of the dispersion of a set of results around the average of samples collected procedures that govern the environmental monitoring program are emphasized.

EMS analysts begin with specific training determined by job assignment. The section's technical work is based on procedures in the WSRC-3Q1 series of manuals:

- "Environmental Sampling Procedures," WSRC-3Q1-3

- "Environmental-RadiochemistryProcedures," WSRC-3Q1-4

- "Environmental Water Quality Procedures," WSRC-3Q1-5

- "Environmental Counting Room Procedures," WSRC-3Q1-6

- "Environmental Data Management and Computer Support Procedures," WSRC-3Q1-10

In 1998, an EMS analyst training plan was completed. The plan was written for analysts in the section's Environmental Sampling and Reporting and Environmental Chemistry and Analysis groups. It includes a description of activities, general and specific job descriptions, specific assignments and qualifications, requirements for job-specific training, and lists of annual required training. Also included in this plan are mathematics, general chemistry, and laboratory skills, both knowledge and practical.

\section{Internal Quality Assurance Program}

Specific QA checks and accepted practices are conducted by each EMS group, as described in the following paragraphs.

\section{Field Sampling Group}

Blind Sample Program EMS routinely conducts a blind sample program for field measurements of $\mathrm{pH}$ to assess the quality and reliability of field data measurements. Measurements of $\mathrm{pH}$ are taken in the field using the same equipment as is used for routine measurements.

During 1998, blind $\mathrm{pH}$ field measurements were taken for 24 samples (table 61, SRS Environmental Data for 1998). All field $\mathrm{pH}$ measurements were within the U.S. Environmental Protection Agency's (EPA) suggested acceptable control limit of $\pm 0.4 \mathrm{pH}$ units of the true (known) value.

Instrumentation Calibration EMS personnel also measure chlorine, dissolved oxygen, and temperature in water samples; but because of the difficulties in providing field standards, these measurements are not suitable for a blind sample program. Therefore, quality control of these analyses relies instead on instrumentation calibration, per the WSRC-3Q1 procedure series.

\section{Chemistry and Counting Laboratories}

Laboratory performance is evaluated through instrument checks, control charts, and data analyses. In the chemistry group, graphical control checks and numerical trending is conducted on technician and method performance, with reports generated for sample results that exceed warning limits. The Counting Laboratory runs source checks and instrument backgrounds and performs calibrations regularly to monitor and characterize instrumentation.

Routine samples prepared and counted in EMS laboratories are subject to a variety of $\mathrm{QC}$ checks to assess and ensure validity. These checks make up 30 percent of the analytical workload. The Environmental Chemistry and Analysis group prepares spikes, blanks, duplicates, and blind samples 
to check the performance of routine analyses. Spikes and blanks are used to calculate a recovery efficiency of an analytical method, to adjust for background radiation, and to evaluate counting equipment performance.

Blind tritium samples provide a continuous assessment of laboratory sample preparation and counting. The tritium activity is unknown to the technicians preparing the samples or the counting laboratory personnel. The blind samples are prepared from National Institute of Standards and Technology (NIST)-traceable material or standardized against NIST material. The results are added to control charts to identify trends. During 1998, 12 blind samples were analyzed for tritium (table 62, SRS

Environmental Data for 1998). All tritium data were within the control limits. The results of these blind samples were used to validate analytical work in the chemistry and counting laboratories.

The EMS laboratory is certified by the South Carolina Department of Health and Environmental Control (SCDHEC) for its alkalinity, chemical oxygen demand, total suspended solids, specific conductance, nitrate-nitrogen, orthophosphate phosphorus, chloride, sulfate, total dissolved solids, 50 volatile organic compounds (VOCs), and field $\mathrm{pH}$ analyses. In the continuing recertification program by SCDHEC through EPA, the laboratory passed all test parameters to receive recertification in 1998 in a performance evaluation report from a water pollution study (WP040).

\section{Data Verification and Validation}

Results received from the counting laboratory are electronically evaluated by the Environmental
Monitoring Computer Automation Program (EMCAP). Sample parameters-such as air flows, counting aliquots, and decay times-are flagged if values exceed preset limits or vary significantly from previous entries. An acceptance range for each analysis, based on historical results, is calculated for all routine environmental samples. Sample results outside the acceptance range are submitted for individual review, which may result in repeating the analyses, recounting, recalculating, or resampling for verification.

Before data are reported, they must be reviewed and validated by qualified personnel. Electronic verification is performed on 100 percent of the data stored in EMS databases. Through this verification, data anomalies are removed or data are rejected if there is disagreement with EMS QA/QC policies. The validation methods and criteria are documented in QAP 21-1 of WSRC-1Q and in "Environmental Geology Procedures," WSRC-3Q1-7. Quality control requirements for managing, evaluating, and publishing environmental monitoring data are defined in WSRC-3Q1-2, section 8250.

\section{External Quality Assurance Program}

In 1998, the EMS laboratory participated in two interlaboratory comparison programs to track performance accuracy. Under these programs, the U.S. Department of Energy (DOE) and EPA send samples to participating laboratories throughout the year and compare the laboratories' results to program values. These comparisons verify the accuracy of EMS radiochemical analytical results. The QC chemist maintains control charts to monitor trends and bias for each matrix (e.g., water, air filter, vegetation, soil) and analysis for various nuclides.

\section{QA Terminology in the Laboratory}

accuracy degree of agreement between a measurement and an accepted reference or true value

bias systematic (constant) underestimation or overestimation of the true value

accuracy measure of mutual agreement among individual measurements of the same property

spiked sample sample to which a known amount of a substance has been added

duplicate sample repeated but independent determinations on the same sample split sample portions taken from the same sample and analyzed by different technicians or laboratories

blind sample (blind duplicate or blind blank) mock sample of known constituent(s) or concentration(s); used as a control

blanks clean samples analyzed to establish a baseline or background value used to adjust or correct results

control chart graphical chart of some measured parameter for a series of samples 


\section{Quality Assurance Program}

The DOE Quality Assurance Program (QAP) tests the quality of environmental data reported to $D O E$ by its contractors. Reference samples for this program-including soil/sediment, water, vegetation, and air filter samples-are prepared by DOE/EML (Environmental Measurements Laboratory) and sent to participating laboratories. Analytical results are reported to DOE/EML and are compared with the test results of other laboratories. DOE/EML evaluates the results and distributes a report to the participating laboratories. Results are rated as acceptable (A), acceptable with warning (W), and not acceptable (N). Control charts are maintained according to DOE/EML control limits. The following EMS analytical methods and instruments are tested in these studies:

- gamma emitters by gamma spectroscopy

- actinides by alpha spectroscopy

- strontium and gross alpha/beta by gas-flow proportional counters

- tritium by liquid scintillation

Work was completed in June on the 48th set of QAP samples from a DOE/EML radiological

intercomparison study. EMS analyzed 15 isotopes in air, five in soil, seven in vegetation, and 11 in water for a total of 38 results. Thirty-two of the results were rated " $A$," two were rated " $W$," and four were rated "N." A performance rating of 90 percent acceptable was achieved for this study.

In QAP set 49, which was completed in December, EMS analyzed 12 isotopes in air, nine in soil, seven in vegetation, and 12 in water for a total of 40 results. Thirty-two of the results were rated "A," seven were rated "W," and one was rated " $N$." A performance rating of 98 percent acceptable was achieved for this study.

The QAP results for the two sets can be found in table 63, SRS Environmental Data for 1998. The table includes the DOE/EML control limits for nonacceptable results.

\section{Quality Assurance Division Program}

The second-program-is-administered-by-the Quality Assurance Division (QAD) of the EPA

Environmental Monitoring System Laboratory in Las Vegas, Nevada. This division is responsible for $\mathrm{QC}$ of environmental radiological measurements. EPA provides participating laboratories with water and air filter samples that contain a variety of radionuclides with activity concentrations near environmental background levels. The samples are distributed according to schedule throughout the year. Control charts are maintained for the $\mathrm{QAD}$ results according to EPA control limits. Historical trends alert EMS to a method bias that may be occurring in its laboratories. The $\mathrm{QAD}$ program enables EMS to document the accuracy of radiological analysis data, to identify instrument and procedural problems, and to compare analysis performance with other participating laboratories.

For the 1998 program, EMS analyzed 11 isotopes in 12 samples for a total of 34 results. Twenty-nine of the results were acceptable, and a performance rating of 85 percent acceptable was achieved for the year. The QAD results can be found in table 64, SRS Environmental Data for 1998.

\section{Quality Assurance/Quality Control for Subcontracted Laboratories}

Subcontracted laboratories providing analytical services must have a documented QA/QC program and meet the quality requirements defined in WSRC-1Q. The subcontracted laboratories used during 1998 and the types of analyses performed are listed in table 11-1, page 190.

EMS personnel perform an annual evaluation of each subcontracted laboratory to ensure that the laboratories maintain technical competence and follow the required QA programs. Each evaluation includes an examination of laboratory performance with regard to sample receipt, instrument calibration, analytical procedures, data verification, data reports, records management, nonconformance and corrective actions, and preventive maintenance. EMS provides reports of the findings and recommendations to each laboratory and conducts followup evaluations as necessary.

\section{Nonradiological Liquid Effluents}

Nonradiological liquid effluent samples are collected at each permitted SRS outfall according to requirements in the National Pollutant Discharge Elimination System (NPDES) permit issued by SCDHEC (discussed in appendix A, page 207). Effluent-samples-are-analyzed-by-three laboratories-two onsite laboratories and one subcontract laboratory. The EMS laboratory performs analyses for temperature, $\mathrm{pH}$, dissolved oxygen, total suspended solids, and total residual chlorine. The WSRC Site Utilities Division (SUD) Wastewater Laboratory performs analyses for $\mathrm{pH}$, dissolved oxygen, biological oxygen demand, and total 
Table 11-1

Subcontracted Laboratories for 1998

General Engineering Laboratories

groundwater nonradiological analyses

soil/sediment

waste characterization

Recra LabNet Philadelphia

groundwater nonradiological analyses

soil/sediment

waste characterization

Environmental Physics, Inc.

groundwater radiological analyses

soil/sediment radiological analyses

waste characterization radiological analyses

\section{ThermoNUtech}

groundwater radiological analyses

soil/sediment radiological analyses waste characterization radiological analyses

QST Environmental, Inc.

groundwater radiological analyses

groundwater nonradiological analyses

EMAX Laboratories, Inc.

groundwater nonradiological analyses

\section{Microseeps}

soil gas

site evaluation

Shealy Environmental Services

NPDES analyses

metals analyses for SRS streams

and the Savannah River

domestic water analysis

suspended solids on sanitary facility wastewater samples. Shealy Environmental Services was the primary subcontractor for the NPDES program throughout 1998.

\section{Interlaboratory Comparison Program}

Interlaboratory comparison studies are used to compare the quality of results between laboratories performing the same analyses. During 1998, Shealy and EMS participated in interlaboratory comparison studies conducted by EPA.

All subcontracted laboratories analyzing NPDES samples must participate in the EPA Discharge Monitoring Report Laboratory Performance Evaluation program. Under this program, EPA sends to participating laboratories performance samples containing constituents normally found in industrial and municipal wastewaters.

These water samples have known chemical parameters, such as chemical oxygen demand, and contain known concentrations of constituents, such as total suspended solids, oil and grease, and certain trace metals. EPA provides a final comprehensive report to the program-participants. The-report - contains a statistical analysis of all data, as well as documentation of the known sample value, with stated acceptance limits and warning limits. Accepted variations from the known sample value depend on a variety of factors, including the precision of the analysis and the extent to which the results can be reproduced.

In 1998, Shealy ran analyses for 46 NPDES parameters under the EPA program. The EMS laboratory performed analyses for 9 parameters. The SUD laboratory performed analyses for $\mathrm{pH}$, biological oxygen demand, total suspended solids, and dissolved oxygen. The EMS laboratory was within acceptable limits for all parameters. The SUD laboratory was within acceptable limits for all parameters except $\mathrm{pH}$. A retest was conducted, and the repeat analysis was within the acceptance limits. No further action was required. Shealy was within acceptable limits for 41 of 46 parameters, an 89 -percent success rate. The NPDES subcontract is required to have a minimum 80 -percent success rate on EPA samples. The parameters that were outside acceptance limits were oil and grease, total Kjeldahl nitrogen, phosphorus, chemical oxygen demand, and mercury. Shealy was required to perform additional analyses for the missed parameters. The repeat analyses were all within acceptance limits. SCDHEC, which administers the EPA program, required no further actions by the laboratory.

The EMS laboratory, as part of a new quality assurance/quality control program, began sending quarterly blind standards to the contract laboratory (table 65, SRS Environmental Data for 1998). For the third quarter of 1998 , Shealy correctly reported results for 14 of 20 parameters. For the fourth quarter, 15 of 19 parameters were reported correctly. Ammonia and iron were outside the acceptance limits in the third quarter. Total suspended solids, total 
organic carbon, nitrate/nitrite, and mercury were outside acceptance limits for both quarters. Shealy initiated an investigation to determine the source of the errors and to provide programmatic or procedural corrective actions as required. Investigation results will be reported in SRS Environmental Report for 1999.

\section{Intralaboratory Comparison Program}

The intralaboratory program compares performance within a laboratory by analyzing duplicate and blind samples throughout the year. One hundred eighteen duplicate samples were analyzed during 1998 by Shealy and the EMS laboratory (table 66, SRS Environmental Data for 1998). Shealy analyzed 91 duplicate samples for various parameters, and the EMS laboratory analyzed 27 duplicate samples for total suspended solids. Percent difference calculations showed that 24 of the 91 samples analyzed by Shealy were outside the EMS internal QA/QC requirement of 20 percent. The results of 21 exceptions were at or near the analytical detection limit, which produces large percent variations for small differences in actual data. For these analyses, the actual difference in results between duplicates was small and not significant. Three exceedances-for aluminum, copper, and zinc-appeared to be related to analytical error at the subcontract laboratory, sample contamination, or improper sampling techniques. The EMS laboratory was within the 20-percent acceptance range on all but one sample, a 96-percent success rate. No EMS action was requested because the total suspended solids result was near the detection limit of the analysis.

Seventy-four blind samples were submitted to the Shealy and EMS laboratories, with 114 analyses performed -83 by Shealy and 31 by EMS.

Eighty-three analyses were performed. (table 67, SRS Environmental Data for 1998). Percent difference calculations showed that 8 total suspended solids analyses, all performed by the EMS laboratory, were outside the acceptance range of 20 percent. All eight of the total suspended solids analyses were very close to the detection limits for the analysis, and the difference between results was not significant. Of the 83 analyses that Shealy conducted, 72 were within the 20-percent acceptance range. Of the 11 analyses outside the acceptance range, 8 were the result of data at or near the analytical detection limit. The remaining three exceedances-for aluminum, ammonia, and lead-appeared to be related to analytical error at the subcontract laboratory, sample contamination, or improper sampling technique.

\section{Stream and River Water Quality}

The water quality program requires quality checks of 10 percent of the samples to verify the analytical results. Analyses are required to be performed by a certified laboratory. Duplicate grab samples from SRS streams and the Savannah River were submitted to Shealy Environmental Services and analyzed for metals, total organic carbon, phosphorus, herbicides, and pesticides. A total of 476 analyses were performed. (table 68, SRS Environmental Data for 1998).

A percent relative difference calculation was performed on each data pair and compared to the acceptance limit of 20 percent. Forty-nine samples were outside the acceptance limit. Nineteen of these results were at or near the detection limit of the analyses, where small variations in results can yield large variations in percent difference calculations. For these analyses, the actual difference in results between duplicates was small and not significant. Twenty of the out-of-range analyses were for aluminum, zinc, nickel, manganese, and iron. In response to the significant number of out-of-range metals from 1997 and to degrading conditions with the existing laboratory instrumentation in 1998, Shealy replaced existing Inductively Conducted Plasma (ICP) instrumentation with state-of-the-art ICP instrument in July. Of the 20 out-of-range analyses, only 4 were performed after instrument replacement. The remaining 10 analyses were all for phosphorus and appear to be related to analytical and/or personnel error at the subcontract laboratory. The laboratory has shown a history of poor performance for phosphorus analysis. Shealy failed the phosphorus analysis on the EPA studies for both 1997 and 1998, as well as the analyses on two unknown certified standards sent to the laboratory by the EMS laboratory in the third and fourth quarters of 1998. Shealy agreed to perform unknown standards with all phosphorus sample runs and to investigate potential causes for the analytical discrepancies. Investigation results will be reported in SRS Environmental Report for 1999.

\section{Groundwater}

Groundwater analyses at SRS are performed by subcontracted laboratories. During 1998, EMAX Laboratories, Inc., General Engineering Laboratories, QST Environmental, Inc., and Recra LabNet Philadelphia were the primary subcontractors for nonradiological analyses. Environmental Physics, Inc., QST Environmental, Inc., and Thermo NUtech were the primary subcontractors for radiological analyses. In addition, Gulf Coast, a laboratory owned by Recra, performed 
pesticides/polychlorinated biphenyls (PCBs) analyses under the auspices of Recra.

Analytes outside or near acceptance limits do not appear to be systematic or to exhibit any identifiable trends. Full results for all QA/QC evaluations, including MRD calculations where appropriate, may be found in the following groundwater reports:

- The Savannah River Site's Groundwater Monitoring Program, First Quarter 1998 (ESH-EMS-98-0568)

- The Savannah River Site's Groundwater Monitoring Program, Second Quarter 1998 (ESH-EMS-98-0569)

- The Savannah River Site's Groundwater Monitoring Program, Third Quarter 1998 (ESH-EMS-98-0570)

- The Savannah River Site's Groundwater Monitoring Program, Fourth Quarter 1998 (ESH-EMS-98-0571)

\section{Internal QA}

During 1998, approximately 5 percent of the samples collected (radiological and nonradiological) for the Resource Conservation and Recovery Act (RCRA) and the Comprehensive Environmental Response, Compensation, and Liability Act (CERCLA) programs were submitted to the primary laboratory for analysis as blind duplicates and to a different laboratory as a QA check. The laboratories' results were evaluated on the basis of the percentage within an acceptable concentration range.

A statistical measure, the mean relative difference (MRD), is calculated to assess result reproducibility and laboratory performance. The laboratories also analyze approximately 10 percent of samples as intralaboratory QA checks. Interlaboratory comparisons were conducted between the following:

- EMAX/Recra LabNet

- Environmental Physics/Thermo NUtech

- General Engineering/Recra LabNet

- General Engineering/QST Environmental

- QST Environmental/EMAX

- QST Environmental/Recra LabNet

- QST Environmental/Thermo NUtech

All comparisons were within the 80-percent acceptance range utilized by the EMS QA/QC program.

\section{External QA (Water Pollution and Water Supply Performance Evaluation Studies)}

EPA conducts water pollution (WP) and water supply (WS) performance evaluation studies to certify laboratories for specific analyses. During 1998, EMAX, QST, and Recra reported results for water pollution study WP037 and WP038, and Recra reported data for water pollution study WP039. EMAX, General Engineering, and QST reported results for water supply study WS038; EMAX and QST reported results for water supply study WS039; and Recra reported results for water supply study WS040. Results outside or near acceptance limits are summarized in table 11-2.

EPA, as part of the recertification process, requires that subcontract laboratories investigate the outside-acceptance-limit results and implement corrective actions as appropriate.

\section{Soil/Sediment}

Environmental investigations of soils and sediments, primarily for RCRA/CERCLA units, are performed by subcontracted laboratories (General Engineering Laboratories, Recra LabNet Philadelphia, Environmental Physics, Inc., ThermoNUtech and Microseeps-table 11-1, page 190).

EMS personnel validated and managed approximately 350,000 analytical records during soil/sediment investigations in 1998. Data are validated according to EPA standards for analytical data quality unless specified otherwise by site customers. EMS delivered 68 project summary reports in 1998; each included

- a project QA/QC summary

- a discussion of validation findings

- tables of validated and qualified data

Although Data Quality Objectives Process for Superfund (EPA-540-R-93-071) identifies QA issues to be addressed, it does not formulate a procedure for how to evaluate these inputs, nor does it propose pass/fail criteria to apply to data and documents. Hence, the validation program necessarily contains elements from-and is influenced by - several other sources, including

- QA/QC Guidance for Removal Activities, interim final guidance, EPA-540-G-90-004

- National Functional Guidelines for Organic Data Review, Multi-Media, Multi-Concentration (OLM 01.0), and Low Concentration Water (OLC 01.0), draft, June 1991

- Test Methods for Evaluating Solid Waste, EPA, November 1986, SW-846, Third Edition 
Table 11-2 Subcontract Laboratory Performance in EPA Water Pollution and Water Supply Studies

\begin{tabular}{|c|c|c|c|c|c|c|}
\hline & WP037 & WP038 & WP039 & WS038 & WS039 & WS040 \\
\hline Labora & atory & & Percel & otable & & \\
\hline EMAX & $96^{a}$ & $91^{b}$ & & $97^{c}$ & $95^{d}$ & \\
\hline QST & $96^{\circ}$ & $93^{f}$ & & $97^{9}$ & $95^{h}$ & \\
\hline Recra & $94^{i}$ & $91^{j}$ & $97^{k}$ & & & 100 \\
\hline Genera & al Engr. & & & $97^{1}$ & & \\
\hline $\mathbf{a}$ & Outside acceptanc & or fluoride, & phorus, an & enolics & & \\
\hline b & $\begin{array}{l}\text { Outside acceptanc } \\
\text { 1,1,1-trichloroethe }\end{array}$ & $\begin{array}{l}\text { for aluminur } \\
\text { acceptable }\end{array}$ & $\begin{array}{l}\text {, fluoride, } \\
\text { the accepte }\end{array}$ & henolics ( $r$ & antimony, & \\
\hline c & Outside acceptanc & for 2,4-D, p & tetrachlorc & and total o & Irbon & \\
\hline d & Outside acceptanc & for $2,4-D, c$ & hloroethyle & one dibromi & iitrate & \\
\hline$\theta$ & $\begin{array}{l}\text { Outside acceptano } \\
\text { was acceptable bu }\end{array}$ & $\begin{array}{l}\text { For total ben } \\
\text { io acceptan }\end{array}$ & I total phen & ilt for carbo & biochemica & demand \\
\hline$f$ & $\begin{array}{l}\text { Results for aldrin, } \\
\text { acceptance limits. }\end{array}$ & m, PCB 12 & ic conducta & total organi & were accer & t near the \\
\hline$g$ & Outside acceptanc & for 2,4-D,ci & hloroethyle & rthophosph & & \\
\hline $\mathrm{h}$ & Outside acceptanc & for beryllium & total cyani & urbidity & & \\
\hline$i$ & $\begin{array}{l}\text { Outside acceptanc } \\
\text { sodium were acce }\end{array}$ & $\begin{array}{l}\text { for calcium, } \\
\text { At near the }\end{array}$ & $\begin{array}{l}\text { nic carbon, } \\
\text { e limits) }\end{array}$ & filterable res & ults for me & and \\
\hline$j$ & $\begin{array}{l}\text { Outside acceptanc } \\
\text { molybdenum, and }\end{array}$ & $\begin{array}{l}\text { for nitrate as } \\
\text { n were acce }\end{array}$ & $\begin{array}{l}\text { nonfilterat } \\
\text { t near the }\end{array}$ & $\begin{array}{l}\ominus, \text { and sulfa } \\
\theta \text { limits) }\end{array}$ & s for arseni & ane, \\
\hline k & Results for chemic & In demand & lene chlori & cceptable & he accepta & \\
\hline 1 & Outside acceptanc & for dicamba & e) and zinc & & & \\
\hline
\end{tabular}

- Data Validation Procedures for Radiochemical Analysis, WHC-SD-EN-SPP-001

Data management personnel in the soil/sediment program perform additional functions to ensure the quality of the data released by EMS. Two people enter the data for each entry to help eliminate errors, and all field, shipping, invoice, and analytical data are 100 percent verified.

Relative percent difference for the soil/sediment program is calculated for field duplicates and laboratory duplicates. A summary of this information is presented in each project report prepared by the Environmental Geochemistry Group of EMS. A detailed description of the activities performed during validation of soil/sediment data can be found in the
Environmental Geochemistry Group Operating Handbook, WSRC-IM-99-00013.

\section{Data Review}

Several detailed data validation activities have been added to the QA program for groundwater and soil/sediment analyses procured from offsite commercial laboratories:

- laboratory data record reviews (since 1993)

- radiological data reviews (since 1996)

- metals interference reviews (since 1997)

The detailed data review is described in section 1110 of the SRS EM Program. 


\title{
Special Surveys and Projects
}

To Read About ... $\quad$ See Page...

APT Site Monitoring .............. 195

Pen Branch Reforestation MAP ....... 195

ANSP River Quality Surveys .......... 199

\author{
Pete Fledderman \\ Environmental Protection Department \\ Eric Nelson \\ Environmental Sciences Section
}

\section{Highlights}

- Reforestation of the Pen Branch corridor and delta by natural succession and planting continued. Several studies to assess the hydrogeochemical aspects normally present in wetland systems were conducted in the restoration area through 1998.

- It was expected that results from both 1997 and 1998 ANSP studies of water quality in the Savannah River would be ready for publication in this report. However, because of unforeseen delays in finalizing a contract with ANSP, Academy personnel were unable to complete their analysis of the 1998 study's results.

- Results of the diatometer and algae and aquatic macrophyte components of the 1997 ANSP study showed no evidence of a negative SRS impact. Several differences were detected in other components of the study, but there was no consistent pattern of difference either within or among components that would indicate an SRS impact.

$\mathrm{I}$ $\mathrm{N}$ addition to routine sampling and special sampling during nonroutine environmental releases, special sampling for radiological and nonradiological surveys is conducted on and off site by personnel from the Savannah River Site (SRS) Environmental Protection Department's Environmental Monitoring Section (EMS) and from other groups, such as the Savannah River Technology Center (SRTC), and the Academy of Natural Sciences of Philadelphia (ANSP).

Both short- and long-term radiological and nonradiological surveys are used to monitor the effects of SRS effluents on the site's environment and in its immediate vicinity.

All conclusions discussed in this chapter are based on samples and analyses that have been completed. Because of sampling and/or analytical difficulties, some sample analyses may be missing, but these analyses typically are small in number and represent only a very small fraction of the total number of samples.

\section{Site Monitoring - Accelerator for the Production of Tritium}

As part of the Accelerator for the Production of Tritium (APT) project, EMS provided preconstruction monitoring support during 1997 and 1998. The preconstruction/preoperational monitoring plan was finalized in 1998, and monitoring in and around APT Site 2 was initiated. Following the December 1998 DOE decision not to pursue tritium production by accelerator at the site, this monitoring was discontinued. Details of the APT preconstruction monitoring will be issued as a separate EMS report.

\section{Mitigation Action Plan for Pen Branch Reforestation}

The final Environmental Impact Statement for the continued operation of K-Reactor, L-Reactor, and P-Reactor at SRS predicted several unavoidable impacts to the site's wetlands. This resulted in the development of a Mitigation Action Plan (MAP) that documented the U.S. Department of Energy (DOE) approach to mitigating these impacts [DOE, 1990]. Permanent closure of these reactors mandated reevaluation of the mitigation strategies identified in the $1991 \mathrm{MAP}$ and its 1992 update. The section on "Mitigation for Wetlands Adversely Impacted by Operations" in the original MAP is the only remaining active program element. All parties involved with the reporting process have agreed that the SRS Environmental Report will be used as the document to report annual progress on the reforestation portion of the commitment. 
A complete history of the regulatory commitment for the reforestation can be found in the MAP 1992 update [DOE, 1992]. Since that time, the change in mission relating to K-Reactor and the increased technical information on the extent of damage and natural recovery in the Pen Branch corridor and delta have altered details of the reforestation effort. The following paragraphs describe 1998 reforestation mitigation actions.

\section{Reforestation of the Pen Branch Corridor and Delta by Natural Succession}

Natural revegetation has been occurring in the Pen Branch delta since K-Reactor last operated for an extended period of time (1988). K-Reactor thermal discharges were determined by a 1992 survey to have caused canopy loss or vegetation damage to 583 acres in the corridor and swamp areas. The survey, which used aerial photography and aircraft-acquired multispectral data, showed less damage than anticipated [Blohm, 1995]. The final Environmental Impact Statement had estimated that 670 acres would be impacted [DOE, 1990].

During 1995, an extensive survey of natural regeneration of forest species was conducted around the outer perimeter of the delta region of Pen Branch. Results of that survey indicated that approximately 100 acres of the delta had sufficient bald cypress seedlings and saplings to consider the area reforested. Stocking tallies taken in 1997 quantified these high densities and the vigor of this natural regeneration. Naturally regenerating areas closer to the terrace areas were heavily stocked with maple, sweetgum, water tupelo, green ash, and bald cypress-and averaged more than 319 seedlings per acre. Areas of natural regeneration in the deeper swamp, stocked primarily with water tupelo and bald cypress, averaged more than 1,087 seedlings per acre. These areas are included in a Geographic Information System layer for mapping of the Pen Branch area. All areas of the Pen Branch corridor above Risher Pond Road (A-13.2) also are considered to have been reforested by natural regeneration to a bottomland hardwood forest type.

\section{Reforestation of the Pen Branch Corridor and Delta by Planting}

The Pen Branch corridor and delta are being reforested by planting with indigenous wetlands species. Seeds were collected from individual trees at SRS and in the Upper Coastal Plain during 1992-1993 to ensure appropriate genetic material for use in the project. The seeds were planted and grown at a State of Georgia nursery during 1993-1995 for use in the Pen Branch seedling planting program. These seedlings - of species appropriate to the area being reforested-subsequently were transplanted to the Pen Branch wetland areas. The reforested areas will be managed until successful reforestation has been achieved. This is the preferred method of mitigation for the Pen Branch corridor and delta because of the brief restoration time allowed by DOE.

The initial and secondary seedling plantings of the entire corridor and delta areas (figure 12-1), in those locations in which it was determined intervention would be required for successful mitigation, have been completed. This intervention consisted of planting approximately 31 acres of the lower corridor with a mixture of flood-tolerant hardwood species and cypress seedlings in 1993. Forty-seven acres of the upper corridor was replanted with a mixture of bottomland hardwood seedlings in 1994. Species planted have included water and pignut hickory, sycamore, green ash, swamp and water tupelo, black gum, persimmon, cherrybark and water oak, bald cypress, and swamp chestnut oak. In 1995, the upper corridor section was replanted with seedlings because of the mortality that resulted from feral hog predation on the original planted seedlings. Also in 1995, the inner delta area was planted for the first time with bald cypress, water tupelo, and-on drier

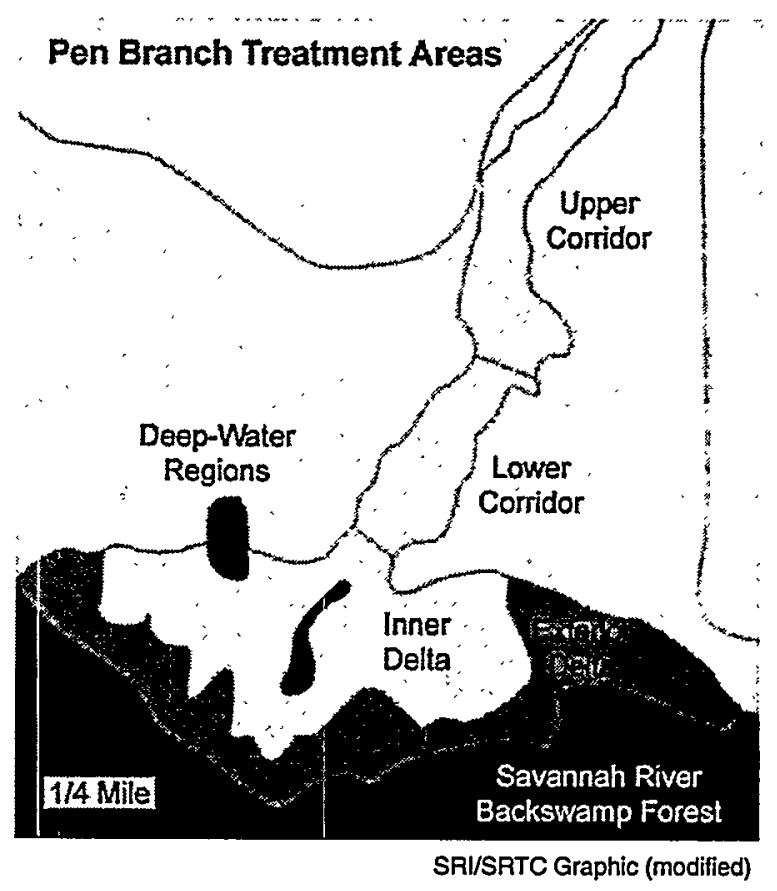

Figure 12-1 Pen Branch Reforestation Areas Each of five areas in the Pen Branch corridor and delta requires a specific regeneration strategy to ensure successful reforestation. 


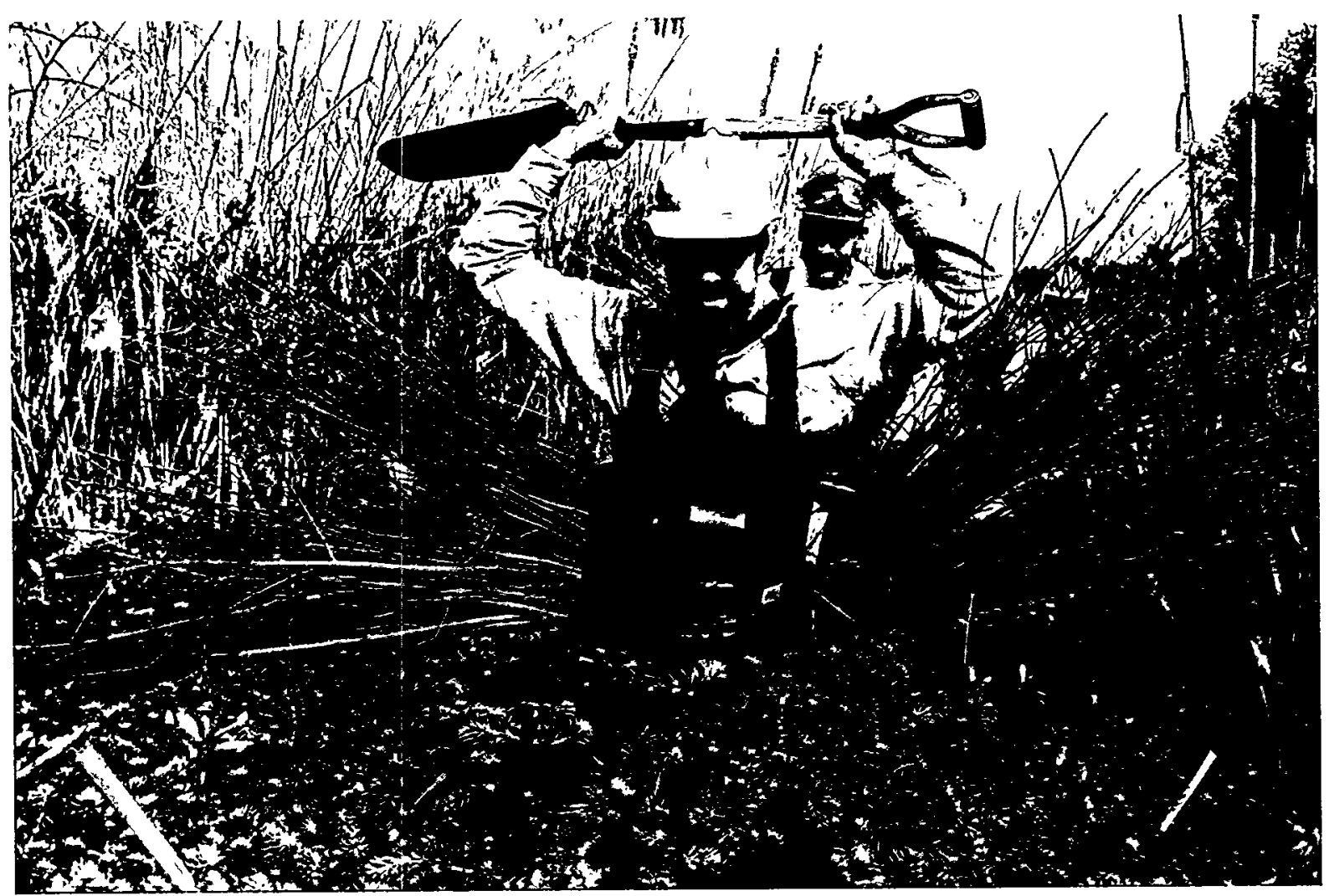

SRI Photo (99X0792.01)

Planting conditions encountered during the Pen Branch reforestation project, especially in the delta area of the branch, often are difficult because water and muck can impede movement. However, the reforestation provides vital information on seedling species selection, seedling size, and planting techniques, which in turn can be applied to other similarly impacted areas in the future.

ridges-green ash seedlings. Approximately 90 acres were planted at densities of 425 seedlings per acre. Approximately 85,000 seedlings were planted during the 3 years of planting (1993-1995) in the corridor and delta areas. An establishment report detailing all activities associated with the reforestation was issued in 1996 and serves as the operational guidebook describing the silvicultural activities have been used to accomplish the mitigation to this point [Dulohery et al., 1996].

A regeneration survey was conducted in 1997 to establish the current stocking levels of desirable species in the different areas of the Pen Branch corridor and delta regions. Results of the survey indicated that appropriate species were present at densities of 160 trees per acre in the corridor and 200 trees per acre in the inner delta. Some mortality will continue to occur over time, but the number of seedlings available in planted areas is considerably above what would be present in a normal undisturbed bottomland hardwood or swamp forest. It is anticipated, therefore, that these stocking levels will provide sufficient numbers of trees to ensure reforestation success. A new survey to confirm this had been planned for the spring of 1999 , but was canceled because of budget/manpower constraints.

Within each area that has been planted are sections that will serve as untreated and unplanted controls to assess the effectiveness of the reforestation effort. Twenty-eight acres in the delta and 20 in the corridor were left in these control sections. This inclusion of control sections has allowed research to compare the treated and untreated areas for the purpose of measuring differences in ecological responses to the treatments. This control acreage is part of that committed to in the MAP. It will be assessed to determine if it will reforest naturally because of its proximity to the mitigated acreage; if it will not, it may receive plantings at a later date.

Because of the control/restoration comparison areas, a number of research and baselining activities have been conducted to document the recovery of the faunal component of the wetland system. Many of these studies have concluded and continued to be 


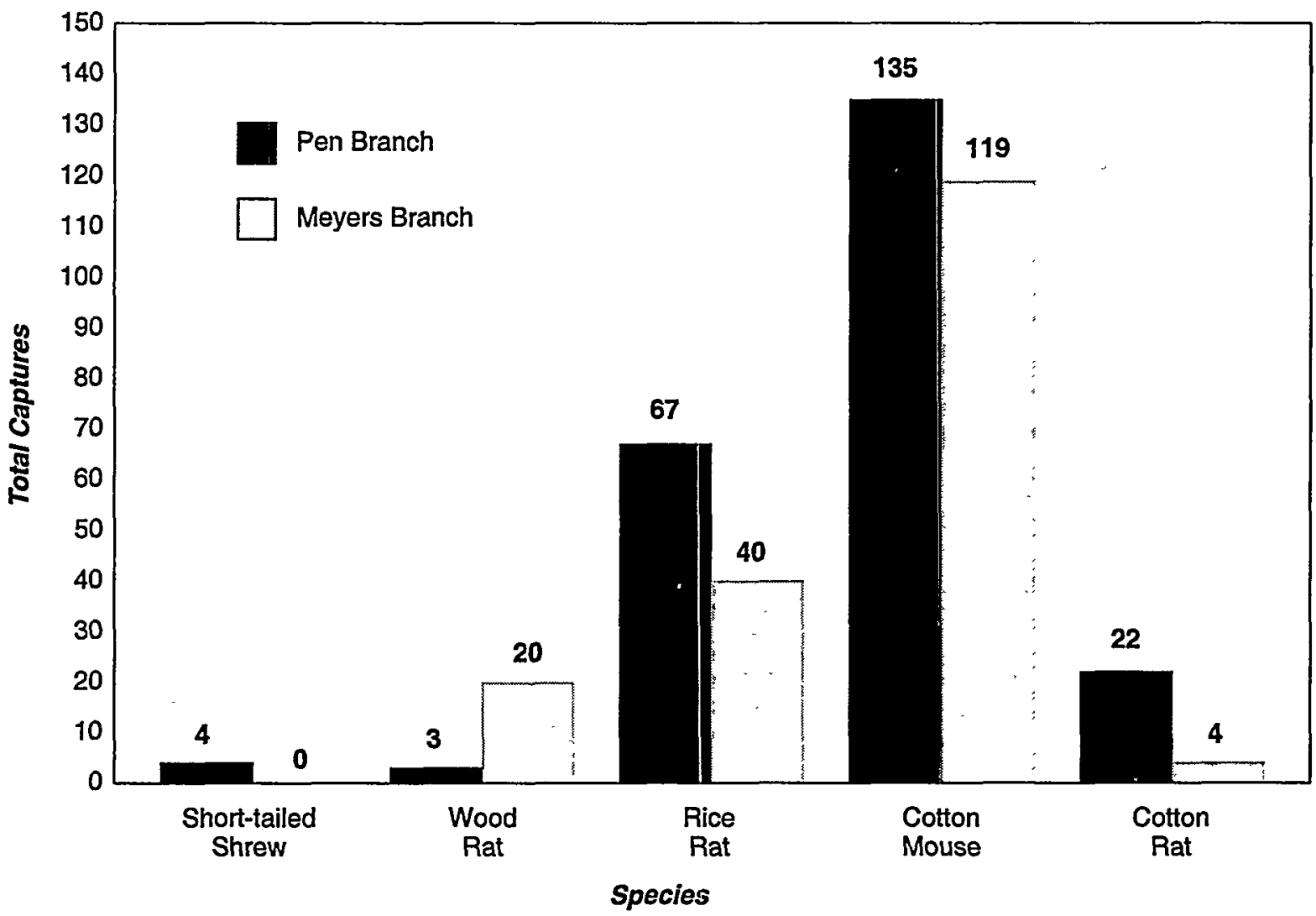

Ileaf Graphic

Figure 12-2 Small-Mammal Captures

The chart compares 1998 small-mammal captures in Pen Branch with those of an undisturbed, forested wetland (Meyers Branch). Values are the total captures resulting from 18 consecutive nights of live trapping transects across the two streams. The cotton mouse (Peromyscus gossypinus) and the rice rat (Oryzomys palustris) were the most common found in both ecosystems. Also present in both systems were the wood rat (Neotoma floridana) and the cotton rat (Sigmodon hispidus), while the short-tailed shrew (Blarina carolinensis) was captured only in Pen Branch.

reported in 1998 at professional meetings, in peer-reviewed publications, and in graduate theses.

A study to identify species composition and the relative abundance of small mammals was concluded in the fall of 1998 to quantify recolonization of the bottomland hardwood forest. Pen Branch was compared to an undisturbed bottomland forest in Meyers Branch. Species diversity was equal in the two systems, but Pen Branch produced greater numbers of captures for the same number of trap nights. As with most prior studies examining the recolonization of the restoration area by various species, the early successional status of Pen Branch again was very productive for the small-mammal component (figure 12-2).

Several studies to assess the hydrogeochemical aspects normally present in wetland systems were begun in the restoration area from fall 1997 through 1998. These studies are examining

- the native seed bank of the corridor and delta

- organic matter production and cycling

- carbon and nutrient fluxes and transportation into and out of the water column

- leaf litter decomposition dynamics

It is anticipated that all the data will be collected before the end of 1999.

These studies have been conducted by cooperators at Clemson University, the University of South Carolina, the University of Georgia, the Savannah River Ecology Laboratory, and the University of South Carolina at Aiken. Monitoring of the wetland hydrology and vegetation development is required to show successful restoration and will continue through the project life. 
Several presentations to professional meetings were given during 1998 to highlight the interdisciplinary assessment methodology being developed at SRS.

Also, the proceedings of a symposium held in 1996 continued to be a regularly cited document relating to the broad effort that has taken place in the Pen Branch ecosystem [Nelson, 1996]. The symposium - organized by the Environmental Sciences Section of SRTC-provided all parties involved in the restoration, monitoring, and research efforts the opportunity to share their preliminary findings. With many of these programs completed in 1998, organization of a new workshop and journal publication to document the final results is scheduled for April 1999.

\section{Compensatory Mitigation}

The option exists to compensate-by enhancing degraded wetlands or creating new wetlands-for an inability to restore Pen Branch. The option will be considered following evaluation of the success of reforesting the Pen Branch corridor and delta in the year 2000. However, it is the least desired option and will be implemented only should the existing efforts in Pen Branch prove unsuccessful.

\section{Academy of Natural Sciences of Philadelphia River Quality Surveys}

(Editor's note: The Patrick Center for Environmental Research of ANSP has been conducting biological and water quality studies of the Savannah River since 1951. It had been anticipated that results from both the 1997 and 1998 studies would be published in this environmental report. However, because of unforeseen delays in finalizing a contract with the Academy for fiscal year 1999-due to budget constraints-Academy personnel were unable to prepare a summary of the 1997 findings, or to complete analyses of the 1998 results, for inclusion in this document. Therefore, only highlights of the 1997 study - as taken from the nontechnical synthesis of the full 1997 report-appear here.)

\section{Overview}

The ANSP water quality studies are designed to assess potential effects of SRS contaminants and warm-water discharges on the general health of the Savannah River and its tributaries. They therefore look for spatial patterns of biological disturbance that are geographically associated with the site, and for temporal patterns of change that indicate improving or deteriorating conditions.
Components of these studies have included basic water chemistry, attached algae, aquatic macrophytes (mosses and rooted aquatic plants), protozoa, aquatic insects and other macroinvertebrates, and fish. The study design includes multiple biological groups spanning a broad range of ecological roles, both because no single group is the best indicator of every component of water quality and because there is widespread agreement that protecting the entire system is important.

Prior to 1997, four basic types of studies were conducted: comprehensive surveys, cursory surveys, diatometer studies, and Plant Vogtle surveys. Comprehensive surveys included the largest number of study components, were carried out roughly every 4 years, and included two sampling periods during the year. Cursory surveys included a reduced set of study components-typically, attached algae, insects, and fish - but were conducted annually, with four sampling periods per year (except in years with comprehensive surveys, which substituted for two of the usual cursory sampling periods). Thus, cursory surveys provided more narrowly focused information but on a more frequent basis. Diatometer studies addressed only the diatom flora but provided year-round annual monitoring. Plant Vogtle surveys, which included the same components as comprehensive surveys but different sampling stations, were initiated in 1985 to assess potential impacts of Georgia Power Company's Vogtle Electric Generating Plant so that these could be separated from potential SRS impacts.

Beginning with the 1997 study, several changes have been made in the monitoring program to reduce the types of studies conducted. The cursory,

comprehensive, and Plant Vogtle surveys have been combined into a single study, which is intermediate in scope between a cursory and a comprehensive survey. Four sampling stations (figure 12-3) are employed in the new biological survey design-three exposed to SRS influence (stations 6, 5, and 2B) and an unexposed reference station upstream (station 1). Multiple exposed stations are employed because of the complex pattern of SRS inputs along the river.

In addition to the redesigned biological survey, the diatometer study was conducted in 1997; however, fewer exposure periods were used than in the past. Sampling stations for the diatometer study include all four used in the biological survey, plus station $2 \mathrm{~A}$. (Stations $2 \mathrm{~A}$ and $2 \mathrm{~B}$ coincide with stations $\mathrm{V}-1$ and $\mathrm{V}-2$ in the discontinued Plant Vogtle surveys.)

As in previous ANSP studies on the Savannah River, potential impacts of SRS are assessed in the redesigned studies by determining whether 


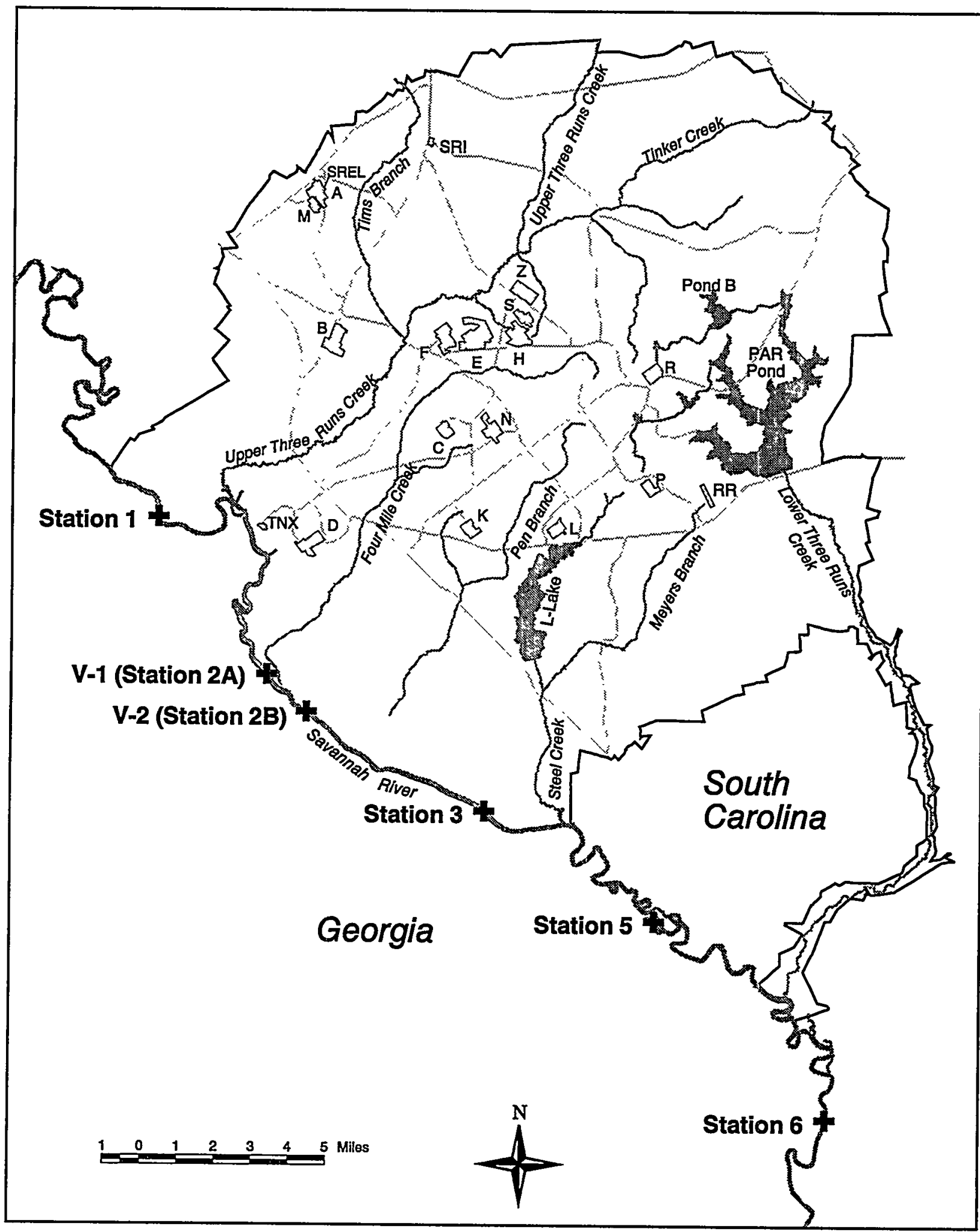

EPD/GIS Map

Figure 12-3 Academy Survey Sampling Sites

The Academy of Natural Sciences of Philadelphia has established specific sampling locations for surveys of the Savannah River-five exposed to SRS and other influences (stations 2A to 6) and one unexposed reference station (station 1). 
differences exist between the exposed and reference stations that are either greater or of a different character than would be expected if they were due merely to natural differences among sampling sites. For example, the character of differences among stations was judged in part by comparing the individual species collected. Evidence of impact exists if a station shows elevated abundances of species known to tolerate pollution and depressed abundances of species known to be sensitive to pollution. If this pattern is detected at the exposed stations, but not at the reference station, further studies would be recommended to determine the exact source. If, however, the pattern is seen at the reference station, the impact must be due to sources upstream from the study area.

Other potential types of evidence for impact include (1) decreased numbers of species and individuals and (2) numerical dominance by a small proportion of the species present. These patterns arise because pollution tends to reduce population growth rates in a majority of species, while a few tolerate or thrive in such conditions.

Determining whether exposed and reference stations differ is complicated by the fact that considerable variation exists even among samples collected at the same time from the same location. Apparent differences may therefore be spurious if each station is characterized by only a single sample. For this reason, several components of the ANSP studies collect multiple samples from each station, making it possible to quantify both of the important components of variation-within and among stations. Compelling evidence for station differences exists if variation among samples from different stations is significantly greater than average variation among samples from the same station, as judged by appropriate statistical techniques (e.g., analysis of variance). Otherwise, apparent station differences can be attributed simply to chance variability.

When statistically significant biological differences among stations are found, it is advisable to determine whether these might be caused by differences in physical characteristics of the stations rather than pollution. For example, the fish fauna at a station with shallow, fast-moving water is likely to differ from that at a station with deep, slow-moving water. The possible role of differences in physical characteristics such as water depth, current speed, and substrate type can be investigated using a statistical technique called analysis of covariance. The basic idea is to determine a simple mathematical relationship between the measured physical and biological characteristics, then use this relationship to statistically remove the effect of station differences in physical characteristics from the biological data. If station differences persist after this adjustment, they probably are caused by something other than the measured physical factors.

Another type of variation the ANSP studies address is variation over time. Important components of temporal variation include seasonal trends, multiyear trends, and trendless variability. All these components can be assessed using the unique dataset generated by the Academy's long-term monitoring program in the Savannah River. Regular sampling has continued with relatively little change in methods since the early 1950 s, making this one of the most comprehensive ecological datasets available for any of the world's rivers.

Such long-term records of biological change are valuable for several reasons. Because they allow the normal degree of year-to-year variability at a site to be quantified, changes observed from one survey to the next can be assessed to determine whether they fall within the normal range, much as one would use a control chart. Changes that are outside this range provide evidence of altered conditions at the study site.

These datasets also are useful in distinguishing between potential impacts of SRS and variation caused by other factors. In particular, part of the biological variation observed over time is caused by documented changes in river flow, wastewater treatment methods, dredging activities, and so on. Correlations between the known history of such changes on the one hand, and components of variation in long-term datasets on the other, provide evidence that these components were not caused by SRS operations.

Finally, long-term datasets can provide compelling evidence for multiyear trends of improvement or deterioration in ecosystem health. For example, the Academy's long-term data suggest there has been a relatively steady increase in the number of species of aquatic insects living in the Savannah River during the last 35 years. Because aquatic insect diversity is believed to be a sensitive measure of environmental quality, this pattern may indicate a long-term trend of improving water quality in the river.

\section{Results}

\section{Diatometer Monitoring}

Catherwood diatometers were deployed at stations 1 , $2 \mathrm{~A}, 2 \mathrm{~B}, 5$, and 6 for 122 -week periods, with retrieval 


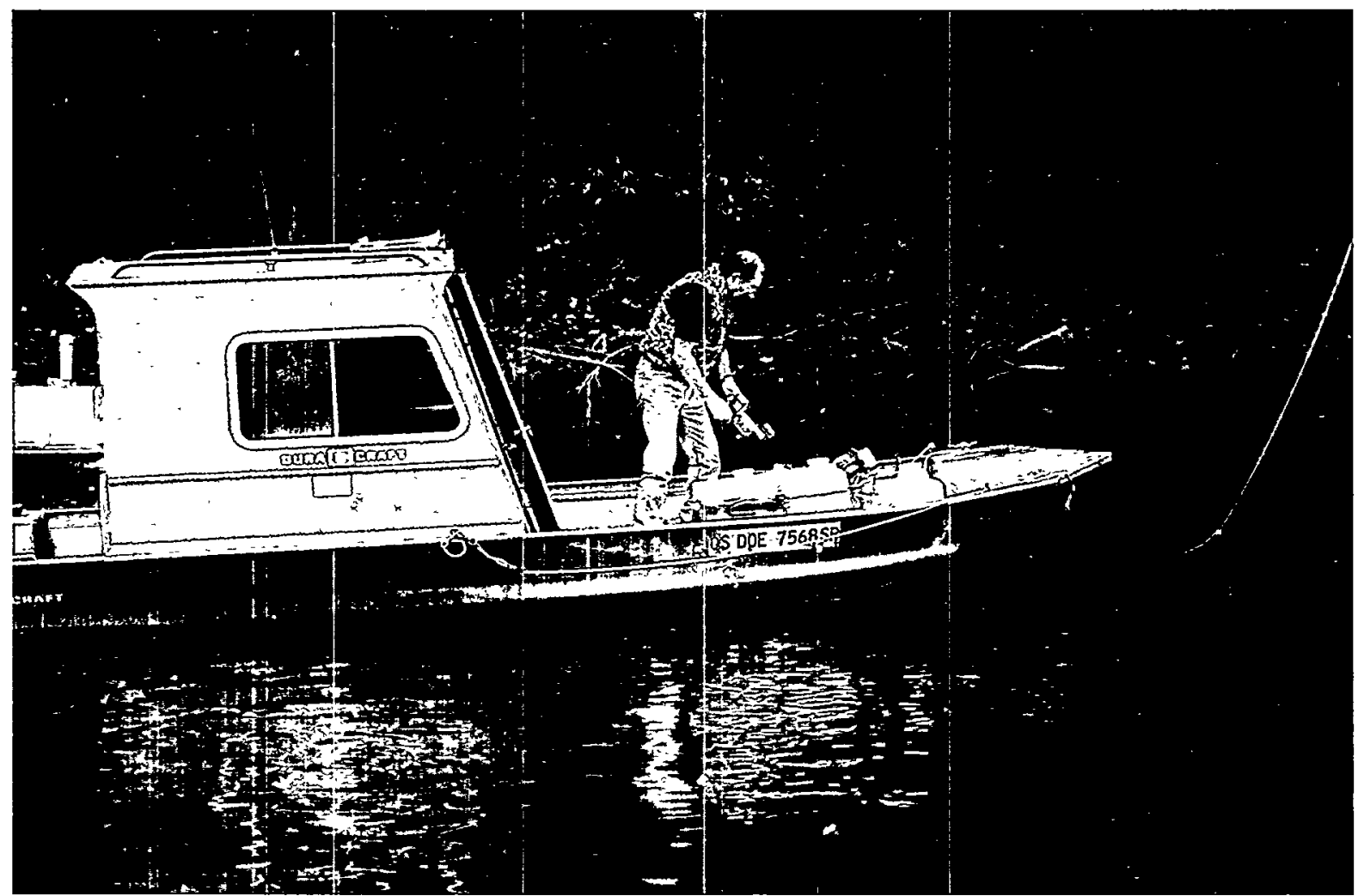

Al Mamatey Photo (99X03269.15)

EMS sampling technicians exchange Catherwood diatometers from a boat on the Savannah River. The diatometers were deployed at various locations along the river as part of the Academy of Natural Sciences of Philadelphia's long-term study of the river's water quality.

dates spanning February 4 to December 30, 1997. All diatoms were identified to species.

The diatom flora on diatometer slides was analyzed for species richness (= number of species), percent dominance ( $=$ percent of total specimen count on a slide comprising dominant species, where a dominant species is operationally defined as one with more than 1,024 counted cells), and relative abundances of dominant species. Species richness and percent dominance data were analyzed statistically using analysis of variance.

No statistically significant among-station variation was detected for either species richness or percent dominance. Species richness at all stations tended to be somewhat lower than the long-term average for previous studies, while percent dominance at station 1 tended to be higher than the long-term average. Ecological tolerances of the dominant diatom species were similar at all stations, with most dominants being characteristic of alkaline waters with moderately high nutrient concentrations. Results of the 1997 diatometer study provide no evidence of a negative SRS impact.

\section{Algae and Aquatic Macrophyte Studies}

Attached algae and aquatic macrophytes were sampled qualitatively (via hand collections) September 5-8, 1997, at stations 1, 2B, 5, and 6. All specimens were identified to species. These data were supplemented with quantitative data from the diatometer study for the same sampling period.

Station and year comparisons were based on the number of species in major taxonomic groups, on known pollution tolerances of individual species, and on their (the species') relative abundances.

The algal flora was similar at all three sampling stations. The diatom flora showed evidence of nutrient enrichment at all stations, apparently from an upstream source. As has been true since 1990 (inclusive), no significant beds of submerged aquatic vegetation were observed. Species richness and composition of both algae and macrophytes were similar to those of previous studies and showed no evidence of SRS impact. 


\section{Noninsect Macroinvertebrate Studies}

Qualitative samples of noninsect macroinvertebrates were collected September 5-8 and September 19-22, 1997, at stations 1, 2B, 5, and 6, with sampling

during the latter period concentrating on

shallow-water mussel habitats.

The Academy's long-term Savannah River database indicates that slightly more species tend to be collected at stations 5 and 6 than at stations 1 or $2 B$

(or 3). A similar pattern was found in 1997, which is opposite the pattern expected if SRS were having a negative impact. The noninsect macroinvertebrate fauna in 1997 was broadly similar to that in recent surveys (1976-1993), though the total number of species was greater in 1997 than in 1993 at all four stations. A noticeably greater number of species was collected in 1972 and was associated with the occurrence of dense beds of submerged aquatic vegetation, which have been absent beginning with the 1990 study.

\section{Insect Studies}

Quantitative samples of aquatic insects were collected July 8-10 and September 16-18, 1997, at stations $1,2 \mathrm{~B}, 5$, and 6 . The samples were collected using standardized artificial substrates, which permit replicate samples at each station and rigorous statistical comparisons. Specimens were identified to the lowest practical taxon (typically genus).

Station and season comparisons were based on quantitative per-sample estimates of three types of metrics, using two-way analysis of variance. The ecological community metrics include total abundance $(=$ total number of individuals of all taxa per $\mathrm{cm}$ ), taxa richness (= total number of taxa), community evenness (a measure of similarity in the numbers of individuals of the various taxa), and Shannon-Wiener diversity (a joint measure of richness and evenness, which is greatest when there are many taxa and all are similar in abundance). The community stress metrics include the EPT index (= total taxa richness of insect orders Ephemeroptera, Plecoptera, and Trichoptera), percent Chironomidae, EPT:Chironomidae ratio, percent dominance (= percent contribution of the taxon with the greatest abundance), and modified Hilsenhoff's genus/species-level and family-level indices of pollution tolerance, based on pollution-tolerance scores assigned to the individual taxa collected. The functional-feeding group metrics include the proportional abundances of the major functional-feeding groups; viz., percent collector-gatherers, percent collector-filterers, percent predators, and percent scrapers. In addition to analysis of variance, potential differences among stations and seasons in taxonomic composition were assessed using cluster analysis and detrended correspondence analysis.

Three of five ecological community metrics revealed station differences: total density was greatest at station 5, but diversity and evenness were greater at station 1 than at station 5 or 6 . Two of seven community stress metrics revealed station differences: percent dominance was greater at station 5 than at station 1, but Hilsenhoff's index of pollution tolerance was greater at station 1 than at station 5 . One of four functional-feeding group metrics revealed a station difference: percent predators was greater at station 1 than at station 5 or 6 . Both cluster analysis and detrended correspondence analysis highlighted the similarity among stations while suggesting relatively weak differences among seasons.

In summary, several metrics showed statistically significant differences among stations, but most did not. Among those that did, comparisons between station 1 and stations 5 and 6 sometimes suggested station 1 was more stressed than the downstream stations and sometimes suggested it was less stressed. Thus, there was no consistent pattern suggesting an SRS impact, and the differences probably reflect other factors.

\section{Fish Studies}

Fish were sampled at stations $1,2 \mathrm{~B}, 5$, and 6 during September 5-10, 1997. The main collection techniques were seining, boat electroshocking in the main channel, and walk-along electroshocking in backwaters. Specimens were identified to species.

Species richness, species diversity (Shannon-Wiener index), and densities of individual species were estimated for each seine sample. Data were analyzed using analysis of variance, analysis of covariance, and $\mathrm{k}$-means cluster analysis.

$\mathrm{K}$-means cluster analysis was performed on the combined data from 1989, 1993, and 1997 for stations 1,5 , and 6 . Three clusters were prescribed to determine whether samples differed mainly by year or by station. The results suggest that the main source of variation was station rather than year, with stations 1 and 6 being most different and station 5 intermediate.

No statistically significant differences among stations were found for species richness, species diversity, or densities of individual species. Both pollution-tolerant and pollution-intolerant species were found at all stations, and there was no pattern 
among stations in abundance of minnows and darters. Thus, though the combined data for 1989, 1993, and 1997 appear to show greater variation among stations than among years, the nature of this variation is not indicative of an SRS impact.

\section{Conclusions}

As in previous Savannah River studies, the 1997 diatometer study and the algal component of the biological survey indicate nutrient enrichment at all stations, evidently due to sources upstream of the study area. Several differences among stations were detected in other components of the survey, but there was no consistent pattern of difference either within or among components that would indicate an SRS impact. 


\section{Appendix A}

\section{Applicable Guidelines, Standards, and Regulations}

$\mathrm{T}$ HE Savannah River Site (SRS) environmental monitoring program is designed to meet state and federal regulatory requirements for radiological and nonradiological programs. These requirements are stated in U.S. Department of Energy (DOE) Order 5400.1, "General Environmental Protection Program," and DOE Order 5400.5, "Radiation Protection of the Public and the Environment"; in the Standards of Performance for New Stationary Sources, also referred to as New Standards of Performance for Stationary Sources (NSPS); in the National Emission Standards for Hazardous Air Pollutants (NESHAP); in the Comprehensive Environmental Response, Compensation, and Liability Act (CERCLA-also known as the Superfund); in the Resource Conservation and Recovery Act (RCRA); in the Clean Water Act (i.e., National Pollutant Discharge Elimination System-NPDES); and in the National Environmental Policy Act (NEPA). Compliance with environmental requirements is assessed by the South Carolina Department of Health and Environmental
Control (SCDHEC) and the U.S. Environmental Protection Agency (EPA).

The SRS environmental monitoring program's objectives incorporate recommendations of the International Commission on Radiological Protection ("Principles of Monitoring for the Radiation Protection of the Public," ICRP Publication 43), of DOE Order 5400.1, and of DOE/EH-0173T, "Environmental Regulatory Guide for Radiological Effluent Monitoring and Environmental Surveillance." In addition, SRS has implemented and adheres to the SRS Environmental Management System Policy. As a result, the site has obtained International Organization for Standardization (ISO) 14001 certification. The full text of the policy in included in this appendix and begins on page 212 .

Drinking water standards and maximum allowable concentrations of toxic air pollutants can be found in appendix B, "Drinking Water Standards," and appendix C, "Standard No. 8 Toxic Air Pollutants." More information about certain media is presented in this appendix.

\section{Air Effluent Discharges}

DOE Order 5400.5 establishes Derived Concentration Guides (DCGs) for radionuclides in air. DCGs, calculated by the Department of Energy (DOE) using methodologies consistent with recommendations found in International Commission on Radiological Protection (ICRP) publications 26 and 30 , are used as reference concentrations for conducting environmental protection programs at DOE sites and for making dose comparisons. DCGs are not considered release limits. DCGs for radionuclides in air are discussed in more detail on page 210 .

In addition, radiological airborne releases are subject to EPA regulations cited in 40 CFR 61 , Subpart H, NESHAP.

Regulation of radioactive and nonradioactive air emissions-both criteria pollutants and toxic air pollutants-has been delegated to SCDHEC. SCDHEC, therefore, must ensure that its air pollution regulations are at least as stringent as federal regulations required by the Clean Air Act. This is accomplished by SCDHEC

Regulation 61-62, "Air Pollution Control Regulations and Standards." As with many regulations found in the Code of Federal Regulations (CFR), many of SCDHEC's regulations and standards are source specific. Each source of air pollution at SRS is permitted or exempted by SCDHEC, with specific emission rate limitations or special conditions identified. The bases for the limitations and conditions are the applicable South Carolina air pollution control regulations and standards. In some cases, specific applicable CFRs are also sited in the permits issued by SCDHEC.

Two SCDHEC standards, which govern criteria and toxic air pollutants and ambient air quality, are applicable to all SRS sources. SCDHEC Air Pollution Control Regulation 61-62.5, Standard No. 2, "Ambient Air Quality Standards," identifies eight 
criteria air pollutants commonly used as indices of air quality (e.g., sulfur dioxide, nitrogen dioxide, and lead) and provides allowable site boundary concentrations for each pollutant as well as the measuring intervals. Compliance with the various pollutant standards is determined by conducting air dispersion modeling for all sources of each pollutant using EPA-approved dispersion models and then comparing the results to the standard. The pollutants, measuring intervals, and allowable concentrations are given in table $\mathrm{A}-1$. The standards are in micrograms per cubic meter unless noted otherwise.

The SCDHEC standard for toxic air pollutants are identified in Regulation 61-62.5, Standard No. 8, "Toxic Air Pollutants." This standard identifies 256 toxic air pollutants and their respective allowable site boundary concentrations. Again, as with Standard No. 2, compliance with this standard is

Table A-1

Criteria Air Pollutants

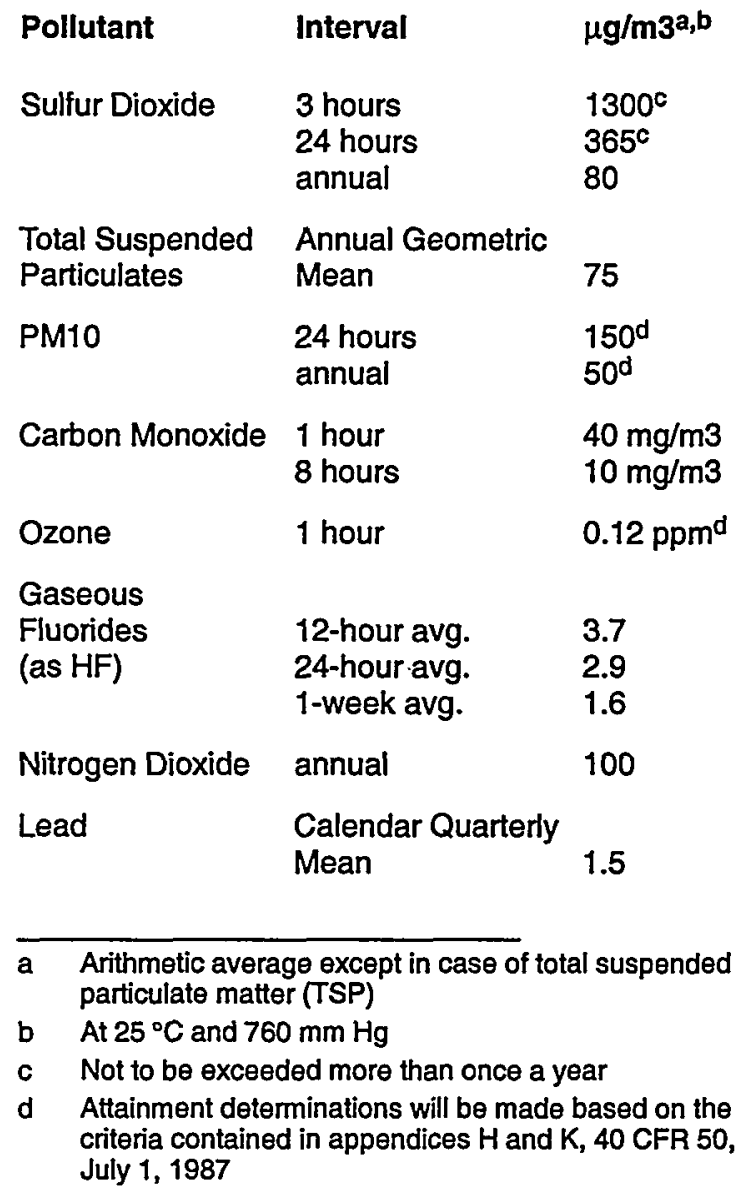

Table A-2

Airborne Emission Standards for SRS Coal-Fired Boilers

Sulfur Dioxide

$3.6 \mathrm{lb} / 10^{6}$ BTU $^{\mathrm{a}}$

Total Suspended Particulates

$0.6 \mathrm{~b} / 10^{6} \mathrm{BTU}$

Opacity

$40 \%$

a British Thermal Unit

determined by air dispersion modeling. The pollutants, chemical abstract numbers (CAS), and maximum allowable concentrations are shown in appendix $\mathrm{C}$.

SCDHEC airborne emission standards for each SRS permitted source may differ, based on size and type of facility, type and amount of expected emissions, and the year the facility was placed into operation. For example, SRS powerhouse coal-fired boilers are regulated by SCDHEC Regulation 61-62.5, Standard No. 1, "Emissions From Fuel Burning Operations." This standard specifies that for powerhouse stacks built before February 11, 1971, the opacity standard is 40 percent. For new sources constructed after this date, the opacity standard typically is 20 percent. The standards for particulate and sulfur dioxide emissions are shown in table A-2.

SCDHEC regulation 61-62.5, Standard No. 3 , "Waste Combustion and Reduction," is applicable to several sources at SRS. Under this standard the Consolidated Incinerator Facility (CIF) in H-Area is considered a hazardous waste incinerator. Several of the standards for the CIF, given in table $\mathrm{A}-3$, are adjusted for British Thermal Unit (BTU) content of the waste being burned.

The catalytic oxidation units (COUs) for SRS soil vapor extraction and ground water air stripper systems in A-Area and M-Area are classified as industrial incinerators under this standard. As such, the COUs have an opacity limit of 20 percent.

Regulation 61-62.5, Standard No. 4, "Emissions from Process Industries," is applicable to all SRS sources except those regulated by a different source specific standard. For some SRS sources, particulate matter emission limits are dependent on the weight of the material being processed and are determined from a table in the regulation. For process and diesel engine stacks in existence on or before December 31, 1985, emissions shall not exhibit an opacity greater than 40 percent. For new sources, where construction was started after 
Table A-3

Airborne Emission Standards for SRS Consolidated Incinerator Facility

\begin{tabular}{ll}
\hline Opacity & $10 \%$ \\
Hydrochloric acid (HCl) & $4 \mathrm{lb} / \mathrm{hr}$ \\
Particulate Matter & $0.08 \mathrm{gr} / \mathrm{DSCF}$ \\
Nickel & $0.11 \mathrm{lb} / \mathrm{hr}^{\mathrm{b}}$ \\
Cadmium & $0.0018 \mathrm{lb} / \mathrm{hr}^{\mathrm{b}}$ \\
Chromium & $0.0090 \mathrm{lb} / \mathrm{hr}^{\mathrm{b}}$ \\
Arsenic & $0.0046 \mathrm{lb} / \mathrm{hr}^{\mathrm{b}}$ \\
Lead & $0.090 \mathrm{lb} / \mathrm{hr}^{\mathrm{b}}$ \\
Organic Compounds & Various \\
Dioxin & $99.9999 \%$ DRE \\
\hline \multicolumn{2}{l}{$\begin{array}{l}\text { Corrected to } 7 \% \text { oxygen } \\
\text { Adjusted for BTU content of waste } \\
\text { c Must be destroyed with an efficiency of at least }\end{array}$} \\
\hline 99.99\%
\end{tabular}

December 31,1985 , the opacity standard is 20 percent.

As previously mentioned, some SRS sources have both SCDHEC and CFRs applicable and identified in their permits. For the package steam generating boilers in $\mathrm{K}$-Area and two portable package boilers, both SCDHEC and federal regulations are applicable. The standard for sulfur dioxide emissions is specified in 40 CFR 60, Subpart Dc, "Standards of Performance for Small Industrial-Commercial-Institutional Steam Generating Units," while the standard for particulate
Table A-4

Airborne Emission Standards for SRS Fuel Oil-Fired Package Boilers

\begin{tabular}{ll} 
Sulfur Dioxide & $0.5 \mathrm{lb} / 10^{6} \mathrm{BTU}$ \\
$\begin{array}{l}\text { Total Suspended } \\
\text { Particulates }\end{array}$ & $0.6 \mathrm{~b} / 10^{6}$ BTU \\
Opacity & $20 \%$ \\
\hline
\end{tabular}

matter is found in SCDHEC Standard No. 1, "Emissions From Fuel Burning Operations." Because these units were constructed after applicability dates found in both regulations, the opacity limit for these units is the same in both regulations. The emissions standards for these boilers are presented in table $A-4$.

Another federal regulation, $40 \mathrm{CFR} 60$, Subpart Kb, "Standards of Performance for Volatile Organic Liquid Storage Vessels (Including Petroleum Liquid Storage Vessels) for which Construction, Reconstruction, or Modification Commenced after July 23,1984 ," specifies types of emission controls that must be incorporated into the construction of a source. In this regulation, the type of control device required is dependent on the size of the tank and the vapor pressures of the material being stored. This regulation is applicable to several sources at SRS, such as the two 30,000-gallon No. 2 fuel oil storage tanks in K-Area or the four mixed solvent storage tanks in H-Area. However, because of the size of these tanks and vapor pressures of the materials being stored, these tanks are not required to have control devices installed. The only requirements applicable to SRS storage tanks are those for record keeping.

\section{(Process) Liquid Effluent Discharges}

DOE Order 5400.5 establishes DCGs for radionuclides in process effluents. (DCGs for radionuclides in water are discussed in more detail on page 211.) DCGs were calculated by DOE using methodologies consistent with recommendations found in ICRP Publications 26 and 30 and are used

- as reference concentrations for conducting environmental protection programs at DOE sites

- as screening values for considering best available technology for treatment of liquid effluents

- for making dose comparisons
DOE Order 5400.5 exempts aqueous tritium releases from best available technology requirements but not from ALARA (as low as reasonably achievable) considerations.

SRS discharges water into site streams and the Savannah River under four NPDES permits: one industrial wastewater permit (SC0000175), one general utility water discharge permit (SCG250162), and two stormwater runoff permits (SCR000000 for industrial discharges and SCR100000 for construction discharges). 
A fifth permit (ND0072125) is a no-discharge water pollution control land application permit that regulates sludge generated at onsite sanitary waste treatment plants.

Detailed requirements for each permitted discharge point-including parameters sampled for, permit limits for each parameter, sampling frequency, and method for collecting each sample - can be found in the individual permits, which are available to the public through SCDHEC's Freedom of Information office at (803) 734-5376.

\section{Site Streams}

SRS streams are classified as "Freshwaters" by the South Carolina Pollution Control Act. Freshwaters are defined as surface water suitable for

- primary- and secondary-contact recreation and as a drinking water source after conventional treatment in accordance with SCDHEC requirements
- fishing and survival and propagation of a balanced indigenous aquatic community of fauna and flora

- industrial and agricultural uses

Table A-5 provides some of the specific guides used in water quality surveillance, but because some of these guides are not quantifiable, they are not tracked in response form (i.e., amount of garbage found).

\section{Savannah River}

Because the Savannah River is defined under the South Carolina Pollution Control Act as a
Freshwater system, the river is regulated in the same manner as are site streams (table A-5).

\section{Drinking Water}

EPA drinking water standards (40 CFR 141) for radionuclides apply at the water treatment plants operated by Beaufort and Jasper counties in South Carolina and Port Wentworth in Georgia. Drinking water standards for specific radionuclides are listed in appendix B, "Drinking Water Standards."

SRS drinking water systems must meet the water quality criteria mandated by SCDHEC State Primary Drinking Water Regulations, R.61-58. Drinking water standards for specific contaminants are provided in appendix B, "Drinking Water Standards."
SRS collects samples from all 9 systems to determine compliance with SCDHEC bacteriological water quality limits. Samples are collected monthly or quarterly, depending on the population served. SRS collects samples from the three largest systems to determine compliance with SCDHEC lead and copper water quality limits. Site systems are monitored semiannually by SRS for chlorocarbon concentrations. SCDHEC periodically collects samples from the ten largest systems to determine compliance with bacteriological, chemical, synthetic organic, volatile organic, and radiological water quality limits.

\section{Groundwater}

The analytical results of samples taken from SRS monitoring wells that exceed various standards are discussed in this report. Constituents discussed are compared to final federal primary drinking water standards (DWS), or other standards if DWS do not exist, because groundwater aquifers are defined as potential drinking water sources by the South Carolina Pollution Control Act. [SCDHEC, 1985]. The DWS can be found in appendix B, "Drinking Water Standards." DWS are not always the standards applied by regulatory agencies to the SRS waste units under their jurisdiction. For instance, standards under RCRA are DWS, groundwater protection standards, background levels, and alternate concentration limits.
Two constituents having DWS-dichloromethane and bis(2-ethylhexyl) phthalate-are not discussed in this report. Both are common laboratory contaminants and are reported in groundwater samples with little or no reproducibility. Both are reported, with appropriate flags and qualifiers, in the data tables of the quarterly reports cited in chapter 10, "Groundwater."

The standard used for lead is the SCDHEC DWS. The federal standard of $15 \mu \mathrm{g} / \mathrm{L}$ is a treatment standard for drinking water at the consumer's tap; thus, it is inappropriate for use as a groundwater standard. 
Table A-5

South Carolina Water Quality Standards for Freshwaters

Note: This is a partial list only of water quality standards for freshwaters.

\section{Parameters Standards}

a. Fecal coliform Not to exceed a geometric mean of $200 / 100 \mathrm{~mL}$, based on five consecutive samples during any 30-day period; nor shall more than 10 percent of the total samples during any 30 -day period exceed $400 / 100 \mathrm{~mL}$.

b. pH Range between 6.0 and 8.5 .

c. Temperature Generally, shall not be increased more than $5^{\circ} \mathrm{F}\left(2.8^{\circ} \mathrm{C}\right)$ above natural temperature conditions or be permitted to exceed a maximum of $90^{\circ} \mathrm{F}\left(32.2^{\circ} \mathrm{C}\right)$ as a result of the discharge of heated liquids. For exceptions, see E-6, Regulation 61-68, State of South Carolina Water Classifications and Standards (May 28, 1993).

\section{d. Dissolved oxygen Daily average not less than $5.0 \mathrm{mg} / \mathrm{L}$, with a low of $4.0 \mathrm{mg} / \mathrm{L}$.}

e. Garbage, cinders, ashes, sludge, None allowed. or other refuse

f. Treated wastes, toxic wastes, deleterious substances, colored or other wastes, except those in (e)

None alone or in combination with other substances or wastes in sufficient amounts to make the waters unsafe or unsuitable for primary-contact recreation or to impair the waters for any other best above.

g. Ammonia, chlorine, and toxic pollutants listed in the federal Clean Water Act (307) and for which EPA has developed national criteria (to protect aquatic life).

See E-7 (list of water quality standards based on organoleptic data) and E-8 (water quality criteria for protection of human health), Regulation $61-68$, State of South Carolina Water Classifications and Standards (May 28, 1993).

SOURCE: [SCDHEC, 1993]

Of the radionuclides discussed, only gross alpha, strontium-90, and tritium are compared to true primary DWS. The regulatory standards for radionuclide discharges from industrial and governmental facilities are set under the Clean Water Act, RCRA, and Nuclear Regulatory Commission and DOE regulations. The proposed drinking water maximum contaminant levels discussed in this report are only an adjunct to these release restrictions and are not used to regulate SRS groundwater.

The standard used for gross beta is a screening standard; when public drinking water exceeds this standard, the supplier is expected to analyze for individual beta and gamma emitters. A gross beta result above the standard is an indication that one or more radioisotopes are present in quantities that would exceed the EPA annual dose equivalent for persons consuming 2 liters daily. Thus, for the individual beta and gamma radioisotopes (other than strontium-90 and tritium), the standard discussed in this report is the activity per liter that would, if only that isotope were present, exceed the dose equivalent. Similarly, the standards for alpha emitters discussed in this report are calculated to present the same risk at the samo rate of ingestion.

Although radium has a DWS of $5 \mathrm{pCi} / \mathrm{L}$ for the sum of radium-226 and radium-228, the standards discussed in this report are the proposed standards of $20 \mathrm{pCi} / \mathrm{L}$ for each isotope separately. Radium-226, an alpha emitter, and radium-228, a beta emitter, cannot be analyzed by a single method. Analyses for total alpha-emitting radium, which consists of 
radium-223, radium-224, and radium-226, are compared to the standard for radium-226.

Four other constituents without DWS are discussed in this report when their values exceed specified levels. These constituents are specific conductance at values equal to or greater than $100 \mu \mathrm{S} / \mathrm{cm}$, alkalinity (as $\left.\mathrm{CaCO}_{3}\right)$ at values equal to or greater than $100 \mathrm{mg} / \mathrm{L}$, total dissolved solids (TDS) at values equal to or greater than $200 \mathrm{mg} / \mathrm{L}$, and $\mathrm{pH}$ at values equal to or less than 4.0 or equal to or greater than 8.5. The selection of these values as standards for comparison is somewhat arbitrary; however, these values exceed levels usually found in background wells at SRS. The occurrence of elevated alkalinity (as $\left.\mathrm{CaCO}_{3}\right)$, specific conductance, $\mathrm{pH}$, and TDS within a single well may indicate leaching of the grouting material used in well construction, rather than degradation of the groundwater.

\section{Potential Dose}

The radiation protection standards followed by SRS are outlined in DOE Order 5400.5 and include EPA regulations on the potential doses from airborne releases and treated drinking water.

The following radiation dose standards for protection of the public in the SRS vicinity are specified in DOE Order 5400.5.

Drinking Water Pathway .... 4 mrem per year Airborne Pathway ...... 10 mrem per year All Pathways ......... 100 mrem per year

The EPA annual dose standard of $10 \mathrm{mrem}$ $(0.1 \mathrm{mSv})$ for the atmospheric pathway, which is contained in "National Emission Standards for Hazardous Air Pollutants-Radionuclides (NESHAP)," 40 CFR Part 61, Subpart $\mathrm{H}$, is adopted in DOE Order 5400.5.

These dose standards are based on recommendations of the ICRP and the National Council on Radiation Protection and Measurements (NCRP).

The DOE dose standard enforced at SRS for drinking water consumed from site drinking water systems, community drinking water systems, and downriver water treatment plants is consistent with the criteria contained in "National Interim Primary Drinking Water Regulations, 40 CFR Part 141." Under these regulations, persons consuming drinking water shall not receive an annual whole body dose-DOE Order 5400.5 interprets this dose as committed effective dose equivalent -of more than $4 \mathrm{mrem}(0.04 \mathrm{mSv})$. Both dose standards are based on a consumption rate of 2 liters of water per day. However, some radionuclide dose conversion factors (including tritium) differ between EPA and DOE.

Because SRS must use DOE-provided, ICRP-based dose conversion factors, a direct comparison of the estimated drinking water doses in chapter 7 , "Potential Radiation Doses," to the EPA drinking water dose standard cannot be made. However, radionuclide concentrations found in drinking water are directly compared to the EPA drinking water concentration standards in chapter 6 , "Radiological Environmental Surveillance."

\section{Comparison of Average Concentrations in Airborne Emissions to DOE Derived Concentration Guides}

Average concentrations of radionuclides in airborne emissions are calculated by dividing the yearly release total of each radionuclide from each stack by the yearly stack flow quantities. These average concentrations then can be compared to the DOE DCGs, which are found in DOE Order 5400.5 for each radionuclide.

DCGs are used as reference concentrations for conducting environmental protection programs at all DOE sites. DCGs, which are based on a 100 -mrem exposure, are applicable at the point of discharge (prior to dilution or dispersion) under conditions of continuous exposure (assumed to be an average inhalation rate of 8,400 cubic meters per year). This means that the DOE DCGs are based on the highly conservative assumption that a member of the public has direct access to and continuously breathes (or is immersed in) the actual air effluent 24 hours a day, 365 days a year. However, because of the large distance between most SRS operating facilities and the site boundary, and because the wind rose at SRS shows no strong prevalence (chapter 7, "Potential Radiation Doses"), this scenario is improbable.

Average annual radionuclide concentrations in SRS air effluent can be referenced to DOE DCGs as a screening method to determine if existing effluent treatment systems are proper and effective. 


\section{Comparison of Average Concentrations in Liquid Releases} to DOE Derived Concentration Guides

In addition to dose standards, DOE Order 5400.5 imposes other control considerations on liquid releases. These considerations are applicable to direct discharges but not to seepage basin and Solid Waste Disposal Facility (SWDF) migration discharges. The DOE order lists DCG values for most radionuclides. DCGs are used as reference concentrations for conducting environmental protection programs at all DOE sites. These DCG values are not release limits but screening values for best available technology investigations and for determining whether existing effluent treatment systems are proper and effective.

Per DOE Order 5400.5, exceedance of the DCGs at any discharge point may require an investigation of best available technology waste treatment for the liquid effluents. Tritium in liquid effluents is specifically excluded from best available technology requirements; however, it is not excluded from other ALARA considerations. DOE DCG compliance is demonstrated when the sum of the fractional DCG values for all radionuclides detectable in the effluent is less than 1.00 , based on consecutive 12 -month average concentrations.

DCGs, based on a 100-mrem exposure, are applicable at the point of discharge from the effluent conduit to the environment (prior to dilution or dispersion). They are based on the highly conservative assumption that a member of the public has continuous direct access to the actual liquid effluents and consumes 2 liters of the effluents every day, 365 days a year. However, because of security controls and the large distance between most SRS operating facilities and the site boundary, this scenario is highly improbable, if not impossible.

For each site facility that releases radioactivity, the site's Environmental Monitoring Section (EMS) compares the monthly liquid effluent concentrations and 12-month average concentrations against the DOE DCGs.

\section{Environmental Management}

SRS began its cleanup program in 1981 . Two major federal statutes provide guidance for the site's environmental restoration and waste management activities-RCRA and CERCLA. RCRA addresses the management of hazardous waste and requires that permits be obtained for facilities that treat, store, or dispose of hazardous or mixed waste. It also requires that $\mathrm{DOE}$ facilities perform appropriate corrective action to address contaminants in the environment. CERCLA (also known as Superfund) addresses the uncontrolled release of hazardous substances and the cleanup of inactive waste sites. This act establishes a National Priority List of sites targeted for assessment and, if necessary, corrective/remedial action. SRS was placed on this list December 21, 1989 [Fact Sheet, 1995]. In August 1993, SRS entered into the Federal Facility Agreement (FFA) with EPA Region IV and SCDHEC. This agreement governs the corrective/remedial action process from site investigation through site remediation. It also describes procedures for setting annual work priorities, including schedules and deadlines, for that process [FFA under section 120 of CERCLA and sections 3008(h) and 6001 of RCRA].

Additionally, DOE is complying with Federal Facility Compliance Act requirements for mixed waste management-including high-level waste, most transuranic waste, and low-level waste with hazardous constituents. This act requires that DOE develop and submit site treatment plans to the U.S. Environmental Protection Agency (EPA) or state regulators for approval.
A Facilities Decommissioning Division was established on site in 1996 to manage SRS excess facilities-from completion of operations shutdown through final disposition. Today, facility disposition activities at the site are conducted according to directives established in DOE Order 430.1, "Life Cycle Asset Management," and DOE Headquarters draft guidance. This order addresses requirements associated with the planning, acquisition, operation, maintenance, leasing, and disposition of physical assets. As such, it replaces 14 previous orders for the management of physical assets-from acquisition through disposition.

\section{Quality Assurance/Quality Control}

DOE Order 5700.6C, "Quality Assurance," sets requirements and guidelines for departmental quality assurance (QA) practices. Westinghouse Savannah River Company (WSRC) developed an 
implementation plan to address the order, entitled "Revised Implementation Plan: DOE Order 5700.6C." To ensure compliance with regulations and to provide overall quality requirements for site programs, WSRC developed the Westinghouse Savannah River Company Quality Assurance Management Plan (WSRC-RP-92-225). The requirements of WSRC-RP-92-225 are implemented by the Westinghouse Savannah River Company Quality Assurance Manual (WSRC 1Q).

The Environmental Monitoring Section Quality Assurance Plan, Volume III (WSRC-3Q1-2), part of the EMS WSRC-3Q1 procedure series, was written to apply the QA requirements of WSRC $1 Q$ to the environmental monitoring and surveillance program. The EMS WSRC-3Q1 procedure series includes procedures on sampling, radiochemistry, and water quality that emphasize the quality control requirements for EMS.

NESHAP defines specific QA requirements for monitoring radiological air emissions [EPA, 1989]. The EMS QA program's plan to comply with these requirements is found in WSRC-3Q1-2, Volume I, Attachment 3-1, "NESHAP QA Plan"

(WSRC-IM-91-60).

To ensure valid and defensible monitoring data, the records and data generated by the monitoring program are maintained according to the requirements of DOE Order 1324.2A, "Records
Disposition," and of WSRC 1Q. QA records include sampling and analytical procedure manuals, logbooks, chain-of-custody forms, calibration and training records, analytical notebooks, control charts, validated laboratory data, and environmental reports. These records are maintained and stored per the requirements of WSRC-1M-93-0060, WSRC Sitewide Records Inventory and Disposition Schedule.

EMS assessments are implemented according to the following documents:

- WSRC-12Q

- WSRC-1Q

- DOE Order 5700.6c, "Quality Assurance"

- DOE/EM-0159P, “Analytical Laboratory Quality Assurance Guidance"

- DOE/EM-0157P, “Laboratory Assessment Plates"

- DOE/EH-0173T, "Program Guidance"

The EMS Self Assessment Plan (ESH-EMS-97-0697) defines the requirements for self assessment and provides for verification of the compliance and effectiveness of the EMS QA/QC program. The plan's purpose is to assist management in evaluating the performance of EMS activities and the effectiveness of management controls and procedures.

\section{Reporting}

DOE Order 231.1, "Environment, Safety and Health Reporting," requires that SRS submit an annual environmental report.

This report, the Savannah River Site Environmental
Report for 1998, is an overview of effluent monitoring and environmental surveillance activities conducted on and in the vicinity of SRS from January 1 through December 31, 1998.

\section{ISO 14001 Environmental Management System}

International Organization for Standardization (ISO) 14001 is the Environmental Management System Standard within the ISO 14000 series of standards, a family of voluntary environmental management standards and guidelines. SRS achieved ISO 14001 certification in 1997 by demonstrating adherence to and programmatic implementation of the SRS Environmental Management System Policy. The full text of the policy (without the names of the signatories) follows.

\section{Savannah River Site (SRS) Environmental Management System Policy Effective February 26, 1997}

OBJECTIVE:

The objective of this policy is to ensure every employee of the DOE Savannah River Operations Office (SR), all contractors, subcontractors, and other agencies performing work at the Savannah River Site (SRS) does so in 
accordance with DOE Order 5400.1 and the mission, the vision, the core values, and the environmental goals and objectives of the Savannah River Strategic Plan.

\section{DIRECTIVE:}

Recognizing that all aspects of operations carried out at the SRS may impact the environment, it is the policy of the DOE-SR that all employees, contractors, subcontractors, and other agencies performing work at the SRS shall abide by the policy directives in this document. In order to ensure implementation of and commitment to this Policy, WSRC, Wackenhut Services; Incorporated-Savannah River Site (WSI-SRS), Savannah River Ecology Laboratory (SREL), and the SR Forest Station shall sign this Policy.

This document is the SRS Environmental Management System Policy and it shall serve as the primary documentation for the environmental goals and objectives of the SRS and shall be available to the public. It shall be centrally maintained and updated as necessary to reflect the changing needs, missions and goals of the SRS.

The Environmental Management System shall pursue and measure continual improvement in performance by establishing and maintaining documented environmental objectives and targets that correspond to the mission, vision, and core values subscribed to at SRS. The environmental objectives and targets shall be established for each relevant function and level within DOE-SR and all contractors, subcontractors, and other agencies performing work at the SRS for all activities having actual or potentially significant environmental impacts.

DOE-SR and all contractors, subcontractors, and other agencies performing work at the SRS shall:

- Emphasize vigilance of SRS resources, products, waste, and contamination. When a threat to human health or the environment is presented by SRS resources, products, waste, and contamination, DOE-SR and all contractors, subcontractors, and other agencies performing work at the SRS shall undertake all reasonable means to eliminate or mitigate that threat at the earliest practicable opportunity.

- Undertake the management of environmental and natural resources to emphasize vigilance and the prompt undertaking of opportunities for improvement for situations that could pose a significant threat to the quality of the environment or public health.

- Implement a pollution prevention program as a strategy to reduce waste generation and pollution releases, minimize environmental impacts, reduce future waste management and pollution control costs, and improve energy efficiency.

- Conduct operations in compliance with the letter and spirit of all applicable federal, state, and local laws, regulations, statutes and Executive Orders, and DOE Directives or Standards/Requirements Identification Documents, as appropriate.

- Work cooperatively and openly with the appropriate local, state and federal agencies, public stakeholders and site employees to prevent pollution, achieve environmental compliance, conduct cleanup and restoration activities, enhance environmental quality, and ensure the protection of workers and the public health.

- Design, develop, construct, operate, and maintain facilities and operations in a manner that shall be resourceefficient and will protect and improve the quality of the environment for future generations and continue to maintain the SRS as a unique national environmental asset.

- Recognize that the responsibility for quality communication rests with each individual employee and that it shall be the responsibility of all employees to identify and communicate ideas for improving the environmental protection activities and programs of the site.

The Office of External Affairs (DOE-SR/OEA) shall be the primary point of contact between SRS and its public stakeholders.

Adherence to and programmatic implementation of this policy shall be monitored by the DOE-SR Assistant Manager of Environmental Quality (AMEQ) in coordination with the contractors, subcontractors and other agencies performing work on the SRS. An annual evaluation of the Environmental Management System with recommendations for improvement shall be provided to the undersigned managers. [Editors' note: The names of the signatories that appeared at the end of the full text of the policy have not been included here.] 



\section{Drinking Water Standards}

\begin{tabular}{|c|c|c|c|c|c|}
\hline \multicolumn{2}{|c|}{ Analyte } & $\begin{array}{c}\text { Maximum } \\
\text { Contaminant Levela }\end{array}$ & Units & Status & Reference $^{b}$ \\
\hline \multicolumn{2}{|l|}{ Note: } & $\begin{array}{l}\text { Ion Agency is revising the } \\
\text { been in effect since } 1977 \text {. }\end{array}$ & $\begin{array}{l}\text { Rational prin } \\
\text { Revisions a }\end{array}$ & $\begin{array}{l}\text { ry drinking wa } \\
\text { expected by }\end{array}$ & $\begin{array}{l}\text { dards for } \\
\text { er } 2000 .\end{array}$ \\
\hline \multicolumn{2}{|c|}{ Alachlor } & 0.002 & $\mathrm{mg} / \mathrm{L}$ & final & CFR, 1997 \\
\hline \multicolumn{2}{|c|}{ Aldicarb } & 0.003 & $\mathrm{mg} / \mathrm{L}$ & final & CFR, 1997 \\
\hline \multicolumn{2}{|c|}{ Aldicarb sulfone } & 0.002 & $\mathrm{mg} / \mathrm{L}$ & final & CFR, 1997 \\
\hline \multicolumn{2}{|c|}{ Aldicarb sulfoxide } & 0.004 & $\mathrm{mg} / \mathrm{L}$ & final & CFR, 1997 \\
\hline \multicolumn{2}{|c|}{ Antimony } & 0.006 & $\mathrm{mg} / \mathrm{L}$ & final & CFR, 1997 \\
\hline \multicolumn{2}{|c|}{ Antimony-125 } & $3 E+02$ & $\mathrm{pCi} / \mathrm{L}$ & interim final & EPA, 1977 \\
\hline \multicolumn{2}{|c|}{ Arsenic } & 0.05 & $\mathrm{mg} / \mathrm{L}$ & final & CFR, 1997 \\
\hline \multicolumn{2}{|c|}{ Asbestos } & $7,000,000$ & fibers $/ L^{c}$ & final & CFR, 1997 \\
\hline \multicolumn{2}{|c|}{ Atrazine } & 0.003 & $\mathrm{mg} / \mathrm{L}$ & final & CFR, 1997 \\
\hline \multicolumn{2}{|c|}{ Barium } & 2.0 & $\mathrm{mg} / \mathrm{L}$ & final & CFR, 1997 \\
\hline \multicolumn{2}{|c|}{ Barium- $140^{d}$} & $9 E+01$ & pCi/L & interim final & EPA, 1977 \\
\hline \multicolumn{2}{|c|}{ Benzene } & 0.005 & $\mathrm{mg} / \mathrm{L}$ & final & CFR, 1997 \\
\hline \multicolumn{2}{|c|}{ Benzo[a]pyrene } & 0.0002 & $\mathrm{mg} / \mathrm{L}$ & final & CFR, 1997 \\
\hline \multicolumn{2}{|c|}{ Beryllium } & 0.004 & $\mathrm{mg} / \mathrm{L}$ & final & CFR, 1997 \\
\hline \multicolumn{2}{|c|}{ Beryllium-7 } & $6 E+03$ & $\mathrm{pCi} / \mathrm{L}$ & interim final & EPA, 1977 \\
\hline \multicolumn{2}{|c|}{$\begin{array}{l}\text { 2-sec-Butyl-4, 6-dinitrophenol } \\
\text { (Dinoseb) }\end{array}$} & 0.007 & $\mathrm{mg} / \mathrm{L}$ & final & CFR, 1997 \\
\hline \multicolumn{2}{|c|}{ Cadmium } & 0.005 & $\mathrm{mg} / \mathrm{L}$ & final & CFR, 1997 \\
\hline \multicolumn{2}{|c|}{ Carbofuran } & 0.04 & $\mathrm{mg} / \mathrm{L}$ & final & CFR, 1997 \\
\hline \multicolumn{2}{|c|}{ Carbon-14 } & $2 E+03$ & pCi/L & interim final & EPA, 1977 \\
\hline \multicolumn{2}{|c|}{ Carbon tetrachloride } & 0.005 & $\mathrm{mg} / \mathrm{L}$ & final & CFR, 1997 \\
\hline \multicolumn{2}{|c|}{ Cerium-141d } & $3 E+02$ & pCill & interim final & EPA, 1977 \\
\hline \multicolumn{2}{|c|}{ Cesium-137 } & $2 E+02$ & pCill & interim final & EPA, 1977 \\
\hline \multicolumn{2}{|c|}{ Chlordane } & 0.002 & $\mathrm{mg} / \mathrm{L}$ & final & CFR, 1997 \\
\hline \multicolumn{2}{|c|}{$\begin{array}{l}\text { Chlorobenzene } \\
\text { (Monochlorobenzene) }\end{array}$} & 0.1 & $\mathrm{mg} / \mathrm{L}$ & final & CFR, 1997 \\
\hline \multicolumn{2}{|c|}{$\begin{array}{l}\text { Chloroethene } \\
\text { (Vinyl chloride) }\end{array}$} & 0.002 & $\mathrm{mg} / \mathrm{L}$ & final & CFR, 1997 \\
\hline \multicolumn{2}{|c|}{ Chloroform ${ }^{\ominus}$} & 0.1 & $\mathrm{mg} / \mathrm{L}$ & final & CFR, 1997 \\
\hline
\end{tabular}

a Standards for beta- and gamma-emitting radionuclides are based on the 4-mrem/yr whole-body dose [CFR, 1997]. Bibliographical information concerning the references is included at the end of this table, page 218 . Longer than $10 \mu \mathrm{m}$

These radionuclides no longer are monitored routinely in groundwater samples because they are consistently below detection or highly unlikely to be detectable in groundwater because or their short half-lives.

e The level for total trihalomethanes is set at $0.1 \mathrm{mg} / \mathrm{L}$. Because bromated methanes are rarely detected in SRS groundwater, the Environmental Protection Department presumes that most of the trihalomethanes present in site groundwater are chloroform. 


\begin{tabular}{|c|c|c|c|c|}
\hline Analyte & $\begin{array}{c}\text { Maximum } \\
\text { Contaminant Levela }\end{array}$ & Units & Status & Reference $b$ \\
\hline Chromium & 0.1 & $\mathrm{mg} / \mathrm{L}$ & final & CFR, 1997 \\
\hline Chromium-51c & $6 E+03$ & $\mathrm{pCi} / \mathrm{L}$ & interim final & EPA, 1977 \\
\hline Cobalt-57 & $1 \mathrm{E}+03$ & $\mathrm{pCi} / \mathrm{L}$ & interim final & EPA, 1977 \\
\hline Cobalt-58 & $9 E+03$ & $\mathrm{pCi} / \mathrm{L}$ & interim final & EPA, 1977 \\
\hline Cobalt-60 & $1 E+02$ & $\mathrm{pCi} / \mathrm{L}$ & interim final & EPA, 1977 \\
\hline Copper & $1^{d}$ & $\mathrm{mg} / \mathrm{L}$ & final & SCDHEC, 1981 \\
\hline Cyanide & 0.2 & $\mathrm{mg} / \mathrm{L}$ & final & CFR, 1997 \\
\hline Dalapon & 0.2 & $\mathrm{mg} / \mathrm{L}$ & final & CFR, 1997 \\
\hline 1,2-Dibromo-3-chloropropane & 0.0002 & $\mathrm{mg} / \mathrm{L}$ & final & CFR, 1997 \\
\hline $\begin{array}{l}\text { 1,2-Dichlorobenzene } \\
\text { (o-Dichlorobenzene) }\end{array}$ & 0.6 & $\mathrm{mg} / \mathrm{L}$ & final & CFR, 1997 \\
\hline $\begin{array}{l}\text { 1,4-Dichlorobenzene } \\
\text { (p-Dichlorobenzene) }\end{array}$ & 0.075 & $\mathrm{mg} / \mathrm{L}$ & final & CFR, 1997 \\
\hline 1,2-Dichloroethane & 0.005 & $\mathrm{mg} / \mathrm{L}$ & final & CFR, 1997 \\
\hline 1,1-Dichloroethylene & 0.007 & $\mathrm{mg} / \mathrm{L}$ & final & CFR, 1997 \\
\hline cis-1,2-Dichloroethylene & 0.07 & $\mathrm{mg} / \mathrm{L}$ & final & CFR, 1997 \\
\hline trans-1,2-Dichloroethylene & 0.1 & $\mathrm{mg} / \mathrm{L}$ & final & CFR, 1997 \\
\hline $\begin{array}{l}\text { Dichloromethane } \\
\text { (Methylene chloride) }\end{array}$ & 0.005 & $\mathrm{mg} / \mathrm{L}$ & final & CFR, 1997 \\
\hline $\begin{array}{l}\text { 2,4-Dichlorophenoxyacetic acid } \\
(2,4-D)\end{array}$ & 0.07 & $\mathrm{mg} / \mathrm{L}$ & final & CFR, 1997 \\
\hline 1,2-Dichloropropane & 0.005 & $\mathrm{mg} / \mathrm{L}$ & final & CFR, 1997 \\
\hline Di(2-ethylhexyl) adipate (Deha) & 0.4 & $\mathrm{mg} / \mathrm{L}$ & final & CFR, 1997 \\
\hline $\begin{array}{l}\text { Di(2-ethylhexyl) phthalate } \\
\text { [Bis(2-ethylhexyl) phthalate] }\end{array}$ & 0.006 & $\mathrm{mg} / \mathrm{L}$ & final & CFR, 1997 \\
\hline $\begin{array}{l}\text { Dioxin }(2,3,7,8-T C D D) \\
\quad(2,3,7,8-T C D D)\end{array}$ & $3.00 E-08$ & $\mathrm{mg} / \mathrm{L}$ & final & CFR, 1997 \\
\hline $\begin{array}{l}\text { Diquat } \\
\text { (Diquat dibromide) }\end{array}$ & 0.02 & $\mathrm{mg} / \mathrm{L}$ & final & CFR, 1997 \\
\hline Endothall & 0.1 & $\mathrm{mg} / \mathrm{L}$ & final & CFR, 1997 \\
\hline Endrin & 0.002 & $\mathrm{mg} / \mathrm{L}$ & final & CFR, 1997 \\
\hline Ethylbenzene & 0.7 & $\mathrm{mg} / \mathrm{L}$ & final & CFR, 1997 \\
\hline $\begin{array}{l}\text { Ethylene dibromide } \\
\qquad(1,2-\text {-Dibromoethane })\end{array}$ & 0.00005 & $\mathrm{mg} / \mathrm{L}$ & final & CFR, 1997 \\
\hline Europium-152 & $2 E+02$ & $\mathrm{pCi} / \mathrm{L}$ & interim final & EPA, 1977 \\
\hline Europium-154 & $2 E+02$ & $\mathrm{pCi} / \mathrm{L}$ & interim final & EPA, 1977 \\
\hline Europium-155 & $6 \mathrm{E}+02$ & $\mathrm{pCi} / \mathrm{L}$ & interim final & EPA, 1977 \\
\hline Fluoride & 4 & $\mathrm{mg} / \mathrm{L}$ & final & CFR, 1997 \\
\hline
\end{tabular}




\begin{tabular}{|c|c|c|c|c|}
\hline Analyte & $\begin{array}{c}\text { Maximum } \\
\text { Contaminant Levela }\end{array}$ & Units & Status & Reference ${ }^{b}$ \\
\hline Glyphosate & 0.7 & $\mathrm{mg} / \mathrm{L}$ & final & CFR, 1997 \\
\hline Gross alpha & 15 & pCi/L & final & CFR, 1997 \\
\hline Heptachlor & 0.0004 & $\mathrm{mg} / \mathrm{L}$ & final & CFR, 1997 \\
\hline Heptachlor epoxide & 0.0002 & $\mathrm{mg} / \mathrm{L}$ & final & CFR, 1997 \\
\hline Hexachlorobenzene & 0.001 & $\mathrm{mg} / \mathrm{L}$ & final & CFR, 1997 \\
\hline Hexachlorocyclopentadiene & 0.05 & $\mathrm{mg} / \mathrm{L}$ & final & CFR, 1997 \\
\hline lodine-129 & $1 E+00$ & $\mathrm{pCi} / \mathrm{L}$ & interim final & EPA, 1977 \\
\hline lodine-131c & $3 E+00$ & pCi/L & interim final & EPA, 1977 \\
\hline Iron-55c & $2 \mathrm{E}+03$ & pCill & interim final & EPA, 1977 \\
\hline Iron-59c & $2 E+02$ & pCi/L & interim final & EPA, 1977 \\
\hline Lanthanum- $140^{\circ}$ & $6 \mathrm{E}+01$ & pCill & interim final & EPA, 1977 \\
\hline Lead & $0.05^{d}$ & $\mathrm{mg} / \mathrm{L}$ & final & SCDHEC, 1981 \\
\hline Lindane & 0.0002 & $\mathrm{mg} / \mathrm{L}$ & final & CFR, 1997 \\
\hline Manganese-54 & $3 E+02$ & $\mathrm{pCi} / \mathrm{L}$ & interim final & EPA, 1977 \\
\hline Mercury & 0.002 & $\mathrm{mg} / \mathrm{L}$ & final & CFR, 1997 \\
\hline Methoxychlor & 0.04 & $\mathrm{mg} / \mathrm{L}$ & final & CFR, 1997 \\
\hline Nickel & 0.1 & $\mathrm{mg} / \mathrm{L}$ & final & CFR, 1997 \\
\hline Nickel-59 & $3 E+02$ & $\mathrm{pCi} / \mathrm{L}$ & interim final & EPA, 1977 \\
\hline Nickel-63 & $5 E+01$ & $\mathrm{pCi} / \mathrm{L}$ & interim final & EPA, 1977 \\
\hline Niobium-95c & $3 E+02$ & $\mathrm{pCi} / \mathrm{L}$ & interim final & EPA, 1977 \\
\hline Nitrate + Nitrite (As N) & 10 & $\mathrm{mg} / \mathrm{L}$ & final & CFR, 1997 \\
\hline Nitrate (as N) & 10 & $\mathrm{mg} / \mathrm{L}$ & final & CFR, 1997 \\
\hline Nitrite (as N) & 1 & $\mathrm{mg} / \mathrm{L}$ & final & CFR, 1997 \\
\hline Nonvolatile beta & 4 & mrem/yr & final & CFR, 1997 \\
\hline Oxamyl (Vydate) & 0.2 & $\mathrm{mg} / \mathrm{L}$ & final & CFR, 1997 \\
\hline $\begin{array}{l}\text { Polychlorinated Biphenyls } \\
\text { (PCBs) }\end{array}$ & 0.0005 & $\mathrm{mg} / \mathrm{L}$ & final & CFR, 1997 \\
\hline Pentachlorophenol & 0.001 & $\mathrm{mg} / \mathrm{L}$ & final & CFR, 1997 \\
\hline Picloram & 0.5 & $\mathrm{mg} / \mathrm{L}$ & final & CFR, 1997 \\
\hline $\begin{array}{l}\text { Total Radium (Radium-226 and } \\
\text { Radium-228) }\end{array}$ & 5 & pCi/L & final & CFR, 1997 \\
\hline Ruthenium-103c & $2 E+02$ & $\mathrm{pCi} / \mathrm{L}$ & interim final & EPA, 1977 \\
\hline Ruthenium-106 & $3 E+01$ & $\mathrm{pCi} / \mathrm{L}$ & interim final & EPA, 1977 \\
\hline Selenium & 0.05 & $\mathrm{mg} / \mathrm{L}$ & final & CFR, 1997 \\
\hline Simazine & 0.004 & $\mathrm{mg} / \mathrm{L}$ & final & CFR, 1997 \\
\hline Strontium-89 & $2 E+01$ & pCi/L & interim final & EPA, 1977 \\
\hline
\end{tabular}

a Standards for beta- and gamma-emitting radionuclides are based on the 4-mrem/yr whole-body dose [CFR, 1997]. Bibliographical information concerning the references is included at the end of this table, page 218 .

These radionuclides no longer are monitored routinely in groundwater samples because they are consistently below detection or highly unlikely to be detectable in groundwater because of their short half-lives.

d This is a South Carolina state drinking water "action level" used by the SRS groundwater monitoring program. 


\begin{tabular}{|c|c|c|c|c|}
\hline Analyte & $\begin{array}{c}\text { Maximum } \\
\text { Contaminant Levela }\end{array}$ & Units & Status & Reference ${ }^{b}$ \\
\hline Strontium-89/90 & $8 \mathrm{E}+00^{c}$ & pCill & final & CFR, 1997 \\
\hline Strontium-90 & $8 \mathrm{E}+00$ & $\mathrm{pCi} / \mathrm{L}$ & final & CFR, 1997 \\
\hline Styrene & 0.1 & $\mathrm{mg} / \mathrm{L}$ & final & CFR, 1997 \\
\hline Technetium-99 & $9 \mathrm{E}+02$ & $\mathrm{pCi} / \mathrm{L}$ & interim final & EPA, 1977 \\
\hline Tetrachloroethylene & 0.005 & $\mathrm{mg} / \mathrm{L}$ & final & CFR, 1997 \\
\hline Thallium & 0.002 & $\mathrm{mg} / \mathrm{L}$ & final & CFR, 1997 \\
\hline $\operatorname{Tin}-113$ & $3 E+02$ & $\mathrm{pCi} / \mathrm{L}$ & interim final & EPA, 1977 \\
\hline Toluene & 1.0 & $\mathrm{mg} / \mathrm{L}$ & final & CFR, 1997 \\
\hline $\begin{array}{l}\text { Total Trihalomethanes } \\
\text { (includes bromodichloro- } \\
\text { methane, bromoform, } \\
\text { chloroform, and } \\
\text { dibromochloromethane) }\end{array}$ & 0.1 & $\mathrm{mg} / \mathrm{L}$ & final & CFR, 1997 \\
\hline Toxaphene & 0.003 & $\mathrm{mg} / \mathrm{L}$ & final & CFR, 1997 \\
\hline 2,4,5-TP (Silvex) & 0.05 & $\mathrm{mg} / \mathrm{L}$ & final & CFR, 1997 \\
\hline 1,2,4-Trichlorobenzene & 0.07 & $\mathrm{mg} / \mathrm{L}$ & final & CFR, 1997 \\
\hline $1,1,1$-Trichloroethane & 0.2 & $\mathrm{mg} / \mathrm{L}$ & final & CFR, 1997 \\
\hline 1,1,2-Trichloroethane & 0.005 & $\mathrm{mg} / \mathrm{L}$ & final & CFR, 1997 \\
\hline Trichloroethylene & 0.005 & $\mathrm{mg} / \mathrm{L}$ & final & CFR, 1997 \\
\hline Tritium & $2 E+01$ & $\mathrm{pCi} / \mathrm{mL}$ & final & CFR, 1997 \\
\hline Xylenes & 10 & $\mathrm{mg} / \mathrm{L}$ & final & CFR, 1997 \\
\hline Zinc-65 & $3 E+02$ & pCi/L & interim final & EPA. 1977 \\
\hline Zirconium-95 & $2 \mathrm{E}+02$ & $\mathrm{pCi} / \mathrm{L}$ & interim final & EPA. 1977 \\
\hline Zirconium/Niobium-95 & $2 E+02$ & $\mathrm{pCi} / \mathrm{L}$ & interim final & EPA. 1977 \\
\hline
\end{tabular}

\section{References:}

CFR (Code of Federal Regulations), 1997. "National Primary Drinking Water Regulations," 40 CFR, Part 141, pp. 288-432, Washington, D.C.

EPA (U.S. Environmental Protection Agency), 1977. "National Interim Primary Drinking Water Regulations," EPA-570/9-76-003. Washington, D.C.

SCDHEC (South Carolina Department of Health and Environmental Control), 1998. "State Primary Drinking Water Regulations," R.61-58.5, Columbia, S.C. 


\section{Appendix C}

\section{Standard No. 8 Toxic Air Pollutants}

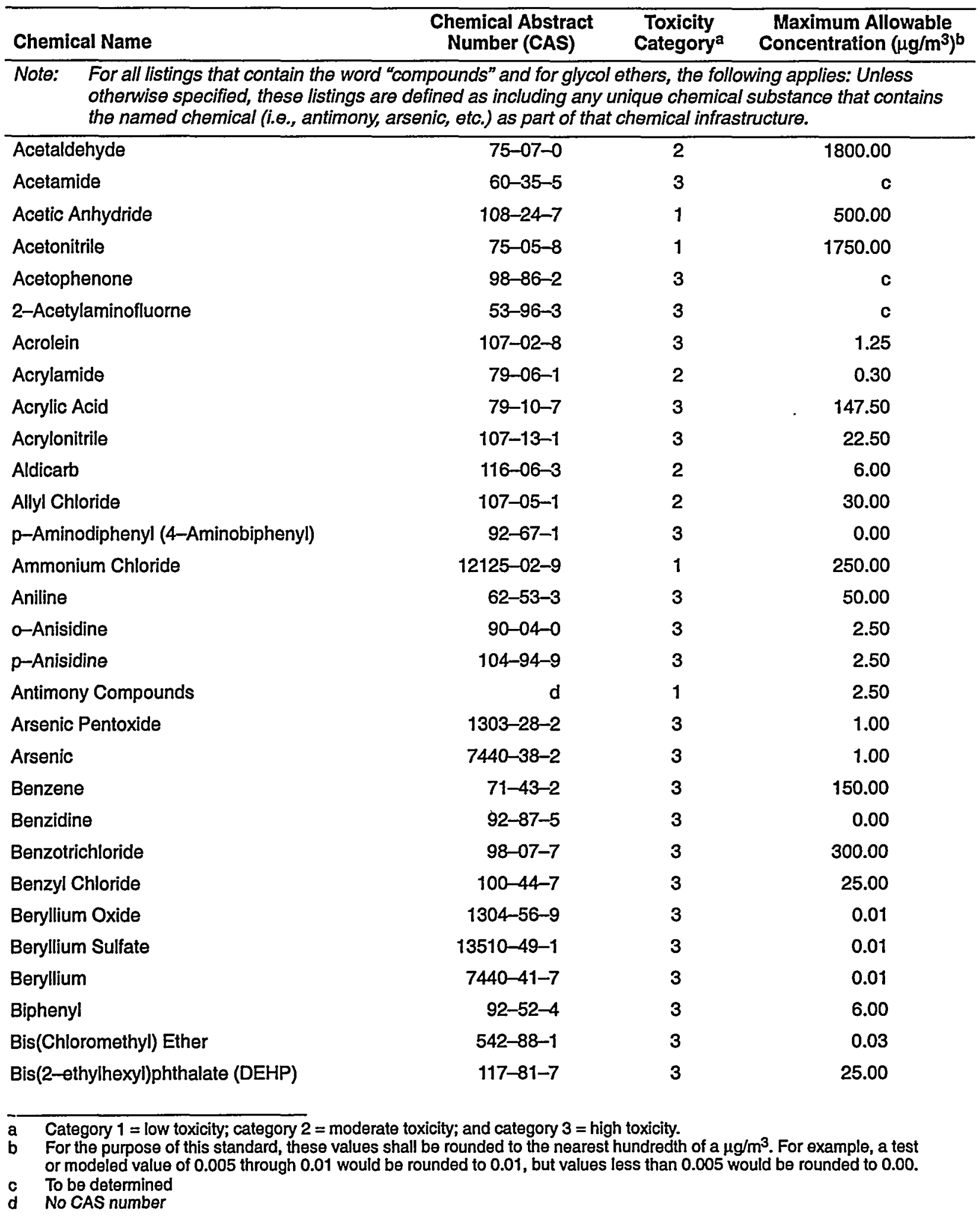




\begin{tabular}{|c|c|c|c|}
\hline Chemical Name & $\begin{array}{l}\text { Chemical Abstract } \\
\text { Number (CAS) }\end{array}$ & $\begin{array}{c}\text { Toxicity } \\
\text { Categorya }\end{array}$ & $\begin{array}{c}\text { Maximum Allowable } \\
\text { Concentration }\left(\mu \mathrm{g} / \mathrm{m}^{3}\right)^{\mathrm{b}}\end{array}$ \\
\hline Bromoform & $75-25-2$ & 3 & 25.85 \\
\hline 1,3-Butadiene & $106-99-0$ & 3 & 110.50 \\
\hline 1-Butanethiol (n-Butyl Mercaptan) & $109-79-5$ & 2 & 15.00 \\
\hline n-Butylamine & $109-73-9$ & 3 & 75.00 \\
\hline Cadmium Oxide & $1306-19-0$ & 3 & 0.25 \\
\hline Cadmium Sulfate & $10124-36-4$ & 3 & 0.20 \\
\hline Cadmium & $7440-43-9$ & 3 & 0.25 \\
\hline Calcium Cyanamide & $156-62-7$ & 3 & 2.50 \\
\hline Caprolactam, vapor & $105-60-2$ & 1 & 500.00 \\
\hline Caprolactam, dust & $105-60-2$ & 1 & 25.00 \\
\hline Captan & $133-06-2$ & 3 & 25.00 \\
\hline Carbaryl & $63-25-2$ & 3 & 25.00 \\
\hline Carbon Disulfide & $75-15-0$ & 3 & 150.00 \\
\hline Carbon Tetrachloride & $56-23-5$ & 3 & 150.00 \\
\hline Carbonyl Sulfide & $463-58-1$ & 3 & 12250.00 \\
\hline Catechol & $120-80-9$ & 3 & 297.00 \\
\hline Chloramben & $133-90-4$ & 3 & c \\
\hline Chlordane & $57-74-9$ & 3 & 2.50 \\
\hline Chlorine & $7782-50-5$ & 1 & 75.00 \\
\hline Chloroacetic Acid & $79-11-8$ & 3 & 900.00 \\
\hline 2-Chloroacetophenone & $532-27-4$ & 1 & 7.50 \\
\hline Chlorobenzene & $108-90-7$ & 3 & 1725.00 \\
\hline Chlorobenzilate & $510-15-6$ & 3 & c \\
\hline Chloroform & $67-66-3$ & 3 & 250.00 \\
\hline Chloromethyl Methyl Ether & $107-30-2$ & 3 & c \\
\hline p-Chloronitrobenzene & $100-00-5$ & 3 & 5.00 \\
\hline Chloroprene & $126-99-8$ & 3 & 175.00 \\
\hline Chromium(+6) Compounds & $d$ & 3 & 2.50 \\
\hline Cobalt Compounds & d & 3 & 0.25 \\
\hline Coke Oven Emissions & $\mathrm{d}$ & 3 & c \\
\hline Cresols/cresylic acid and mixture & $1319-77-3$ & 3 & 220.00 \\
\hline m-Cresol & $108-39-4$ & 3 & 110.50 \\
\hline o-Cresol & $95-48-7$ & 3 & 110.50 \\
\hline$p$-Cresol & $106-44-5$ & 3 & 110.50 \\
\hline Cumene & $98-82-8$ & 2 & $9.00^{\ominus}$ \\
\hline Cyanamide & $420-04-2$ & 1 & 50.00 \\
\hline \multicolumn{4}{|c|}{$\begin{array}{l}\text { Category } 1=\text { low toxicity; category } 2=\text { moderate toxicity; and category } 3=\text { high toxicity. } \\
\text { For the purpose of this standard, these values shall be rounded to the nearest hundredth of a } \mu \mathrm{g} / \mathrm{m}^{3} \text {. For example, a test } \\
\text { or modeled value of } 0.005 \text { through } 0.01 \text { would be rounded to } 0.01 \text {, but values less than } 0.005 \text { would be rounded to } 0.00 \text {. } \\
\text { To be determined } \\
\text { No CAS number } \\
\text { Verified reference concentration (RfC) established by the US. Environmental Protection Adency }\end{array}$} \\
\hline
\end{tabular}




\begin{tabular}{|c|c|c|c|}
\hline Chemical Name & $\begin{array}{l}\text { Chemical Abstract } \\
\text { Number (CAS) }\end{array}$ & $\begin{array}{c}\text { Toxicity } \\
\text { Category }\end{array}$ & $\begin{array}{l}\text { Mbaximum Allowable } \\
\text { Concentration }\left(\mu \mathrm{g} / \mathrm{m}^{3}\right)^{\mathrm{b}}\end{array}$ \\
\hline Cyanic Acid & $420-05-3$ & 1 & 500.00 \\
\hline Cyanide & $57-12-5$ & 1 & 125.00 \\
\hline Cyanide compounds ${ }^{c}$ & $d$ & 1 & $e$ \\
\hline Cyanoacetamide & $107-91-5$ & 1 & 125.00 \\
\hline Cyanogen & $460-19-5$ & 1 & 500.00 \\
\hline 2,4-D,salts and esters & $94-75-7$ & 3 & 50.00 \\
\hline DDE & $3547-04-4$ & 3 & e \\
\hline Diazomethane & $334-88-3$ & 3 & 2.00 \\
\hline Dibenzofuran & $132-64-9$ & 3 & e \\
\hline 1,2-Dibromo-3-chloropropane & $96-12-8$ & 3 & 0.05 \\
\hline Dibutylphthalate & $84-74-2$ & 3 & 25.00 \\
\hline p-Dichlorobenzene & $106-46-7$ & 2 & 4500.00 \\
\hline 3,3-Dichlorobenzidine & $91-94-1$ & 3 & 0.15 \\
\hline 1,3-Dichloropropene & $542-75-6$ & 3 & $20.00^{f}$ \\
\hline Dichlorvos & $62-73-7$ & 3 & 4.52 \\
\hline Diethanolamine & $111-42-2$ & 2 & 129.00 \\
\hline$n, n$-Diethylaniline(n,n-Dimethylaniline) & $121-69-7$ & 2 & 250.00 \\
\hline Diethyl Phthalate & $84-66-2$ & 3 & 25.00 \\
\hline Diethyl Sulfate & $64-67-5$ & 3 & e \\
\hline Diisodecyl Phthalate & $2671-40-0$ & 2 & 50.00 \\
\hline 3,3-Dimethoxybenzidine & $119-90-4$ & 3 & 0.30 \\
\hline 3,3'-Dimethyl Benzidine & $119-93-7$ & 3 & e \\
\hline Dimethyl Carbamoyl Chloride & $79-44-7$ & 3 & e \\
\hline Dimethyl Formamide & $68-12-2$ & 2 & 300.00 \\
\hline 1,1-Dimethyl Hydrazine & $57-14-7$ & 3 & 5.00 \\
\hline 1,2-Dimethyl Hydrazine & $540-73-8$ & 3 & 5.00 \\
\hline Dimethyl Phthalate & $131-11-3$ & 3 & 25.00 \\
\hline Dimethyl Sulfate & $77-78-1$ & 3 & 2.50 \\
\hline 4-Dimethylaminoazobenzene & $60-11-7$ & 3 & 125.00 \\
\hline m-Dinitrobenzene & $99-65-0$ & 2 & 10.00 \\
\hline 4,6-Dinitro-o-cresol and salts & $534-52-1$ & 2 & 2.00 \\
\hline 2,4-Dinitrophenol & $51-28-5$ & 3 & $\theta$ \\
\hline 2,4-Dinitrotoluene & $121-14-2$ & 3 & 1.50 \\
\hline Dioctyl Phthalate & $117-84-0$ & 2 & 50.00 \\
\hline 1,4-Dioxane & $123-91-1$ & 3 & 450.00 \\
\hline
\end{tabular}

a Category 1 = low toxicity; category 2 = moderate toxicity; and category $3=$ high toxicity.

b For the purpose of this standard, these values shall be rounded to the nearest hundredth of a $\mu \mathrm{g} / \mathrm{m}^{3}$. For $\theta x a m p l e$, a test or modeled value of 0.005 through 0.01 would be rounded to 0.01 , but values less than 0.005 would be rounded to 0.00 .

c $\mathrm{XCN}$ where $\mathrm{X}=\mathrm{H}+$ or any other group where a formal dissociation may occur. For example, $\mathrm{KCN}$ or $\mathrm{Ca}(\mathrm{CN})_{2}$.

d No CAS number

e To be determined

$f$ Verified reference concentration (RfC) established by the U.S. Environmental Protection Agency 


\begin{tabular}{|c|c|c|c|}
\hline Chemical Name & $\begin{array}{l}\text { Chemical Abstract } \\
\text { Number (CAS) }\end{array}$ & $\begin{array}{c}\text { Toxicity } \\
\text { Category }\end{array}$ & $\begin{array}{c}\text { Maximum Allowable } \\
\text { Concentration }\left(\mu \mathrm{g} / \mathrm{m}^{3}\right)^{\mathrm{b}}\end{array}$ \\
\hline 1,2-Diphenylhydrazine & $122-66-7$ & 3 & c \\
\hline Epichlorohydrin & $106-89-8$ & 3 & 50.00 \\
\hline 1,2-Epoxybutane & $106-88-7$ & 3 & c \\
\hline Ethanethiol & $75-08-1$ & 2 & 10.00 \\
\hline Ethanolamine & $141-43-5$ & 1 & 200.00 \\
\hline Ethyl Acrylate & $140-88-5$ & 3 & 102.50 \\
\hline Ethyl Benzene & $100-41-4$ & 2 & 4350.00 \\
\hline Ethyl Chloride & $75-00-3$ & 2 & 26400.00 \\
\hline Ethylene Dibromide & $106-93-4$ & 2 & 770.00 \\
\hline Ethylene Dichloride & $107-06-2$ & 3 & 200.00 \\
\hline Ethylene Glycol & $107-21-1$ & 3 & 650.00 \\
\hline Ethylene Oxide & $75-21-8$ & 3 & 10.00 \\
\hline Ethylene Thiourea & $96-45-7$ & 3 & c \\
\hline Ethylene Imine & $151-56-4$ & 3 & 5.00 \\
\hline Ethylidene Dichloride & $75-34-3$ & 3 & 2025.00 \\
\hline Formaldehyde & $50-00-0$ & 2 & 15.00 \\
\hline Formamide & $75-12-7$ & 1 & 750.00 \\
\hline Formic Acid & $64-18-6$ & 1 & 225.00 \\
\hline Furfural & $98-01-1$ & 1 & 200.00 \\
\hline Furfuryl Alcohol & $98-00-0$ & 2 & 400.00 \\
\hline Glycidaldehyde & $765-34-4$ & 3 & 75.00 \\
\hline $\begin{array}{l}\text { Glycol Ethers } \\
\text { (mono- and di-ethers of diethylene giycol } \\
\text { or triethylene glycol) }\end{array}$ & e & 1 & c \\
\hline $\begin{array}{l}\text { Glycol Ethersd } \\
\text { (mono- and di-ethers of ethylene glycol) }\end{array}$ & e & 3 & c \\
\hline Heptachlor & $76-44-8$ & 3 & 2.50 \\
\hline Hexachlorobenzene & $118-74-1$ & 3 & c \\
\hline Hexachlorobutadiene & $87-68-3$ & 3 & 1.20 \\
\hline Hexachlorocyclohexane (multiple isomers) & $608-73-1$ & 2 & 5.00 \\
\hline Hexachlorocylopentadiene & $77-47-4$ & 3 & 0.50 \\
\hline Hexachloroethane & $67-72-1$ & 3 & 48.50 \\
\hline Hexachloronapthalene & $1335-87-1$ & 3 & 1.00 \\
\hline Hexamethylene-1,6-diisocyanate & $822-06-0$ & 2 & 0.34 \\
\hline Hexamethylphosphoramide & $680-31-9$ & 3 & 14.50 \\
\hline
\end{tabular}

a Category 1 = low toxicity; category 2 = moderate toxicity; and category $3=$ high toxicity.

b For the purpose of this standard, these values shall be rounded to the nearest hundredth of a $\mu \mathrm{g} / \mathrm{m}^{3}$. For example, a test or modeled value of 0.005 through 0.01 would be rounded to 0.01 , but values less than 0.005 would be rounded to 0.00 .

c To be determined

d Includes mono- and di-ethers of ethylene glycol, diethylene glycol, and triethylene glycol $\mathrm{R}-\left(\mathrm{OCH}_{2} \mathrm{CH}_{2}\right) \mathrm{n}-\mathrm{OR}^{\prime}$, where $n=1,2$, or $3 ; R=a l k y l$ or aryl groups; and $R^{\prime}=R, H$, or groups which, when removed, yield glycol ethers with the structure: $\mathrm{R}-\left(\mathrm{OC} \mathrm{H}_{2} \mathrm{CH}\right) n-\mathrm{OH}$. Polymers are excluded from the glycol category.

e No CAS number 


\begin{tabular}{|c|c|c|c|}
\hline Chemical Name & $\begin{array}{l}\text { Chemical Abstract } \\
\text { Number (CAS) }\end{array}$ & $\begin{array}{c}\text { Toxicity } \\
\text { Categorya }\end{array}$ & $\begin{array}{c}\text { Maximum Allowable } \\
\text { Concentration }\left(\mu \mathrm{g} / \mathrm{m}^{3}\right)^{\mathrm{b}}\end{array}$ \\
\hline Hexane & $110-54-3$ & 3 & 900.00 \\
\hline Hydrazine & $302-01-2$ & 3 & 0.50 \\
\hline Hydrochloric Acid & $7647-01-0$ & 1 & 175.00 \\
\hline Hydrogen Cyanide & $74-90-8$ & 1 & 250.00 \\
\hline Hydrogen Sulfide & $7783-06-4$ & 2 & 140.00 \\
\hline Hydroquinone & $123-31-9$ & 2 & 20.00 \\
\hline Isophorone & $78-59-1$ & 2 & 250.00 \\
\hline Isopropylamine & $75-31-0$ & 1 & 300.00 \\
\hline Kepone (Chlordecone) & $143-50-0$ & 3 & 0.00 \\
\hline Ketene & $463-51-4$ & 3 & 4.50 \\
\hline Lead Arsenate & $7645-25-2$ & 3 & 0.75 \\
\hline Lead(+2) Arsenate & $7784-40-9$ & 3 & 0.75 \\
\hline Lindane & $58-89-9$ & 3 & 2.50 \\
\hline Malathion & $121-75-5$ & 2 & 100.00 \\
\hline Maleic Anhydride & $108-31-6$ & 2 & 10.00 \\
\hline Manganese Compounds & c & 3 & 25.00 \\
\hline Mercury & $7439-97-6$ & 3 & 0.25 \\
\hline Methanol & $67-56-1$ & 3 & 1310.00 \\
\hline Methoxychlor & $72-43-5$ & 3 & 50.00 \\
\hline Methyl Bromide & $74-83-9$ & 3 & 100.00 \\
\hline Methyl Chloride & $74-87-3$ & 3 & 515.00 \\
\hline Methyl Chloroform $(1,1,1-$ Trichloroethane $)$ & $71-55-6$ & 3 & 9550.00 \\
\hline Methylene Biphenyl Isocyanate & $101-68-8$ & 2 & 2.00 \\
\hline 4,4-Methylene Bis (2-chloroaniline) & $101-14-4$ & 3 & 1.10 \\
\hline 4,4-Methylenedianiline & $101-77-9$ & 3 & 4.00 \\
\hline Methyl Ethyl Ketone (2-Butone) & $78-93-3$ & 1 & 14750.00 \\
\hline Methyl Hydrazine & $60-34-4$ & 3 & 1.75 \\
\hline Methyl lodide & $74-88-4$ & 3 & 58.00 \\
\hline Methyl Isobutyl Ketone & $108-10-1$ & 2 & 2050.00 \\
\hline Methyl Isocyanate & $624-83-9$ & 3 & 0.23 \\
\hline Methyl Mercaptan & $74-93-1$ & 2 & 10.00 \\
\hline Methyl Methacrylate & $80-62-6$ & 1 & 10250.00 \\
\hline Methylamine & $74-89-5$ & 1 & 300.00 \\
\hline Methylene Chloride & $75-09-2$ & 1 & 8750.00 \\
\hline Methyl-t-Butyl Ether & $1634-04-4$ & 1 & d \\
\hline
\end{tabular}

a Category 1 = low toxicity; category 2 = moderate toxicity; and category 3 = high toxicity.

b For the purpose of this standard, these values shall be rounded to the nearest hundredth of a $\mu \mathrm{g} / \mathrm{m}^{3}$. For example, a test or modeled value of 0.005 through 0.01 would be rounded to 0.01 , but values less than 0.005 would be rounded to 0.00 .

c No CAS number

d To be determined 


\begin{tabular}{|c|c|c|c|}
\hline Chemical Name & $\begin{array}{l}\text { Chemical Abstract } \\
\text { Number (CAS) }\end{array}$ & $\begin{array}{l}\text { Toxicity } \\
\text { Categorya }\end{array}$ & $\begin{array}{c}\text { Maximum Allowable } \\
\text { Concentration }\left(\mu \mathrm{g} / \mathrm{m}^{3}\right)^{\mathrm{b}}\end{array}$ \\
\hline Mineral Fibers, Fine ${ }^{c}$ & $\bar{d}$ & 3 & $\bar{e}$ \\
\hline Mineral Oil Mist (Paraffin Oil) & $8012-95-1$ & 3 & 25.00 \\
\hline Mirex & $2385-85-5$ & 3 & 4500.00 \\
\hline Naphthalene & $91-20-3$ & 1 & 1250.00 \\
\hline a-Naphthylamine & $134-32-7$ & 3 & 0.00 \\
\hline b-Naphthylamine & $91-59-8$ & 3 & 0.00 \\
\hline Nickel Carbonyl & $13463-39-3$ & 3 & 1.75 \\
\hline Nickel Oxide & $1313-99-1$ & 3 & 5.00 \\
\hline Nickel Sulfate & $7786-81-4$ & 3 & 5.00 \\
\hline Nickel & $7440-02-0$ & 3 & 0.50 \\
\hline Nitric Acid & $7697-37-2$ & 1 & 125.00 \\
\hline p-Nitroaniline & $100-01-6$ & 3 & 15.00 \\
\hline Nitrobenzene & $98-95-3$ & 3 & 25.00 \\
\hline 4-Nitrobiphenyl & $92-93-3$ & 3 & 0.00 \\
\hline Nitrogen Mustard & $51-75-2$ & 3 & 0.00 \\
\hline Nitroglycerin & $55-63-0$ & 2 & 5.00 \\
\hline p-Nitrophenol & $100-02-7$ & 3 & 0.00 \\
\hline 1-Nitropropane & $108-03-2$ & 1 & 2250.00 \\
\hline 2-Nitropropane & $79-46-9$ & 3 & 182.00 \\
\hline p-Nitrosophenol & $104-91-6$ & 3 & 0.00 \\
\hline n-Nitroso-n-methylurea & $684-93-5$ & 3 & e \\
\hline n-Nitrosodimethylamine & $62-75-9$ & 3 & 0.00 \\
\hline n-Nitrosomorpholine & $59-89-2$ & 3 & 5000.00 \\
\hline p-Nitrotoluene & $99-99-0$ & 3 & 5.50 \\
\hline Octachloronaphthalene & $2234-13-1$ & 3 & 0.50 \\
\hline Oxalic Acid & $144-62-7$ & 2 & 10.00 \\
\hline Paraquat & $1910-42-5$ & 3 & 0.50 \\
\hline Parathion & $56-38-2$ & 3 & 0.50 \\
\hline Pentachloronitrobenzene (Quintobenzene) & $82-68-8$ & 3 & e \\
\hline Pentachlorophenol & $87-86-5$ & 2 & 5.00 \\
\hline Phenol & $108-95-2$ & 2 & 190.00 \\
\hline p-Phenylenediamine & $106-50-3$ & 2 & 1.00 \\
\hline Phenylhydrazine & $100-63-0$ & 2 & 200.00 \\
\hline Phosgene (Carbonyl Chloride) & $75-44-5$ & 2 & 4.00 \\
\hline Phosphine & $7803-51-2$ & 3 & 2.09 \\
\hline
\end{tabular}

a Category $1=$ low toxicity; category $2=$ moderate toxicity; and category $3=$ high toxicity.

b For the purpose of this standard, these values shall be rounded to the nearest hundredth of a $\mu \mathrm{g} / \mathrm{m}^{3}$. For example, a test or modeled value of 0.005 through 0.01 would be rounded to 0.01 , but values less than 0.005 would be rounded to 0.00 .

c Includes mineral fiber emissions from facilities manufacturing or processing glass, rock, and slag fibers (or other mineral-derived fibers) of average diameter 1 micrometer or less

d No CAS number

e To be determined 


\begin{tabular}{|c|c|c|c|}
\hline Chemical Name & $\begin{array}{l}\text { Chemical Abstract } \\
\text { Number (CAS) }\end{array}$ & $\begin{array}{l}\text { Toxicity } \\
\text { Categorya }\end{array}$ & $\begin{array}{c}\text { Maximum Allowable } \\
\text { Concentration }\left(\mu \mathrm{g} / \mathrm{m}^{3}\right)^{\mathrm{b}}\end{array}$ \\
\hline Phosphoric Acid & $7664-38-2$ & 1 & 25.00 \\
\hline Phosphorus & $7723-14-0$ & 2 & 0.50 \\
\hline Phthalic Anhydride & $85-44-9$ & 3 & 30.30 \\
\hline Picric Acid & $88-89-1$ & 2 & 1.00 \\
\hline $\begin{array}{l}\text { Polychlorinated Biphenyls (PCB) } \\
\text { (multiple compounds) }\end{array}$ & c & 3 & 2.50 \\
\hline Polycyclic Organic Matterd & c & 3 & 160.00 \\
\hline 1,3-Propane Sultone & $1120-71-4$ & 3 & e \\
\hline b-Propiolactone & $57-57-8$ & 3 & 7.50 \\
\hline Proprionaldehyde & $123-38-6$ & 1 & e \\
\hline Propoxur & $114-26-1$ & 3 & 2.50 \\
\hline Propylene Dichloride & $78-87-5$ & 3 & 1750.00 \\
\hline Propylene Oxide & $75-56-9$ & 3 & 250.00 \\
\hline 1,2-Propylenimine & $75-55-8$ & 3 & 23.35 \\
\hline Pyrethrin I & $121-21-1$ & 3 & 25.00 \\
\hline Pyrethrin II & $121-29-9$ & 3 & 25.00 \\
\hline Pyrethrum & $8003-34-7$ & 2 & 50.00 \\
\hline Quinoline & $91-22-5$ & 3 & e \\
\hline Quinone & $106-51-4$ & 3 & 2.00 \\
\hline Rotenone & $83-79-4$ & 2 & 50.00 \\
\hline Selenium Compounds & c & 3 & 1.00 \\
\hline Sodium Hydroxide & $1310-73-2$ & 1 & 50.00 \\
\hline Styrene & $100-42-5$ & 1 & 5325.00 \\
\hline Styrene Oxide & $96-09-3$ & 3 & e \\
\hline Sulfuric Acid & $7664-93-9$ & 2 & 10.00 \\
\hline Tetrachlorinate Dibenzo-p-dioxins & $1746-01-6$ & 3 & 0.00 \\
\hline $\begin{array}{l}\text { 1,1,2,2-Tetrachloroethane } \\
\text { (Ácetylene Tetrachloride) }\end{array}$ & $79-34-5$ & 3 & 35.00 \\
\hline Tetrachloroethylene (Perchloroethylene) & $127-18-4$ & 2 & 3350.00 \\
\hline Titanium Tetrachloride & $7550-45-0$ & 1 & 2500.00 \\
\hline Toluene & $108-88-3$ & 3 & 2000.00 \\
\hline 2,4-Toluenediamine & $95-80-7$ & 3 & e \\
\hline Toluene Diisocyanate & $26471-62-5$ & 2 & 0.40 \\
\hline Toluene-2,4- diisocyanate & $584-84-9$ & 2 & 0.40 \\
\hline o-Toluidine & $95-53-4$ & 3 & 43.85 \\
\hline
\end{tabular}

a Category 1 = low toxicity; category 2 = moderate toxicity; and category $3=$ high toxicity.

b For the purpose of this standard, these values shall be rounded to the nearest hundredth of a $\mu \mathrm{g} / \mathrm{m}^{3}$. For example, a test or modeled value of 0.005 through 0.01 would be rounded to 0.01 , but values less than 0.005 would be rounded to 0.00 .

c No CAS number

d Includes organic compounds with more than one benzene ring and that have a boiling point greater than or equal to $100^{\circ} \mathrm{C}$

e To be determined

$f$ The use of sodium hydroxide in a scrubber for air pollution control purposes is exempt from this standard. 


\begin{tabular}{lccc}
\hline Chemical Name & $\begin{array}{c}\text { Chemical Abstract } \\
\text { Number (CAS) }\end{array}$ & $\begin{array}{c}\text { Toxicity } \\
\text { Category }\end{array}$ & $\begin{array}{c}\text { Maximum Allowable } \\
\text { Concentration }\left(\mu \mathbf{g}^{3} \mathbf{m}^{\mathbf{b}} \mathbf{b}^{\mathrm{m}}\right.\end{array}$ \\
\hline Toxaphene & $8001-35-2$ & 3 & 2.50 \\
$1,2,4-$ Trichlorobenzene & $120-82-1$ & 2 & 400.00 \\
1,1,2-Trichloroethane & $79-00-5$ & 3 & 273.00 \\
Trichloroethylene & $79-01-6$ & 1 & 6750.00 \\
$2,4,5-$ Trichlorophenol & $95-95-4$ & 3 & $\mathrm{c}$ \\
$2,4,6-$ Trichlorophenol & $88-06-2$ & 3 & $\mathrm{c}$ \\
Triethylamine & $121-44-8$ & 3 & 207.00 \\
Trifluralin & $1582-09-8$ & 3 & $\mathrm{c}$ \\
$2,2,4-$ Trimethylpentane & $540-84-1$ & 1 & 8750.00 \\
Urethane (Carbamic Acid Ethyl Ester) & $51-79-6$ & 2 & 5000.00 \\
Vinyl Acetate & $108-05-4$ & 3 & 176.00 \\
Vinyl Bromide & $593-60-2$ & 3 & 100.00 \\
Vinyl Chloride & $75-01-4$ & 3 & 50.00 \\
Vinyl Fluoride & $75-02-5$ & 2 & 19.00 \\
Vinylidene chloride & $75-35-4$ & 3 & 99.00 \\
Xylene & $1330-20-7$ & 2 & 4350.00 \\
m-Xylene & $108-38-3$ & 2 & 4350.00 \\
O-Xylene & $95-47-6$ & 2 & 4350.00 \\
p-Xylene & $106-42-3$ & 2 & 4350.00 \\
Xylidine & $1300-73-8$ & 3 & 50.00
\end{tabular}

a Category 1 = low toxicity; category 2 = moderate toxicity; and category $3=$ high toxicity.

b For the purpose of this standard, these values shall be rounded to the nearest hundredth of a $\mu \mathrm{g} / \mathrm{m}^{3}$. For example, a test or modeled value of 0.005 through 0.01 would be rounded to 0.01 , but values less than 0.005 would be rounded to 0.00 .

c To be determined 


\section{Radionuclide and Chemical Nomenclature}

\begin{tabular}{|c|c|c|c|c|c|}
\hline \multirow[b]{2}{*}{ Radionuclide } & \multicolumn{4}{|c|}{ Nomenclature and Half-Life for Radionuclides } & \multirow[b]{2}{*}{ Half-life $e^{a, b}$} \\
\hline & Symbol & Half-life ${ }^{a, b}$ & Radionuclide & Symbol & \\
\hline Actinium-228 & Ac-228 & $6.15 \mathrm{~h}$ & Plutonium-238 & Pu-238 & $87.7 y$ \\
\hline Americium-241 & $A m-241$ & $432.7 y$ & Plutonium-239 & Pu-239 & $2.41 E 4$ y \\
\hline Americium-243 & Am-243 & 7.37E3 y & Plutonium-240 & Pu-240 & $6.56 E 3 y$ \\
\hline Antimony-124 & $\mathrm{Sb}-124$ & $60.2 d$ & Plutonium-241 & Pu-241 & $14.4 \mathrm{y}$ \\
\hline Antimony-125 & $\mathrm{Sb}-125$ & $2.758 y$ & Plutonium-242 & Pu-242 & 3.75E5 y \\
\hline Barium-133 & $\mathrm{Ba}-133$ & $10.53 y$ & Potassium-40 & $\mathrm{K}-40$ & $1.28 E 09 y$ \\
\hline Beryllium-7 & $\mathrm{Be}-7$ & $53.28 \mathrm{~d}$ & Promethium-144 & Pm-144 & $360 \mathrm{~d}$ \\
\hline Bismuth-212 & $\mathrm{Bi}-212$ & $2.14 \mathrm{~m}$ & Promethium-147 & Pm-147 & $2.6234 \mathrm{y}$ \\
\hline Bismuth-214 & $\mathrm{Bi}-214$ & $19.9 \mathrm{~m}$ & Protactinium-231 & Pa-231 & $3.28 E 4$ y \\
\hline Carbon-14 & C-14 & $5,730 y$ & Protactinium-234 & $\mathrm{Pa}-234$ & $6.69 \mathrm{~h}$ \\
\hline Cerium-144 & Ce-144 & $284.6 \mathrm{~d}$ & Radium-226 & Ra-226 & $1.6 \mathrm{E} 3 \mathrm{y}$ \\
\hline Cesium-134 & Cs-134 & $2.065 y$ & Radium-228 & Ra-228 & $5.76 y$ \\
\hline Cesium-137 & Cs-137 & $30.17 y$ & Ruthenium-103 & Ru-103 & $39.27 d$ \\
\hline Cobalt-57 & Co-57 & $271.8 \mathrm{~d}$ & Ruthenium-106 & Ru-106 & $1.020 y$ \\
\hline Cobalt-58 & Co-58 & $70.88 \mathrm{~d}$ & Selenium-79 & Se-79 & $6.5 E 4 y$ \\
\hline Cobalt-60 & Co-60 & $5.271 \mathrm{y}$ & Sodium-22 & $\mathrm{Na}-22$ & $2.605 y$ \\
\hline Curium-242 & $\mathrm{Cm}-242$ & $162.8 d$ & Strontium-89 & Sr-89 & $50.52 \mathrm{~d}$ \\
\hline Curium-244 & $\mathrm{Cm}-244$ & $18.1 y$ & Strontium-90 & Sr-90 & 29.1 y \\
\hline Curium-245 & $\mathrm{Cm}-245$ & 8.5E3 y & Strontium-89,90 & Sr-89,90 & 29.1 y \\
\hline Europium-152 & Eu-152 & $13.48 \mathrm{y}$ & Technetium-99 & TC-99 & $2.13 E 05 y$ \\
\hline Europium-154 & Eu-154 & $8.59 \mathrm{y}$ & Thallium-208 & $\mathrm{TI}-208$ & $3.05 \mathrm{~m}$ \\
\hline Europium-155 & Eu-155 & $4.71 \mathrm{y}$ & Thorium-228 & Th-228 & $1.913 y$ \\
\hline lodine-129 & $\mid-129$ & 1.57E7 y & Thorium-230 & Th-230 & $7.54 \mathrm{E} 4 \mathrm{y}$ \\
\hline lodine-131 & $\mid-131$ & $8.04 \mathrm{~d}$ & Thorium-232 & Th-232 & $1.40 E 10 y$ \\
\hline lodine-133 & $1-133$ & $8.040 \mathrm{~d}$ & Thorium-234 & Th-234 & $24.10 d$ \\
\hline Krypton-85 & $\mathrm{Kr}-85$ & $10.73 y$ & $\operatorname{Tin}-126$ & $S n-126$ & 1E5 y \\
\hline Lead-212 & $\mathrm{Pb}-212$ & $10.64 \mathrm{~h}$ & Tritium & $H-3$ & $12.3 y$ \\
\hline Lead-214 & $\mathrm{Pb}-214$ & $27 \mathrm{~m}$ & Uranium-233 & U-233 & $1.592 E 5 y$ \\
\hline Manganese-54 & $M n-54$ & $312.2 \mathrm{~d}$ & Uranium-234 & $\mathrm{U}-234$ & $2.46 E 5 y$ \\
\hline Neptunium-237 & Np-237 & $2.14 E 6 y$ & Uranium-235 & U.235 & 7.04E8 y \\
\hline Neptunium-239 & $\mathrm{Np}-239$ & $2.35 d$ & Uranium-236 & $U-236$ & 2.342E7 y \\
\hline Nickel-59 & $\mathrm{Ni}-59$ & $7.6 \mathrm{E} 4 \mathrm{y}$ & Uranium-238 & $\mathrm{U}-238$ & 4.47E9 y \\
\hline Nickel-63 & $\mathrm{Ni}-63$ & $100 y$ & Zinc-65 & $Z n-65$ & $243.8 d$ \\
\hline Niobium-95 & $\mathrm{Nb}-95$ & $34.97 \mathrm{~d}$ & Zirconium-95 & Zr-95 & $64.02 \mathrm{~d}$ \\
\hline
\end{tabular}

a $m=$ minute; $h=$ hour $d=$ day; $y=$ year

b Reference: Chart of the Nuclides, 14th edition, revised to April 1988, General Electric Company 


\begin{tabular}{|c|c|c|c|c|}
\hline \multicolumn{2}{|c|}{ Constituent } & \multicolumn{2}{|c|}{$\begin{array}{l}\text { Jomenclature for Elements and Chemical Constituent Analyses } \\
\text { Symbol Constituent }\end{array}$} & \multirow{2}{*}{$\frac{\text { Symbol }}{\text { es in this }}$} \\
\hline Note: & $\begin{array}{l}\text { Some of the symbols li. } \\
\text { book and are included }\end{array}$ & $\begin{array}{l}\text { In this table came fr } \\
\text { to assist the reader }\end{array}$ & $\begin{array}{l}\text { various databases used to format } \\
\text { Inderstanding the tables. }\end{array}$ & \\
\hline \multicolumn{2}{|c|}{ Aluminum } & Al (or AL) & Particulate Matter <10 microns & $\mathrm{PM}_{10}$ \\
\hline \multicolumn{2}{|c|}{ Ammonia } & $\mathrm{NH}_{3}$ & Perclene & PERCL \\
\hline \multicolumn{2}{|c|}{ Ammonia as Nitrogen } & $\mathrm{NH}_{3}-\mathrm{N}$ (or AN) & $\mathrm{pH}$ & $\mathrm{pH}$ (or $\mathrm{PH})$ \\
\hline \multicolumn{2}{|c|}{ Antimony } & $\mathrm{Sb}$ (or SB) & Phenol & PHE \\
\hline \multicolumn{2}{|c|}{ Arsenic } & As (or AS) & Phosphorus & $P$ \\
\hline \multicolumn{2}{|c|}{ Barium } & $\mathrm{Ba}$ (or $\mathrm{BA}$ ) & Phosphate & $\mathrm{PO}_{4}$ (or PO4-P or \\
\hline \multicolumn{2}{|c|}{ Biochemical Oxygen Demand } & BOD & & \\
\hline \multicolumn{2}{|c|}{ Benzene } & BEN & Phosphate as Phosphorus & Phosphate P \\
\hline \multicolumn{2}{|c|}{ Beryllium } & $\mathrm{Be}$ & Polychlorinated Biphenyl & PCB \\
\hline \multicolumn{2}{|c|}{ Boron } & B & Potassium & $K$ \\
\hline \multicolumn{2}{|c|}{ Cadmium } & Cd (or $C D)$ & Radium & $\mathrm{Ra}$ \\
\hline \multicolumn{2}{|c|}{ Calcium } & $\mathrm{Ca}$ & Rhenium & Re \\
\hline \multicolumn{2}{|c|}{ Calcium Carbonate } & $\mathrm{CaCO}_{3}$ & Selenium & Se (or SE) \\
\hline \multicolumn{2}{|c|}{ Carbon } & C & Silver & $\mathrm{Ag}$ (or $\mathrm{AG})$ \\
\hline \multicolumn{2}{|c|}{ Chemical Oxygen Demand } & COD & Sodium & $\mathrm{Na}$ \\
\hline \multicolumn{2}{|c|}{ Chlorine } & $\mathrm{Cl}$ (or $\mathrm{CHL}$ ) & Sulfate & $\mathrm{SO}_{4}$ (or SO4) \\
\hline \multicolumn{2}{|c|}{ Chromium } & $\mathrm{Cr}$ (or $\mathrm{CR})$ & Sulfur Dioxide & $\mathrm{SO}_{2}$ \\
\hline \multicolumn{2}{|c|}{ cis-1,2-dichloroethene } & 1,2-DCE & Temperature & $\begin{array}{l}\text { TMP (or T or } \\
\text { TEMP) }\end{array}$ \\
\hline Cobalt & & $\begin{array}{l}\mathrm{Co} \\
\mathrm{Cu} \text { (or CU) }\end{array}$ & $\begin{array}{l}\text { Tetrachloroethylene } \\
\text { (Perchloroethylene) }\end{array}$ & PERCL \\
\hline \multicolumn{2}{|c|}{ Cyanide } & $\mathrm{CN}$ & Trichloroethylene & TRICL \\
\hline \multicolumn{2}{|c|}{ Dissolved Oxygen } & DO & 1,1,1-Trichloroethane & TCE \\
\hline \multicolumn{2}{|c|}{ Fecal Coliform } & FEC & Thallium & $\mathrm{TI}$ \\
\hline \multicolumn{2}{|l|}{ Flow } & FLO & Tin & SN \\
\hline Fluori & & $F$ & Total Dissolved Solids & TDS \\
\hline Iron & & $\mathrm{Fe}$ (or FE) & Total Kjeldahl Nitrogen & TKN \\
\hline Lead & & $\mathrm{Pb}$ (or $\mathrm{PB})$ & Total Organic Carbon & TOC \\
\hline Lithiur & & $\mathrm{Li}$ & Total Organic Halogens & $\mathrm{TOH}$ \\
\hline Magn & sium & $\mathrm{Mg}$ (or MG) & Total Phosphates & $\begin{array}{l}\mathrm{TPO}_{4} \text { (or Total } \\
\text { Phos) }\end{array}$ \\
\hline $\begin{array}{l}\text { Mang } \\
\text { Mercu }\end{array}$ & nese & $\begin{array}{l}\text { Mn (or MN) } \\
\mathrm{Hg} \text { (or } H G \text { ) }\end{array}$ & Total Residual Chlorine & TRC \\
\hline Nicke & & $\mathrm{Ni}(\operatorname{or} \mathrm{NI})$ & Total Solids & TS \\
\hline Nitrog & & $N$ & Total Suspended Solids & TSS \\
\hline Nitrate & as Nitrogen & $\mathrm{NO}_{3}-\mathrm{N}$ & Total Volatile Solids & TVS \\
\hline Nitrite & as Nitrogen & $\mathrm{NO}_{2}-\mathrm{N}$ & Uranium & $U$ \\
\hline Nitrite & Nitrate & $\begin{array}{l}\mathrm{NO} 2, \mathrm{NO} 3 \text { (or } \\
\mathrm{NO}_{2}, \mathrm{NO}_{3} \text { ) }\end{array}$ & $\begin{array}{l}\text { Uranium } \\
\text { (tested as a heavy metal) }\end{array}$ & $\mathrm{U}_{3} \mathrm{O}_{8}$ \\
\hline Oil an & Grease & O\&G & Vanadium & V \\
\hline Ortho & Phosphate-P & $\mathrm{O}-\mathrm{PO}_{4}-\mathrm{P}$ & Vinyl Chloride & VC \\
\hline Oxyge & & 0 & Volatile Organic Compound & VOC \\
\hline Ozone & & $\mathrm{O}_{3}$ & Zinc & $\mathrm{Zn}$ (or $\mathrm{ZN}$ ) \\
\hline
\end{tabular}




\section{Appendix $E$ Errata from 1997 Report}

The following information was reported incorrectly in the Savannah River Site Environmental Report for 1997 (WSRC-TR-97-00322):

Page xxiii, right column, sixth line: The reference to $0.065 \mathrm{mSv}$ should have been to $0.0065 \mathrm{mSv}$.

Page 13, 1997 Highlights, fourth bullet; page 19, left column, last paragraph; page 20, figure $2-1$; and page 21, table 2-1: The release total of the seven toxic chemicals reported for 1996 in the highlights and on pages 19 and 20 as 24,268 pounds and on page 21 as 24,628 pounds should have been reported as 31,582 pounds.

Page 93, right column, fourth paragraph, second sentence: The highest average concentration of tritium in the Savannah River in 1997-measured at the Vogtle discharge location-should have been reported as $(1.40 \pm 1.86) \mathrm{E}+03 \mathrm{pCi} / \mathrm{L}$.
Page 123, description of pie chart: The sentence beginning "During 1996, . . ." should have begun "During 1997, ...."

\section{Errata from 1996 Report}

The following information was reported incorrectly in the Savannah River Site Environmental Report for 1996 (WSRC-TR-97-0171):

Page 34, table 2-8, "Underground Storage Tanks" totals: The four references to footnote "a" should have been to footnote "b." 
- . - 


\section{Glossary}

A

accuracy - Closeness of the result of a measurement to the true value of the quantity.

activity - See radioactivity.

air flow - Rate of flow, measured by mass or volume per unit of time.

air stripping - Process used to decontaminate groundwater by pumping the water to the surface,"stripping" or evaporating the chemicals in a specially-designed tower, and pumping the cleansed water back to the environment.

alkalinity - Alkalinity is a measure of the buffering capacity of water, and since $\mathrm{pH}$ has a direct effect on organisms as well as an indirect effect on the toxicity of certain other pollutants in the water, the buffering capacity is important to water quality.

alpha particle - Positively charged particle emitted from the nucleus of an atom having the same charge and mass as that of a helium nucleus (two protons and two neutrons).

ambient air - Surrounding atmosphere as it exists around people, plants, and structures.

analyte - Constituent or parameter that is being analyzed.

analytical detection limit - Lowest reasonably accurate concentration of an analyte that can be detected; this value varies depending on the method, instrument, and dilution used.

aquifer - Saturated, permeable geologic unit that can transmit significant quantities of water under ordinary hydraulic gradients.
Atomic Energy Commission - Federal agency created in 1946 to manage the development, use, and control of nuclear energy for military and civilian application. It was abolished by the Energy

Reorganization Act of 1974 and succeeded by the Energy Research and Development Administration (now part of the U.S. Department of Energy and the U.S. Nuclear Regulatory Commission).

bailer - Container lowered into a well to remove water. The bailer is allowed to fill with water and then is removed from the well.

best available technology - Technology that is the best available at the time to treat waste. See best available demonstrated technology.

best management practices - Sound engineering practices that are not, however, required by regulation or by law.

beta particle - Negatively charged particle emitted from the nucleus of an atom. It has a mass and charge equal to those of an electron.

blank - Control sample that is identical, in principle, to the sample of interest, except that the substance being analyzed is absent. In such cases, the measured value or signal for the substance being analyzed is believed to be due to artifacts. Under certain circumstances, that value may be subtracted from the measured value to give a net result reflecting the amount of the substance in the sample. The Environmental Protection Agency does not permit the subtraction of blank results in Environmental Protection Agency-regulated analyses.

blind blank - Sample container of deionized water sent to a laboratory under an aliàs name as a quality control check.

blind replicate - In the Environmental Monitoring Section groundwater monitoring program, a second sample taken from the same well at the same time as the primary sample, assigned an alias well name, and sent to a laboratory for analysis (as an unknown to the analyst). 
blind sample - Control sample of known concentration in which the expected values of the constituent are unknown to the analyst.

calibration - Determination of variance from a standard of accuracy of a measuring instrument to ascertain necessary correction factors.

Carolina bay - Type of shallow depression commonly found on the coastal Carolina plains. Carolina bays are typically circular or oval. Some are wet or marshy, while others are dry.

Central Savannah River Area (CSRA) Eighteen-county area in Georgia and South Carolina surrounding Augusta, Georgia. The Savannah River Site is included in the Central Savannah River Area. Counties are Richmond, Columbia, McDuffie, Burke, Emanuel, Glascock, Jenkins, Jefferson, Lincoln, Screven, Taliaferro, Warren, and Wilkes in Georgia and Aiken, Edgefield, Allendale, Barnwell, and McCormick in South Carolina.

chemical oxygen demand - Indicates the quantity of oxidizable materials present in a water and varies with water composition, concentrations of reagent, temperature, period of contact, and other factors.

chlorocarbons - Compounds of carbon and chlorine, or carbon, hydrogen, and chlorine, such as carbon tetrachloride, chloroform, tetrachloroethylene, etc. They are among the most significant and widespread environmental contaminants. Classified as hazardous wastes, chlorocarbons may have a tendency to cause detrimental effects, such as birth defects.

cleanup - Actions taken to deal with release or potential release of hazardous substances. This may mean complete removal of the substance; it also may mean stabilizing, containing, or otherwise treating the substance so that it does not affect human health or the environment.

closure - Control of a hazardous waste management facility under Resource Conservation and Recovery Act requirements.

compliance - Fulfillment of applicable requirements of a plan or schedule ordered or approved by government authority.

composite - Blending of more than one portion to make a sample for analysis.
Comprehensive Environmental Response, Compensation, and Liability Act (CERCLA) - This act addresses the cleanup of hazardous substances and establishes a National Priorities List of sites targeted for assessment and, if necessary, restoration (commonly known as "Superfund").

\section{Comprehensive Environmental Response, Compensation, and Liability Act (CERCLA)-reportable release - Release to the environment that exceeds reportable quantities as defined by the Comprehensive Environmental Response, Compensation, and Liability Act.}

concentration - Amount of a substance contained in a unit volume or mass of a sample.

conductivity - Measure of water's capacity to convey an electric current. This property is related to the total concentration of the ionized substances in a water and the temperature at which the measurement is made.

contamination - Deposition of unwanted material on the surfaces of structures, areas, objects, or personnel.

cosmic radiation - Ionizing radiation with very high energies, originating outside the earth's atmosphere. Cosmic radiation is one source contributing to natural background radiation.

count - Signal that announces an ionization event within a counter; a measure of the radiation from an object or device.

criteria pollutant - any of the pollutants commonly used as indices for air quality that can have a serious effect on human health and the environment, including sulfur dioxide, nitrogen dioxide, total suspended particulates, $\mathrm{PM}_{10}$, carbon monoxide, ozone, gaseous fluorides, and lead.

curie - Unit of radioactivity. One curie is defined as $3.7 \times 10^{10}$ (37 billion) disintegrations per second. Several fractions and multiples of the curie are commonly used:

kilocurie $(\mathrm{kCi})-10^{3} \mathrm{Ci}$, one thousand curies; $3.7 \mathrm{x}$ $10^{13}$ disintegrations per second.

millicurie (mCi) $-10^{-3} \mathrm{Ci}$, one-thousandth of a curie; $3.7 \times 10^{7}$ disintegrations per second.

microcurie $(\mu \mathrm{Ci})-10^{-6} \mathrm{Ci}$, one-millionth of a curie; $3.7 \times 10^{4}$ disintegrations per second.

picocurie ( $\mathrm{pCi})-10^{-12} \mathrm{Ci}$, one-trillionth of a curie; 0.037 disintegrations per second. 
decay (radioactive) - Spontaneous transformation of ofe radionuclide into a different radioactive or nonradioactive nuclide, or into a different energy state of the same radionuclide.

decay time - Time taken by a quantity to decay to a stated fraction of its initial value.

deactivation - The process of placing a facility in a stable and known condition, including the removal of hazardous and radioactive materials to ensure adequate protection of the worker, public health and safety, and the environment-thereby limiting the long-term cost of surveillance and maintenance.

decommissioning - Process that takes place after deactivation and includes surveillance and maintenance, decontamination, and/or

dismantlement.

decontamination - The removal or reduction of residual radioactive and hazardous materials by mechanical, chemical, or other techniques to achieve a stated objective or end condition.

deactivation and decommissioning - Program that reduces the environmental and safety risks of surplus facilities at SRS.

derived concentration guide - Concentration of a radionuclide in air or water that, under conditions of continuous exposure for one year by one exposure mode (i.e., ingestion of water, submersion in air or inhalation), would result in either an effective dose equivalent of $0.1 \mathrm{rem}(1 \mathrm{mSv})$ or a dose equivalent of $5 \mathrm{rem}(50 \mathrm{mSv})$ to any tissue, including skin and lens of the eye. The guides for radionuclides in air and water are given in Department of Energy Order 5400.5 .

detection limit - See analytical detection limit, lower limit of detection, minimum detectable concentration.

detector - Material or device (instrument) that is sensitive to radiation and can produce a signal suitable for measurement or analysis.

diatometer - Diatom collection equipment consisting of a series of microscope slides in a holder that is used to determine the amount of algae in a water system. diatoms - Unicellular or colonial algae of the class Bacillariophyceae, having siliceous cell walls with two overlapping, symmetrical parts. Diatoms represent the predominant periphyton (attached algae) in most water bodies and have been shown to be reliable indicators of water quality.

disposal - Permanent or temporary transfer of DOE control and custody of real property to a third party, which thereby acquires rights to control, use, or relinquish the property.

disposition - Those activities that follow completion of program mission-including, but not limited to, surveillance and maintenance, deactivation, and decommissioning.

dissolved oxygen - Desirable indicator of satisfactory water quality in terms of low residuals of biologically available organic materials. Dissolved oxygen prevents the chemical reduction and subsequent leaching of iron and manganese from sediments.

dose - Energy imparted to matter by ionizing radiation. The unit of absorbed dose is the rad, equal to 0.01 joules per kilogram in any medium.

absorbed dose - Quantity of radiation energy absorbed by an organ, divided by the organ's mass. Absorbed dose is expressed in units of rad (or gray) ( 1 $\mathrm{rad}=0.01 \mathrm{~Gy}$ ).

dose equivalent - Product of the absorbed dose (rad) in tissue and a quality factor. Dose equivalent is expressed in units of rem (or sievert) $(1 \mathrm{rem}=0.01$ sievert).

committed dose equivalent - Calculated total dose equivalent to a tissue or organ over a 50 -year period after known intake of a radionuclide into the body. Contributions from external dose are not included. Committed dose equivalent is expressed in units of rem (or sievert).

committed effective dose equivalent - Sum of the committed dose equivalents to various tissues in the body, each multiplied by the appropriate weighting factor. Committed effective dose equivalent is expressed in units of rem (or sievert).

effective dose equivalent - Sum of the dose equivalents received by all organs or tissues of the body after each one has been multiplied by an appropriate weighting factor. The effective dose equivalent includes the committed effective dose equivalent from internal deposition of radionuclides and the effective dose equivalent attributable to sources external to the body. 
collective dose equivalent/collective effective dose equivalent - Sums of the dose equivalents or effective dose equivalents of all individuals in an exposed population within a $50-\mathrm{mile}(80-\mathrm{km})$ radius, and expressed in units of person-rem (or personsievert). When the collective dose equivalent of interest is for a specific organ, the units would be organ-rem (or organ-sievert). The 50-mile distance is measured from a point located centrally with respect to major facilities or DOE program activities.

dosimeter-Portable detection device for measuring the total accumulated exposure to ionizing radiation.

downgradient - In the direction of decreasing hydrostatic head.

drinking water standards - Federal primary drinking water standards, both proposed and final, as set forth by EPA.

duplicate result - Result derived by taking a portion of a primary sample and performing the identical analysis on that portion as is performed on the primary sample.

effluent - Any treated or untreated air emission or liquid discharge to the environment.

effluent monitoring - Collection and analysis of samples or measurements of liquid and gaseous effluents for purposes of characterizing and quantifying the release of contaminants, assessing radiation exposures of members of the public, and demonstrating compliance with applicable standards.

environmental compliance - Actions taken in accordance with government laws, regulations, orders, etc., that apply to site operations' effects on onsite and offsite natural resources and on human health; used interchangeably in this document with regulatory compliance.

environmental monitoring - Program at Savannah River Site that includes effluent monitoring and environmental surveillance with dual purpose of (1) showing compliance with federal, state, and local regulations, as well as with U.S. Department of Energy orders, and (2) monitoring any effects of site operations on onsite and offsite natural resources and on human health. environmental restoration - Department of Energy program that directs the assessment and cleanup of inactive waste units and groundwater (remediation) contaminated as a result of nuclear-related activities.

environmental surveillance - Collection and analysis of samples of air, water, soil, foodstuffs, biota, and other media from Department of Energy sites and their environs and the measurement of external radiation for purposes of demonstrating compliance with applicable standards, assessing radiation exposures to members of the public, and assessing effects, if any, on the local environment.

exceedance - Term used by the Environmental Protection Agency and the South Carolina Department of Health and Environmental Control that denotes a report value is more than the upper guide limit. This term is found on the Discharge Monitoring Report forms that are submitted to the Environmental Protection Agency or the South Carolina Department of Health and Environmental Control.

exposure (radiation) - Incidence of radiation on living or inanimate material by accident or intent. Background exposure is the exposure to natural background ionizing radiation. Occupational exposure is that exposure to ionizing radiation which takes place during a person's working hours. Population exposure is the exposure to the total number of persons who inhabit an area.

exposure pathway - Route that materials follow to get to the environment and then to people.

fallout - See worldwide fallout.

Federal Facility Agreement (FFA) - Agreement negotiated among the Department of Energy, the Environmental Protection Agency, and the South Carolina Department of Health and Environmental Control, specifying how the Savannah River Site will address contamination or potential contamination to meet regulatory requirements at the Savannah River Site waste units identified for evaluation and, if necessary, cleanup.

feral hog - Hog that has reverted to the wild state from domestication. 
gamma ray - High-energy, short wavelength electromagnetic radiation emitted from the nucleus of an excited atom. Gamma rays are identical to $\mathrm{X}$-rays except for the source of the emission.

gamma-emitting radionuclide - Radionuclide that emits gamma rays.

gamma spectrometry - System consisting of a detector, associated electronics, and a multichannel analyzer that is used to analyze samples for gamma-emitting radionuclides.

grab sample - Sample collected instantaneously with a glass or plastic bottle placed below the water surface to collect surface water samples (also called dip samples).

half-life (radiological) - Time required for half of a given number of atoms of a specific radionuclide to decay. Each nuclide has a unique half-life.

heavy water - Water in which the molecules contain oxygen and deuterium, an isotope of hydrogen that is heavier than ordinary hydrogen.

hydraulic gradient - Difference in hydraulic head over a specified distance.

hydraulic head-Elevation of the water in a well or piezometer.

hydrology - Science that treats the occurrence, circulation, distribution, and properties of the waters of the earth, and their reaction with the environment.

in situ - In its original place. Field measurements taken without removing the sample from its origin; remediation performed while groundwater remains below the surface.

inorganic - Involving matter other than plant or animal. ion exchange - Process in which a solution containing soluble ions is passed over a solid ion exchange column that removes the soluble ions by exchanging them with labile ions from the surface of the column. The process is reversible so that the trapped ions are removed (eluted) from the column and the column is regenerated.

irradiate - Expose to radiation.

irradiation - Exposure to radiation.

isotopes - Forms of an element having the same number of protons in their nuclei but differing in the number of neutrons.

long-lived isotope - Radionuclide that decays at such a slow rate that a quantity of it will exist for an extended period (half-life is greater than three years).

short-lived isotope - Radionuclide that decays so rapidly that a given quantity is transformed almost completely into decay products within a short period (half-life is two days or less).

laboratory blank - Deionized water sample generated by the laboratory; a laboratory blank is analyzed with each batch of samples as an in-house check of analytical procedures. Also called an internal blank.

legacy - Anything handed down from the past; inheritance, as of nuclear waste.

lower limit of detection - Smallest concentration/amount of analyte that can be reliably detected in a sample at a 95 percent confidence level.

$\mathbf{M}$

macroinvertebrates - Size-based classification used for a variety of insects and other small invertebrates; as defined by the Environmental Protection Agency, those organisms that are retained by a No. 30 (590 micron) U.S. Standard Sieve.

macrophyte - A plant that can be observed with the naked eye.

manmade radiation - Radiation sources such as consumer products, medical procedures, and nuclear industry. 
maximally exposed individual - Hypothetical individual who remains in an uncontrolled area and would, when all potential routes of exposure from a facility's operations are considered, receive the greatest possible dose equivalent.

mean relative difference - Percentage error based on statistical analysis.

mercury - Silver-white, liquid metal solidifying at $-38.9^{\circ} \mathrm{C}$ to form a tin-white, ductile, malleable mass. It is widely distributed in the environment and biologically is a nonessential or nonbeneficial element. Human poisoning due to this highly toxic element has been clinically recognized.

migration - Transfer or movement of a material through the air, soil, or groundwater.

minimum detectable concentration - Smallest amount or concentration of a radionuclide that can be distinguished in a sample by a given measurement system at a preselected counting time and at a given confidence level.

moderate - To reduce the excessiveness of; to act as a moderator.

moderator - Material, such as heavy water, used in a nuclear reactor to moderate or slow down neutrons from the high velocities at which they are created in the fission process.

monitoring - Process whereby the quantity and quality of factors that can affect the environment and/or human health are measured periodically in order to regulate and control potential impacts.

$\mathbf{N}$

nonpoint source - any source that does not meet the definition for point source (National Emission Standards for Hazardous Air Pollutants radionuclide program).

nonroutine radioactive release - Unplanned or nonscheduled release of radioactivity to the environment.

nuclide - Atom specified by its atomic weight, atomic number, and energy state. A radionuclide is a radioactive nuclide.
0

organic-Of, relating to, or derived from living organisms (plant or animal).

outcrop - Place where groundwater is discharged to the surface. Springs, swamps, and beds of streams and rivers are the outcrops of the water table.

outfall - Point of discharge (e.g., drain or pipe) of wastewater or other effluents into a ditch, pond, or river.

P

parameter - Analytical constituent; chemical compound(s) or property for which an analytical request may be submitted.

permeability - Physical property that describes the ease with which water may move through the pore spaces and cracks in a solid.

person-rem - Collective dose to a population group. For example, a dose of one rem to 10 individuals results in a collective dose of 10 person-rem.

$\mathrm{pH}-$ Measure of the hydrogen ion concentration in an aqueous solution. Acidic solutions have a $\mathrm{pH}$ from $0-6$, basic solutions have a $\mathrm{pH}>7$, and neutral solutions have a $\mathrm{pH}=7$.

piezometer - Instrument used to measure the potentiometric surface of the groundwater. Also, a well designed for this purpose.

plume - Volume of contaminated air or water originating at a point-source emission (e.g., a smokestack) or a waste source (e.g., a hazardous waste disposal site).

point source - stack or vent (National Emission Standards for Hazardous Air Pollutants radionuclide program).

population dose - See collective dose equivalent under dose.

process sewer - Pipe or drain, generally located underground, used to carry off process water and/or waste matter.

purge - To remove water prior to sampling, generally by pumping or bailing. 
quality assurance (QA) - In the Environmental Monitoring System program, QA consists of the system whereby the laboratory can assure clients and other outside entities, such as government agencies and accrediting bodies, that the laboratory is generating data of proven and known quality.

quality control (QC) - In the Environmental Monitoring System program, QC refers to those operations undertaken in the laboratory to ensure that the data produced are generated within known probability limits of accuracy and precision.

rad - Unit of absorbed dose deposited in a volume of material.

radioactivity - Spontaneous emission of radiation, generally alpha or beta particles, or gamma rays, from the nucleus of an unstable isotope.

radioisotopes - Radioactive isotopes.

radionuclide - Unstable nuclide capable of spontaneous transformation into other nuclides by changing its nuclear configuration or energy level. This transformation is accompanied by the emission of photons or particles.

real-time instrumentation - Operation in which programmed responses to an event are essentially simultaneous with the event itself.

reforestation - Process of planting new trees on land once forested.

regulatory compliance - Actions taken in accordance with government laws, regulations, orders, etc., that apply to site operations' effects on onsite and offsite natural resources and on human health; used interchangeably in this document with environmental compliance.

release - Any discharge to the environment. Environment is broadly defined as any water, land, or ambient air. rem - Unit of dose equivalent (absorbed dose in rads $x$ the radiation quality factor). Dose equivalent is frequently reported in units of millirem (mrem) which is one-thousandth of a rem.

remediation - Assessment and cleanup of Department of Energy sites contaminated with waste as a result of past activities. See environmental restoration.

remediation design - Planning aspects of remediation, such as engineering characterization, sampling studies, data compilation, and determining a path forward for a waste site.

replicate - In the Environmental Monitoring Section groundwater monitoring program, a second sample from the same well taken at the same time as the primary sample and sent to the same laboratory for analysis.

\section{Resource Conservation and Recovery Act} (RCRA) - Federal legislation that regulates the transport, treatment, and disposal of solid and hazardous wastes. This act also requires corrective action for releases of hazardous waste at inactive waste units.

Resource Conservation and Recovery Act (RCRA) site - Solid waste management unit under Resource Conservation and Recovery Act regulation. See Resource Conservation and Recovery Act.

retention basin - Unlined basin used for emergency, temporary storage of potentially contaminated cooling water from chemical separations activities.

RFI Program - RCRA Facility Investigation Program; Environmental Protection Agency-regulated investigation of a solid waste management unit with regard to its potential impact on the environment.

RFI/RI Program - RCRA Facility Investigation/Remedial Investigation Program. At the Savannah River Site, the expansion of the RFI Program to include Comprehensive Environmental Response, Compensation, and Liability Act and hazardous substance regulations.

routine radioactive release - Planned or scheduled release of radioactivity to the environment.

$\mathbf{S}$

seep - Area, generally small, where water moves slowly to the land surface. 
seepage basin - Excavation that receives wastewater. Insoluble materials settle out on the floor of the basin and soluble materials seep with the water through the soil column where they are removed partially by ion exchange with the soil. Construction may include dikes to prevent overflow or surface runoff.

sensitivity - Capability of methodology or instruments to discriminate between samples with differing concentrations or containing varying amounts of analyte.

settling basin - Temporary holding basin (excavation) that receives wastewater which is subsequently discharged.

site stream - Any natural stream on the Savannah River Site. Surface drainage of the site is via these streams to the Savannah River.

source-Point or object from which radiation or contamination emanates.

source check - Radioactive source with a known amount of radioactivity used to check the performance of the radiation detector instrument.

source term - Quantity of radioactivity released in a set period of time that is traceable to the starting point of an effluent stream or migration pathway.

spent nuclear fuel - used fuel elements from reactors.

spike - Addition of a known amount of reference material containing the analyte of interest to a blank sample.

split sample - Two samples taken at the same time and sent to two different laboratories for analysis.

stable - Not radioactive or not easily decomposed or otherwise modified chemically.

stack - Vertical pipe or flue designed to exhaust airborne gases and suspended particulate matter.

standard deviation - Indication of the dispersion of a set of results around their average.

stormwater runoff - Surface streams that appear after precipitation.

Superfund - see Comprehensive Environmental Response, Compensation, and Liability Act (CERCLA). supernate - Portion of a liquid above settled materials in a tank or other vessel.

surface water - All water on the surface of the earth, as distinguished from groundwater.

T

tank farm - Installation of interconnected underground tanks for storage of high-level radioactive liquid wastes.

temperature - Thermal state of a body considered with its ability to communicate heat to other bodies.

thermoluminescent dosimeter (TLD) - Device used to measure external gamma radiation.

total dissolved solids - Dissolved solids and total dissolved solids are terms generally associated with freshwater systems and consist of inorganic salts, small amounts of organic matter and dissolved materials.

total phosphorus - When concentrations exceed $25 \mathrm{mg} / \mathrm{L}$ at the time of the spring turnover on a volume-weighted basis in lakes or reservoirs, it may occasionally stimulate excessive or nuisance growths of algae and other aquatic plants.

total suspended particulates - Refers to the concentration of particulates in suspension in the air irrespective of the nature, source, or size of the particulates.

transport pathway - pathway by which a released contaminant physically is transported from its point of discharge to a point of potential exposure to humans. Typical transport pathways include the atmosphere, surface water, and groundwater.

transuranic waste - Solid radioactive waste containing primarily alpha-emitting elements heavier than uranium.

turbidity - Measure of the concentration of sediment or suspended particles in solution.

V

vitrify - Change into glass.

vitrification - Process of changing into glass.

volatile organic compounds - Broad range of organic compounds, commonly halogenated, that vaporize at ambient, or relatively low, temperatures (e.g., acetone, benzene, chloroform, and methyl alcohol). 
W

waste management - The Department of Energy uses this term to refer to the safe, effective management of various kinds of nonhazardous, hazardous, and radioactive waste generated on site.

waste unit - Inactive area that is known to have received contamination or had a release to the environment.

water table - Planar, underground surface beneath which earth materials, as soil or rock, are saturated with water. weighting factor - Value used to calculate dose equivalents. It is tissue specific and represents the fraction of the total health risk resulting from uniform, whole-body irradiation that could be contributed to that particular tissue. The weighting factors used in this report are recommended by the International Commission on Radiological Protection (Publication 26).

wetlands - Lowland area, such as a marsh or swamp, inundated or saturated by surface or groundwater sufficiently to support hydrophytic vegetation typically adapted for life in saturated soils.

wind rose - Diagram in which statistical information concerning direction and speed of the wind at a location is summarized.

worldwide fallout - Radioactive debris from atmospheric weapons tests that has been deposited on the earth's surface after being airborne and cycling around the earth. 



\section{References}

Bebbington, 1990 Bebbington, W.P., 1990, History of Du Pont at the Savannah River Site, E.I. du Pont de Nemours and Company, Wilmington, Del.

BEIR V, 1990 National Research Council, 1990, Health Effects of Exposure to Low Levels of Ionizing Radiation, BEIR V Report, Washington, D.C., 1982.

Blohm, 1995 Blohm, J.D., 1995, Pen Branch Stream Corridor and Delta Wetlands Change Assessment, Savannah River Site, EGG-11265-1013, Savannah River Site, Aiken, S.C. (available to the public from the National Technical Information Service, U.S. Department of Commerce, 5285 Port Royal, Springfield, Va. 22161)

Carlton et al., 1994 Carlton, W.H., C.E. Murphy, Jr., and A.G. Evans, 1994, "Radiocesium in the Savannah River Site Environment," Health Physics, Volume 67, Number 3, Williams \& Wilkins, Baltimore, Md.

Cook, 1997 Cook, et al., 1997, "Composite Analysis - E-Area Vaults and Saltstone Disposal Facilities," WSRC-RP-97-311, Rev. 0, Savannah River Site, Aiken, S.C.

Davis et al., 1989 Davis, H.A., D.K. Martin, and J.L. Todd, 1989, Savannah River Site Environmental Report for 1988, WSRC-RP-89-59-1, Savannah River Site, Aiken, S.C.

DOE, 1988 U.S. Department of Energy, 1988, External and Internal Dose Conversion Factors for Calculation of Dose to the Public, DOE/EH-0070\&71, U.S. Department of Energy, Washington, D.C.

DOE, 1990 U.S. Department of Energy, 1990, Final Environmental Impact Statement, Continued Operation of K-, L-, and P-Reactors, Savannah River Site, Aiken, South Carolina, DOE/EIS-0147.

DOE, 1991 U.S. Department of Energy, 1991, Environmental Regulatory Guide for Radiological Effluent Monitoring and Environmental Surveillance, DOE/EH-0173T, National Technical Information Service, Springfield, Va.

DOE, 1992 U.S. Department of Energy, 1992, Mitigation Action Plan, 1992 Annual Update, Continued Operation of $K-, L-$, and P-Reactors, Environmental Impact Statement, DOE/EIS-0147.

DOE, 1996 U.S. Department of Energy, 1996, Nuclear Weapons Nonproliferation Policy Concerning Foreign Research Reactor Spent Nuclear Fuel, Record of Decision, Washington, D.C.

DOE EM, 1991 U.S. Department of Energy Office of Environmental Restoration and Waste Management, 1991, Environmental Restoration and Waste Management (EM) Program An Introduction, DOE/EM-0013P, U.S. Department of Energy, Washington, D.C.

Dulohery, 1996 Dulohery, N.J., C.S. Bunton, C.C. Trettin, and W.H. McKee, Jr., 1996, Reforestation of the Pen Branch Corridor and Delta, WSRC-TR-96-0005, U.S. Department of Agriculture Forest Service, Establishment Report, Center for Forested Wetlands Research, Charleston, S.C.

EMS, 1997 Environmental Protection Department Environmental Monitoring Section, 1997, Westinghouse Savannah River Company Environmental Monitoring Section Self-Assessment Plan, ESH-EMS-97-1029, Savannah River Site, Aiken, S.C.

EPA, 1989 U.S. Environmental Protection Agency, 1989, "National Emission Standards for Hazardous Air Pollutants; Radionuclides," Title 40 Code of Federal Regulations, Part 61, Volume 54, No. 240, Washington, D.C.

EPA, 1991 U.S. Environmental Protection Agency, 1991, Risk Assessment Guidance for Superfund, Volume I: Human Health Evaluation Manual Supplemental Guidance "Standard Default Exposure Factors," OSWER Directive: 9285.6-03, Washington, D.C.

EPA, 1995 U.S. Environmental Protection Agency, 1995, Health Effects Assessment Summary Tables FY 1995, 11/95 Supplement, Publication 9200.6-303 (95-1), Washington, D.C. 
Fact Sheet, 1995 Westinghouse Savannah River Company, 1992, "Environmental Restoration," Fact Sheet, WSRC-MS-96-0623, Savannah River Site, Aiken, S.C.

Fact Sheet, 1996a Westinghouse Savannah River Company, 1996, "Savannah River Site," Fact Sheet, WSRC-MS-96-0620, Rev 1, Savannah River Site, Aiken, S.C.

Fact Sheet, 1996b Westinghouse Savannah River Company, 1996, "H Canyon," Fact Sheet, WSRC-MS-97-0228, Savannah River Site, Aiken, S.C.

Fact Sheet, 1996c Westinghouse Savannah River Company, 1996, "High-Level Waste Processing Facilities," Fact Sheet, WSRC-MS-96-0619, Rev 1, Savannah River Site, Aiken, S.C.

Flach, 1996 Flach, G.P., et al, 1996, "Groundwater Flow and Tritium Migration from the SRS Old Burial Ground to Fourmile Branch (U)," Savannah River Site, Aiken, S.C.

Fledderman, 1995 Fledderman, P.D., 1995, Interview with William G. Weil, Water Operations Superintendent - City of Savannah Industrial and Domestic Water Supply, January 9, 1995, Savannah, Ga.

Hamby, 1991 Hamby, D.M., 1991, Land and Water Use Characteristics in the Vicinity of the Savannah River Site (U), WSRC-RP-91-17, Savannah River Site, Aiken, S.C.

Hamby, 1993 Hamby, D.M., 1993, "A Probabilistic Estimation of Atmospheric Tritium Dose," Health Physics, Volume 65, Number 1, Williams \& Wilkins, Baltimore, Md.

Hamby and Bauer, 1994 Hamby, D.M., and L.R. Bauer, 1994, "The Vegetation-to-air Concentration Ratio in a Specific Activity Atmospheric Tritium Model," Health Physics, Volume 66, Number 3, Williams \& Wilkins, Baltimore, Md.

Hunter, 1990 Hunter, C.H., 1990, A Climatological Description of the Savannah River Site, WSRC-RP-89-313, Savannah River Site, Aiken, S.C.

ICRP, 1990 International Commission on Radiation Protection, 1990, Recommendations of the ICRP, Publication 60, Elmsford, N.Y.

Jannik, 1997 Jannik, 1997, "Assessment of SRS Radiological Liquid and Airborne Contaminants and Pathways (U)", WSRC-TR-97-0152, Savannah River Site, Aiken, S.C.

Klaassen et al., 1986 Klaassen, C.D., M.D. Amdur, and J. Doull (editors), 1986, Casarett and Doull's Toxicology, The Basic Science of Poisons, third edition, MacMillan Pharmacology 33:120-126, New York, N.Y.

Looney, 1993 Looney, B.B., et al, 1993, Projected Tritium Releases from $F$ \& H Area Seepage Basins and the Solid Waste Disposal Facilities to Fourmile Branch (U), WSRC-RP-93-459, Savannah River Site, Aiken, S.C.

NCRP, 1979 National Council on Radiation Protection and Measurements, 1979, Tritium in the Environment, NCRP Report No. 62, Bethesda, Md.

NCRP, 1987 National Council on Radiation Protection and Measurements, 1987, lonizing Radiation Exposure of the Population of the United States, NCRP Report No. 93, Bethesda, Md.

Nelson, 1996 Nelson, E.A., ed., 1996, The Restoration of Pen Branch: Defining and Measuring the Progress of a Thermally Impacted Stream Becoming a Functional Wetland Ecosystem, WSRC-MS-96-0257X, Savannah River Site, Aiken, S.C.

NRC, 1977 U.S. Nuclear Regulatory Commission, 1977, Regulatory Guide 1.109, Calculation of Annual Doses to Man from Routine Releases of Reactor Effluents for the Purpose of Evaluating Compliance with 10 CFR 50, Appendix I, Revision 1, Washington, D.C.

SCDHEC, 1985 South Carolina Department of Health and Environmental Control, 1985, Savannah River Plant, Aiken, Allendale, and Barnwell Counties, NPDES Permit 0000175, Columbia, S.C.

SCDHEC, 1993 South Carolina Department of Health and Environmental Control, 1993, South Carolina State Primary Drinking Water Regulations R.61-68, "Water Classifications and Standards," Columbia, S.C. 
Soldat et al., 1974 Soldat, J.K., N.M. Robinson, and D.A. Baker, 1974, Models and Computer Codes for Evaluating Environmental Radiation Doses, BNWL-1754, Battelle Pacific Northwest Laboratories.

SRFS, 1982 Savannah River Forest Station, 1982, "Thirty Years of Progress," Savannah River Forest Station Savannah River Plant Newspaper, January 1982, Savannah River Forest Station, Department of Agriculture, Aiken, S.C.

SRS Data, 1997 Environmental Protection Department Environmental Monitoring Section, 1997, Savannah River Site Environmental Data for 1997, WSRC-TR-97-00324, Savannah River Site, Aiken, S.C.

SRS Data, 1998 Environmental Protection Department Environmental Monitoring Section, 1998, Savannah River Site Environmental Data for 1998, WSRC-TR-98-00314, Savannah River Site, Aiken, S.C.

SRS EM Program, 1995 Savannah River Site Environmental Monitoring Section Plans and Procedures, WSRC-3Q1-2, Volume 1, Section 1100, Savannah River Site, Aiken, S.C.

SRS Groundwater, 1998a The Savannah River Site's Groundwater Monitoring Program, First Quarter 1998, ESH-EMS-98-0568, Savannah River Site, Aiken, S.C.

SRS Groundwater, 1998b The Savannah River Site's Groundwater Monitoring Program, Second Quarter 1998, ESH-EMS-98-0569, Savannah River Site, Aiken, S.C.

SRS Groundwater, 1998c The Savannah River Site's Groundwater Monitoring Program, Third Quarter 1998, ESH-EMS-98-0570, Savannah River Site, Aiken, S.C.

SRS Groundwater, 1998d The Savannah River Site's Groundwater Monitoring Program, Fourth Quarter 1998, ESH-EMS-98-0571, Savannah River Site, Aiken, S.C.

WHO, 1990 World Health Organization, 1990, Environmental Health Criteria 101: Methylmercury, Geneva, Switzerland.

WSRC, 1992 Westinghouse Savannah River Company, 1992, Quality Assurance Management Plan (WSRC-RP-92-225, Rev. 7, Savannah River Site, Aiken, S.C.

WSRC, 1997 Westinghouse Savannah River Company, 1997, Removal Site Evaluation Report for the Ford Building Seepage Basin (904-91G) (U), WSRC-RP-97-129, Savannah River Site, Aiken, S.C.

WSRC, 1999 Westinghouse Savannah River Company, 1999, Environmental Geochemistry Group Operating Handbook, Volumes I and II, WSRC-IM-99-00013, Savannah River Site, Aiken, S.C. 



\section{Numbers}

320-M Chemical Laboratory, 69

321-M Fuel Fabrication Facility, 69

322-M Metallurgical Laboratory, 69

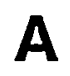

A-Area, 10

A-Area and M-Area, groundwater monitoring results, 159

Academy of Natural Sciences of Philadelphia river quality surveys, 199

results of, 201

algae and aquatic macrophyte studies, 202

diatom monitoring, 201

fish studies, 203

insect studies, 203

noninsect macroinvertebrate studies, 203

sampling sites for, 200

accelerated cleanup plan, 52

Accelerator for Production of Tritium

as backup option, 8

preconstruction/preoperational monitoring for, 195

actinide transport, 80

administration area, 10

Affirmative Procurement Program, 51

air, radiological surveillance of, 86

sampling stations for, 87

air dispersion modeling, 134, 141

air emissions inventory, 28, 132

See also Clean Air Act

airborne emissions

nonradiological monitoring of, 131

radiological monitoring of, 72 comparison of average concentrations to

Derived Concentration Guides, 73

diffuse and fugitive sources, 72

results of, 73

ambient air quality, 134, 141 appraisals and surveillances of environmental program, 34

aquatic food products. See fish, radiological surveillance of

archaeology at SRS and public outreach, 56

areas of Savannah River Site

A-Area, 10

administration, 10

B-Area, 10

D-Area, 7

F-Area, 7

G-Area, 10

H-Area, 7

Heavy Water Reprocessing Area, 7

M-Area, 7

Multipurpose Pilot Plant Campus, 10

N-Area, 10

reactor, 7

reactor materials, 7

separations, 7

TNX, 10

waste management, 8

as low as reasonably achievable concept, 71

asbestos removal program, 28

See also Clean Air Act

assets-for-services pilot program, 67

Atomic Energy Commission, 1

Atoms for Peace program, 7

B

B-Area, 10

groundwater monitoring results, 183

Babcock \& Wilcox Savannah River Company, as Savannah River Site contractor, 2

bald eagle, 31

Beaufort-Jasper Water Treatment Plant, 4

beavers, radiological surveillance of, 104

Bechtel Savannah River, Inc., as Savannah River Site contractor, 1

beef. See food products, radiological surveillance of

British Nuclear Fuels Savannah River Corporation, as Savannah River Site contractor, 2 


\section{C}

C-Area, groundwater monitoring results, 163

canyons, 7, 64

CAP88, 112

Carolina bays, 4

Central Savannah River Area Radiological Environmental Monitoring Program, 54

Central Savannah Watershed environmental restoration project, 58

Chemical Commodity Management Center, 51

chemicals, management of excess, 51

chemicals, metals, and pesticides pits, groundwater monitoring results, 174

Citizens Advisory Board, 51 and information exchange, 54

and public involvement, 52

Citizens for Environmental Justice, 54

City of Savannah Industrial and Domestic Water Supply Plant, 4

Clean Air Act, 26

air emissions inventory, 28

asbestos removal program, 28

compliance with National Emissions Standards of Hazardous Air Pollutants, 122

National Emission Standards for Hazardous Air Pollutants, 27

ozone-depleting substances, 29

Title V Operating Program, 29

Clean Water Act, 24

construction in navigable waters, 26

dredge and fill permitting, 25

National Pollutant Discharge Elimination

System program, 24

reportable occurrences, 33

rivers and harbors, 25

climate of Savannah River Site, 2

coal-fired boilers

capacities of, 133

stack test results of, 133

Commercial Light Water Reactor, 8

compensatory mitigation, for Pen Branch, 199

Comprehensive Environmental Response, Compensation, and Liability Act, 17

reportable occurrences, 33

Superfund Amendments and Reauthorization Act, 17

conservation of energy, 50
Consolidated Incineration Facility, 10, 62

construction in navigable waters, 26

See also Clean Water Act

continuous monitoring, 72, 75

courtesy notifications to regulators, 33

criteria pollutant air emissions (1996), 133

critical pathways analysis, 48

CRITR, 129

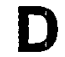

D-Area, 7 groundwater monitoring results, 165 power plant, 7

D-Ash Basin sampling, 58

data verification and validation, 188

deactivation and decommissioning of facilities, 35

Decontamination Facility, 65

deer

dose from consumption of, 125

radiological surveillance of, 102

Defense Waste Processing Facility, 10, 64, 65

Derived Concentration Guides, 73, 75

diffuse and fugitive sources, radioactive releases from, 72

dose

calculating for children, 112

calculating, by Savannah River Site, 112

calculation models, 112

contributions to average individual, 124

definition of in this report, 111

to maximally exposed individual, 112, 118

10-year history, 124

uncertainty in calculation of, 115

dose calculation results

air pathway, 120

atmospheric concentrations, 120

atmospheric source terms, 120

collective dose (population dose), 122

maximally exposed individual, 121,122

National Emissions Standards for Hazardous

Air Pollutants compliance, 122

all-pathway, 123

aquatic animal organisms, 128

comparison of, to standard, 125

deer and hog consumption pathway, 125

drinking water pathway, 119

fish consumption pathway, 125

liquid pathway, 116

collective effective dose equivalent

(population dose), 119 
irrigation, 120

liquid release source terms, 116

maximally exposed individual, 118, 119

maximally exposed individual, (sector-specific), 123

sportsman dose, 123

deer and hog consumption pathway, 125

fish consumption pathway, 125

Dose Reconstruction Study, 49

dredge and fill permitting, 25

See also Clean Water Act

drinking water

nonradiological surveillance of, 144

radiological surveillance of, 98

drinking water systems (site), 145

Du Pont, 1

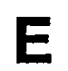

E.I. du Pont de Nemours and Company, 1

E-Area, groundwater monitoring results, 168

effluent monitoring, definition of, 44

effluent monitoring responsibilities, 71

nonradiological, 131

Effluent Treatment Facility, 8

EMAX Laboratories, Inc., 156, 191

EMCAP (Environmental Monitoring Computer

Automation Program), 188

Emergency Planning and Community

Right-to-Know Act, 18

reportable occurrences, 33

endangered and threatened species, 4

Endangered Species Act, 31

energy conservation, 50

Energy Reorganization Act of 1974, 1

Energy Research and Development

Administration, 1

Enhanced Tritium Monitoring program, 49

Environmental Advisory Committee, 54

Environmental Bulletin, 55

environmental compliance

33/50 Pollution Prevention Program, 19

appraisals and surveillances of environmental programs, 34

Clean Air Act, 26

Clean Water Act, 24
Comprehensive Environmental Response, Compensation, and Liability Act, 17

courtesy notifications to regulators, 33

Emergency Planning and Community Right-to-Know Act, 18

Endangered Species Act, 31

Executive Order 11988, 32

Executive Order 11990, 32

Executive Order 12856, 19

Federal Facility Agreement, 17

Federal Facility Compliance Act, 15

Federal Facility Compliance Agreement, 15

Federal Insecticide, Fungicide, and Rodenticide Act, 26

floodplain management (Executive Order 11988), 32

key regulations for, 14

land disposal restrictions, 15

National Emission Standards for Hazardous Air Pollutants, 27

National Environmental Policy Act, 20

National Historic Preservation Act, 32

National Pollutant Discharge Elimination System, 24

permits, 35

Resource Conservation and Recovery Act, 15 3004(u) Program, 17

Safe Drinking Water Act, 23

Site Item Reportability and Issues Management program, 33

Superfund Amendments and Reauthorization Act, 17

Tier II Inventory Report, 18

Toxic Chemical Release Inventory, 18

toxic chemical releases, 19, 20

Toxic Substances Control Act, 30

training, 35

underground storage tanks, 16

waste tank closure, 16

wetlands protection (Executive Order 11990), 32

environmental justice (Executive Order 12898), 54

Environmental Management System, 43

environmental monitoring program, 44

1998 changes in, 49

and radioactive contaminants, 45

environmental regulations for, 48

measurement capabilities as factors in, 49

objectives of, 47

policy for, 47

public concerns about releases, 49

rationale for, 47

Environmental Physics, Inc., 156, 191

environmental restoration, description of program, 58 
environmental surveillance, definition of, 44

environmental surveillance responsibilities nonradiological, 141

radiological, 85

\section{Executive Order}

11988,32

11990,32

12856,19

12898,54

exposure pathways, and environmental monitoring program, 48

Extended Sludge Processing Facility, 9, 64

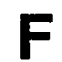

F-Area, groundwater monitoring results, 168

F-Canyon operations, 7

facility decommissioning, 65

1998 accomplishments, 65

Federal Facility Agreement, 17

Federal Facility Compliance Act, 15

See also Resource Conservation and Recovery Act

Federal Facility Compliance Agreement, 15

Federal Insecticide, Fungicide, and Rodenticide Act, 26

fish

dose from consumption of, 125

nonradiological surveillance of, 147

radiological surveillance of, 100

risk from consumption of, 127

sampling locations for, 101

fish monitoring in the Savannah River, and public concern, 49

fish monitoring plan, 126

floodplain management (Executive Order 11988), 32

flow rate measurements, 72,75

food products, radiological surveillance of, 98

Ford Building tank removal, 58

freshwater fish. See fish, radiological surveillance of

Freshwaters, classification of, 142 fruit. See food products, radiological surveillance of

G

G-Area, 10

gamma radiation, radiological surveillance of, 89

General Engineering Laboratories, 156, 191

general separations area, groundwater monitoring results, 168

general separations areas, groundwater monitoring results. See E-Area, F-Area, H-Area, S-Area, Z-Area

geology of Savannah River Site, 2

GeoSiphon cell, 58

geosynthetic capping, 59

grains. See food products, see radiological surveillance of

grassy vegetation. See vegetation, radiological surveillance of

greens. See food products, radiological surveillance of

groundwater

and quality assurance, 191

changes in 1998 monitoring program for, 157 description of monitoring program for, 153-157 monitoring well network (map), 150

movement of, 149-153

quality control for, 156

groundwater monitoring results, 157-184

A-Area and M-Area, 159

B-Area, 183

C-Area, 163

chemicals, metals, and pesticides pits, 174

D-Area, 165

E-Area, 168

F-Area, 168

H-Area, 168

K-Area, 172

L-Area, 174

N-Area, 177

P-Area, 179

R-Area, 181

S-Area, 168

Sanitary Landfill, 183

TNX, 165

Z-Area, 168 
GTS Duratek, Inc., 69

Gulf Coast, 156, 191

\section{H}

H-Area, 7

groundwater monitoring results, 168

H-Canyon operations, 7

hazardous waste, 62

Heavy Water Components Test Reactor, 68

Heavy Water Facility, 7

Heavy Water Reprocessing Area, 7

high-level waste management, 64

1998 accomplishments of, 65

hogs

dose from consumption of, 125

radiological surveillance of, 102

hydrology of Savannah River Site, 2

In-Tank Precipitation Facility, 10, 64

information exchange, 54

Interagency Information Exchanges, 54

interlaboratory comparison

for National Pollutant Discharge Elimination System, 190

Quality Assurance Division (Environmental Protection Agency), 189

Quality Assurance Program (Department of Energy), 189

intralaboratory comparison, for National Pollutant

Discharge Elimination System, 191

ISO 14001,44

\section{K}

K-Area, groundwater monitoring results, 172

key regulations for environmental compliance, 14
L-Lake, construction of, 4

L-Area, groundwater monitoring results, 174

laboratory data reviews and quality assurance, 193

LADTAPII, 112

land disposal restrictions, 15

See also Resource Conservation and Recovery Act

land resources of Savannah River Site, 4

liquid discharges

direct, 75

nonradiological monitoring of, 134

monthly discharge monitoring report, 136

radiological monitoring of, 74

comparison of average concentrations to

Derived Concentration Guides, 75

results of, 75

seepage basins and Solid Waste Disposal

Migration, 76

Liquid Effluent Treatment Facility, 7

low-level waste, 61

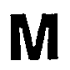

M-Area, 7

M-Area Vendor Treatment Facility, 69

marine fish. See fish, radiological surveillance of

MAXIGASP, 112

meat. See food products, radiological surveillance of

mercury in fish, 147

meteorological data as input for dose calculations, 113

Microseeps, 192

milk

See also food products, radiological surveillance of

radiological surveillance of, 99

mission of Savannah River Site, 4

mitigation, compensatory, for Pen Branch, 199

Mitigation Action Plan for Pen Branch

Reforestation, 195

mixed waste, 62 
monthly discharge monitoring report, 136

Multipurpose Pilot Plant Campus, 10

\section{$\mathbf{N}$}

N-Area, 10

groundwater monitoring results, 177

National Emissions Standards for Hazardous Air Pollutants, 27

See also Clean Air Act

compliance with for dose calculation, 122

National Environmental Policy Act, 20

documentation activities, 23

public involvement activities, 52

National Environmental Research Park, designation of Savannah River Site as, 4, 5

National Environmental Training Office, 53

National Historic Preservation Act, 32

National Pollutant Discharge Elimination System, 24

See also Clean Water Act

1998 exceedances, 139

.and quality assurance, 189

Environmental Protection Agency Discharge

Monitoring Report Laboratory Performance

Evaluation program, 190

history of exceedances, 138

Notice of Violation, 25

program results, 136

National Priority List, 17

See also Superfund Amendments and

Reauthorization Act

nonradiological effluent monitoring responsibilities, 131

nonradiological environmental surveillance responsibilities, 141

nonradiological monitoring and surveillance. See individual medium

Notice of Violation

National Pollutant Discharge Elimination System, 25

RCRA, 16

Nuclear Regulatory Commission, 1
0

Off-Site Fuels Policy, 8

Oil Pollution Prevention regulation, 25

outreach

communications, 54

education, 55

environmental justice, 54

public notice requirements, 55

ozone-depleting substances, 26, 29, 51

See also Clean Air Act

\section{$\mathbf{P}$}

P-Area, groundwater monitoring results, 179

PAR Pond, construction of, 4

pathways

examples of exposure, 48

surveillance of radiation exposure, 85

Patrick Center for Environmental Research, 199

Pen Branch reforestation

by natural succession, 196

by planting, 196

Mitigation Action Plan for, 195

permits, summary list of construction and

operating, 36

permits for environmental compliance, 35

plant and animal life at Savannah River Site, 4

pollution prevention, 49,63

33/50 Pollution Prevention Program, 19

Pollution Prevention Act of 1990, 18

POPGASP, 112

population database and distribution as input for dose calculations, 115

Prioritized Risk Ranked Listing, 65

public

concerns about releases, 49

notification to, about environmental plans and activities, 55

outreach, 54

public drinking water supply monitoring, and public concern, 49

public involvement, 51

accelerated cleanup plan, 52

Citizens Advisory Board, 52

environmental restoration, 51

material and facility stabilization, 52

National Environmental Policy Act , 52 
risk communication, 52

purple coneflower, 31

\section{Q}

QST Environmental, Inc., 156, 191

quality assurance definition of terms, 187, 188

external program, 188

for Environmental Monitoring Section laboratories, 186

for groundwater analyses, 191

for National Pollutant Discharge Elimination System analyses, 189

for soil and sediment analyses, 192

for stream and river water analyses, 191

for subcontracted laboratories, 189

internal program, 187

relevant guidance documents for, 186

Quality Assurance Division (Environmental Protection Agency), 189

Quality Assurance Program (Department of Energy), 189

quality control practices for groundwater, 156

Quanterra Incorporated, 156

\section{$\mathbf{R}$}

R-Area, groundwater monitoring results, 181

Radiation Assessment Program, 129

radiological effluent monitoring responsibilities, 71

radiological environmental surveillance responsibilities, 85

radiological monitoring and surveillance. See individual medium

rainwater, radiological surveillance of, 88

reactor areas, 7

reactor materials area, 7

reactors, history of, 7

real-time instrumentation, 72

Receiving Basin for Offsite Fuel, 8, 64

Recra LabNet Philadelphia, 156, 191

recycled products, affirmative procurement of, 51

recycling, of solid waste, 50 red-cockaded woodpecker, 31

Replacement Tritium Facility, 8

reportable occurrences for environmental compliance

Clean Water Act, 33

Comprehensive Emergency Response, Compensation, and Liability Act, 33

Emergency Planning and Community Right-to-Know Act, 33

Site Item Reportability and Issues Management program, 33

reporting

courtesy notifications to regulators, 33

of environmental releases, 32

research and development at Savannah River Site, 11

Resource Conservation and Recovery Act, 15 3004(u) Program, 17

Federal Facility Compliance Act, 15

land disposal restrictions, 15

Notice of Violation, 16

underground storage tanks, 16

risk communication, 52

risk from consumption of fish, 126

compared to dose standards, 127

risk ranking of inactive facilities, 65

river flow rate data as input for dose calculations, 115

river water system shutdown, 35

Rivers and Harbor Act, 25

See also Clean Water Act

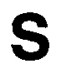

S-Area, groundwater monitoring results, 168

Safe Drinking Water Act, 23

Saltstone Facility, 10, 63

sampling locations

nonradiological

fish, 101

sediment, 146

surface water, 143

radiological

air, 87

fish, 101

sediment, 107

soil, 105

surface water (seepage basins, streams,

Savannah River), 92

vegetation, 109 
Sanitary Landfill, groundwater monitoring results, 183

sanitary waste, 60

Savannah River, radiological surveillance of, 95

sampling locations for, 92

tritium transport, 97

Savannah River Archaeological Research

Program, 12

and public outreach, 56

Savannah River Ecology Laboratory, 12

and public outreach, 56

Savannah River Natural Resource Management and Research Institute, 12

and public outreach, 55

Savannah River Site

areas, 6

as National Environmental Research Park, 4, 5

climate of, 2

criteria for locale for, 2

geology of, 2

history, 1

hydrology of, 2

land resources of, 4

location of, 2,3

map of areas, 6

mission of, 4

plant and animal life at, 4

research and development at, 11

tours of, 54

water resources of, 2

wildlife at, 4

Savannah River Technology Center, 11

Savannah State University and environmental justice, 55

sediment

nonradiological surveillance of, 144

sampling locations for, 146

radiological surveillance of, 104

sampling locations for, 107

seepage basins

history of, in F-Area and H-Area, 9

migration results, 76

radiological surveillance of, 90

sampling locations for, 92

separations areas, 7

Sequoyah Reactor, 8

Shealy Environmental Services, 190

shellfish. See fish, radiological surveillance of

shortnose sturgeon, 31
Site Item Reportability and Issues Management program, reportable occurrences, 33

Site Treatment Plan, 15

soil, radiological surveillance of, 104 sampling locations for, 105

Solid Waste Disposal Facility, 8

migration results, 76

solid waste management, 60 1998 accomplishments of, 60

Solid Waste Management Facility, 8

solid waste recycling, 50

source terms

air pathway, 120

liquid pathway, 116

South Carolina Electric and Gas Company and D-Area Power Plant, 7

Speakers Bureau, 54

spent fuel activities at Savannah River Site, 7

steam boilers, capacities of, 133

stratospheric ozone protection, 29

streams, radiological surveillance of, 91

sampling locations for, 92

tritium transport, 97

subcontracted laboratories, 190

Superfund Amendments and Reauthorization Act, 17

See also Comprehensive Environmental

Response, Compensation, and Liability Act

surface water

See also seepage basins, streams, Savannah

River (radiological surveillance of)

nonradiological surveillance of, 142

sampling locations for, 143

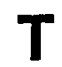

tank farms, 8

evaporator facilities, 64,65

Tennessee Valley Authority's Watts Bar and Sequoyah reactors, 8

terrestrial food products. See food products, radiological surveillance of

Thermo NUtech, 156, 191

thermoluminescent dosimeter program

and public concern, 49

and radiological surveillance, 89

Tier II Inventory Report, 18 
Title V Operating Program, 29

See also Clean Air Act

TNX, 10 groundwater monitoring results, 165

tours of Savannah River Site, 54

Toxic Chemical Release Inventory, 18, 50

toxic chemicals, releases of, 19, 20

Toxic Substances Control Act, 30

training employee environmental, 53 for environmental compliance, 35 for quality assurance, 186

transition of site facilities, 35

transuranic waste, 62

Tritium Extraction Facility, 8

tritium facilities, 8

tritium transport in streams and Savannah River, 97

turkeys, radiological surveillance of, 103

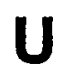

underground storage tanks, 16

See also Resource Conservation and Recovery Act

Upper Three Runs environmental restoration project, 58

\section{V}

vegetation, radiological surveillance of, 106 sampling locations for, 109

Vendor Treatment Facility, 10
Visitors Program, 54

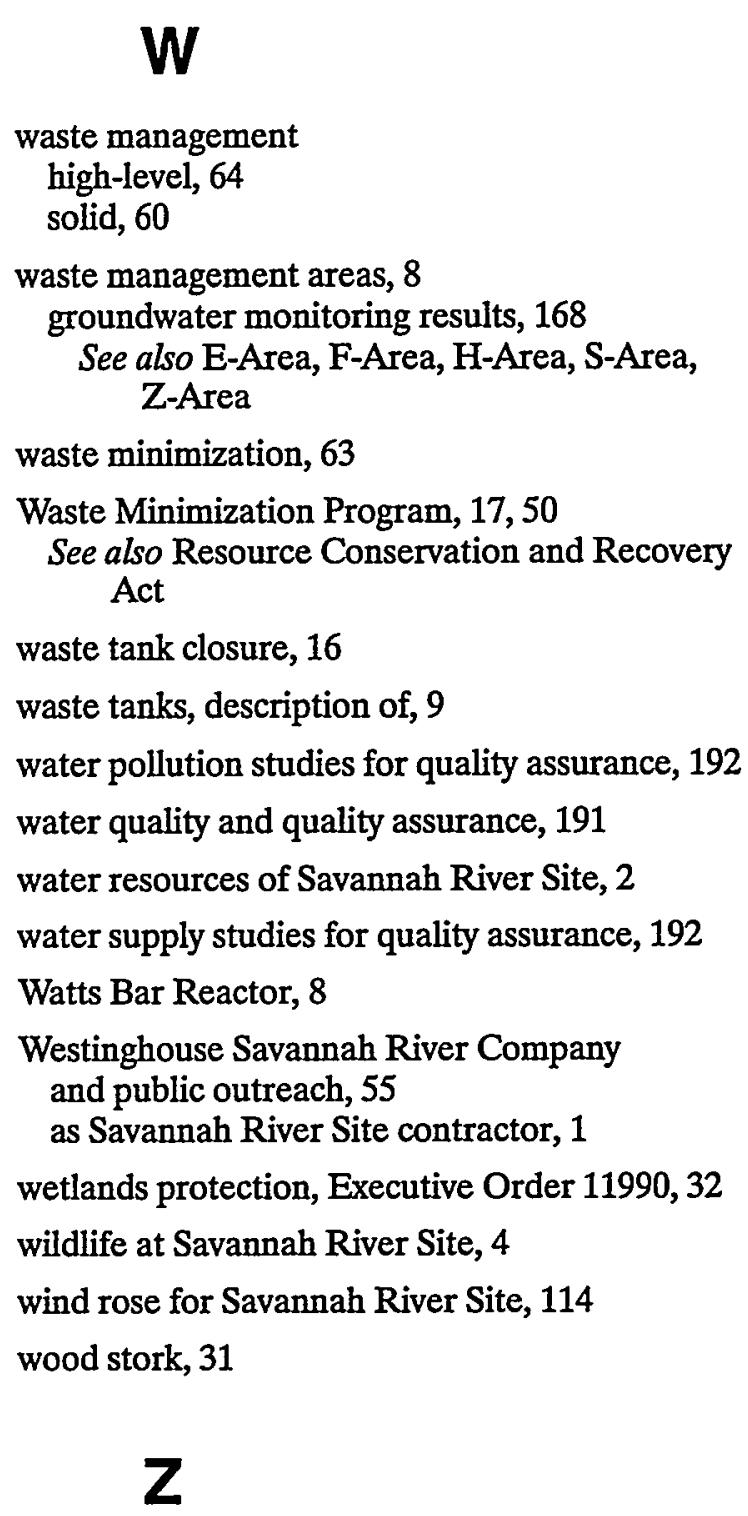

Z-Area, groundwater monitoring results, 168 


\begin{tabular}{|c|c|c|c|}
\hline \multicolumn{2}{|c|}{ Units of Measure } & \multicolumn{2}{|c|}{ Units of Measure } \\
\hline Symbol & Name & Symbol & Name \\
\hline Temperatu & & Concentration & \\
\hline${ }^{\circ} \mathrm{C}$ & degrees Centigrade & $\mathrm{ppb}$ & parts per billion \\
\hline${ }^{\circ} \mathrm{F}$ & degrees Fahrenheit & ppm & parts per million \\
\hline \multicolumn{4}{|l|}{ Time } \\
\hline d & day & Rate & \\
\hline h & hour & cfs & cubic feet per second \\
\hline$y$ & year & gpm & gallons per minute \\
\hline \multicolumn{4}{|l|}{ Length } \\
\hline $\mathrm{cm}$ & centimeter & Conductivity & \\
\hline $\mathrm{ft}$ & foot & $\mu \mathrm{mho}$ & micromho \\
\hline in. & inch & & \\
\hline $\mathrm{km}$ & kilometer & & \\
\hline $\mathrm{m}$ & meter & Radioactivity & \\
\hline $\mathrm{mm}$ & millimeter & $\mathrm{Ci}$ & curie \\
\hline \multirow[t]{2}{*}{$\mu \mathrm{m}$} & micrometer & $\mathrm{cpm}$ & counts per minute \\
\hline & & $\mathbf{m C i}$ & millicurie \\
\hline Mass & & $\mu \mathrm{Ci}$ & microcurie \\
\hline g & gram & $\mathrm{pCi}$ & picocurie \\
\hline kg & kilogram & $\mathrm{Bq}$ & becquerel \\
\hline $\mathrm{mg}$ & milligram & & \\
\hline \multirow[t]{2}{*}{$\mu \mathrm{g}$} & microgram & Radiation Dose & \\
\hline & & mrad & millirad \\
\hline Area & & mrem & millirem \\
\hline $\mathrm{mi}^{2}$ & square mile & Sv & sievert \\
\hline \multirow[t]{2}{*}{$\mathrm{ft}^{2}$} & square foot & $\mathrm{mSv}$ & millisievert \\
\hline & & $\mu S v$ & microsievert \\
\hline Volume & & $\mathbf{R}$ & roentgen \\
\hline gal & gallon & $\mathrm{mR}$ & milliroentgen \\
\hline $\mathbf{L}$ & liter & $\mu R$ & microroentgen \\
\hline $\mathrm{mL}$ & milliliter & Gy & gray \\
\hline
\end{tabular}




\begin{tabular}{|ccccc|}
\hline \multicolumn{5}{c|}{ Fractions and Multiples of Units } \\
\hline Multiple & Decimal Equivalent & Prefix & Symbol & $\begin{array}{c}\text { Report } \\
\text { Format }\end{array}$ \\
\hline $10^{6}$ & $1,000,000$ & mega- & $\mathrm{M}$ & $\mathrm{E}+06$ \\
$10^{3}$ & 1,000 & kilo- & $\mathrm{K}$ & $\mathrm{E}+03$ \\
$10^{2}$ & 100 & hecto- & $\mathrm{h}$ & $\mathrm{E}+02$ \\
10 & 10 & deka- & $\mathrm{da}$ & $\mathrm{E}+01$ \\
$10^{-1}$ & 0.1 & deci- & $\mathrm{d}$ & $\mathrm{E}-01$ \\
$10^{-2}$ & 0.01 & centi- & $\mathrm{C}$ & $\mathrm{E}-02$ \\
$10^{-3}$ & 0.001 & milli- & $\mathrm{m}$ & $\mathrm{E}-03$ \\
$10^{-6}$ & 0.000001 & micro- & $\mu$ & $\mathrm{E}-06$ \\
$10^{-9}$ & 0.000000001 & nano- & $\mathrm{n}$ & $\mathrm{E}-09$ \\
$10^{-12}$ & 0.000000000001 & pico- & $\mathrm{p}$ & $\mathrm{E}-12$ \\
$10^{-15}$ & 0.000000000000001 & femto- & $\mathrm{f}$ & $\mathrm{E}-15$ \\
$10^{-18}$ & 0.000000000000000001 & atto- & $\mathrm{a}$ & $\mathrm{E}-18$ \\
\hline
\end{tabular}

\begin{tabular}{|lll|}
\hline \multicolumn{3}{|c|}{ Conversion Table (Units of Radiation Measure) } \\
\hline Current System & Systéme International & Conversion \\
\hline curie (Ci) & becquerel $(\mathrm{Bq})$ & $1 \mathrm{Ci}=3.7 \times 10^{10} \mathrm{~Bq}$ \\
rad (radiation absorbed dose) & gray (Gy) & $1 \mathrm{rad}=0.01 \mathrm{~Gy}$ \\
rem (roentgen equivalent man) & sievert (Sv) & $1 \mathrm{rem}=0.01 \mathrm{~Sv}$ \\
\hline
\end{tabular}

\begin{tabular}{|lll|lll|}
\hline \multicolumn{7}{c|}{ Conversion Table } \\
\hline Multiply & By & To Obtain & Multiply & By & To Obtain \\
\hline in. & 2.54 & $\mathrm{~cm}$ & $\mathrm{~mm}$ & 0.394 & $\mathrm{in}$. \\
$\mathrm{ft}$ & 0.305 & $\mathrm{~m}$ & $\mathrm{~m}$ & 3.28 & $\mathrm{ft}$ \\
$\mathrm{mi}$ & 1.61 & $\mathrm{~km}$ & $\mathrm{~km}$ & 0.621 & $\mathrm{mi}$ \\
$\mathrm{lb}$ & 0.4536 & $\mathrm{~kg}$ & $\mathrm{~kg}$ & 2.205 & $\mathrm{lb}$ \\
$\mathrm{liq} \mathrm{qt}$-U.S. & 0.946 & $\mathrm{~L}$ & $\mathrm{~L}$ & 1.057 & $\mathrm{liq} \mathrm{qt-U.S.}$ \\
$\mathrm{ft}^{2}$ & 0.093 & $\mathrm{~m}^{2}$ & $\mathrm{~m}^{2}$ & 10.764 & $\mathrm{ft}^{2}$ \\
$\mathrm{mi}^{2}$ & 2.59 & $\mathrm{~km}^{2}$ & $\mathrm{~km}$ & 0.386 & $\mathrm{mi}^{2}$ \\
$\mathrm{ft}^{3}$ & 0.028 & $\mathrm{~m}^{3}$ & $\mathrm{~m}$ & 35.31 & $\mathrm{ft}^{3}$ \\
$\mathrm{~d} / \mathrm{m}$ & 0.450 & $\mathrm{pCi}$ & $\mathrm{pCi}$ & 2.22 & $\mathrm{~d} / \mathrm{m}$ \\
$\mathrm{pCi}$ & $10^{-6}$ & $\mu \mathrm{Ci}$ & $\mu \mathrm{Ci}$ & $10^{6}$ & $\mathrm{pCi}$ \\
$\mathrm{pCi} / \mathrm{L}$ (water) & $10^{-9}$ & $\mu \mathrm{Ci} / \mathrm{mL}$ (water) & $\mu \mathrm{Ci} / \mathrm{mL}$ (water) & $10^{9}$ & $\mathrm{pCi} / \mathrm{L}$ (water) \\
$\mathrm{pCi} / \mathrm{m}^{3}$ (air) & $10^{-12}$ & $\mu \mathrm{Ci} / \mathrm{mL}$ (air) & $\mu \mathrm{Ci} / \mathrm{mL}$ (air) & $10^{12}$ & $\mathrm{pCi} / \mathrm{m}^{3}$ (air) \\
\hline
\end{tabular}

